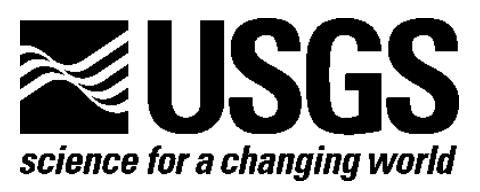

\title{
Safety of Spray-Dried Powder Formulated Pseudomonas fluorescens Strain CL145A Exposure to Subadult/Adult Unionid Mussels During Simulated Open-Water Treatments
}

By James A. Luoma, Kerry L. Weber, Diane L. Waller, Jeremy K. Wise, Denise A. Mayer, and Douglas B. Aloisi

Open-File Report 2015-1064

U.S. Department of the Interior U.S. Geological Survey 


\section{U.S. Department of the Interior \\ SALLY JEWELL, Secretary}

\section{U.S. Geological Survey \\ Suzette M. Kimball, Acting Director}

U.S. Geological Survey, Reston, Virginia: 2015

For more information on the USGS—-the Federal source for science about the Earth, its natural and living resources, natural hazards, and the environment-visit http://www.usgs.gov or call 1-888-ASK-USGS (1-888-275-8747)

For an overview of USGS information products, including maps, imagery, and publications, visit http://www.usgs.gov/pubprod

To order this and other USGS information products, visit http://store.usgs.gov

Any use of trade, firm, or product names is for descriptive purposes only and does not imply endorsement by the U.S. Government.

Although this information product, for the most part, is in the public domain, it also may contain copyrighted materials as noted in the text. Permission to reproduce copyrighted items must be secured from the copyright owner.

\section{Suggested citation:}

Luoma, J.A., Weber, K.L., Waller, D.L., Wise, J.K., Mayer, D.A., and Aloisi, D.B., 2015, Safety of spray-dried powder formulated Pseudomonas fluorescens strain CL145A exposure to subadult/adult unionid mussels during simulated open-water treatments: U.S. Geological Survey Open-File Report 2015-1064, 248 p., http://dx.doi.org/10.3133/ofr20151064.

ISSN 2331-1258 (online) 


\section{Acknowledgments}

This study was funded through a grant from the U.S. Environmental Protection Agency Great Lakes Restoration Initiative awarded to the New York State Education Department and U.S. Geological Survey appropriated funds.

The authors would like to thank the staff of the Genoa National Fish Hatchery for the many hours dedicated to propagating the seven species of mussels and for their expert advice, which was integral to the study design and execution. The Wisconsin Department of Natural Resources assisted in the permitting required for the study, and the La Crosse Regional Airport (La Crosse, Wisconsin) allowed us to conduct study operations on their property.

The authors thank Mr. Hugh McMath (USGS), who assisted in study conduct as well as data and sample collection. We also thank Mr. Mark Gaikowski (USGS) for his assistance in study design and data analysis. 


\section{Contents}

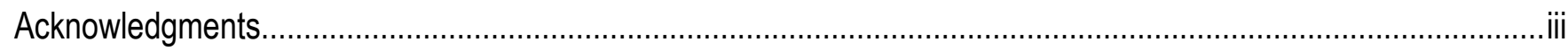

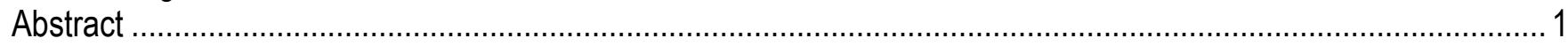

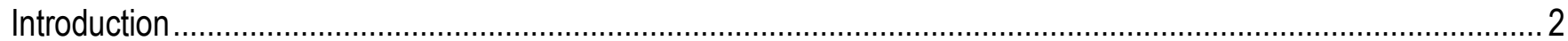

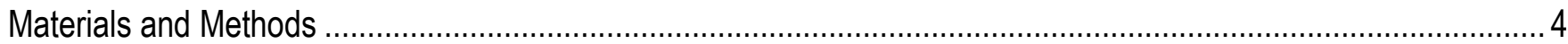

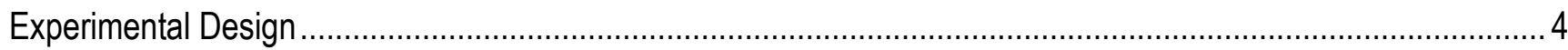

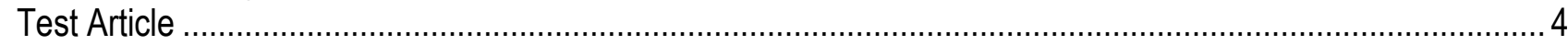

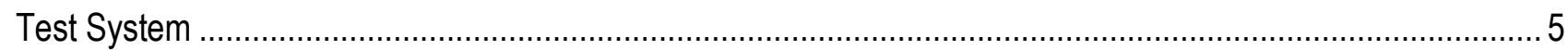

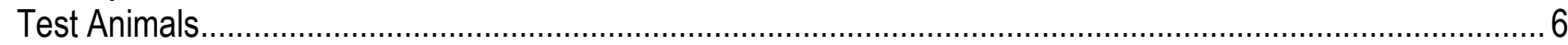

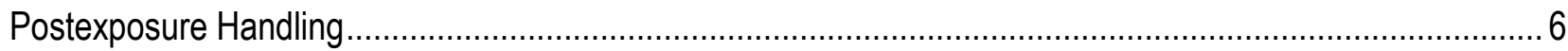

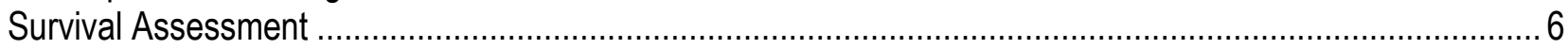

Dosing and Dose Verification .........................................................................................................

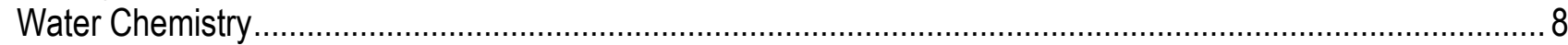

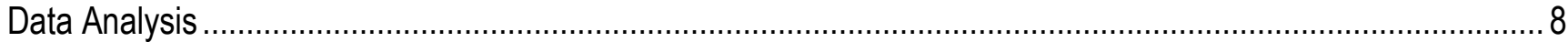

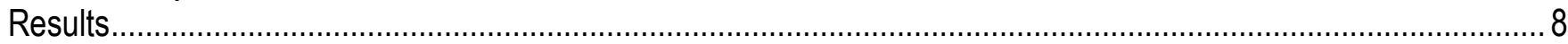

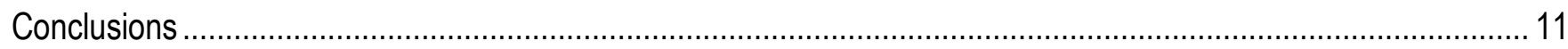

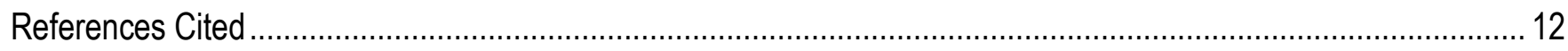

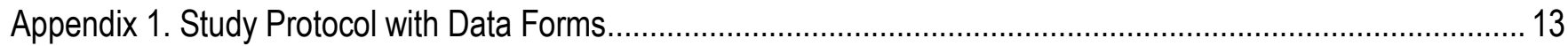

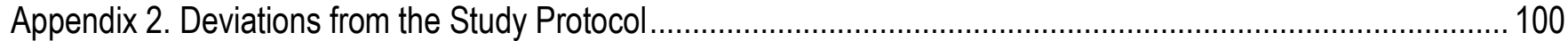

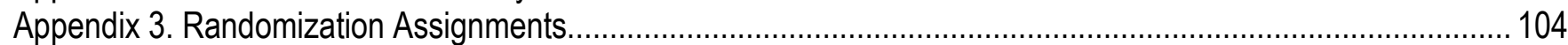

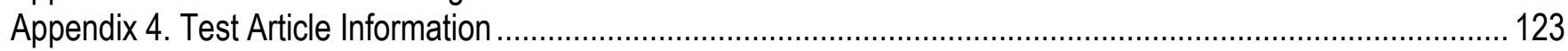

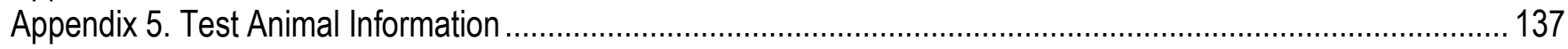

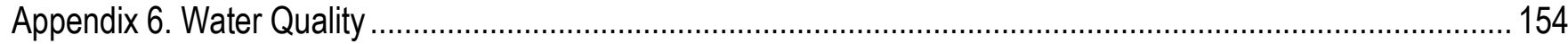

Appendix 7. Spectrophotometric Summary, SAS Program, Output and Log ................................................. 167

Appendix 8. Statistical Analysis including SAS Programs, Outputs and Logs for Survival and Treatment Concentration

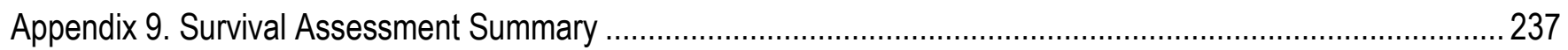




\section{Figures}

Figure 1. Exposure and postexposure test animal holding location. .......................................................... 3

Figure 2. Test tanks positioned in the mobile bioassay laboratory (left) and containment baskets positioned in test tank (right)

Figure 3. Example specimens of the seven unionid mussel species tested (left) and alphanumeric-tagged mussels (right).

Figure 4. Example wire mesh cage used to hold mussels during the postexposure period.

\section{Tables}

Table 1. Scientific and common name, source, lifestage, mean (standard deviation) length, and total number of test animals used in the study.......

Table 2. Mean (standard deviation) percent survival of mussels exposed to SDP by treatment group and exposure duration.

Table 3. Mean (standard deviation) dissolved oxygen, temperature and $\mathrm{pH}$ range observed for each treatment group during the study period.

Table 4. Mean (standard deviation) alkalinity, hardness, conductivity, total ammonia nitrogen (TAN), and un-ionized ammonia $\left(\mathrm{NH}_{3}\right)$ observed during the exposure period.

Table 5. Mean (standard deviation) exposure concentration for each treatment group throughout the exposure period. 


\section{Conversion Factors}

International System of Units to Inch/Pound

\begin{tabular}{|c|c|c|}
\hline Multiply & By & To obtain \\
\hline \multicolumn{3}{|c|}{ Length } \\
\hline centimeter $(\mathrm{cm})$ & 0.3937 & inch (in.) \\
\hline micrometer $(\mu \mathrm{m})$ & $3.937 \times 10^{-5}$ & inch (in.) \\
\hline millimeter $(\mathrm{mm})$ & 0.03937 & inch (in.) \\
\hline \multicolumn{3}{|c|}{ Volume } \\
\hline liter (L) & 1.057 & quart (qt) \\
\hline milliliter $(\mathrm{mL})$ & 0.03382 & ounce, fluid (fl. oz) \\
\hline \multicolumn{3}{|c|}{ Flow rate } \\
\hline milliliter per minute $(\mathrm{mL} / \mathrm{min})$ & 0.0002642 & gallon per minute (gal/min) \\
\hline \multicolumn{3}{|c|}{ Mass } \\
\hline milligram (mg) & $3.527 \times 10^{-5}$ & ounce, avoirdupois (oz) \\
\hline
\end{tabular}

Temperature in degrees Celsius $\left({ }^{\circ} \mathrm{C}\right)$ may be converted to degrees Fahrenheit $\left({ }^{\circ} \mathrm{F}\right)$ as ${ }^{\circ} \mathrm{F}=\left(1.8 \times{ }^{\circ} \mathrm{C}\right)+32$.

Specific conductance is given in microsiemens per centimeter at 25 degrees Celsius $\left(\mu \mathrm{S} / \mathrm{cm}\right.$ at $\left.25^{\circ} \mathrm{C}\right)$.

Concentrations of chemical constituents in water are given in milligrams per liter (mg/L).

\section{Abbreviations}

$\begin{array}{ll}\mathrm{AEH} & \text { Aquatic Ecosystem Health Branch } \\ \mathrm{CaCO}_{3} & \text { calcium carbonate } \\ \mathrm{DO} & \text { dissolved oxygen } \\ \mathrm{ID} & \text { inner diameter } \\ \mathrm{NH}_{3} & \text { un-ionized ammonia } \\ \mathrm{SDP} & \text { spray dried powder } \\ \mathrm{SDP} / \mathrm{L} & \text { spray dried powder per liter } \\ \text { TAN } & \text { total ammonia nitrogen } \\ \text { TEMP } & \text { temperature } \\ P f & \text { Pseudomonas fluorescens } \\ \mu \mathrm{S} / \mathrm{cm} & \text { microsiemens per centimeter }\end{array}$




\title{
Safety of Spray-Dried Powder Formulated Pseudomonas fluorescens Strain CL145A Exposure to Subadult/Adult Unionid Mussels During Simulated Open-Water Treatments
}

By James A. Luoma, ${ }^{1}$ Kerry L. Weber, ${ }^{1}$ Diane L. Waller, ${ }^{1}$ Jeremy K. Wise, ${ }^{1}$ Denise A. Mayer, ${ }^{2}$ and Douglas B. Aloisi ${ }^{3}$

\begin{abstract}
The exposure effects of a commercially prepared spray dried powder (SDP) formulation of Pseudomonas fluorescens (strain CL145A) on the survival of seven species of unionid mussels endemic to the Great Lakes and Mississippi River basins was evaluated in this study. The study exposures were completed within replicated 350-liter test tanks contained within a mobile bioassay laboratory sited on the shores of the Black River near La Crosse, Wisconsin. The test tanks were supplied with flowing, filtered river water which was interrupted during the exposure period.

Two groups of seven species of mussels were used in equal proportions in the study. The first group was exposed to SDP for 8 hours, and the second group was exposed to SDP for 24 hours. Individually tagged mussels were randomly allocated to test tanks until all test tanks contained 8 to 10 mussels of each species (dependent upon the number available for testing).

The experimental unit for the trial was the individual test tank, and treatment group was assigned using a randomized block design. The treatment groups for each exposure duration consisted of (1) an untreated control group, (2) a group that received an application of 50 milligrams SDP per liter (mg SDP/L), and (3) a group that received an application of $100 \mathrm{mg} \mathrm{SDP} / \mathrm{L}$. All mussel species and both exposure duration groups were exposed concurrently (that is, one-half of the mussels were removed after 8 hours of SDP exposure and the remaining mussels were removed after 24 hours of SDP exposure). All treatment concentrations are reported as active ingredient.

After exposure, the mussels were consolidated into wire mesh cages and placed in the Black River for a 27-28 day postexposure period, after which time survival of mussels was assessed. Of the 1,170 mussels tested in the study, 3 were confirmed dead and 5 were not recovered and treated as mortalities in the analysis. The effect and interactions of species, SDP exposure concentration, and SDP exposure duration were analyzed and did not affect mussel survival ( $p>0.98$ ). The results from this study indicate that SDP exposure at the maximum approved open-water concentration of $100 \mathrm{mg} / \mathrm{L}$ for up to 3 times the maximum approved open-water exposure duration of 8 hours (in other words for 24 hours of exposure) is unlikely to reduce survival of subadult or adult mussels.
\end{abstract}

\footnotetext{
${ }^{1}$ U.S. Geological Survey.

${ }^{2}$ New York State Education Department.

${ }^{3}$ U.S. Fish and Wildlife Service.
} 


\section{Introduction}

Native freshwater mussels of North America were historically considered the most diverse in the world, with about 297 recognized taxa consisting of 281 species and 16 subspecies (Williams and others, 1993). Mussels are largely sedentary in nature, relying on movement of host fish during glochidial attachment as means of transport. Thus, they are particularly vulnerable to a variety of anthropogenic influences, including habitat degradation and alteration, pollution, and overharvest. Neves (2004) reported that 70 species of freshwater mussels in the United States are listed as threatened or endangered, and 40 are candidates for possible listing. The International Union for Conservation of Nature's Red List has 95 species of North American freshwater bivalves currently listed as vulnerable, endangered, or critically endangered and 29 listed as extinct or possibly extinct (http://www.iucnredlist.org/, accessed February, 2014). Ricciardi and Rasmussen (1999) suggested that 127 mussel species will become extinct in the next 100 years; this is claimed to be a conservative extinction rate of 6.4 percent per decade given that it did not take into account extirpations caused by invasive dreissenid mussels (zebra mussel, Dreissena polymorpha, and quagga mussel, D. bugensis). Concerns for native mussels in the Southeast are even greater given that only 25 percent of the 269 species historically present are reported as stable compared to the 13 percent presumed extinct and the 28, 14, and 18 percent listed, respectively, as endangered, threatened, or of special concern (Neves and others, 1997).

Many mussels endemic to North America were imperiled prior to epizoic colonization by zebra and quagga mussels. The introduction of these dreissenids, however, has dramatically heightened concerns for the continued survival of native mussel species. Zebra mussels were reported to be responsible for the extirpation of unionid mussels from waters in Europe as early as 1937 (Sebestyen, 1937; cited in Burlakova and others, 2000). Severe declines in unionid abundance in Europe (Karatayev and Burlakova, 1995; and Burlakova, 1998; cited in Burlakova and others, 2000) and North America (Haag and others, 1993; Nalepa, 1994; Ricciardi and others, 1996; Neves, 2004) have since been well documented in the literature.

The 1973 Endangered Species Act brought forth the need to recognize, protect, and recover rare mussels in the United States. The U.S. Fish and Wildlife Service is responsible for developing recovery plans for threatened and endangered species. Recovery plans can include restoring and acquiring critical habitat, removing introduced or invasive species, and captive propagation and release into historic ranges.

One potential tool for limited, open-water control of dreissenid mussels in critical, high-value habitats is a commercially prepared spray dried powder (SDP) formulation of a specific strain (CL145A) of the common soil bacterium Pseudomonas fluorescens. The SDP formulation is produced by Marrone Bio Innovations, Inc. (Davis, California) and it was registered by the U.S. Environmental Protection Agency $\left(\right.$ Zequanox $^{\circledR}$; registration \# 84059-15) for controlling dreissenid mussels in industrial water conveyance systems (for example, cooling and service water systems) in 2012 and for controlling dreissenid mussels in open-water systems in 2014. Evaluation of SDP exposure effects on nontarget animals, particularly sedentary filter feeding animals such as native unionid mussels, is a critical step before SDP should be applied to control dreissenid mussels in open-water environments.

The study objective was to determine the survival of unionid mussels after exposure to SDP up to the maximum approved open-water application concentration (100 milligrams per liter [mg/L]) and up to 3 times the maximum approved open-water exposure duration (8 hours). The SDP exposures were completed within a mobile bioassay laboratory sited along the Black River (La Crosse, Wisconsin) and after the exposures the test animals were held in the Black River adjacent to the exposure location (fig. 1). 


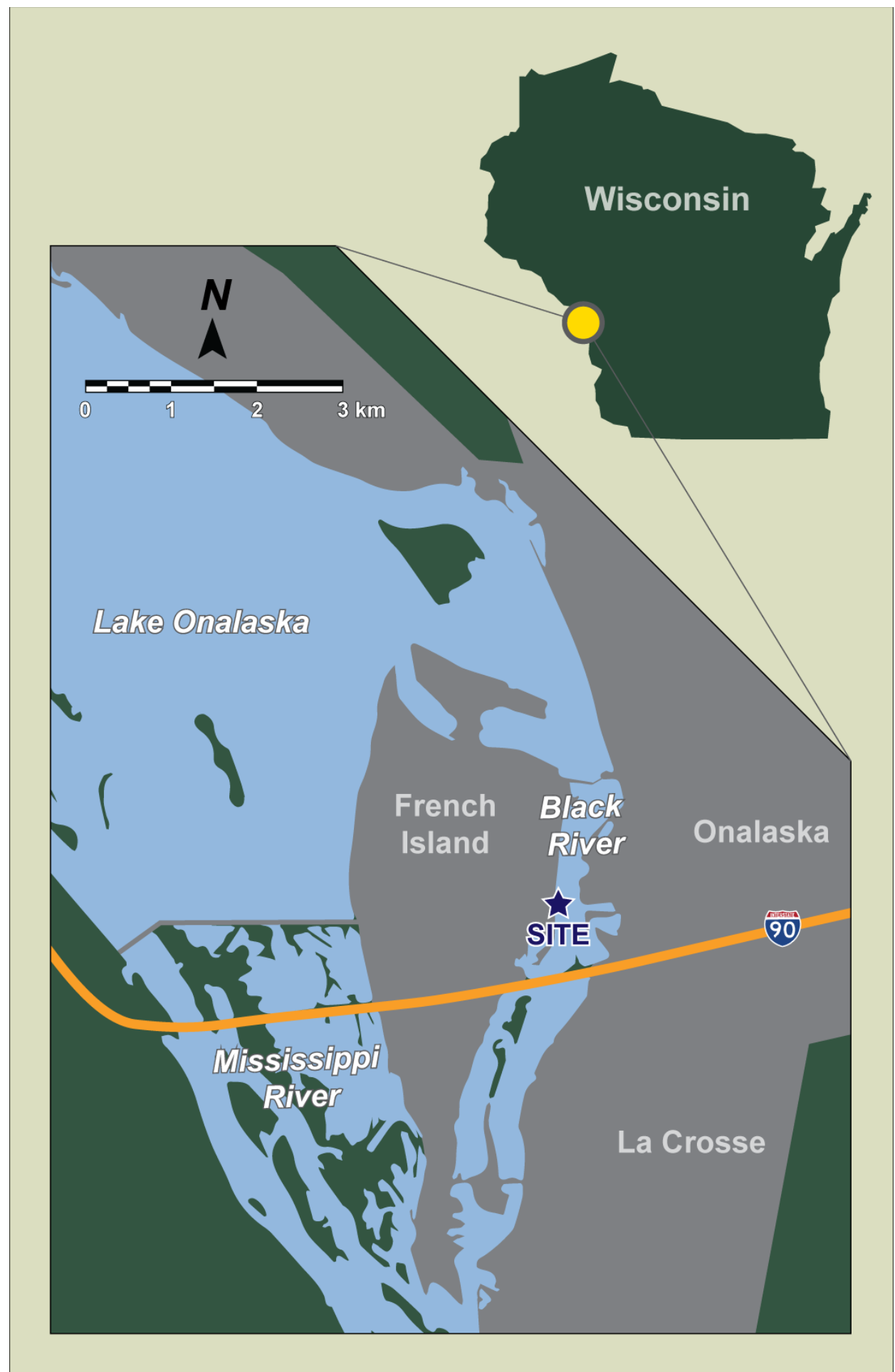

Figure 1. Exposure and postexposure test animal holding location. 


\section{Materials and Methods}

The protocol and amendments for this study are contained in appendix 1 (items 1-2). All methods and materials followed the written protocol except those instances that were identified as deviations (appendix 2, items 1-3).

\section{Experimental Design}

The study was designed to assess the survival of unionid mussels after exposure to target concentrations of 50 and $100 \mathrm{mg} / \mathrm{L}$ of SDP for 8 and 24 hours. Five species of subadult and two species of adult unionid mussels were evaluated (table 1). A total of 1,170 mussels were individually tagged, measured, and randomly assigned (appendix 3, item 2) to test tanks in equal proportions. Each test tank contained two containment baskets, one to hold mussels for the 8-hour exposure group and one for the 24-hour exposure group. Each exposure group consisted of 8-10 mussels of each species.

Treatment was assigned to each test tank by using a randomized block design (appendix 3, item 1). Three treatment groups were tested in triplicate and included (1) an untreated control group, (2) a group that received an application of 50 milligrams SPD per liter (mg SDP/L), and (3) a group that received an application of $100 \mathrm{mg}$ SDP/L. The experimental unit for the trial was the individual test tank. At the conclusion of the exposure period, the mussels were consolidated into wire mesh cages and placed in the Black River (La Crosse, Wis.) for a 27-28 day postexposure period, after which time survival was assessed.

Table 1. Scientific and common name, source, lifestage, mean (standard deviation) length, and total number of test animals used in the study.

[mm, millimeter]

\begin{tabular}{cccccc}
\hline Scientific name & Common name & Source & Lifestage & $\begin{array}{c}\text { Mean length } \\
(\mathbf{m m})\end{array}$ & $\begin{array}{c}\text { Total number } \\
\text { used }\end{array}$ \\
\hline Megalonaias nervosa & Washboard & Propagated & Subadult & $44.0(3.8)$ & 180 \\
Lampsilis cardium & Plain pocketbook & Propagated & Subadult & $39.2(4.2)$ & 162 \\
Obovaria olivaria & Hickorynut & Propagated & Subadult & $30.9(2.2)$ & 180 \\
Lampsilis siliquoidea & Fatmucket & Propagated & Subadult & $57.0(4.8)$ & 180 \\
Lampsilis higginsii & Higgins eye & Propagated & Subadult & $23.8(2.3)$ & 144 \\
Amblema plicata & Threeridge & Wild & Adult & $63.2(8.3)$ & 180 \\
Fusconaia flava & Wabash pigtoe & Wild & Adult & $51.1(8.0)$ & 144 \\
\hline
\end{tabular}

\section{Test Article}

The test article was a commercially formulated SDP formulation of Pseudomonas fluorescens, strain CL145A (Zequanox ${ }^{\circledR}$ ) containing 50 percent active ingredient (weight to weight ratio [w/w] P. fluorescens, strain CL145A); provided by Marrone Bio Innovations as a mixed lot [401P12163C and 401P12164C]; Certificates of Analysis, appendix 4, items 2 and 3). Test article use was documented in the test chemical log books (appendix 4, item 7). Concentrations of test article are reported as active 
ingredient. Retention of test article biological activity was assessed after the study by the New York State Museum Field Research Laboratory, using their standard dreissenid mussel bioassay. Results of the test article biological activity verification bioassay demonstrated the retention of test article biological activity as indicated by a mean zebra mussel mortality of $98.7 \pm 2.3$ percent in the SDPtreated group compared with mean mortality of $0.0 \pm 0.0$ percent in the untreated control (appendix 4, item 6).

\section{Test System}

The test system was a series of nine independent circular test tanks (76.2 x 95.3 centimeters [cm], diameter $\times$ high; 350-L capacity [fig. 2]) contained within a mobile bioassay laboratory. The test system utilized filtered Black River water for the static exposures, containment baskets to confine the test animals, and substrate to allow for test animal positioning. River water was supplied to the test system using a 3-horsepower submersible pump (ITT Goulds Pumps, Seneca Falls, New York, model 18GS30). Water was filtered (200 micrometer) using an automatic backwashing microscreen filtration system (Forsta Filter Inc., Los Angeles, Calif.; model M2-90). Filtered water was delivered to a headbox (55.9 x $114.3 \times 30.5 \mathrm{~cm}$, width $\times$ length $\mathrm{x}$ height) positioned over each row of test tanks and gravity fed to each test tank at $\approx 6$ liters per minute for approximately one tank-exchange per hour. Water flow was interrupted during the exposure period. Water during the preexposure period was discharged to the river; SDP treated exposure water was retained in portable frame tanks, collected by a state-licensed septic hauler, and discharged to the La Crosse, Wis., sanitary treatment system.

Two semi-rigid plastic mesh containment baskets were positioned within each test tank (fig. 2). The baskets were secured to a frame constructed with 1.9 and $2.5-\mathrm{cm}$ wide $\times 0.3$-cm-thick welded aluminum that had an attached aluminum rod handle $(0.95 \times 76.0 \mathrm{~cm}$, diameter $\times$ length $)$. The containment baskets were used to confine the test animals during the exposure period and to facilitate removal after exposure. Approximately $2.5 \mathrm{~cm}(\approx 11.4 \mathrm{~kg})$ of washed sand substrate (River Run Products, Inc. Marathon, Wis.) was placed in the test tanks after the placement of the containment baskets. The substrate facilitated test animal positioning and normal behavior (that is, siphoning).

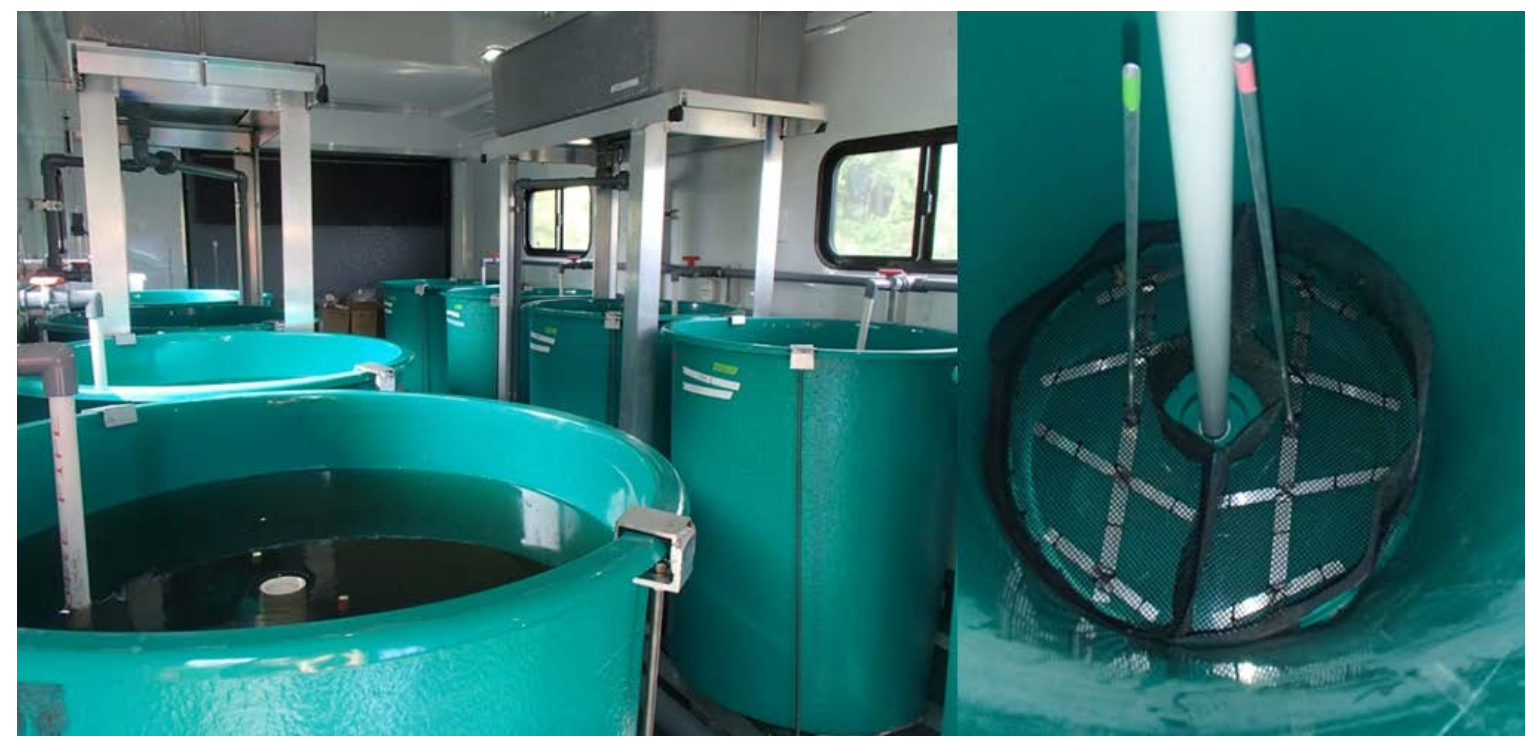

Figure 2. Test tanks positioned in the mobile bioassay laboratory (left) and containment baskets positioned in test tank (right). 


\section{Test Animals}

A total of seven species of unionid mussels, composed of five species of subadult mussels and two species of adult mussels, were used as the test animals (table 1; fig. 3). Subadult mussels were propagated animals, $\leq 3$ years of age, obtained from the U.S. Fish and Wildlife Service's Genoa National Fish Hatchery (NFH). The adult mussels were wild collected from the Upper Mississippi River at river mile 670.5 by Genoa NFH biologists. A Hallprint ${ }^{\circledR}$ shellfish tag with a unique alphanumeric code was fixed to each mussel shell with cyanoacrylate glue (fig. 3), and individual shell length was measured parallel to the hinge. The mussels were maintained at the Genoa NFH in flowing pond water then transported to the test location. Prior to distribution, the mussels were acclimated to Black River water by periodic additions of Black River water to the transportation coolers.

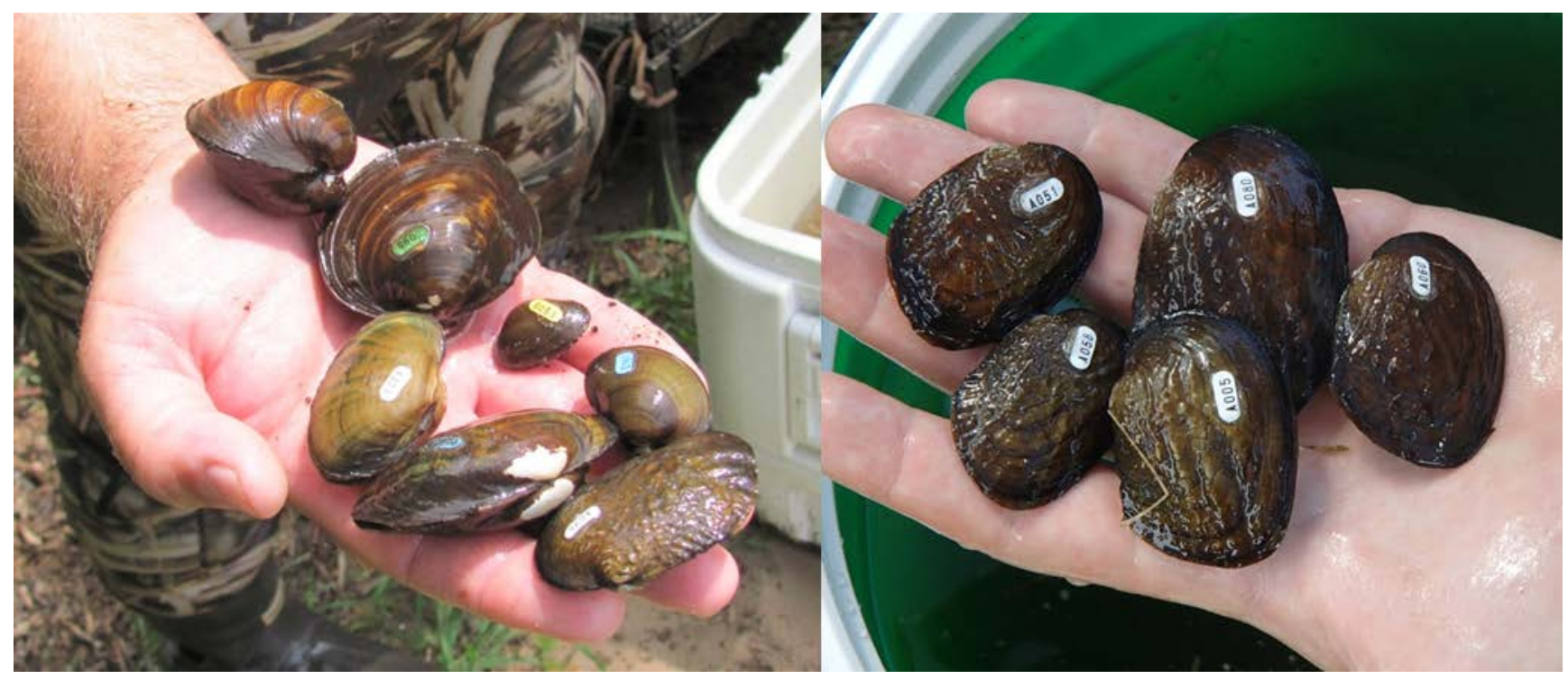

Figure 3. Example specimens of the seven unionid mussel species tested (left) and alphanumeric-tagged mussels (right).

\section{Postexposure Handling}

At exposure termination ( 8 and 24 hours), the assigned containment baskets were removed and the mussels were consolidated into one of six wire mesh cages, constructed according to Brady and others (2010; fig. 4), for the postexposure period. Mussels from one test tank replicate of each treatment group and exposure duration were placed into a single wire mesh (that is, mussels removed at the same exposure termination from a control, a $50 \mathrm{mg} / \mathrm{L}$ replicate and a $100 \mathrm{mg} / \mathrm{L}$ replicate were placed into the same wire mesh cage). The wire mesh cages were placed in $\approx 3$ meters of water in the Black River (15 T 064099mE 4858943mN, fig. 1) for the postexposure period.

\section{Survival Assessment}

Survival of mussels was assessed at 27 or 28 days after exposure. Survival was defined as valve or foot movement in response to tactile stimuli or resistance to valve pressure by adductor muscle contraction. The mussels recovered from each wire mesh cage were sorted by species and individually assessed for survivorship. 


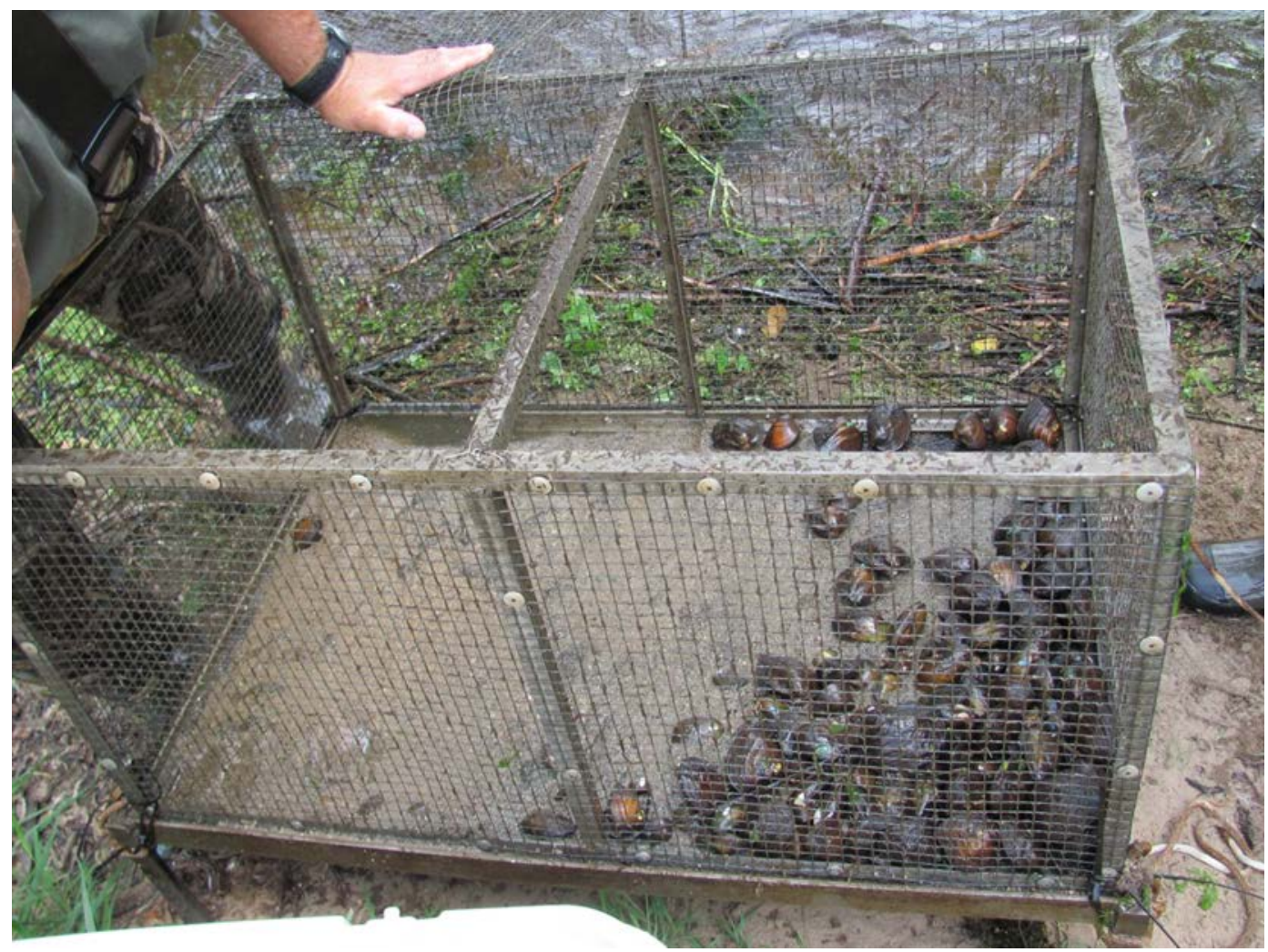

Figure 4. Example wire mesh cage used to hold mussels during the postexposure period.

\section{Dosing and Dose Verification}

One of three treatments was assigned to each test tank according to a randomized design scheme (appendix 3, item 1). Three treatment groups were assigned in triplicate and consisted of (1) an untreated control group, (2) a 50-mg SDP/L group, and (3) a 100-mg SDP/L group. A dosing stock solution was prepared from the test article and immediately applied to each test tank. Depending on treatment assignment, a premeasured amount of SDP (0 grams [g] for control; $35 \mathrm{~g}$ for 50-mg SDP/L treatment; $70 \mathrm{~g}$ for 100-mg SDP/L treatment) was added to $\approx 12 \mathrm{~L}$ of test tank water and mechanically mixed for 3-5 minutes with a paint mixer attached to an electric drill. Immediately after mixing, the stock solution was poured through a strainer, and clumps of test article were macerated with a pestle and rinsed into the stock solution. The resulting stock solutions for each test tank contained the amount of SDP required to achieve the desired concentration. The SDP treatments were administered to the test tanks by gently pouring the stock solution into the test tank. The stock solution and water within the test tank were gently mixed by hand, using a polyvinyl chloride pipe. Care was used to minimize substrate disturbance.

Water samples were collected to verify SDP exposure and total ammonia nitrogen (TAN) concentrations. Water samples were collected by submersing a $50-\mathrm{mL}$ beaker below the water surface of each test tank. The SDP exposure concentrations were determined by comparison to a linear regression curve created from known concentrations (0, 25, 50, 100 and $200 \mathrm{mg} / \mathrm{L}$ [as SDP active ingredient]) and absorbance of the test article. Sample absorbance was measured on a Beckman-Coulter model DU-800 spectrophotometer at 660 nanometers. A linear regression equation (appendix 7, items 1-2) was fit using the Statistical Analysis Software Proc Reg procedure (SAS ${ }^{\circledR}$ Version 9.3, SAS Institute, Inc., 
Cary, North Carolina), and the exposure concentrations were determined from the linear regression (appendix 7, item 1). Exposure concentrations are reported as active ingredient.

\section{Water Chemistry}

Dissolved oxygen, $\mathrm{pH}$, and temperature were measured in each test tank before treatment and $\approx 1,6,12,18$ and 24 hours thereafter. Water hardness, alkalinity, and conductivity were measured prior to treatment on samples collected from each headbox and from water samples collected from each test tank $\approx 3$ hours after administering the treatment. Immediately before the exposure period was terminated, water samples were collected and analyzed for total ammonia nitrogen content by the UMESC water quality laboratory, using the automated phenate method (Standard Method 4500G; American Public Health Association and others, 2012). The un-ionized ammonia fractions were calculated by using the sample $\mathrm{pH}$ and temperature measured at the time of sample collection according to the formula identified by Emerson and others (1975). Temperature loggers (Onset, Bourne, Massachusetts, $\mathrm{HOBO}^{\circledR}$ Pendent Temperature/Light Data Logger) were attached to each wire mesh cage and recorded water temperature every 6 hours during the postexposure period.

\section{Data Analysis}

Statistical comparisons of mussel survival were completed using Statistical Analysis Software (SAS ${ }^{\circledR}$ Version 9.3, SAS Institute, Inc., Cary, N.C.). Significance for all analyses was declared at $\alpha \leq 0.05$. A generalized linear mixed model was used to analyze the effect and interactions of species, SDP exposure concentration, and exposure duration on the survival of mussels. The proportion of mortalities ([number of dead + unrecovered mussels]/total number of mussels in the sample) were modeled by using the SAS Proc GLIMMIX procedure with a binomal distribution and a logit link function (appendix 8, item 1). A scale parameter was added to the model by using the “random_residual_” statement. Mussel survival in each active treatment group was individually compared to the mussel survival of the untreated control group by using a two-sided means comparison test.

Data analyses for water chemistry were limited to simple descriptive statistics. The SAS Software Proc Means procedure was used to determine the mean exposure concentration by individual test tank and by treatment group (appendix 7, items 1-2). All concentrations are reported as active ingredient.

\section{Results}

Statistical analyses for survival output are presented in appendix 8 (item 3), and the summarized data are presented in appendix 9 (items 1-8). Survival of mussels in each treatment group is summarized in table 2. Mean survival of all mussel species in both the 8- and the 24-hour exposure duration groups exceeded 95 percent for all treatment groups, and mussel survival exceeded 87 percent for all test replicates, regardless of species, treatment group, or exposure duration. Of the 1,170 mussels used in the study, there were a total of 3 confirmed mortalities and 5 test animals that were not recovered. The unrecovered mussels were treated as mortalities in the data analyses. No difference in mussel survival was detected ( $p>0.98$ ) when comparing the effects and interactions of species, exposure concentration, and exposure duration.

The water chemistry data are presented in appendix 6 (items 1-4). Water chemistry parameters (dissolved oxygen, $\mathrm{pH}$, and temperature) observed during the study period are summarized in table 3. Dissolved oxygen in each test tank remained above the minimum level recommended (4.0 mg/L) for 
laboratory tests with freshwater mussels (ASTM International, 2013) throughout the first 12 hours of exposure. The mean dissolved oxygen concentration of the untreated control tanks at 18 and 24 hours was 3.3 and $2.7 \mathrm{mg} / \mathrm{L}$, respectively. The mean dissolved oxygen concentration of the treated tanks at 18 and 24 hours was $<1.0 \mathrm{mg} / \mathrm{L}$. The test water hardness, alkalinity, conductivity, and ammonia observed during the study period are summarized in table 4 . The mean alkalinity ranged from 42 to $45 \mathrm{mg} / \mathrm{L}$ as calcium carbonate $\left(\mathrm{CaCO}_{3}\right)$, hardness from 52 to $57 \mathrm{mg} / \mathrm{L}$ as $\mathrm{CaCO}_{3}$, conductivity from 103 to 115 microsiemens per centimeter, $\mathrm{pH}$ from 6.05 to 7.19; and un-ionized ammonia concentrations were $<0.01 \mathrm{mg} / \mathrm{L}$. The mean water temperature during the preexposure and exposure period ranged from 16.2 to 18.7 degrees Celsius $\left({ }^{\circ} \mathrm{C}\right)$. The mean daily water temperature during the postexposure period ranged from 16.9 to $25.0^{\circ} \mathrm{C}$.

Table 2. Mean (standard deviation) percent survival of mussels exposed to SDP by treatment group and exposure duration.

[Means with the same letter are not significantly different $(\alpha>0.05)$; $\mathrm{mg} / \mathrm{L}$, milligram per liter]

\begin{tabular}{|c|c|c|c|c|c|c|}
\hline \multirow{2}{*}{ Species } & \multicolumn{3}{|c|}{ 8-hour exposure } & \multicolumn{3}{|c|}{ 24-hour exposure } \\
\hline & Control & $50 \mathrm{mg} / \mathrm{L}$ & $100 \mathrm{mg} / \mathrm{L}$ & Control & $50 \mathrm{mg} / \mathrm{L}$ & $100 \mathrm{mg} / \mathrm{L}$ \\
\hline \multirow{2}{*}{ Megalonaias nervosa } & $100^{\mathrm{a}}$ & $96.7^{\mathrm{a}}$ & $100^{\mathrm{a}}$ & $100^{\mathrm{a}}$ & $100.0^{\mathrm{a}}$ & $100^{\mathrm{a}}$ \\
\hline & (0) & (5.8) & (0) & $(0)$ & $(0.0)$ & (0) \\
\hline \multirow{2}{*}{ Lampsilis cardium } & $100^{\mathrm{a}}$ & $100^{\mathrm{a}}$ & $100^{\mathrm{a}}$ & $100^{\mathrm{a}}$ & $96.3^{\mathrm{a}}$ & $96.3^{\mathrm{a}}$ \\
\hline & (0) & (0) & (0) & $(0)$ & (6.4) & (6.4) \\
\hline \multirow{2}{*}{ Obovaria olivaria } & $100^{\mathrm{a}}$ & $100^{\mathrm{a}}$ & $100^{\mathrm{a}}$ & $100^{\mathrm{a}}$ & $100^{\mathrm{a}}$ & $96.7^{\mathrm{a}}$ \\
\hline & (0) & $(0)$ & (0) & $(0)$ & $(0)$ & (5.8) \\
\hline \multirow{2}{*}{ Lampsilis siliquoidea } & $100^{\mathrm{a}}$ & $100^{\mathrm{a}}$ & $100^{\mathrm{a}}$ & $100^{\mathrm{a}}$ & $100^{\mathrm{a}}$ & $100^{\mathrm{a}}$ \\
\hline & (0) & $(0)$ & $(0)$ & $(0)$ & $(0)$ & (0) \\
\hline \multirow{2}{*}{ Lampsilis higginsii } & $95.8^{\mathrm{a}}$ & $100^{\mathrm{a}}$ & $100^{\mathrm{a}}$ & $95.8^{\mathrm{a}}$ & $95.8^{\mathrm{a}}$ & $95.8^{\mathrm{a}}$ \\
\hline & $(7.2)$ & (0) & $(0)$ & $(7.2)$ & $(7.2)$ & $(7.2)$ \\
\hline \multirow{2}{*}{ Amblema plicata } & $100^{\mathrm{a}}$ & $100^{\mathrm{a}}$ & $100^{\mathrm{a}}$ & $100^{\mathrm{a}}$ & $100^{\mathrm{a}}$ & $100^{\mathrm{a}}$ \\
\hline & (0) & (0) & $(0)$ & $(0)$ & $(0)$ & $(0)$ \\
\hline \multirow{2}{*}{ Fusconaia flava } & $100^{\mathrm{a}}$ & $100^{\mathrm{a}}$ & $100^{\mathrm{a}}$ & $100^{\mathrm{a}}$ & $100^{\mathrm{a}}$ & $100^{\mathrm{a}}$ \\
\hline & $(0)$ & $(0)$ & $(0)$ & $(0)$ & $(0)$ & (0) \\
\hline
\end{tabular}

The individual test tank SDP exposure concentrations and group means are presented in appendix 7 (items 1-2); the exposure concentrations for each treatment group are summarized in table 5. The mean SDP concentrations measured throughout the 24-hour exposure period were within 5 percent of the target concentrations of 50 and $100 \mathrm{mg}$ SDP/L with the exception of the initial sample $(\approx 1$ hour after SDP application) and the 12-hour sample. The mean initial SDP exposure concentrations were $72.6 \mathrm{mg} / \mathrm{L}$ and $127.3 \mathrm{mg} / \mathrm{L}$ in the 50 - and $100-\mathrm{mg} / \mathrm{L}$ treatment groups, respectively. The mean 12 -hour exposure concentrations were 72.5 and $104.9 \mathrm{mg} / \mathrm{L}$ in the 50- and 100-mg/L treatment groups, respectively. The elevated concentrations were most likely caused by sediment disturbance that occurred (1) during initial mixing of the SDP stock solution with the test tank water and (2) when the 
containment baskets were removed from the test tanks at the conclusion of the 8-hour exposure period. Sediment disturbance increased the turbidity which interfered (increased spectrophotometer readings) with the absorbance measurements.

Table 3. Mean (standard deviation) dissolved oxygen, temperature and $\mathrm{pH}$ range observed for each treatment group during the study period.

[mg/L, milligram per liter; ${ }^{\circ} \mathrm{C}$, degree Celsius; pre, preexposure]

\begin{tabular}{|c|c|c|c|c|c|c|c|c|c|}
\hline \multirow[b]{2}{*}{ Time } & \multicolumn{3}{|c|}{ Control } & \multicolumn{3}{|c|}{$50 \mathrm{mg} / \mathrm{L}$} & \multicolumn{3}{|c|}{$100 \mathrm{mg} / \mathrm{L}$} \\
\hline & $\mathrm{pH}$ & $\begin{array}{c}\text { DO } \\
(\mathrm{mg} / \mathrm{L})\end{array}$ & $\begin{array}{c}\text { Temp } \\
\left({ }^{\circ} \mathrm{C}\right)\end{array}$ & $\mathrm{pH}$ & $\begin{array}{c}\text { DO } \\
\text { (mg/L) }\end{array}$ & $\begin{array}{c}\text { Temp } \\
\left({ }^{\circ} \mathrm{C}\right)\end{array}$ & $\mathrm{pH}$ & $\begin{array}{c}\text { DO } \\
\text { (mg/L) }\end{array}$ & $\begin{array}{c}\text { Temp } \\
\left({ }^{\circ} \mathrm{C}\right)\end{array}$ \\
\hline Pre & 7.15-7.19 & $\begin{array}{r}6.59 \\
(0.06)\end{array}$ & $\begin{array}{l}16.2 \\
(0.0)\end{array}$ & 7.16-7.18 & $\begin{array}{r}6.64 \\
(0.03)\end{array}$ & $\begin{array}{l}16.2 \\
(0.0)\end{array}$ & 7.06-7.18 & $\begin{array}{r}6.69 \\
(0.09)\end{array}$ & $\begin{array}{l}16.2 \\
(0.0)\end{array}$ \\
\hline 1 & 7.07-7.08 & $\begin{array}{r}6.32 \\
(0.01)\end{array}$ & $\begin{array}{l}16.8 \\
(0.0)\end{array}$ & 7.04-7.06 & $\begin{array}{r}6.51 \\
(0.04)\end{array}$ & $\begin{array}{l}16.8 \\
(0.0)\end{array}$ & 6.42-6.61 & $\begin{array}{r}6.54 \\
(0.09)\end{array}$ & $\begin{array}{l}16.9 \\
(0.0)\end{array}$ \\
\hline 6 & $6.98-7.00$ & $\begin{array}{r}5.38 \\
(0.09)\end{array}$ & $\begin{array}{l}17.7 \\
(0.1)\end{array}$ & $6.99-7.00$ & $\begin{array}{r}5.83 \\
(0.03)\end{array}$ & $\begin{array}{l}17.8 \\
(0.2)\end{array}$ & 6.97-6.99 & $\begin{array}{r}5.76 \\
(0.04)\end{array}$ & $\begin{array}{l}17.9 \\
(0.1)\end{array}$ \\
\hline 8 & 6.94-6.97 & $\begin{array}{r}4.85 \\
(0.14)\end{array}$ & $\begin{array}{l}18.1 \\
(0.0)\end{array}$ & 6.92-6.94 & $\begin{array}{r}5.48 \\
(0.04)\end{array}$ & $\begin{array}{r}18.0 \\
(0.1)\end{array}$ & 6.93 & $\begin{array}{r}5.42 \\
(0.07)\end{array}$ & $\begin{array}{l}18.2 \\
(0.1)\end{array}$ \\
\hline 12 & $6.45-6.71$ & $\begin{array}{r}4.18 \\
(0.08)\end{array}$ & $\begin{array}{l}18.4 \\
(0.2)\end{array}$ & 6.72-6.82 & $\begin{array}{r}4.38 \\
(0.14)\end{array}$ & $\begin{array}{l}18.4 \\
(0.2)\end{array}$ & 6.83-6.86 & $\begin{array}{r}4.15 \\
(0.09)\end{array}$ & $\begin{array}{l}18.4 \\
(0.1)\end{array}$ \\
\hline 18 & 6.99-7.02 & $\begin{array}{r}3.27 \\
(0.13)\end{array}$ & $\begin{array}{l}18.5 \\
(0.1)\end{array}$ & 6.77-6.80 & $\begin{array}{r}0.63 \\
(0.14)\end{array}$ & $\begin{array}{r}18.5 \\
(0.1)\end{array}$ & 6.63-6.66 & $\begin{array}{r}0.16 \\
(0.01)\end{array}$ & $\begin{array}{l}18.6 \\
(0.1)\end{array}$ \\
\hline 24 & 6.90-6.99 & $\begin{array}{r}2.71 \\
(0.19)\end{array}$ & $\begin{array}{l}18.6 \\
(0.1)\end{array}$ & 6.39-6.42 & $\begin{array}{r}0.04 \\
(0.00)\end{array}$ & $\begin{array}{l}18.7 \\
(0.1)\end{array}$ & $6.05-6.13$ & $\begin{array}{r}0.03 \\
(0.00)\end{array}$ & $\begin{array}{l}18.7 \\
(0.1)\end{array}$ \\
\hline
\end{tabular}

Table 4. Mean (standard deviation) alkalinity, hardness, conductivity, total ammonia nitrogen (TAN), and un-ionized ammonia $\left(\mathrm{NH}_{3}\right)$ observed during the exposure period. [mg/L, milligram per liter; $\mu \mathrm{S} / \mathrm{cm}$, microsiemens per centimeter at 25 degrees Celsius]

\begin{tabular}{cccccc}
\hline $\begin{array}{c}\text { Treatment } \\
\text { group }\end{array}$ & $\begin{array}{c}\text { Alkalinity } \\
(\mathrm{mg} / \mathrm{L})^{1}\end{array}$ & $\begin{array}{c}\text { Hardness } \\
(\mathrm{mg} / \mathrm{L})^{1}\end{array}$ & $\begin{array}{c}\text { Conductivity } \\
(\mu \mathrm{S} / \mathrm{cm})\end{array}$ & $\begin{array}{c}\text { TAN } \\
\left(\mathrm{mg} \mathrm{NH}_{3}-\mathrm{N} / \mathrm{L}\right)\end{array}$ & $\begin{array}{c}\mathrm{NH3} \\
(\mathrm{mg} / \mathrm{L})\end{array}$ \\
\hline \multirow{2}{*}{ Control } & 42 & 52 & 103 & 0.25 & $<0.01$ \\
& $(0)$ & $(2)$ & $(2)$ & $(0.01)$ & $(<0.01)$ \\
$50 \mathrm{mg} / \mathrm{L}$ & 43 & 53 & 111 & 0.07 & $<0.01$ \\
& $(1)$ & $(1)$ & $(0)$ & $(0.01)$ & $(<0.01)$ \\
$100 \mathrm{mg} / \mathrm{L}$ & 44 & 53 & 115 & 0.07 & $<0.01$ \\
& $(1)$ & $(1)$ & $(1)$ & $(0.02)$ & $(<0.01)$ \\
\hline
\end{tabular}

${ }^{1}$ Reported as calcium carbonate $\left(\mathrm{CaCO}_{3}\right)$. 
Table 5. Mean (standard deviation) exposure concentration for each treatment group throughout the exposure period.

[mg/L, milligram per liter; ND, not detectable/below detection limit]

\begin{tabular}{cccccc}
\hline $\begin{array}{c}\text { Treatment } \\
\text { group }\end{array}$ & $\mathbf{1}$ & $\mathbf{6}$ & $\mathbf{1 2}$ & $\mathbf{1 8}$ & $\mathbf{2 4}$ \\
\cline { 2 - 6 } Control & $\mathrm{ND}$ & $\mathrm{ND}$ & 5.0 & ND & ND \\
& & & $(5.1)$ & & \\
\multirow{2}{*}{$50 \mathrm{mg} / \mathrm{L}$} & 72.6 & 49.0 & 72.5 & 51.9 & 51.2 \\
& $(3.7)$ & $(4.1)$ & $(12.6)$ & $(2.9)$ & $(3.7)$ \\
\multirow{2}{*}{$100 \mathrm{mg} / \mathrm{L}$} & 127.3 & 99.3 & 104.9 & 95.0 & 95.7 \\
& $(11.6)$ & $(3.1)$ & $(7.9)$ & $(3.1)$ & $(4.6)$ \\
\hline
\end{tabular}

\section{Conclusions}

Regardless of species, the application of Zequanox up to the maximum approved open-water application concentration of $100 \mathrm{mg} / \mathrm{L}$ (as active ingredient) for up three times the maximum approved open-water exposure duration (24 hours; the maximum approved open-water exposure duration is 8 hours) did not reduce the survival of the unionid mussels $(p>0.98)$. The results of this study indicate that exposure of up to $100 \mathrm{mg}$ of SDP active ingredient/L for up to 24 hours is unlikely to reduce the survival of subadult or adult unionid mussels. Dissolved oxygen suppression was observed in treated tanks after 12 hours of exposure; however, the maximum approved exposure duration for open-water application is 8 hours. 


\section{References Cited}

American Public Health Association, American Water Works Association, and Water Environment Federation, 2012, Standard methods for examination of water and wastewater (22d ed): Washington, D.C., American Public Health Association, 1,360 p.

ASTM International, 2013, ASTM Standard E2455-06 (2013)—Standard guide for conducting laboratory toxicity tests with freshwater mussels: West Conshohocken, Pa., ASTM International, 52 p.

Brady, T.R., Aloisi, D., Gordon, D and Wege G., 2010, A method for Culturing Mussels Using In-River Cages: Journal of Fish and Wildlife Management, v. 2, no. 1, p.85-89.

Burlakova, L.E., Karatayev, A.Y., and Padilla, D.K., 2000, The impact of Dreissena polymorpha (PALLAS) invasion on unionid bivalves: International Review of Hydrobiology, v. 85, no. 5-6, p. 529-541.

Emerson, K., Russo, R.C., Lund, R.E., and Thurston, R.V., 1975, Aqueous ammonia equilibrium calculations-Effect of $\mathrm{pH}$ and temperature: Journal of the Fisheries Research Board of Canada, v. 32, p. 2379-2383.

Haag, W.R., Berg, D.L., Garton, D.W., and Farris, J.L., 1993, Reduced survival and fitness in native bivalves in response to fouling by the introduced zebra mussel (Dreissena polymorpha) in western Lake Erie: Canadian Journal of Fisheries and Aquatic Sciences, v. 50, no. 1, p. 13-19.

Nalepa, T.F., 1994, Decline of native unionids in Lake St. Clair after infestation by the zebra mussel, Dreissena polymorpha: Canadian Journal of Fisheries and Aquatic Sciences, v. 51, p. 2227-2233.

Neves, R.J., 2004, Propagation of endangered freshwater mussels in North America: Journal of Conchology, special publication 3, p. 69-80.

Neves, R.J., Bogan, A.E., Williams, J.D., Ahlstedt, S.A., and Hartfield, P.W., 1997, Status of aquatic mollusks in the southeastern United States-A downward spiral of diversity, in Benz, G.W., and Collins, D.E., eds., Aquatic fauna in peril—The southeastern perspective: Decatur, Ga., Southeastern Aquatic Research Institute, Lenz Design and Communications, p. 43-85.

Ricciardi, A., Whoriskey F.G., and Rasmussen J.B., 1996, Impact of the Dreissena invasion on native unionid bivalves in the upper St. Lawerence River, Canadian Journal of Fisheries and Aquatic Sciences, v. 53, p. 1434-1444.

Ricciardi, A., and Rasmussen, J.B., 1999, Extinction rates of North American freshwater fauna: Conservation Biology, v. 13, no. 5, p. 1220-1222.

Williams, J.D., Warren, M.L., Jr., Cummings, K.S., Harris, J.L., and Neves, R.J., 1993, Conservation status of freshwater mussels of the United States and Canada: Fisheries, v. 18, no. 9, p. 6-22. 


\section{Appendix 1. Study Protocol With Data Forms}

\begin{tabular}{|c|c|c|c|}
\hline $\begin{array}{l}\text { Item } \\
\text { Number }\end{array}$ & Item Description & $\begin{array}{l}\text { Number } \\
\text { of } \\
\text { Pages }\end{array}$ & $\begin{array}{l}\text { Report } \\
\text { Page } \\
\text { Number }\end{array}$ \\
\hline 1 & $\begin{array}{l}\text { Protocol: "Safety of Spray Dried Powder (SDP) Formulated Pseudomonas fluorescens } \\
\text { strain CL 145A (Zequanox) Exposure to Sub-Adult Unionid Mussels During } \\
\text { Simulated Open Water Treatments" }\end{array}$ & 32 & 14 \\
\hline 2 & Amendment 1 Revision of Study Protocol, Study \# AEH-13-PSEUDO-06 & 12 & 46 \\
\hline 3 & Test Chemical Stock Preparation Datasheet & 1 & 58 \\
\hline 4 & Alkalinity Datasheet & 1 & 59 \\
\hline 5 & Conductivity and Hardness Datasheet & 1 & 60 \\
\hline 6 & Water Quality Datasheet & 1 & 61 \\
\hline 7 & Mussel Histology Samples Datasheet & 1 & 62 \\
\hline 8 & Plain Pocketbook Survival Assessment & 5 & 63 \\
\hline 9 & Hickorynut Survival Assessment & 5 & 68 \\
\hline 10 & Washboard Survival Assessment & 5 & 73 \\
\hline 11 & Higgins Eye Survival Assessment & 5 & 78 \\
\hline 12 & Fatmucket Survival Assessment & 5 & 83 \\
\hline 13 & Threeridge Survival Assessment & 5 & 88 \\
\hline 14 & Wabash Pigtoe Survival Assessment & 5 & 93 \\
\hline 15 & Native Mussel Lengths Datasheet (version 1) & 1 & 98 \\
\hline 16 & Native Mussel Lengths Datasheet (version 2; revised) & 1 & 99 \\
\hline
\end{tabular}




\section{Protocol Title:}

Safety of Spray Dried Powder (SDP) Formulated Pseudomonas fluorescens strain CL145A (Zequanox) Exposure to Sub-Adult Unionid Mussels During Simulated Open

Water Treatments

Study Number: AEH-13-PSEUDO-06

Test Facilities and Study Sponsor

Upper Midwest Environmental Sciences Center (UMESC)

US Geological Survey

2630 Fanta Reed Rd.

La Crosse, Wisconsin 54603

Proposed Experimental Start Date: April 2013

Proposed Experimental Termination Date: December 2013

\section{Protocol Approval}

Reviewed by:

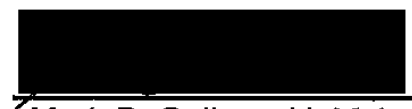

Mark P. Gaikowski, M.A. Supervisory Biologist

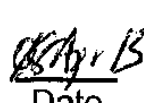

Dáte

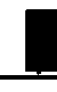

Approved by:

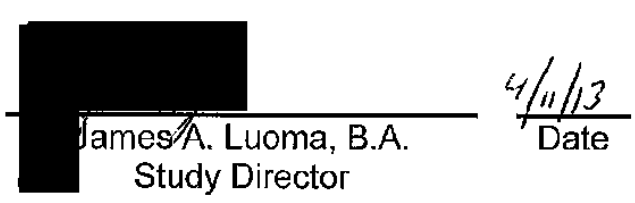

File Folder:

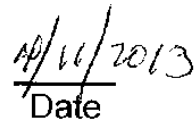

Center Director

File Folder:

Page 1 of 32

Item Number: 1 


\section{TABLE OF CONTENTS}

1. INTRODUCTION

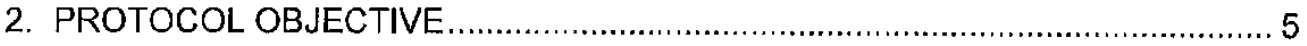

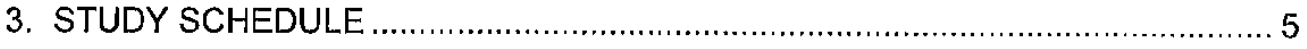

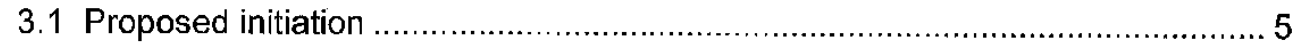

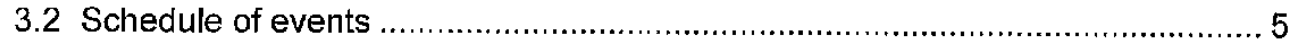

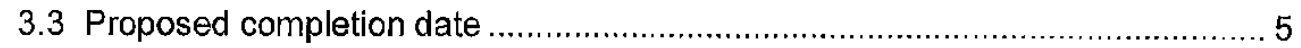

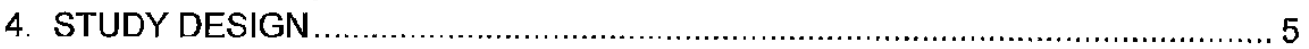

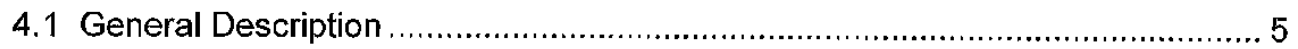

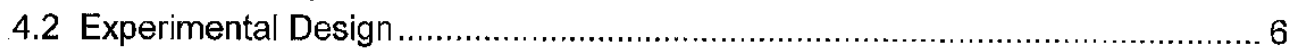

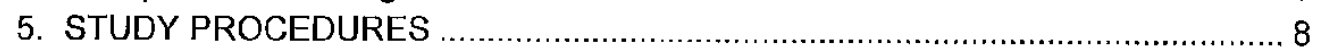

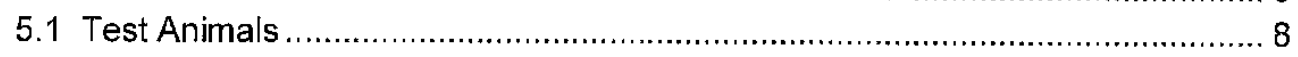

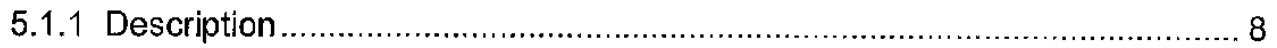

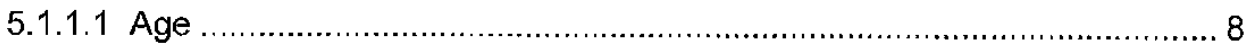

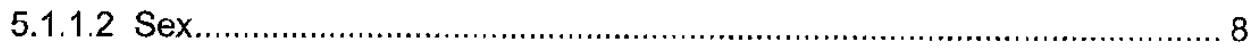

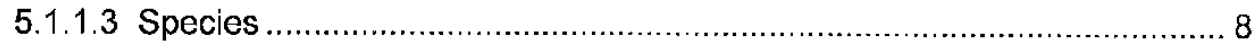

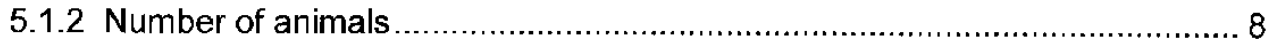

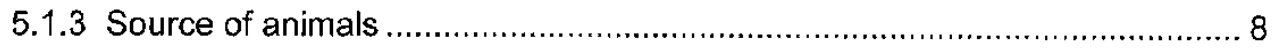

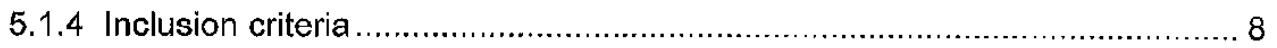

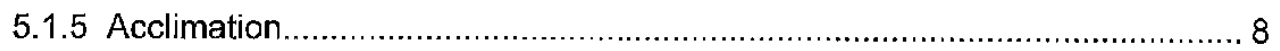

5.1.6 Distribution to exposure replicates .................................................... 8

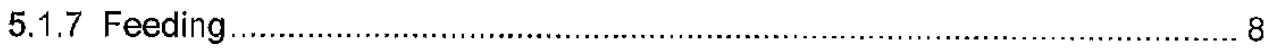

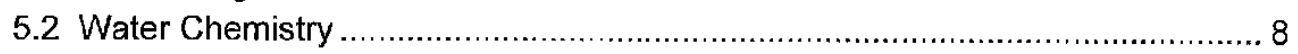

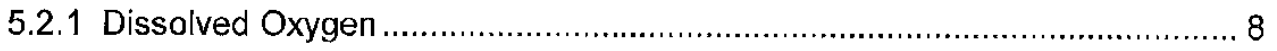

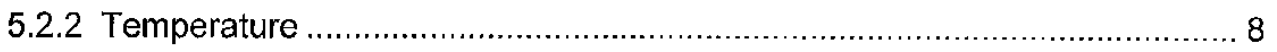

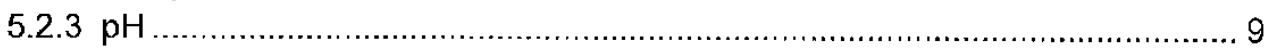

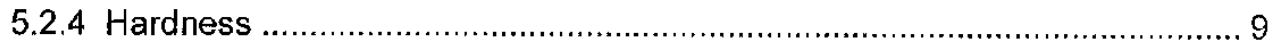

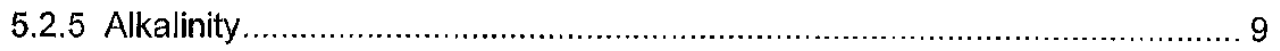

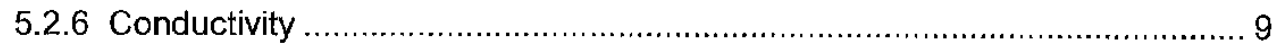

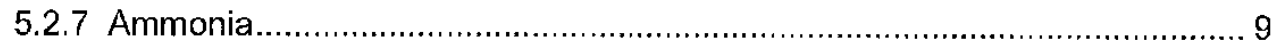

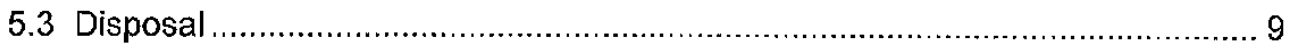

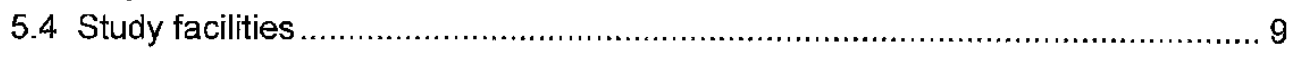

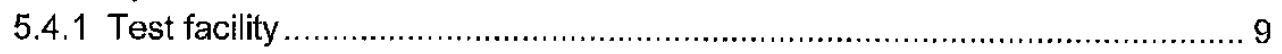

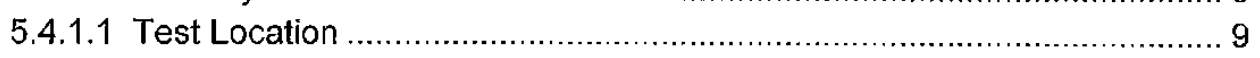

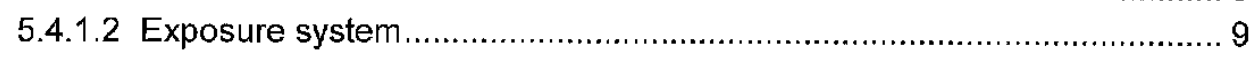

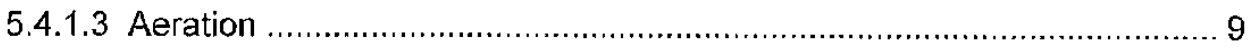

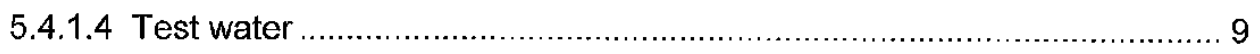

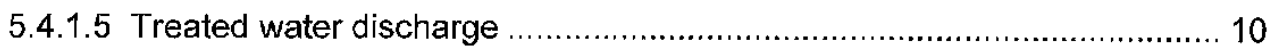

Page 2 of 32 


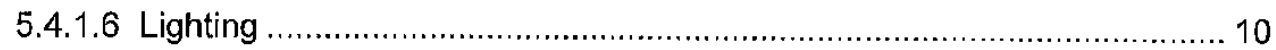

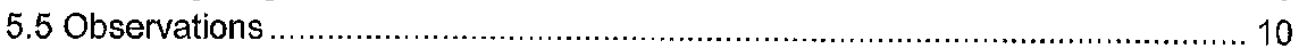

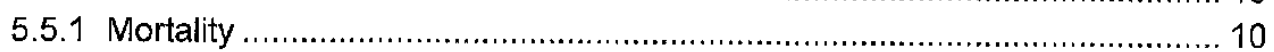

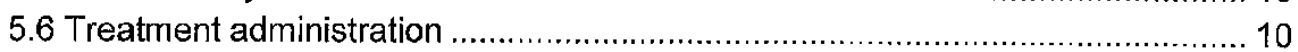

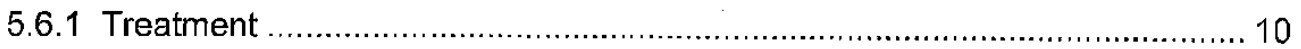

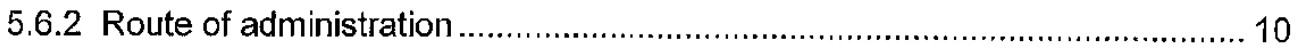

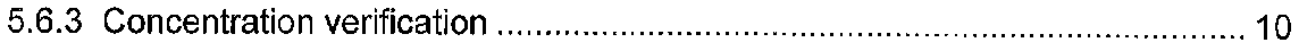

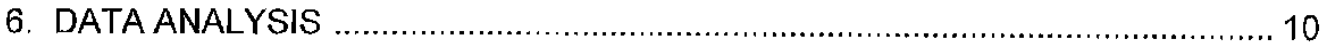

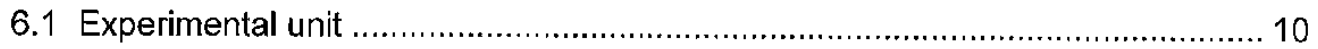

6.2 Number of exposures and replicates .......................................................... 10

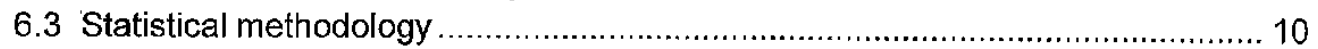

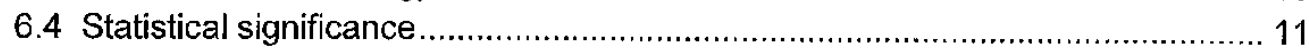

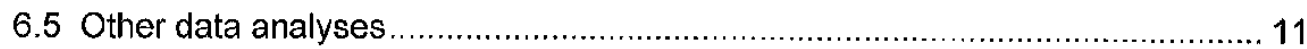

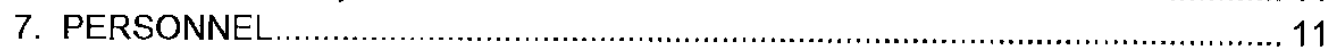

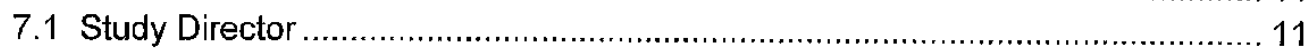

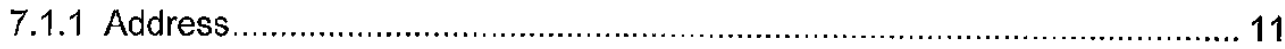

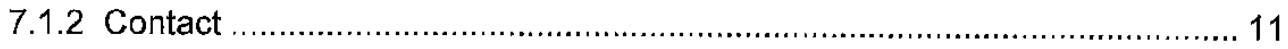

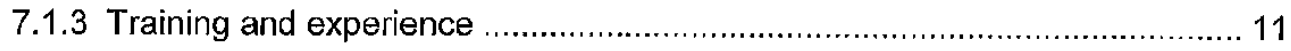

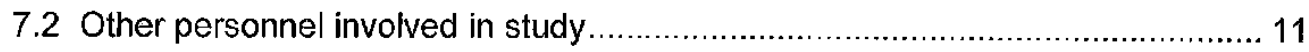

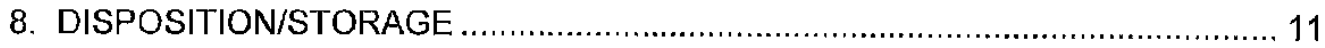

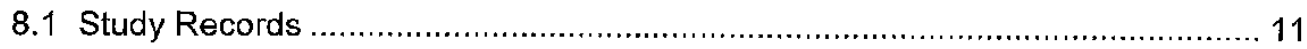

9. AMENDMENT/DEVIATIONS TO THE PROTOCOL ......................................... 11

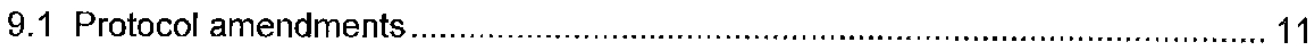

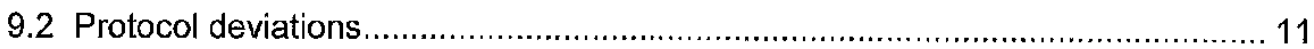

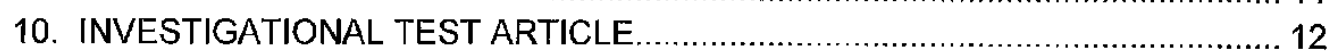

10.1 Test substance.

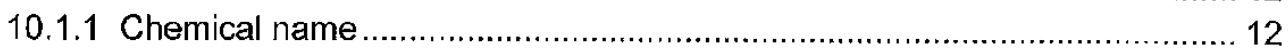

10.1.2 Trade name

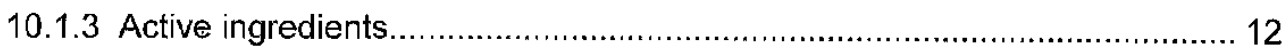

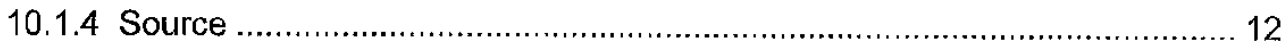

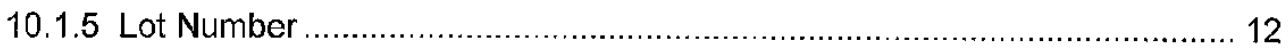

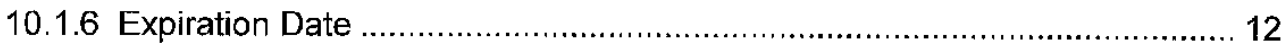

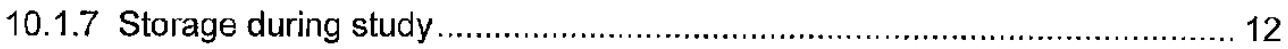

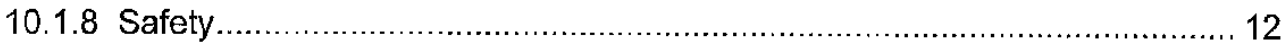

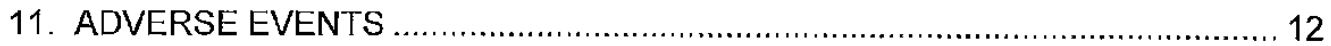

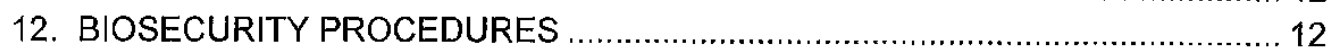

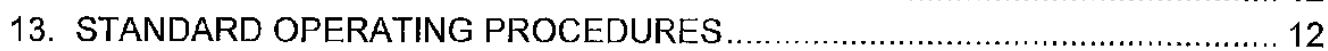

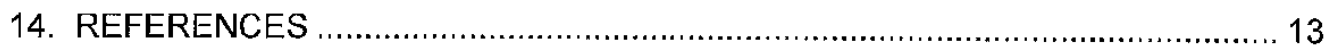

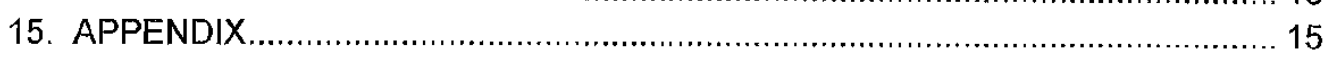

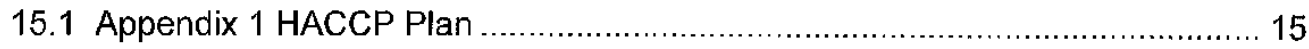

Page 3 of 32 


\section{INTRODUCTION}

Native freshwater mussel populations of North America were historically considered the most diverse in the world with about 297 recognized taxa consisting of 281 species and 16 subspecies (Williams et al., 1993). Mussels are largely sedentary in nature, relying on movement of host fish during glochidial attachment as means of transport. They are thus particularly vulnerable to a variety of anthropogenic influences including habitat degradation and alteration, pollution and overharvest. A Nature Conservancy survey (Master, 1990) found 55\% of North America's mussels as extinct or imperiled compared to $7 \%$ of terrestrial species, even though terrestrial species traditionally receive far greater attention. Projections in 1999 (Ricciadi and Rasmussen, 1999) suggested that at least 127 imperiled mussel species will be lost in the next 100 years - a conservative extinction rate of $6.4 \%$ per decade given it did not take into account extirpations caused by invasive dreissenid mussels (zebra mussel Dreissena polymorpha and quaqqa mussel $D$. bugensis).

Concerns for native mussels in the Southeast are potentially even greater given that only $25 \%$ of the 269 species historically present are reported as stable compared to the $13 \%$ presumed extinct and the 28,14 and $18 \%$ listed, respectively, as endangered, threatened or of special concern. (Neves et al., 1997)

Many unionid mussels in North America were imperiled prior to epizoic colonization by zebra and quaqqa mussels though the introduction of dreissenid mussels have dramatically heightened concerns for the continued survival of native mussels. Zebra mussels were reported to be responsible for the extirpation of unionids from waters in Europe as early as 1937 (Sebestyen, 1937). Severe declines in unionid abundance in Europe (Karatayev and Burlakova, 1995; Burlakova, 1998) and North America (Haag et al., 1993; Nalepa, 1994; Ricciardi et al., 1996) have since been well documented in the literature.

The 1973 Endangered Species Act (ESA) brought forth the need to recognize, protect and recover rare mussels in the United States. The United States Fish and Wildlife Service (USFWS) develops recovery plans for threatened and endangered species which utilize a range of tools to promote recovery of the species including restoring and acquiring critical habitat, removing introduced or invasive species and captive propagation and release into historic ranges.

Biologists at the New York State Museum (NYSM) Field Research Laboratory have been researching dreissenid mussel control techniques since 1991. They discovered that cell components of a strain of common bacterium isolated from soils (Pseudomonas fluorescens [PfCL145A]) are capable of causing mortality when ingested by dreissenid mussels by degrading the epithelial celis lining the dreissenid digestive system. The NYSM also demonstrated that that efficacy for $P f$-CL145A to induce dreissenid mussel mortality was retained when using dead vs. live cells.

Marrone Bio Innovations (MB|; Davis, $\mathrm{CA}$ ) has developed a dead cell, spray dried formulation (SDP) of this bacterium called Zequanox $\circledast$. Zequanox ${ }^{\circledR}$ is currently registered with the USEPA 
for use within closed systems such as power generating plant cooling systems. The NYSM, USFWS (Genoa NFH) and United States Geological Survey's (USGS) Upper Midwest Environmental Sciences Center (UMESC) were awarded a grant from the US Environmental Protection Agency Great Lakes Restoration Initiative entitled "Safe Dreissena Control: Promise for Unionid Restoration". The goal of this grant is to determine the suitability of this product for limited open water zebra mussel control applications including treatment of native mussel propagation cages or native mussel beds. Reference to any specific commercial products, process, or service by trade name, trademark, manufacturer, or otherwise, does not constitute or imply its endorsement, recommendation, or favoring by the United States government. Throughout the remainder of this document the formulated Pf-CL145A product (Zequanox®) will be referred to as sprayed dried powder (SDP).

Naturally occurring surface waters may be unique in their chemical and biological properties which may alter the effects of applied control agents such as SDP. The research to be completed according to this protocol will assess the non-target animal impacts of SDP exposure on sub-adult unionid mussels during simulated open water treatments. The exposures will be conducted in a mobile laboratory supplied with filtered river water. The exposures will simulate anticipated open water treatment concentrations and duration while allowing for replication treatment groups and control of treated water.

\section{PROTOCOL OBJECTIVE}

To assess the non-target animal impacts of SDP exposure on sub-adult unionid mussels during simulated open water treatments.

\section{STUDY SCHEDULE}

\subsection{Proposed initiation: April 2013}

3.2 Schedule of events: A proposed schedule of events is provided in Table 1.

3.3 Proposed completion date: December 2013

Table 1. Proposed Schedule of Events

\begin{tabular}{cc}
\hline Date & Activity \\
\hline April 2013-May 2013 & SDP field exposures \\
May 2013-June 2013 & Post exposure assessment \\
December 2013 & final report submission \\
\hline
\end{tabular}

\section{STUDY DESIGN}

\subsection{General Description}

Up to seven species (Table 2) of sub-adult unionid mussels will be exposed to one of two treatment concentrations of SDP in the UMESC mobile wet laboratory. The wet laboratory will be position stream-side in one of two locations (northern and southern) in the Upper Mississippi River system. The exposures will utilize river water to mimic in situ 
treatment but allow the capture of treated effluent water for disposal. The mussels will be held in the river for approximately $30-d$ post exposure prior to evaluation for treatment related effects. Samples will be collected from no less than 1-2 species for histological examination to determine sub-lethal treatment related effects.

Table 2. Unionid mussel species that may be evaluated for formulated Pseudomonas fluorescens strain CL-145A (SDP) exposure effects.

\begin{tabular}{cc}
\hline Common name & Scientific name \\
\hline Fatmucket & Lampsilis siliquoidea \\
Hickorynut & Obovaria olivaria \\
Higgins eye & Lampsilis higginsii \\
Mucket & Actinonaias ligamentina \\
Plain pocketbook & Lampsilis cardium \\
Threeridge & Amblema plicata \\
Wabash Pigtoe & Fusconaia flava \\
Washboard & Megalonaias nervosa \\
\hline
\end{tabular}

\subsection{Experimental Design}

Major study activities are summarized in Figure 1.

To restrict the movement of test animals (sub-adult unionid mussels) within the Upper Mississippi River System, a northern and southern testing location will be utilized and only mussels cultured or collected from the surrounding watershed will be used in the appropriate exposure trial. The testing locations will be the St. Croix River near Stillwater, MN (northern) and the Black River, directly adjacent to the UMESC campus (southern).

The tests will be conducted in the UMESC mobile wet laboratory. The exposures will be conducted in nine $350 \mathrm{~L}$ cylindrical fiberglass tanks and each tank will be supplied with a washed sand substrate and flowing $200 \mu \mathrm{m}$ filtered river water ( $\geq 1$ tank exchange/h). The water flow will be interrupted during the exposure period. The $350 \mathrm{~L}$ fiberglass tanks will be the exposure chamber replicates and they will be the experimental unit.

Sub-adult native mussel test animals will be provided from Genoa National Fish Hatchery propagation stocks or wild collected from the Upper Mississippi River. Individual mussels will be uniquely tagged or marked and assigned to an exposure chamber replicate according to a randomized distribution scheme. Up to 135 native mussels ( 15 per replicate $\times 9$ replicates) of each species will be randomly placed in each exposure chamber. Up to 4 species will be distributed to each exposure chamber replicate and exposed concurrently. If insufficient numbers of a particular species are available for testing, then the number of animals in each exposure chamber replicate may be reduced (e.g. from 15 to 10 animals) or the $50 \mathrm{mg} / \mathrm{L} \mathrm{A.l}$ treatment group may be excluded for that species. Deviations from the target number of test animals (15) for each exposure chamber replicate/species will be documented in the study records. 
Native mussels will be subjected to one of three treatments levels, 1) a non-exposed control group, 2) a $50 \mathrm{mg} / \mathrm{L} \mathrm{A.l}$, treatment group, and 3) a $100 \mathrm{mg} / \mathrm{L} \mathrm{A.l.} \mathrm{treatment} \mathrm{group.}$ There will be 3 replicates exposure chambers per treatment levels. Treatment level will be assigned to each replicate according to a randomized assignment scheme.

An appropriate amount of a freshly prepared SDP stock solution will be added and thoroughly mixed into the water within each exposure chamber replicate. The SDP concentration, temperature, dissolved oxygen, $\mathrm{pH}$ and conductivity will be monitored in each exposure chamber replicate.

Immediately following the 8-h exposure period, the SDP treated water will be drained from the exposure chambers, the exposure chambers will be rinsed with and refilled with clean river water. The SDP treated water and rinsate will be collected in frame tanks for disposal. Water flow will be restored to the exposure chambers until the mussels are transferred to wire mesh holding cages $(\sim 0.9 \mathrm{~m}$ long $\times 0.6 \mathrm{~m}$ wide $\times 0.45 \mathrm{~m}$ high; either $1.27-\mathrm{cm}$ or $0.635-\mathrm{cm}$, dependent on animal size) for a post-exposure evaluation phase. The holding cages containing mussels and a washed sand substrate will be placed in the river for approximately $30-d$ post exposure prior to evaluating the mussels for treatment related mortality. Representative treatment level sample specimens will be collected during the mortality assessment from at least 1-2 species. The samples will be subjected to histological examination to determine sub-lethal treatment related effects as permitted by funding.

Figure 1. Flow chart of major study activities for each test location

Set up mobile laboratory and water systems, collect, consolidate, tag and measure sub-adult unionid test animals.

?

Randomly distribute test animals to the exposure chamber replicates $(15$ per species per replicate $\times 9$

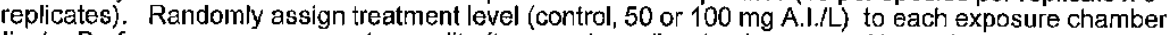
replicate. Perform pre-exposure water quality (temperature, dissolved oxygen, $\mathrm{pH}$, conductivity, hardness and alkalinity).

I?

Initiate SDP exposures (8-h duration, static) $\geq 12-\mathrm{h}$ after test animal placement in exposure chambers. Monitor SDP concentration, temperature, dissolved oxygen, $\mathrm{pH}$ and conductivity in each exposure chamber replicate.

Drain, rinse, refill and restore water flow to each exposure chamber replicate at the termination of the treatment period. Treated water and rinsate will be collected for disposal.

(s.

Place holding cages containing mussels in the river for approximately $30-\mathrm{d}$ post exposure then evaluate the mussels for treatment related mortality. Collect treatment level sample specimens from 1-2 species for histological examination to determine sub-lethal treatment related effects.

lis

Decontaminated all equipment prior to removal from the test site

Page 7 of 32 


\section{STUDY PROCEDURES}

\subsection{Test Animals}

\subsubsection{Description}

5.1.1.1 Age - Native mussels $\leq 3$ yrs

5.1.1.2 Sex - Test animals will be used without regard to sex.

5.1.1.3 Species - see table 2

5.1.2 Number of animals: Approximately 135 native mussels of each species will be used ( 9 replicates $\times 15$ mussels each $=135$ ). If 135 mussels are not available, the number of animals in each replicate may be reduced to 10 and/or the species may be excluded from the low treatment level $(50 \mathrm{mg} / \mathrm{L} \mathrm{A.I.)}$. The number of test animals planned is consistent with the objective of the study and contemporary scientific standards.

5.1.3 Source of animals: Test animals will be provided from Genoa National Fish Hatchery production stocks or wild collected animals from the Upper Mississippi River. Collection of animals will be conducted by Genoa National Fish Hatchery mussel biologists.

5.1.4 Inclusion criterion: Native mussels in apparent good health will be used.

5.1.5 Acclimation: Mussels will be acclimated to treatment conditions for $\geq 12-\mathrm{h}$ prior to exposure initiation.

5.1.6 Distribution to treatment replicates: Up to 15 uniquely identified and measured mussels will be distributed to each exposure replicate according to a predetermined randomization scheme. Five mussels will be placed in each exposure replicate in each distribution round. Three distribution rounds will be completed for each species.

5.1.7 Feeding: No supplemental feed will be offered throughout the acclimation, exposure and post-exposure holding periods.

\subsection{Water Chemistry}

5.2.1 Dissolved oxygen: Dissolved oxygen will be measured and recorded in each exposure chamber replicate during the acclimation, exposure and post-exposure holding periods. Dissolved oxygen will be measured and recorded at least once during the pre- and post-exposure periods and at least twice during the exposure period with the last measurement observed $\leq 30$ minutes prior to exposure termination (UMESC SOP AEH 394 or equivalent).

5.2.2 Temperature: Temperature will be measured and recorded in each exposure chamber replicate during the acclimation, exposure and post-exposure holding periods. Temperature will be measured and recorded at least once during the pre- and post-exposure periods and at least twice during the exposure period with the last measurement observed $\leq 30$ minutes prior to exposure termination. 
5.2.3 $\mathrm{pH}: \mathrm{pH}$ will be measured and recorded in each exposure chamber replicate during the acclimation, exposure and post-exposure holding periods. $\mathrm{pH}$ will be measured and recorded at least once during the pre- and post-exposure periods and at least twice during the exposure with the last measurement observed $\leq 30$ minutes prior to exposure termination (UMESC SOP AEH 335 or equivalent).

5.2.4 Hardness: Hardness will be measured and recorded prior to exposure initiation on the filtered water supply (UMESC SOP AEH 712).

5.2.5 Alkalinity: Alkalinity will be measured and recorded prior to exposure initiation on the filtered water supply (UMESC SOP AEH 706).

5.2.6 Conductivity: Conductivity will be measured and recorded prior to exposure initiation on the filtered water supply (UMESC SOP AEH 188 or equivalent).

5.2.7 Ammonia: Samples for total ammonia-nitrogen will be collected at the termination of the exposure period for each exposure replicate. Ammonia samples will be filtered through a 0.45 micron syringe filter, acidified $(\sim \mathrm{pH} 2.5)$ with sulfuric acid and then stored at $\sim 4^{\circ} \mathrm{C}$ until analyzed by the UMESC Long Term Resources Monitoring (LTRM) Water Quality Laboratory using the automated phenate method.

5.3 Disposal: All live mussels at the conclusion of the mortality assessment that are not subjected to histological examination will be returned to the custody of the Genoa NFH. 5.4 Study facilities

5.4.1 Test Facility

U.S. Geological Survey, Upper Midwest Environmental Sciences Center

Mobile Research Laboratory

2630 Fanta Reed Rd

La Crosse, Wisconsin 54603

5.4.1.1 Test location: Black River; La Crosse, Wl; and St. Croix River; Stillwater, MN.

5.4.1.2 Exposure system: The test system consists of nine $76.2 \mathrm{~cm}$ diameter $\times 91.4 \mathrm{~cm}$ deep fiberglass circular exposure tanks in two rows of 4 or 5 tanks. The tanks are supplied surface water through a pump, filter and headbox system. Each exposure tank will be supplied $3-5 \mathrm{~cm}$ of wash sand for substrate and flowing $200 \mu \mathrm{m}$ filtered river water ( $\geq 1$ tank exchange/h). The water flow will be interrupted during the exposure period. Each tank will be uniquely identified to allow for identification treatment type and replicate number. Coding procedures will be documented in the study records.

5.4.1.3 Aeration: Supplemental aeration will not be supplied during the acclimation, SDP exposures and the post exposure observation periods.

5.4.1.4 Water supply: Filtered $(200 \mu \mathrm{m})$ river water will be supplied continuously ( $\sim 5 \mathrm{~L} / \mathrm{min})$ to achieve a $\sim$ tank-volume exchange/h during the pre- and postexposure periods. Water supply will be interrupted during the SDP exposures.

Page 9 of 32 
5.4.1.5 Water discharge: Untreated water will be returned to the water supply source. SDP treated water will be collected for disposal as required by DNR regulation.

5.4.1.6 Lighting: Overhead lighting will be provided during the exposure period. Light intensity will be measured using a Milwaukee photometer (AEH SOP 308 or equivalent) and recorded in the study records.

\subsection{Observations}

\subsubsection{Mortality:}

Unionid mussels that are gapping and do not respond to tactile stimuli by shell closure will be coded as a mortality. Unionid mussels that have closed shells (closed shells will be gently pried to assure that the anterior adductor muscle contraction is holding the shell closed) or respond to tactile stimuli by shell closure will be coded as alive.

\subsection{Treatment administration}

5.6.1 Treatment: Each treatment will consist of three SDP concentrations (ie: 0 [control], 50 $\mathrm{mg} / \mathrm{L}$ A.l. or $100 \mathrm{mg} / \mathrm{L}$ A.l.) with a single 8-h exposure duration. All treatment concentrations will have three replicate exposure chambers. A minimum of 10 and a maximum of 15 unionid mussels of each species will be placed in each exposure chamber replicate. Up to 4 species will be used in each treatment.

5.6.2 Route of administration: Exposures will be initiated by addition of an appropriate amount of a SDP stock solution. The tank will be gently mixed to achieve a uniform distribution of test material.

5.6.3 Concentration verification: Concentration will be determined spectrophotometrically. A standard curve will be prepared using a known mass of SDP. The absorbance of exposure solutions will be compared to the standard curve to determine the exposure concentration. Absorbance will be determined using a Barnstead/Thermolyne Corporation Model: Turner SP-830 Plus Beckman spectrophotometer (UMESC SOP AEH 302).

\section{DATA ANALYSIS}

6.1 Experimental unit: The experimental unit will be the exposure chamber replicate.

6.2 Number of exposures and replicates: There will be a total of 3 treatment levels (0 [control], 50 and $100 \mathrm{mg} \mathrm{SDP} / \mathrm{L}$ ) and 1 treatment duration (8-h). There will be a total of 3 independent exposures chambers for each treatment level which will serve as the replicates. All treatment levels, replicates, and up to 4 species will be run concurrently.

6.3 Statistical methodology

Survival data will be analyzed using a generalized linear mixed model (SAS PROC GLIMMIX). In every analysis, the exposure will be treated as the experimental unit. The change in proportion of survivors will be analyzed using a generalized linear mixed model where the distribution is binomial and the link used is the logit function.

If a significant effect of treatment is identified then pairwise comparison tests will be completed to compare each treatment group to the control group using unadjusted least squares means

Page 10 of 32 
6.4 Statistical significance: Statistical significance will be declared at $p<0.05$.

6.5 Other data analyses: Statistical methods for other study data collected will include simple statistics such as the calculation of means, standard deviations and coefficients of variation. The statistical procedures used will be described in detail in the final study report.

\section{PERSONNEL}

7.1 Study Director: James A. Luoma, B.A.

7.1.1 Address: Upper Midwest Environmental Sciences Center, US Geological Survey, 2630 Fanta Reed Rd., La Crosse, Wisconsin 54603

7.1.2 Contact: Tel: (608) 781-6391, Fax: (608) 783-6066; jluoma@usgs.gov

7.1.3 Training and experience: $\mathrm{CV}$ on file at UMESC.

7.2 Other personnel involved in study: Technical staff involved in the study will be identified in the study raw data to include study function. UMESC technical staff training and experience will be documented in CVs included in the study raw data.

\section{DISPOSITION/STORAGE}

8.1 Study Records: All data generated in the study will be recorded in bound laboratory notebooks, electronic files or kept in file folders. All data sheets, file folders, laboratory notebooks and computer disks will be encoded with the study number when the data are generated. Raw data, laboratory notebooks and electronic files (including a CDROM containing the annotated SAS program used for the statistical analysis, the data files, SAS $\log$ and SAS output files) generated by UMESC and contract laboratory reports will be filed in the UMESC archives (SOP No. GEN 007) of the Upper Midwest Environmental Sciences Center, La Crosse Wisconsin, before the final report is signed by the Study Director. The final report will then be signed and archived.

\section{AMENDMENTIDEVIATIONS TO THE PROTOCOL}

9.1 Protocol amendments: A signed copy of the Study Protocol will be retained on-site. Proposed amendiments to the protocol shall be brought to the attention of UMESC Management. When the Study Director and Management agree verbally, the study can proceed with the change. As soon as possible, the Study Director will then prepare a written protocol amendment that is signed by the Study Director and Branch Chief. The amendment then becomes an official part of the protocol.

9.2 Protocol deviations: All deviations from this approved protocol will be documented and reviewed by the Study Director. The Study Director will make a judgment on the impact of the deviations. The Study Director will notify Management, as soon as possible, of any deviations to the protocol, including their impact on the study. 


\section{INVESTIGATIONAL TEST ARTICLE}

10.1 Test Substance(s): Pseudomonas fluorescens strain CL145A (Pf-CL145A), SDP formulation

10.1.1 Chemical name: Pseudomonas fluorescens strain CL.145A (Pf-CL145A)

10.1.2 Trade name: Zequanox

10.1.3 Active ingredients: Pseudomonas fluorescens strain CL145A (Pf-CL145A), 50\% active ingredient (A.I.) by weight.

10.1.4 Source: Marrone Bio Innovations (MBI); Davis, CA

10.1.5 Lot number: Lot number(s) will be included in the test chemical log books, lab notebook, and study files.

10.1.6 Expiration date: As determined by the manufacturer. An aliquot of each lot tested will be returned to the NYSM or MBI at the conclusion of exposures for post-exposure zebra mussel bioassay tests (the standard testing protocol to assess Pseudomonas fluorescens [Pf-CL145A] formulation activity). Results of these confirmation bioassays will be used to validate the retention of activity of the Pseudomonas fluorescens (Pf-CL145A) SDP and will be included in the study files when available.

10.1.7 Storage during study: The test chemical will be stored refrigerated. Test material will be transported in a cooler with ice packs to maintain proper storage temperature $\left(4-10^{\circ} \mathrm{C}\right)$

10.1.8 Safety: A NIOSH approved respirator will be used when preparing stock solutions to avoid inhalation. Protective eyewear, gloves and lab coats will be worn at all times when working with the test substance.

\section{ADVERSE EVENTS}

Any adverse event will be recorded in the study logbook and the Study Director will be notified.

\section{BIOSECURITY PROCEDURES}

All personnel involved in the study will review the UMESC biosecurity (UMESC SOP APP 075) and project HACCP plans. Testing will be conducted in a field setting. All equipment will be thoroughly cleaned and disinfected prior to return to UMESC. Waste generated will be placed in plastic garbage bags and disposed of in accordance with local and state regulations. See Appendix 1 for the HACCP plan for this project.

\section{STANDARD OPERATING PROCEDURES}

A complete list of the standard operating procedures used in the study will be included in the study guide. The follow SOP's were cited in this protocol: 
UMESC SOP APP 075 - Procedures to Minimize the Risk of Transfer of Pathogens and Invasive Species

UMESC SOP AEH 188 - Accumet Portable Waterproof Conductivity meter Model \# AP75

UMESC SOP AEH 302 - Instrument Operating Procedure: Barnstead/Thermolyne

Corporation Model: Turner SP-830 Plus Beckman spectrophotometer Serial \#

1365070560781

UMESC SOP AEH 308 - Instrument Operating Procedure: Milwaukee light meter, model

SM7000

UMESC SOP AEH 335 - Beckman Portable $\mathrm{pH} / \mathrm{mV}$ Meter, Model 250

UMESC SOP AEH 394 - YSI Handheld Dissolved Oxygen Meter, Model 55/12FT,

Serials 94C17261 \& 97F0837AG

UMESC SOP AEH 706 - Determination of Total Alkalinity by the Titrimetric $(\mathrm{pH} 4.5)$

Method

UMESC SOP AEH 712 - Determination of Total Hardness

\section{REFERENCES}

Burlakova, L.E., 1998. Ecology of Dreissena polymorpha (PALLAS) and its role in the structure and function of aquatic ecosystems. Candidate dissertation, Zoology Institute of the Academy of Science Republic Belarus, 168 p. (in Russian) in Burlakova L.E., A.Y. Karatayev and D. K. Padilla. 2000. The impact of Dreissena polymorpha (PALLAS) invasion on Unionid bivalves. Internat, Rev. hydrobiol. 85 (5-6):529-541.

Haag, W.R., D.L. Berg, D.W. Garton, and J.L. Farris, 1993. Reduced survival and fitness in native bivalves in response to fouling by the introduced zebra mussel (Dreissena polymorpha) in western Lake Erie. Canadian Journal of Fisheries and Aquatic Sciences 50(1):13-19.

Karatayev, A.Y. and L.E. Burlakova, 1995. Present and future patterns in Dreissena population development in the Narochanskaya lakes system. Vestisi Akad. Navuk Belarusi. Ser. Biyol. Navuk 3: 95098 (in Belarussian) in Burlakova L.E., A.Y. Karatayev and D. K. Padilla. 2000. The impact of Dreissena polymorpha (PALLAS) invasion on Unionid bivalves. Internat. Rev. hydrobiol. 85 (5-6):529-541.

Master, L., 1990. The imperiled status of North American aquatic animals. Biodiversity Network News 3(3):5-8.

Napela, T.F., 1994. Decline of native unionid bivalves in Lake St. Clair after infestation by the zebra mussel, Dreissena polymorpha. Can. J. Fish. Aquat. Sci. 51:2227-2233.

Neves R. J., 2004. Propagation of endangered freshwater mussels in North America. Journal of Conchology, special publication 3:69-80. 
Neves, R.J., A.E. Bogan, J.D. Williams, S.A. Ahlstedt, and P.W. Hartfield, 1997. Status of aquatic mollusks in the southeastern United States: a downward spiral of diversity. Pages 4385 in G.W. Benz and D.E. Collins, editors. Aquatic fauna in peril: the southeastern perspective. Southeastern Aquatic Research Institute, Lenz Design and communications, Decatur, Georgia.

Ricciardi, A. F.G. Whoriskey, and J.B. Rasamussen, 1996. Impact of the Dreissena invasion on native unionid bivalves in the upper St. Lawerance River. Can. J. Fish. Aquat. Sci. 53:14341444.

Ricciardi A., and J.B. Rasmussen, 1999. Extinction rates of North American freshwater fauna. Conservation Biology. Vol. 13 (5):1220-1222.

Sebestyn, O., 1937. Colonization of two new fauna-elements of Pontus-origin (Dreissena polymorpha Pall. And Corophuim curvispinum G.O. Sars forma devium Wundsch) in Lake Balaton, Verh. Int. Ver. Theor. Angew. Limnol. 8:169-182 in

Burlakova L.E., A.Y. Karatayev and D. K. Padilla. 2000. The impact of Dreissena polymorpha (PALLAS) invasion on Unionid bivalves. Internat. Rev. hydrobiol. 85 (5-6):529-541.

Williams, J.D., M.L. Warren Jr., K.S. Cummings, J.L. Harris, and R.J. Neves. 1993. Conservation status of freshwater mussels of the United States and Canada. Fisheries 18(9):622. 


\section{APPENDIX}

15.1 Appendix 1: HACCP PLAN for the study Safety of Formulated Pseudomonas fluorescens strain CL145A (Zequanox) exposure to Sub-Adult Unionid Mussels

\section{Step 1 - Activity Description}

\begin{tabular}{|c|c|}
\hline $\begin{array}{l}\text { Facility: US Geological Surve } \gamma \text {-Upper Midwest Environmental Sciences } \\
\text { Center }\end{array}$ & $\begin{array}{c}\text { Site: Various - St. Croix River; Stillwater, WI } \\
\text { UMR, Harpers Ferry, IA }\end{array}$ \\
\hline Site Coordinator: Jim Luoma & \multirow{4}{*}{$\begin{array}{l}\text { Activity: Safety of Formulated Pseudomonas fluorescens strain } \\
\text { CL.145A (Zequanox) exposure to Sub-Adult Unionid Mussels }\end{array}$} \\
\hline Site Manager: Mark Gaikowski & \\
\hline $\begin{array}{c}\text { Address: } 2630 \text { Fanta Reed Road } \\
\text { La Crosse WI, } 54601\end{array}$ & \\
\hline Phone: $608-781-6322$ & \\
\hline \multicolumn{2}{|c|}{ Project Description } \\
\hline $\begin{array}{l}\text { The objective of this study is to assess the non-target animal impacts } \\
\text { water treatments. }\end{array}$ & fDP exposure on sub-adult unionid mussels during simulated open \\
\hline
\end{tabular}

Step 2 - Potential Hazards: Species which may potentially be moved/introduced

Vertebrates:

Multiple species of freshwater fish, eggs and gametes found in the Upper Mississippi River (UMR) Basin.

Invertebrates:

Zebra mussel (Dreissena poiymorpha)

Asian clam (Corbicula fluminea)

Multiple uther endemic species found in the UMR Basin

\section{Plants:}

Multiple endemic species found in the UMR Basin

Other biologicals (disease, pathogen, parasite):

Largemouth Bass Virus

Spring Viremia of Carp Virus

Bluegill Virus

Infectious Pancreatic Necrosis Virus

Viral Hemorrhagic Septicemia

Furunculosis Aeromonas salmonicido

Enteric Redmouth Disease Yersinia ruckeri

Bacterial Kidney Disease Renibacterium salmoninarum

Other Assorted parasites/pathogens found in the UMR Basin

Other: 
Step 3 - Flow Dlagram

Flow dlagram outlining sequential tasks to complete actlvity/project

\begin{tabular}{|c|c|}
\hline Task 1 & Exposure test siles identified and equipment deployed \\
\hline \multicolumn{2}{|r|}{ (1) } \\
\hline Task 2 & Sub-adult mussels are obtained from Genoa NFH propagation cages or wild collected, tagged and measured \\
\hline \multicolumn{2}{|r|}{ - } \\
\hline Task 3 & Native mussels are placed in exposures chambers and acclimated to test conditions \\
\hline \multicolumn{2}{|r|}{ 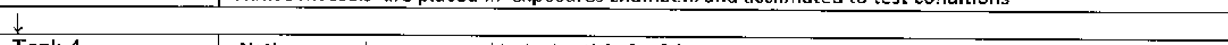 } \\
\hline Task 4 & Native mussels are exposed to test article for 8-h \\
\hline \multicolumn{2}{|l|}{$\downarrow$} \\
\hline Task 5 & Treatment is terminated, treated water is disposed of and mussels are placed in holding cages for 30-d \\
\hline \multicolumn{2}{|r|}{ S } \\
\hline Task 6 & Equipment is decontaminated and returned to UMESC \\
\hline \multicolumn{2}{|l|}{$\downarrow$} \\
\hline Task 7 & Mussels are removed from holding cages and assessed for survival \\
\hline \multicolumn{2}{|r|}{ 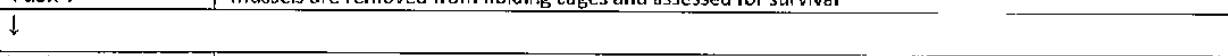 } \\
\hline Task 8 & Samples of mussels are collected for histolngy and the remaining returned to the custody of the Genoa NFH \\
\hline \multicolumn{2}{|r|}{ 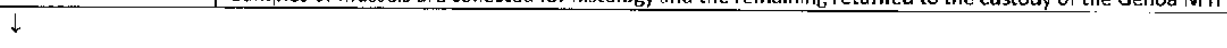 } \\
\hline Task 9 & All remaining equipment and cages are decontaminated and returned to UMESC \\
\hline
\end{tabular}

\begin{tabular}{|c|c|c|c|c|c|}
\hline $\begin{array}{c}1 \\
\text { Tasks } \\
\text { [from HACCP Step } 3 \\
\text { - Flow Diagram) }\end{array}$ & $\begin{array}{c}2 \\
\text { Potentlal hazards } \\
\text { Identifled In HACCP } \\
\text { Step } 2\end{array}$ & $\begin{array}{c}3 \\
\text { Are any potential } \\
\text { hazards probable? } \\
\text { (yes/no] }\end{array}$ & $\begin{array}{l}4 \\
\begin{array}{l}\text { Justify evaluation for } \\
\text { column } 3\end{array}\end{array}$ & $\begin{array}{c}5 \\
\text { What control } \\
\text { measures can be } \\
\text { applied to prevent } \\
\text { undesirable results? }\end{array}$ & $\begin{array}{l}6 \\
\text { Is this task a critical } \\
\text { control point? } \\
\text { (yes/no) }\end{array}$ \\
\hline $\begin{array}{l}\text { Task } 1 \\
\text { Exposure test sites } \\
\text { identified and } \\
\text { equipment deployed }\end{array}$ & Vertebrates & yes & $\begin{array}{l}\text { Surface water } \\
\text { contains multiple } \\
\text { vertebrate species }\end{array}$ & $\begin{array}{l}\text { Assure the thorough } \\
\text { decontamination all } \\
\text { equipment with } \\
\text { steam, } \\
\text { chemosterilants, or } \\
\text { other approved } \\
\text { methods prior to } \\
\text { removal from location, } \\
\text { unless impractical, } \\
\text { then decontamination } \\
\text { shall be done as soon } \\
\text { as possible and must } \\
\text { be done before } \\
\text { equipment is deployed } \\
\text { again. Inspect all } \\
\text { equipment prior to sct } \\
\text { up and repeat } \\
\text { decontomination if } \\
\text { warranted. }\end{array}$ & no \\
\hline
\end{tabular}

Page 16 of 32 


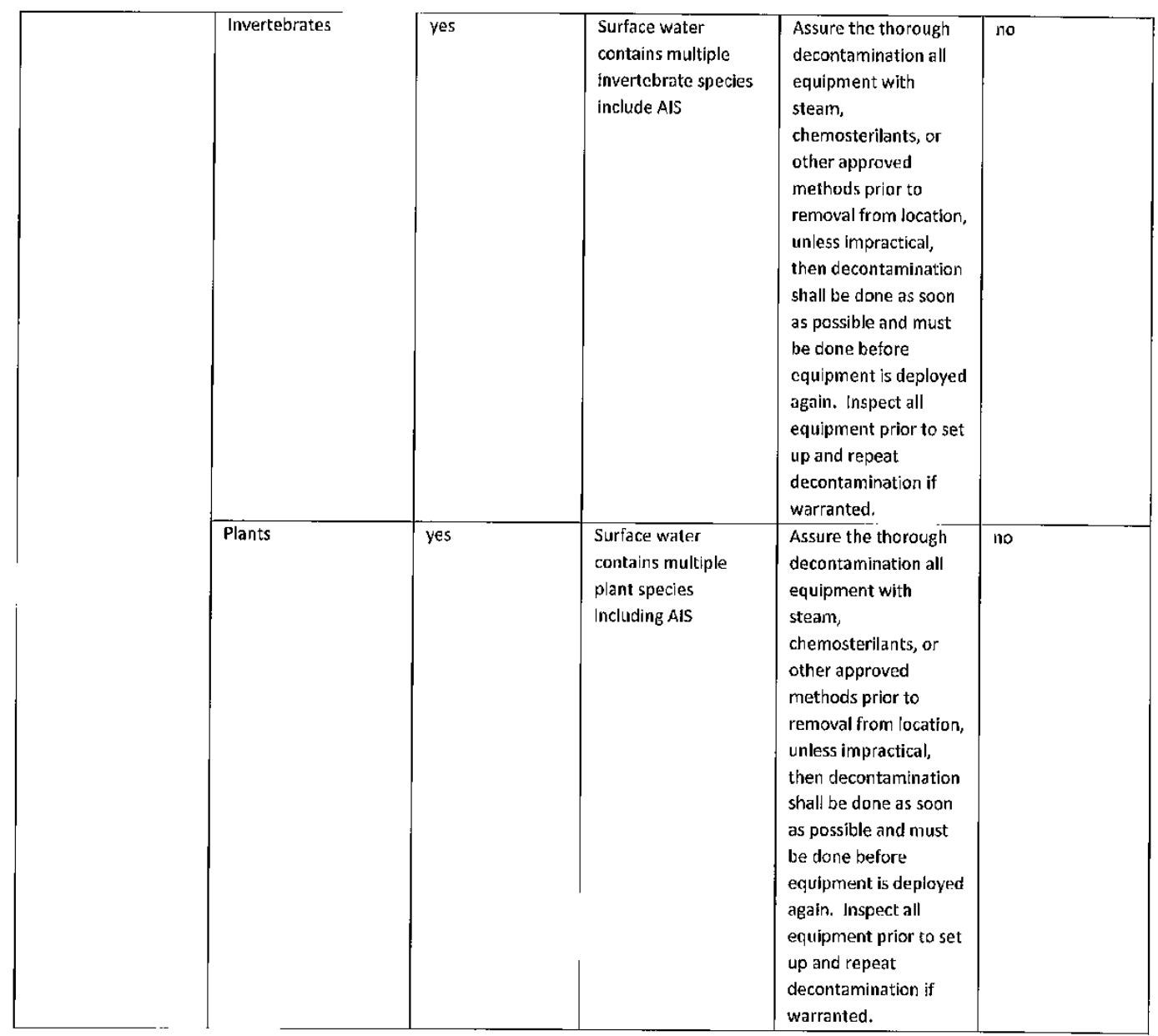

Page 17 of 32 


\begin{tabular}{|c|c|c|c|c|c|}
\hline & Others & yes & $\begin{array}{l}\text { Surface water has } \\
\text { potential to transfer } \\
\text { fish diseases }\end{array}$ & $\begin{array}{l}\text { Assure the thorough } \\
\text { decontaminatlon all } \\
\text { equipment with } \\
\text { steam, } \\
\text { chemosterilants, or } \\
\text { other approved } \\
\text { methods prior to } \\
\text { removal from location, } \\
\text { unless impractical, } \\
\text { then decontamination } \\
\text { shall be done as soon } \\
\text { ds possible and must } \\
\text { be done before } \\
\text { equipment is deployed } \\
\text { again. Inspect all } \\
\text { equipment prior to set } \\
\text { up and repeat } \\
\text { decontamination if } \\
\text { warranted. Do not } \\
\text { proceed if any fish } \\
\text { disease outbreak (i.e.: } \\
\text { vHS) is documented in } \\
\text { the waterbody }\end{array}$ & yes \\
\hline $\begin{array}{l}\text { Task } 2 \\
\text { Sub-adult mussels } \\
\text { are obtained from } \\
\text { Genoa NFH } \\
\text { propagation cages or } \\
\text { wild collected, tagged } \\
\text { and measured }\end{array}$ & Vertebrates & yes & $\begin{array}{l}\text { Surface water } \\
\text { contains multiple } \\
\text { vertebrate species }\end{array}$ & $\begin{array}{l}\text { Assure the thorough } \\
\text { decontamination all } \\
\text { equipment including } \\
\text { all potentially } \\
\text { wetted surfaces with } \\
\text { steam, } \\
\text { chemosterilants, or } \\
\text { other approved } \\
\text { methods prior to } \\
\text { removal from } \\
\text { location, unless } \\
\text { impractical, then } \\
\text { decontamination } \\
\text { shall be done as } \\
\text { soon as possible and } \\
\text { must be done before } \\
\text { equipment is } \\
\text { deployed again. } \\
\text { Inspect all } \\
\text { equipment prior to } \\
\text { set up and repeat } \\
\text { decontamination if } \\
\text { warranted. }\end{array}$ & no \\
\hline
\end{tabular}

Page 18 of 32 


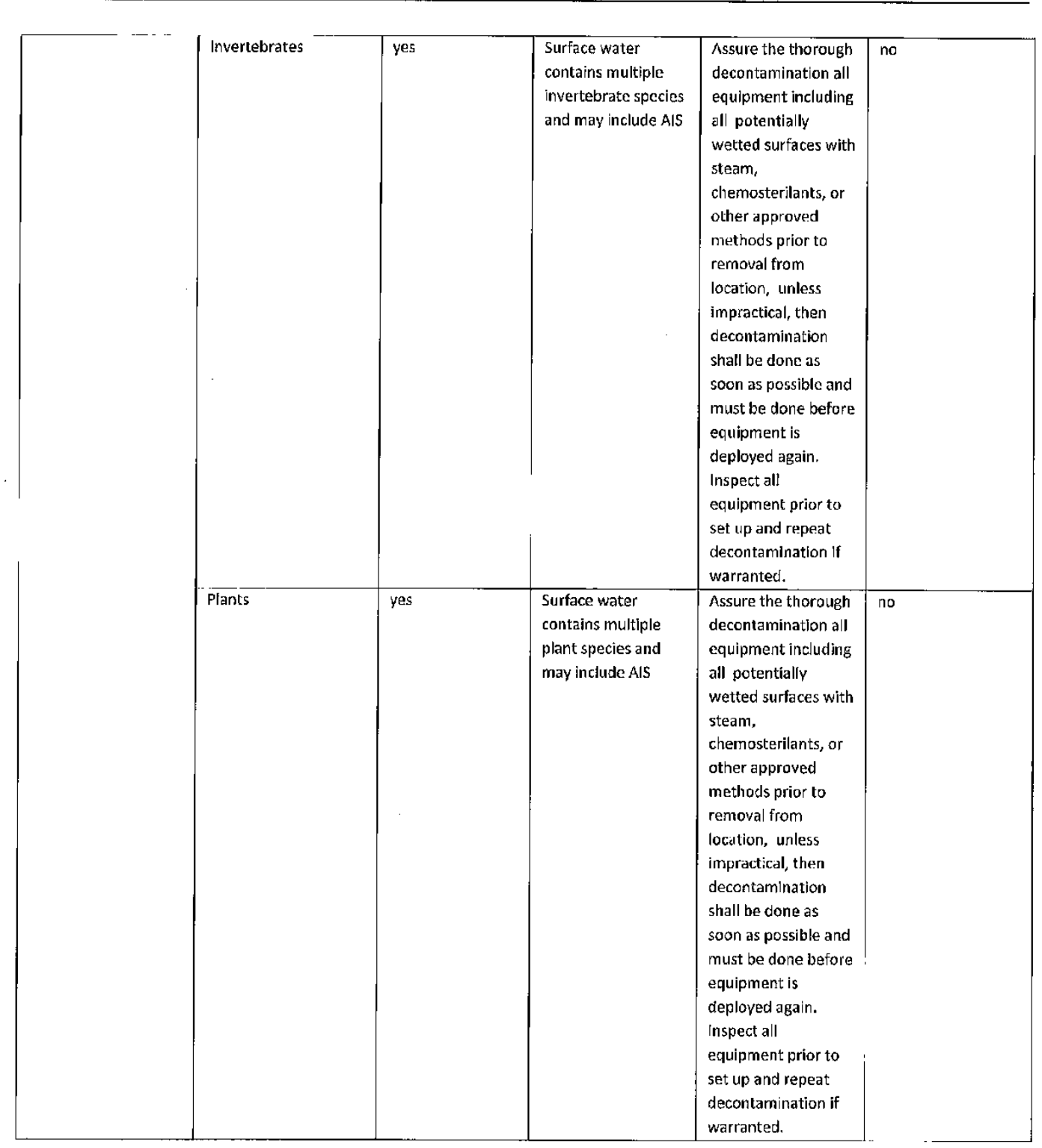

Page 19 of 32 
STUDY NO. AEH-13-PSEUDO-06

\begin{tabular}{|c|c|c|c|c|c|c|}
\hline & Others & yes & $\begin{array}{l}\text { Surface water has } \\
\text { potential to transfer } \\
\text { fish diseases }\end{array}$ & $\begin{array}{l}\text { Assure the thorough } \\
\text { decontamination all } \\
\text { equipment including } \\
\text { all potentially } \\
\text { wetted surfaces with } \\
\text { steam, } \\
\text { chemcsterilants, or } \\
\text { other approved } \\
\text { methods prior to } \\
\text { removal from } \\
\text { location, unless } \\
\text { impractical, then } \\
\text { decontamination } \\
\text { shall be done as } \\
\text { soon as possible and } \\
\text { must be done before } \\
\text { equipment is } \\
\text { deployed again. } \\
\text { lnspect all } \\
\text { equipment prior to } \\
\text { set up and repeat } \\
\text { decontamination if } \\
\text { warranted. Do not } \\
\text { proceed if any fish } \\
\text { disease outbreak } \\
\text { (i.e.: vHS) is } \\
\text { documented in the } \\
\text { waterbody } \\
\end{array}$ & no & \\
\hline $\begin{array}{l}\text { Task } 3 \\
\text { Native mussels are } \\
\text { placed in exposures } \\
\text { chambers and } \\
\text { acclimated to test } \\
\text { conditions }\end{array}$ & Vertebrates & ves & $\begin{array}{l}\text { Surface water contain } \\
\text { multiple vertebrate } \\
\text { species }\end{array}$ & \multicolumn{2}{|c|}{$\begin{array}{l}\text { Assure the thorough } \\
\text { decontamination all } \\
\text { equipment including all } \\
\text { potentially wetted } \\
\text { surfaces with steam, } \\
\text { chemosterilants, or } \\
\text { other approved } \\
\text { methods prior to } \\
\text { removal from location, } \\
\text { unless impractical, } \\
\text { then decontaminatlon } \\
\text { shall be done as soon } \\
\text { as possible and must } \\
\text { be done before } \\
\text { equipment is deployed } \\
\text { again. Inspect all } \\
\text { equipment prior to set } \\
\text { up and repeat } \\
\text { decontamination if } \\
\text { warranted. }\end{array}$} & no \\
\hline
\end{tabular}

Page $\mathbf{2 0}$ of $\mathbf{3 2}$ 


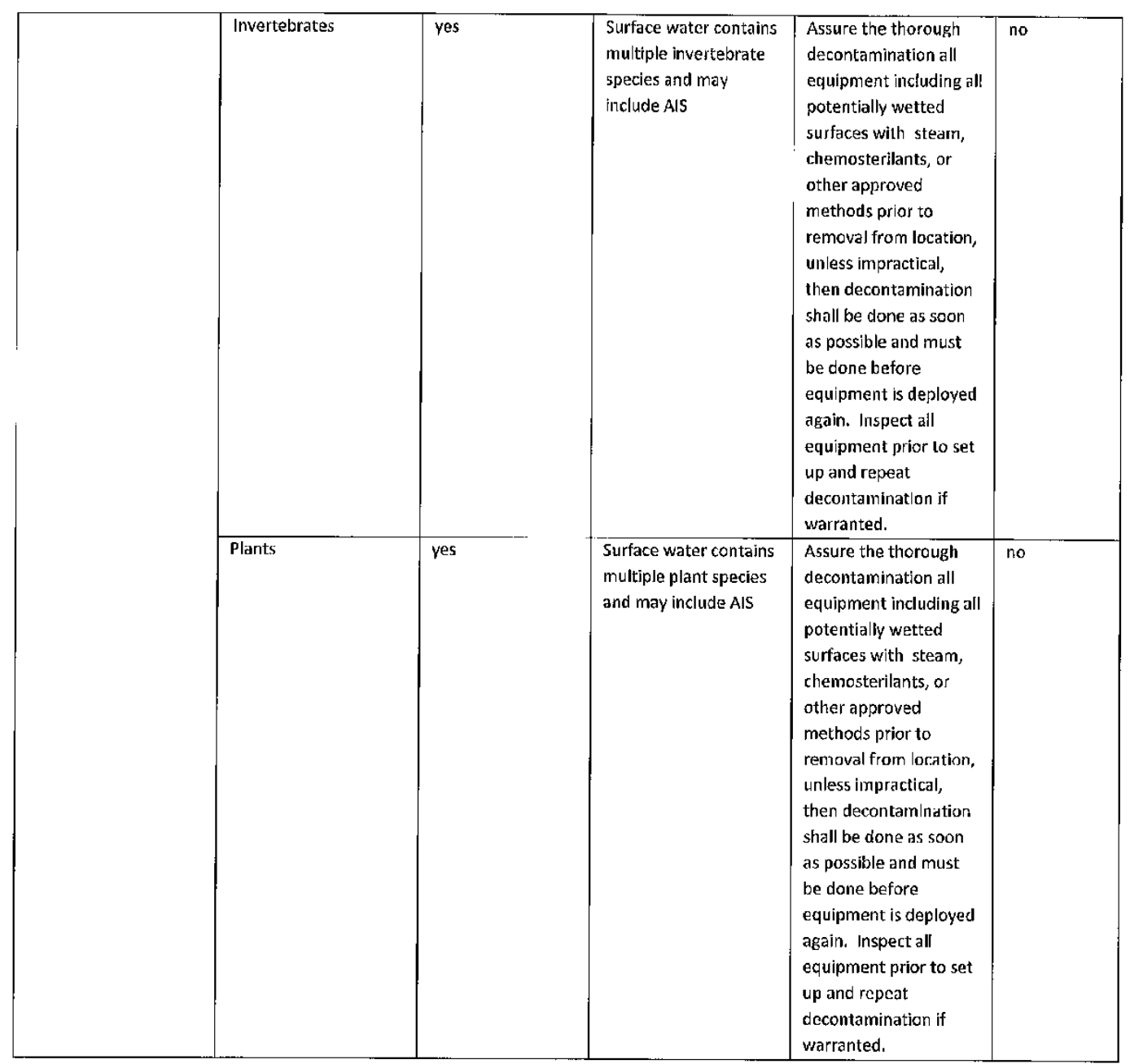

Page 21 of 32 


\begin{tabular}{|l|l|l|l|l|}
\hline & Others & yes & $\begin{array}{l}\text { Surface water has } \\
\text { potential to transfer } \\
\text { fish diseases }\end{array}$ & $\begin{array}{l}\text { Assure the therough } \\
\text { decontamination all } \\
\text { equipment including all } \\
\text { potentially wetted } \\
\text { surfaces with steam, } \\
\text { chemosterilants, or } \\
\text { other approved } \\
\text { methods prior to } \\
\text { removal from location, } \\
\text { unless impractical, } \\
\text { then decontamination } \\
\text { shall be done as soon } \\
\text { as possible and must } \\
\text { be done before } \\
\text { equipment is deployed } \\
\text { again. Inspect all } \\
\text { equipment prior to set } \\
\text { up and repeat } \\
\text { decontamination if } \\
\text { warranted. }\end{array}$ \\
\hline
\end{tabular}

\begin{tabular}{|l|l|l|l|l|}
\hline Task 1 & Vertebrates & ves & $\begin{array}{l}\text { Surface water contains } \\
\text { multiple vertebrate } \\
\text { species }\end{array}$ & $\begin{array}{l}\text { Assure the thorough } \\
\text { decontamination all } \\
\text { equipment including all } \\
\text { to test article for 8-h } \\
\text { surfaces with steam, } \\
\text { chemosterilants, or } \\
\text { other approved } \\
\text { methods prior to } \\
\text { removal from location, } \\
\text { unless impractical, } \\
\text { then decontamination } \\
\text { shall be done as soon } \\
\text { as possible and must } \\
\text { be done before } \\
\text { equipment is deployed } \\
\text { again. Inspect all } \\
\text { ecquipment prior to set } \\
\text { up and repeat } \\
\text { decontamination if } \\
\text { warranted. }\end{array}$ \\
\hline
\end{tabular}

Page 22 of 32 


\begin{tabular}{|c|c|c|c|c|}
\hline Invertebrates & yes & $\begin{array}{l}\text { Surface water contains } \\
\text { multiple invertebrate } \\
\text { species and may } \\
\text { include AIS }\end{array}$ & $\begin{array}{l}\text { Assure the thorough } \\
\text { decontamination all } \\
\text { equipment including all } \\
\text { potentially wetted } \\
\text { surfaces with steam, } \\
\text { chemosterilants, or } \\
\text { other approved } \\
\text { methods prior to } \\
\text { removal from location, } \\
\text { unless impractical, } \\
\text { then decontamination } \\
\text { shall be done as soon } \\
\text { as possible and must } \\
\text { be done before } \\
\text { equipment is deployed } \\
\text { again. Inspect all } \\
\text { equipment prior lo set } \\
\text { up and repeat } \\
\text { decontamination if } \\
\text { warranted. }\end{array}$ & No \\
\hline Plants & yes & $\begin{array}{l}\text { Surface water contains } \\
\text { multiple plant species } \\
\text { and may include AIS }\end{array}$ & $\begin{array}{l}\text { Assure the thorough } \\
\text { decontamination all } \\
\text { equipment including all } \\
\text { potentially wetted } \\
\text { surfaces with steam, } \\
\text { chemosterilants, or } \\
\text { other approved } \\
\text { methods prior to } \\
\text { removal from location, } \\
\text { unless impractical, } \\
\text { then decontamination } \\
\text { shall be done as soon } \\
\text { as possible and must } \\
\text { be done before } \\
\text { equipment is deployed } \\
\text { again. Inspect all } \\
\text { equipment prior to set } \\
\text { up and repeat } \\
\text { decontamination if } \\
\text { warranted. }\end{array}$ & No \\
\hline
\end{tabular}

Page 23 of $\mathbf{3 2}$ 


\begin{tabular}{|c|c|c|c|c|c|}
\hline . & Others & yes & $\begin{array}{l}\text { Surface water has } \\
\text { potential to transfer } \\
\text { fish diseases }\end{array}$ & $\begin{array}{l}\text { Assure the thorough } \\
\text { decontamination all } \\
\text { equipment including all } \\
\text { potentially welted } \\
\text { surfaces with steam, } \\
\text { chemosterllants, or } \\
\text { other approved } \\
\text { methods prior to } \\
\text { removal from location, } \\
\text { unless impractical, } \\
\text { then decontamination } \\
\text { shall be done as soon } \\
\text { as possible and must } \\
\text { be done before } \\
\text { equipment is deployed } \\
\text { again. Inspect all } \\
\text { equipment prior to set } \\
\text { up and repeat } \\
\text { decontamination if } \\
\text { warranted. }\end{array}$ & No \\
\hline $\begin{array}{l}\text { Task } 5 \\
\text { Treatment is } \\
\text { terminated, treated } \\
\text { water is disposed of } \\
\text { and mussels are } \\
\text { placed in holding } \\
\text { cages for } 30-d\end{array}$ & Vertebrates & yes & $\begin{array}{l}\text { Surface water contains } \\
\text { multiple vertebrate } \\
\text { species }\end{array}$ & $\begin{array}{l}\text { Assure the thorough } \\
\text { cecontamination all } \\
\text { equipment including all } \\
\text { potentially wetted } \\
\text { surfaces with steam, } \\
\text { chemosterilants, or } \\
\text { other approved } \\
\text { methods prior to } \\
\text { removal from location, } \\
\text { unless impractical, } \\
\text { then decontamination } \\
\text { shall be done as soon } \\
\text { as possible and must } \\
\text { be done before } \\
\text { equipment is deployed } \\
\text { again. Inspect all } \\
\text { equipment prior to set } \\
\text { up and repeat } \\
\text { decontamination if } \\
\text { warranted. }\end{array}$ & No \\
\hline
\end{tabular}

Page 24 of $\mathbf{3 2}$ 
STUDY NO. AEI-13-PSEUDO-06

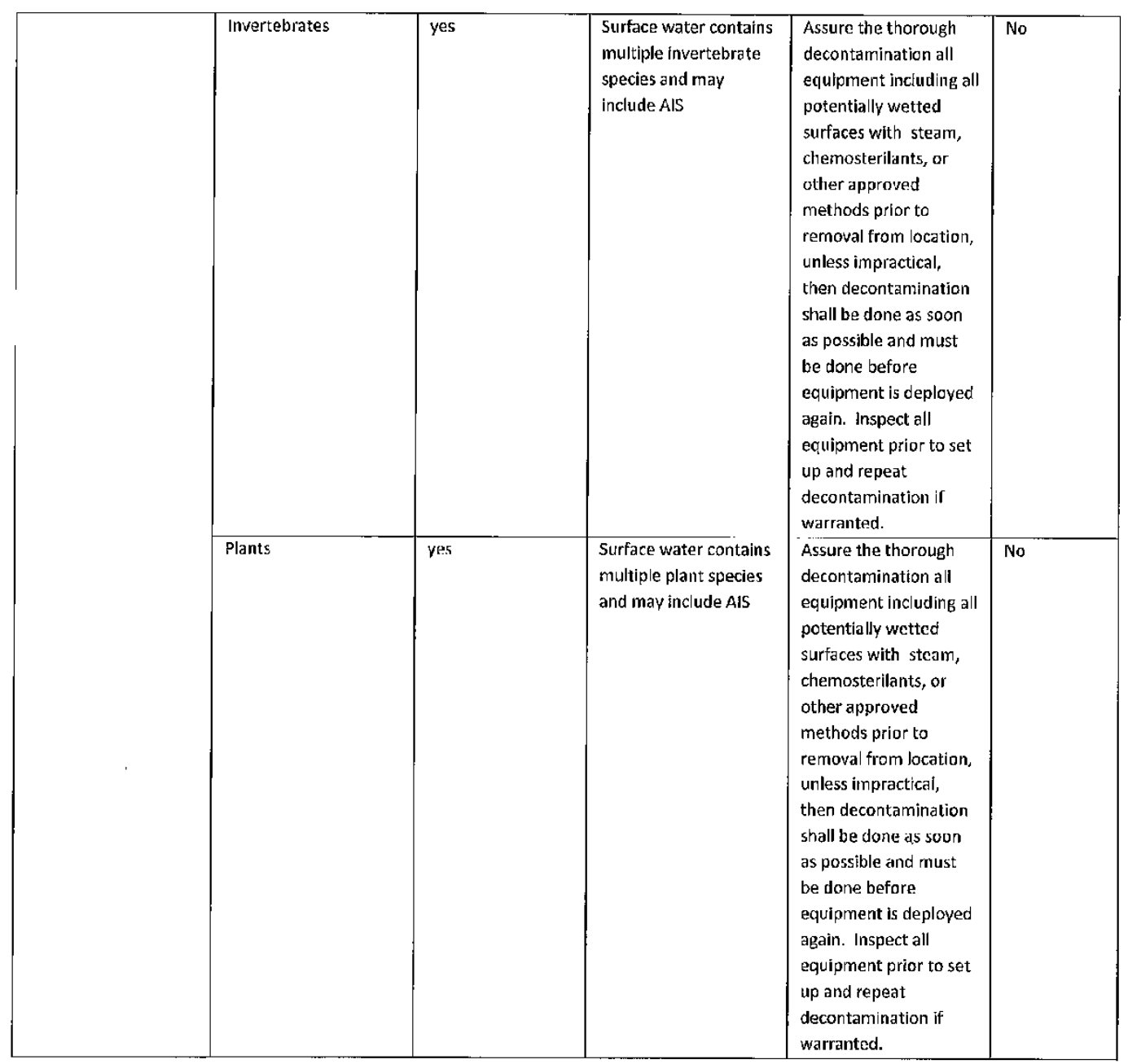

Page $\mathbf{2 5}$ of $\mathbf{3 2}$ 


\begin{tabular}{|l|l|l|l|l|}
\hline & Oes & yes & $\begin{array}{l}\text { Surface water has } \\
\text { potential to transfer } \\
\text { fish cliseases }\end{array}$ & $\begin{array}{l}\text { Assure the thorough } \\
\text { decontamination all } \\
\text { equipment including all } \\
\text { potentially wetted } \\
\text { surfaces with steam, } \\
\text { chemosterilants, or } \\
\text { other approved } \\
\text { methods prior to } \\
\text { removal from location, } \\
\text { unless impractical, } \\
\text { then decontamination } \\
\text { shall be done as soon } \\
\text { as possible and must } \\
\text { be done before } \\
\text { equipment is deployed } \\
\text { again. Inspect all } \\
\text { equipment prior to set } \\
\text { up and repeat } \\
\text { decontamination if } \\
\text { warranted. } \\
\text { and }\end{array}$ \\
\hline
\end{tabular}

\begin{tabular}{|c|c|c|c|c|c|}
\hline \multirow[t]{2}{*}{$\begin{array}{l}\text { Task } 6 \\
\text { Equipment is } \\
\text { decontaminated and } \\
\text { returned to UMESC }\end{array}$} & Vertebrates & yes & $\begin{array}{l}\text { Surface water contains } \\
\text { multiple vertebrate } \\
\text { species }\end{array}$ & $\begin{array}{l}\text { Physical removal of all } \\
\text { visible vertebrates. } \\
\text { Assure the thorough } \\
\text { decontamination all } \\
\text { equipment including all } \\
\text { internal and external } \\
\text { potentially wetted } \\
\text { surfaces with steam, } \\
\text { chemosterilants, or } \\
\text { other approved } \\
\text { methods prior to } \\
\text { removal from location, } \\
\text { unless impractical, } \\
\text { then decontamination } \\
\text { shall be done as soon } \\
\text { as possible and must } \\
\text { be done before } \\
\text { equipment is deployed } \\
\text { again. }\end{array}$ & Yes \\
\hline & Invertebrates & yes & $\begin{array}{l}\text { Surface water contains } \\
\text { multiple invertebrate } \\
\text { species and may } \\
\text { include AlS }\end{array}$ & $\begin{array}{l}\text { Physical removal of all } \\
\text { visible invertebrates. } \\
\text { Assure the thorough } \\
\text { decontamination all } \\
\text { equipment including all } \\
\text { internal and external } \\
\text { potentially wetted } \\
\text { surfaces with steam, } \\
\text { chemosterilants, or } \\
\text { other approved } \\
\text { methods prior to } \\
\text { removal from location, } \\
\text { unless impractical, } \\
\text { then decontamination } \\
\text { shall be done as soon } \\
\text { as possible and must } \\
\text { be done before } \\
\text { equipment is deployed } \\
\text { again. }\end{array}$ & Yes \\
\hline
\end{tabular}

Page $\mathbf{2 6}$ of $\mathbf{3 2}$ 


\begin{tabular}{|c|c|c|c|c|c|}
\hline \multirow[t]{2}{*}{. } & Plants & yes & $\begin{array}{l}\text { Surface water contains } \\
\text { multiple plant species } \\
\text { and may include AlS }\end{array}$ & $\begin{array}{l}\text { Physical removal of all } \\
\text { visibie plants. Assure } \\
\text { the thorough } \\
\text { decontamination all } \\
\text { equipment including all } \\
\text { internal and external } \\
\text { potentially wetted } \\
\text { surfaces with steam, } \\
\text { chemosterilants, or } \\
\text { other approved } \\
\text { methods prior to } \\
\text { removal from location, } \\
\text { unless impractical, } \\
\text { then decontamination } \\
\text { shall be done as soon } \\
\text { as possible and must } \\
\text { be done before } \\
\text { equipment is deployed } \\
\text { again. }\end{array}$ & Yes \\
\hline & Others & yes & $\begin{array}{l}\text { Surface water has } \\
\text { potential to transfer } \\
\text { fish diseases }\end{array}$ & $\begin{array}{l}\text { Assure the thorough } \\
\text { decontamination all } \\
\text { equipment including all } \\
\text { internal and external } \\
\text { potentially wetted } \\
\text { surfaces with steam, } \\
\text { chemosterilants, or } \\
\text { other approved } \\
\text { methods prior to } \\
\text { removal from location, } \\
\text { unless impractical, } \\
\text { then decontamination } \\
\text { shall be done as soon } \\
\text { as possible and must } \\
\text { be done before } \\
\text { equipment is deployed } \\
\text { again. }\end{array}$ & Yes \\
\hline $\begin{array}{l}\text { Task } 7 \\
\text { Mussels are removed } \\
\text { from the holding } \\
\text { cages and assessed for } \\
\text { survival }\end{array}$ & Vertebrates & yes & $\begin{array}{l}\text { Surface water contains } \\
\text { multiple vertebrate } \\
\text { species }\end{array}$ & $\begin{array}{l}\text { Assure the thorough } \\
\text { decontamination all } \\
\text { equipment including all } \\
\text { internal and external } \\
\text { potentially wetted } \\
\text { surfaces with steam, } \\
\text { chemosterilants, or } \\
\text { other approved } \\
\text { methods prior to } \\
\text { removal from location, } \\
\text { unless impractical, } \\
\text { then decontamination } \\
\text { shall be done as soon } \\
\text { as possible and must } \\
\text { be done before } \\
\text { equipment is deployed } \\
\text { again. }\end{array}$ & no \\
\hline
\end{tabular}

Page $\mathbf{2 7}$ of $\mathbf{3 2}$ 


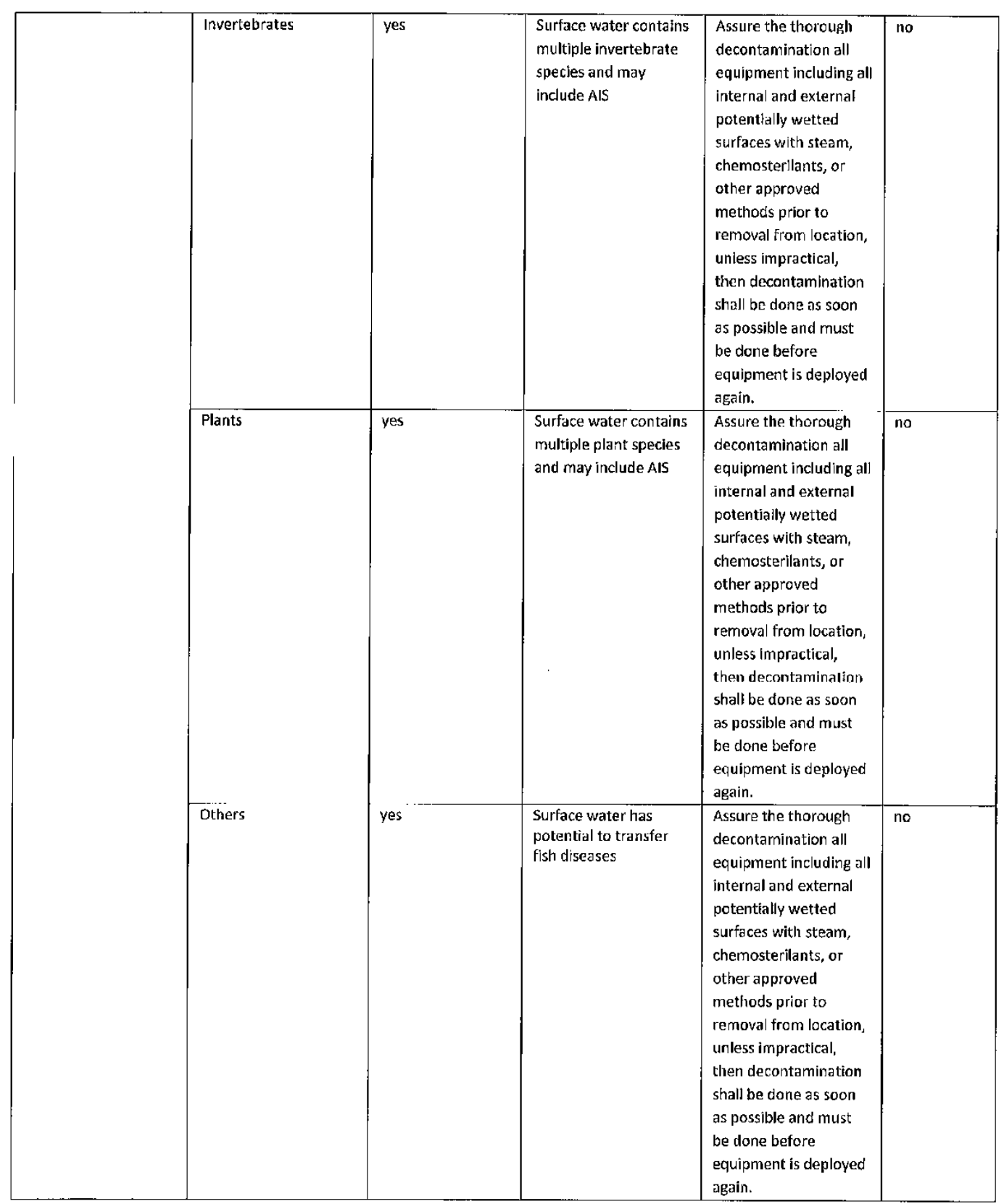

Page 28 of $\mathbf{3 2}$ 
STUDY NO. AEH-13-PSEUDO-06

\begin{tabular}{|c|c|c|c|c|c|}
\hline \multirow[t]{3}{*}{$\begin{array}{l}\text { Task } 8 \\
\text { Samples of mussels } \\
\text { are collected for } \\
\text { histology and the } \\
\text { remaining returned to } \\
\text { the custody of the } \\
\text { Genoa NFH }\end{array}$} & Vertebrates & yes & $\begin{array}{l}\text { Surface water contains. } \\
\text { multiple vertebrate } \\
\text { species }\end{array}$ & $\begin{array}{l}\text { Assure the thorough } \\
\text { decontamination all } \\
\text { equipment including all } \\
\text { internal and external } \\
\text { potentially wetted } \\
\text { surfaces with steam, } \\
\text { chemosterilants, or } \\
\text { other approved } \\
\text { methods prior to } \\
\text { removal from location, } \\
\text { unless Impractical, } \\
\text { then decontamination } \\
\text { shall be done as soon } \\
\text { as possible and must } \\
\text { be done before } \\
\text { equipment is deployed } \\
\text { again. }\end{array}$ & no \\
\hline & Invertebrates & res & $\begin{array}{l}\text { Surface water contains } \\
\text { multiple invertebrate } \\
\text { species and may } \\
\text { include AIS }\end{array}$ & $\begin{array}{l}\text { Assure the thorough } \\
\text { decontamination all } \\
\text { equipment including all } \\
\text { internal and external } \\
\text { potentially wetted } \\
\text { surfaces with steam, } \\
\text { chemosterilants, or } \\
\text { other approved } \\
\text { methods prior to } \\
\text { removal from location, } \\
\text { unless impractical, } \\
\text { then decontamination } \\
\text { shall be done as soon } \\
\text { as possible and must } \\
\text { be done before } \\
\text { equiprnent is deployed } \\
\text { again. }\end{array}$ & no \\
\hline & Plants & yes & $\begin{array}{l}\text { Surface water contains } \\
\text { multiple plant species } \\
\text { and may include AIS }\end{array}$ & $\begin{array}{l}\text { Assure the thorough } \\
\text { decontamination all } \\
\text { equipment including all } \\
\text { internal and external } \\
\text { potentially wetted } \\
\text { surfaces with steam, } \\
\text { chemosterilants, or } \\
\text { other approved } \\
\text { methods prior to } \\
\text { removal from location, } \\
\text { unless impractical, } \\
\text { then decontaminatlon } \\
\text { shall be done as soon } \\
\text { as possible and must } \\
\text { be done before } \\
\text { equipment is deploved } \\
\text { again. }\end{array}$ & no \\
\hline
\end{tabular}

Page 29 of 32 


\begin{tabular}{|c|c|c|c|c|c|}
\hline & Others & yes & $\begin{array}{l}\text { Surface water has } \\
\text { potential to transfer } \\
\text { fish diseases }\end{array}$ & $\begin{array}{l}\text { Assure the thorough } \\
\text { decontamination all } \\
\text { equipment including all } \\
\text { internal and external } \\
\text { potentially wetted } \\
\text { surfaces with steam, } \\
\text { chemosterilants, or } \\
\text { other approved } \\
\text { methods prior to } \\
\text { removal from location, } \\
\text { unless impractical, } \\
\text { then decontamination } \\
\text { shall be done as soon } \\
\text { as possible and must } \\
\text { be done before } \\
\text { equipment is deployed } \\
\text { again. }\end{array}$ & no \\
\hline $\begin{array}{l}\text { Task } 9 \\
\text { All remaining } \\
\text { equipment and cages } \\
\text { are decontaminated } \\
\text { and returned to } \\
\text { UMESC }\end{array}$ & Vertebrates & yes & $\begin{array}{l}\text { Surface water contains } \\
\text { multiplc vertebrate } \\
\text { species }\end{array}$ & $\begin{array}{l}\text { Physical removal of all } \\
\text { visible vertebrates. } \\
\text { Assure the thorough } \\
\text { decontamination all } \\
\text { equipment including all } \\
\text { internal and external } \\
\text { potentially wetted } \\
\text { surfaces with steam, } \\
\text { chemosterilants, or } \\
\text { oiher approved } \\
\text { methods prior to } \\
\text { removal from location, } \\
\text { unless impractical, } \\
\text { then decontamination } \\
\text { shall be done as soon } \\
\text { as possible and must } \\
\text { be done before } \\
\text { equipment is deployed } \\
\text { aga Physical removal or } \\
\text { all visible vertebrates. } \\
\text { Assure the thorough } \\
\text { decontamination all } \\
\text { equipment including all } \\
\text { internal and externa! } \\
\text { potentially wetted } \\
\text { surfaces with steam, } \\
\text { chemosterilants, or } \\
\text { other approved } \\
\text { methods prior to } \\
\text { removal from location, } \\
\text { unless impractical, } \\
\text { then decontamination } \\
\text { shall be done as soon } \\
\text { as possible and must } \\
\text { be done before } \\
\text { equipment is deployed } \\
\text { again. } \\
\end{array}$ & Yes \\
\hline
\end{tabular}

Page 30 of 32 


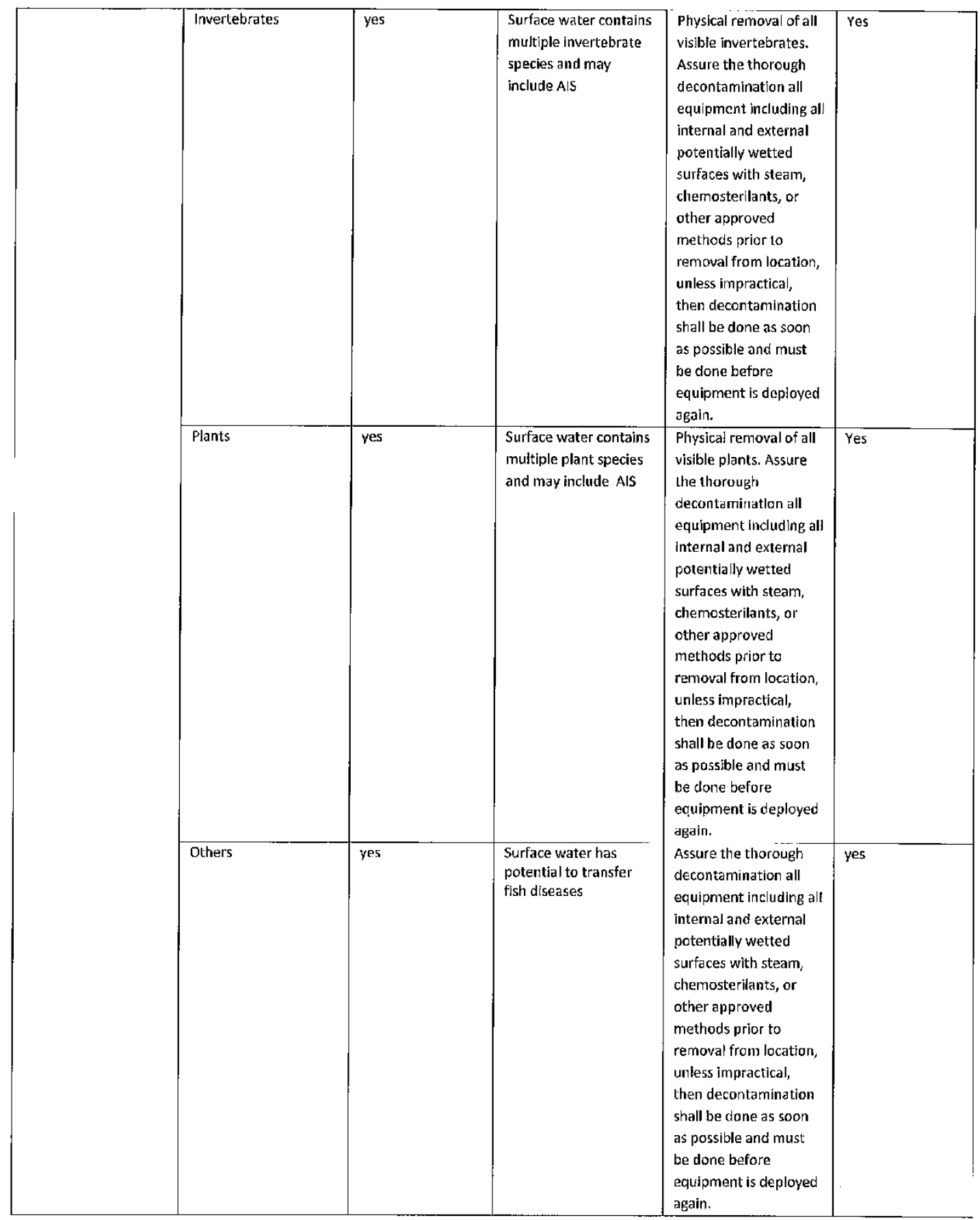

Page 31 of 32 


\begin{tabular}{|c|c|c|c|c|c|c|c|c|}
\hline \multicolumn{9}{|c|}{$\begin{array}{l}\text { HACCP Plan Form } \\
\text { olumn } 6 \text { of HACCP Step } 4-\text { Hazard Analysis Worksheet) }\end{array}$} \\
\hline \multirow[b]{2}{*}{$\begin{array}{l}\text { Critical } \\
\text { Control } \\
\text { Point } \\
\text { (CCP) }\end{array}$} & \multirow[b]{2}{*}{$\begin{array}{l}\text { Signiffcant } \\
\text { Hazard(s) }\end{array}$} & \multirow[b]{2}{*}{$\begin{array}{l}\text { Limits for each } \\
\text { Control Measure }\end{array}$} & \multicolumn{4}{|c|}{ Monitoring } & \multirow[b]{2}{*}{$\begin{array}{l}\text { Evaluation \& } \\
\text { Corrective } \\
\text { Actlon(s) } \\
\text { (if needed) }\end{array}$} & \multirow[b]{2}{*}{$\begin{array}{l}\text { Supporting } \\
\text { Documentation } \\
\quad \text { (if any) }\end{array}$} \\
\hline & & & What & How & Frequency & Who & & \\
\hline $\begin{array}{l}\text { Tasks 1, 2, } \\
3,6,7,8 \& 9\end{array}$ & $\begin{array}{c}\text { Transfer of } \\
\text { endemic and } \\
\text { Als including } \\
\text { vertebrates, } \\
\text { invertebrates, } \\
\text { plants and } \\
\text { pathogens }\end{array}$ & $\begin{array}{l}\text { Transfer of } \\
\text { vertcbrates, } \\
\text { invertebrates, } \\
\text { plants and } \\
\text { pathogens must } \\
\text { not occur. All } \\
\text { equipment must } \\
\text { be thoraughly } \\
\text { inspected and } \\
\text { disinfected as } \\
\text { soon as possible } \\
\text { and inspected } \\
\text { and/or re- } \\
\text { decontaminated } \\
\text { prior to setup at } \\
\text { new location. }\end{array}$ & $\begin{array}{l}\text { Equipment } \\
\text { disinfection }\end{array}$ & \begin{tabular}{|c|} 
Mechanical \\
cleaning/remo \\
val, pressure \\
washing, \\
steam \\
cleaning, \\
chemosterilant \\
or other \\
approved \\
methods.
\end{tabular} & $\begin{array}{c}\text { Prior to } \\
\text { equipment } \\
\text { arrival, upon } \\
\text { deployment, } \\
\text { prior to } \\
\text { movement } \\
\text { from location } \\
\text { or asap }\end{array}$ & $\begin{array}{l}\text { Technicians } \\
\text { /lead field } \\
\text { supervisor }\end{array}$ & $\begin{array}{c}\text { Supervisor and staff } \\
\text { are responsible for } \\
\text { methodical } \\
\text { decontaminatlon using } \\
\text { established } \\
\text { procedures. } \\
\text { corrective actions } \\
\text { required to complete } \\
\text { decontamination must } \\
\text { be performed prior to } \\
\text { any equipment } \\
\text { movement from test } \\
\text { location or as soon as } \\
\text { feasible. } \\
\text { Decontamination and } \\
\text { inspection must be } \\
\text { completed asap }\end{array}$ & $\begin{array}{c}\text { Records in log } \\
\text { books all } \\
\text { procedures used } \\
\text { for } \\
\text { decontainination }\end{array}$ \\
\hline \multicolumn{5}{|c|}{$\begin{array}{l}\text { Facillty: } \\
\text { Upper Midwest Env|ronmental Sciences Center } \\
\text { Mobile Research Laboratory }\end{array}$} & \multicolumn{4}{|c|}{$\begin{array}{l}\text { Activity: } \\
\text { Efficacy of } P \text { seudomonas fluorescens ( } \rho \text { f-CL.145A) SDP for } \\
\text { controlling zebra mussels within fleld exposures }\end{array}$} \\
\hline \multicolumn{5}{|c|}{$\begin{array}{l}\text { Address: } \\
\text { 2630 Fanta Reed Road, La Crosse, WI 5A601 }\end{array}$} & & & & \\
\hline \multicolumn{4}{|l|}{ Signature: } & . & Date: & & & \\
\hline
\end{tabular}

File Folder: 3 


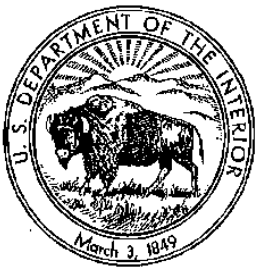

\author{
United States Department of the Interior \\ U.S. GEOLOGICAL SURVEY \\ Biological Resources Division \\ Upper Midwest Environmental Sciences Center \\ 2630 Fanta Reed Road \\ La Crosse, Wisconsin 54603
}

Date: May 13, 2013

To: The Record Study Number AEH-13-PSEUDO-06

Subject: Amendment 1- Amendment to the study number AEH-13-PSEUDO-06 entitled

"Safety of Spray Dried Powder (SDP) Formulated Pseudomonas fluorescens strain CL145A (Zequanox) Exposure to Sub-Adult Unionid Mussels During Simulated Open

Water Treatments"

Revision of Study Protocol, Study \# AEH-13-PSEUDO-06 is proposed as detailed on page 2 of this amendment. Revised text is indicated in bold.

This amendment 1) eliminates the St. Croix River (Stillwater, MN) test location, 2) adds up to 5 additional test animals per test replicate, and 3) adds a 24-h exposure duration to evaluate the effects of an extended duration exposure.

\title{
Reviewed by:
}

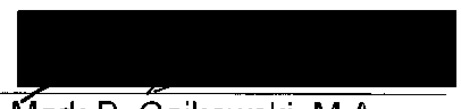

Mark P. Gaikowski, M.A.

Supervisory Biologist

Aquatic Ecosystem Health,

UMESC $^{1}$

\section{$\frac{13 \mathrm{May} / 3}{\text { Date }}$}

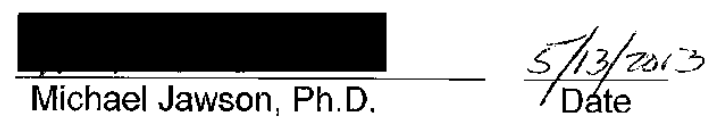

Center Director, UMESC

Approved by:
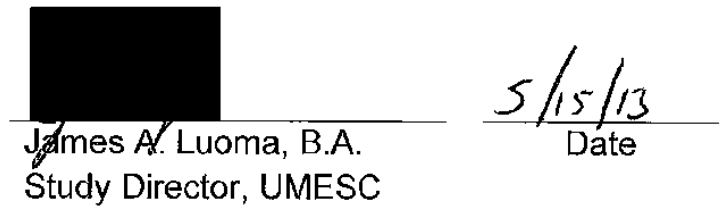

${ }^{1}$ UMESC: U.S. Geological Survey, Upper Midwest Environmental Sciences Center

Study\# AEH-13-PSEUDO-06 Amendment \#1

File Folder:

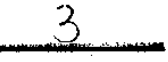

Page 1 of 12

Nem Number: 2 
This amendment eliminates the St. Croix River test location and adds a 24-h exposure duration to evaluate the effects of an extended duration exposure. When possible, up to 45 additional test animals per species will be added to increase the sample size. All species and treatment durations will be exposed concurrently with test animal removal at the prescribed exposure duration.

All changes to the protocol text are listed in bold.

\section{CURRENT TEXT:}

\section{STUDY DESIGN}

4.1 General Description

Up to seven species (Table 2) of sub-adult unionid mussels will be exposed to one of two treatment concentrations of SDP in the UMESC mobile wet laboratory. The wet laboratory will be position stream-side in one of two locations (northern and southern) in the Upper Mississippi River system. The exposures will utilize river water to mimic in situ treatment but allow the capture of treated effluent water for disposal. The mussels will be held in the river for approximately 30-d post exposure prior to evaluation for treatment related effects. Samples will be collected from no less than 1-2 species for histological examination to determine sub-lethal treatment related effects.

Table 2. Unionid mussel species that may be evaluated for formulated Pseudomonas fluorescens strain CL-145A (SDP) exposure effects.

\begin{tabular}{cc}
\hline Common name & Scientific name \\
\hline Fatmucket & Lampsilis siliquoidea \\
Hickorynut & Obovaria olivaria \\
Higgins eye & Lampsilis higginsii \\
Mucket & Actinonaias ligamentina \\
Plain pocketbook & Lampsilis cardium \\
Threeridge & Amblema plicata \\
Wabash Pigtoe & Fusconaia flava \\
Washboard & Megalonaias nervosa \\
\hline
\end{tabular}

\subsection{Experimental Design}

Major study activities are summarized in Figure 1.

To restrict the movement of test animals (sub-adult unionid mussels) within the Upper Mississippi River System, a northern and southern testing location will be utilized and only mussels cultured or collected from the surrounding watershed will be used in the appropriate exposure trial. The testing locations will be the St. Croix River near Stillwater, MN (northern) and the Black River, directly adjacent to the UMESC campus (southern).

The tests will be conducted in the UMESC mobile wet laboratory. The exposures will be conducted in nine $350 \mathrm{~L}$ cylindrical fiberglass tanks and each tank will be 
supplied with a washed sand substrate and flowing $200 \mu \mathrm{m}$ filtered river water ( $\geq$ 1 tank exchange/h). The water flow will be interrupted during the exposure period. The $350 \mathrm{~L}$ fiberglass tanks will be the exposure chamber replicates and they will be the experimental unit.

Sub-adult native mussel test animals will be provided from Genoa National Fish Hatchery propagation stocks or wild collected from the Upper Mississippi River. Individual mussels will be uniquely tagged or marked and assigned to an exposure chamber replicate according to a randomized distribution scheme. Up to 135 native mussels (15 per replicate $\times 9$ replicates) of each species will be randomly placed in each exposure chamber. Up to 4 species will be distributed to each exposure chamber replicate and exposed concurrently. If insufficient numbers of a particular species are available for testing, then the number of animals in each exposure chamber replicate may be reduced (e.g. from 15 to 10 animals) or the $50 \mathrm{mg} / \mathrm{L}$. A.I. treatment group may be excluded for that species. Deviations from the target number of test animals (15) for each exposure chamber replicate/species will be documented in the study records. Native mussels will be subjected to one of three treatments levels, 1) a nonexposed control group, 2) a $50 \mathrm{mg} / \mathrm{L}$ A.I. treatment group, and 3) a $100 \mathrm{mg} / \mathrm{L} \mathrm{A.I.}$ treatment group. There will be 3 replicates exposure chambers per treatment levels. Treatment level will be assigned to each replicate according to a randomized assignment scheme.

An appropriate amount of a freshly prepared SDP stock solution will be added and thoroughly mixed into the water within each exposure chamber replicate. The SDP concentration, temperature, dissolved oxygen, $\mathrm{pH}$ and conductivity will be monitored in each exposure chamber replicate.

Immediately following the 8-h exposure period, the SDP treated water will be drained from the exposure chambers, the exposure chambers will be rinsed with and refilled with clean river water. The SDP treated water and rinsate will be collected in frame tanks for disposal. Water flow will be restored to the exposure chambers until the mussels are transferred to wire mesh holding cages $(\sim 0.9 \mathrm{~m}$ long $\times 0.6 \mathrm{~m}$ wide $\times 0.45 \mathrm{~m}$ high; either $1.27-\mathrm{cm}$ or $0.635-\mathrm{cm}$, dependent on animal size) for a post-exposure evaluation phase. The holding cages containing mussels and a washed sand substrate will be placed in the river for approximately 30-d post exposure prior to evaluating the mussels for treatment related mortality. Representative treatment level sample specimens will be collected during the mortality assessment from at least $1-2$ species. The samples will be subjected to histological examination to determine sub-lethal treatment related effects as permitted by funding.

\section{STUDY PROCEDURES}

\subsection{Test Animals}

\subsubsection{Description}
5.1.1.1 Age - Native mussels $\leq 3$ yrs
5.1.1.2 Sex - Test animals will be used without regard to sex.
5.1.1.3 Species -see table 2 
Figure 1. Flow chart of major study activities for each test location

Set up mobile laboratory and water systems, collect, consolidate, tag and measure subraduit unionid test animals.

Randomly distribute test animals to the exposure chamber replicales (15 per species per replicate $\times 9$

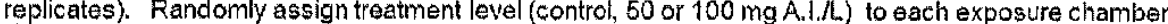
replicate. Perform pre-exposure water quality (temperature, dissolved oxygen, $\mathrm{pH}$, conductivity, hardness and alkalinity).

Initiate SDP exposures (8-h duration, static) $\geq 12$-h after test animal placement in exposure chambers. Monitor SDP concentration, temperature, dissolved oxygen, $\mathrm{pH}$ and conductivity in each exposure chamber replicate.

Drain, rinse, refill and resiore water flow to each exposure chamber replicate at the termination of the treatment period. Treated water and rinsate will be collected for disposal.

Place holding cages containing mussels in the river for approximately $30-d$ post exposure then evaluate the mussels for treatment related mortality. Collect treatment level sample specimens from 1-2 species for histological examination to determine sub-lethal treatment related effects.

Decontaminated all equipment prior to removal from the test site

5.1.2 Number of animals: Approximately 135 native mussels of each species will be used (9 replicates $\times 15$ mussels each $=135$ ). If 135 mussels are not available, the number of animals in each replicate may be reduced to 10 and/or the species may be excluded from the low treatment level $(50 \mathrm{mg} / \mathrm{L}$ A.I.). The number of test animals planned is consistent with the objective of the study and contemporary scientific standards.

5.1.3 Source of animals: Test animals will be provided from Genoa National Fish Hatchery production stocks or wild collected animals from the Upper Mississippi River. Collection of animals will be conducted by Genoa National Fish Hatchery mussel biologists.

5.1.4 Inclusion criterion: Native mussels in apparent good health will be used.

5.1.5 Acclimation: Mussels will be acclimated to treatment conditions for $\geq 12-\mathrm{h}$ prior to exposure initiation.

5.1.6 Distribution to treatment replicates: Up to 15 uniquely identified and measured mussels will be distributed to each exposure replicate according to a predetermined randomization scheme. Five mussels will be placed in each exposure replicate in each distribution round. Three distribution rounds will be completed for each species.

5.1.7 Feeding: No supplemental feed will be offered throughout the acclimation, exposure and post-exposure holding periods.

\subsection{Water Chemistry}

5.2.1 Dissolved oxygen: Dissolved oxygen will be measured and recorded in 
each exposure chamber replicate during the acclimation, exposure and post-exposure holding periods. Dissolved oxygen will be measured and recorded at least once during the pre- and post-exposure periods and at least twice during the exposure period with the last measurement observed $\leq 30$ minutes prior to exposure termination (UMESC SOP AEH 394 or equivalent).

5.2.2 Temperature: Temperature will be measured and recorded in each exposure chamber replicate during the acclimation, exposure and postexposure holding periods. Temperature will be measured and recorded at least once during the pre- and post-exposure periods and at least twice during the exposure period with the last measurement observed $\leq 30$ minutes prior to exposure termination.

5.2.3 pH: pH will be measured and recorded in each exposure chamber replicate during the acclimation, exposure and post-exposure holding periods. pH will be measured and recorded at least once during the preand post-exposure periods and at least twice during the exposure with the last measurement observed $\leq 30$ minutes prior to exposure termination (UMESC SOP AEH 335 or equivalent).

5.2.4 Hardness: Hardness will be measured and recorded prior to exposure initiation on the filtered water supply (UMESC SOP AEH 712).

5.2.5 Alkalinity: Alkalinity will be measured and recorded prior to exposure initiation on the filtered water supply (UMESC SOP AEH 706).

5.2.6 Conductivity: Conductivity will be measured and recorded prior to exposure initiation on the filtered water supply (UMESC SOP AEH 188 or equivalent).

5.2.7 Ammonia: Samples for total ammonia-nitrogen will be collected at the termination of the exposure period for each exposure replicate. Ammonia samples will be filtered through a 0.45 micron syringe filter, acidified $(\sim \mathrm{pH} 2.5)$ with sulfuric acid and then stored at $\sim 4^{\circ} \mathrm{C}$ until analyzed by the UMESC Long Term Resources Monitoring (LTRM) Water Quality Laboratory using the automated phenate method.

5.3 Disposal: All live mussels at the conclusion of the mortality assessment that are not subjected to histological examination will be returned to the custody of the Genoa NFH.

5.4 Study facilities

5.4.1 Test Facility

U.S. Geological Survey, Upper Midwest Environmental Sciences Center

Mobile Research Laboratory

2630 Fanta Reed Rd

La Crosse, Wisconsin 54603

5.4.1.1 Test location: Black River; La Crosse, Wl; and St. Croix River; Stillwater, MN. 
5.4.1.2 Exposure system: The test system consists of nine $76.2 \mathrm{~cm}$ diameter $x$ $91.4 \mathrm{~cm}$ deep fiberglass circular exposure tanks in two rows of 4 or 5 tanks. The tanks are supplied surface water through a pump, filter and headbox system. Each exposure tank will be supplied $3-5 \mathrm{~cm}$ of wash sand for substrate and flowing $200 \mu \mathrm{m}$ filtered river water $(\geq 1$ tank exchange/h). The water flow will be interrupted during the exposure period. Each tank will be uniquely identified to allow for identification treatment type and replicate number. Coding procedures will be documented in the study records.

5.4.1.3 Aeration: Supplemental aeration will not be supplied during the acclimation, SDP exposures and the post exposure observation periods.

5.4.1.4 Water supply: Filtered $(200 \mu \mathrm{m})$ river water will be supplied continuously $(\sim 5 \mathrm{~L} / \mathrm{min})$ to achieve a $\sim$ tank-volume exchange/h during the pre- and post-exposure periods. Water supply will be interrupted during the SDP exposures.

5.4.1.5 Water discharge: Untreated water will be returned to the water supply source. SDP treated water will be collected for disposal as required by DNR regulation.

5.4.1.6 Lighting: Overhead lighting will be provided during the exposure period. Light intensity will be measured using a Milwaukee photometer (AEH SOP 308 or equivalent) and recorded in the study records.

\subsection{Observations}

\subsubsection{Mortality:}

Unionid mussels that are gapping and do not respond to tactile stimuli by shell closure will be coded as a mortality. Unionid mussels that have closed shells (closed shells will be gently pried to assure that the anterior adductor muscle contraction is holding the shell closed) or respond to tactile stimuli by shell closure will be coded as alive.

\subsection{Treatment administration}

5.6.1 Treatment: Each treatment will consist of three SDP concentrations (ie: 0 [control], $50 \mathrm{mg} / \mathrm{L}$ A.I. or $100 \mathrm{mg} / \mathrm{L}$ A.I.) with a single 8-h exposure duration. All treatment concentrations will have three replicate exposure chambers. A minimum of 10 and a maximum of 15 unionid mussels of each species will be placed in each exposure chamber replicate. Up to $\mathbf{4}$ species will be used in each treatment.

5.6.2 Route of administration: Exposures will be initiated by addition of an appropriate amount of a SDP stock solution. The tank will be gently mixed to achieve a uniform distribution of test material.

5.6.3 Concentration verification: Concentration will be determined spectrophotometrically. A standard curve will be prepared using a known mass of SDP. The absorbance of exposure solutions will be compared to the 
standard curve to determine the exposure concentration. Absorbance will be determined using a Barnstead/Thermolyne Corporation Model: Turner SP-830 Plus Beckman spectrophotometer (UMESC SOP AEH 302).

\section{DATA ANALYSIS}

6.1 Experimental unit: The experimental unit will be the exposure chamber replicate.

6.2 Number of exposures and replicates: There will be a total of 3 treatment levels ( 0 [control], 50 and $100 \mathrm{mg} \mathrm{SDP/L}$ ) and 1 treatment duration (8-h). There will be a total of 3 independent exposures chambers for each treatment level which will serve as the replicates. All treatment levels, replicates, and up to 4 species will be run concurrently.

\section{REVISED TEXT:}

\section{STUDY DESIGN}

4.1 General Description

Up to seven species (Table 2) of sub-adult unionid mussels will be exposed to one of two treatment concentrations of SDP in the UMESC mobile wet laboratory. The wet laboratory will be position stream-side along the Black River, adjacent to UMESC property. The exposures will utilize river water to mimic in situ treatment but allow the capture of treated effluent water for disposal. The mussels will be held in the river for approximately 30-d post exposure prior to evaluation for treatment related effects. Samples will be collected from no less than 1-2 species for histological examination to determine sub-lethal treatment related effects.

Table 2. Unionid mussel species that may be evaluated for formulated Pseudomonas fluorescens strain CL-145A (SDP) exposure effects.

\begin{tabular}{cc}
\hline Common name & Scientific name \\
\hline Fatmucket & Lampsilis siliquoidea \\
Hickorynut & Obovaria olivaria \\
Higgins eye & Lampsilis higginsii \\
Mucket & Actinonaias ligamentina \\
Plain pocketbook & Lampsilis cardium \\
Threeridge & Amblema plicata \\
Wabash Pigtoe & Fusconaia flava \\
Washboard & Megalonaias nervosa \\
\hline
\end{tabular}

\subsection{Experimental Design}

Major study activities are summarized in Figure 1.

Animals reared in the St. Croix River will be collected from propagation cages by Genoa NFH personnel and temporarily held at the Genoa NFH prior to testing. Only mussels cultured or collected from the Upper Mississippi River system will be used in the exposure trial. The testing 
location will be the Black River, directly adjacent to the UMESC campus. The tests will be conducted in the UMESC mobile wet laboratory. The exposures will be conducted in nine $350 \mathrm{~L}$ cylindrical fiberglass tanks and each tank will be supplied with a washed sand substrate and flowing $200 \mu \mathrm{m}$ filtered river water ( $\geq 1$ tank exchange/h). The water flow will be interrupted during the exposure period. The $350 \mathrm{~L}$ fiberglass tanks will be the exposure chamber replicates and they will be the experimental unit.

Sub-adult native mussel test animals will be provided from Genoa National Fish Hatchery propagation stocks or wild collected from the Upper Mississippi River. Individual mussels will be uniquely tagged or marked and assigned to an exposure chamber replicate according to a randomized distribution scheme. Up to $\mathbf{1 8 0}$ native mussels (20 per replicate $x \mathbf{9}$ replicates) of each species will be randomly placed in each exposure chamber. Up to 7 species will be distributed to each exposure chamber replicate and exposed concurrently. If insufficient numbers of a particular species are available for testing, then the number of animals in each exposure chamber replicate and duration may be reduced (e.g. from 10 to 5 animals) or the $50 \mathrm{mg} / \mathrm{L} \mathrm{A.l.} \mathrm{treatment} \mathrm{group} \mathrm{or} \mathrm{24-h}$ exposure duration may be excluded for that species. Deviations from the target number of test animals for each exposure chamber replicate/species (ie: $\mathbf{N}=20$ ) will be documented in the study records.

Native mussels will be subjected to one of three treatments levels, 1) a nonexposed control group, 2) a $50 \mathrm{mg} / \mathrm{L}$ A.I. treatment group, and 3) a $100 \mathrm{mg} / \mathrm{L}$ A.I. treatment group.

Additionally, each treatment level replicate will include an 8-h exposure and 24-h exposure duration. There will be 3 replicates exposure chambers per treatment levels. Treatment level will be assigned to each replicate according to a randomized assignment scheme. An appropriate amount of a freshly prepared SDP stock solution will be added and thoroughly mixed into the water within each exposure chamber replicate. The SDP concentration, temperature, dissolved oxygen, $\mathrm{pH}$ and conductivity will be monitored in each exposure chamber replicate.

Following the 8-h and 24-h exposure periods a basket containing a predetermined number of mussels (i.e: 10 per species, depending on availability) will be removed and transferred to wire mesh holding cages $(\sim 0.9 \mathrm{~m}$ long $\times 0.6 \mathrm{~m}$ wide $\times 0.45 \mathrm{~m}$ high; either $1.27-\mathrm{cm}$ or $0.635-\mathrm{cm}$, dependent on animal size) for a post-exposure evaluation phase.

The holding cages containing mussels and a washed sand substrate will be placed in the river for approximately 30 -d post exposure prior to evaluating the mussels for treatment related mortality. Representative treatment level sample specimens will be collected during the mortality assessment from at least 1-2 species. The samples will be subjected to histological examination to determine sub-lethal treatment related effects as permitted by funding. 
Figure 1. Flow chart of major study activities for each test location

Set up mobile laboratory and water systems, collect, consolidate, tag and measure sub-adult unionid test animals.

Randomly distribule test animals to the exposure chamber replicates (20 per species per replicate $\times 9$ replicates). Randomly assign treatment level (control, 50 or $100 \mathrm{mg}$ A.I.L) to each exposure chamber replicate. Perform pre-exposure water quality (temperature, dissolved oxygen, $\mathrm{pH}$, conductivity, hardness and alkalinity).

Initiate SDP exposures (8-h and 24-h duration, static) $\geq 12-h$ after test animal placement in exposure chambers, Monitor SDP concentration, temperature, dissolved oxygen, $\mathrm{pH}$ and conductivity in each exposure chamber replicate.

Remove test animals from each treatment replicate al the termination of each treatment period. Treated water and rinsate wili be collected for disposal

Place halding cages containing mussels in the river for approximately $30-d$ post exposure then evaluate the mussels for treatment related mortality. Collect treatment level sample specimens from $1-2$ species for histological oxamination to cletermine sub-lethal treatment related effects.

\section{STUDY PROCEDURES}

\subsection{Test Animals}

\subsubsection{Description}

5.1.1.1 Age - Native mussels $\leq 3$ yrs

5.1.1.2 Sex - Test animals will be used without regard to sex.

\subsubsection{Species - see table 2}

5.1.2 Number of animals: Up to $\mathbf{1 8 0}$ native mussels of each species will be used (9 replicates $\times \mathbf{2 0}$ mussels each $=\mathbf{1 8 0}$ ). If $\mathbf{1 8 0}$ mussels are not available, the number of animals in each replicate may be reduced to 5 and/or the species may be excluded from the low treatment level $(50 \mathrm{mg} / \mathrm{L} \mathrm{A.I.})$ or the extended treatment duration. The number of test animals planned is consistent with the objective of the study and contemporary scientific standards.

5.1.3 Source of animals: Test animals will be provided from Genoa National Fish Hatchery production stocks or wild collected animals from the Upper Mississippi River. Collection of animals will be conducted by Genoa National Fish Hatchery mussel biologists.

5.1.4 Inclusion criterion: Native mussels in apparent good health will be used.

5.1.5 Acclimation: Mussels will be acclimated to treatment conditions for $\geq 12-h$ prior to exposure initiation.

5.1.6 Distribution to treatment replicates: Up to $\mathbf{2 0}$ uniquely identified and 
measured mussels will be distributed to each exposure replicate according to a predetermined randomization scheme. Five mussels will be placed in each exposure replicate in each distribution round. Up to four distribution rounds will be completed for each species.

5.1.7 Feeding: No supplemental feed will be offered throughout the acclimation, exposure and post-exposure holding periods.

\subsection{Water Chemistry}

5.2.1 Dissolved oxygen: Dissolved oxygen will be measured and recorded in each exposure chamber replicate during the acclimation, exposure and post-exposure holding periods. Dissolved oxygen will be measured and recorded at least once during the pre- and post-exposure periods and at least twice during the exposure period with the last measurement observed $\leq 30$ minutes prior to exposure termination (UMESC SOP AEH 394 or equivalent).

5.2.2 Temperature: Temperature will be measured and recorded in each exposure chamber replicate during the acclimation, exposure and postexposure holding periods. Temperature will be measured and recorded at least once during the pre- and post-exposure periods and at least twice during the exposure period with the last measurement observed $\leq 30$ minutes prior to exposure termination.

5.2.3 $\mathrm{pH}: \mathrm{pH}$ will be measured and recorded in each exposure chamber replicate during the acclimation, exposure and post-exposure holding periods. $\mathrm{pH}$ will be measured and recorded at least once during the preand post-exposure periods and at least twice during the exposure with the last measurement observed $\leq 30$ minutes prior to exposure termination (UMESC SOP AEH 335 or equivalent).

5.2.4 Hardness: Hardness will be measured and recorded prior to exposure initiation on the filtered water supply (UMESC SOP AEH 712).

5.2.5 Alkalinity: Alkalinity will be measured and recorded prior to exposure initiation on the filtered water supply (UMESC SOP AEH 706).

5.2.6 Conductivity: Conductivity will be measured and recorded prior to exposure initiation on the filtered water supply (UMESC SOP AEH 188 or equivalent).

5.2.7 Ammonia: Samples for total ammonia-nitrogen will be collected at the termination of each exposure period for each exposure replicate. Ammonia samples will be filtered through a 0.45 micron syringe filter, acidified ( $\sim \mathrm{pH} 2.5)$ with sulfuric acid and then stored at $\sim 4^{\circ} \mathrm{C}$ until analyzed by the UMESC Long Term Resources Monitoring (LTRM) Water Quality Laboratory using the automated phenate method.

5.3 Disposal: All live mussels at the conclusion of the mortality assessment that are not subjected to histological examination will be returned to the custody of the Genoa $\mathrm{NFH}$.

5.4 Study facilities 
5.4.1 Test Facility

U.S. Geological Survey, Upper Midwest Environmental Sciences Center

Mobile Research Laboratory

2630 Fanta Reed Rd

La Crosse, Wisconsin 54603

\subsubsection{Test location: Black River; La Crosse, WI}

5.4.1.2 Exposure system: The test system consists of nine $76.2 \mathrm{~cm}$ diameter $x$ $91.4 \mathrm{~cm}$ deep fiberglass circular exposure tanks in two rows of 4 or 5 tanks. The tanks are supplied surface water through a pump, filter and headbox system. Each exposure tank will be supplied 3-5 cm of wash sand for substrate and flowing $200 \mu \mathrm{m}$ filtered river water ( $\geq 1$ tank exchange/h). The water flow will be interrupted during the exposure period. Each tank will be uniquely identified to allow for identification treatment type and replicate number. Coding procedures will be documented in the study records.

5.4.1.3 Aeration: Supplemental aeration will not be supplied during the acclimation, SDP exposures and the post exposure observation periods.

5.4.1.4 Water supply: Filtered $(200 \mu \mathrm{m})$ river water will be supplied continuously ( $\sim 5 \mathrm{~L} / \mathrm{min}$ ) to achieve $\mathrm{a} \sim$ tank-volume exchange/h during the pre- and post-exposure periods. Water supply will be interrupted during the SDP exposures.

5.4.1.5 Water discharge: Untreated water will be returned to the water supply source. SDP treated water will be collected for disposal as required by DNR regulation.

5.4.1.6 Lighting: Overhead lighting will be provided during the exposure period. Light intensity will be measured using a Milwaukee photometer (AEH SOP 308 or equivalent) and recorded in the study records.

5.5 Observations

5.5.1 Mortality:

Unionid mussels that are gapping and do not respond to tactile stimuli by shell closure will be coded as a mortality. Unionid mussels that have closed shells (closed shells will be gently pried to assure that the anterior adductor muscle contraction is holding the shell closed) or respond to tactile stimuli by shell closure will be coded as alive.

5.6 Treatment administration

5.6.1 Treatment: Each treatment will consist of three SDP concentrations (ie: 0 [control], $50 \mathrm{mg} / \mathrm{L}$ A.I. or $100 \mathrm{mg} / \mathrm{L}$ A.I.) with exposure durations of $8-\mathrm{h}$ and 24-h. All treatment concentrations and durations will have three replicate exposure chambers. A minimum of 3 and a maximum of 10 unionid mussels of each species will be placed in each exposure chamber 
replicate for each exposure duration. Up to 7 species will be used in each treatment.

5.6.2 Route of administration: Exposures will be initiated by addition of an appropriate amount of a SDP stock solution. The tank will be gently mixed to achieve a uniform distribution of test material.

5.6.3 Concentration verification: Concentration will be determined spectrophotometrically. A standard curve will be prepared using a known mass of SDP. The absorbance of exposure solutions will be compared to the standard curve to determine the exposure concentration. Absorbance will be determined using a Barnstead/Thermolyne Corporation Model: Turner SP-830 Plus Beckman spectrophotometer (UMESC SOP AEH 302).

\section{DATA ANALYSIS}

6.1 Experimental unit: The experimental unit will be the exposure chamber replicate.

6.2 Number of exposures and replicates: There will be a total of 3 treatment levels ( 0 [control], 50 and $100 \mathrm{mg} \mathrm{SDP/L)}$ and 2 treatment duration (8-h and 24-h). There will be a total of 3 independent exposures chambers for each treatment level/exposure duration which will serve as the replicates. All treatment levels, replicates, exposure durations and up to 7 species will be run concurrently.

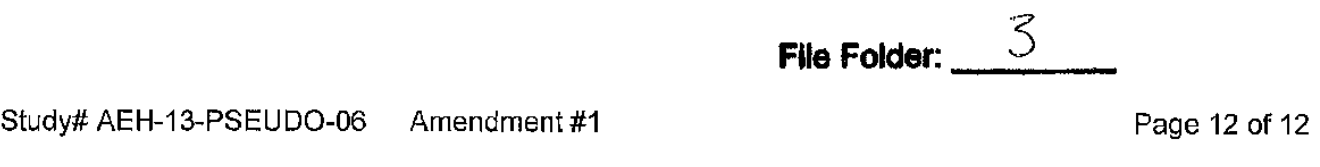

Nem Number: 2 
Study Number: AEH-13-PSEUDO-06

File Folder:

Lab book/pgs:

Reviewed by:

Verified by:

Date:

Date:

\section{Test Chemical Stock Preparation}

Test Chemical: Pseudomonas fluroescens strain 145A

Test Chemical Lot \#: 401P12163C and 401P12164C Mix Date Rec'd: 7-AUG-12 Exp. Date: 21-JUN-12 Test Location: Instruments Used

Weights of Chemical Samples:

\begin{tabular}{|c|c|c|c|c|}
\hline Sample ID & Sample Weight & Comments & Date & Initials \\
\hline & & & & \\
\hline & & & & \\
\hline & & & & \\
\hline & & & & \\
\hline & & & & \\
\hline & & & & \\
\hline & & & & \\
\hline & & & & \\
\hline & & & & \\
\hline & & & & \\
\hline
\end{tabular}

NOTE: Chemical samples to be stored refrigerated until used for stock preparation.

Stock Solution Preparation:

\begin{tabular}{|c|c|c|c|c|c|c|}
\hline Sample ID & $\begin{array}{c}\text { Dilution } \\
\text { Volume (mL) }\end{array}$ & $\begin{array}{c}\text { Dilution } \\
\text { Time }\end{array}$ & Use & $\begin{array}{c}\text { Exposure } \\
\text { Time }\end{array}$ & Date & Inltials \\
\hline & & & & & & \\
\hline & & & & & & \\
\hline & & & & & & \\
\hline & & & & & & \\
\hline & & & & & & \\
\hline & & & & & & \\
\hline & & & & & & \\
\hline & & & & & & \\
\hline & & & & & & \\
\hline
\end{tabular}

Item Number:

File Folder: 16

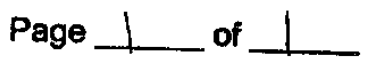




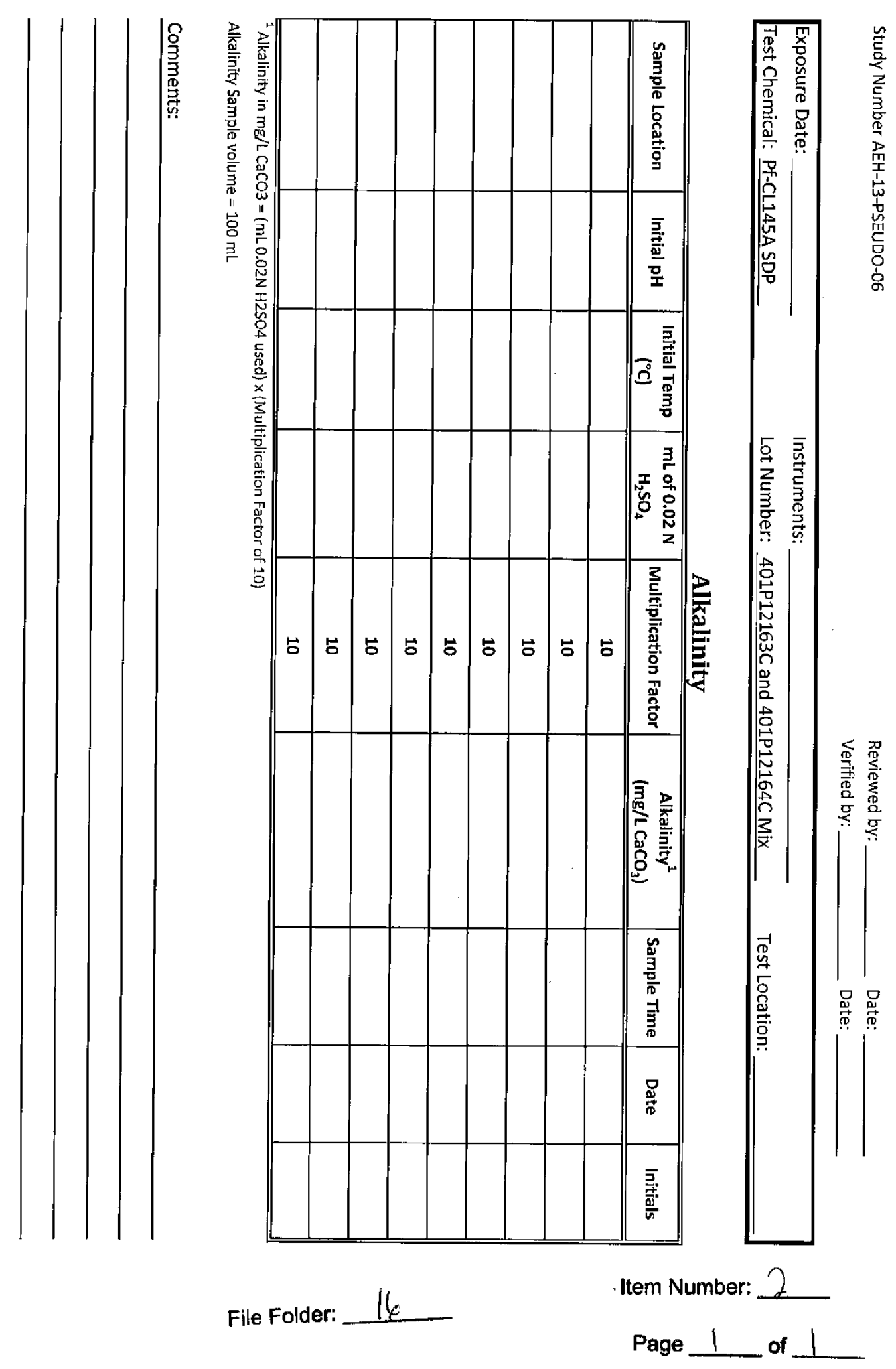




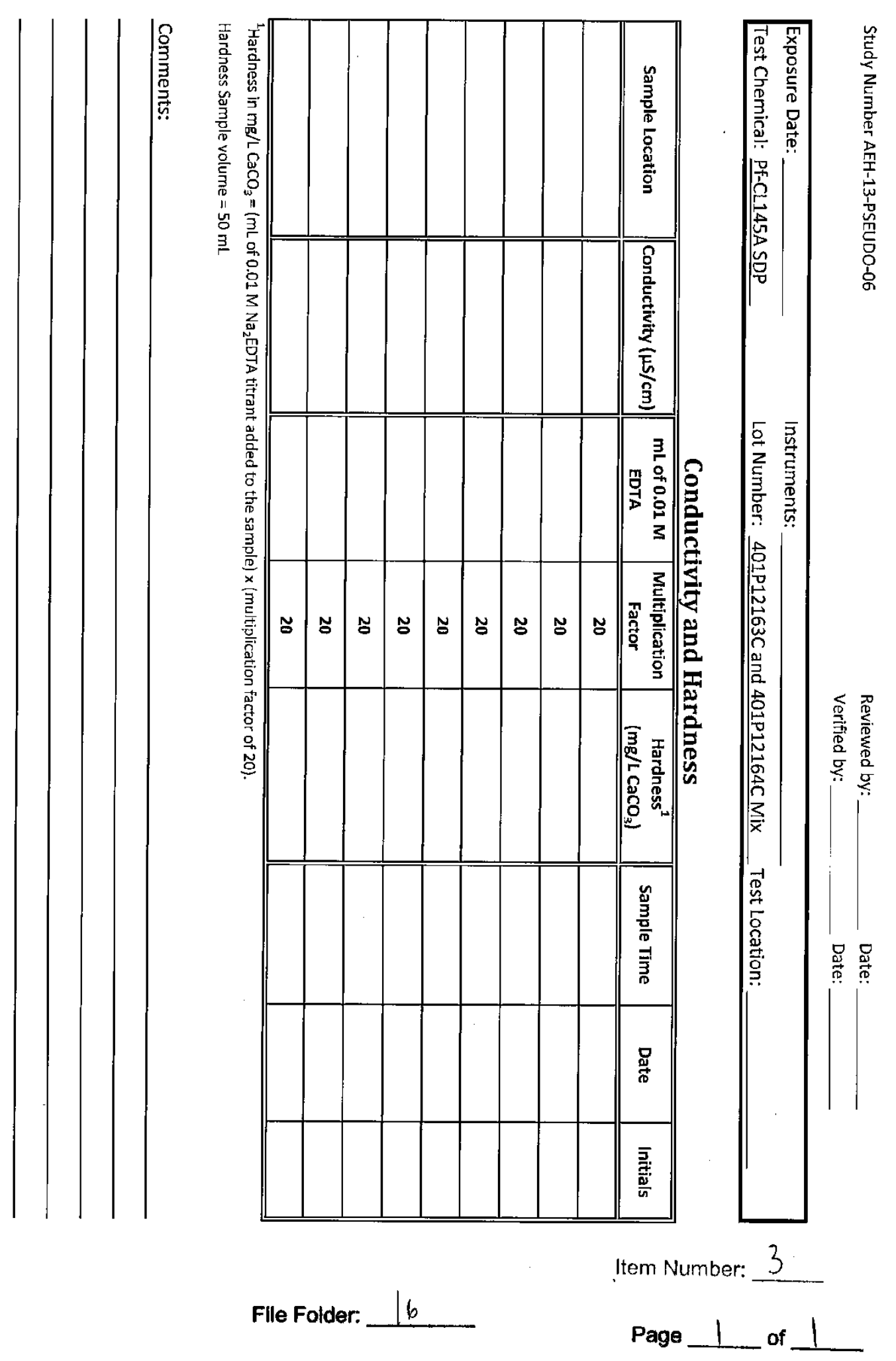


Study Number: AEH-13-PSEUDO-06

File Folder:

Lab book/ogs:
Reviewed by:

Verified by:

Date:

Date:

\section{Water Quality}

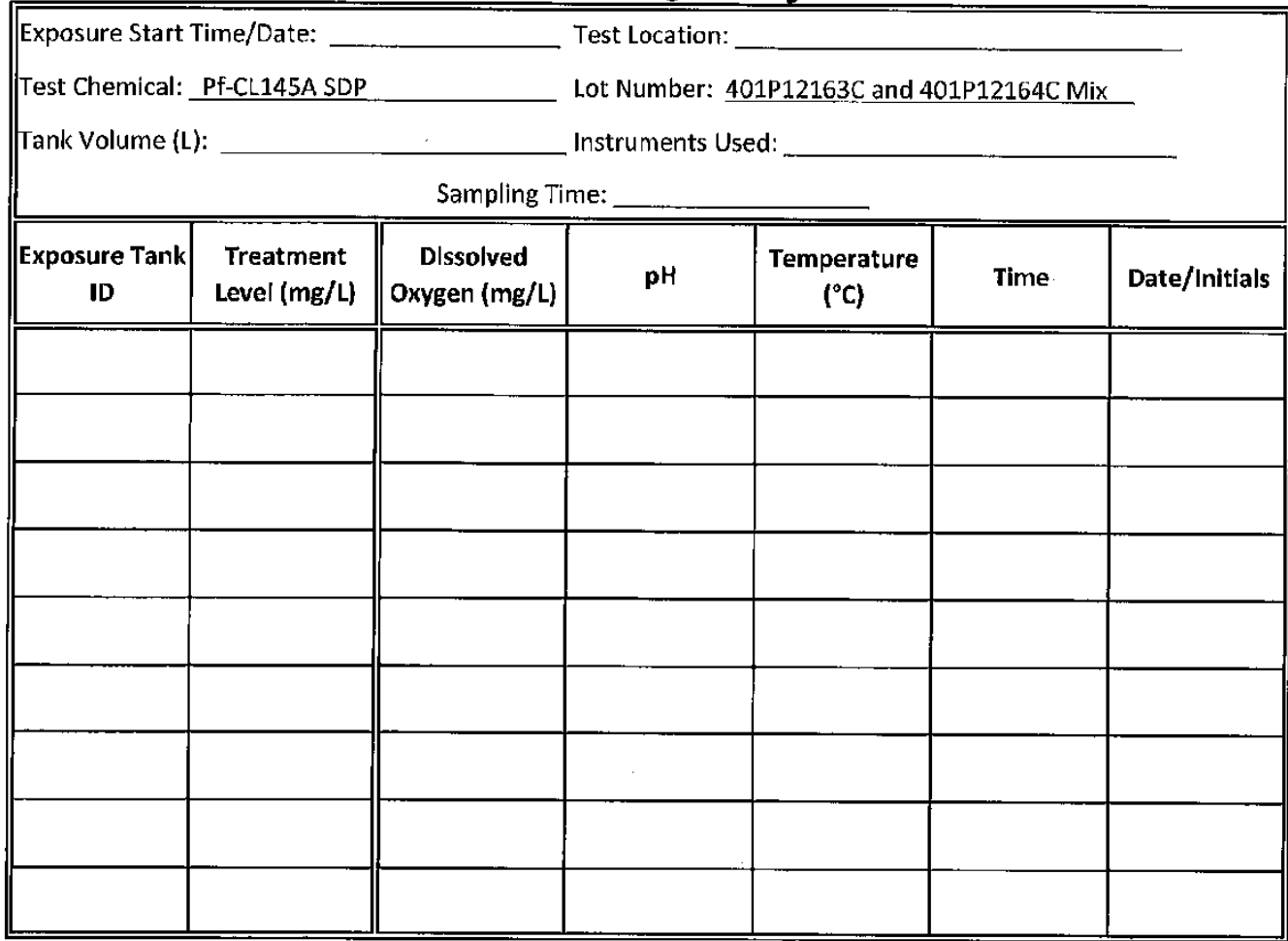

\begin{tabular}{|c|c|c|}
\hline $\begin{array}{c}\text { Light } \\
\text { Measurement }\end{array}$ & $\begin{array}{c}\text { Measurement } \\
\text { Location }\end{array}$ & Date/Initials \\
\hline & & \\
\hline
\end{tabular}

Comments:

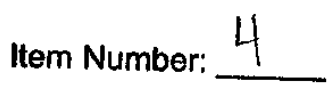

File Folder: 16

Page $\_$of 1 
Study Number: AEH-13-PSEUDO-06

File Folder:

Lab book/pgs:
Reviewed by:

verified by:
Date:

Date:

\section{Mussel Histology Samples}

\begin{tabular}{|c|c|c|c|c|c|c|c|c|}
\hline $\begin{array}{l}\text { Exposure Sta } \\
\text { Test Chemica }\end{array}$ & $\begin{array}{l}\text { t Time/Date } \\
: \text { Pf-CLI45 }\end{array}$ & SDP & & & $\begin{array}{l}\text { Test Locati } \\
\text { Lot Numbe }\end{array}$ & $401 \mathrm{P} 12163 \mathrm{C}$ & $401 P 1$ & CMix \\
\hline $\begin{array}{c}\text { Container } \\
\text { Number }\end{array}$ & $\begin{array}{c}\text { Exposure } \\
\text { Tank }\end{array}$ & $\begin{array}{c}\text { Treatment } \\
\text { Level }(\mathrm{mg} / \mathrm{L})\end{array}$ & $\begin{array}{c}\text { Sampling } \\
\text { Time }\end{array}$ & $\begin{array}{l}\text { Mussel } \\
\text { Species }\end{array}$ & Tag ID & $\begin{array}{c}\text { Number of } \\
\text { Cassettes }\end{array}$ & Date & Initials \\
\hline & & & & & & & & \\
\hline & & & & & & & & \\
\hline & & & & & & & & \\
\hline & & & & & & & & \\
\hline & & & & & & & & \\
\hline & & & & & & & & \\
\hline & & & & & & & & \\
\hline & & & & & & & & \\
\hline & & & & & & & & \\
\hline & & & & & & & & \\
\hline & & & & & & & & \\
\hline & & & & & & & & \\
\hline & & & & & & & & \\
\hline & & & & & & & & \\
\hline & & & & & & & & \\
\hline & & & & & & & & \\
\hline & & & & & & & & \\
\hline & & & & & & & & \\
\hline & & & & & & & & \\
\hline & & & & & & & & \\
\hline & & & & & & & & \\
\hline & & & & & & & & \\
\hline
\end{tabular}

Comments:

File Folder: 16

Item Number: $\underline{6}$

Page 1 of 1 


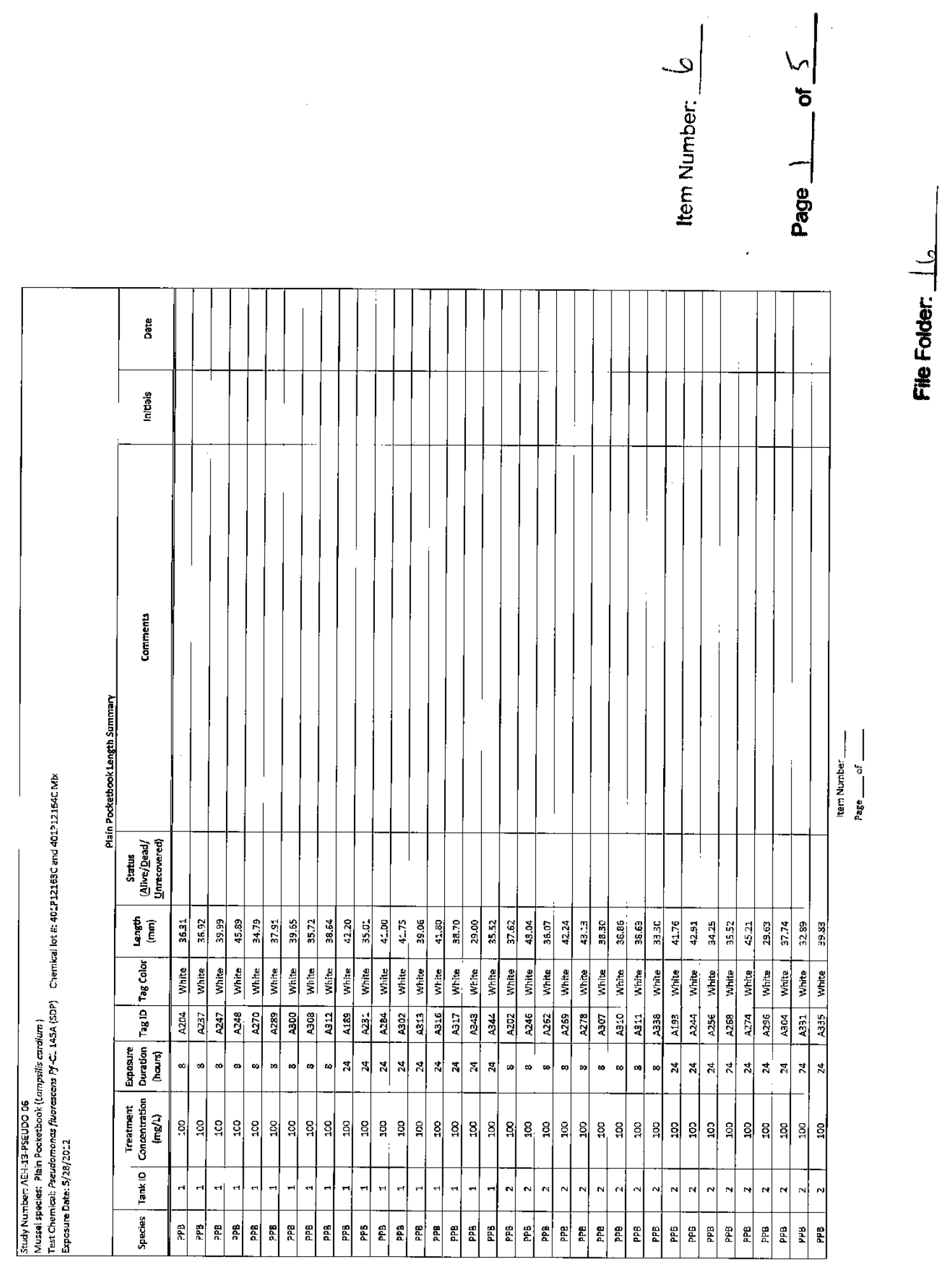




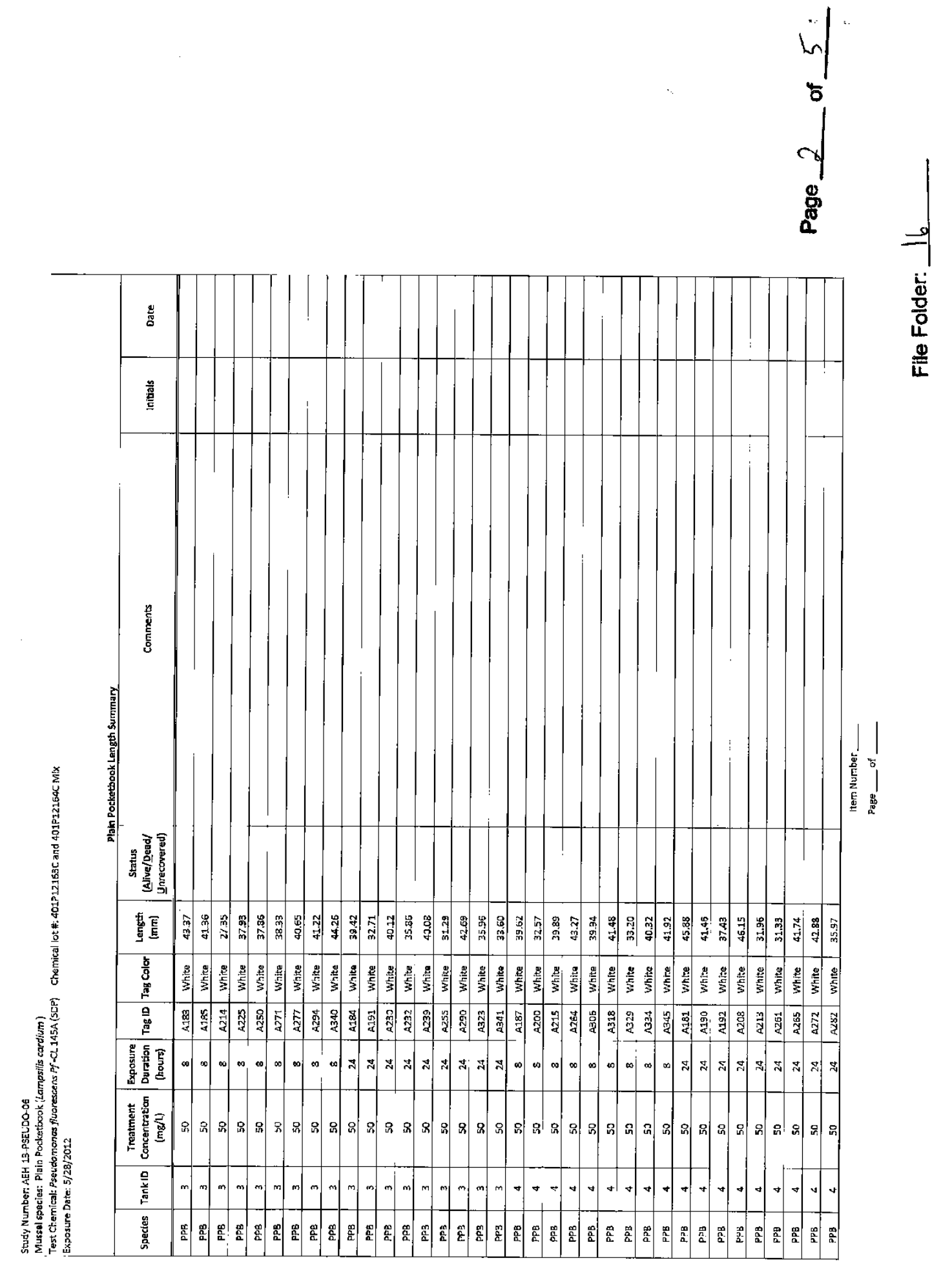




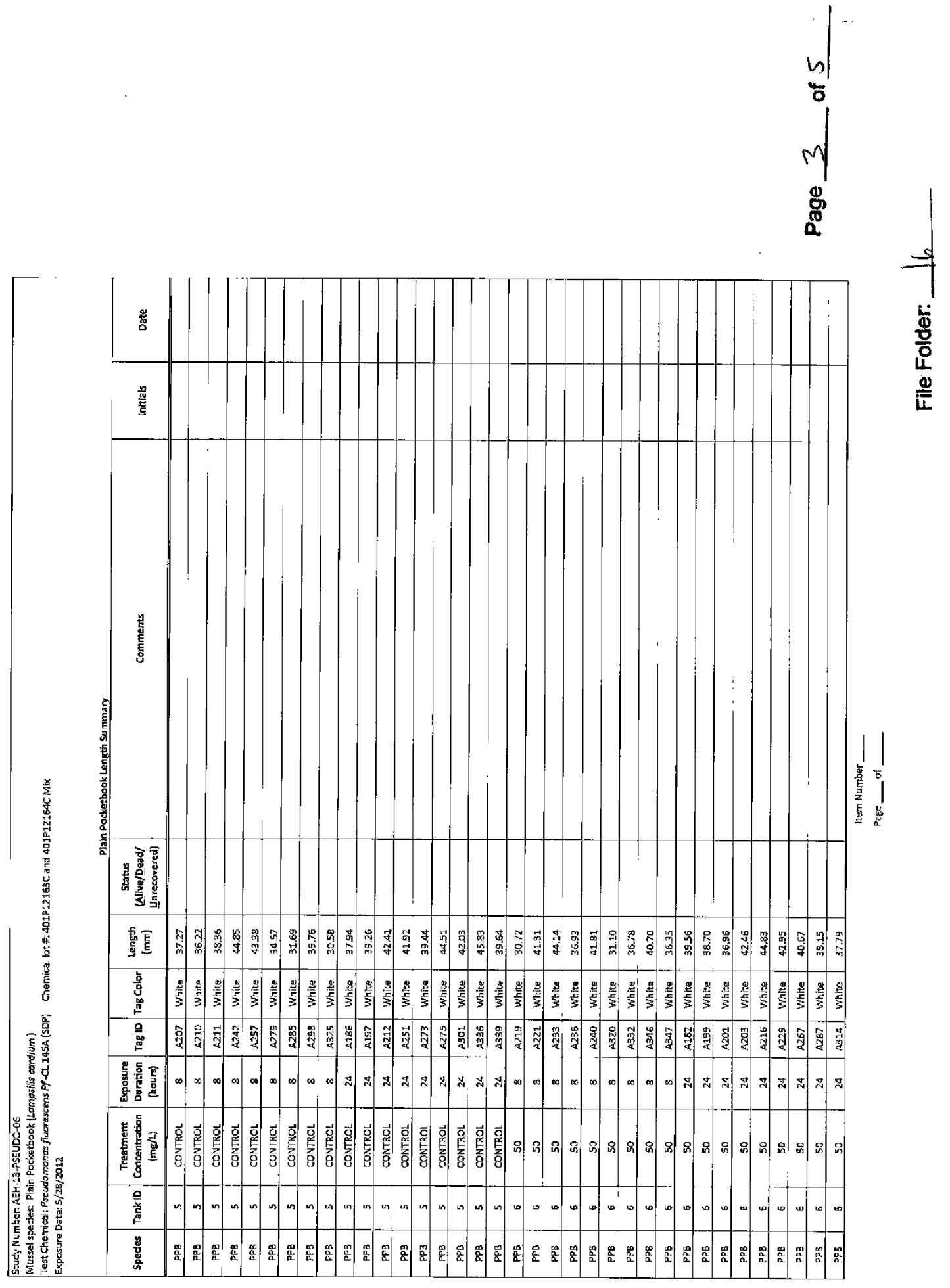




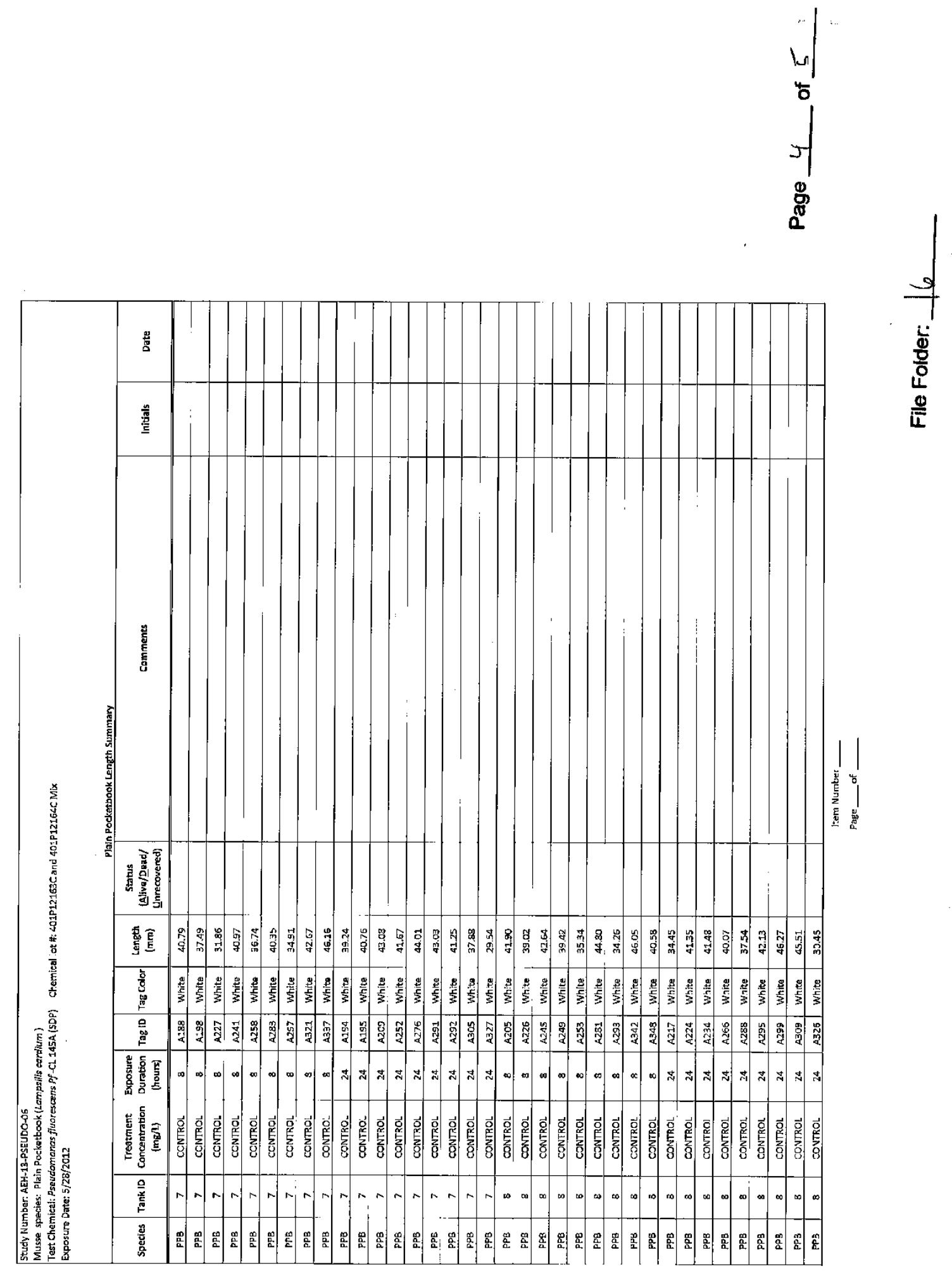




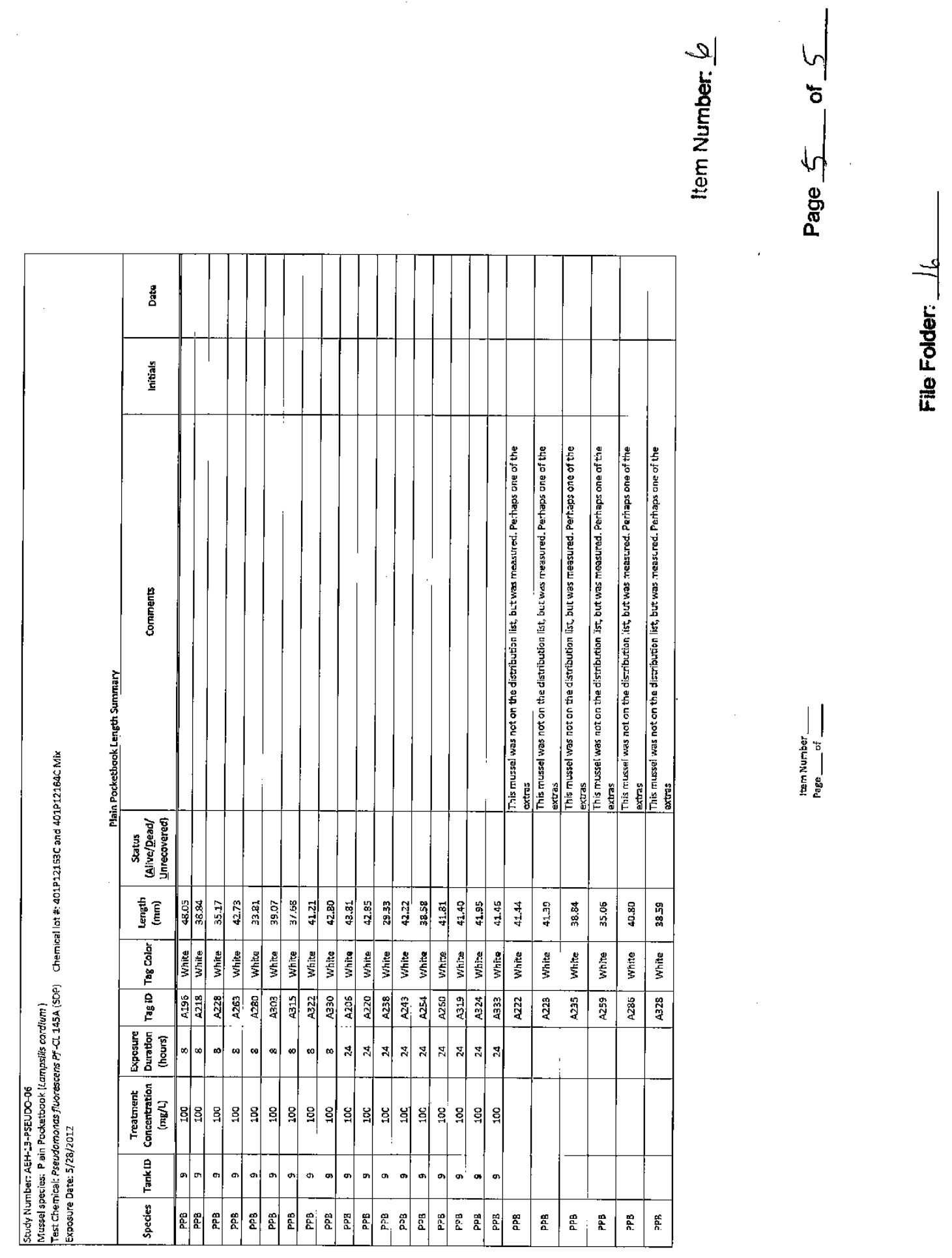




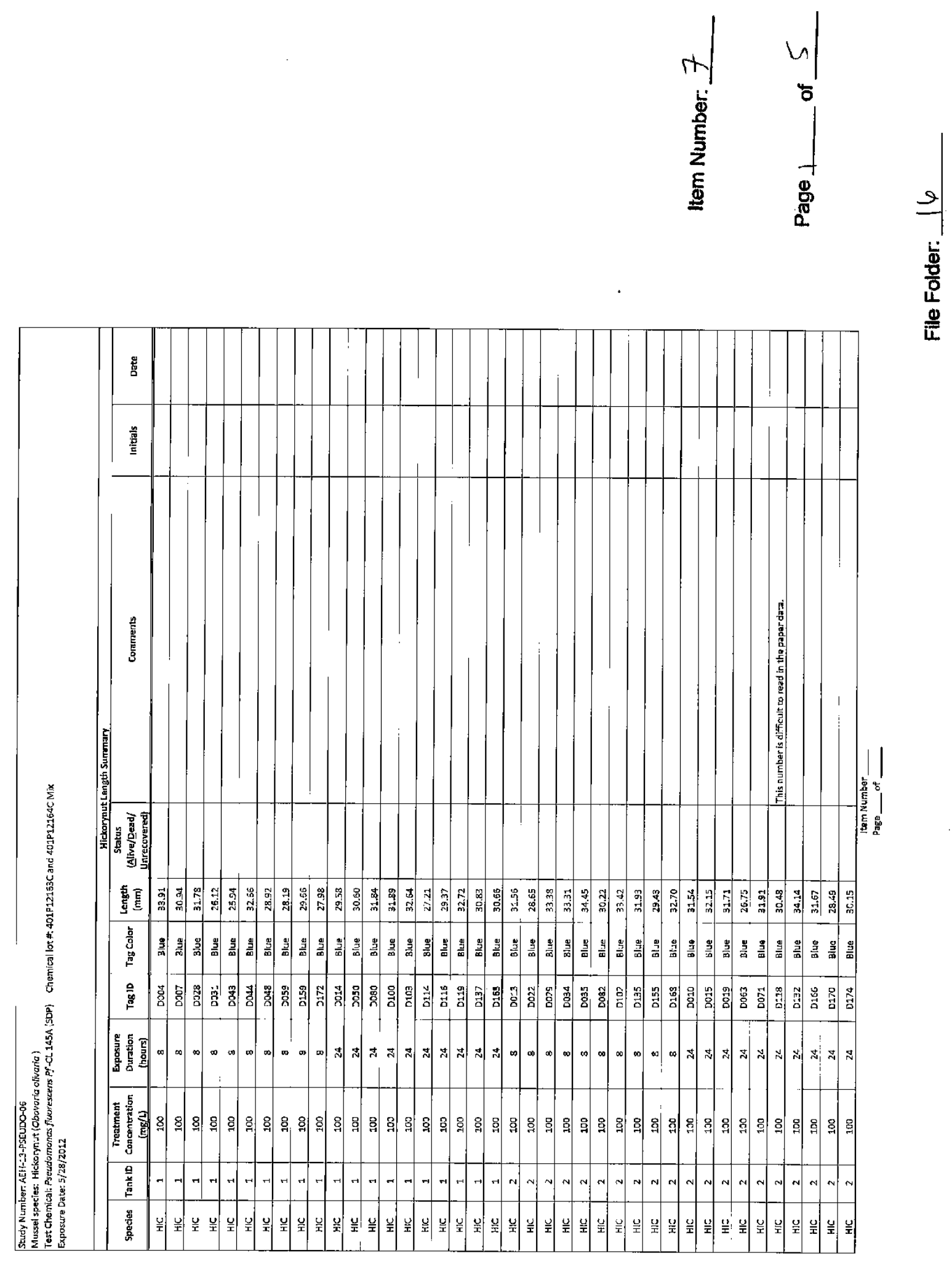



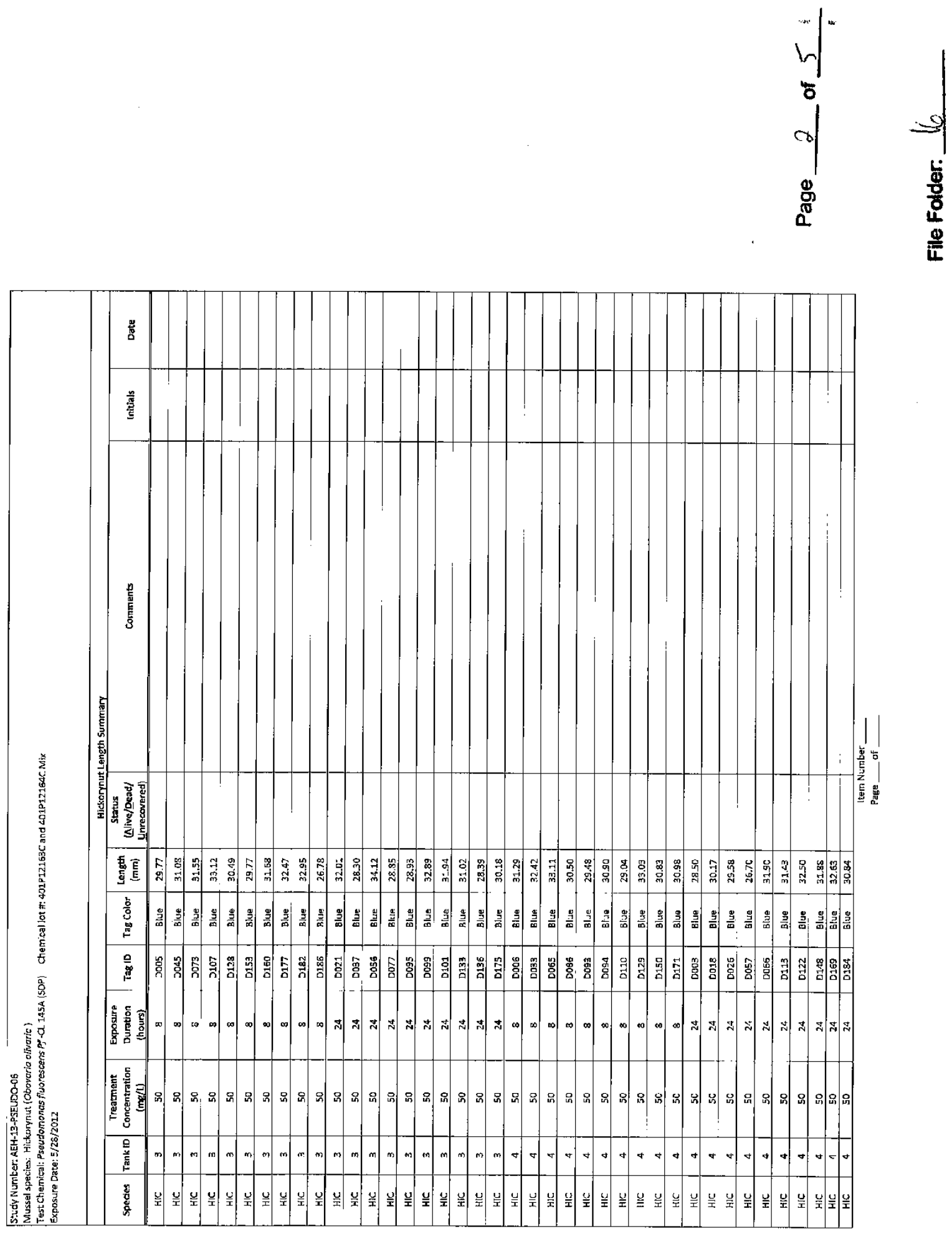

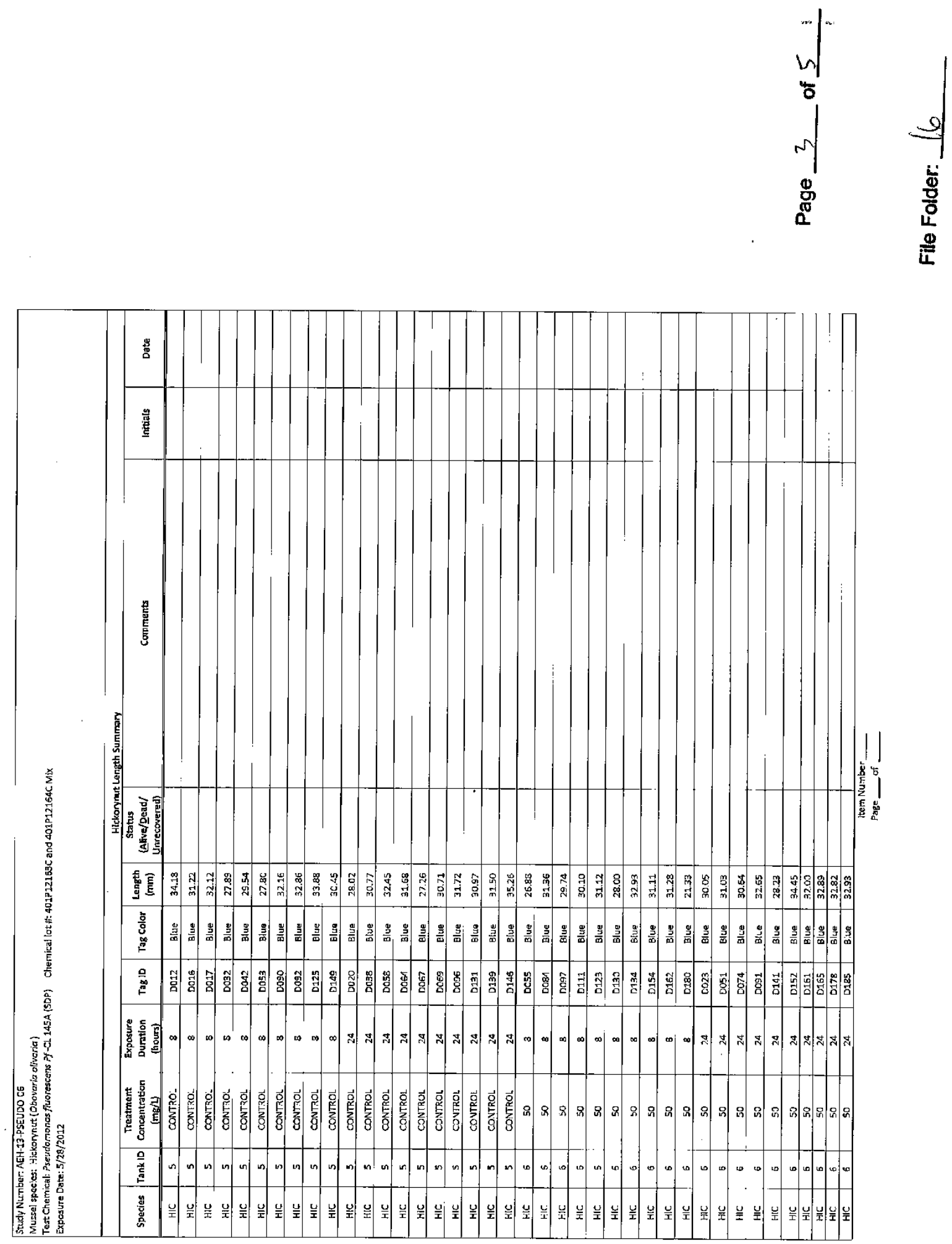
4
1
5
0
0
0
0
0

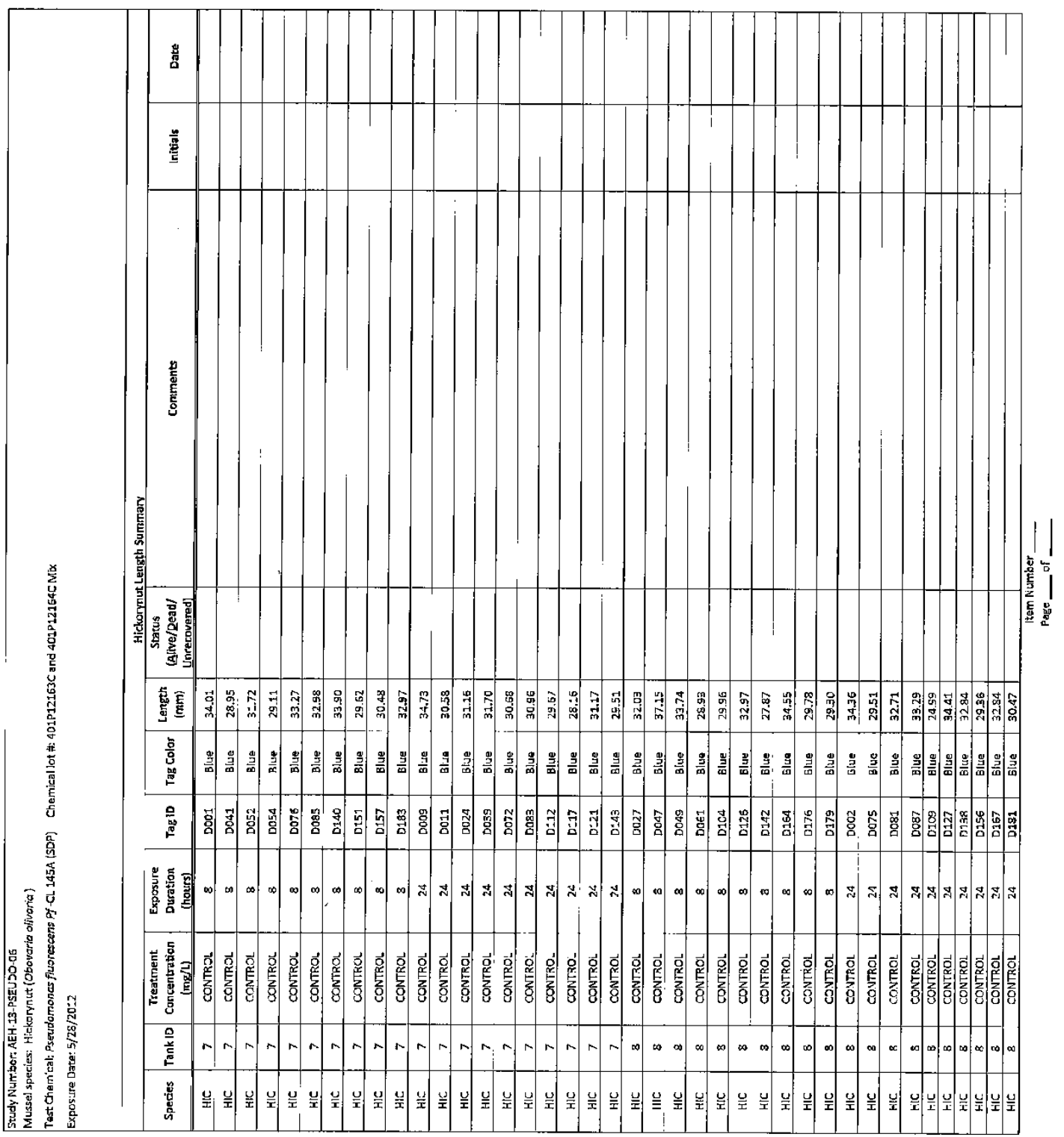



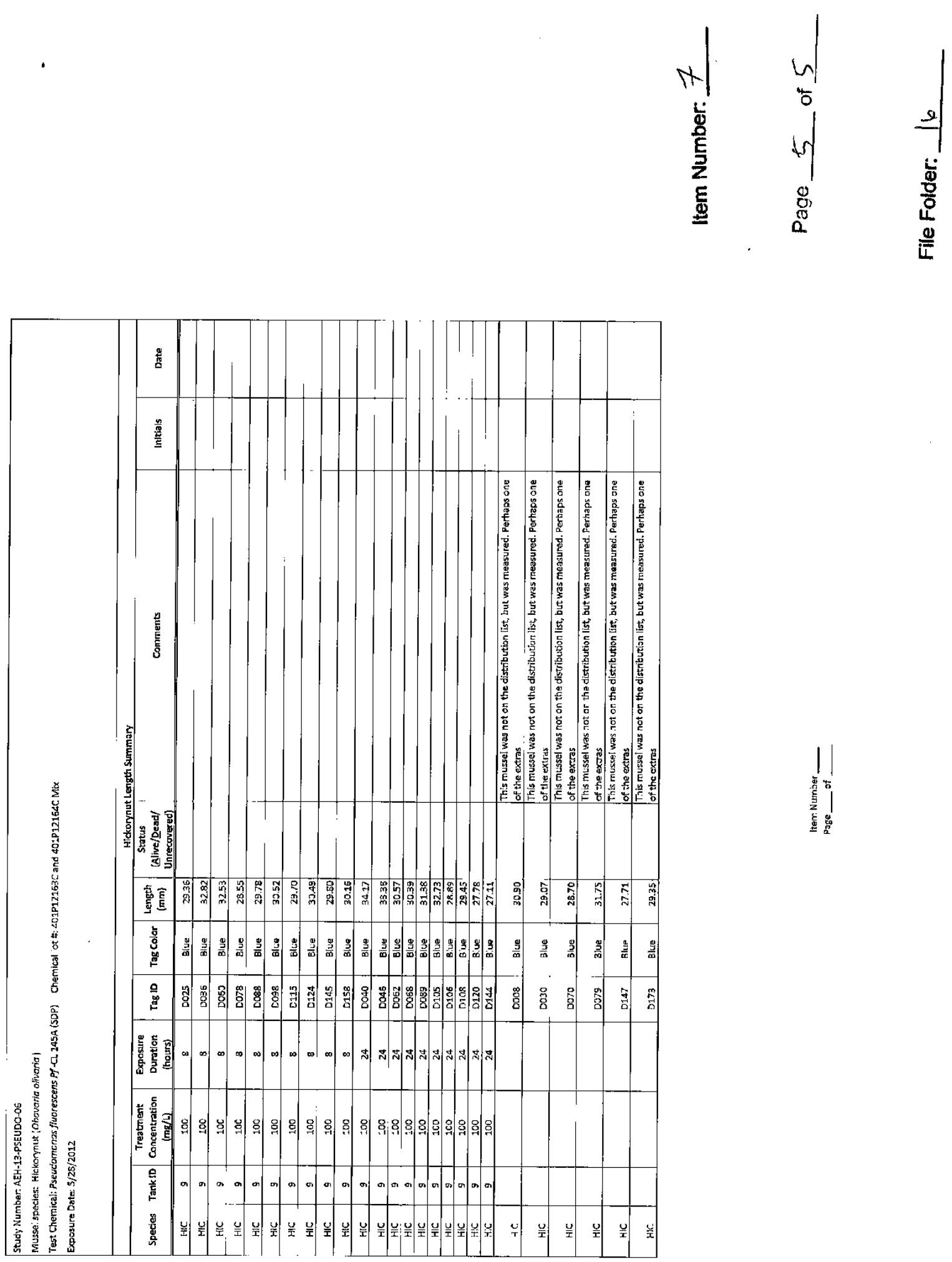

$\mid$ 

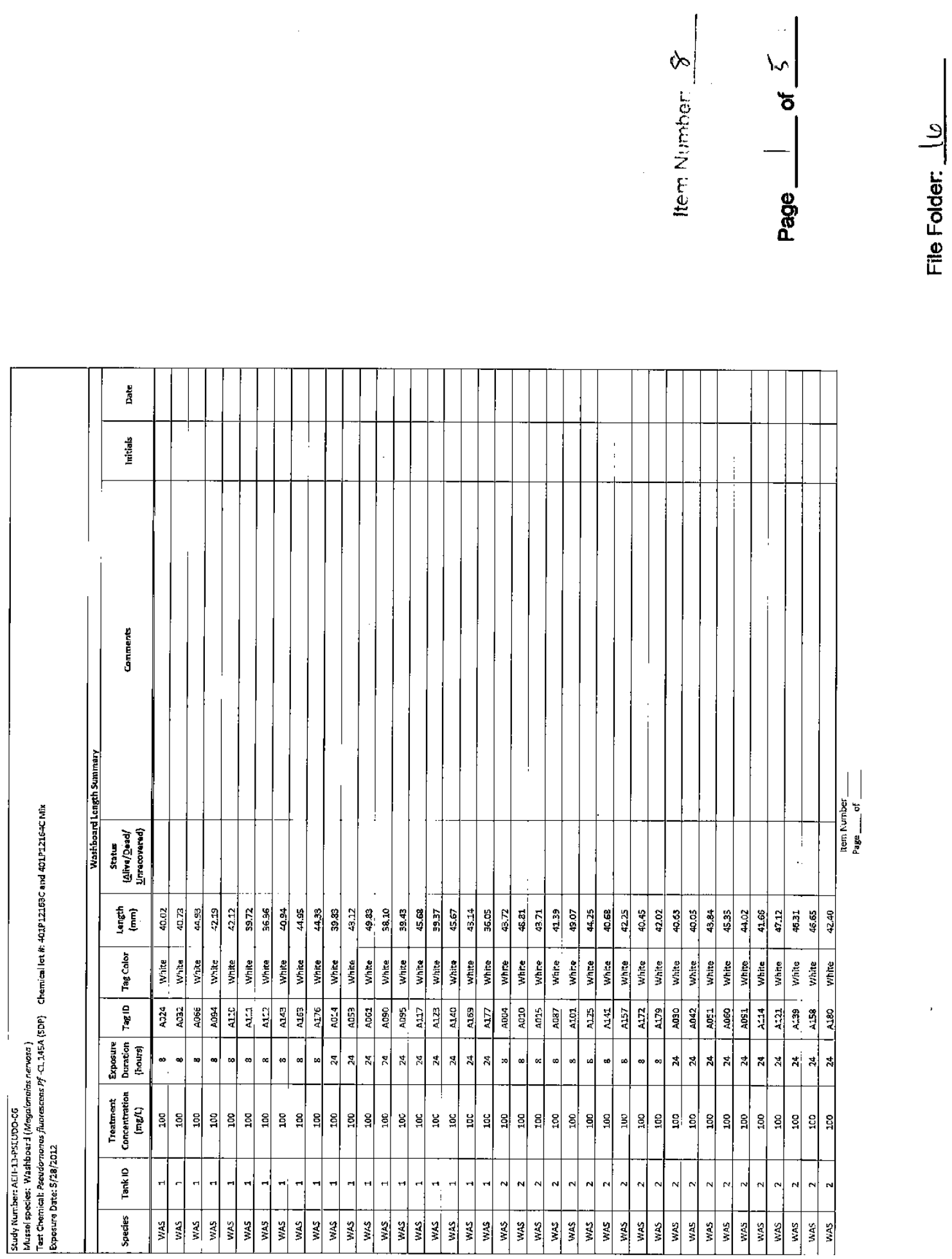

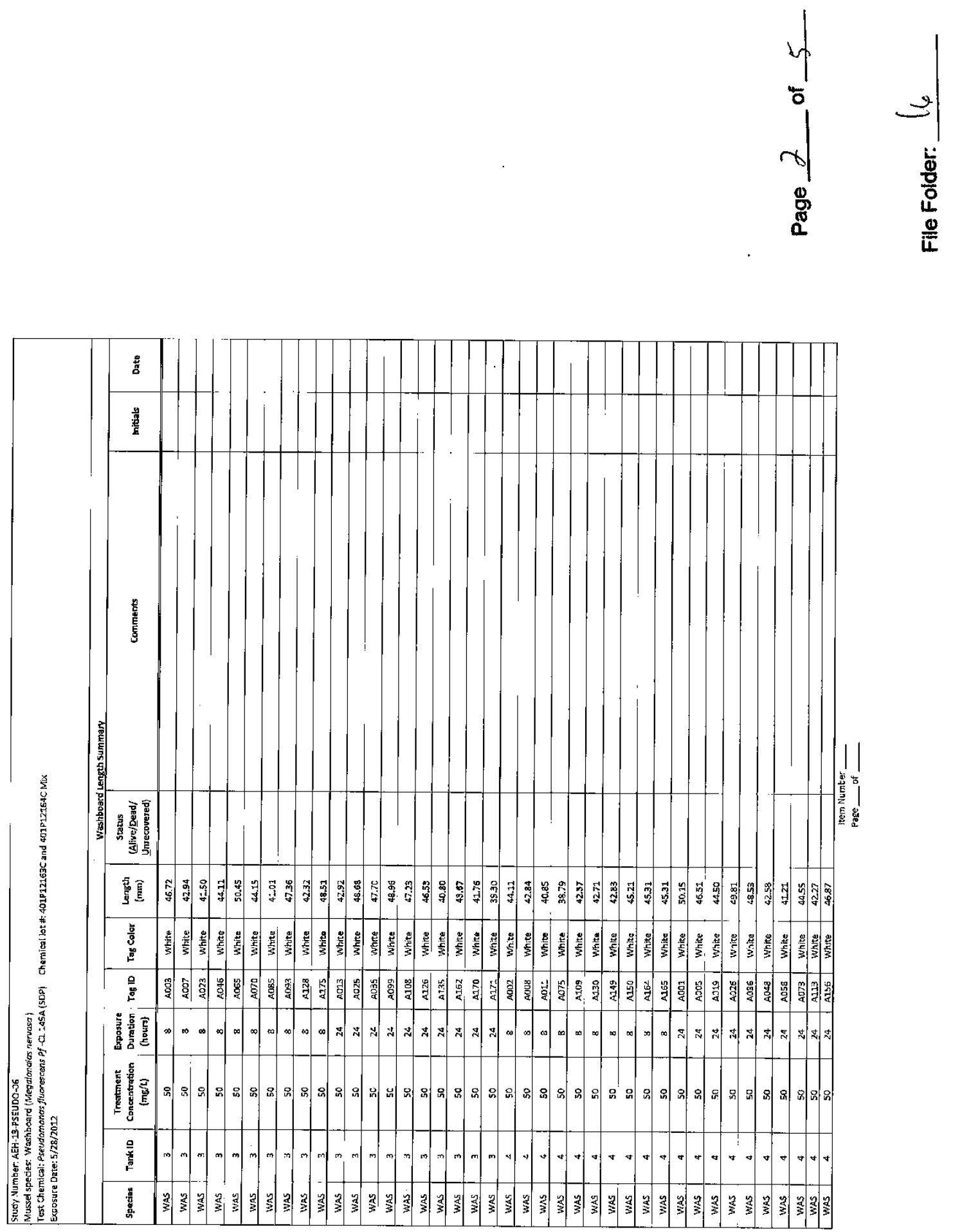

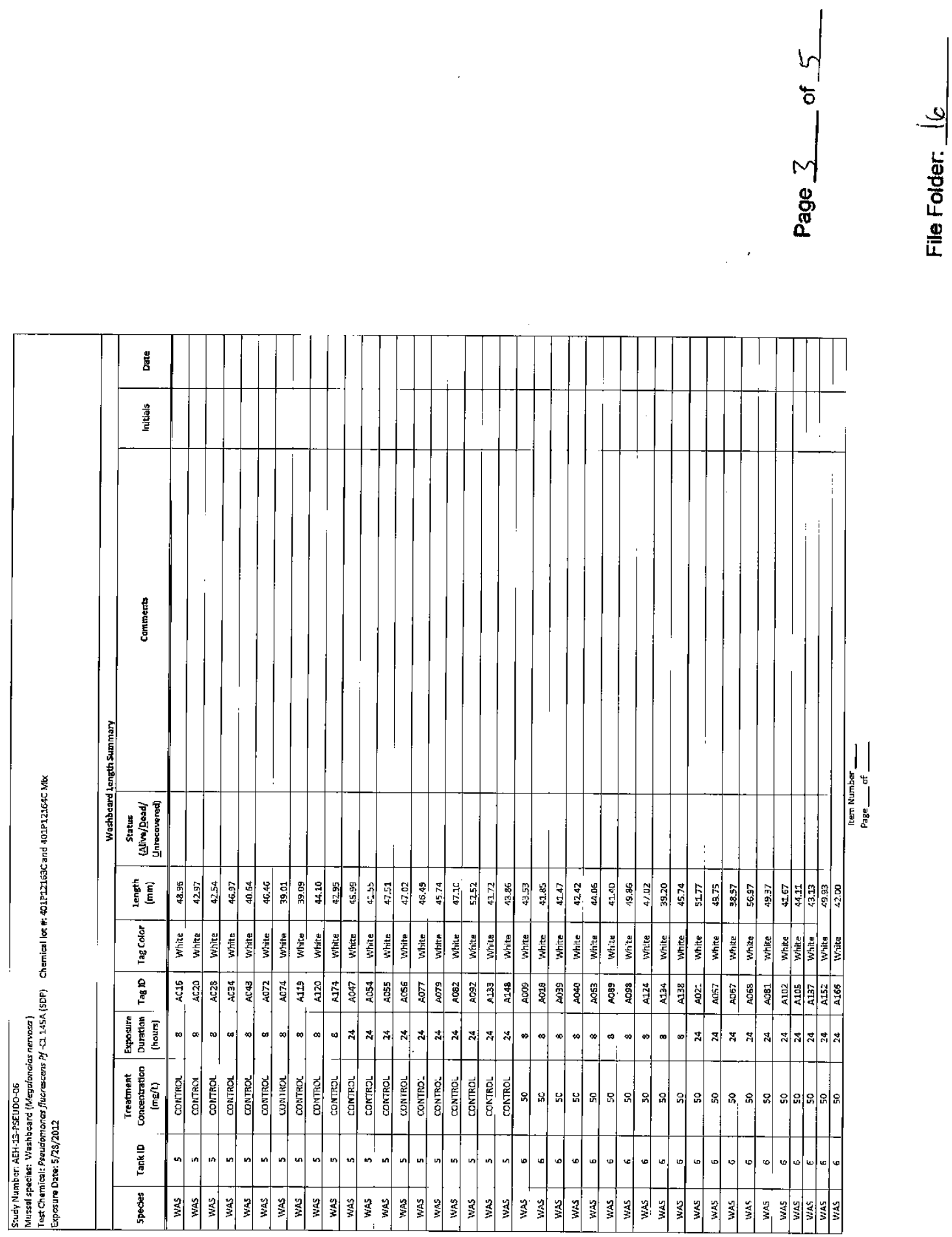

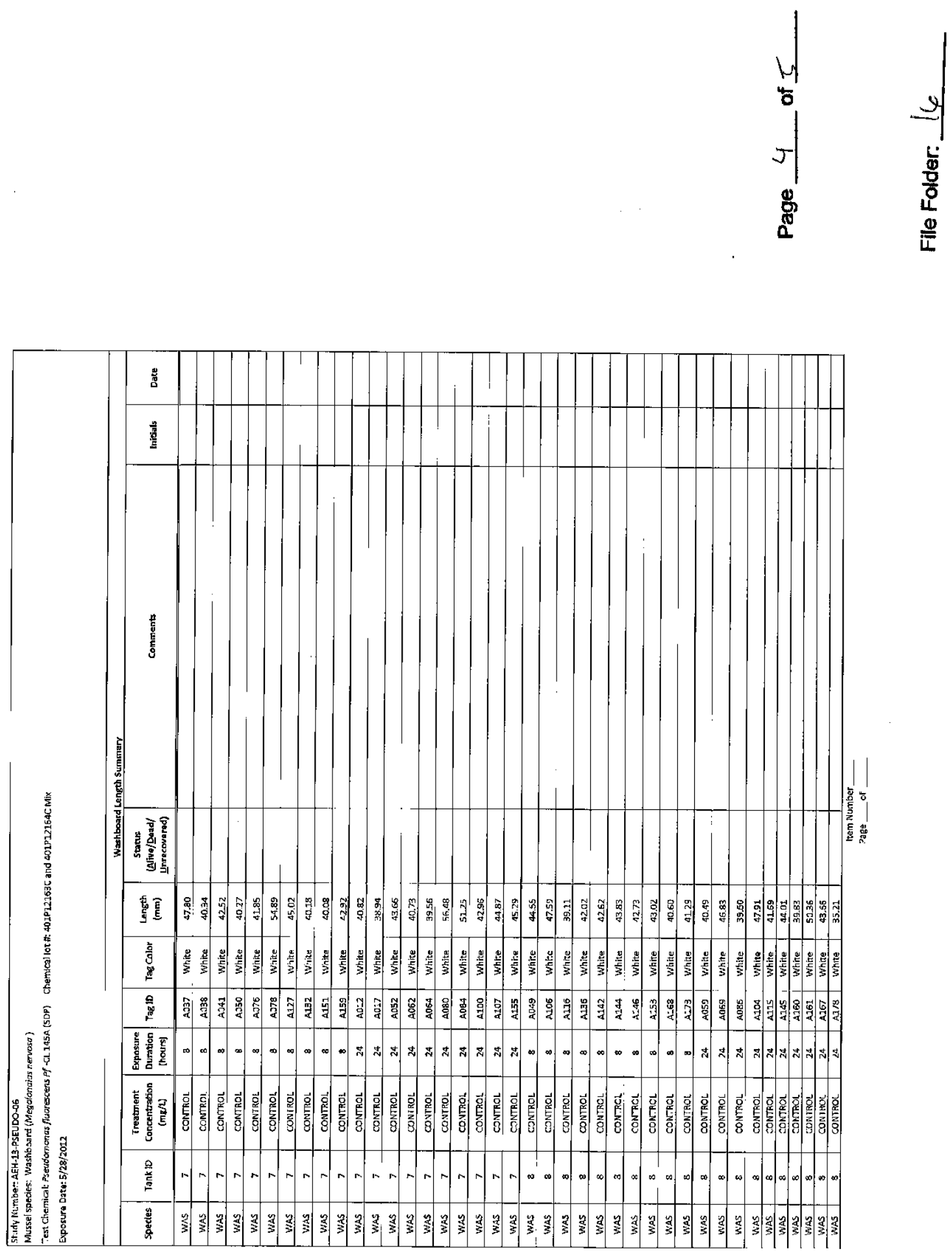

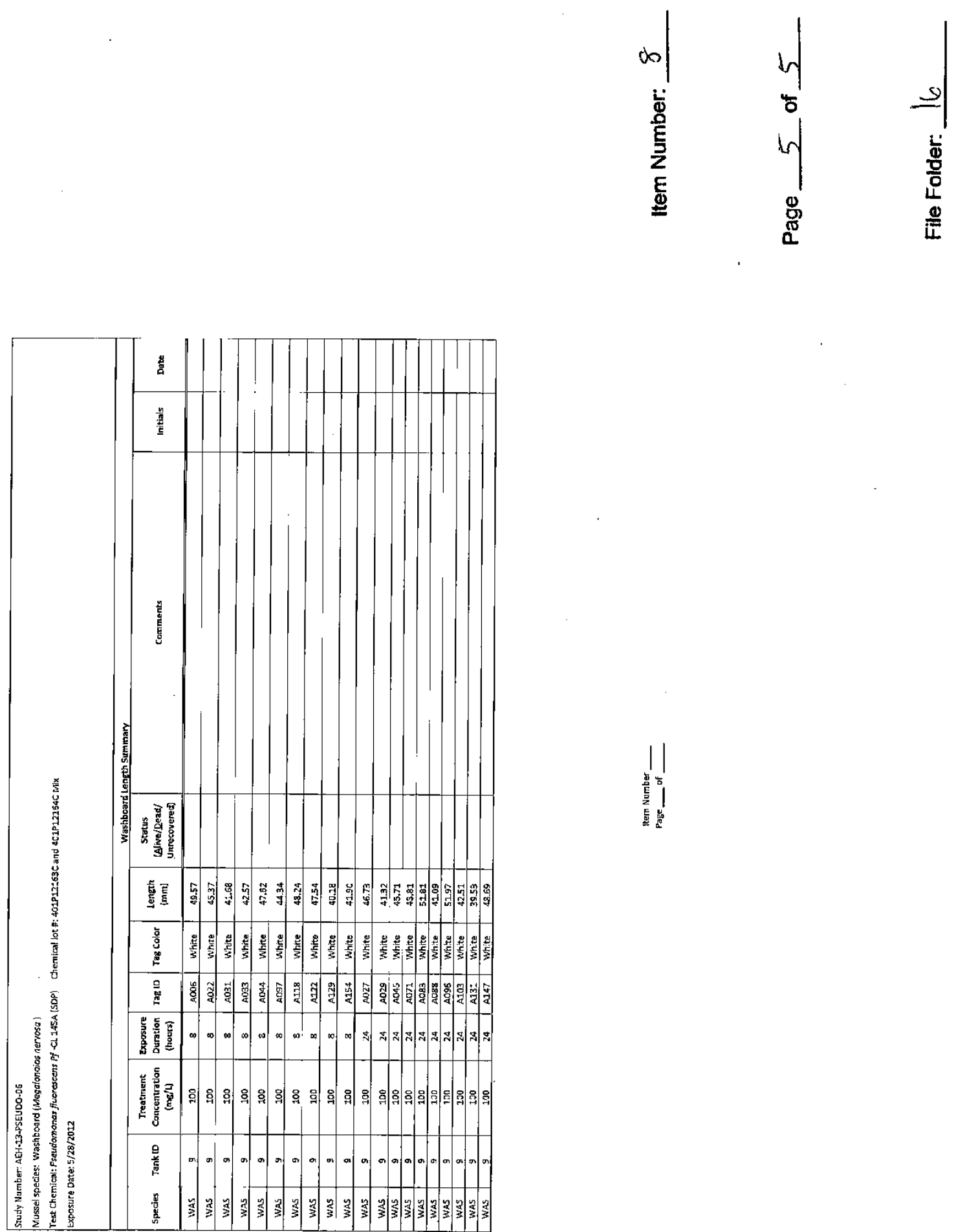

| 

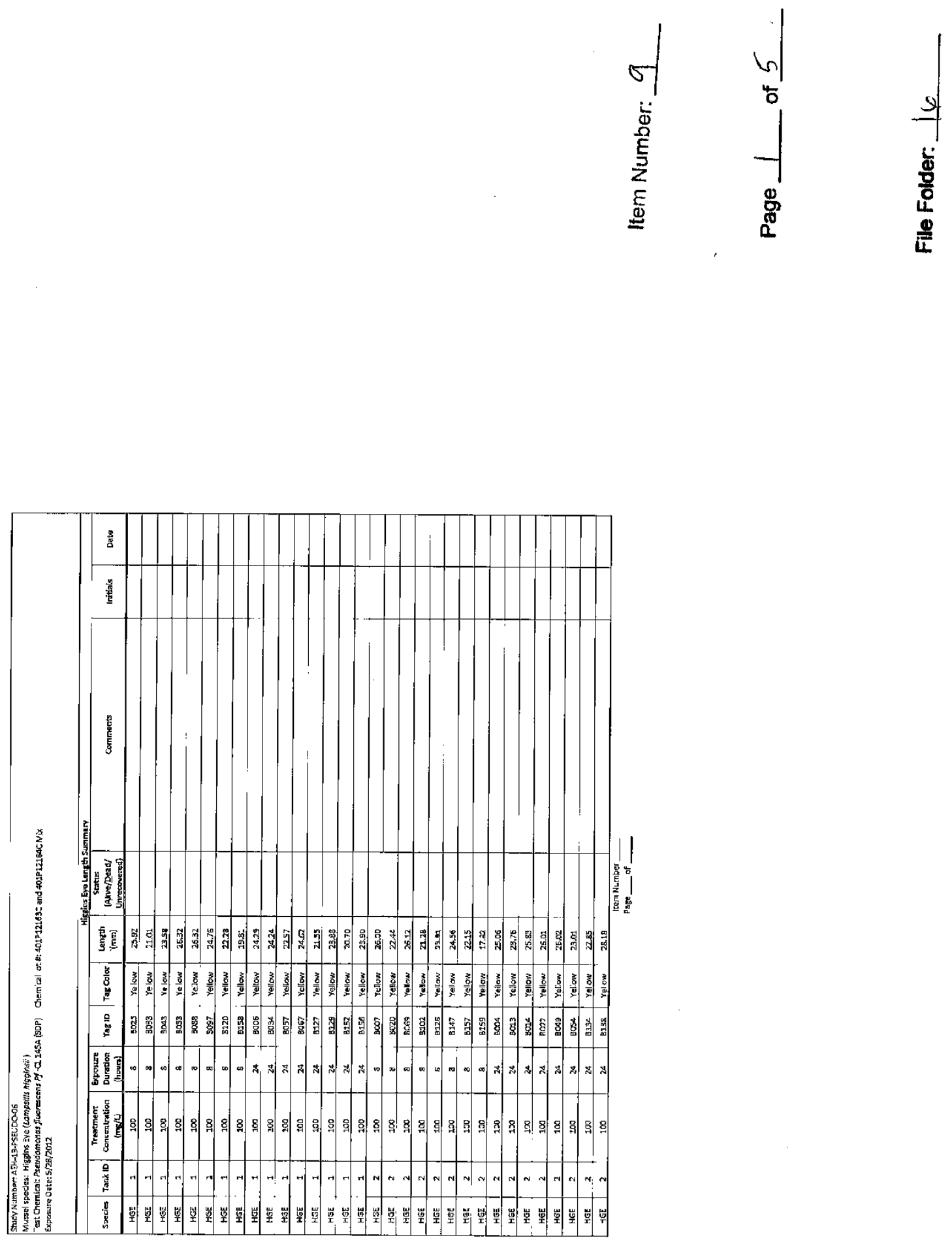

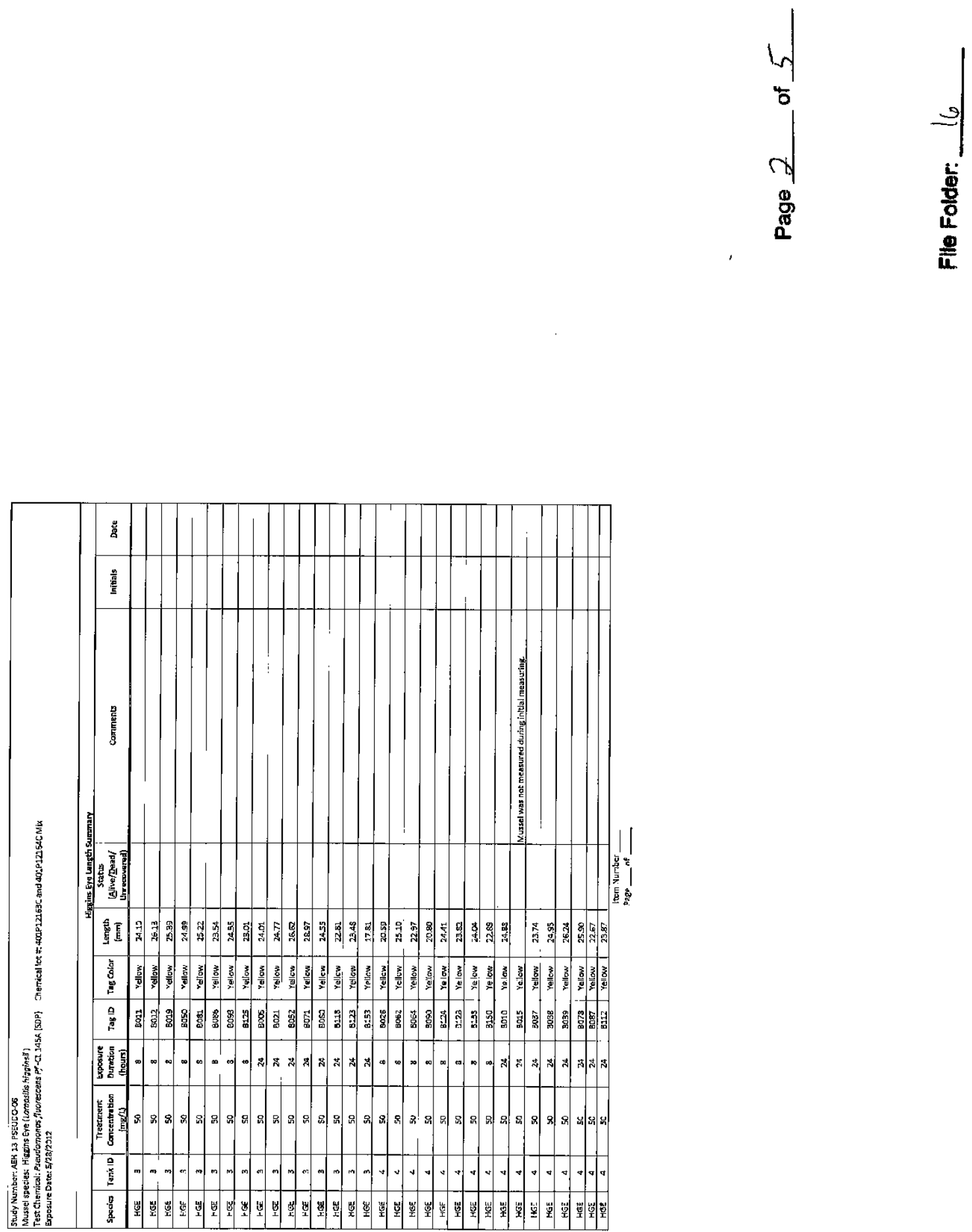

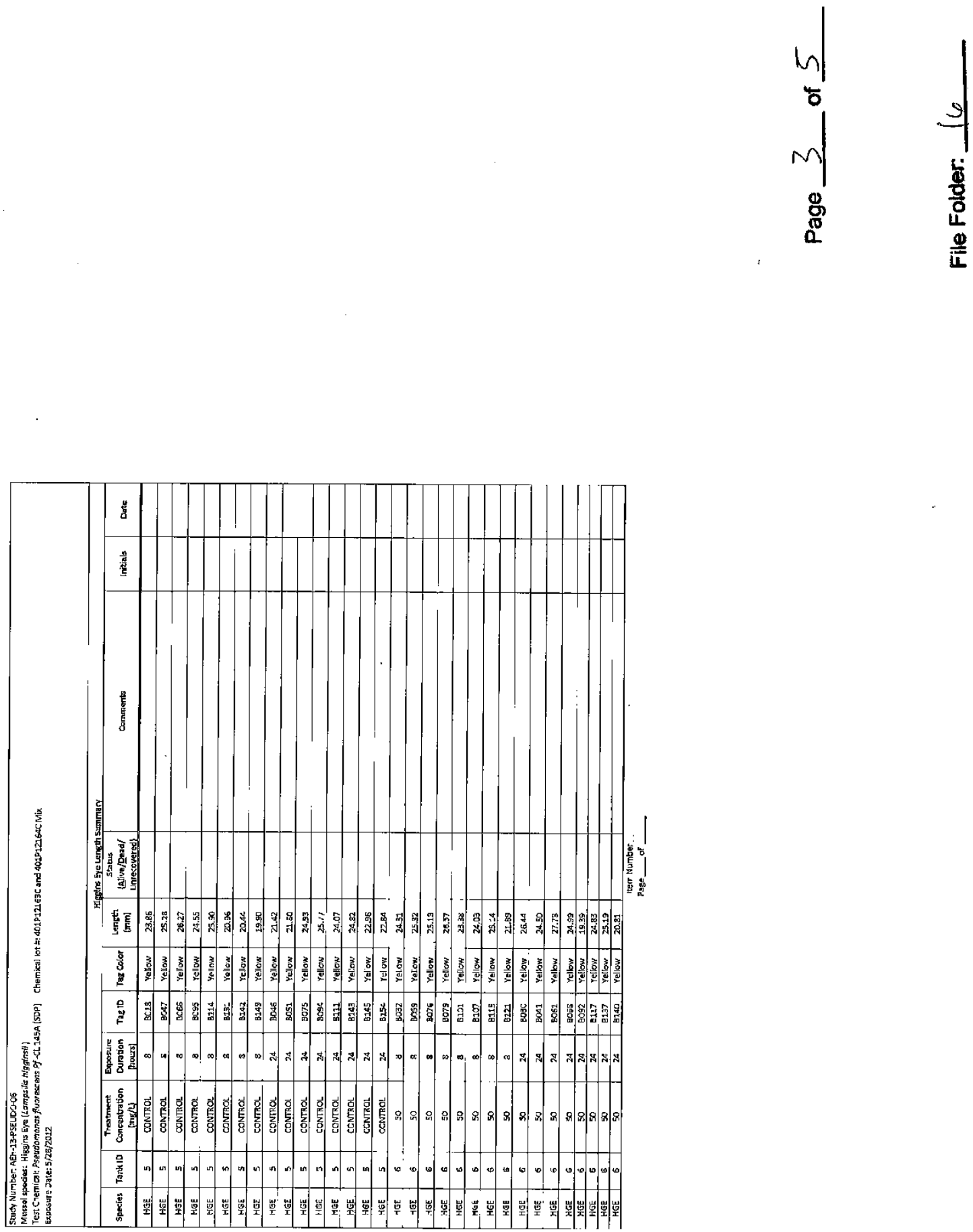

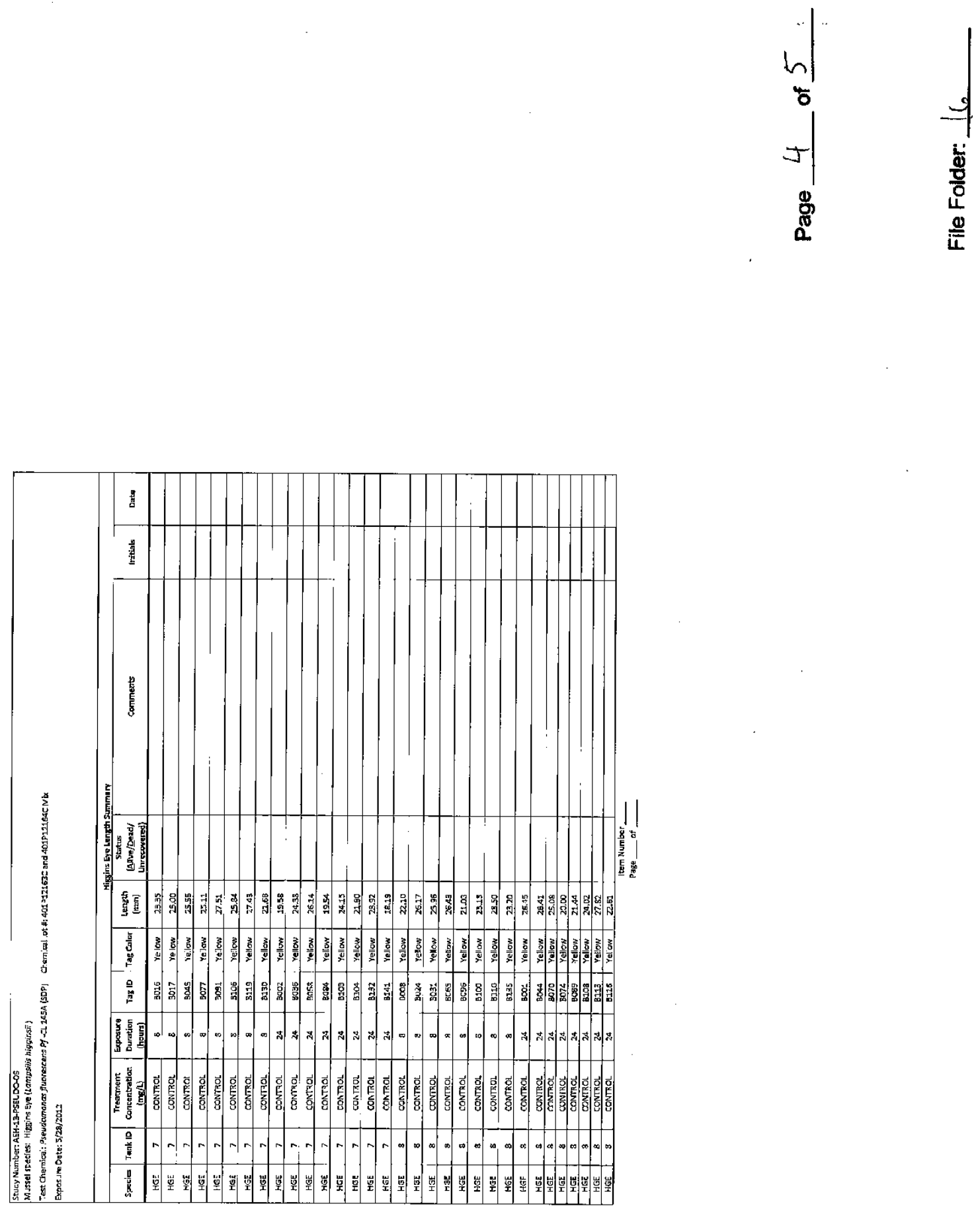

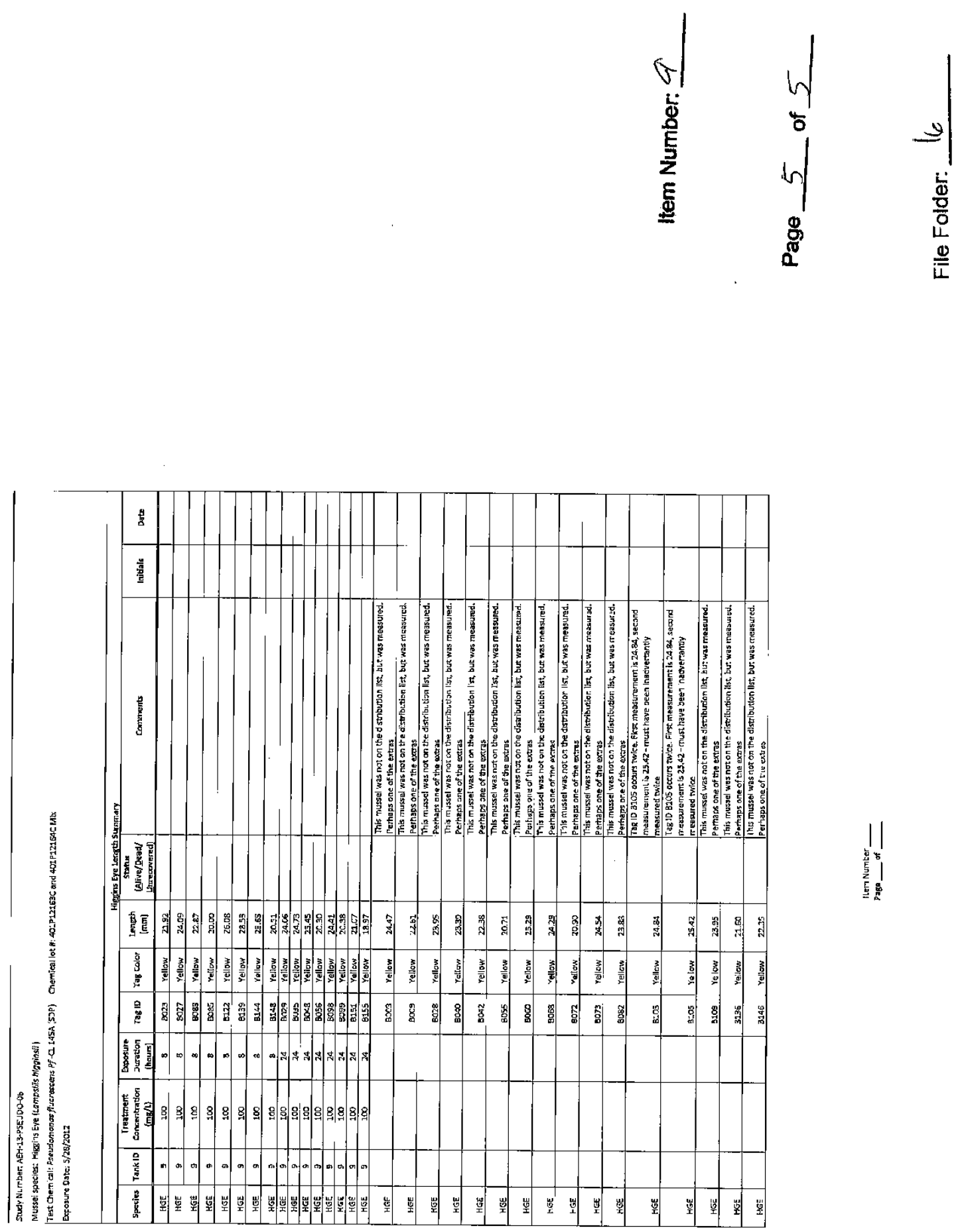

$\mid$ 

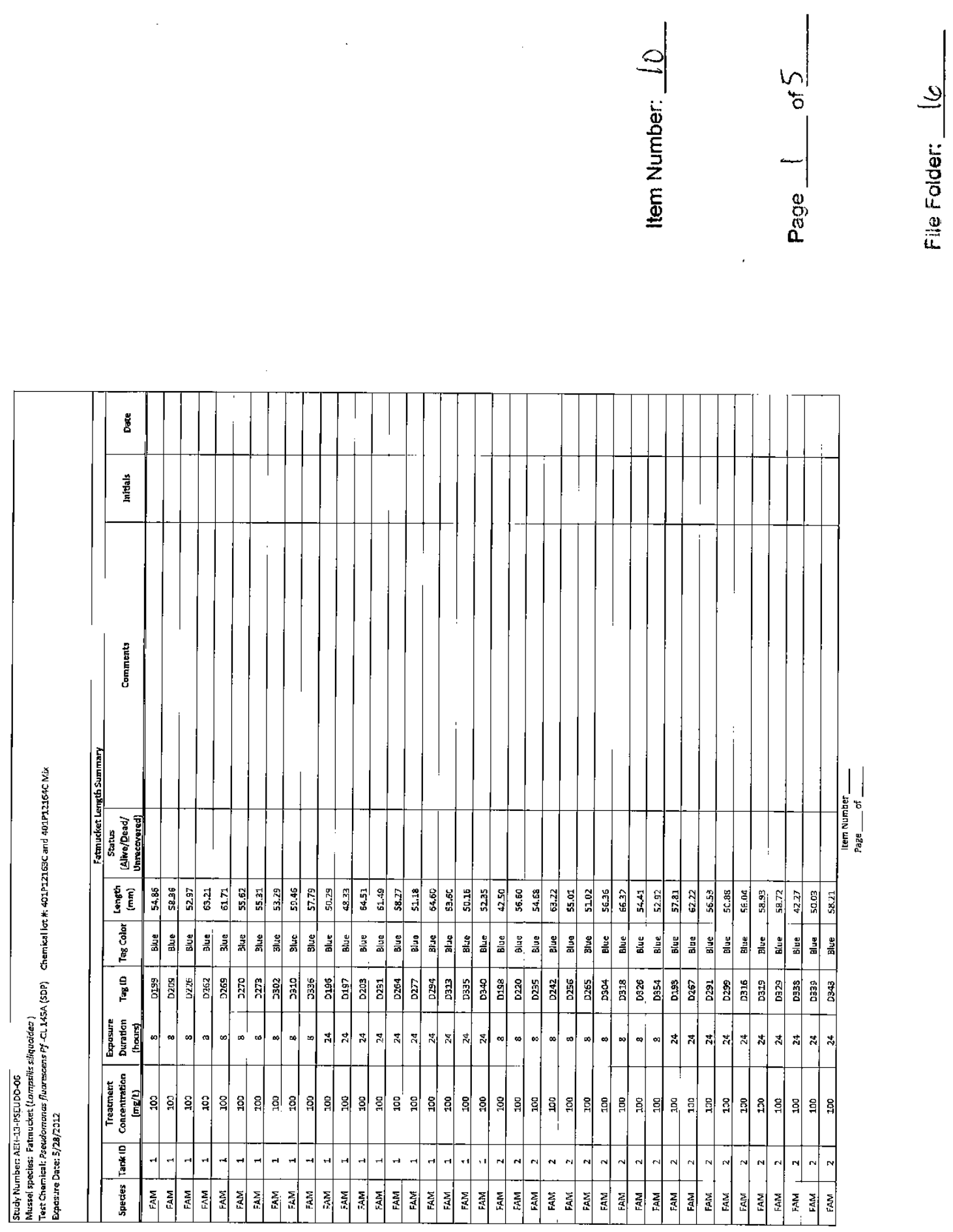

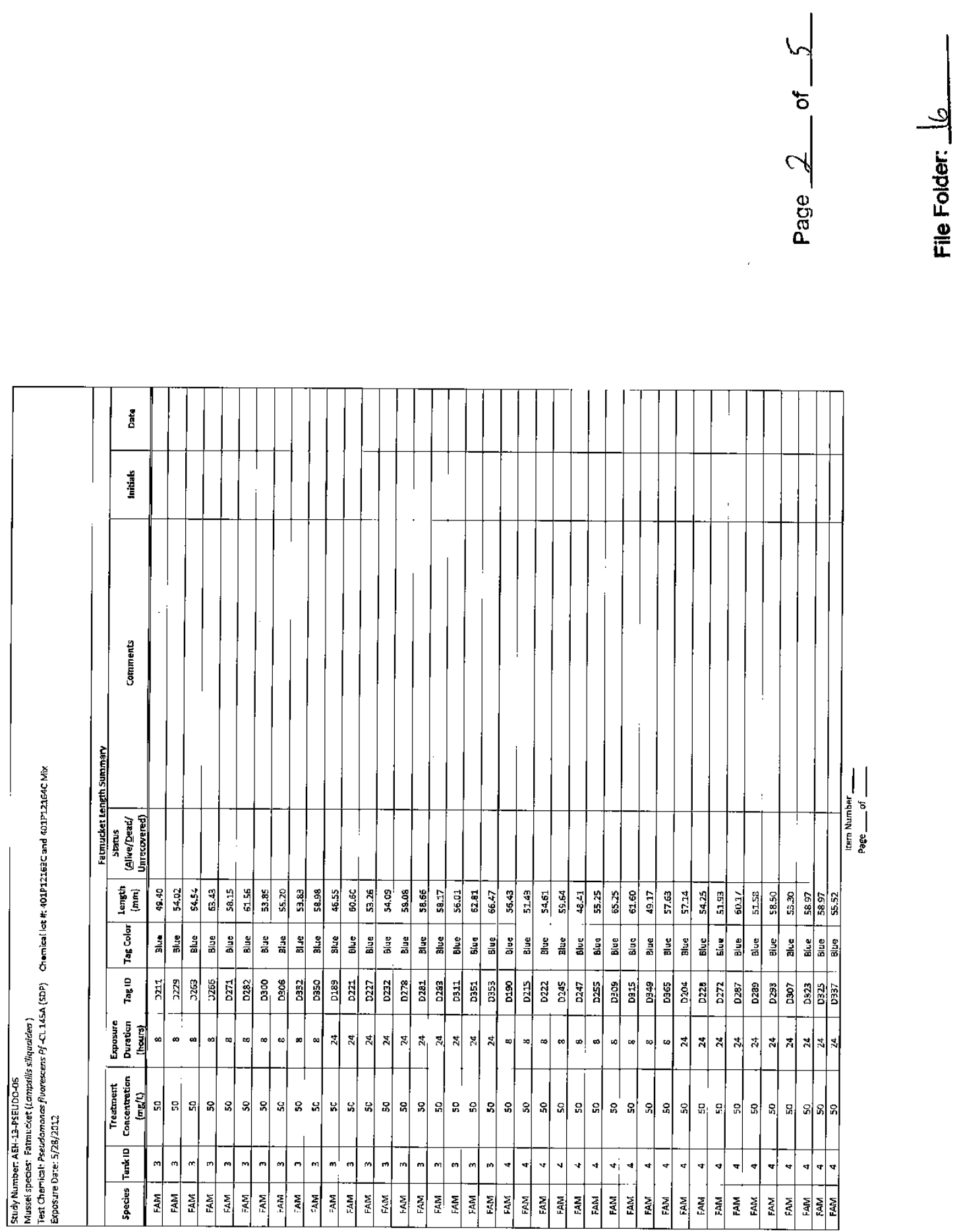
W

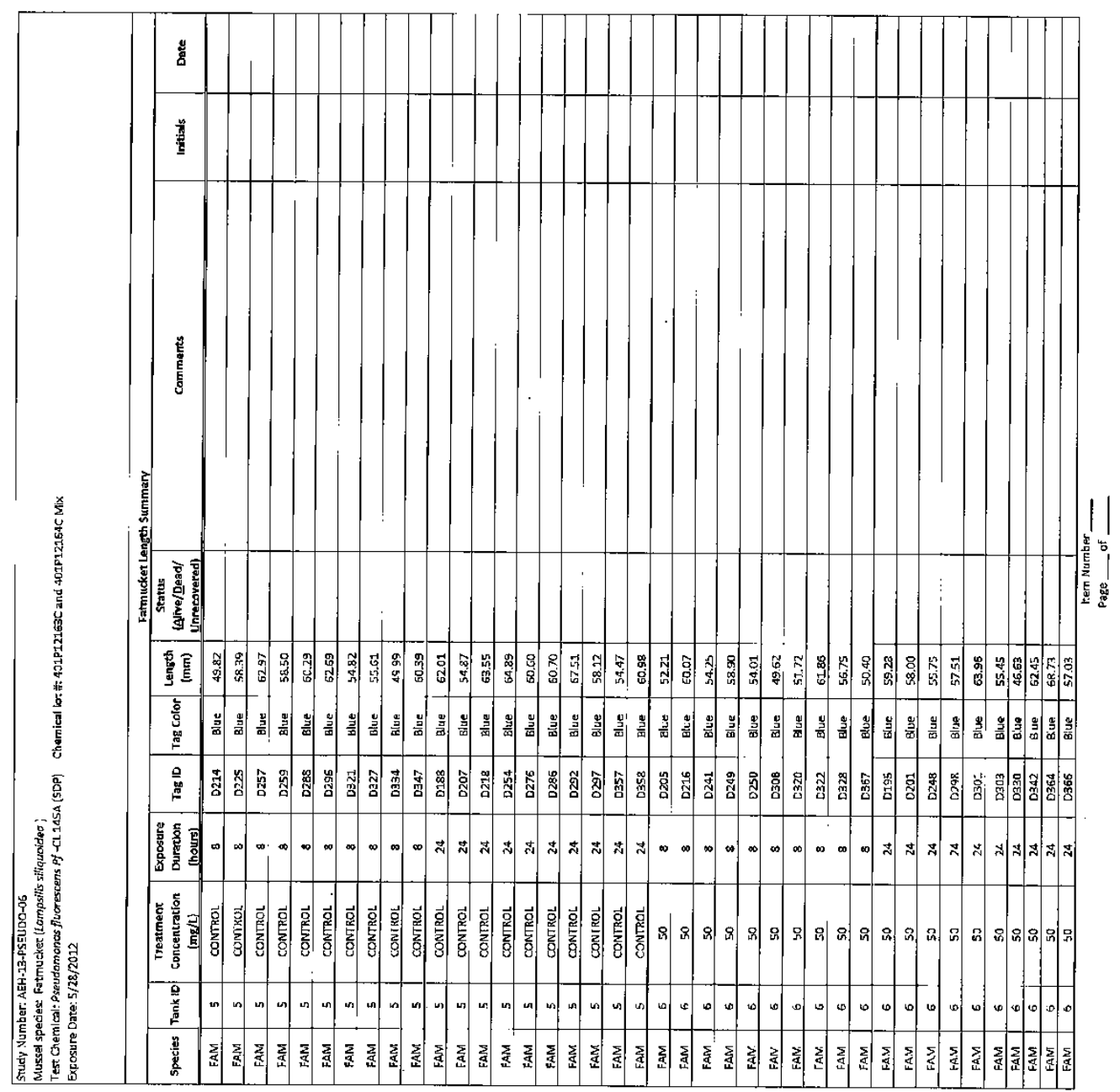



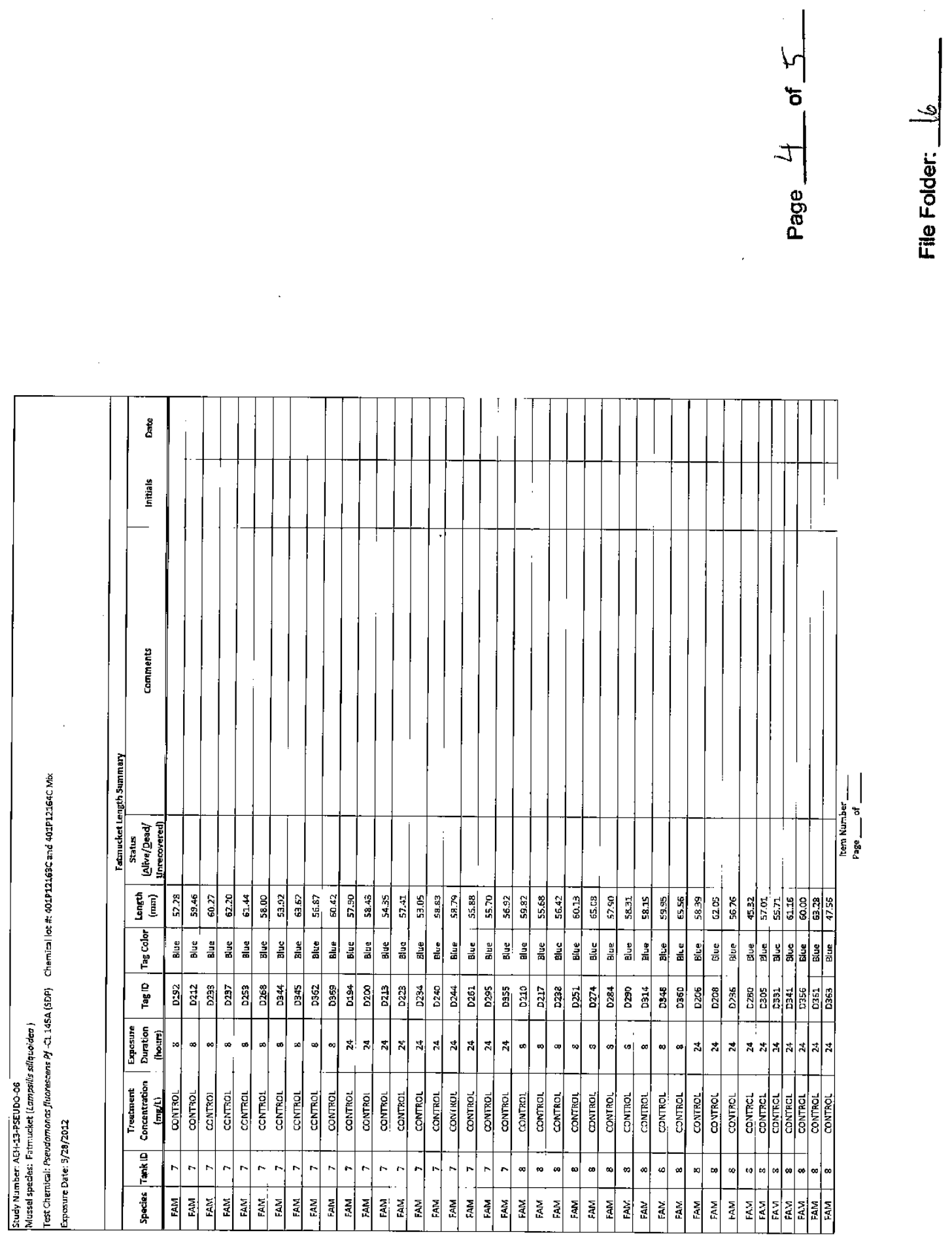
O|

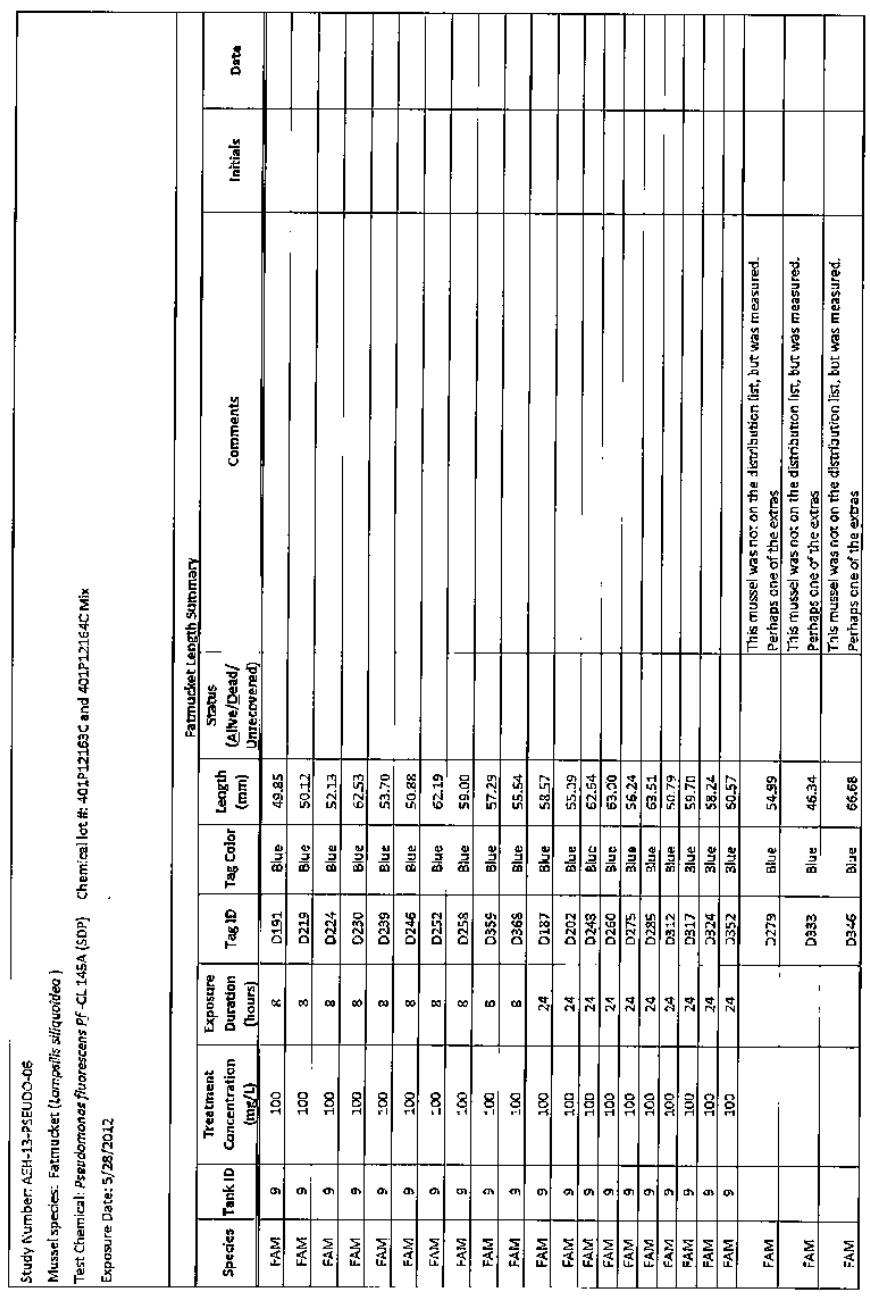

$\mid$ 

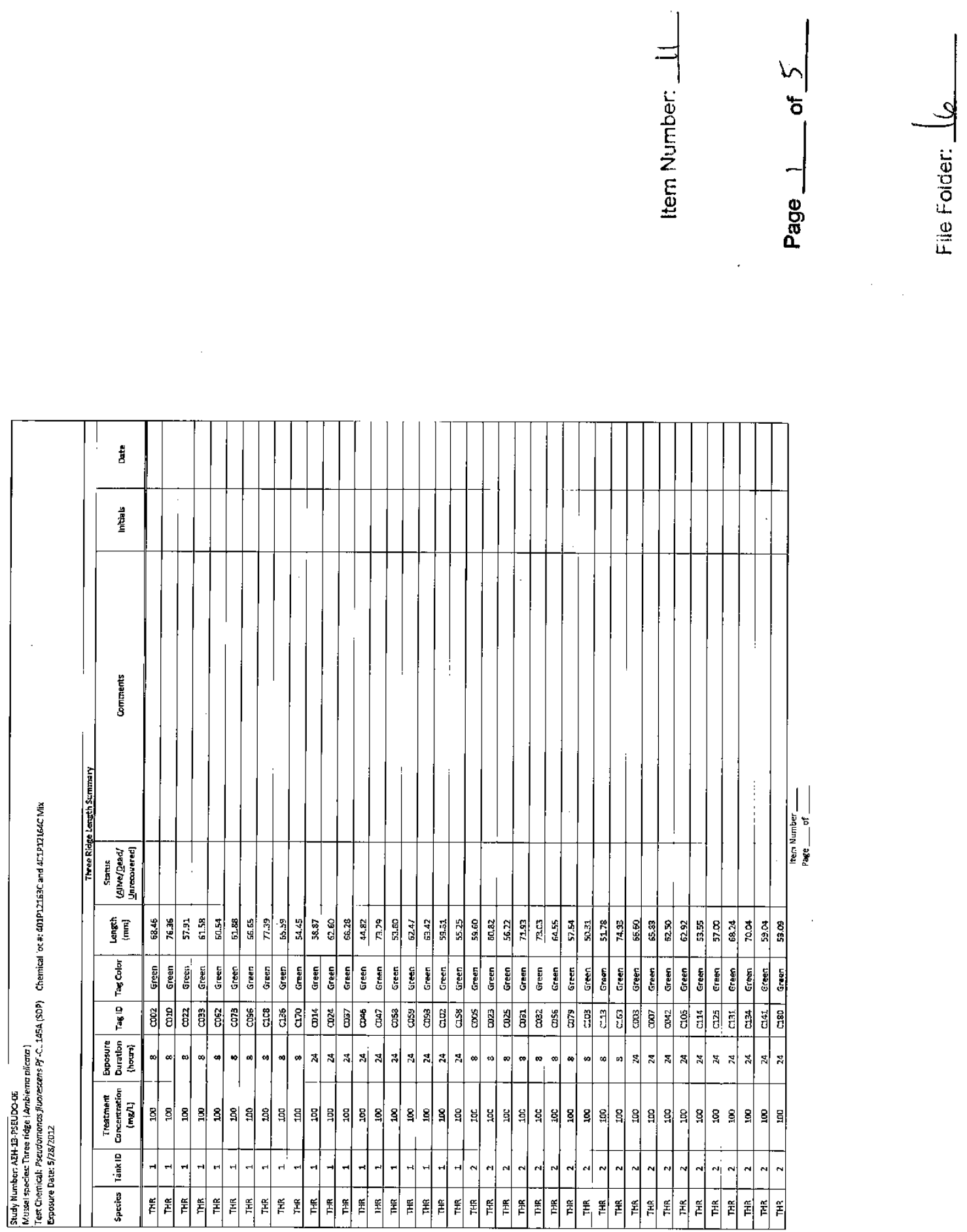
r|

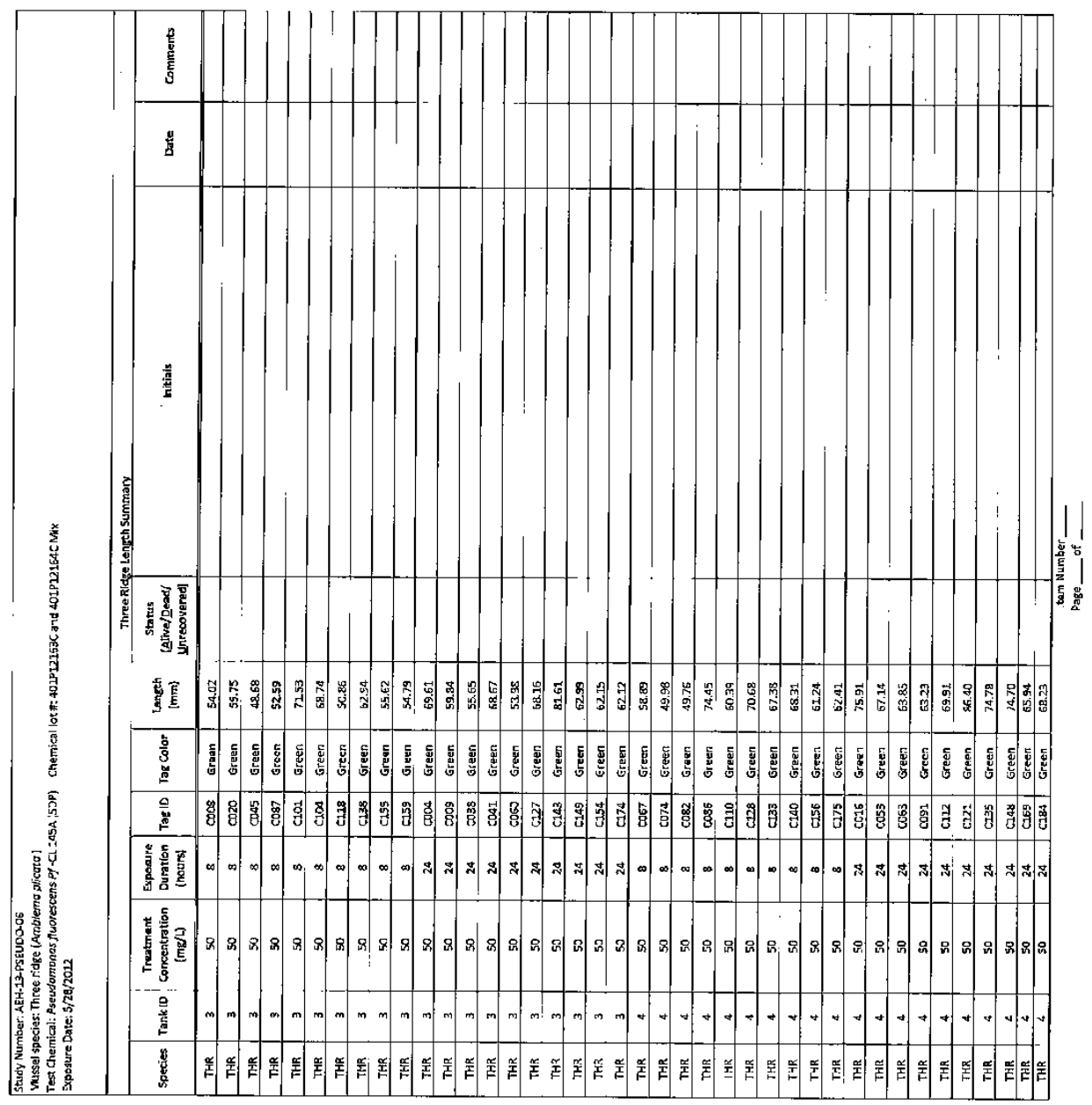



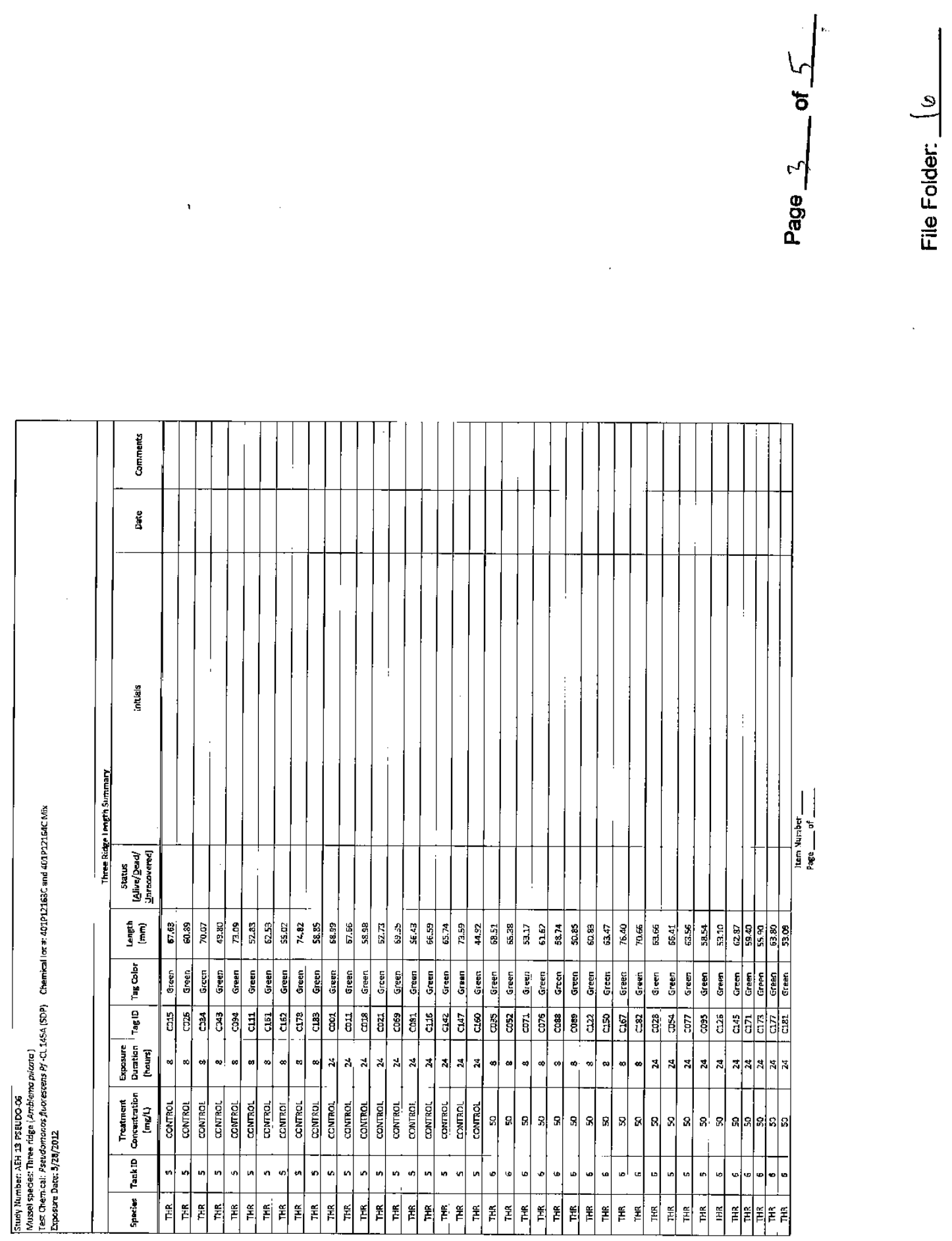

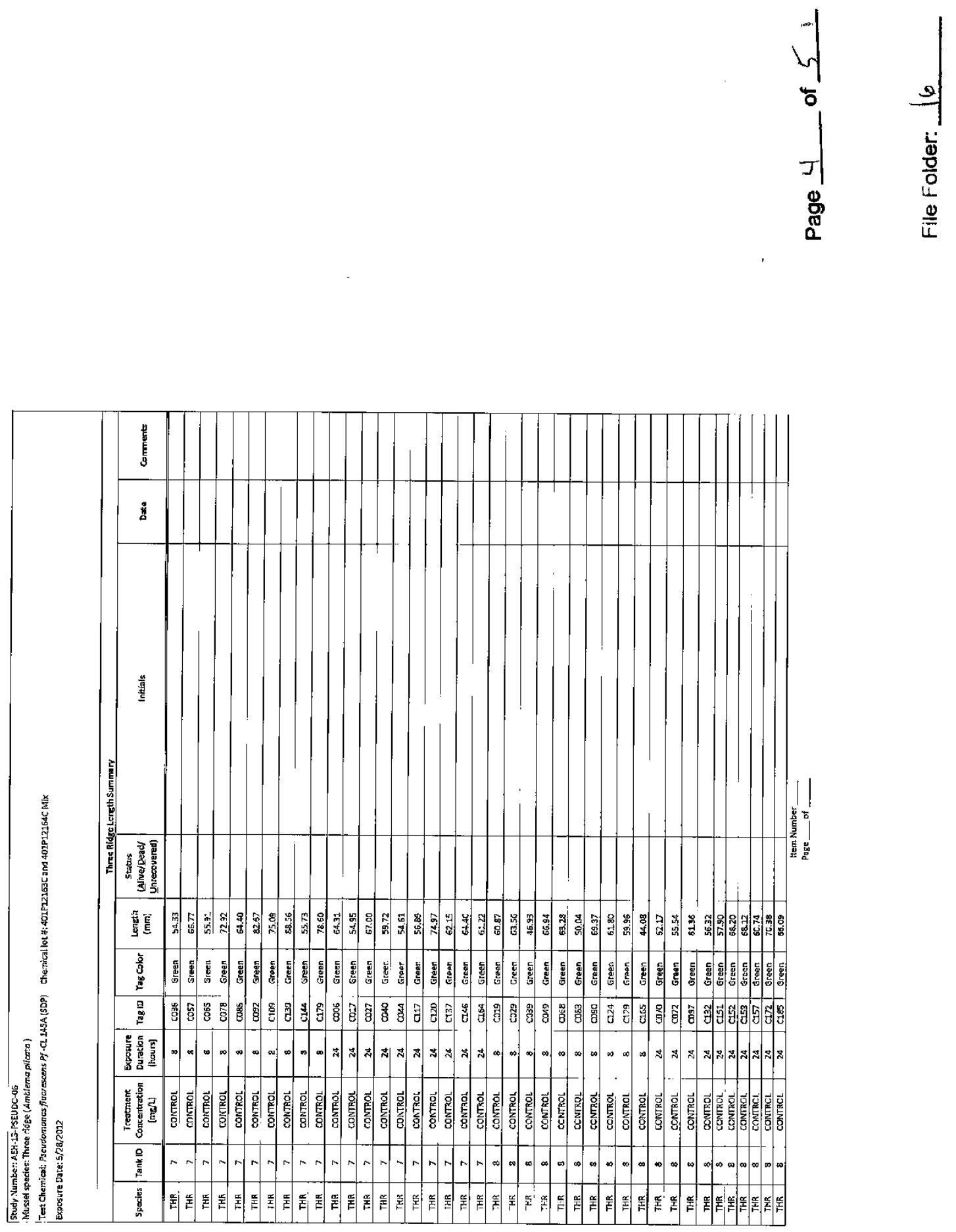
$=\mid$

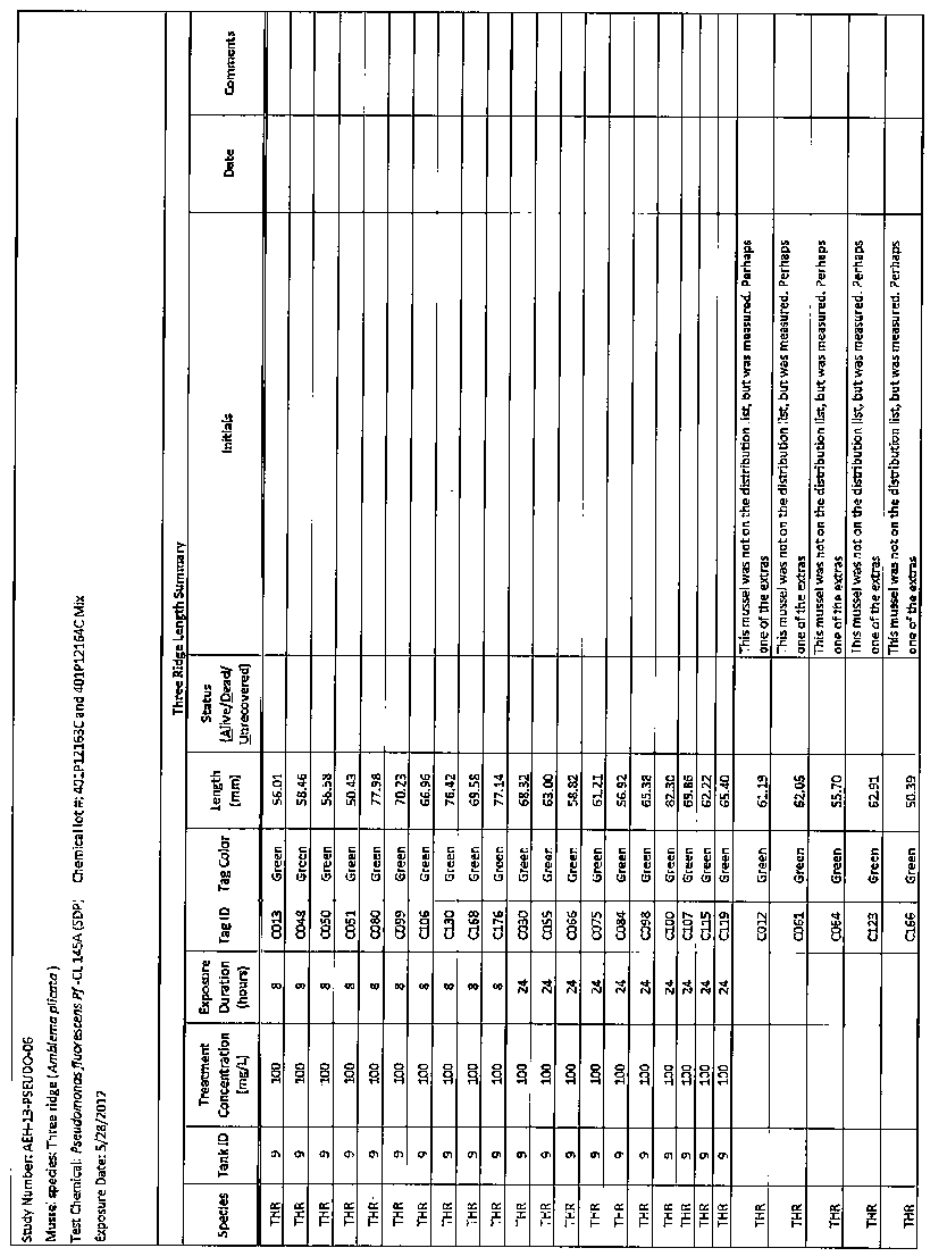

$\mid$ 

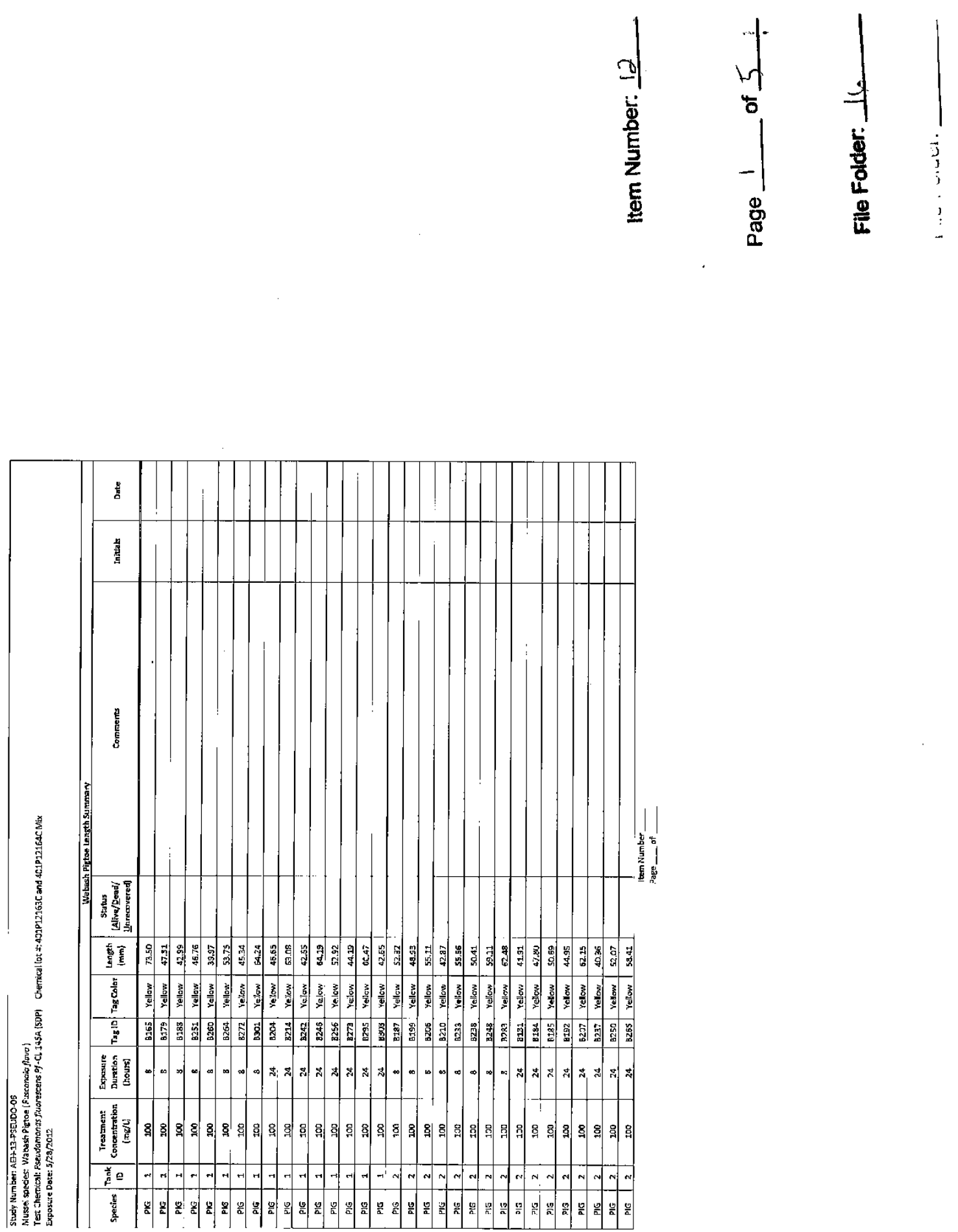

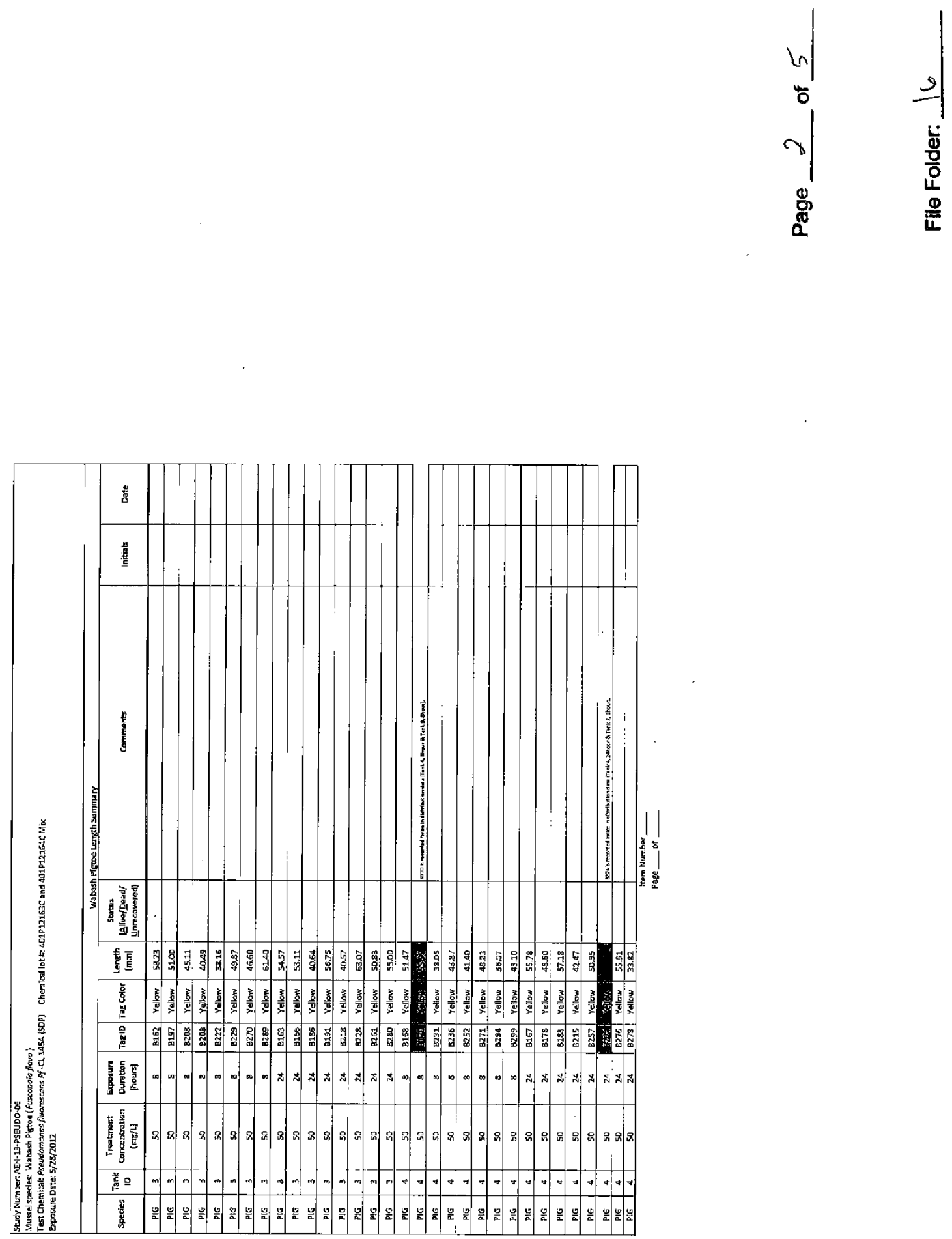

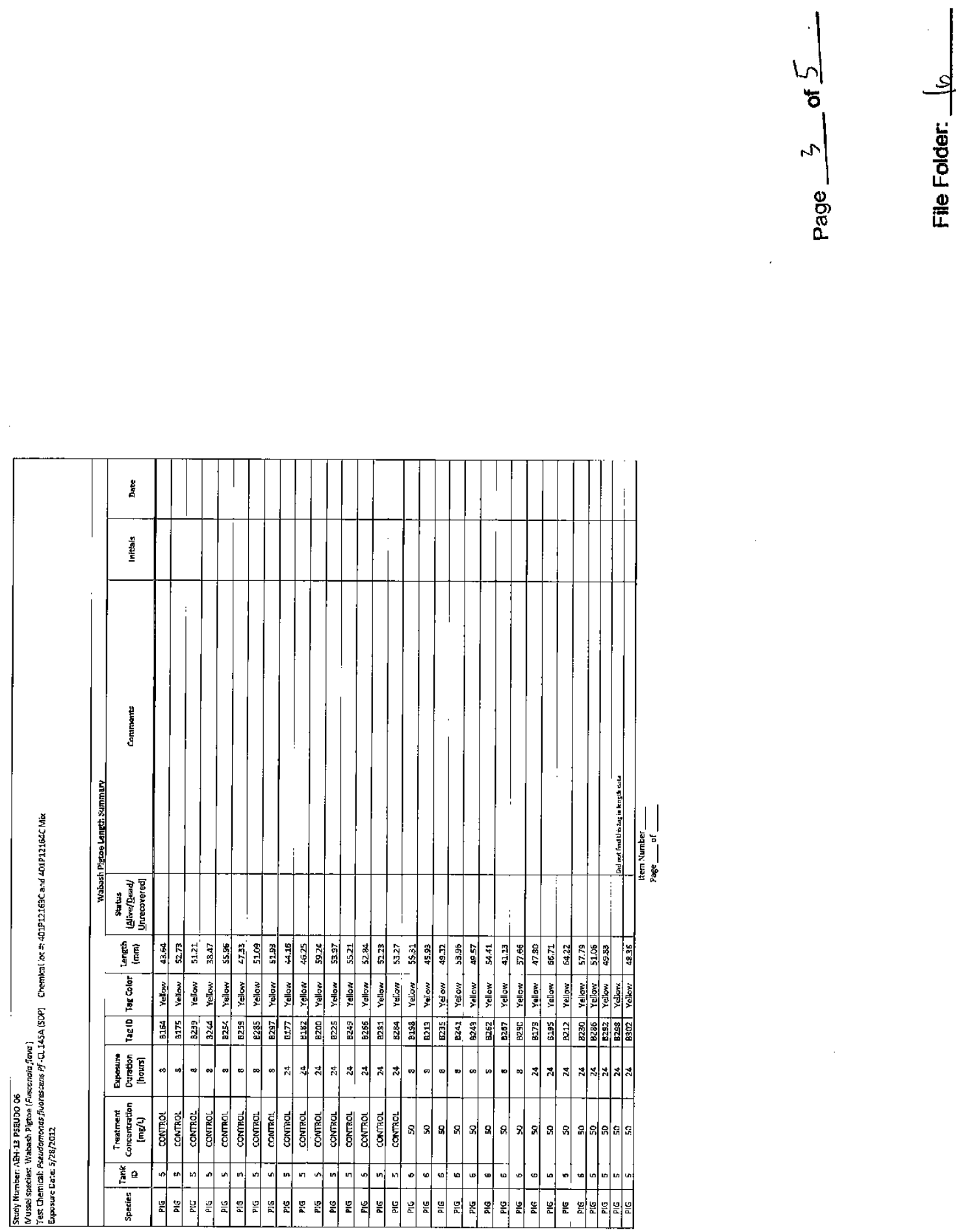

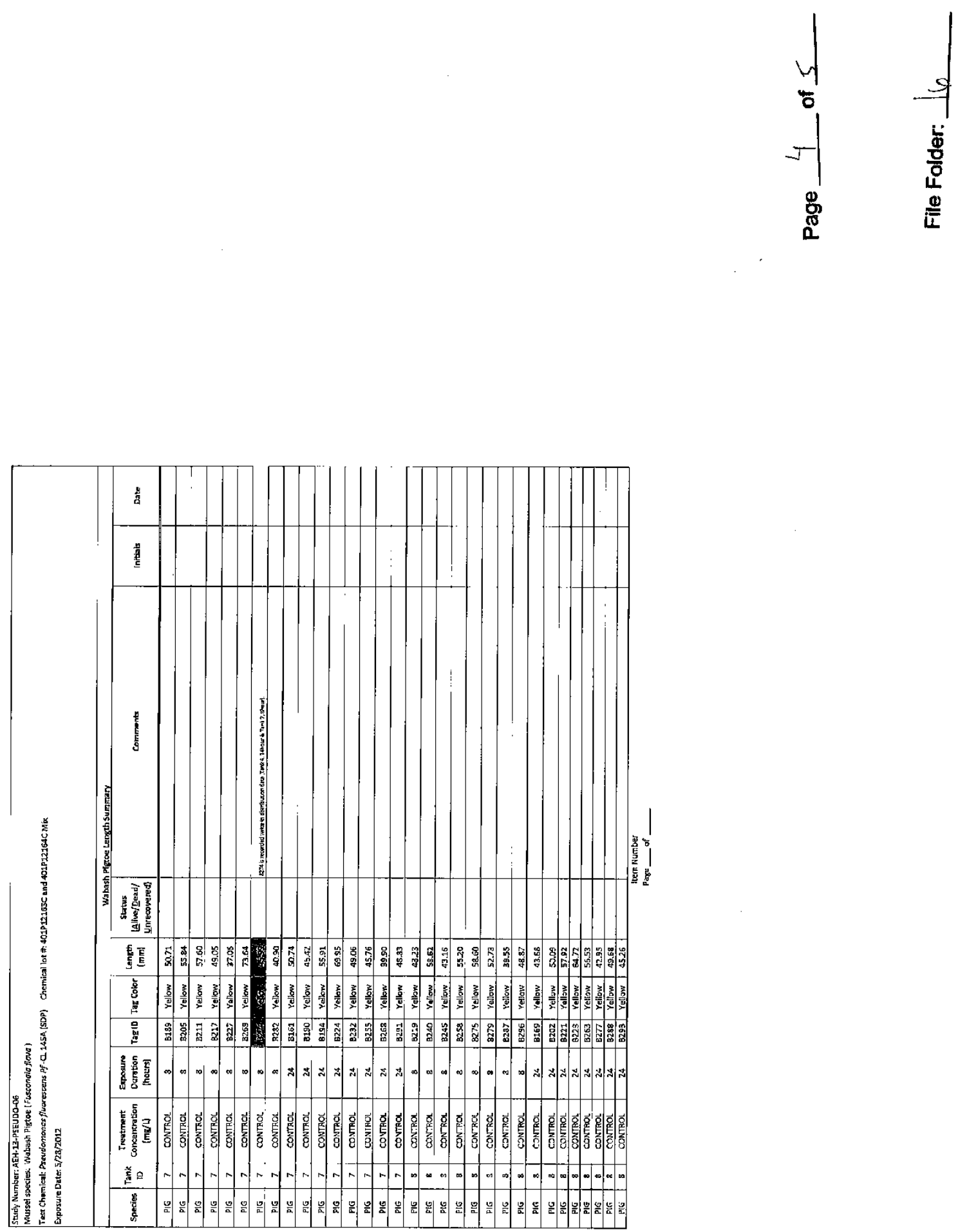

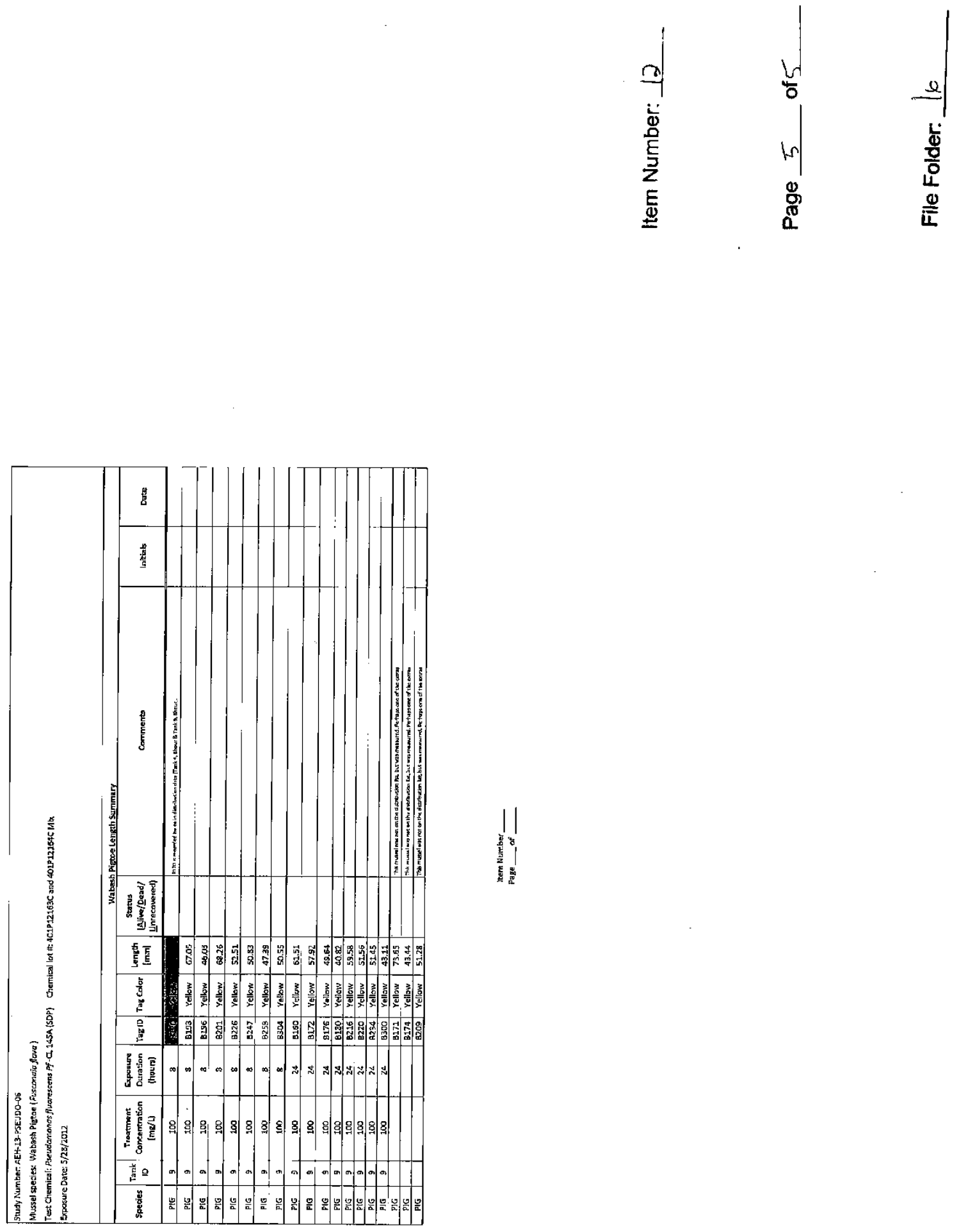

$\mid$ 
Study Number: AEH-13-PSEUDO-06

File Folder:

Lab book/pgs:
Reviewed by:

verifled by:

Date:

Date

\section{Native Mussel Lengths}

\begin{tabular}{|c|c|c|c|c|c|c|c|}
\hline $\begin{array}{l}\text { Exposure } \\
\text { Test Chem }\end{array}$ & $\begin{array}{l}\text { ate: } \\
\text { cal: } \underline{P f-C L 1}\end{array}$ & $45 \mathrm{~A}$ SDP & 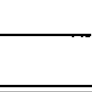 & $\begin{array}{l}\text { Test Loc } \\
\text { Lot \#: } 4\end{array}$ & on: & $01 \mathrm{P} 12164 \mathrm{CN}$ & - \\
\hline $\begin{array}{l}\text { Mussel } \\
\text { Species }\end{array}$ & $\begin{array}{l}\text { Mussel } \\
\text { Number }\end{array}$ & $\begin{array}{c}\text { Tag } \\
\text { Number }\end{array}$ & $\begin{array}{l}\text { Tag } \\
\text { Color }\end{array}$ & $\begin{array}{c}\text { Glue } \\
\text { Dot } \\
\text { (Y/N) }\end{array}$ & $\begin{array}{c}\text { Shell } \\
\text { Length } \\
(\mathrm{mm})\end{array}$ & Comments & Date/Initials \\
\hline & & & & & & & \\
\hline & & & & & & & \\
\hline & & & & & & & \\
\hline & & & & & & & \\
\hline & & & & & & & \\
\hline & & & & & & & \\
\hline & & & & & & & \\
\hline & & & & & & & \\
\hline & & & & & & & \\
\hline & & & & & & & \\
\hline & & & & & & & \\
\hline & & & & & & & \\
\hline & & & & & & & \\
\hline & & & & & & & \\
\hline & & & & & & & \\
\hline & & & & & & & \\
\hline & & & & & & & \\
\hline & & & & & & & \\
\hline & & & & & & & \\
\hline & & & & & & & \\
\hline & & & & & & & \\
\hline & & & & & & & \\
\hline & & & & & & & \\
\hline & & & & & & & \\
\hline & & & & & & & \\
\hline & & & & & & & \\
\hline & & & & & & & \\
\hline
\end{tabular}

Item Number: 13

File Folder: 16

Page 1 of 1 
Study Number: AEH-13-PSEUDO-06

File Folder:
Reviewed by

Verified by:

Date:

Date:

Native Mussel Lengths

\begin{tabular}{|c|c|c|c|c|c|c|c|}
\hline \multicolumn{4}{|c|}{$\begin{array}{l}\text { Exposure Date: } \\
\text { Test Chemical: pf-CL145A SDP }\end{array}$} & \multicolumn{4}{|c|}{$\begin{array}{l}\text { Test Location: } \\
\text { Lot \#: 401P12163C and 401P12164C Mix }\end{array}$} \\
\hline $\begin{array}{l}\text { Mussel } \\
\text { Specles }\end{array}$ & $\begin{array}{l}\text { Mussel } \\
\text { Number }\end{array}$ & $\begin{array}{c}\text { Tag } \\
\text { Number }\end{array}$ & $\begin{array}{l}\text { Tag } \\
\text { Color }\end{array}$ & $\begin{array}{c}\text { Shell } \\
\text { Length } \\
(\mathrm{mm}) \\
\end{array}$ & Tank ID & Sampling Time & Date/Initials \\
\hline & & & & & & & \\
\hline & & & & & & & \\
\hline & & & & & & & \\
\hline & & & & & & & \\
\hline & & & & & & & \\
\hline & & & & & & & \\
\hline & & & & & & & \\
\hline & & & & & & & \\
\hline & & & & & & & \\
\hline & & & & & & & \\
\hline & & & & & & & \\
\hline & & & & & & & \\
\hline & & & & & & & \\
\hline & & & & & & & \\
\hline & & & & & & & \\
\hline & & & & & & & \\
\hline & & & & & & & \\
\hline & & & & & & & \\
\hline & & & & & & & \\
\hline & & & & & & & \\
\hline & & & & & & & \\
\hline & & & & & & & \\
\hline & & & & & & & \\
\hline & & & & & & & \\
\hline & & & & & & & \\
\hline & & & & & & & \\
\hline & & & & & & & \\
\hline
\end{tabular}

Item Number: 14

File Folder: 16

Page 1 of 1 


\section{Appendix 2. Deviations From the Study Protocol}

\begin{tabular}{clcc}
\hline $\begin{array}{c}\text { Item } \\
\text { Number }\end{array}$ & \multicolumn{1}{c}{ Item Description } & $\begin{array}{c}\text { Number } \\
\text { of } \\
\text { Pages }\end{array}$ & $\begin{array}{c}\text { Report } \\
\text { Page } \\
\text { Number }\end{array}$ \\
\hline 1 & $\begin{array}{c}\text { Deviation \#1 - Native mussels recovered from tanks/equipment after the termination } \\
\text { of the assigned treatment period }\end{array}$ & 1 & 101 \\
2 & Deviation \#2 - Native mussels not recovered after 30 day holding period & 1 & 102 \\
3 & Deviation \#3 - Native mussel used in exposure >3 years of age & 1 & 103 \\
\hline
\end{tabular}




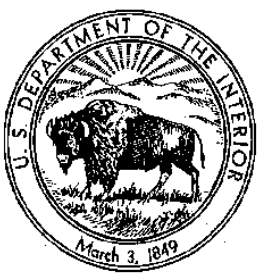

\author{
United States Department of the Interior \\ U.S. GEOLOGICAL SURVEY \\ Biological Resources Division \\ Upper Midwest Environmental Sciences Center \\ 2630 Fanta Reed Road \\ La Crosse, Wisconsin 54603
}

\title{
MEMORANDUM
}

Date: January 29,2014

To: $\quad$ The Record of Study Number AEH-13-PSEUDO-06

Subject: Deviation 1 to study AEH-13-PSEUDO-06 "Safety of Spray Dried Powder (SDP) Formulated Pseudomonas fluorescens strain CL145A (Zequanox) Exposure to Sub-Adult Unionid Mussels During Simulated Open Water Treatments"

Deviation \#1 - Native mussels recovered from tanks/equipment after the termination of the assigned treatment period

After exposure termination, the tanks were emptied for cleaning and two mussels were found buried in the sediment of their respective tanks. Mussel A296 ( $L$. cardium; $100 \mathrm{mg} / \mathrm{L}$ 24-h treatment group) from Tank 2 and mussel B089 ( $L$. higginsii; 0 mg/L 24-h treatment group) from Tank 8 were recovered alive and placed into the appropriate replicate wire mesh holding cage for the post-exposure period. Both mussels were alive upon assessment at the conclusion of the 30 day post-exposure holding period.

Upon study breakdown mussel B150 (L. higginsii; 50mg/L 8-h treatment group) from Tank 4 was discovered in a corner of retention basket used to contain the mussels during the treatment. The retention basket had been removed from study tank 4 for $\sim 16 \mathrm{~h}$ before the mussel was discovered alive and placed into a wire mesh holding cage for the post-exposure period. During the survival assessment (June 26-27, 2013) mussel B150 was originally thought to have been unrecovered, however, mussel B150 was recovered alive in the wire mesh holding cage housing the test animals from $50 \mathrm{mg} / \mathrm{L}$ 24-h treatment group during the postexposure holding period.

There are no adverse impacts as a result of this deviation as all animals were recovered alive at the termination of the post-exposure holding period and there are sufficient numbers of other test animals from the affected treatment groups to perform statistical analyses.

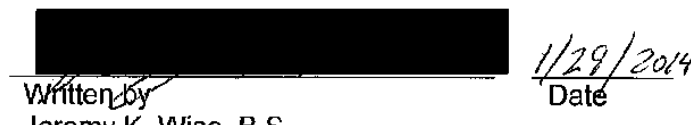

Jeremy K. Wise, B.S.

Bio. Science Tech. II, UMESC

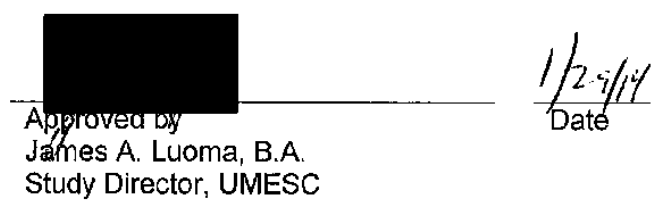

CC: UMESC QAU

Flle Folder: 3

Page 1 of 1

tem Number: 3 


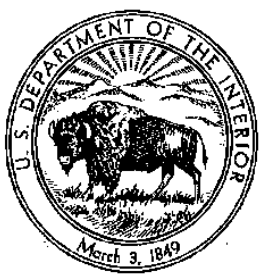

United States Department of the Interior

U.S. GEOLOGICAL SURVEY

Biological Resources Division

Upper Midwest Environmental Sciences Center

2630 Fanta Reed Road

La Crosse, Wisconsin 54603

MEMORANDUM

Date: January 29, 2014

To: The Record of Study Number AEH-13-PSEUDO-06

Subject: Deviation 2 to study AEH-13-PSEUDO-06 "Safety of Spray Dried Powder (SDP) Formulated Pseudomonas fluorescens strain CL145A (Zequanox) Exposure to Sub-Adult Unionid Mussels During Simulated Open Water Treatments"

Deviation \#2 - Native mussels not recovered after 30 day holding period

During the native mussel survival assessment conducted after 30 day holding period, five mussels from 3 treatment groups and 4 replicates were not recovered from the wire mesh hoiding cages. The unrecovered mussels species, corresponding tag numbers, treatment group and treatment replicate (i.e. tank) are identified in table 1.

Table 1. Mussels not recovered during survival assessment.

\begin{tabular}{|c|c|c|c|}
\hline Species & $\begin{array}{c}\text { Tag } \\
\text { number }\end{array}$ & $\begin{array}{c}\text { Treatment } \\
\text { group }\end{array}$ & $\begin{array}{c}\text { Treatment } \\
\text { Tank }\end{array}$ \\
\hline L. cardium & $\mathrm{A} 193$ & $100 \mathrm{mg} / \mathrm{L} 24 \mathrm{~h}$ & 2 \\
\hline L. cardium & $\mathrm{A} 191$ & $50 \mathrm{mg} / \mathrm{L} 24$ & 3 \\
\hline L. higginsii & $\mathrm{B} 051$ & $0 \mathrm{mg} / \mathrm{L} 24 \mathrm{~h}$ & 5 \\
\hline L. higginsii & $\mathrm{B} 117$ & $50 \mathrm{mg} / \mathrm{L}: 24 \mathrm{~h}$ & 6 \\
\hline O. olivaria & $\mathrm{D} 010$ & $100 \mathrm{mg} / \mathrm{L} 24 \mathrm{~h}$ & 2 \\
\hline
\end{tabular}

These mussels are identified as unrecovered in the study records and if they are used in the statistical analysis they will be treated conservatively as mortalities.

No adverse impacts are anticipated as a result of this deviation. Any impacts to the study as a result of this deviation will be addressed in the final report.

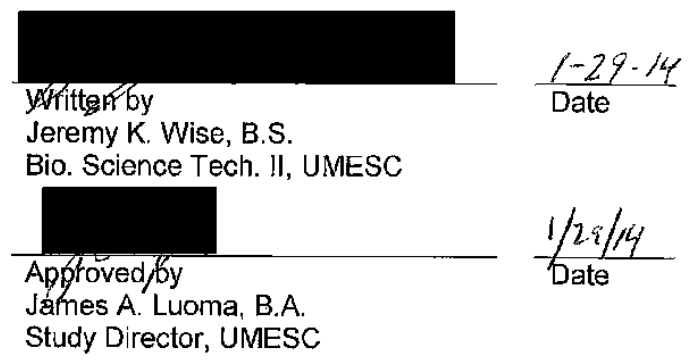

CC: UMESC QAU

File Folder: 3

Page 1 of 1

Item Number: 4 


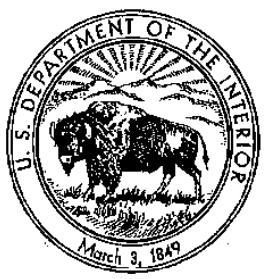

\author{
United States Department of the Interior \\ U.S. GEOLOGICAL SURVEY \\ Biological Resources Division \\ Upper Midwest Environmental Sciences Center \\ 2630 Fanta Reed Road \\ La Crosse, Wisconsin 54603
}

MEMORANDUM

Date: March 7, 2014

To: The Record of Study Number AEH-13-PSEUDO-06

Subject: Deviation 3 to study AEH-13-PSEUDO-06 "Safety of Spray Dried Powder (SDP) Formulated Pseudomonas fluorescens strain CL145A (Zequanox) Exposure to Sub-Adult Unionid Mussels During Simulated Open Water Treatments"

Deviation $\# 3$ - Native mussel $>3$ years of age

Wabash pigtoe (Fusconaia flava) and threeridge (Amblema plicata) mussels used in study were wild collected on May 10, 2013 from the Upper Mississippi River (RM 670.5), at Black Hawk Park, Vernon County, Wisconsin by Genoa National Fish Hatchery Biologist. Although not confirmed, the age of these mussels appeared to be greater than three years old and many appeared to be sexually mature individuals. These mussels would be more appropriately classified as adult specimens and not sub-adult specimens.

No adverse impacts are anticipated as a result of this deviation. Any impacts to the study as a result of this deviation will be addressed in the final report.

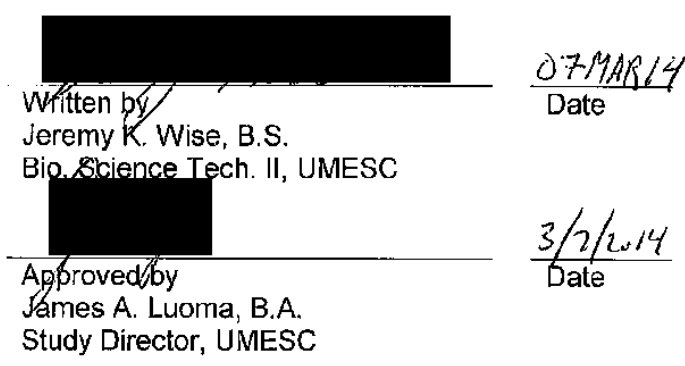

cC: UMESC QAU

nem Number: 5

Page 1 of 1

Hemontumer:

Illegible. JKW OFMARIA
File Folder: 3 


\section{Appendix 3. Randomization Assignments}

\begin{tabular}{clcc}
\hline $\begin{array}{c}\text { Item } \\
\text { Number }\end{array}$ & \multicolumn{1}{c}{ Item Description } & $\begin{array}{c}\text { Number } \\
\text { of } \\
\text { Pages }\end{array}$ & $\begin{array}{c}\text { Report } \\
\text { Page } \\
\text { Number }\end{array}$ \\
\hline 1 & SAS generated random assignment of treatment to experimental tanks. & 5 & 105 \\
2 & SAS generated random assignment of mussels to test tanks/time sections. & 6 & 110 \\
3 & Hickorynut assignment to treatment tanks & 1 & 116 \\
4 & Washboard assignment to treatment tanks & 1 & 117 \\
5 & Higgins eye assignment to treatment tanks & 1 & 118 \\
6 & Fatmucket assignment to treatment tanks & 1 & 129 \\
7 & Threeridge assignment to treatment tanks & 1 & 120 \\
8 & Wabash Pigtoe assignment to treatment tanks & 1 & 121 \\
9 & Plain Pocketbook assignment to treatment tanks & 1 & 122 \\
\hline
\end{tabular}




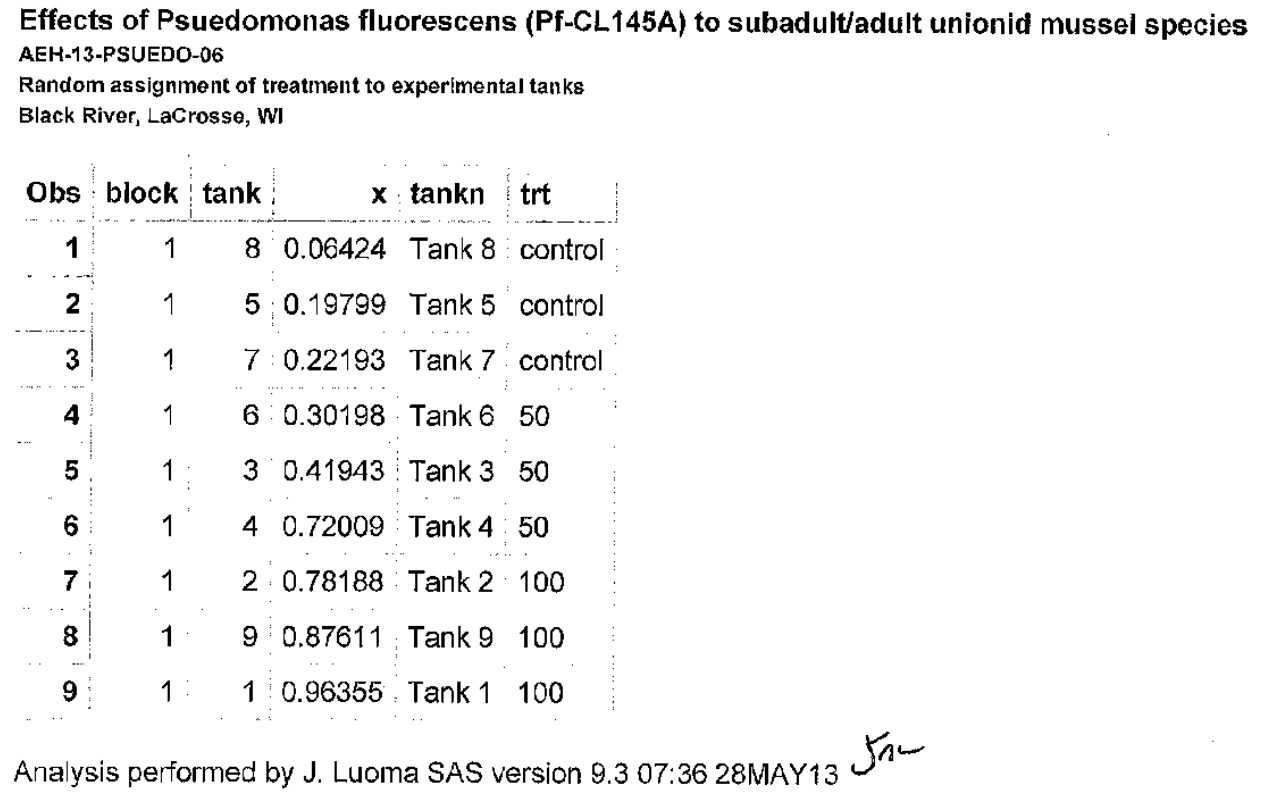

\section{AEH-13-PSEUDO-06}

File Folder: 14

Item Number: 1 Page 1 of 5 


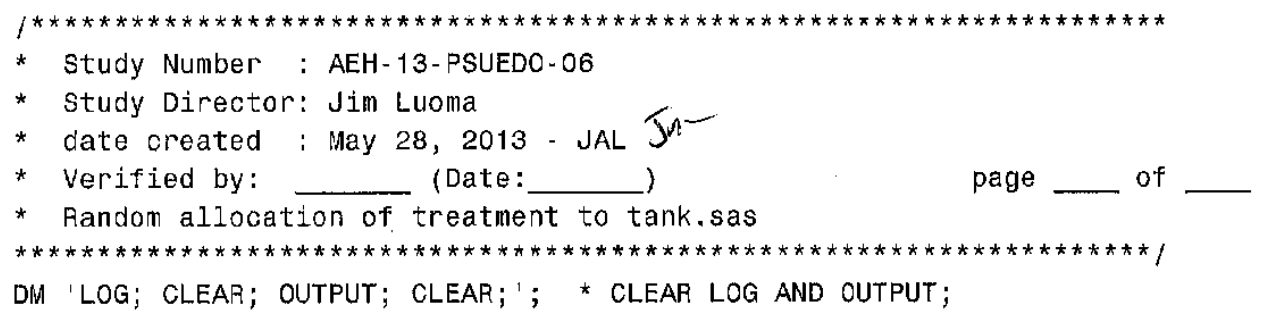

FOOTNOTE1 'Analysis performed by $J$. Luoma SAS version ' \&SYSVER \&SYSTIME \&SYSDATE;

options $/{ }^{*} \mathrm{ls}=85 \mathrm{ps}=40$ formalim=' $\cdot$ * $/$ pageno $=1$ nocenter nodate nosource2;

$I^{*}$ Random assignment of treatment to experimental tanks*/

/*AEH-PSEUDO-06; Subadult/adult mussels; Black River, Lacrosse, WI*/

data MUS;

do block $=1$ to 1 by 1 ;

do $\operatorname{tank}=1$ to 9 by 1 ;

$x=\operatorname{ranuni}(-1) ;$

output;

end;

end;

run;

data MUS2; set MUS;

if block $=1$ and tank $=1$ then $\operatorname{tankn}=$ 'Tank $1^{\prime}$;

if block $=1$ and $\operatorname{tank}=2$ then tankn = 'Tank $2^{\prime}$;

if block $=1$ and tank $=3$ then tankn $={ }^{\prime}$ Tank $3^{\prime}$;

if block $=1$ and tank $=4$ then $\operatorname{tankn}=$ 'Tank 4 ';

if block $=1$ and tank $=5$ then tankn $={ }^{\prime}$ Tank $5^{\prime}$;

if block $=1$ and $\operatorname{tank}=6$ then tankn $={ }^{\prime}$ Tank $6^{\prime}$;

if block $=1$ and $\operatorname{tank}=7$ then tankn $={ }^{\prime}$ Tank $7^{\prime}$;

if block $=1$ and tank $=8$ then tankn $=$ 'Tank $8^{\prime}$;

if block $=1$ and tank $=9$ then tankn $={ }^{\prime}$ Tank $9^{\prime}$;

if block $=2$ and tank $=1$ then $\operatorname{tankn}=$ 'Tank $1^{\prime}$;

if block $=2$ and tank $=2$ then tankn = 'Tank $2^{\prime}$;

if block $=2$ and tank $=3$ then tankn $=$ 'Tank $3^{\prime}$;

if block $=2$ and tank $=4$ then tankn = 'Tank $4^{\prime}$;

if block $=2$ and tank $=5$ then tankn $=$ Tank 5 ;

if block $=2$ and $\operatorname{tank}=6$ then $\operatorname{tankn}={ }^{\prime}$ Tank $6^{\prime}$;

if block $=2$ and tank $=7$ then $\operatorname{tankn}={ }^{\prime}$ Tank $7^{\prime}$;

if block $=2$ and tank $=8$ then tankn $=$ 'Tank $8^{\prime}$;

if block $=2$ and tank $=9$ then $\operatorname{tankn}={ }^{\prime}$ Tank $9 '$;

if block $=3$ and tank $=1$ then tankn $={ }^{\text {Tank }} 1^{\prime}$;

if block $=3$ and tank $=2$ then $\operatorname{tankn}={ }^{\prime}$ Tank $2^{\prime}$;

if block $=3$ and $\tan k=3$ then tankn $=$ 'Tank $3^{\prime}$;

if block $=3$ and tank $=4$ then tankn $=$ 'Tank $4^{\prime}$;

AEH-13-PSEUDO-06

if block $=3$ and tank $=5$ then tankn $=$ 'Tank 5 ;

if block $=3$ and $\operatorname{tank}=6$ then $\operatorname{tankn}={ }^{\prime}$ Tank $6^{\prime}$;

if block $=3$ and tank $=7$ then $\operatorname{tankn}={ }^{\prime}$ Tank $7 '$;

if block $=3$ and tank $=8$ then tankn $=$ 'Tank $8^{\prime}$;

if block $=3$ and tank $=9$ then tankn $=$ 'Tank $^{\prime} 9^{\prime}$;

Page 2 of 5

run;

proc sort data=mus2; 
by $x$;

run;

data assign_trt_MUS; set MUS2;

if $n_{-}=1$ then trt = 'control';

if $n_{-}=2$ then trt = 'control';

if _n_ $=3$ then trt $=$ 'control';

if $n_{-}=4$ then trt $=150^{\prime}$;

if $n_{-}=5$ then trt $=150^{\prime}$;

if $\bar{n}_{-}=6$ then trt $=150^{\prime}$;

if $n_{-}=7$ then trt $=1100^{\prime}$;

if $n_{-}=8$ then trt $=1100^{\prime}$;

if ${ }_{-} n_{-}=9$ then trt $=1001$;

run;

proc print data= assign_trt_MUS;

title1 $h=2$ 'Effects of Psuedomonas fluorescens (Pf-CL145A) to subadult/adult unionid mussel species';

title2 h=1.5 'AEH-13-PSUEDO-06';

titles $h=1$ 'Random assignment of treatment to experimental tanks';

title4 $h=1$ 'Black River, Lacrosse, 'WI';

run;

AEH-13-PSEUDO-06

Page 3 of 5 


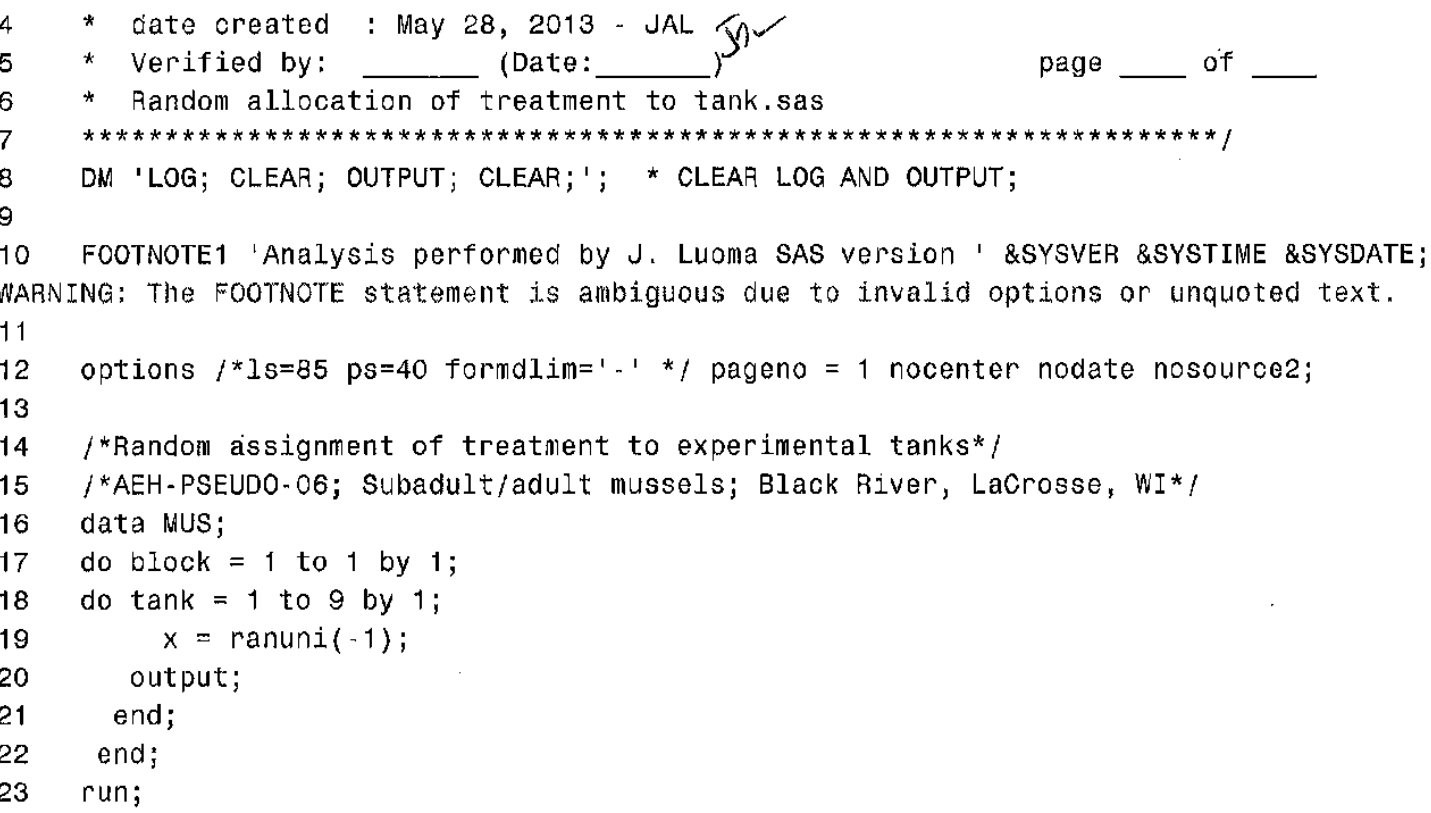

NOTE: The data set WORK.MUS has 9 observations and 3 variables.

NOTE: DATA statement used (Total process time):
real time
0.10 seconds
cpu time
0.01 seconds

data MUS2; set MUS;
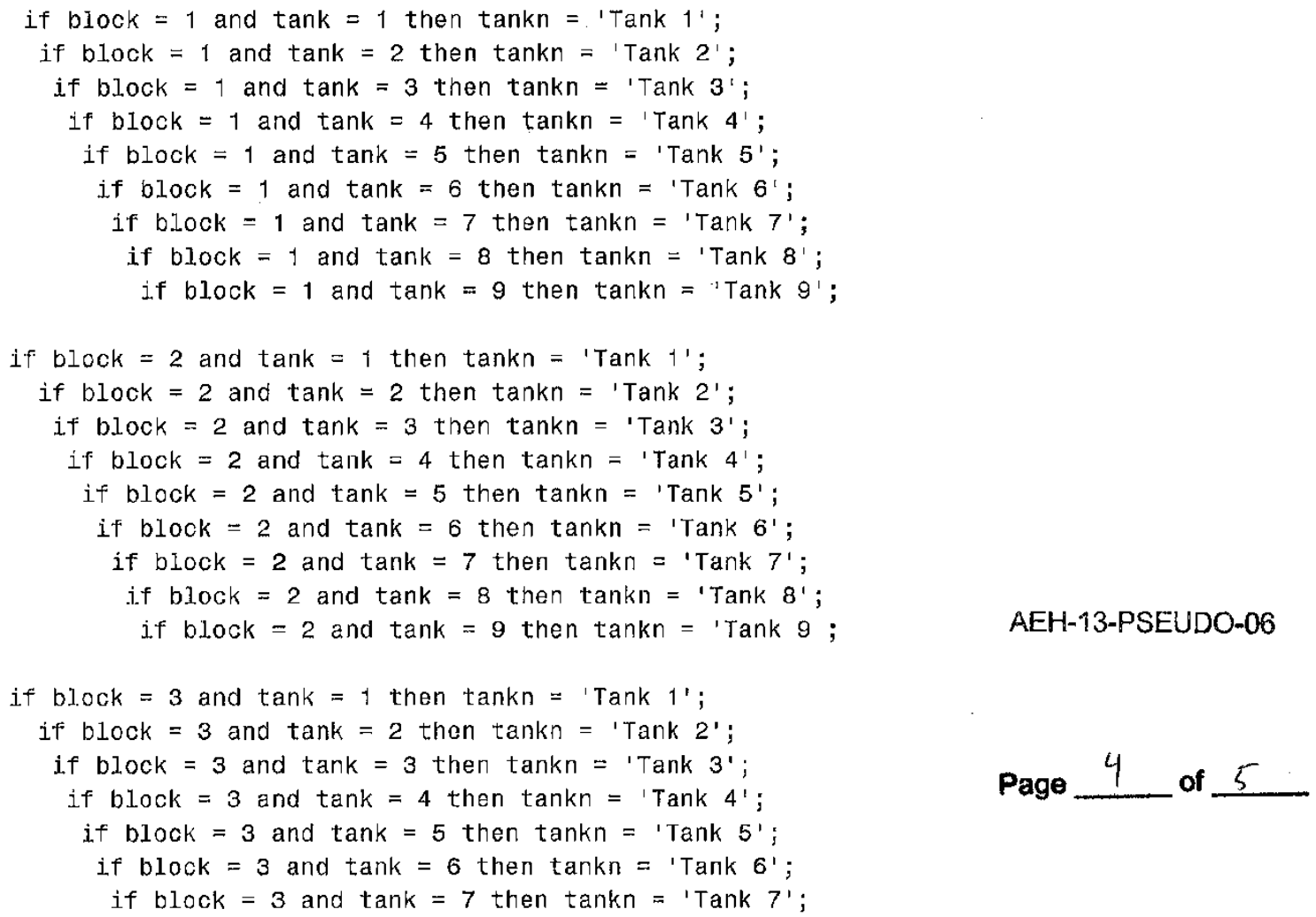
54

55

NOTE: There were 9 observations read from the data set WORK.MUS.

NOTE: The data set WORK.MUS2 has 9 observations and 4 variables.

NOTE: DATA statement used (Total process time):
real time
0.03 seconds

cpu time

0.03 seconds
56 proc sort data=MUS2;
57 by $x ;$
58 run;

NOTE: There were 9 observations read from the data set WORK.MUS2.

NOTE: The data set WORK. MUS2 has 9 observations and 4 variables.

NOTE: PROCEDURE SORT used (Total process time):
real time
0.03 seconds
cpu time
0.00 seconds

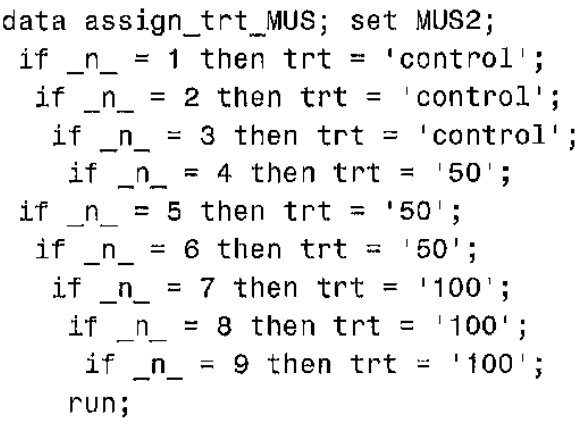

NOTE: There were 9 observations read from the data set WORK.MUS2.

NOTE: The data set WORK.ASSIGN_TRT_MUS has 9 observations and 5 variables,

NOTE: DATA statement used (Total process time):

real time $\quad 0.01$ seconds

cpu time $\quad 0.01$ seconds

71 proc print data= assign_trt_Mus;

NOTE: Writing HTML Body file: sashtml.htm

72 title1 $h=2$ :Effects of Psuedomonas fluorescens (PF-CL145A) to subadult/adult unionid mussel

72 ! species';

73 title2 $n=1.5$ 'AEH-13-PSUEDO-06';

74 titles $h=1$ 'Random assignment of treatment to experimental tanks';

AEH-13-PSEUDO-06

75 title4 $h=1$ 'Black River, LaCrosse, WI';

76 run;

NOTE: There were 9 observations read from the data set WORK.ASSIGN_TRT_MUS.

NOTE: PROCEDURE PRINT used (Total process time):
real time
0.67 seconds
cpu time
0.29 seconds

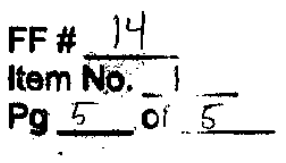


Effects of Psuedomonas fluorescens (Pf-CL145A) to subadult/adult mussels AEH-13-PSUEDO-06

Random assignment of mussels to tost tanks/time sections

Combined speciesitime exposures-Black River, Lacrosse, in $\mathrm{fn}^{2}$

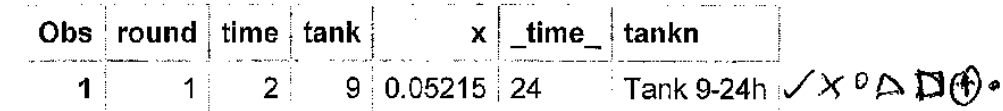

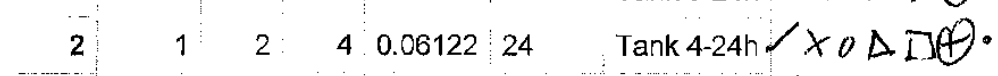

$$
\begin{aligned}
& 3 \quad 1 \quad 1 \quad 90.07230 \text { 8h Tank } 9-8 \mathrm{~h} / \times 0 \Delta D \text {. } \\
& 4 \quad 1 \quad 1 \quad 70.190258 \mathrm{~h} \quad \text { Tank } 7-8 \mathrm{~h} / X 0 \Delta D \theta \text {. }
\end{aligned}
$$

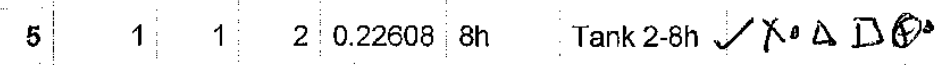

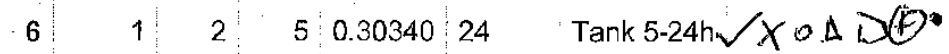

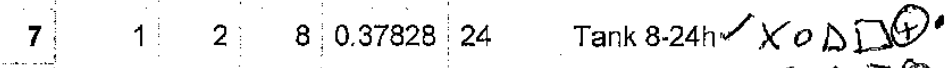

$$
\begin{aligned}
& \begin{array}{l|l|lllll}
8 & 1 & 2 & 2 & 0.38032 & 24 & \text { Tank } 224 h \triangle X \circ \triangle D
\end{array} \\
& 9 \quad 1 \quad 1 \quad 10.439048 \mathrm{~h} \text { Tank 1-8h } / X_{0} \Delta D \mathbb{0} .
\end{aligned}
$$

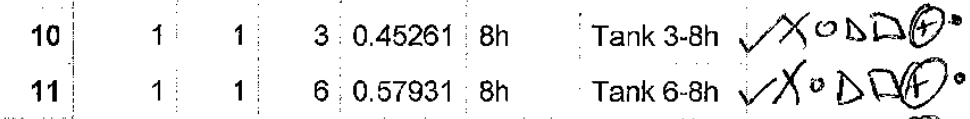

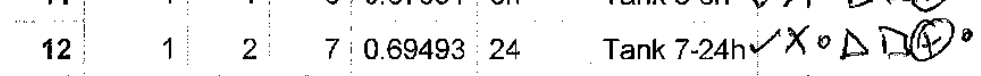

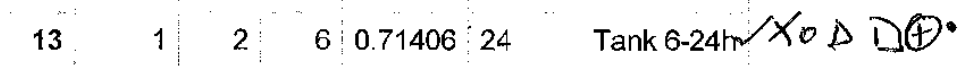

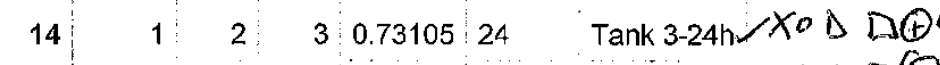

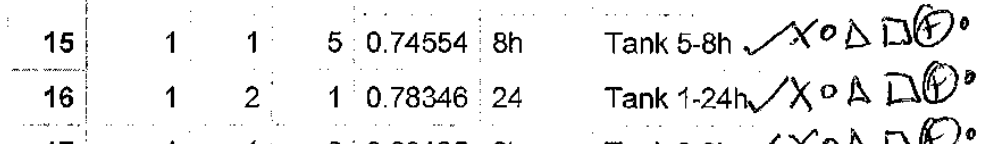

$$
\begin{aligned}
& 17 \quad 1 \quad 1: 80.80125 \text { 8h Tank } 8 \text {-8h } \checkmark X \circ \Delta \square(4) \\
& 18 \quad 1 \quad 1 \quad 4: 0.84428 \text { 8h Tank 4-8h } \angle \circ \Delta D \text {. } \\
& \begin{array}{llllll}
19 & 2 & 2 & 5 & 0.1403524 & \text { Tank 5-24h } / X \circ D D Q
\end{array} \\
& 20 \quad 2 \quad 2 \quad 60.1811124 \text { Tank 6-24h } X^{\circ} \Delta D(9 \\
& \begin{array}{llllll}
21 & 2 & 2 & 9 & 0.1945124 & \text { Tank } 9-24 h / X \circ D \\
-
\end{array} \\
& 22 \quad 2 \quad 1 \quad 80.26810 \text { 8h Tank } 8-8 h \backslash x \circ \Delta D A \text {. } \\
& \begin{array}{lllllllll}
23 & 2 & 1 & 7 & 0.26833 & 8 \mathrm{~h} & \text { Tank } 7-8 \mathrm{~h} / X \circ \Delta \square \Theta . \\
24 & 2 & 2 & 1.0 .35685: 24 & \text { Tank } 1-24 \mathrm{~h} \backslash X \circ \Delta \square \notin 0
\end{array} \\
& 25 \quad 2: 1 \quad 60367788 \mathrm{~h} \quad \text { Tank 6-8h } \checkmark X \circ \Delta D \notin \\
& 26 \quad 2: 1 \quad 30.40863 \text { 8h Tank 3-8h } \checkmark X \circ D \square \in . \\
& 27 \quad 2 \quad 1 \quad 90.414808 \mathrm{~h} \quad \text { Tank 9-8h } \checkmark \text { X } D \Delta \Theta . \\
& \begin{array}{llllllll}
28 & 2 & 2 & 7 & 0.41865 & 24 & \text { Tank } 7-24 h / X_{0} \Delta \square & \Delta .
\end{array} \\
& 29 \quad 2 \quad 2 \quad 30.5470624 \quad \text { Tank 3-24h } / X \circ \triangle D \Theta .
\end{aligned}
$$

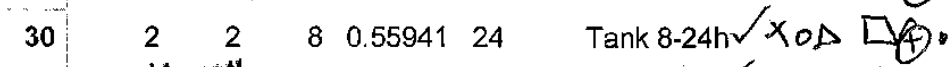

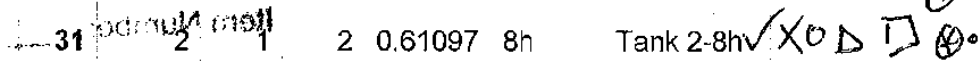$$
\text { ................. }
$$

Fille Foldefition 1 in
A mark was placed next is the tank as mossels were distribsted. $\sqrt{ }=$ Trure ridge moseds $x=$ Fat mucket mussels - Wabash Pigtoe mussals $\Delta=$ Hickoryn $\square=$ Washbourd mossels (1) = Plain Pocketbook mussels
- Higgins Eye Mussols
xWO
13 FeB2014

\section{AEH-13-PSEUDO-06}

Item Number: 2 incercates

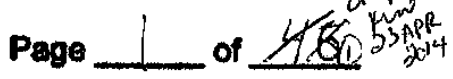




\begin{tabular}{|c|c|c|c|c|c|c|c|}
\hline 32 & 2 & 1 & 1 & 0.62183 & $8 \mathrm{~h}$ & Tank 1-8h $/ x_{\circ} \triangle \square(4)$ & \\
\hline 33 & 2 & 2 & 4 & 0.69710 & 24 & Tank 4-24h $/ X \circ \Delta \square X$ & AEH-13-PSEUDO-06 \\
\hline 34 & 2 & 1 & 5 & 0.73459 & $8 h$ & Tank 5-8h $\checkmark X O D D \otimes \bullet$ & \\
\hline 35 & 2 & 2 & 2 & 0.76445 & 24 & Tank 2-24h $\checkmark \times \circ \triangle D Q$ & \\
\hline 36 & 2 & 1 & 4 & 0.90646 & $8 \mathrm{~h}$ & Tank 4-8h $/ X \circ \Delta D \theta$ & \\
\hline
\end{tabular}

Analysis performed by $\mathrm{J}$. Luoma SAS version $9.308: 1728 \mathrm{MAY} 13 \sqrt{\mathrm{r}-}$

:admuth mont

10 0889

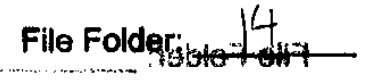

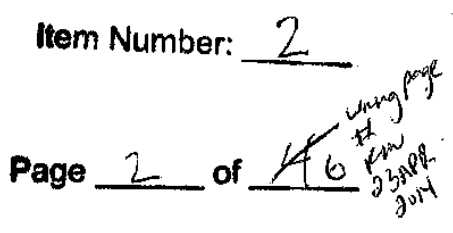




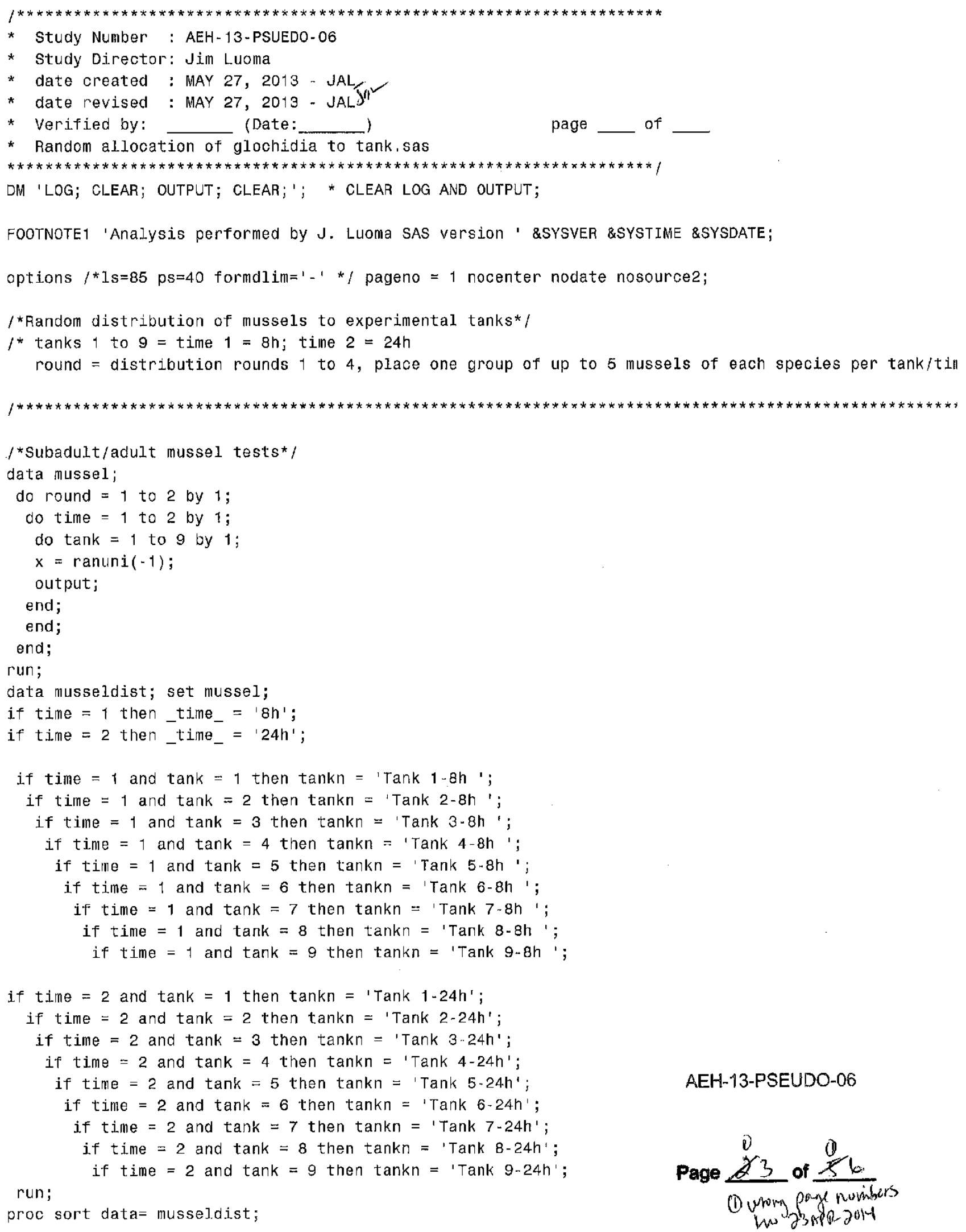


by rounó $x$;

run;

proc print data $=$ musseldist;

title1 $\mathrm{h}=2$ 'Effects of Psuedomonas fluorescens (Pf-CL145A) to subadult/adult mussels';

title2 $\mathrm{h}=1.5$ 'AEH-13-PSUEDO-06';

title3 $h=1$ 'Random assignment of mussels to test tanks/time sections';

title4 $h=1$ 'Combined species/time exposures-Black River, Lacrosse, WI';

run;

AEH-13-PSEUDO-06

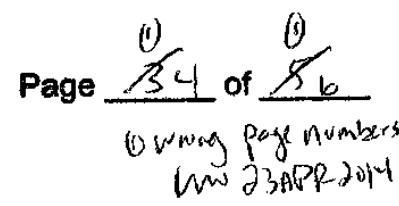




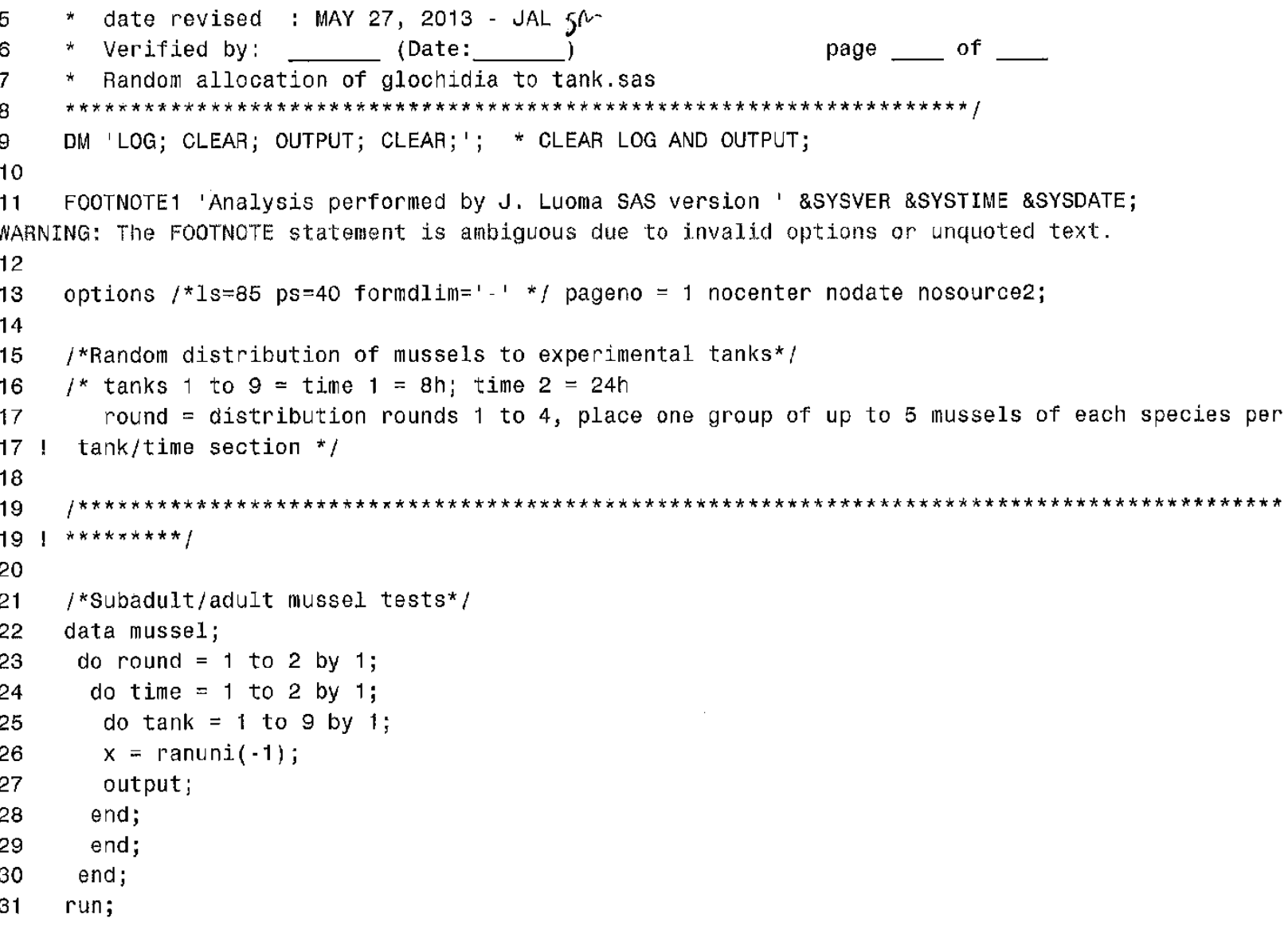

NOTE: The data set WORK. MUSSEL has 36 observations and 4 variables.

NOTE: DATA statement used (Total process time):
real time
0.01 seconds
cpu time
0.01 seconds

data musseldist; set mussel;

if time $=1$ then time_ $={ }^{\prime} 8 \mathrm{~h} '$;

if time $=2$ then _time_ $=' 24 \mathrm{~h}^{\prime}$;

if time $=1$ and $\operatorname{tank}=1$ then $\operatorname{tankn}=\operatorname{tTank}^{1-8 \mathrm{~h}}{ }^{\prime}$;

if time $=1$ and $\tan k=2$ then $\operatorname{tankn}={ }^{\prime}$ Tank $2-8 \mathrm{~h} '$;

if $\operatorname{time}=1$ and tank $=3$ then $\operatorname{tankn}=\operatorname{Tank} 3-8 \mathrm{~h} '$ ';

if time $=1$ and tank $=4$ then tankn $=$ 'Tank $4-8 \mathrm{~h} '$ ';

if time $=1$ and $\tan k=5$ then $\operatorname{tankn}=\operatorname{tank}^{2}-8 \mathrm{~h}$ ' ;

i.f time $=1$ and $\operatorname{tank}=6$ then $\operatorname{tankn}=\operatorname{Tank} 6-8 \mathrm{~h}$ ';

if time $=1$ and $\tan k=7$ then $\operatorname{tankn}=\operatorname{Tank} 7-8 \mathrm{~h} '$;

if time $=1$ and $\tan k=8$ then $\operatorname{tankn}=\operatorname{Tank} 8-8 \mathrm{~h}$ ';

if time $=1$ and $\operatorname{tank}=9$ then $\operatorname{tankn}=1$ Tank $9-8 \mathrm{~h}$ ';

AEH-13-PSEUDO-06

if time $=2$ and tank $=1$ then tankn $={ }^{\prime}$ Tank $1-24 \mathrm{~h}^{\prime}$;

if time $=2$ and $\operatorname{tank}=2$ then tankn = 'Tank $2-24 \mathrm{~h}^{\prime}$;

if time $=2$ and tank $=3$ then tankn $=\operatorname{tank}^{\prime}-24 \mathrm{~h}^{\prime}$;

if time $=2$ and tank $=4$ then tankn = 'Tank $4-24 \mathrm{~h}$;

if time $=2$ and tank $=5$ then tankn = 'Tank $5-24 \mathrm{~h}^{\prime}$;

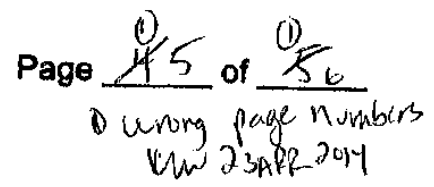



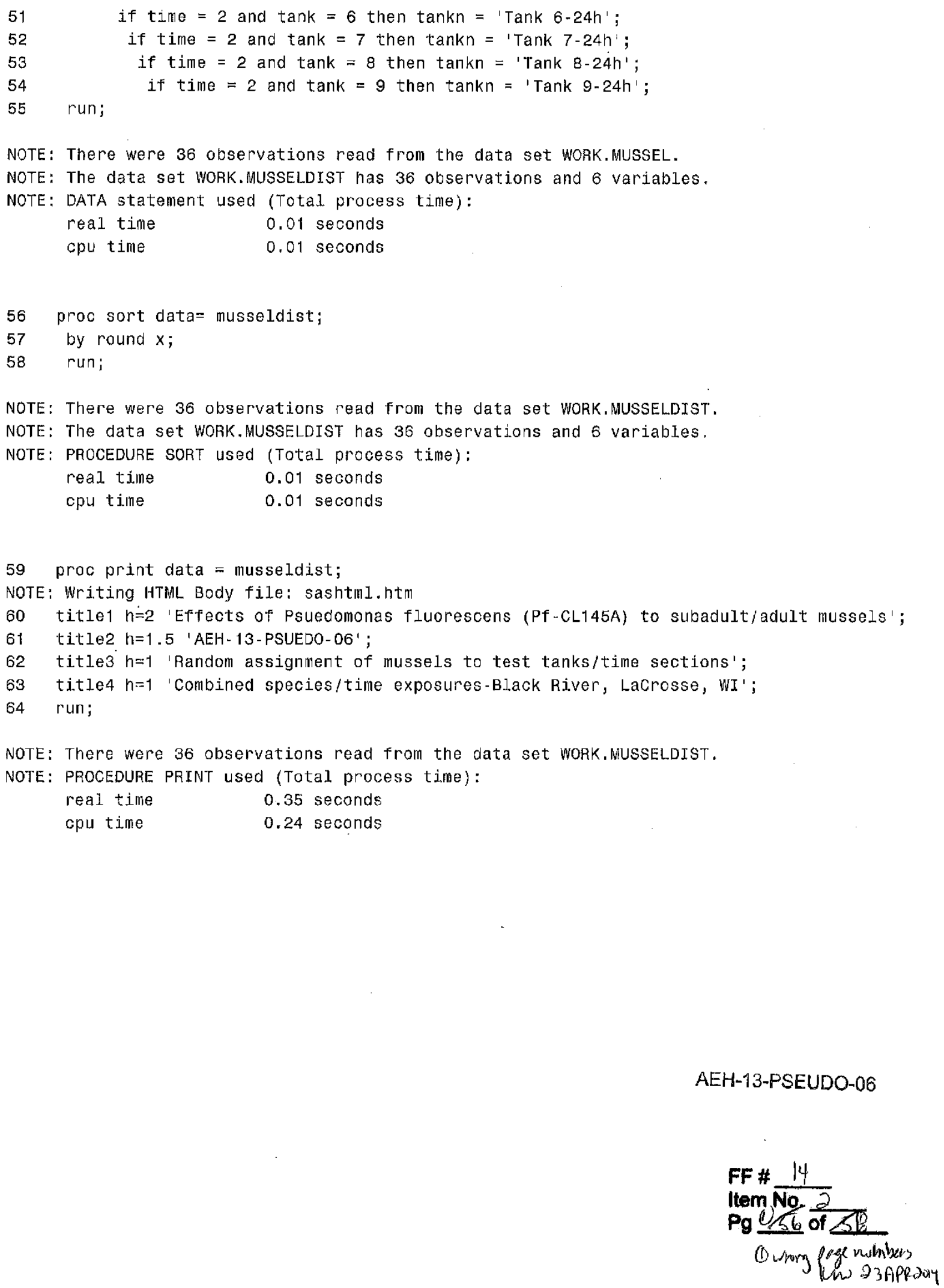
(5) Wrong study priated an datashret originally. JRW $245 A N / 4$

\begin{tabular}{|c|c|c|}
\hline Species:flickongnot & AEH-13-PSEUDO-06 & Lab book/pgs: $1-\log p \cdot 6$ \\
\hline Tag Color:Blue & & 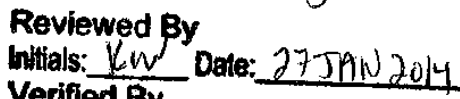 \\
\hline Mark on Randomization: $\Delta$ & & Initials: $J_{32}$ Date: $4 / 23 / 14$ \\
\hline
\end{tabular}

Distribution Tag Numbers

\begin{tabular}{|c|c|c|c|}
\hline Tank & 8 hour & 24 hour & Date/Initials \\
\hline 1 & $\begin{array}{l}D 043, D 172, D 007, D 025, D 159 \\
D 031, D 054, D 004, D 048, D 04 / 4\end{array}$ & 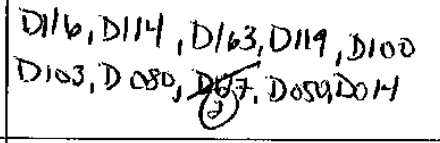 & $\begin{array}{l}28 \mathrm{SH} \text { H, } \\
\mathrm{km}\end{array}$ \\
\hline 2 & $\begin{array}{l}\text { D135,D155, D168, D035,D082 } \\
\text { D022, D102, D 034,D027, D013 }\end{array}$ & $\begin{array}{l}\text { Do15,DI66, DI } 70, \text { Do 0, D130 } \\
\text { Do19,D118, D 174,D063,D071 }\end{array}$ & $A$ \\
\hline 3 & $\begin{array}{l}\text { D160, D107, Dow5, D182, D128 } \\
\text { DoHS, D153, D17, D186,Do73 }\end{array}$ & $\begin{array}{l}\text { Diol, D175, D037, Do95, Do79 } \\
\text { Do99,D021, D056, D136, D133 }\end{array}$ & \\
\hline 4 & 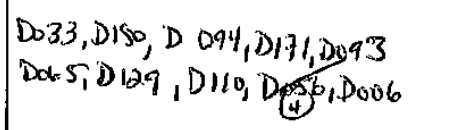 & $\begin{array}{l}\text { D122,D169, Do18, D184,Du03 } \\
\text { DE57, D113,D666, D148,D026 }\end{array}$ & \\
\hline 5 & 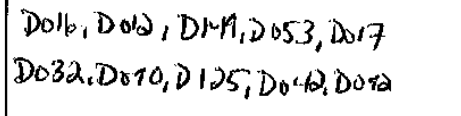 & $\begin{array}{l}\text { D139,D020,D067,D069, DN46 } \\
\text { D076,D131,D064,D038,D058 }\end{array}$ & \\
\hline 6 & 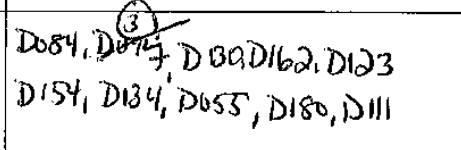 & 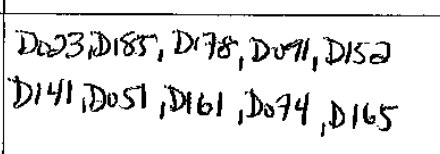 & \\
\hline 7 & $\begin{array}{l}D 140, D 157, D 157, D 0 x y, D 055 \\
D 001, D 052, D 076, D 04, D 183\end{array}$ & 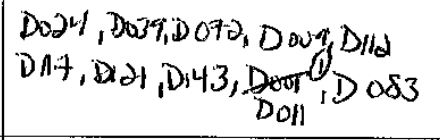 & \\
\hline 8 & $\begin{array}{l}\text { D179, Do47, Do27, Do6/, Do49 } \\
\text { D104, D12k, D/76, D142, D/64 }\end{array}$ & $\begin{array}{l}\text { D16F, D1 38, D 109, D127, D 002 } \\
\text { D181,Do87, DO81, D1 56,D D75 }\end{array}$ & \\
\hline 9 & $\begin{array}{l}\text { D060,D124,D058,D 036,D 115 } \\
\text { Dis8,D005,D 078,DM5, D098 }\end{array}$ & $\begin{array}{l}\text { Dob8, Do46, D O62, D O8, D } 144 \\
D 106, D 089, D / 20, D / 05, D 040\end{array}$ & $\begin{array}{c}28 \mu \mu_{13} \\
\text { kn }\end{array}$ \\
\hline
\end{tabular}

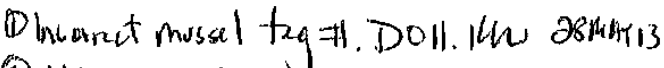

(2) NL. D137. KW 20,Nw2013 (3) NL. D 097. KI 20 Jor 2013

Item Number: 4

(9) NL. D086. Kar diJUW 2013

Fille Folder: 14 Page 11 of 1 
(D) Wrony study $\#$ printed on datasheet orifinally 3KW 2954 N24 AEH-13-PSEUDO-03- (3)

species: Washboard

AEH-13-PSEUDO-06

Tag color: white.

Mark on Randomization: $\square$

Lab book/pgs: $\frac{e-\log \rho \cdot b}{\log }$

Reviewed By Inittals: Kw Verified By Initials: $\sqrt{3}$ Date: $4 / 23 / 4 \%$

Distribution Tag Numbers

\begin{tabular}{|c|c|c|c|}
\hline Tank & 8 hour & 24 hour & Date/Initials \\
\hline 1 & $\begin{array}{l}\text { A143, A094, A024, BD50, } 9110 \\
\text { A176, } 4066, A 112, A 111, A 163\end{array}$ & 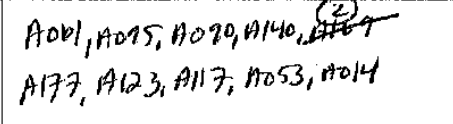 & $\begin{array}{l}28 \mathrm{H}^{493} 3 \\
\text { How }\end{array}$ \\
\hline 2 & $\begin{array}{l}\text { A010, Alol, A179, A170, A087 } \\
\text { A125, A157, A141, A0024,A015 }\end{array}$ & 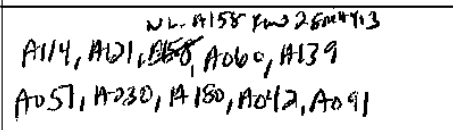 & \\
\hline 3 & $\begin{array}{l}\text { A070, } 4003, A 007, A 065, A 085 \\
\text { A04 } 4,4175,4013,128,0023\end{array}$ & $\begin{array}{l}A 013, A 126, A 162,14171,4035 \\
A 135, A 170,4025,1469, A 099\end{array}$ & \\
\hline 4 & $\begin{array}{l}\text { Aloq, A011, } 4164, A 149, A 075 \\
\text { A008, A1C5, A15, A2002, A130 }\end{array}$ & 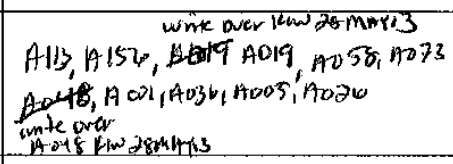 & \\
\hline 5 & $\begin{array}{l}A 020, M 022, A 074, H 016, A 120 \\
A-119, A 0)-8, A 174, A 043, A 034\end{array}$ & $\begin{array}{l}\text { A082, } 9047,1012,1055,11054 \\
A 148,19133,4079,4052,4077\end{array}$ & \\
\hline 6 & $\begin{array}{l}\text { C40.3, Ho40, A03\%, A018, A018 } \\
A 138, A 124, A .089,4009, A 134\end{array}$ & $\begin{array}{l}A D 67, A 137, A 105, A 152,4065 \\
A(66, A 02) A 051, A 057, A 102\end{array}$ & \\
\hline 7 & 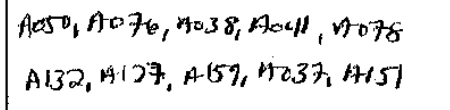 & $\begin{array}{l}\text { A062, A064, A100, A030, A052 } \\
\text { A.55, A017, A 012, A107, A084 }\end{array}$ & \\
\hline 8 & $\begin{array}{l}\text { A136, A041, A153, A144, A106 } \\
\text { A173, A168, A1L16, A/42, A1/6 }\end{array}$ & $\begin{array}{l}\text { A167, } 4069,4084,19053,4104 \\
\text { A161, } 0115, A 15,4160,0178\end{array}$ & $V$ \\
\hline 9 & $\begin{array}{l}\text { A033, } 1097,142 \%, A 044, A 006 \\
\text { A022, A118, A031, A122, A152 }\end{array}$ & 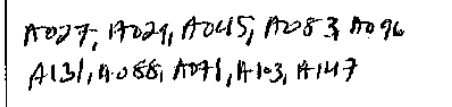 & $\begin{array}{l}28 M 1413 \\
10 W\end{array}$ \\
\hline
\end{tabular}

(1) NL. A032. Kin 20Jun2013

(2) NL. A 169 . Ku 20 tur 2013

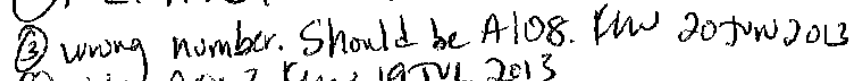

(4) WL AOb3. Kew 19T2 2013

Fille Folder: 14 Page 1 . 1 of 1 
-AEH+13-PSEUOO-O3 B (3) Wrong study printed on datajheet originally JKW $295 \mathrm{AN} / 4$
SPlecies: tighgins eye.

Tag Color:

Reviewed By Initials: Mun Date:275Andoly

Verified By

Mark on Randomization: .

Lab bookjpgs: $2-\operatorname{lig} \rho .6$ Initials: The Date: $4 / 23 / 14$

Distribution Tag Numbers

\begin{tabular}{|c|c|c|c|}
\hline Tank & 8 hour & 24 hour & Date/Initials \\
\hline 1 & 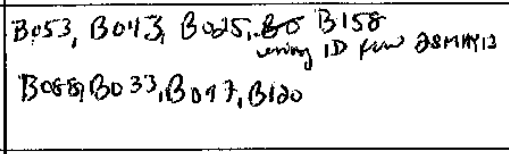 & $\begin{array}{l}B 034, B 067, B 057, B 124 \\
B 152, B 006, B 156, B 129\end{array}$ & $\begin{array}{c}28 \operatorname{Mn}_{13} \\
100 \\
\Lambda\end{array}$ \\
\hline 2 & $\begin{array}{l}B=20, B 00,7, B 159,5147 \\
B 069, B 102, B 126,3157\end{array}$ & $\begin{array}{l}B 054, B 004, B 022, B 138 \\
B 049, B 013, B 014, B 134\end{array}$ & \\
\hline 3 & $\begin{array}{l}\text { BO43, BO14, BO81, BO12 } \\
B 052, B 125, B 086, B \circ 11\end{array}$ & $\begin{array}{l}3118, B 005,8052, B 123 \\
B 153,8071,8021,3050\end{array}$ & \\
\hline 4 & $\begin{array}{l}B 090, B 026,6150,3064 \\
B 062,3124, B 133, B 128\end{array}$ & $\begin{array}{l}B 112, B 037, B 078, B 010 \\
B 039, B 087, B 03,8, B 015\end{array}$ & \\
\hline 5 & $\begin{array}{l}B 047, B 142, B 018, B 025 \\
B 131, B 149,6066, B 114\end{array}$ & $\begin{array}{l}B 094,6046, B 075, B M 11 \\
B 051, B 154, B 1-13, B / 45\end{array}$ & \\
\hline 6 & $\begin{array}{l}B 101, B 107, B 121, B 059 \\
B 115, B 076, B 032, B 079\end{array}$ & $\begin{array}{l}B 137, B 092, B H 17, B 063 \\
B 140, B 061,6030, B 041\end{array}$ & \\
\hline 7 & $\begin{array}{l}B 106, B 091, B, 30, B 119 \\
B 0,47, B 045, B 017, B 016\end{array}$ & 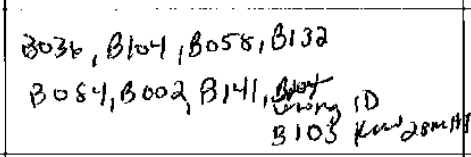 & \\
\hline 8 & $\begin{array}{l}B 135, B 02 Y, B 096, B 065 \\
B 008, B 110, B 031, B 100\end{array}$ & $\begin{array}{l}B 1 / 6, B 001, B 11, B 044 \\
B 074, B 108, B 079, B 089 P\end{array}$ & \\
\hline 9 & $\begin{array}{l}B 148, B 144, B 139, B 122 \\
B 085, B 083, B 023, B 027\end{array}$ & $\begin{array}{l}B 098, B 151, B 035, B 029 \\
B 155, B 056, B 048, B 099\end{array}$ & $\begin{array}{l}\text { QSHAPIS } \\
\text { kin }\end{array}$ \\
\hline
\end{tabular}

(1) Mussel BOS9 recoverned from buttom of the tank upon drainity@21035 kow 30 matibaw Cand in busket during dean-up. Fum 30 mayB

Nem Number: 6

File Folder: 14 Page 1 of 1 
AEH-13-PSE $B$ BO-O3-(2)
(2) Wrong study pristed on datasheat .AEH-13-PSEUDO-06
Species: Fatmucket

Tag color: Blue.

Mark on Randomization: $\times$
Lab book/pgs: $e-\log f 16$

\section{Reviewed By}

Initials: Inw Date: 27 J9h 204

Verified By

Initials: $\sqrt{9-}$ Date: $4 / 23 / \mu 1$

Distribution Tag Numbers

\begin{tabular}{|c|c|c|c|}
\hline Tank & 8 hour & 24 hour & Date/Initials \\
\hline 1 & $\begin{array}{l}\text { D270, D 260, D336, D199, D273 } \\
\text { D 269,D224, D201,D310, D 302 }\end{array}$ & 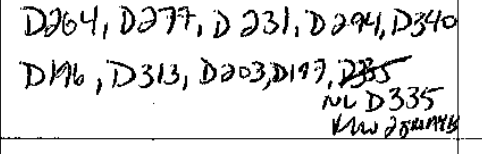 & $\begin{array}{c}2 S M 4 \times 13 \\
k W \\
A\end{array}$ \\
\hline 2 & $\begin{array}{l}\text { D20,D256,D235,D318,D265 } \\
\text { D304,D242,D326,D148, D354 }\end{array}$ & $\begin{array}{l}D 319, D 193, D 291, D 316, D 299 \\
D 267, D 339, D 343, D 338, D 321\end{array}$ & \\
\hline 3 & $\begin{array}{l}D 266, D 350, D 300,0306, D 282 \\
D 332, D 229, D 263, D 271, D 211\end{array}$ & $\begin{array}{l}\text { D281, D189,D275,D283,D353 } \\
\text { D232,D227, D311,D351, D221 }\end{array}$ & \\
\hline 4 & 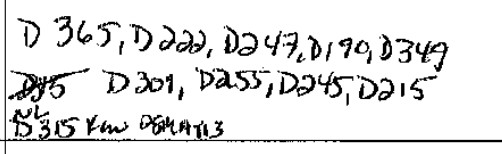 & $\begin{array}{l}D 323, D 33+, D 204, D 289, D 272 \\
D 307, D 293, D 228, D 325,0287\end{array}$ & \\
\hline 5 & $\begin{array}{l}\text { D296,D214,D 334,D321,D257 } \\
\text { D225,D 347,D288,D 327, D257 }\end{array}$ & $\begin{array}{l}D 286_{1} D 207, D 357, D 254, D 218 \\
D 297, D 292, D 188, D 358, D 274\end{array}$ & \\
\hline 6 & $\begin{array}{l}\text { D249, D216,0250,0320, D367 } \\
\text { D } 308, D 328, D 322, D 2+1, D 26\end{array}$ & $\begin{array}{l}D 3412, D 248, D 364, D 2,18, D 201 \\
D 366, D 195, D 301, D 303, D 330\end{array}$ & \\
\hline 7 & $\begin{array}{l}D 345, D 253, D 260, D 192, D 233 \\
D 362, D 344, D 237, D 369, D 212\end{array}$ & $\begin{array}{l}\text { D223,D213,D244,D D55, D240 } \\
D 261, D 295, D 194,0200, D 234\end{array}$ & \\
\hline 8 & $\begin{array}{l}D 217, D 238, D 360, D 348, D 210 \\
D 274 . D 284, D 290, D 257, D 314\end{array}$ & $\begin{array}{l}D 208, D 356, D 363, D 236, D 206 \\
D 305, D 331, D 280, D 361, D 34\end{array}$ & \\
\hline 9 & $\begin{array}{l}D 2 x 4, D 258, D 23 \%, D 252, D 141 \\
D 368, D 230, D 219, D 359, D 246\end{array}$ & $\begin{array}{l}D 275, D 285, D 2160, D 352, D 34 \\
D 243, D 317, D 312, D 187, D 202\end{array}$ & $\begin{array}{l}3 B M A T B \\
\text { KWW }\end{array}$ \\
\hline
\end{tabular}

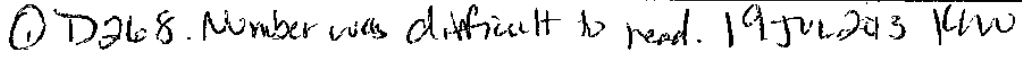

Nem Number: 7

File Folder:

14

Page 1 of 1 
(2) Wrong 37uly $\#$ printed on daEH-13-PSEUDO-06 Species: Three fidge Gidge Tag Color: Green

Mark on Randomization:

Lab bookipgs: $e-\log p 6$

Reviewed By

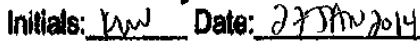

Verifted By

Initials: Jal

Date: $4 / 23 / 14$

Distribution Tag Numbers

\begin{tabular}{|c|c|c|c|}
\hline Tank & 8 hour & 24 hour & Date/Initials \\
\hline 1 & 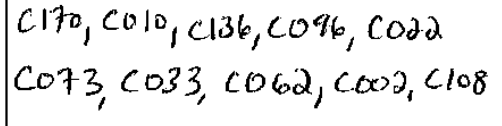 & $\begin{array}{l}\operatorname{cod} 7, \cos , 6046, \cos 8, c 093 \\
\cot 4, \cos 9, \cos 7, \cos 2, \operatorname{col} 4\end{array}$ & $\begin{array}{l}28 M A Y 13 \\
\text { KWW }\end{array}$ \\
\hline 2 & $\begin{array}{l}\cos 3, \operatorname{col} 3, c_{0} 056, c 023, \mathrm{Cl} 103 \\
\operatorname{cof} 9, \cos 2, \cos 5, \cos , \mathrm{C} 113\end{array}$ & 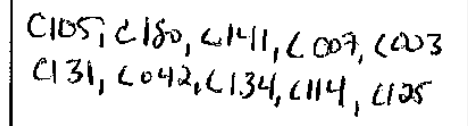 & \\
\hline 3 & 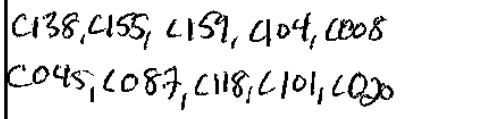 & $\begin{array}{l}\operatorname{coog},(143,<004,6174,149 \\
\cos 38^{\circ}, 127,6154, \operatorname{col} 1, \angle 060\end{array}$ & \\
\hline 4 & 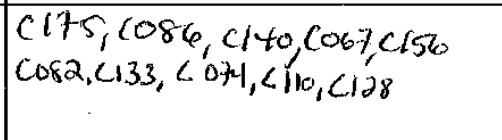 & $\begin{array}{l}\text { C.16 } 9, \operatorname{co} 1,6016, \mathrm{C} 184,0135 \\
\mathrm{C148,}, 053,6121,6063,0112\end{array}$ & \\
\hline 5 & $\begin{array}{l}\cos 43, C 178,6161,6034, \angle 015 \\
C 111, \angle 183, C 026,(162), \cos 4\end{array}$ & 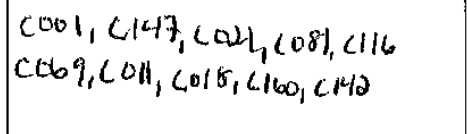 & \\
\hline 6 & $\begin{array}{l}C 167, \cos 2, \cot 1,6122, \cos (1) \\
\cos 9, \cot 4, \cos , 6150,4182 .\end{array}$ & 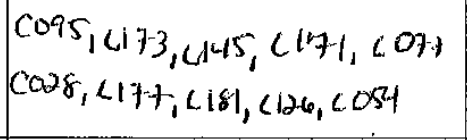 & \\
\hline 7 & 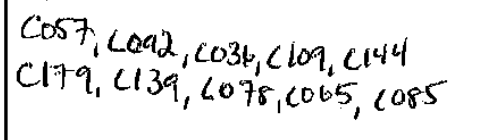 & 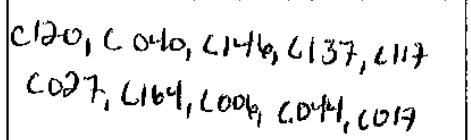 & \\
\hline 8 & $\begin{array}{l}\text { c129, c029, c083, c049, c068 } \\
\text { c124, c039, c019, c090, } 2165\end{array}$ & $\begin{array}{l}0153,(157,6132,<172,<070 \\
c 152, c 185, c 072,4157,<097\end{array}$ & \\
\hline 9 & 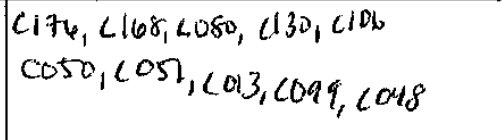 & 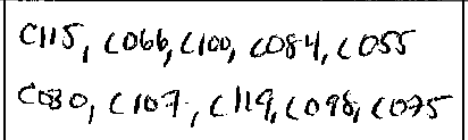 & $\begin{array}{l}\text { OSMHYis } \\
\text { Kun }\end{array}$ \\
\hline
\end{tabular}

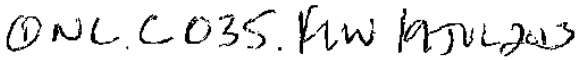

Item Number:

File Folder:

14

Page 1 of 1 
-AEH-13-PSEUDO-03-(3) AEH-13-PSEUDO-06

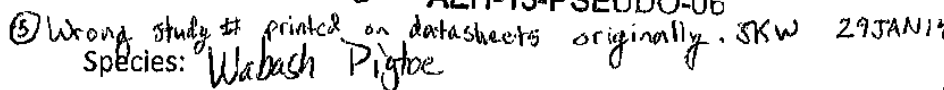

Tag color: Yellow

Lab book/pgs: $e-\log _{f} p$

Mark on Randomization: 0

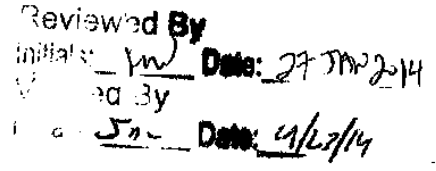

Distribution Tag Numbers

\begin{tabular}{|c|c|c|c|}
\hline Tank & 8 hour & 24 hour & Date/Initials \\
\hline${ }_{1}^{(1)}$ & $\begin{array}{l}D 179, B 301+, B 18 \delta, D 251 \\
D 165, B 240, B 372, B 26,4\end{array}$ & $\begin{array}{l}\text { B242, B246, 6303, } 8295 \\
\text { B204, B24, B256, B273 }\end{array}$ & 28MAGris \\
\hline $2^{(1)}$ & $\begin{array}{l}B 283, D 233, B 210, B 248 \\
B 187, B 238, B 199, B 206\end{array}$ & $\begin{array}{l}B 250, B 185, B 207, B 265 \\
B 181, B 142, B 237, B 184\end{array}$ & \\
\hline 3 & $\begin{array}{l}B 208, B 289, B 227, B 187 \\
B 203, B 162, B 270, B 222\end{array}$ & $\begin{array}{l}B 141, B 186, B 163, B 261 \\
B 218, B 166, B 228, B 280\end{array}$ & \\
\hline 4 & $\begin{array}{l}3271, B 294, B 299, B 170 \\
B 231, B 252, B 236, B 168\end{array}$ & $\begin{array}{l}B 183, B 178, B / 67, B 276 \\
B 215, B 257, B 278, B 27+(A)\end{array}$ & \\
\hline 5 & $\begin{array}{l}\text { B244,B297,B175,B254 } \\
B 255, B 259, B 239, B 164\end{array}$ & $\begin{array}{l}\text { B200, B281, B284, B249 } \\
B 225,3266, B 17+, B 182\end{array}$ & \\
\hline 6 & $\begin{array}{l}B 213, B 262, B 235, B 243 \\
B 290, B 198, B 26,7, B 241\end{array}$ & $\begin{array}{l}B 286,6230, B 298^{*}, B 195(2) \\
B 292, B 173, B 302, B 212\end{array}$ & \\
\hline 7 & $\begin{array}{l}\text { B211,B265, B181, B269 } \\
\text { B227, B282,B274,B217 }\end{array}$ & $\begin{array}{l}B 194, B 291, B 255, B 268 \\
B 232, B 161, B 224, B 190\end{array}$ & \\
\hline 8 & $\begin{array}{l}B 279, B 275, B 296,8258 \\
B 219,3240, B 245,6287\end{array}$ & $\begin{array}{l}B 277, B 221, B 288, B 223 \\
B 202, B 263, B 293, B / 69\end{array}$ & \\
\hline 9 & $\begin{array}{l}B 196, B P F, B 247, B 193 \\
B 226, B 253, B 201, B 304\end{array}$ & $\begin{array}{l}B 220, B<34, B 216, B 160 \\
B 17 b_{1} B 180, B 300, B 172\end{array}$ & $\begin{array}{l}28 M A Y B \\
\text { KWw }\end{array}$ \\
\hline
\end{tabular}

* Numbar han torcad. Kino $28 \mathrm{maj}$

(1) Nomber DS should be "B" not "D" MN 20 Junjal3

(2) Number was not writth down, bot was in e-log, flow 20 JuNdo1s

Item Number: 9

3) Incorrect the number. Correct trag iD is 171 based on mussel tags

iDed during assessment. F W 14 JVL 2013

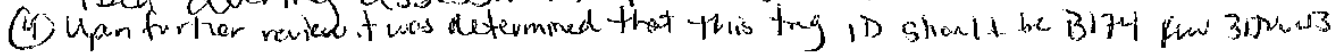


AEH-13-PSEHBO-O3- AEH-13-PSEUDO-06

Wrong study th pristed on datasheet originally. JKw $295 \mathrm{AN}$ (4)

Species: Plain pocketbouk

Tag Color: White

Mark on Randomization: $\mathscr{A}$
Lab book/pgs: $\ell-\log \rho \cdot 6$

Reviewed By

Initids: KW Date: 2757 w 2014

Verified By

Initialsithe Date: $4 / 23 / 14$

Distribution Tag Numbers

\begin{tabular}{|c|c|c|c|}
\hline Tank & 8 hour & 24 hour & Date/Initials \\
\hline 1 & 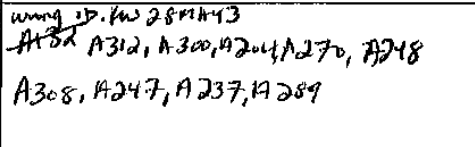 & $\begin{array}{l}A 302, A 314, A 231, A 3114, A 2 S 4 \\
A 317, A 343, A 313, A 189\end{array}$ & $28 \mathrm{mati3}$ \\
\hline 2 & $\begin{array}{l}A 310, A 246, A 262,4278, A 202 \\
A 335, A 327, A 311, \pi 269\end{array}$ & $\begin{array}{l}\text { A296, A3OU, } 4208, A 256, A 493 \\
\text { A335,A331, A27, A244 }\end{array}$ & \\
\hline 3 & $\begin{array}{l}\text { A185, } 1271, A 25, \text { A 225,A277 } \\
\text { A214, A340,A294,A183 }\end{array}$ & $\begin{array}{l}A 18 \%, A 323, A 341, A 239,4232 \\
A 290, A 230, A 255, A 191\end{array}$ & \\
\hline 4 & $\begin{array}{l}A 264, A 215, A 345, A 318, A 187 \\
A 324,1200, A 334, A 30 \%\end{array}$ & $\begin{array}{l}A 213, A 265, A 208, A 272, A 181 \\
A 282, A 261, A-190, A 192\end{array}$ & \\
\hline 5 & $\begin{array}{c}A-279,19298, A 207,19242,19285 \\
A 211, A 200, A 257,13225\end{array}$ & 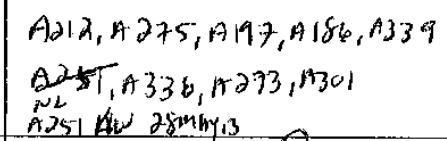 & \\
\hline 6 & $\begin{array}{l}A 219, A 236,1233, A 346, A 24 \\
A 320, A 240, A 332, A 347\end{array}$ & 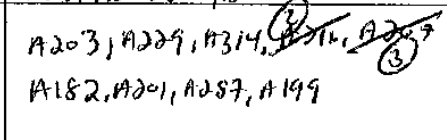 & \\
\hline 7 & $\begin{array}{l}\text { A } 258, A 188,1333, A 211,1321 \\
\text { A283, } 19198, A 227, A 297\end{array}$ & $\begin{array}{l}A 195, A 327, n 194,4209, A 241 \\
A 276, A 252, n 305, A 292\end{array}$ & \\
\hline 8 & 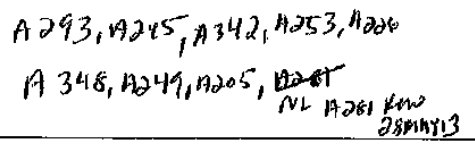 & $\begin{array}{l}\text { A } 234, A 324, A d 46, A 224, A 249 \\
\text { A309, A285, } 1295, \text { Ad17 }\end{array}$ & $y$ \\
\hline 9 & 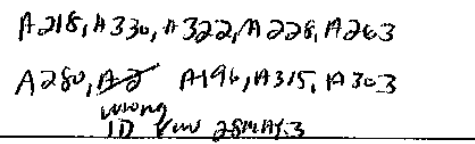 & $\begin{array}{l}A 260, A 243, A 31 \% A 324, A 206 \\
A 333, \frac{A 2 B 5}{14}, A 220, A 254\end{array}$ & $\begin{array}{c}28 \mathrm{mLAYB} \\
\mathrm{kmm}\end{array}$ \\
\hline
\end{tabular}

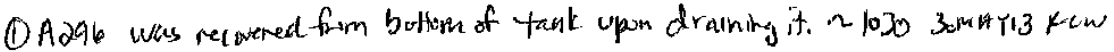

(2) WL A216. Kow 2onwol3

(3) NL A267. KMw 20Jund2013

(4) NL. A238. km 200w2013

Fille Folder:

Wrong
skem $3 / 13 / 14$
0

Item Number: 3

Page 1 of 1 


\section{Appendix 4. Test Article Information}

\begin{tabular}{clcc}
\hline $\begin{array}{c}\text { Item } \\
\text { Number }\end{array}$ & \multicolumn{1}{c}{ Item Description } & $\begin{array}{c}\text { Number } \\
\text { of } \\
\text { Pages }\end{array}$ & $\begin{array}{c}\text { Report } \\
\text { Page } \\
\text { Number }\end{array}$ \\
\hline 1 & Material Safety Data Sheet: Zequanox ${ }^{\circledR}$ & 2 & 124 \\
2 & MBI-401 SDP (lot \# 401P12163C) Test Article: Certificate of Analysis & 1 & 126 \\
3 & MBI-401 SDP (lot \# 401P12164C) Test Article: Certificate of Analysis & 1 & 127 \\
4 & MBI-401 SDP (lots \# 401P12163C and 401P121164C) Test Article: Packing List & 1 & 128 \\
5 & $\quad$ USPS (shipped to James Luoma 08/06/2012) & 1 & 129 \\
6 & Test Article Stock Preparation & 2 & 130 \\
7 & New York State Museum Post-Exposure Product Validation Assay & 5 & 132 \\
\hline
\end{tabular}




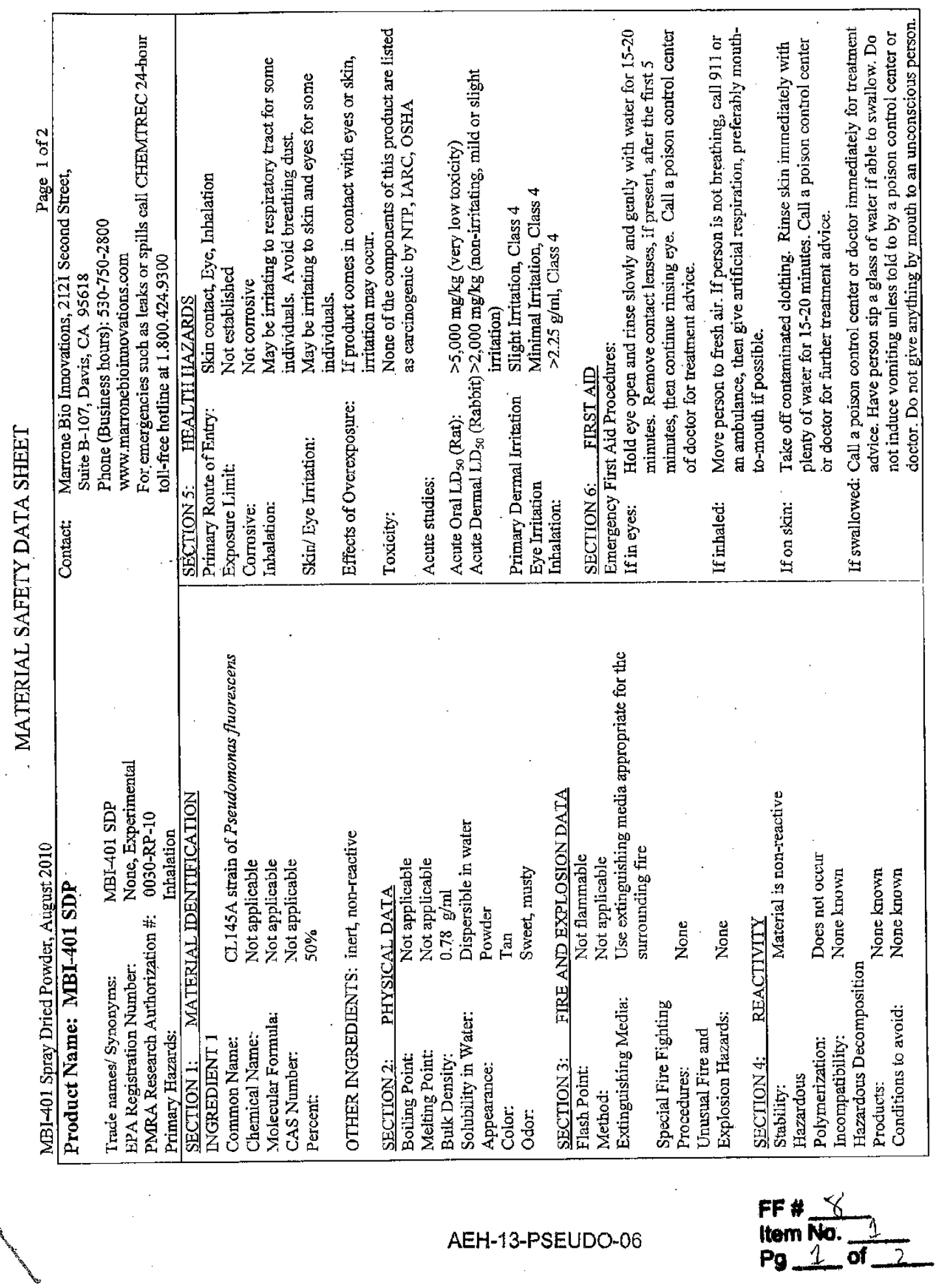




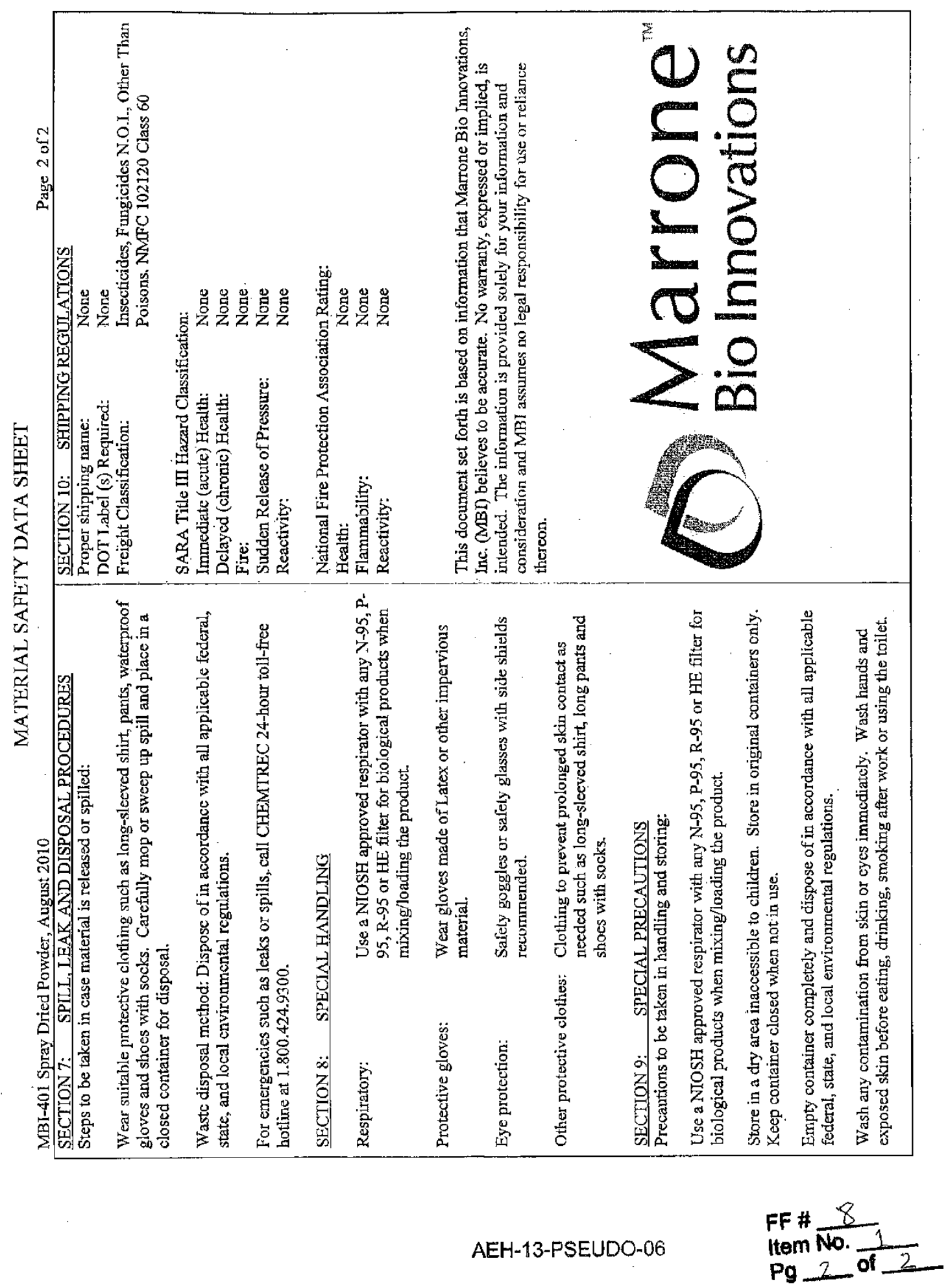




\section{CERTIFICATE OF ANALYSIS}

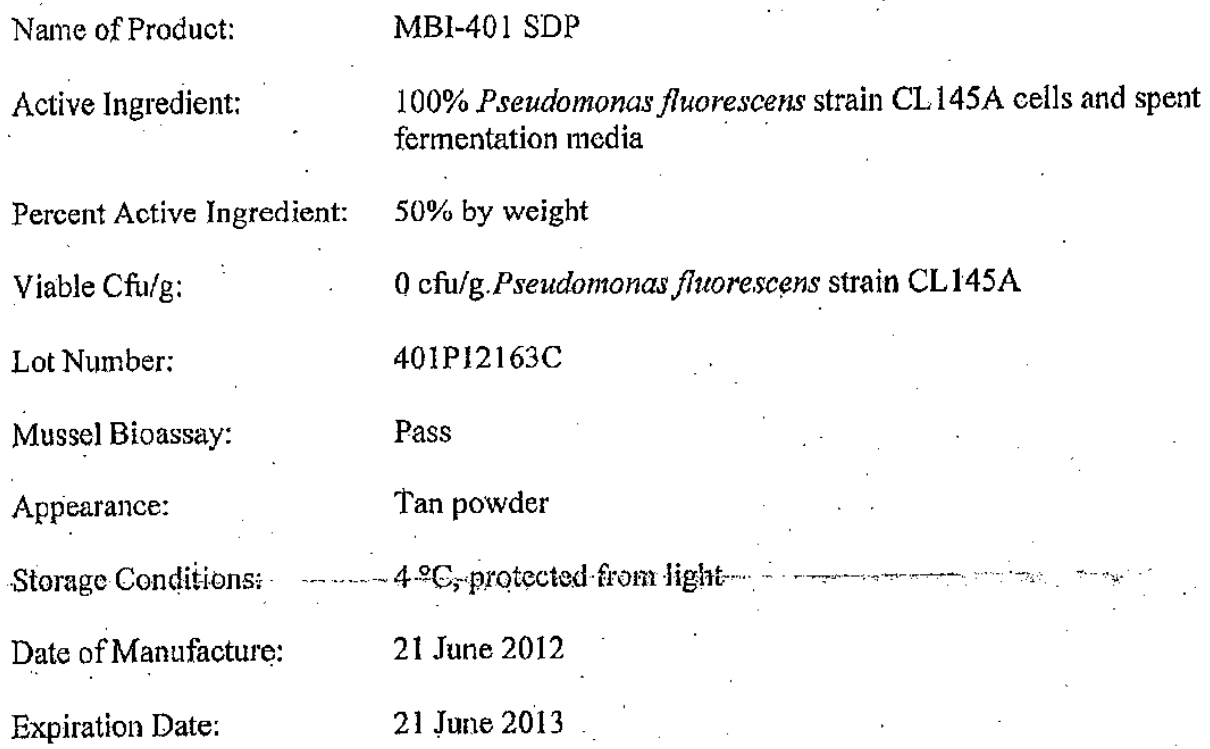

I hereby certify that the above information is true and correct.

Quality Control:

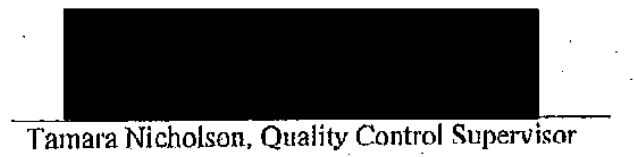




\title{
CERTIFICATE OF ANALYSIS
}

\author{
Name of Product: \\ MBI-401 SDP \\ Active Ingredient: \\ $100 \%$ Pseudomonas fluorescens strain CL145A cells and spent \\ fermentation media \\ Percent Active Ingredient: $\quad 50 \%$ by weight \\ Viable Cfu/g: \\ $0 \mathrm{cfu} / \mathrm{g}$ Pseudomonas fluorescens strain CL145A \\ Lot Number: \\ $401 \mathrm{P} 12164 \mathrm{C}$ \\ Mussel Bioassay: \\ Pass \\ Appearance: \\ Tan powder \\ Storage Conditions: \\ $4 \circ$, protected from light \\ Date of Manufacture: \\ 21 June 2012 \\ Expiration Date: \\ 21 June 2013
}

I hercby certify that the above information is true and correct.

Quality Control:

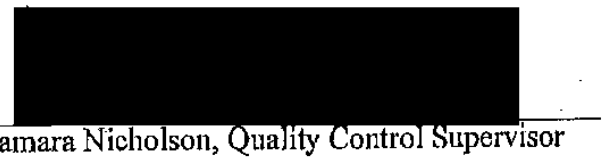

Date: 01 August 2012

2121 Second Street, Suite B-107

- Davis, CA 95618

- Phone: 530-750-2800

AEH-13-PSEUDO-06

FF \# 8

Item No.

$\mathrm{Pg} Z$ of 2 


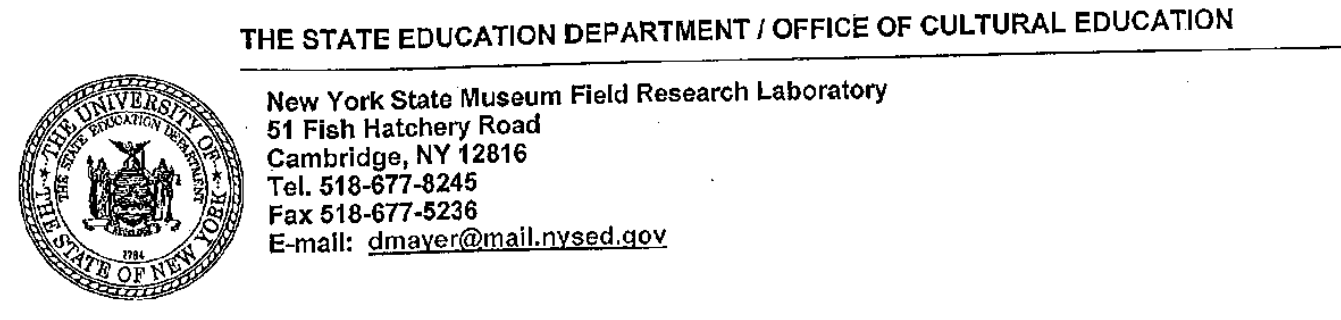

PACKING LIST

DATE OF SHIPMENT - 2012/08/06

Ship from:

Denise Mayer

New York State Museum

Field Research Laboratory

51 Fish Hatchery Road

Cambridge, NY 12816
Ship To:

Jim Luoma

USGS UMESC

2630 Fanta Reed Road

La Crosse, W1 54603

Shipping Method: UPS Next Day Air

Required by: 2012/08/07

Item Description:

MBI-401 SDP Lot \# 401P12163C and 401P12164C Mix in six containers of approximately 0.5 $\mathrm{Kg}$ each (total weight $3 \mathrm{Kg}$ ):

Packaged by D. Mayer.

Shipped on ice. Store at $4^{\circ} \mathrm{C}$, protected from light.

Manufactured: 06-21-2012

Expiration date 06-21-2013

AEH-13-PSEUDO-06

FF \# 8

ltem No.

$\operatorname{Pg} 1$ of 1 
Study Nu mber: AEH-13-PSEUDO-06

File Folder: 8
Lab book/pgs: E-log 5

\section{Test Chemical Stock Preparation}

Test Chemical: Pseudomonas fluroescens strain $145 \mathrm{~A}$
Reviewed by: KKW

Verified by: In-
Date: $2 / 19 / 2014$ Date: $4 / 23 / / 4$

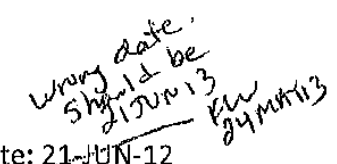

Test Chemical Lot \#: 401P12163C and 401P12164C Mix Date Rec'd: 7-AUG-12 Exp. Date: 21 - tuK-12

Test Location: Block River, La Lrossz wI. Instruments Used: Metther Tredo PG2003-S S/N

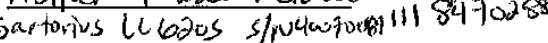
Sartonies R2000 S/N 20903620

Weights of Chemical Samples:

\begin{tabular}{|c|c|c|c|c|}
\hline Sample ID & Sample Weight & Comments & Date & Initials \\
\hline Stock \#1 & 35.00 & & 2444913 & kn \\
\hline stak $* 2$ & 35.02 & & $\lambda$ & $\lambda$ \\
\hline Stock $\# 3$ & 35,00 & & & \\
\hline Stock $\# 4$ & 70.02 & & & \\
\hline Stock $\# 5$ & 70.02 & & & \\
\hline 5 fouk $\neq 16$ & 70.02 & & & \\
\hline Analutical & 2,00071 & & $\forall$ & $\checkmark$ \\
\hline Analytical $\# 2$ & 2.00033 & & 2ImIAYis & fun \\
\hline-1 & & & & \\
\hline
\end{tabular}

NOTE: Chemical samples to be stored refrigerated until used for stock preparation.

Stock Solution Preparation:

\begin{tabular}{|c|c|c|c|c|c|c|}
\hline Sample to & $\begin{array}{l}\text { "Dilution } \\
\text { Volume (mL) }\end{array}$ & $\begin{array}{c}\text { Dilution } \\
\text { Time }\end{array}$ & Use & $\begin{array}{c}\text { Exposure } \\
\text { Time } \\
\end{array}$ & Date & Initials \\
\hline Analybical \#1 & 500 & 0830 & Standard curve & Oh & $29 M A 415$ & Hew \\
\hline 5 tock 4 & & 0924 & Tank 1 & oh & $29 \mathrm{May} / 3$ & $D L W$ \\
\hline Stock $\# 5$ & & 0943 & $\operatorname{Tan} k 2$ & oh & 2-9 May & $D<\omega$ \\
\hline Stock $* 6$ & & 0952 & Tank ? & oh & $29 \mathrm{Moy} / 3$ & DLW \\
\hline Stock $\# 2$ & & 1000 & Tank 3 & oh & 29 May 13 & $D L w$ \\
\hline stock \# I & & 1008 & Tank 4 & oh & 29 May is & Deu \\
\hline Stock " 3 & $\sqrt{ }$ & 1014 & Tank 6 & oh & 29 May/l & $D \& L C$ \\
\hline Hnalytical \#2 & 500 & $2200(i)$ & Standard check & $12 h$ & $29(4)+313$ & Kin \\
\hline & & & & & & \\
\hline & & & & & & \\
\hline
\end{tabular}

AEH-13-PSEUDO-06

File Folder:

Item Number: 4

Page 1 of 1 


\title{
NYSM Post-Treatment Product Validation Assay MBI-401 SDP 401P12163C and 401P12164C Mix (USGS Study \#AEH-13-PSEUDO-06 Sub-adult unionids)
}

\author{
Date product received from USGS: $2013 / 06 / 19$
}

Date of start of test: $2013 / 06 / 20$

BACKGROUND: As standard protocol for the USEPA project, each time a batch of Zequanox product is used in a test a UMESC, a portion of the product is bioassayed by the NYSM to validate toxicity post-treatment.

- MBI-401 SDP 401P12163C and 401P12164C Mix

- USGS Study \#AEH-13-PSEUDO-06; Sub-adult unionids

PURPOSE: Post-test product validation of MBI-401 SDP 401P12163C and 401P12164C Mix from USGS-UMESC.

\section{MATERIALS AND METHODS:}

Preparation of product for testing:

Product was shipped under cold conditions and held in the laboratory refrigerator at $4^{\circ} \mathrm{C}$ until use. Within 30 min of treatment application, prepare each at treatment stock of each MBI-401 formulated product:

MBI-401 SDP 401P12163C and 401P12164C Mix (SDP - 50\% active ingredient): $3 \mathrm{~g}$ of the powder from each sample was added slowly to a beaker with dilution water with stirring on a stir plate for even suspension and then the total volume was adjusted to $30 \mathrm{ml}$ with dilution water. The suspension was transferred to a $50 \mathrm{ml}$ centrifuge and stored in refrigerator until ready to use. The suspension, when evenly dispersed was $100 \mathrm{mg}$ product $/ \mathrm{ml}$ or $50 \mathrm{mg}$ a.i./ml. For $200 \mathrm{ppm}$ a.i. treatments in testing jars, $2 \mathrm{ml}$ were added to each testing jar $(500 \mathrm{mi})$.

Cambridge CF (Standard for Positive Controls):

As an efficacy standard, we used $P$-CL145A killed CF that was maintained at $-80^{\circ} \mathrm{C}$ (Cambridge CF). Since its production in 2005 , this material has becn valuable as a reference standard. The Cambridge CF was produced in 2005 (2005-0027) in 100-L batches 10,11 and 12 and E-beamed to kill the cells. The solution, at $110 \mathrm{mg} / \mathrm{ml}$ dry weight, is stored in $1 \mathrm{~cm}$ thick sheets in the Cambridge ultrafreezer at $-80^{\circ} \mathrm{C}$. $\Lambda$ section of the sheet was broken off and weighed to determine volume (ca. $1 \mathrm{~g}: 1 \mathrm{ml}$ ).

For this bioassay, a positive control suspension was produced on $06 / 18 / 2012$ from the frozen blocks described above and dispensed into multiple $50-\mathrm{ml}$ centrifuge tubes for single-use treatment of bioassays. The dry weight of the material was $68.15 \mathrm{mg} / \mathrm{ml}$; therefore $1.5 \mathrm{ml}$ was added to each testing jar to treat at $200 \mathrm{ppm}$.

\section{Mussel collections:}

Mussels were scraped from substrates (rocks) in the field and brought back to the lab in coolers. The same day mussels were carefully examined and placed into testing jars and allowed to attach overnight at ambient laboratory temperature (ca. $20^{\circ} \mathrm{C}$ ).

AEH-13-PSEUDO-06

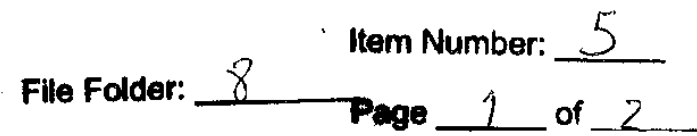


2013-0012 MBI-401 SDP 401P12163C and 64C Mix Post-lest Validation

Mussel collection and handling:

\begin{tabular}{|c|c|c|c|c|}
\hline Species & Collection site & Collection date & Date in lab $\left(20^{\circ} \mathrm{C}\right)$ & Picked for test \\
\hline $\begin{array}{c}\text { Zebra } \\
\text { mussels }\end{array}$ & $\begin{array}{c}\text { Hedges Lake } \\
\text { (Washington Counly) }\end{array}$ & $06 / 19 / 2013$ & $06 / 19 / 2013$ & $06 / 19 / 2013$ \\
\hline
\end{tabular}

Experimental design:

For validation of efficacy the following treatments will be set up: Zebra musscls (25 musscls/jar): 3 - Untreated Con

$\operatorname{trol}(\mathrm{A}, \mathrm{B}, \mathrm{C})$

3 - $200 \mathrm{ppm}$ (a.i.) Cambridge CF Positive Control (Pf-CL145A killed cells) (A, B, C)

3-200 ppm (a.i.) 401P12163C and 401P12164C Mixed (A, B, C)

Total of 9 testing jars.

Testing jar bioassay protocol:

On the day prior to trcatment $(06 / 19 / 2013)$ mussels were carefully examined and 25 mussels placed into each testing jar containing ca. $100 \mathrm{ml}$ aerated hard water and allowed to attach overnight. The next morning (06/20/2013), unattached mussels were removed and replaced with attached mussels from an extra glass Pctri dish. Watcr was replaced with $500 \mathrm{ml}$ fresh acrated hard water.

After at least one hour, the treatment was applied. The optical density of each jar was ineasured in duplicate ( $\mathrm{A}_{660 \text { um }}$ Genesys Spectrophotometer).

After 24 hr of treatment, mussel mortality was checked and mussels were transferred to squarc plastic dishes with fresh aerated hard water. Mortality was checked and recorded each day with water replacements, for an additional 7 days ( 8 days total). On the final day of mortality checks, 20 mussels were measured from the untreated controls using a caliper.

\section{Results:}

Mussel length: Zebra mussels $17.67 \pm 3.15 \mathrm{~mm}$.

Optical density of treatments:

\begin{tabular}{|c|c|}
\hline Treatment & Mean (tSD) OD $\left(\mathrm{A}_{660 \mathrm{~mm}}\right)$ \\
\hline \hline Untreated Control & $0.001 \pm 0.002$ \\
\hline Cambridge CF (Positive Control) & $0.202 \pm 0.004$ \\
\hline MBI-401 SDP 401P12163C and 401P12164C Mixed & $0.220 \pm 0.005$ \\
\hline
\end{tabular}

Zebra mussel mortality: Mussels were treated in triplicate testing jars $(500 \mathrm{ml})$ at $20^{\circ} \mathrm{C}$ for $24 \mathrm{hr}$ and mortality was recorded for a total of 10 days.

\begin{tabular}{|c|c|}
\hline Treatment & $\begin{array}{c}\text { Mean \% mortality } \\
( \pm \text { SD) }\end{array}$ \\
\hline \hline Untreated Control & $0.0 \pm 0.0 \%$ \\
\hline Cambridge CF (Positive Control) & $100.0 \pm 0.0 \%$ \\
\hline MBI-401 SDP 401P12163C and 401P12164C Mixed & $98.7 \pm 2.3 \%$ \\
\hline
\end{tabular}

MBI-401 SDP 401P12163C and 401P12164C Mixed PASSED the post-test bioassay validation (98\% mortality). Untreated control mortality was $0 \%$.

AEH-13-PSEUDO-06

File Folder: $\frac{8 \quad \text { item Number: } \frac{5}{2}}{\text { Page } 2}$ 


\title{
CHEMICAL LOG BOOK
}

\author{
MBI-401 SDP
}

Marrone Bio Innovations

Davis, California

\author{
LOT NUMBERS: \\ 401P12163C \\ and \\ 401P12164C \\ (Received Mixed in Containers)
}

Container 5 of 6

AEH-13-PSEUDO-06

File Folder:

18
Item Number:

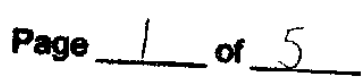


All personnel making an entry in this log must fill out the form below in accordance with SOP GEN 009.

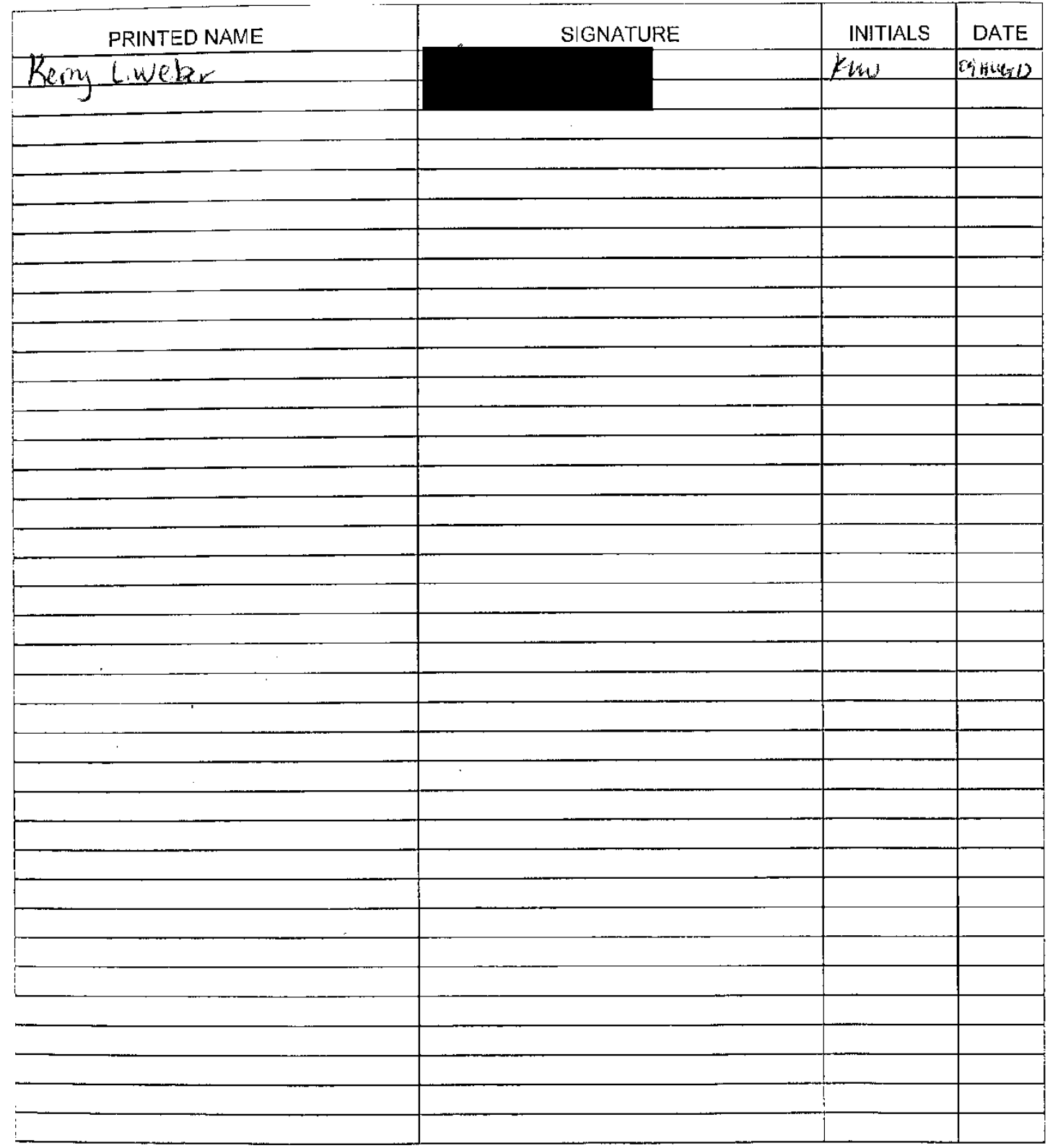

"This Use and Maintenance Log Book has been inspected and found to be in compliance with SOP GEN 009.

Inspected and sealed on $\frac{2 i s,}{1}$ Date

AEH-13-PSEUDO-06
File Folder: 18

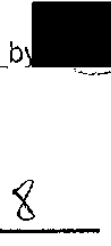

Quality Assuránce Unit

Item Number:

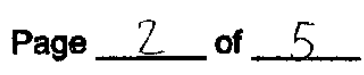




\section{ORIGINAL}

SOP No. GEN 012.3

Page 5 of 7

Form GEN 012.3a

Page 1 of 1

TEST CHEMICAL DATA IORM

Test Chemical (Chemical Name) MBL-401 SDP

Circle one: Test Article Control Article

Trade Name of Test Chemical (Synonyms) If - CL 145A; Zequatrex

Source of Test Chemical (Manufacturer) Marrone Biv Inhovations

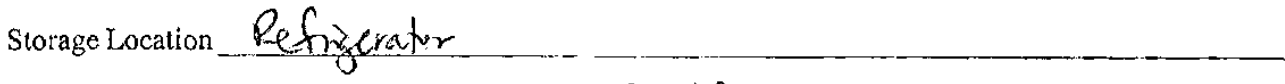

Date Received of Aut 12 \&w Date Opened 20MAR2013 Expiration Date DAMN 2013

(h) (5 years unless otherwise stated)

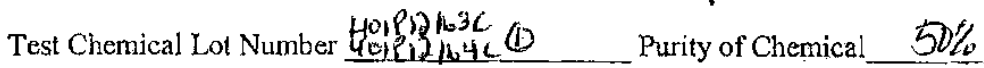

Amount of Test Chemical Available or Received (if known) $-2500 \mathrm{c}$

Initial Mass (with cover on) of Test Chemical and Container $509.76 \mathrm{~g}$

Characterization of Test Chemical: Color Tan

Physica! State: liquid _ solid $X$

Chemical Abstract Service Number N/A

Solid Form: powderX_ crystal _. pellet

Manufacturer Certificate of Analysis Yes $\underline{X}$ No

Additional Comments about the Test Chemical:

\section{Q Received mixed from manufacturer. Kew oatucald}

Sample Placed in Archives: Yes _._. No X (Entries should also be made on Form GEN 012.b)

Archive Location Matcrial Safety Data Sheet Avajlable: Yes $\underline{X}$ No

Signature of Study Director or designee initiating Test Chemical Use Log and date:

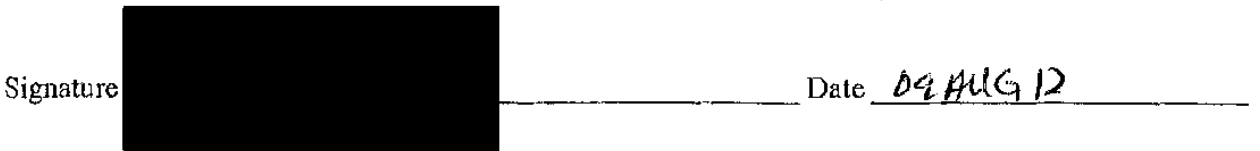

Item Number:

AEH-13-PSEUDO-06

File Folder: 18

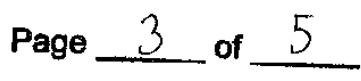




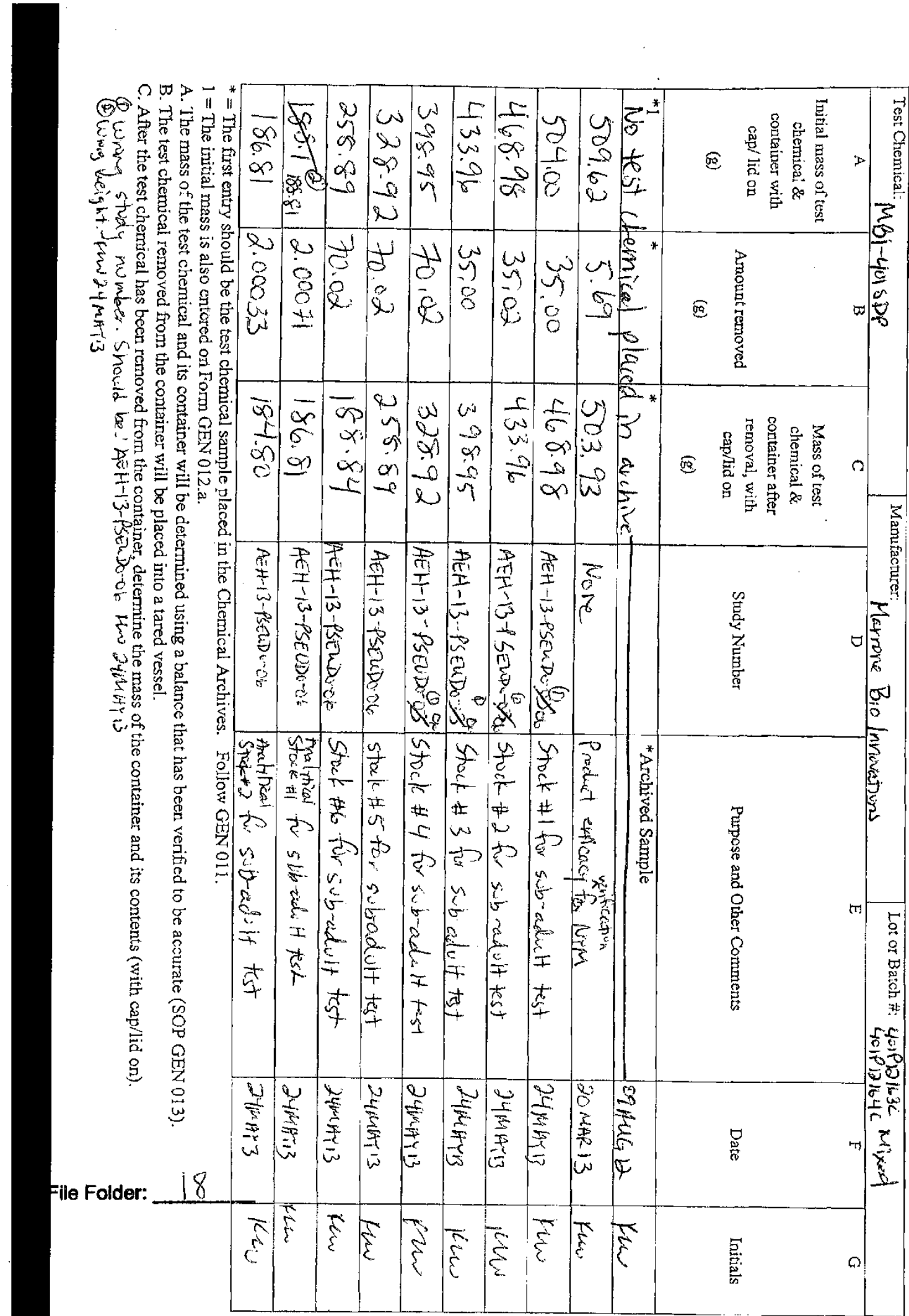

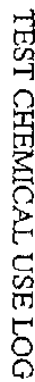

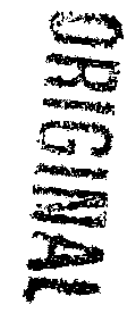

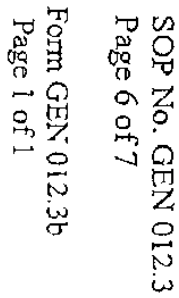

Item Number:

Page 4 of 5

AEH-13-PSEUDO-06 


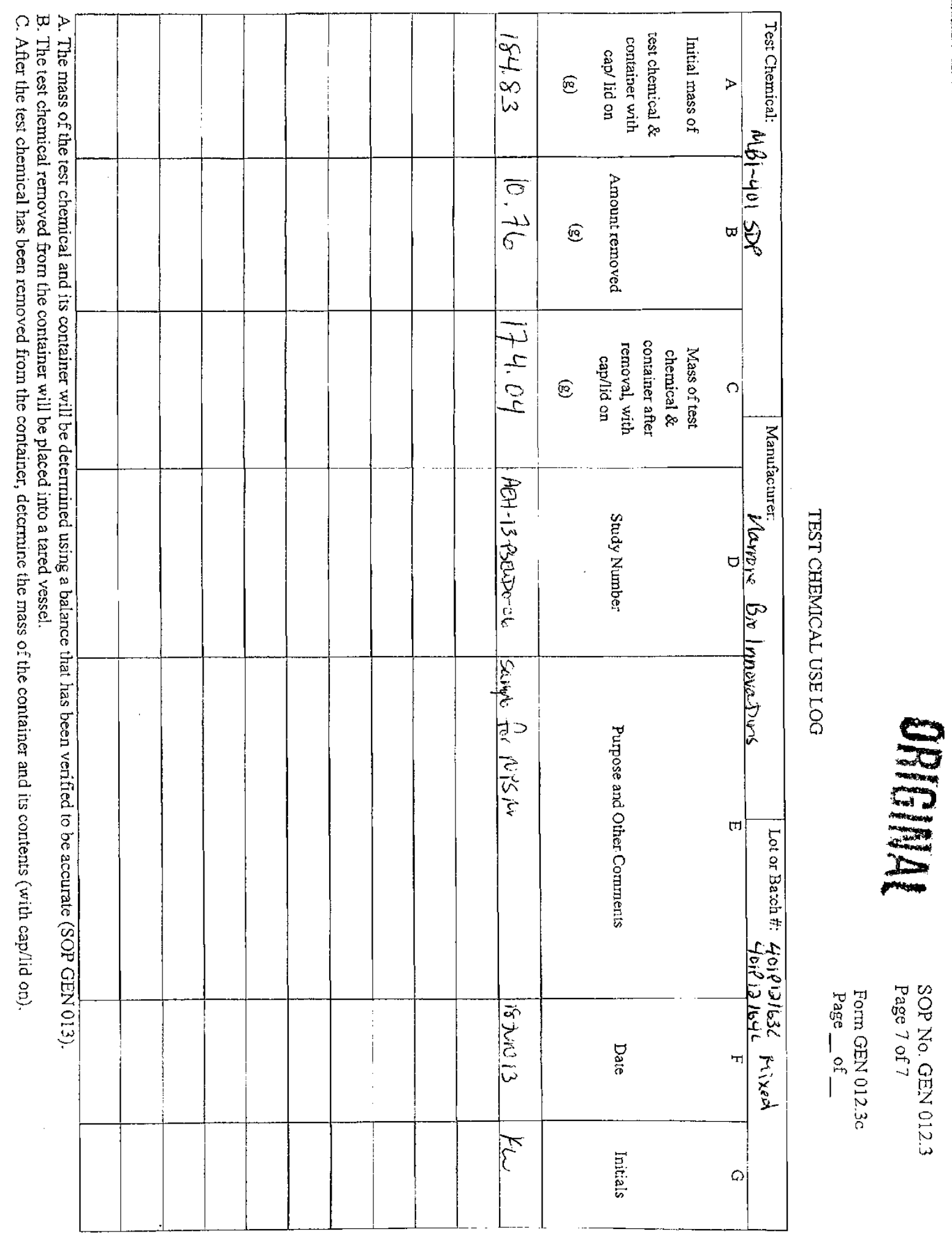

AEH-13-PSEUDO-06

Page 5 of 5

File Folder:

Item Number: 1 


\section{Appendix 5. Test Animal Information}

\begin{tabular}{clcc}
\hline $\begin{array}{c}\text { Item } \\
\text { Number }\end{array}$ & \multicolumn{1}{c}{ Item Description } & $\begin{array}{c}\text { Number } \\
\text { of } \\
\text { Pages }\end{array}$ & $\begin{array}{c}\text { Report } \\
\text { Page } \\
\text { Number }\end{array}$ \\
\hline 1 & Email from GNFH: Origin of Test Organisms & 2 & 138 \\
2 & Native Mussel Lengths - Data Summary & 1 & 140 \\
3 & Plain Pocketbook (L. cardium) Length Summary & 1 & 141 \\
4 & Hickorynut (O. olivaria) Length Summary & 1 & 142 \\
5 & Washboard (M. nervosa) Length Summary & 1 & 143 \\
6 & Higgins Eye (L. higginsii) Length Summary & 1 & 144 \\
7 & Fatmucket (L. siliquoidea) Length Summary & 1 & 145 \\
8 & Threeridge (A. plicata) Length Summary & 1 & 146 \\
9 & Wabash Pigtoe (F. flava) Length Summary & 1 & 147 \\
10 & Histological Examination of native mussel test organisms - Summary & 6 & 148 \\
\hline
\end{tabular}




\section{mussel info}

Luoma, James <jluoma@usgs.gov>

Thu, May 23, 2013 at 12:54 PM

To: Kerry Weber <klweber@usgs.gov

fyi

Forwarded message

From: Eckert, Nathan <nathan eckert@fws.gov

Dato: Thu, May 23, 2013 at 12:50 PM

Subject: Re: mussel info

To: "Luoma, James" <jluoma@usgs.gov

OK, Here Goes.

Washboard -- Sac River, Caplinger Mills, Cedar County of Missouri, Collected fall 2010 Transformed in February of 2011, reared in buckets at Missouri State U. up to $3 \mathrm{~mm}$ and then in floating upwellers at the KC Zoo until transfer to Genoa on $5 / 17 / 13$

Threeridge/Wabash Pigtoe - Collected from the Mississippi River @ Blackhawk Park, Vernon County WI on $5 / 10 / 13$.

Hickorynut - lowa River at Hills, Johnson County, IA. Collected Spring 2010, cultured in cages on the St. Croix River summer '10, '11, '12. Retrieved from the cages $5 / 13 / 13$

Fatmucket -- St. Croix River, WI, Collected Spring 2010, cultured in cages on the St. Croix River summer '10, '11, '12. Retrieved from the cages $5 / 13 / 13$

Higgins' Eye -- St. Croix River, Hudson, WI. Collected 4/29/11. Cultured in cages on the St. Croix River Summer 111 \& '12. Retrieved from the cages $5 / 13 / 13$

Plain pocketbook - Mississippi River, likely PdC, Collected Spring 2010. Juveniles recovered in the lab and held in bucket system through Spring '11. Mussels cultured in MARS trailer Summer '11/'12 held over winter at GNFH in pond water.

I realize that some detail is lacking here. That said a few of these species were propagated prior to my arrival at GNFH. The hatchery records say that a "Luoma" was part of the infestations.

Nathan

[Quoted text hidden]

AEH-13-PSEUDO-06

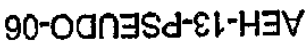

Nathan L. Eckert

Mussel Biologist

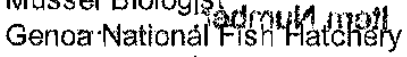

S5631 State Hwy 35 sbio 3 ati

Genoa, WI 54632

File Folder: 7

608-689-2605

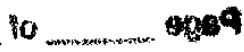

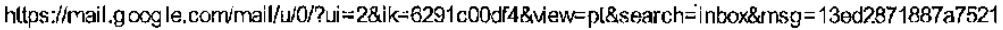

Nem Number: 1 
James A. Luoma

Research Fisheries Biologist

AEH

Upper Midwest Environmental Sciences Center

2630 Fanta Reed Rd

LaCrosse, WI 54603

Office (608)781-6391

Cell (608)799-1723

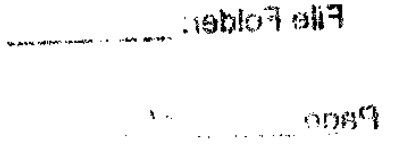

vextruth moll
AEH-13-PSEUDO-06 item \#9FE B 14

Item Number: $\rightarrow 1$

; File Folder:

Page 2 of 2 


\begin{tabular}{|c|c|c|c|}
\hline \multirow{2}{*}{$\begin{array}{l}\text { Study Number: AEH-13-PSEUDO-06 } \\
\text { Electronic Logbook (Pages 5-6) }\end{array}$} & Action & Date & Inltials \\
\hline & Created...... & $1 / 21 / 2014$ & $J \mathrm{KW}$ kWw \\
\hline \multirow{3}{*}{ Data Source: "Native Mussel Length" File Folder: 11a-11: } & Revised...... & $4 / 24 / 2014$ & KLW tow \\
\hline & Revlewed... & xysury & Fnn \\
\hline & Certlfted...... & $12 / 12 / 4$ & $J_{j 2}$ \\
\hline
\end{tabular}

\section{Native Mussel Length Data}

Test Article: Pseudomonas fluorescens Pf -CL 145A (SDP); lot \#: 401P12163C and 401P12164C Mix Test Location: Black River, La Crosse, W|

Exposure Date: $5 / 29 / 2013$

Assessment Dates: $6 / 26-27 / 2013$

Fliename(s)

I: AEEK-13-PSEUDO-06 DatałData SUmmaries \[AEH-13-PSEUDO-06 Native Mussel Length Data.x|sx]PPB Length Summary I: AEH-13-PSEUDC-06\Data\Data Summarles\/AEH-13-PSEUDO-06 Native Musset Length Data.x|sx]HIC Length Summary 1: $\mid A E 1$-13-PSEUDC-06\DatałData Summaries\[AEH-13-PSEUDO-06 Native Mussei Length Data.xisx]WAS Length Summary I:AEEH-23-PSEUDO-06 \Data\Data Summarles\\AEH-13-PSEUDO-06 Natlve Mussel Length Data,xl5x]HGE Length Summary I:YAEH-13-PSEUDO-06\DatałData Summa:ies》[AEH-13-PSEUDO-06 Native Mussel L.ength Data.x|sx]FAM Leng:h Summary I:AAEH-13-PSEUDO-06\Data\Data Summaries\[AEH-13-PSEUDO-06 Native Mussel Length Data.xIsx]THR Length Summary I:|AEH-13-PSEUDO-06\Data\Data SUmmaries\[AEH-13-PSEUDO-06 Native Mussel Length Data.xlsx]P|G Length Summary

Test Organisms:

Common name, scientific name, three letter abbreviation

Plain Pocketbook, Lampsilis cardium, PPB

Hickorynut, Obovaria offvarla, HIC

Washboard, Megalonalas nervosa, WAS

Higgins Eye, Lampsilis higginsil, HGE

Fatmucket, Lampsills silicuoldea, FAM

Threeridge, Amblema pilicata, THR

Wabash Pigtoe, Fusconaia flava, PIG

Mean (stondard deviatlon) Test Antmat Length (mml

\begin{tabular}{|l|ccccccc|}
\hline & PPB & HIC & WAS & HGE & FAM & THR & \multicolumn{1}{c|}{ P|G } \\
\hline \hline Mean & 39.21 & 30.97 & 44.03 & 23.77 & 57.04 & 63.18 & 51.07 \\
(SD) & $(4.16)$ & $(2.19)$ & $(3.76)$ & $(2.27)$ & $(4.77)$ & $(8.30)$ & $(8.00)$ \\
MIN & 27.35 & 21.33 & 35.21 & 17.81 & 42.27 & 43.80 & 33.82 \\
MAX & 48.05 & 37.15 & 56.97 & 28.97 & 68.73 & 88.56 & 73.65 \\
\hline
\end{tabular}

Data Explanation:

Mussel Species: Three letter code abbrevlations

$\mathrm{N}$ : tetal individuals of given species.

Lengths: length (mm) of mussel as measured parallel to hinge

Data Anomalies and Devlations:

NONE

Statistical Analysls

Mean length: Mean ie $z$ th of Individuals w thin mussel species.

Standard Devlatlon: Standard deviation of all lengths within mussel specles population.

Minlmum Length: Mlnimum length within population of mussel species.

Maxlmum Length: Maximum length wit in population of mussel specles.

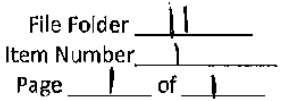




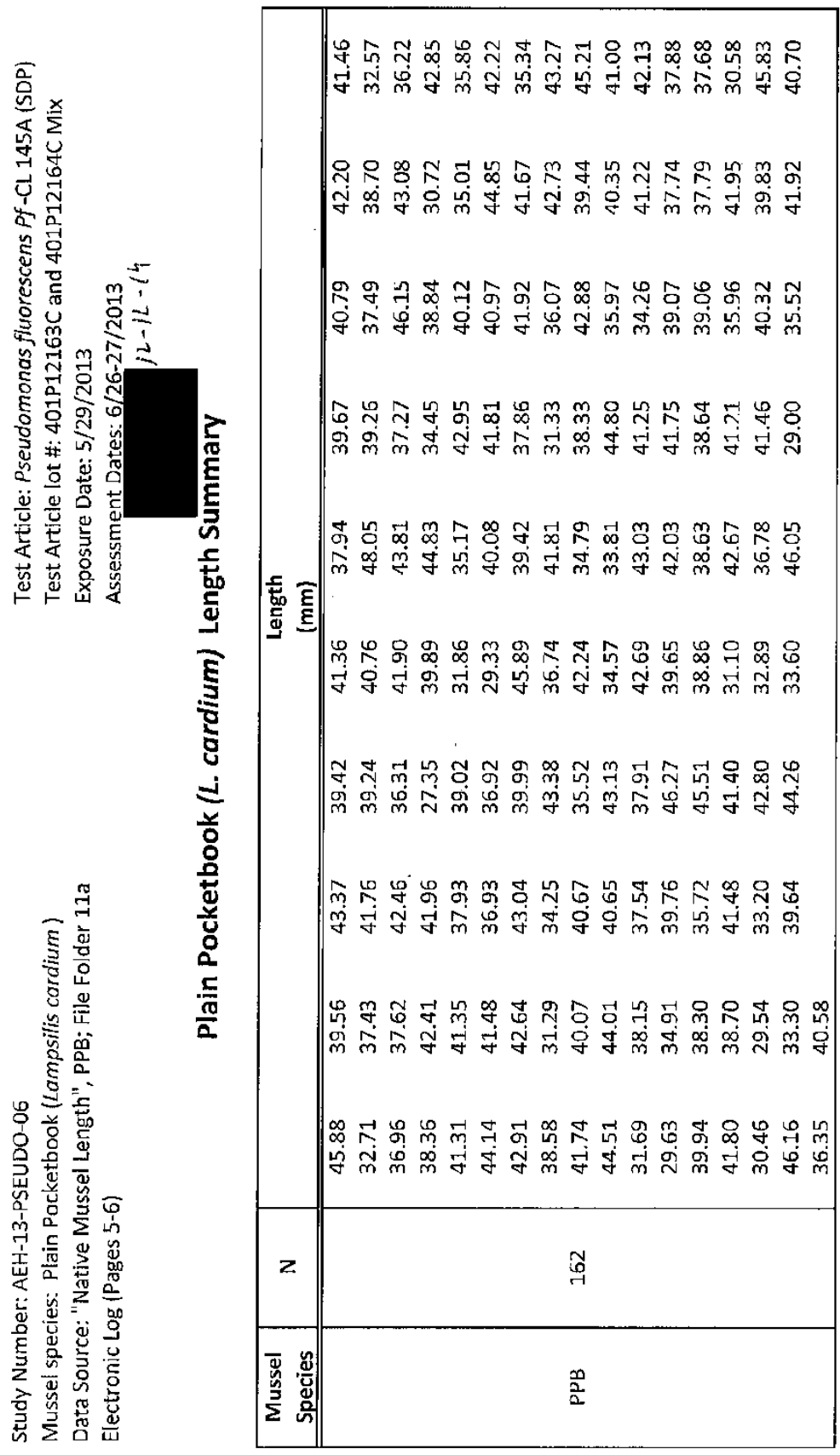

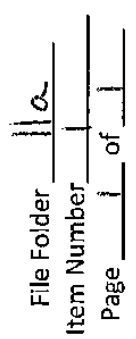

고웜

感过令

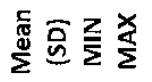




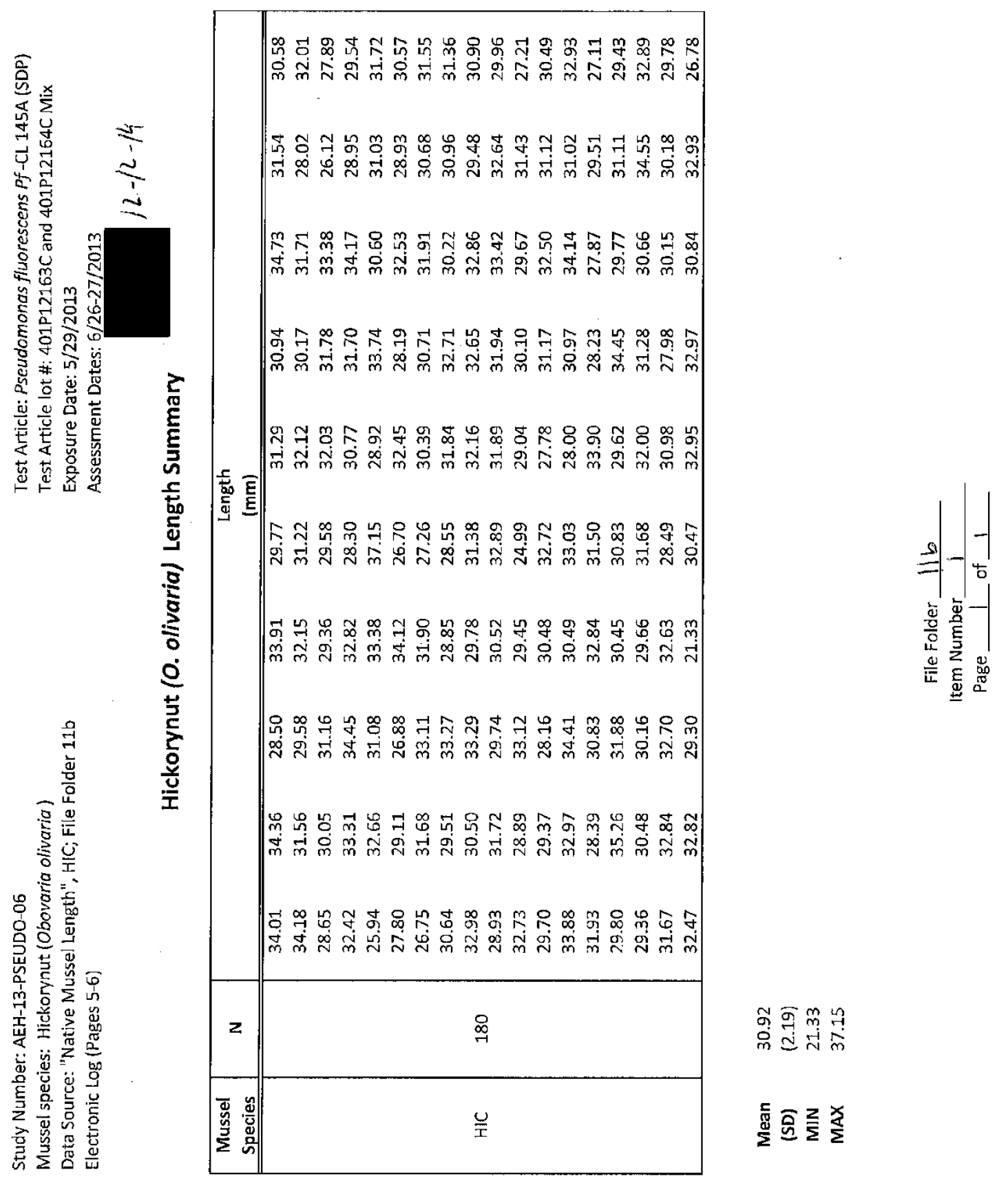




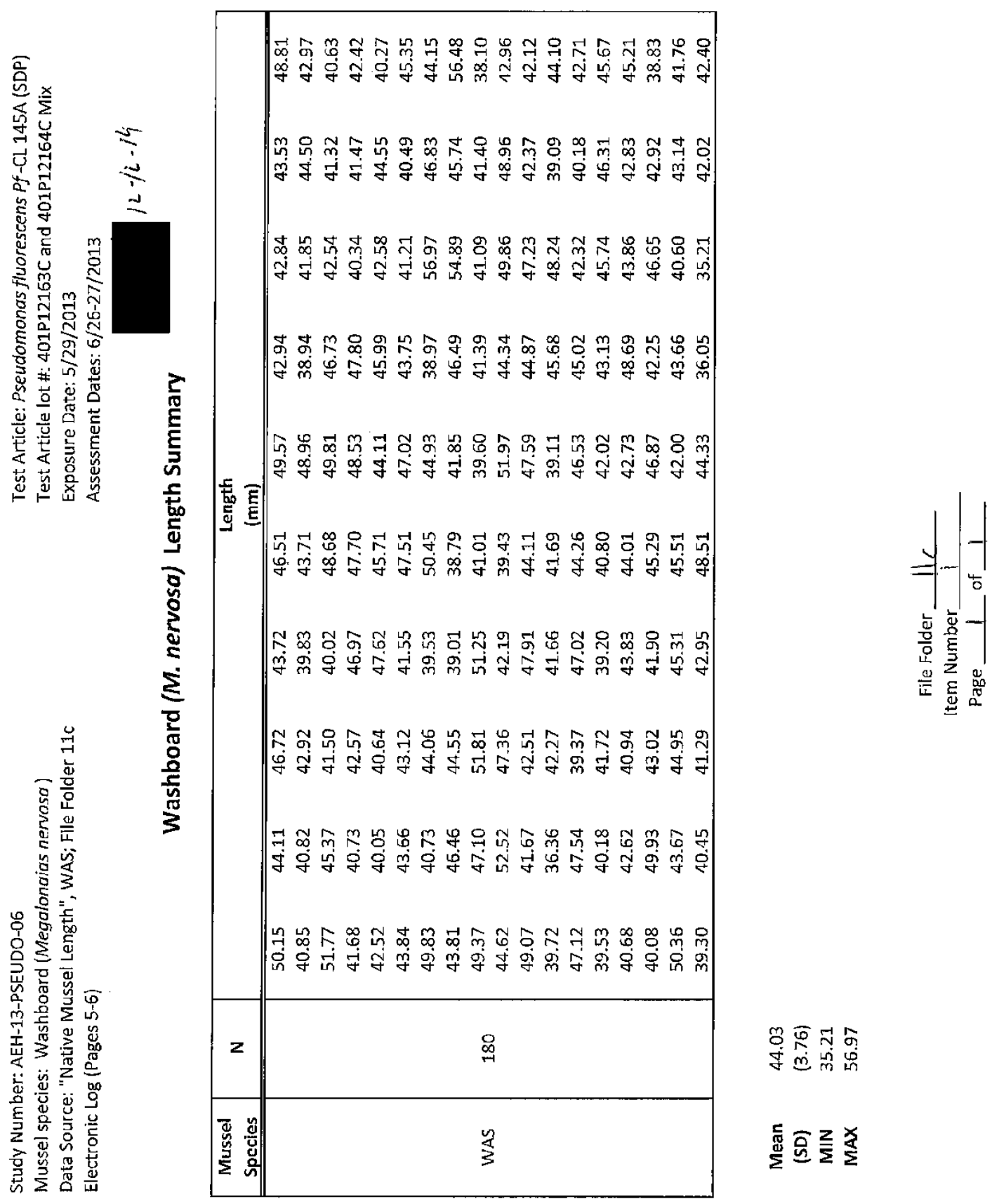



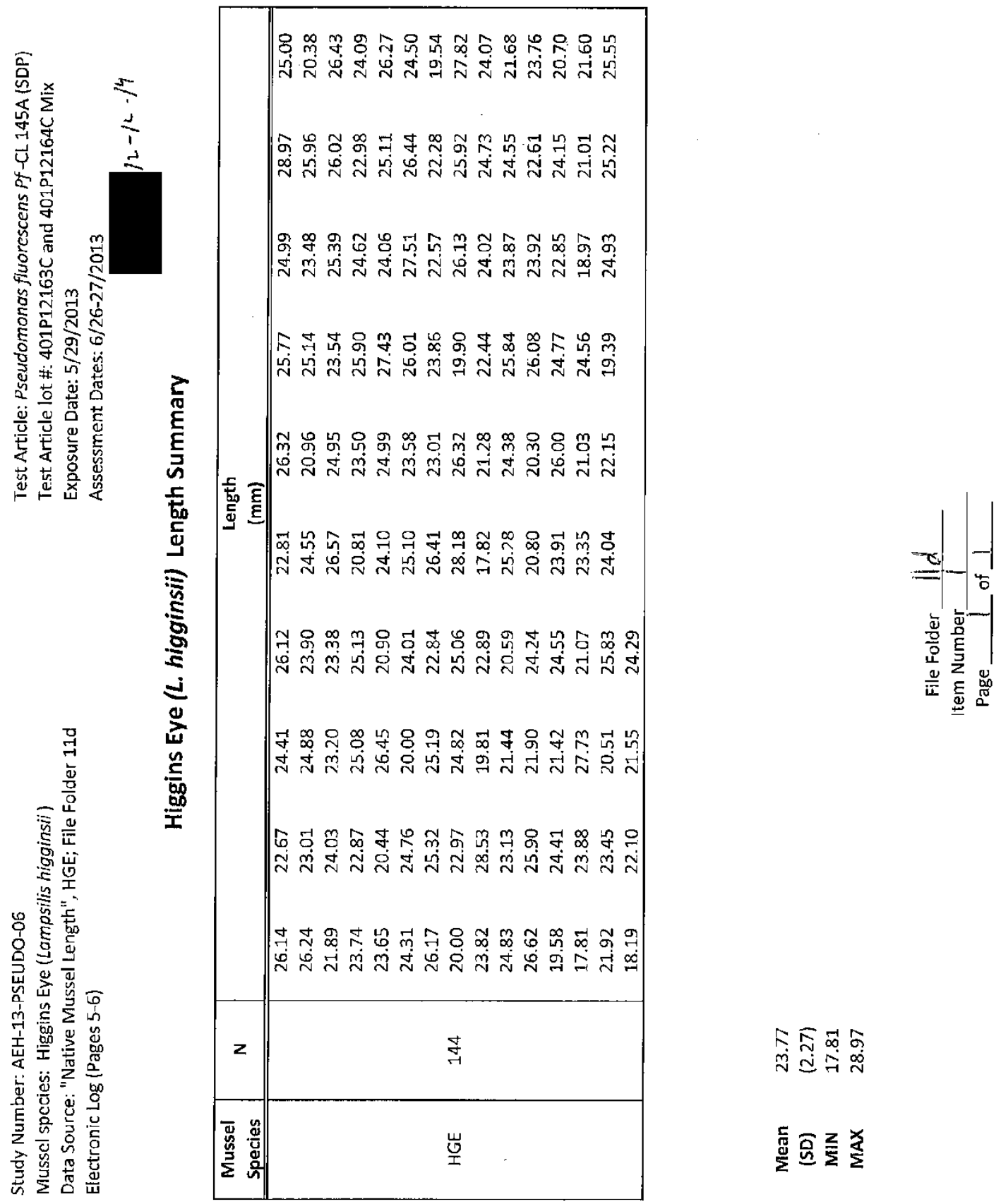

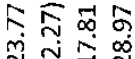

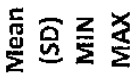




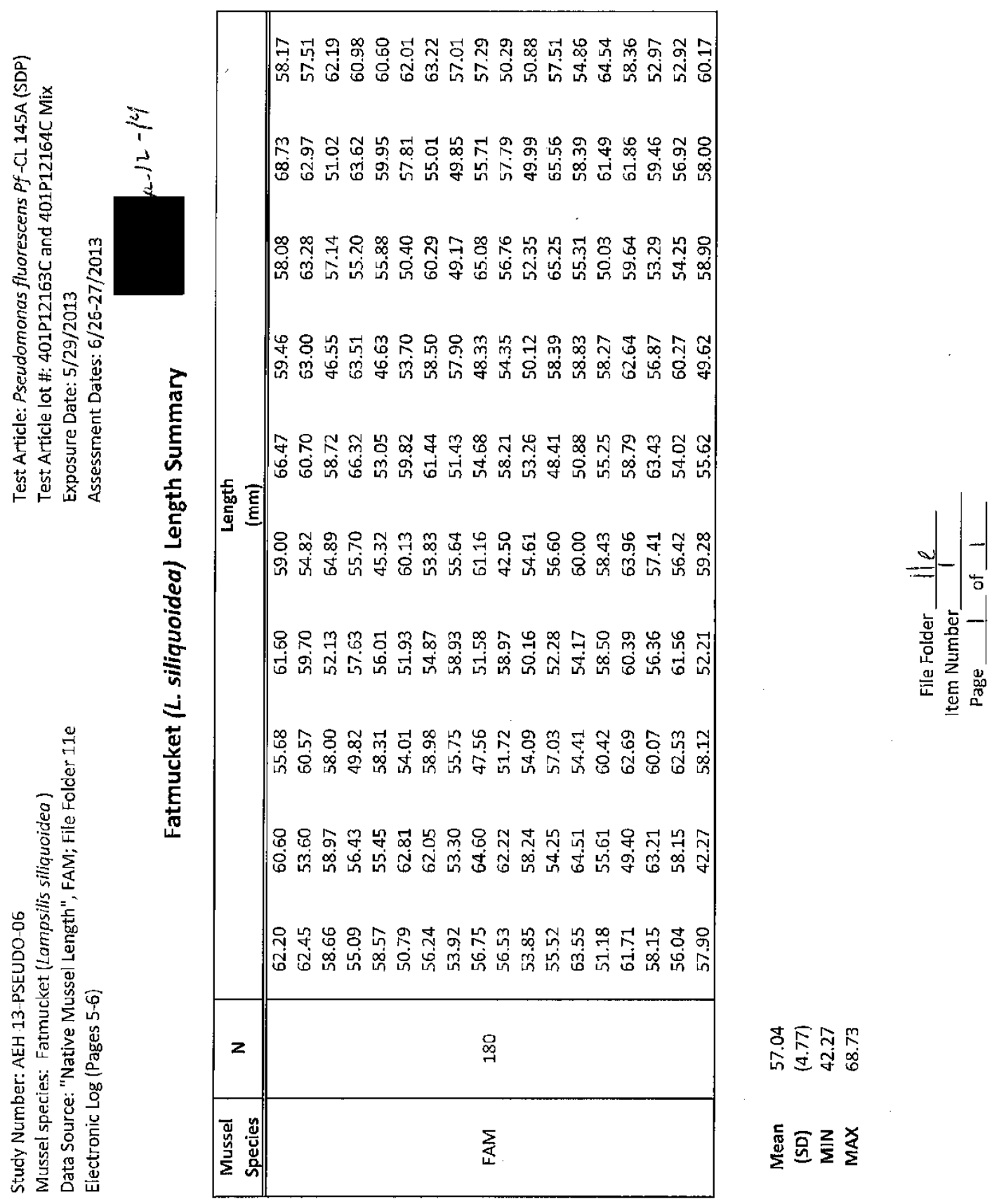



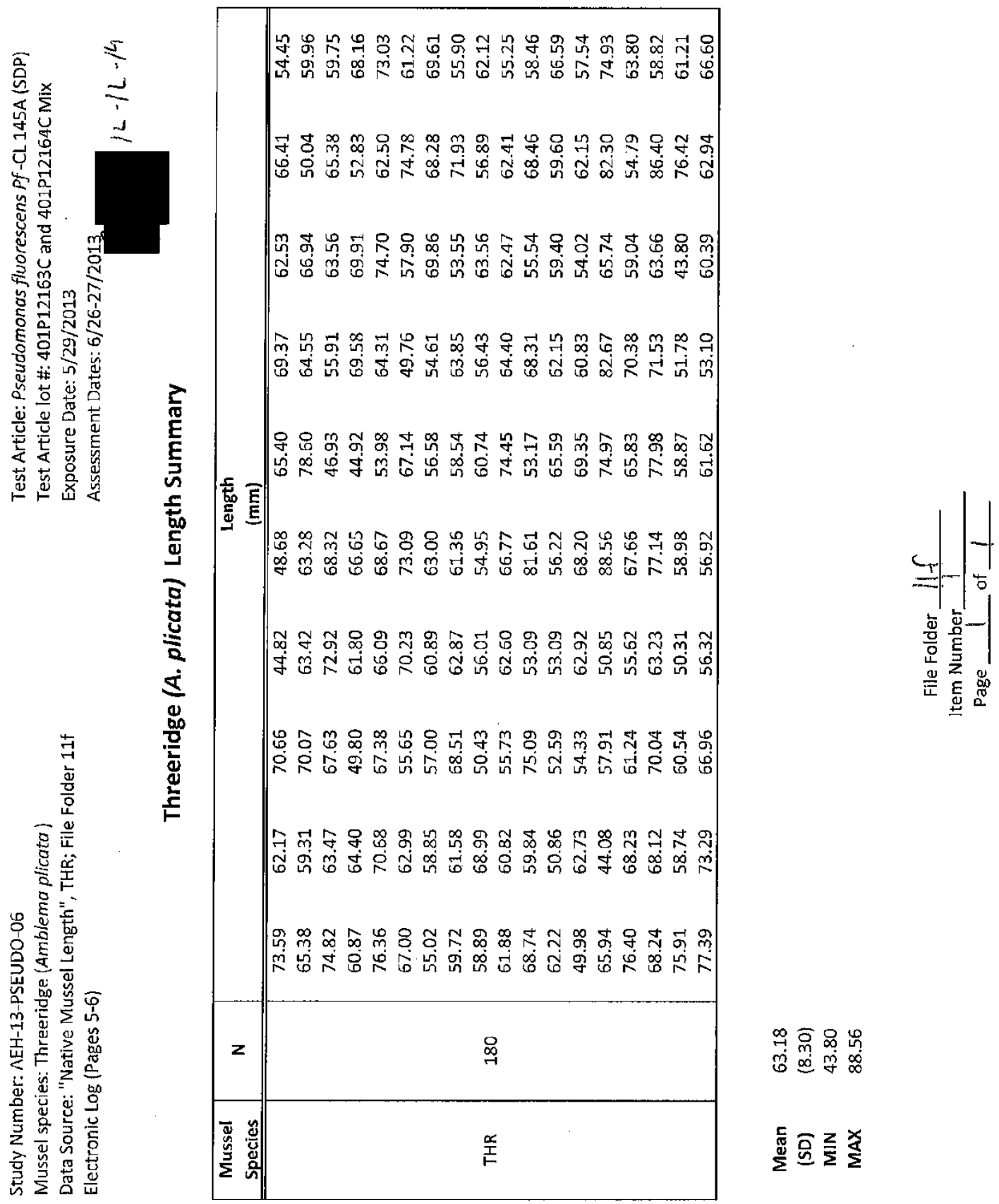

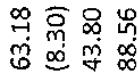

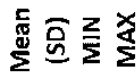



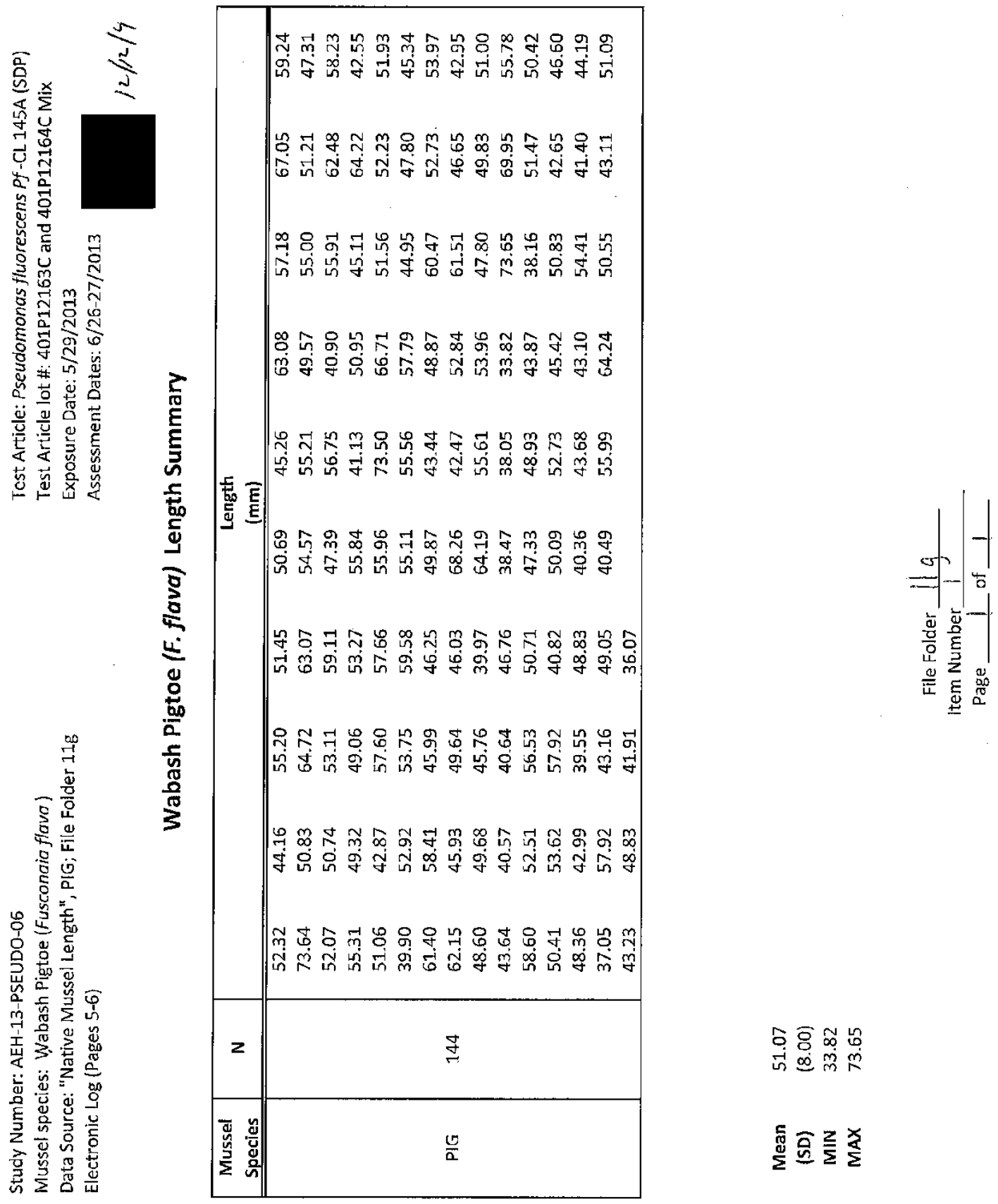

훙훙요 능

जे

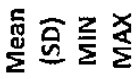




\begin{tabular}{|c|c|c|c|}
\hline \multirow{5}{*}{$\begin{array}{l}\text { Study Number: AEH-13-PSEUDO-06 } \\
\text { Electronic Log (pages 10-11) } \\
\text { Data Source: "Mussel Histology Samples" File Folder } 7\end{array}$} & Action & Date & injtlals \\
\hline & Created...... & $5 / 7 / 2013$ & KLW im \\
\hline & Revised...... & $4 / 23 / 2014$ & KLW N $\mathrm{km}$ \\
\hline & Reviewed... & $23 \mathrm{APC}$ & hing \\
\hline & Certified...... & $/ L / / 2 / / 1$ & $5-$ \\
\hline
\end{tabular}

\section{Histology Summary}

Test Article: Pseudomonas fiuorescens Pf -CL 145A (SDP); lot \#: 401P12163C and 401P12164C Mix

Test Location: Black River, La Crosse, WI

Exposure Date: 5/29/2013

Assessment Dates: 6/26-27/2013

Filename(s)

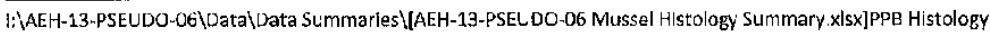

I:AEEH-13-PSEUDO-06 \DatajData Summaries \AEH-13-PSELDO-06 Mussel Hlstology Summary.xlsx]HIC Histology

i: AAEH-13-PSEUDO-06 \Data\Data Summarles \AEH-13-PSELDO-06 Mussel Histology Summary.xlsx]FAM Histology

I:'AEH-13-PSEUDO-06\Data\Data Summarles\[AEH-13-PSELDO-06 Mussel HIstology Summary.xIsx]THR Histology

1: \AEH-13-PSEUDO-06\Data\Data Summarles\[AEH-13-PSELDO-06 Mussel HIstology Summary.xlsx]PIG Histology

Test Organisms:

Common name, sclentific name, three letter abbreviation

Plain Pocketbook, Lampsilis cardium, PPB

Hickorynut, Obovaria olivaria, HIC

Fatmucket, Lampsilis slliquoldea, FAM

Threeridge, Amblema plicata, THR

Wabash Pigtoe, Fusconaia flava, PIG

Data Explanation:

Three mussels of each species, excluding WAS and HGE, originating from each test tank and exposure duration were sampled for histological examination 28 days post-exposure. A total of 54 mussels ( 3 per test tank $\times 9$ test tanks $\times 2$ exposure durations) of each species were sampled.

Species (Three Letter Abbreviation)

Test Tank \#: $1-9$

Treatment Group: Control $(0 \mathrm{mg} / \mathrm{L}), 50 \mathrm{mg} / \mathrm{L}$, ano $100 \mathrm{mg} / \mathrm{L}$

Exposure Duration: 8 Hour or 24 Hour

Tag ID: Letter Prefix and code number (i.e., A123)

Number of Cassettes: Total number of cassettes used to contain an individual mussel tissue for histological examination.

Container Number: Storage container where individual mussel histology cassette is located.

Data Anomalies and Deviations:

NONE

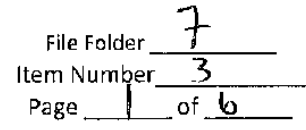


Study Number: AEH-13-PSEUDO-06

Electronic Log (pages 10-11)

Data Source: "Mussel Histology Samples" File Folder 7
Test Article; Pseudomonas fluorescens Pf -CL 145A (SDP)

Test Article lot \#: 401P12163C and 401P12164C Mlx

Exposure Date: 5/29/2013 Assessment Dates: 6/26-27/2013

Plain Pocketbook (L. cardium) Histology

\begin{tabular}{|c|c|c|c|c|c|c|}
\hline $\begin{array}{l}\text { Mussel } \\
\text { Species }\end{array}$ & Test Tank & $\begin{array}{c}\text { Treatment } \\
\text { Group } \\
(\mathrm{mg} / \mathrm{L})\end{array}$ & $\begin{array}{l}\text { Exposure } \\
\text { Duration }\end{array}$ & Tag ID & $\begin{array}{l}\text { Number of } \\
\text { Cassettes }\end{array}$ & $\begin{array}{c}\text { Container } \\
\text { Number }\end{array}$ \\
\hline \multirow{54}{*}{ PPB } & \multirow{6}{*}{1} & \multirow{6}{*}{100} & \multirow{3}{*}{8} & A204 & 1 & 2 \\
\hline & & & & $A 270$ & 1 & 2 \\
\hline & & & & A300 & 1 & 3 \\
\hline & & & \multirow{3}{*}{24} & A284 & 1 & 10 \\
\hline & & & & A189 & 1 & 11 \\
\hline & & & & A313 & 1 & 11 \\
\hline & \multirow{6}{*}{2} & \multirow{6}{*}{100} & \multirow{3}{*}{8} & A269 & 1 & 5 \\
\hline & & & & A338 & 1 & 5 \\
\hline & & & & A311. & 1 & 6 \\
\hline & & & \multirow{3}{*}{24} & A256 & 1 & 13 \\
\hline & & & & A335 & 1 & 14 \\
\hline & & & & A274 & 1 & 15 \\
\hline & \multirow{6}{*}{3} & \multirow{6}{*}{50} & \multirow{3}{*}{8} & A183 & 1 & 2 \\
\hline & & & & A250 & 1 & 3 \\
\hline & & & & A340 & 1 & 3 \\
\hline & & & \multirow{3}{*}{24} & A232. & 1 & 11 \\
\hline & & & & A341 & 1 & 12 \\
\hline & & & & A 323 & 1 & 12 \\
\hline & \multirow{6}{*}{4} & \multirow{6}{*}{50} & \multirow{3}{*}{8} & A200 & 1 & 5 \\
\hline & & & & A329 & 1 & 6 \\
\hline & & & & A215 & 1 & 6 \\
\hline & & & \multirow{3}{*}{24} & A265 & 1 & 13 \\
\hline & & & & A181 & 1 & 13 \\
\hline & & & & A208 & 1 & 15 \\
\hline & & & \multirow{3}{*}{8} & A279 & 1 & 2 \\
\hline & & & & A257 & 1 & 3 \\
\hline & 5 & CONTRO1 & & A285 & 1 & 3 \\
\hline & 3 & CONIRUL & & A251 & 1 & 11 \\
\hline & & & 24 & A275 & 1 & 11 \\
\hline & & & & A197 & 1 & 12 \\
\hline & & & & A236 & 1 & 8 \\
\hline & & & 8 & A219 & 1 & 9 \\
\hline & 6 & 50 & & A233 & 1 & 9 \\
\hline & 6 & & & A203 & 1 & 17 \\
\hline & & & 24 & A314 & 1 & 17 \\
\hline & & & & A182 & 1 & 18 \\
\hline & & & & A258 & 1 & 6 \\
\hline & & & 8 & A29? & 1 & 6 \\
\hline & 7 & CONTR & & A337 & 1 & 6 \\
\hline & 7 & CONTROL & & A305 & 1 & 13 \\
\hline & & & 24 & A195 & 1 & 15 \\
\hline & & & & A276 & 1 & 15 \\
\hline & & & & A249 & 1 & 8 \\
\hline & & & 8 & A348 & 1 & 8 \\
\hline & o & 1 & & A253 & 1 & 8 \\
\hline & 8 & LUHFU & & A30S & 1 & 17 \\
\hline & & & 24 & A217 & 1 & 18 \\
\hline & & & & A266 & 1 & 18 \\
\hline & & & & A228 & 1 & 7 \\
\hline & & & 8 & A196 & 1 & 8 \\
\hline & g & 100 & & A280 & 1 & 9 \\
\hline & 9 & 100 & & A206 & 1 & 18 \\
\hline & & & 24 & A31S & 1 & 18 \\
\hline & & & & A260 & 1 & 18 \\
\hline
\end{tabular}

Page 2 of 6 
Study Number; AEH-13-PSEUDO-06

Electronic Log (pages 10-11)

Data Source: "Mussel Histology Samples' File Folder 7
Test Article: Pseudomonas fiuorescens of $-\mathrm{CL}$ 145A (SDP) Test Article lot \#: 401P12163C and 4J1P12164C Mix

Exposure Date; 5/29/2013 Assessment Dates: 6/26-27/2013

Hickorynut (O. olivaria ) Histology Samples

\begin{tabular}{|c|c|c|c|c|c|c|}
\hline $\begin{array}{l}\text { Mussel } \\
\text { Species }\end{array}$ & Test Tank & $\begin{array}{c}\text { Treatment } \\
\text { Group } \\
\text { (mg/L) }\end{array}$ & $\begin{array}{l}\text { Exposure } \\
\text { Duration }\end{array}$ & Tag ID & $\begin{array}{l}\text { Number of } \\
\text { Cassettes }\end{array}$ & $\begin{array}{c}\text { Container } \\
\text { Number }\end{array}$ \\
\hline \multirow{54}{*}{$\mathrm{HIC}$} & \multirow{6}{*}{1} & \multirow{6}{*}{100} & \multirow{3}{*}{8} & 0007 & 1 & 1 \\
\hline & & & & D028 & 1 & 2 \\
\hline & & & & D172 & 1 & 3 \\
\hline & & & \multirow{3}{*}{24} & D137 & 1 & 11 \\
\hline & & & & 0100 & 1 & 11 \\
\hline & & & & D080 & 1 & 12 \\
\hline & \multirow{6}{*}{2} & \multirow{6}{*}{100} & \multirow{3}{*}{8} & D013 & 1 & 4 \\
\hline & & & & D102 & 1 & 6 \\
\hline & & & & D168 & 1 & 6 \\
\hline & & & \multirow{3}{*}{24} & 0019 & 1 & 13 \\
\hline & & & & D063 & 1 & 14 \\
\hline & & & & D166 & 1 & 14 \\
\hline & \multirow{6}{*}{3} & \multirow{6}{*}{50} & \multirow{3}{*}{$B$} & D186 & 1 & 1 \\
\hline & & & & D005 & 1 & 1 \\
\hline & & & & DO73 & 1 & 2 \\
\hline & & & \multirow{3}{*}{24} & Do95 & 1 & 10 \\
\hline & & & & 0056 & 1 & 10 \\
\hline & & & & D021 & 1 & 11 \\
\hline & \multirow{6}{*}{4} & \multirow{6}{*}{50} & \multirow{3}{*}{8} & 0006 & 1 & 4 \\
\hline & & & & Dog4 & 1 & 5 \\
\hline & & & & 0129 & 1 & 6 \\
\hline & & & \multirow{3}{*}{24} & D148 & 1 & 13 \\
\hline & & & & D018 & 1 & 13 \\
\hline & & & & D122 & 1 & 13 \\
\hline & & & \multirow{3}{*}{8} & D053 & 1 & 2 \\
\hline & & & & D012 & 1 & 2 \\
\hline & 5 & CONTROI & & D092 & 1 & 2 \\
\hline & 3 & CUIVIKuL & & $\mathrm{D} 139$ & 1 & 11 \\
\hline & & & 24 & D020 & 1 & 11 \\
\hline & & & & D069 & 1. & 12 \\
\hline & & & & D111 & 1 & 7 \\
\hline & & & 8 & 0130 & 1 & 8 \\
\hline & 6 & 50 & & D097 & 1 & 9 \\
\hline & 6 & 50 & & 0.185 & 1 & 18 \\
\hline & & & 24 & 0091 & 1 & 18 \\
\hline & & & & 0178 & 1. & 18 \\
\hline & & & & D183 & 1 & 4 \\
\hline & & & 8 & D001 & 1. & 4 \\
\hline & 7 & CONTROI & & D085 & 1 & 4 \\
\hline & 7 & CONIRUL & & D143 & 1 & 13 \\
\hline & & & 24 & D117 & 1 & 13 \\
\hline & & & & D083 & 1. & 13 \\
\hline & & & & D164 & 1 & 7 \\
\hline & & & 8 & D176 & 1 & 8 \\
\hline & & CONTROI & & D142 & 1 & 8 \\
\hline & 8 & CONIROL & & 0167 & 1 & 16 \\
\hline & & & 24 & $\mathrm{D} 002$ & 1 & 18 \\
\hline & & & & D127 & 1. & 18 \\
\hline & & & & 0060 & 1 & 7 \\
\hline & & & 8 & D088 & 1 & 9 \\
\hline & & & & D145 & 1 & 9 \\
\hline & 9 & 100 & & D040 & 1 & 18 \\
\hline & & & 24 & D089 & 1 & 18 \\
\hline & & & & 0105 & 1 & 18 \\
\hline
\end{tabular}

Page 3 of 6 
Study Number: AEH-13-PSEUDO-06

Electronic Log (pages 10-11)

Data Source: "Mussel Ilistology Samples" File Folder 7
Test Article: Pseudomonos fluorescens of -CL 145A (SDP) Test Article lot H: 401P12163C and 401P12164C Mix

Exposure Date: 5/29/2013 Assessment Dates: 6/26-27/2013

Threeridge (A, plicata)Histology Samples

\begin{tabular}{|c|c|c|c|c|c|c|}
\hline $\begin{array}{l}\text { Mussel } \\
\text { Species }\end{array}$ & Test Tank & $\begin{array}{c}\text { Treatment } \\
\text { Group } \\
\text { (mg/L) }\end{array}$ & $\begin{array}{l}\text { Exposure } \\
\text { Duration }\end{array}$ & Tag ID & $\begin{array}{l}\text { Number of } \\
\text { Cassettes }\end{array}$ & $\begin{array}{l}\text { Container } \\
\text { Number }\end{array}$ \\
\hline \multirow{54}{*}{ THR } & \multirow{6}{*}{1} & \multirow{6}{*}{100} & \multirow{3}{*}{8} & $\mathrm{C073}$ & 1 & 1 \\
\hline & & & & $\mathrm{C} 062$ & 1 & 1 \\
\hline & & & & C170 & 1 & 1 \\
\hline & & & \multirow{3}{*}{24} & $\cos 3$ & 2 & 10 \\
\hline & & & & $\mathrm{CO} 24$ & 1 & 10 \\
\hline & & & & C059 & 1 & 10 \\
\hline & \multirow{6}{*}{2} & \multirow{6}{*}{100} & \multirow{3}{*}{8} & C079 & 1 & 4 \\
\hline & & & & $\mathrm{CO23}$ & 1 & 4 \\
\hline & & & & C113 & 1 & 4 \\
\hline & & & \multirow{3}{*}{24} & C125 & 1 & 13 \\
\hline & & & & C134 & 1 & 14 \\
\hline & & & & $\mathrm{COO} 3$ & 2 & 15 \\
\hline & \multirow{6}{*}{3} & \multirow{6}{*}{50} & \multirow{3}{*}{8} & $\cos 7$ & 1 & 1 \\
\hline & & & & C159 & 1 & 2 \\
\hline & & & & CO45 & 1 & 2 \\
\hline & & & \multirow{3}{*}{24} & C174 & 1 & 10 \\
\hline & & & & $\operatorname{coog}$ & 1 & 11 \\
\hline & & & & C133 & 1 & 4 \\
\hline & \multirow{6}{*}{4} & \multirow{6}{*}{50} & \multirow{3}{*}{8} & $\mathrm{CO} 67$ & 1 & 4 \\
\hline & & & & CO74 & 1 & 5 \\
\hline & & & & $C 121$ & 2 & 14 \\
\hline & & & \multirow{3}{*}{24} & C1.48 & 1 & 14 \\
\hline & & & & $\cos 3$ & 2 & 15 \\
\hline & & & & C183. & 1 & 1 \\
\hline & & & \multirow{3}{*}{8} & Ci11 & 1 & 1 \\
\hline & & & & $\mathrm{CO43}$ & 1 & 2 \\
\hline & 5 & CONTROL & & COR1 & 1 & 10 \\
\hline & 3 & LOTVIRUL & & 0018 & 1 & 10 \\
\hline & & & 24 & $\mathrm{Co11}$ & 1 & 10 \\
\hline & & & & $\mathrm{CO21}$ & 1 & 11 \\
\hline & & & & C088 & 1 & 8 \\
\hline & & & 8 & $\cos 9$ & 1 & 8 \\
\hline & & & & C167 & 2 & 9 \\
\hline & 6 & 50 & & 0077 & 1 & 16 \\
\hline & & & 24 & C171 & 1 & 17 \\
\hline & & & & C181 & 1 & 17 \\
\hline & & & & c036 & 1 & 4 \\
\hline & & & 8 & CO65 & 1 & 4 \\
\hline & & & & $\cos 7$ & 2 & 4 \\
\hline & 7 & CONTROL & & C146 & 1 & 14 \\
\hline & & & 24 & CO44 & 1 & 14 \\
\hline & & & & C027. & 2 & 15. \\
\hline & & & & $6049^{\circ}$ & 2 & 7 \\
\hline & & & 8 & $\cos 0$ & 2 & 8 \\
\hline & & CONTROL & & cos & 1 & 9 \\
\hline & 8 & COINIKUL & & 009 & 1 & 16 \\
\hline & & & 24 & C151 & 1 & 16 \\
\hline & & & & $\mathrm{C} 070$ & 1 & 17 \\
\hline & & & & $\cos 0$ & 1 & 7 \\
\hline & & & 8 & $\mathrm{CO} 48$ & 1 & 8 \\
\hline & & & & $\mathrm{C} 013$ & 1 & 9 \\
\hline & 9 & 100 & & $\mathrm{C119}$ & 1 & 16 \\
\hline & & & 24 & C115 & 1 & 16 \\
\hline & & & & $\mathrm{CO} 075$ & 1 & 17 \\
\hline
\end{tabular}

Page 4 of 6 
Study Number: AEH-13-PSEUDO-06

Electronic Log (pages 10-11)

Data Source: "Mussel Histology Samples" Flle Folder 7
Test Article: Pseudomonas fivorescens Pf -CL 145A (SDP) Test Article lot H: 401P12163C and 401P12164C Mix Exposure Date: 5/29/2013 Assessment Dates: 6/26-27/2013

Fatmucket (L. sillquoldea) Histology Samples

\begin{tabular}{|c|c|c|c|c|c|c|}
\hline $\begin{array}{l}\text { Mussel } \\
\text { Species }\end{array}$ & Test Tank & $\begin{array}{c}\text { Treatment } \\
\text { Group } \\
\text { (mg/L) }\end{array}$ & $\begin{array}{l}\text { Exposure } \\
\text { Duration }\end{array}$ & Tag ID & $\begin{array}{c}\text { Number of } \\
\text { Cassettes }\end{array}$ & $\begin{array}{l}\text { Container } \\
\text { Number }\end{array}$ \\
\hline \multirow{54}{*}{ FAM } & \multirow{6}{*}{1} & \multirow{6}{*}{100} & \multirow{3}{*}{8} & 0270 & 1 & 1 \\
\hline & & & & $\mathrm{D} 269$ & 1 & 2 \\
\hline & & & & 0310 & 1 & 3 \\
\hline & & & \multirow{3}{*}{24} & 0203 & 1 & 10 \\
\hline & & & & D264 & 1 & 11 \\
\hline & & & & D335 & 1 & 12 \\
\hline & \multirow{6}{*}{2} & \multirow{6}{*}{100} & \multirow{3}{*}{8} & D326 & 1 & 5 \\
\hline & & & & D265 & 1 & 6 \\
\hline & & & & D256 & 1 & 6 \\
\hline & & & \multirow{3}{*}{24} & D3.19 & 1 & 13 \\
\hline & & & & D267 & 1 & 13 \\
\hline & & & & D299 & 1 & 13 \\
\hline & \multirow{6}{*}{3} & \multirow{6}{*}{50} & \multirow{3}{*}{8} & 0300 & 1 & 1 \\
\hline & & & & D332 & 1 & 2 \\
\hline & & & & D211 & 1 & 3 \\
\hline & & & \multirow{3}{*}{24} & 0283 & 1 & 11 \\
\hline & & & & D232 & 1 & 12 \\
\hline & & & & 0351 & 1 & 12. \\
\hline & \multirow{6}{*}{4} & \multirow{6}{*}{50} & \multirow{3}{*}{8} & D215 & 1 & 5 \\
\hline & & & & D309 & 1 & 5 \\
\hline & & & & 0349 & 1 & 6 \\
\hline & & & \multirow{3}{*}{24} & D289 & 1 & 13 \\
\hline & & & & D337 & 1 & 15 \\
\hline & & & & 0778 & 1 & 15 \\
\hline & & \multirow{6}{*}{ CONTROL } & & D327 & 1 & 1 \\
\hline & & & 8 & D288 & 1 & 1 \\
\hline & & & & D214 & 1 & 3 \\
\hline & 5 & & & D358 & 1 & 11 \\
\hline & & & 24 & $\mathrm{D} 27.97$ & 1 & 12 \\
\hline & & & & D286 & 1 & 12 \\
\hline & & & & D322 & 1 & 7 \\
\hline & & & 8 & D249 & 1 & 7 \\
\hline & 6 & 50 & & D320 & 1 & 9 \\
\hline & 6 & 50 & & 0366 & 1 & 17 \\
\hline & & & 24 & D342 & 1 & 17 \\
\hline & & & & D195 & 1 & 17 \\
\hline & & & & D268 & 1 & 4 \\
\hline & & & 8 & D344 & 1 & 5 \\
\hline & 7 & CONTROI & & D192 & 1 & 6 \\
\hline & 7 & CONTROL & & 0234 & 1 & 14 \\
\hline & & & 24 & D200 & 1 & 15 \\
\hline & & & & D2.95 & 1 & 15 \\
\hline & & & & D238 & $\overline{1}$ & 9 \\
\hline & & & 8 & D360 & 1 & 9 \\
\hline & & & & D314 & 1 & 9 \\
\hline & 8 & CONTROL & & D206 & 1 & 16 \\
\hline & & & 24 & v331 & 1 & 16 \\
\hline & & & & D341 & 1 & 18 \\
\hline & & & & $\overline{D 252}$ & 1 & 8 \\
\hline & & & 8 & D246 & 1 & 8 \\
\hline & & & & D219 & 1 & 9 \\
\hline & 9 & 100 & & D312 & 1 & 16 \\
\hline & & & 24 & D187 & 1 & 17 \\
\hline & & & & D275 & 1 & 17 \\
\hline
\end{tabular}

Page 5 of 6 
Wabash Pigtoe (F. flava) Histology Samples

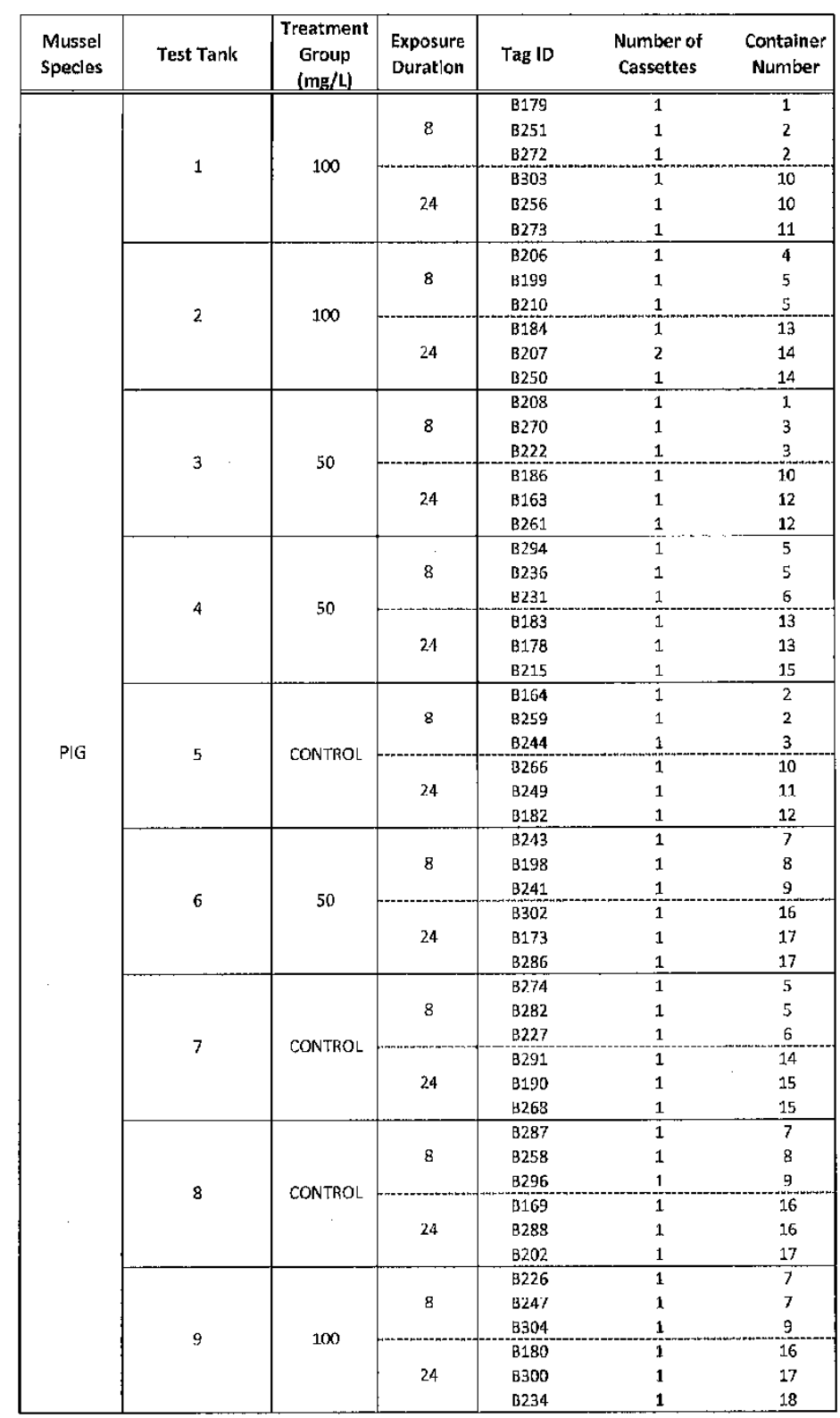

Flle folder 


\section{Appendix 6. Water Quality}

\begin{tabular}{clcc}
\hline $\begin{array}{c}\text { Item } \\
\text { Number }\end{array}$ & \multicolumn{1}{c}{ Item Description } & $\begin{array}{c}\text { Number } \\
\text { of } \\
\text { Pages }\end{array}$ & $\begin{array}{c}\text { Report } \\
\text { Page } \\
\text { Number }\end{array}$ \\
\hline 1 & Water Chemistry - Data Summary (Preexposure and exposure) & 4 & 155 \\
2 & Ammonia - Data Summary & 3 & 159 \\
3 & Report of Analysis - Ammonia Report from Water Quality Laboratory at UMESC & 1 & 162 \\
4 & Data Logger (HOBO) 30 day Temperature Summary - Data Summary & 4 & 163 \\
\hline
\end{tabular}




\begin{tabular}{|c|c|c|c|}
\hline \multicolumn{4}{|l|}{ Study Number: AEH-13-PSEUDO-06 } \\
\hline Electronic logbook (pages: 10) & Created..... & $6 / 11 / 2014$ & KLW $/ 2 \omega$ \\
\hline File Folder: 10 & Revised...... & $4 / 24 / 2014$ & KLWKW \\
\hline Forms: Alka inity, Hardness and Conductlvity, Water Quality & Reviewed... & WAAQ14 & Vhw \\
\hline & Certified... & $1 / 41^{2} / 14$ & $5 a-$ \\
\hline
\end{tabular}

\section{Pre-Exposure Water Chemistry}

Test Article: Pseudomonas fluorescens Pf -CL. 145A (SDP); lot \#: 401P12163C and 401P12164C Mix

Test Location: Black River, L.a Crosse, WI

Exposurc Date: $5 / 29 / 2013$

Assessment Dates: 6/26-27/2013

Test Organlsms:

Common name, scientific name, three letter abbreviation

Plain Pocketbook, Lampsilis cardium, PPB

Hickorynut, Obovaria olivaria, HIC

Washboard, Megalonaias nervosa, WAS

Higgins Eye, Lampsilis higginsii, HGE

Fatmucket, Lampsills sillquoidea, FAM

Threeridge, Amblema plicata, THR

Wabash Pigtoe, Fusconaia flava, PIG

Data Explanation:

Pre-Exposure Water Chemistry - Dissolved oxygen, $\mathrm{pH}$, and temperature were measured prior to exposure initiation in all test tanks.

Alkalinity, hardness, and conductivlty were measured in water samples collected from the head-boxes. (Head-box 1 supplied test

tanks 1-5; hcad-box 2 supplied test tank 6.9.)

Data anomalies and deviatlons

NONE

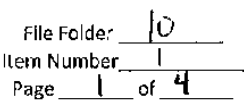


Study Number: AEH-13-PSEUDO-06

Electronic logbook (pages: 8-10)

File Folder: 10

Forms: Alkalinity, Hardness and Conductivity, Water Quality
Test Article: Pseudomonas fluorescens Pf-C 145A (SDP) Lot 1 ; 401P12163C and 401P12164C (Mixed from MBI)

Exposure Date: $5 / 29 / 2013$

Assessment Dates: 6/26-27/2013

Pre-Exposure Water Chemistry

\begin{tabular}{|c|c|c|c|c|}
\hline $\begin{array}{c}\text { Treatment Group } \\
(\mathrm{mg} / \mathrm{L})\end{array}$ & Test Tank & $\mathbf{p H}$ & $\begin{array}{c}\mathrm{DO} \\
(\mathrm{mg} / \mathrm{L})\end{array}$ & $\begin{array}{c}\text { Temp } \\
\left({ }^{\circ} \mathrm{C}\right)\end{array}$ \\
\hline \multirow{3}{*}{0} & 5 & 7.19 & 6.67 & 16.2 \\
\hline & 7 & 7.15 & 6.56 & 16.2 \\
\hline & 8 & 7.16 & 6.54 & 16.2 \\
\hline \multirow{2}{*}{\multicolumn{2}{|c|}{$\begin{array}{c}\text { Mean } \\
\text { (SD) }\end{array}$}} & N/A & 6.59 & 16.2 \\
\hline & & $\mathrm{N} / \mathrm{A}$ & $(0.06)$ & $(0.0)$ \\
\hline \multirow{3}{*}{50} & 3 & 7.16 & 6.67 & 16.2 \\
\hline & 4 & 7.18 & 6.65 & 16.2 \\
\hline & 6 & 7.17 & 6.60 & 16.2 \\
\hline \multirow{2}{*}{\multicolumn{2}{|c|}{$\begin{array}{l}\text { Mean } \\
\text { (SD) }\end{array}$}} & $\mathrm{N} / \mathrm{A}$ & 6.64 & 16.2 \\
\hline & & $N / A$ & $(0.03)$ & $\{0.0\}$ \\
\hline \multirow{3}{*}{100} & 1 & 7.06 & 6.77 & 16.3 \\
\hline & 2 & 7.18 & 6.73 & 16.2 \\
\hline & 9 & 7.17 & 6,56 & 16.2 \\
\hline \multirow{2}{*}{\multicolumn{2}{|c|}{$\begin{array}{l}\text { Mean } \\
(S D)\end{array}$}} & N/A & 6.69 & 16.2 \\
\hline & & $\mathrm{N} / \mathrm{A}$ & $(0.09)$ & $(0.0)$ \\
\hline \multicolumn{2}{|c|}{ Grand Mean } & $\mathrm{N} / \mathrm{A}$ & 6.64 & 16.2 \\
\hline \multicolumn{2}{|c|}{$(S D)$} & $N / A$ & $(0.04)$ & $(0.0)$ \\
\hline \multicolumn{2}{|c|}{ MIN } & 7,06 & 6.54 & 16.2 \\
\hline & 7.19 & 6.77 & 16.3 \\
\hline
\end{tabular}

\begin{tabular}{|c|c|c|c|}
\hline $\begin{array}{l}\text { Headbox } \\
\text { Number }\end{array}$ & $\begin{array}{c}\text { Alkalinity } \\
\left(\mathrm{mg} / \mathrm{L} \text { as } \mathrm{CaCO}_{3}\right)\end{array}$ & $\begin{array}{c}\text { Hardness } \\
\left(\mathrm{mg} / \mathrm{L} \text { as } \mathrm{CaCO}_{3}\right) \\
\end{array}$ & $\begin{array}{c}\text { Conductivity } \\
(\mu S)\end{array}$ \\
\hline 1 & 477 & 62 & 103.2 \\
\hline 2 & 42 & 52 & 106.6 \\
\hline
\end{tabular}

Page 2 of 4 


\begin{tabular}{|c|c|c|c|}
\hline \multirow{5}{*}{$\begin{array}{l}\text { Study Number: AEH-13-PSEUDO-06 } \\
\text { Electronic logbook (pages: 8-10) } \\
\text { File Folder: } 10 \\
\text { Farms: Alkallinl:y, Hardness and Conductlvity, Water Quality }\end{array}$} & Actlon & Date & $\ln |t| a \mid s$ \\
\hline & Created...... & $6 / 11 / 2013$ & KLW Kins \\
\hline & Revised ....... & $4 / 24 / 2014$ & KLW KouJ \\
\hline & Reviewed... & 94 APR 2 CA & gow \\
\hline & Certifted... & $2 / 12 / 14$ & $5 n^{\circ}$ \\
\hline
\end{tabular}

\title{
Exposure Period Water Chemistry
}

\author{
Test Artlc.le: Pseudomonas fiuorescens of -CL 145A (SDP); lot \$: 401P12163C and 401P12154C MlK \\ Test Location: Black River, La Crosse, W \\ Exposure Date: 5/29/2013 \\ Assessmert Dates: 6/26-27/2013 \\ Test Organisms: \\ Common name, sclentiflc name, three letter abbreviation \\ Plain Pocketbook, Lampsilis cardium, PPB \\ Hickorynut, Obovaria olivaria, HC \\ Washboard, Megaionalas nervosa, WAS \\ Higgins Eye, Lampsilts hlggirisli, HGE \\ Fatmucket Lampsilis sillquoldea, FAM \\ Threerldge, Amblema plicata, THR \\ Wabash Plgtoe, Fusconcia flava, PIG \\ Data Explanatlon \\ Exposure Perlod Water Chemistry- Dlssolved oxygen, $\mathrm{pH}$, anc temperaturc were measured and recorded at 1, 6, 8, 12, 18, and 24h. Water samples \\ were collected from all test tanks to measure alkalinity, hardress, and conductlvlty 3 hours after treatment administration. \\ Data anomalies and deviations \\ NONE
}

\author{
Page 3 of 4
}



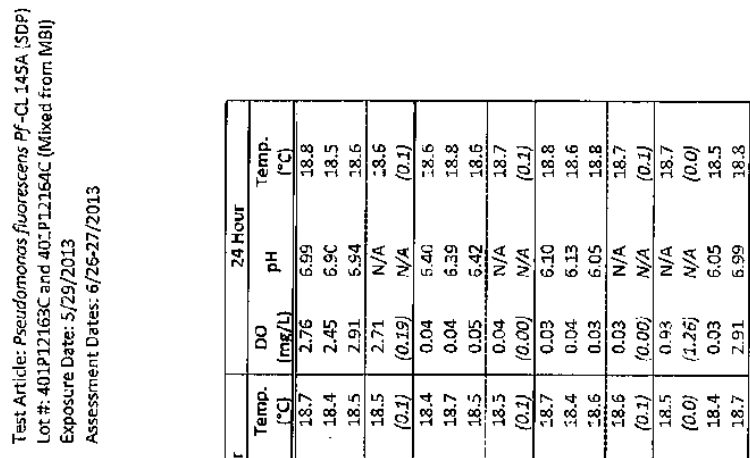

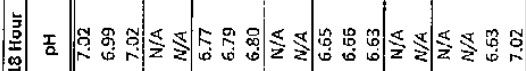

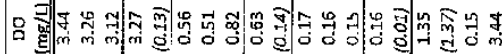

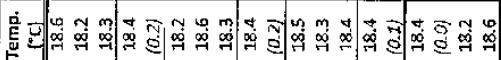

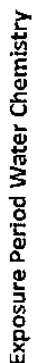

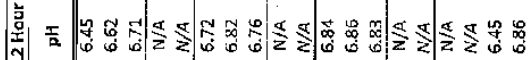

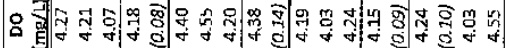

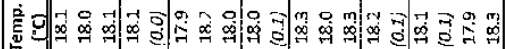

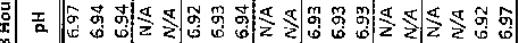

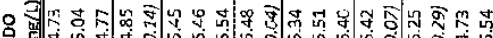

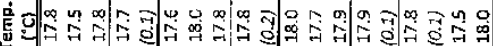

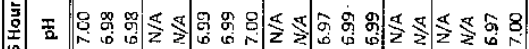

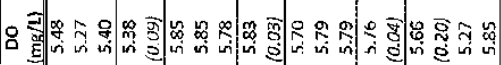

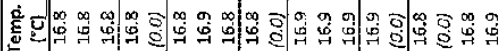

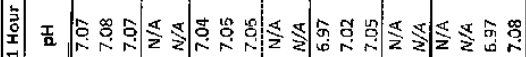

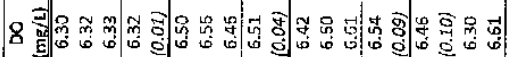

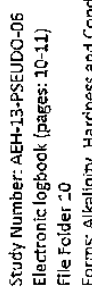

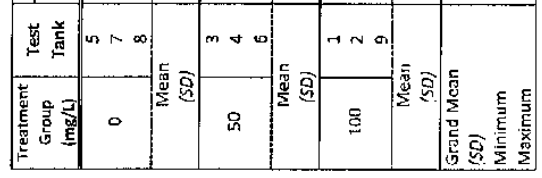

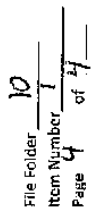

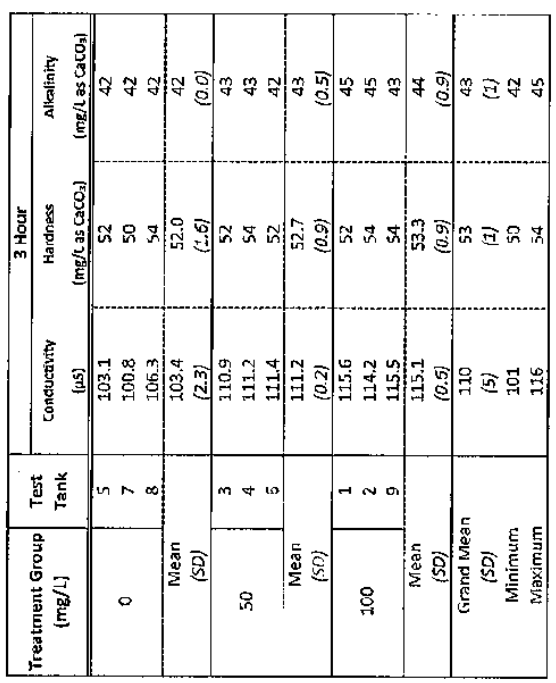




\begin{tabular}{|c|c|c|c|}
\hline \multirow{5}{*}{$\begin{array}{l}\text { Study Number: AEH-13-PSE } \backsim \text { DO-06 } \\
\text { Electronic Log (Page 8) } \\
\text { TAN Data Source: LTRMP Report (File Folder 10) } \\
\text { pH and Temperature Data Source: File Folder 10; } 24 \mathrm{~h} \text { Water Quality }\end{array}$} & Action & Date & Initials \\
\hline & Created...... & $1 / 19 / 2014$ & JKW f \\
\hline & Revised...... & $4 / 25 / 2014$ & KLW WV \\
\hline & Reviewed... & $35 \mathrm{Ap} 14$ & lin \\
\hline & Certified............ & $12 / 2 L / 14$ & Ithe \\
\hline
\end{tabular}

Total Nitrogen and Un-ionized Ammonia

Test Article: Pseudomonas fluorescens Pf-CL. 145A (SDP); lot H: 401P12163C and 401P12164C Mix

Test Location: Black Rlver, La Crosse, WI

Exposure Date: $5 / 29 / 2013$

Assessment Dates: 6/26-27/2013

Data Explanation:

1) Water samples were collected at $24 \mathrm{~h}$ immediately prior to exposure terminatlon from each exposure tank, filtered $(0.45$ $\mu \mathrm{m}$ ), acidified with sulfuric acid and stored at $4^{\circ} \mathrm{C}$ until analyzed for total ammonia nitrogen (TAN) content using the Automated Phenate Method (Standard Methods for the Examination of Water and Wastewater, 21st Edition, 2005) on a Technicon Autoanalyzer II by the UMESC water quallty laboratory.

2) The un-ionized ammonia fractions were calculated using the sample $\mathrm{pH}$ and tempera*ure measured at the time of sample collection accordlng to the formula in Emerson et al. (1975).

Data Anomalies and Deviations:

NONE

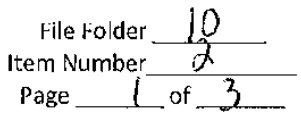



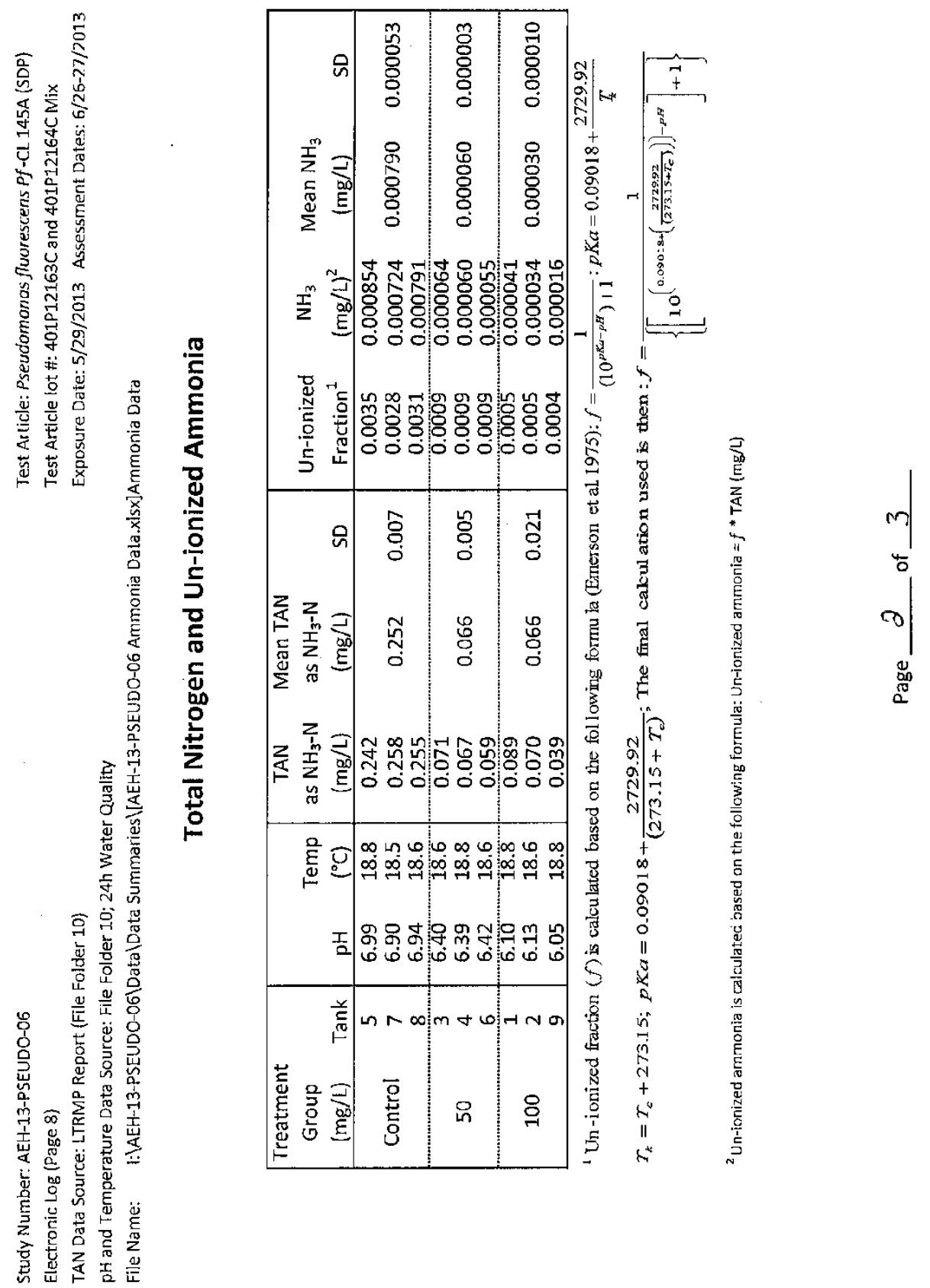

인

잉 눙응

岁造

字 $\infty \sum_{\infty}^{0}$

志品喜党

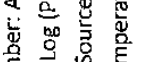

है

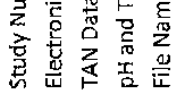




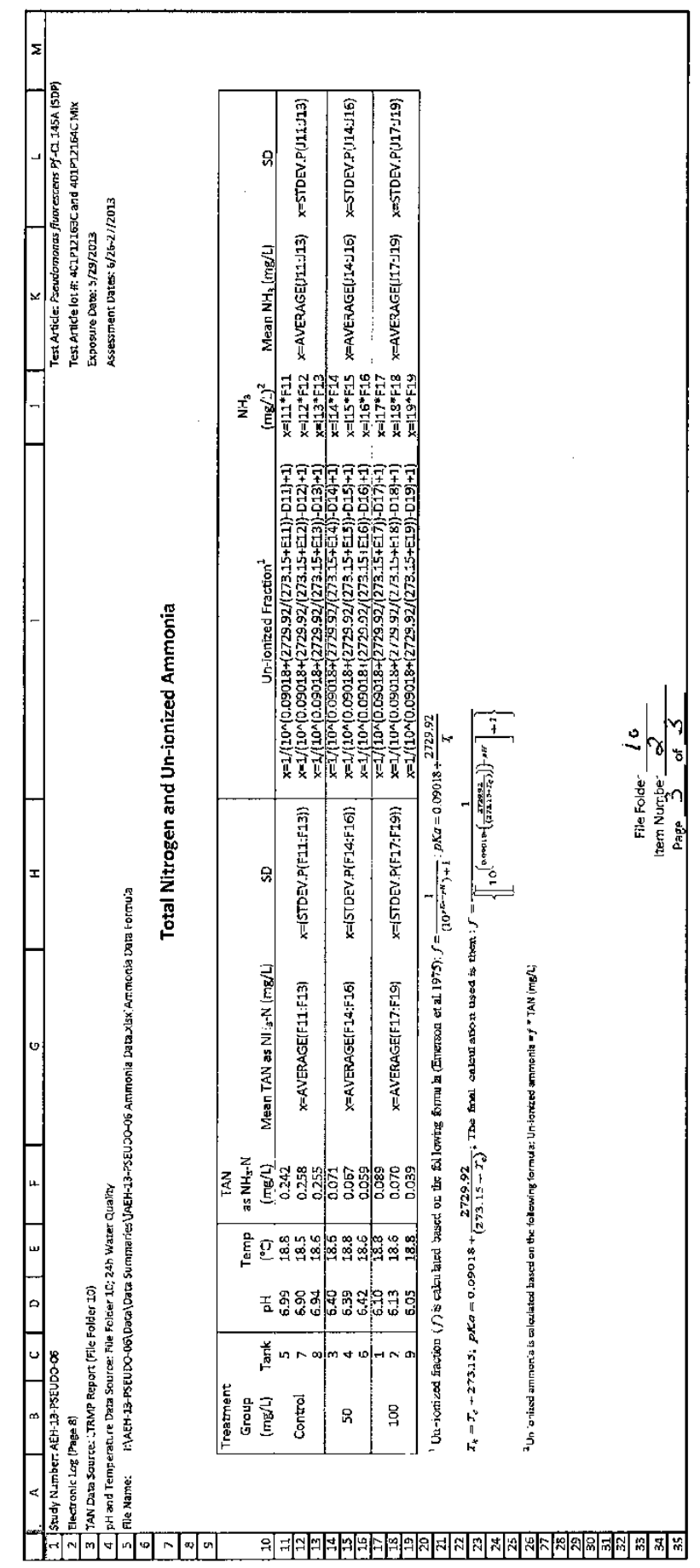


Sample Description: $3 \mathrm{~mL}$ acidified exposure water $(0.45 \mu \mathrm{m}$ filtrated Study \#: AEH-13-PSEUDO-06

Upper Midwest Environmental Sciences Center attn: James Luoma

2630 Fanta Reed Road

La Crosse, Wi54603

REPORT OF ANALYSIS

Sample Code

BRT24HT1C10D

BRT24HT2C100

BRT24HT3C50

BRT24HT4C50

BRT24HTSCO

BRT24HT6C50

BRT24HT7CO

BRT24HT8CO

BRT24HTSC100

USGS

Water Quality Laboratory

Laboratory Director
Water Quality Laboratory

Upper Midwest Environmental Sciences Center

USGS

2630 Fanta Reed Road

La Crosse, WI 54603

Analyzing Date:06/13/2013

Report Date: 06/19/2013

Xiaoli Yuan

Results (Total Ammonia Nitrogen, mg $\mathrm{NH}_{3}-\mathrm{N} /$ L)

0.089

0.07

0.071

0.067

0.242

0.059

0.258

0.255

0.039

Item Number: 14

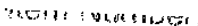

Fils Folder: 10

Page 1 of 1 


\begin{tabular}{|c|c|c|c|}
\hline Study Namber: AEH-13-PSEUDO-D6 & Action & Date & Initials \\
\hline Electronlc l.og: N/A & Created...... & $1 / 31 / 2014$ & JKW I UN \\
\hline Data Source: Temperature Logger outputs: I:AEH-13-PSEUDO-06\Data\HOBO Data & Revised...... & $4 / 25 / 2014$ & KLW KW \\
\hline Forms: N/A & Reviewed... & $25+4 P-14$ & 12 \\
\hline File Folder: 10 & Certified... & $12 / 12 / 19$ & $5 n \omega$ \\
\hline
\end{tabular}

HOBO Data Logger Post-Exposure Temperature Summary

Test Ar:lde: Pseudomonas fluorescens Pf $\rightarrow \mathrm{CL} 145 \mathrm{~A}$ (SDP)

Lot \#: 401P12163C and 401P12164C (Recelved mixed from MBI)

Test Location: Black River, La Crosse, W

Exposure Date: $5 / 29 / 2013$

Assessment Dates: 6/26-27/2013

$\begin{array}{ll}\text { Data Logger 1 } & \text { Serlal number: } 10020139 \\ \text { Data Logger 2 } & \text { Serlal number: } 10330145 \\ \text { Data Logger 3 } & \text { Serlal numbe*: } 10020134 \\ \text { Data Logger 4 } & \text { Serlal number: } 20020138 \\ \text { Data Logger 5 } & \text { Serial number: } 20020141\end{array}$

Data Explanation:

Jate: Date of temperature data collection, 5/30/2013-6/27/2013

Time: Specific time assoclated with Indlvidual temperature data point. Gathered dally at $0000,0600,1200$, and $1800 \mathrm{~h}$.

Data Logger H: All temperature data points recorded by speclfic data logger over 30 day holding perlod,

Mean and Standard Deviation: Mean temperature and standard deviation of temperatures recorded from all five data loggers from a given day.

Data anomalies and deviations:

Temperatures recorded on 5/30/2013 and at 12:00:00 on 6/27/2013 were omitted from data analysis as some data loggers were not situated in water when data po'nts were logged. Retaining these data points would skew mean temperature.

\begin{tabular}{|c|c|c|}
\hline \multicolumn{3}{|c|}{ Post-exposure Temperature Summary } \\
\hline Date & Mean & $(S D)$ \\
\hline $5 / 31 / 2013$ & 19.01 & $(0.72)$ \\
\hline $6 / 1 / 2013$ & 20.42 & $(0.09)$ \\
\hline $6 / 2 / 2013$ & 20.05 & $(0.32)$ \\
\hline $6 / 3 / 2013$ & 9.10 & (0.25) \\
\hline $6 i 4 / 2013$ & 19.51 & $(0.34)$ \\
\hline $6 / 5 / 2013$ & 18,15 & $(0.25)$ \\
\hline $6 / 6 / 2013$ & 17.41 & (0.18) \\
\hline $6 / / / 2013$ & 16.89 & (0.23) \\
\hline $6 / 8 / 2013$ & 18.57 & $(0.77)$ \\
\hline $6 / 9 / 2013$ & 18.26 & $(0.60)$ \\
\hline $6 / 10 / 2013$ & 18.02 & (0.18) \\
\hline $6 / 11 / 2013$ & 19.53 & $(0.36)$ \\
\hline $6 / 12 / 2013$ & 20.21 & (0.38) \\
\hline $6 / 13 / 2013$ & 20.76 & $(0.86)$ \\
\hline $6 / 14 / 2013$ & 21.94 & $(0.44)$ \\
\hline $6 / 15 / 2013$ & 22.39 & $(0.39)$ \\
\hline $6 / 16 / 2013$ & 23.12 & $(0.63)$ \\
\hline $6 / 17 / 2013$ & 24.43 & (0.41) \\
\hline $6 / 18 / 2013$ & 25.00 & $(0.28)$ \\
\hline $6 / 19 / 2013$ & 23.76 & $(0.64)$ \\
\hline $6 / 20 / 2013$ & 2.4 .08 & $(0.65)$ \\
\hline $6 / 21 / 2013$ & 24.12 & $(0,35)$ \\
\hline $6 / 22 / 2013$ & 24.03 & (0.37) \\
\hline $6 / 23 / 2013$ & 23.80 & $(0.30)$ \\
\hline $6 / 24 / 2013$ & 24.05 & $(0.11)$ \\
\hline $6 / 25 / 2013$ & 23.63 & $(0.19)$ \\
\hline $6 / 26 / 2013$ & 24.45 & (0.82) \\
\hline $6 / 27 / 2.013$ & 24.85 & $(0.12)$ \\
\hline
\end{tabular}

$$
\begin{aligned}
& \text { File Folder } \frac{10}{15} \\
& \text { Item number } 15.4 \\
& \text { Page } 1 \text { of }
\end{aligned}
$$


Study Number: AEH-13-PSEUDO-06

Electronlc logbook: N/A

Data Source: Filte Folder 10

Forms: N/A

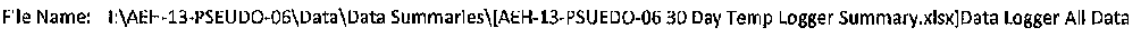

Post-Exposure Temperature Summary

\begin{tabular}{|c|c|c|c|c|c|c|c|}
\hline \multirow{3}{*}{ Date } & \multirow{3}{*}{ Time } & \multicolumn{5}{|c|}{ Data Logger Number } & \multirow{3}{*}{$\begin{array}{l}\text { Mean } \\
\text { (STD) }\end{array}$} \\
\hline & & 1 & 2 & 3 & 4 & 5 & \\
\hline & & \multicolumn{5}{|c|}{ Temperature ("C) } & \\
\hline \multirow{2}{*}{$05 / 30 / 13$} & $12: 00: 00^{1}$ & $24.448^{1}$ & $23.773^{1}$ & $18.806^{1}$ & $25.222^{1}$ & $24.448^{1}$ & \\
\hline & $18: 00: \infty^{1}$ & $18.045^{1}$ & $17.950^{1}$ & $17.950^{\circ}$ & $18.140^{1}$ & $17.855^{1}$ & \\
\hline \multirow{4}{*}{$05 / 31 / 13$} & $00: 00 ; 00$ & 18,331 & 18.236 & 18.331 & 18.426 & 18.236 & 19.01 \\
\hline & $06: 00: 00$ & 18.521 & 18.521 & 18.521 & 18.616 & 18.331 & $(0.72)$ \\
\hline & $12: 00: 00$ & 19.092 & 19.092 & 19.092 & 19.187 & 18.996 & \\
\hline & 18:00:00 & 20.138 & 20.138 & 20.138 & 20.234 & 20.043 & \\
\hline \multirow{4}{*}{$06 / 01 / 13$} & $00: 00: 00$ & 20.424 & 20.329 & 20.329 & 20.519 & 20.329 & 20.42 \\
\hline & $06: 00: 00$ & 20.424 & 20.424 & 20.424 & 20.424 & 20.234 & $(0.09)$ \\
\hline & $12: 00: 00$ & 20.424 & 20.424 & 20.424 & 20.519 & 20.329 & \\
\hline & $18: 00: 00$ & 20.519 & 20.424 & 20.519 & 20.615 & 20.329 & \\
\hline \multirow{4}{*}{$06 / 02 / 13$} & $00: 00: 00$ & 20.519 & 20.519 & 20.519 & 20.615 & 20.424 & 20.05 \\
\hline & $06: 00: 00$ & 20.138 & 20.138 & 20.138 & 20.234 & 20.043 & $(0.32)$ \\
\hline & $12: 00: 00$ & 19.853 & 19.758 & 19.758 & 19.948 & 19.758 & \\
\hline & $18: 00: 00$ & 19.758 & 19.758 & 19.758 & 19.853 & 19.567 & \\
\hline \multirow{4}{*}{$06 / 03 / 13$} & $00: 00: 00$ & 19.567 & 19,472 & 19.472 & 19.567 & 19.377 & 19.10 \\
\hline & $06: 00: 00$ & 19.092 & 19.092 & 19.092 & 19.187 & 18.901 & (0.25) \\
\hline & $12: 00: 00$ & 18.996 & 18.901 & 18.901 & 18.996 & 18.806 & \\
\hline & $18: \infty 0: 00$ & 18.901 & $18.90^{\circ}$ & 18.901 & 18.996 & 18.806 & \\
\hline \multirow{4}{*}{$06 / 04 / 13$} & $00: 00: 00$ & 19.662 & 19.472 & 19.567 & 20.138 & 19.758 & 19.51 \\
\hline & $06: 00: 00$ & 19.662 & 19.662 & 19.758 & 20.138 & 19.758 & $(0.34)$ \\
\hline & $12: 00: 00$ & 19.567 & 19.472 & 19.472 & 19.662 & 19.377 & \\
\hline & $18: 00: 00$ & 19.092 & 18.990 & 18.996 & 19.092 & 18.901 & \\
\hline \multirow{4}{*}{$06 / 05 / \cdot 3$} & $00: 00: 00$ & 18.616 & 18.521 & 18.521 & 18.616 & 18.426 & 18,15 \\
\hline & $06: 00: 00$ & 18.236 & 18.140 & 18.140 & 18.236 & 18.045 & $(0.25)$ \\
\hline & $12: 00: 00$ & 18.045 & 17.950 & 17.950 & 18.045 & 17.855 & \\
\hline & $18: 00: 00$ & 17.950 & 17.950 & 17.950 & 18.045 & 17.855 & \\
\hline \multirow{4}{*}{$06 / 06 / 13$} & $00: 00: 00$ & 17.665 & 17.665 & 17.665 & 17.760 & 17.570 & 17.41 \\
\hline & $06: 00: 00$ & 17.475 & 17.379 & 17.379 & 17.475 & 17.284 & (0.18) \\
\hline & $12: 00: 00$ & 17.379 & 17.379 & 17.379 & 17.475 & 17.284 & \\
\hline & $18: 00: 00$ & 17.284 & 17.189 & 17.180 & 17.284 & 17.094 & \\
\hline \multirow{4}{*}{$06 / 07 / 13$} & $00: 00: 00$ & 17.094 & 16.999 & 16.999 & 17.094 & 16.903 & 16.89 \\
\hline & $06: 00: 00$ & 16.713 & 16.713 & 16.713 & 16.808 & 16.523 & $(0.23)$ \\
\hline & $12: 00: 00$ & 16.713 & 16.618 & 16.713 & 16.808 & 16.618 & \\
\hline & $18: 00 ; 00$ & 17.189 & 17.084 & 17.094 & 17.379 & 17.094 & \\
\hline \multirow{4}{*}{$08 / 08 / 13$} & $00: 00: 00$ & 18.331 & 18.236 & 18.331 & 18.426 & 18.236 & 18.57 \\
\hline & $06: 00: 00$ & 18.236 & 18.140 & 18.140 & 18.236 & 18.045 & $(0.77)$ \\
\hline & $12: 00: 00$ & 17.950 & 17.760 & 17.855 & 18.236 & 17.950 & \\
\hline & 18:00:00 & 19.853 & 19.567 & 19.758 & 20.234 & 19.853 & \\
\hline \multirow{4}{*}{$06 / 09 / 13$} & $00: 00: 00$ & 18.711 & 18.806 & 18.996 & 19.472 & 18.996 & 18.25 \\
\hline & $06: 00: 00$ & 18.521 & 18.616 & 18.616 & 18.711 & 18.521 & $(0.60)$ \\
\hline & $12: 00: 00$ & 17.570 & 17.475 & 17.475 & 17,570 & 17.379 & \\
\hline & $18: 00: 00$ & 17.950 & 17.855 & 17,950 & 18.140 & 17.855 & \\
\hline
\end{tabular}

'Temperatures from these time points not used in mean and standard deviation calculation as missel holding cages may not have been submerged when data was recorded.
Test Article: Psevdomonas fluorescens Pf-C. 145A (SDP) : 401P12163C and 401P12164C (Mixed from MBD) Exposure Date: 5/29/2013 Assessmert Dates: 6/26-27/2013 
Study Number: AEH-13-PSEUDO-06

Electronic logbook: $N / A$

Cata Source: Flle Folder 10

Forms: N/A

Flle Name: I: AAFH-13-PSFUDO-06\Data\Data Summaries\[AEH-13-PSUEDO-06 30 Day Temp Logger Summary.xlsx]Uata Logger All Data

\begin{tabular}{|c|c|c|c|c|c|c|c|}
\hline \multirow{3}{*}{ Date } & \multirow{3}{*}{ Time } & \multicolumn{5}{|c|}{ Data Logger Number } & \multirow{3}{*}{$\begin{array}{l}\text { Mean } \\
\text { (STD) }\end{array}$} \\
\hline & & 1 & 2 & 3 & 4 & 5 & \\
\hline & & \multicolumn{5}{|c|}{ Tomperature ("C) } & \\
\hline \multirow{4}{*}{$06 / 10 / 13$} & $00: 00: 00$ & 18.045 & 18.045 & 18.045 & 18.140 & 17.950 & 18.02 \\
\hline & $06: 00: 00$ & 17.855 & 17.760 & 17.855 & 17.950 & 17.665 & $(0,18)$ \\
\hline & $12: 00: 00$ & 17.950 & 17.950 & 17.950 & 18.045 & 17.855 & \\
\hline & $18: 00: \infty$ & 18.236 & 18.236 & 18.238 & 18.426 & 18.140 & \\
\hline \multirow{4}{*}{$06 / 11 / 13$} & $00: 00: 00$ & 18.472 & 19.377 & 19.472 & 19.758 & 19.377 & 19.53 \\
\hline & $06: 00: 00$ & 19.662 & 19.567 & 19.758 & 19.948 & 19.662 & $(0.36)$ \\
\hline & $12: 00: 00$ & 18.996 & 18.996 & 18.996 & 19.282 & 18.806 & \\
\hline & 18:00:00 & 19.853 & 19.853 & 19.853 & 20.138 & 19.853 & \\
\hline \multirow{4}{*}{$08 / 12 / 13$} & $00: 00: 00$ & 20.043 & 19.948 & 19.948 & 20.138 & 19.853 & 20.22 \\
\hline & $06: 00: 00$ & 20.234 & 20.234 & 20.234 & 20.329 & 20.138 & $(0.38)$ \\
\hline & $12: 00: 00$ & 19.948 & 19.853 & 19.853 & 20.043 & 19.758 & \\
\hline & $18: 00: 00$ & 20.615 & 20.329 & 20.519 & 21.378 & 20.805 & \\
\hline \multirow{4}{*}{$06 / 13 / 13$} & $00: 00: 00$ & 20.519 & 20.424 & 20.519 & 20.710 & 20.424 & 20.76 \\
\hline & $06: 00: 00$ & 20.234 & 20.043 & 20.138 & 20.329 & 20.043 & $(0.86)$ \\
\hline & $12: 00: 00$ & 20.138 & 20,043 & 20.043 & 20.615 & 20.138 & \\
\hline & $18: 00: 00$ & 22.142 & 21.760 & 21.855 & 22.812 & 22.333 & \\
\hline \multirow{4}{*}{$06 / 14 / 13$} & $00: 00: 00$ & 21.951 & 21.760 & 21.855 & 22.238 & 21.951 & 21.94 \\
\hline & $06: 00: 00$ & 21.664 & 21.569 & 21.569 & 21.664 & 21.473 & $(0.44)$ \\
\hline & $12 ; 00 ; 00$ & 21.664 & 21.569 & 21.569 & 21.760 & 21.473 & \\
\hline & $18: 00: 00$ & 22,429 & 22.429 & 22.525 & 23.100 & 22.525 & \\
\hline \multirow{4}{*}{$06 / 15 / \cdot 3$} & $00: 00: 00$ & 22.621 & 22.621 & 22.621 & 23.004 & 22.525 & 22.39 \\
\hline & $06: 00: 00$ & 22.238 & 22.238 & 22.238 & 22.333 & 22.046 & $(0.39)$ \\
\hline & $12: 00: 00$ & 21.855 & 21.855 & 21.855 & 21.951 & 21.760 & \\
\hline & $18: 00: 00$ & 22.812 & 22.717 & 22.717 & 23.004 & 22.717 & \\
\hline \multirow{4}{*}{$06 / 16 / 13$} & $00: 00,00$ & 23.004 & 22.908 & 22.908 & 23.004 & 22.812 & 23.12 \\
\hline & $06: 00: 00$ & 22.621 & 22.525 & 22.525 & 22,621 & 22.429 & $(0.63)$ \\
\hline & $12: 00: 00$ & 22.908 & 22.812 & 22.812 & 23.004 & 22.717 & \\
\hline & 18:00:00 & 24.158 & 24.158 & 24.158 & 24.448 & 23.966 & \\
\hline \multirow{4}{*}{$06 / 17 / 13$} & $00: 00: 00$ & 24.931 & 24.931 & 24.931 & 25.028 & 24.835 & 24.43 \\
\hline & $06: 00: 00$ & 24.158 & 24.158 & 24.158 & 24.255 & 24.062 & $(0.41)$ \\
\hline & $12: 00: 00$ & 23.966 & 23.869 & 23.966 & 24.062 & 23.869 & \\
\hline & $18: 00: 00$ & 24.545 & 24.545 & 24.641 & 25.125 & 24,545 & \\
\hline \multirow{4}{*}{$06 / 18 / 13$} & $00: 00: 00$ & 26.319 & 25.222 & 25.222 & 25.319 & 25.125 & 25.00 \\
\hline & $06: 00: 00$ & 24.641 & 24.545 & 24.641 & 24.641 & 24.448 & $(0.28)$ \\
\hline & $12: 00: 00$ & 25.028 & 24.931 & 25.028 & 25.319 & 24.931 & \\
\hline & 18:00:00 & 25.125 & 25.028 & 25.125 & 25.416 & 24.931 & \\
\hline \multirow{4}{*}{$06 / 19 / 13$} & $00: 00: 00$ & 24.158 & 24.158 & 24.158 & 24.255 & 24.062 & 23.76 \\
\hline & $06: 00: 00$ & 23,100 & 23.004 & 23.004 & 23.004 & 22.908 & $(0.64)$ \\
\hline & $12: 00: 00$ & 23.388 & 23.292 & 23.292 & 23.388 & 23.96 & \\
\hline & $18: 00: 00$ & 24.545 & 24.545 & 24.545 & 24.835 & 24.448 & \\
\hline \multirow{4}{*}{$06 / 20 / 13$} & $00: 00: 00$ & 24.062 & 24.158 & 24.255 & 24.148 & 24062 & 24.08 \\
\hline & $06: 00: 00$ & 23.388 & 23.388 & 23.388 & 23.388 & 23.196 & $(0.65)$ \\
\hline & $12: 00: 00$ & 23.773 & 23.677 & 23.677 & 23.773 & 23.581 & \\
\hline & $18: 00: 00$ & 25.125 & 25.028 & 25.028 & 25.222 & 24.931 & \\
\hline \multirow{4}{*}{$06 / 21 / 13$} & $00: 00: 00$ & 24.545 & 24.545 & 24.545 & 24,641 & 24,448 & 24.12 \\
\hline & 06:00:00 & 24.255 & 24.255 & 24.255 & 24.351 & 24.158 & $(0.35)$ \\
\hline & 12:00:00 & 23.677 & 23.581 & 23.581 & 23.677 & 23,484 & \\
\hline & 18:00:00 & 24.062 & 24.062 & 24.062 & 24.158 & 23,966 & \\
\hline
\end{tabular}

1 Temperatures from these time points not used In mean and standard devlation calculation as mussel holding cages may not have been submerged when data was recorded.

$$
\text { Page } 3 \text { of } 4
$$

Test Article: Pseudomonas fluorescens Pf -CL. 145A (SDP) Lot H: 401P12163C and 401P12164C (MIxed from $\mathrm{YBI}$ ) Exposure Date: 5/29/2013 Assessment Dates: 6/26-27/2013 
Forms: $N / A$

File Name: I: $\backslash$ AEH-13-PSEUDO-06\Data\Data Summaries\[AEH-13-PSUEDO-06 30 Day Temp Logger Sunmary.x|sx]Data Logger All Data

\begin{tabular}{|c|c|c|c|c|c|c|c|}
\hline \multirow{3}{*}{ Date } & \multirow{3}{*}{ Time } & \multicolumn{5}{|c|}{ Data Logger Number } & \multirow{3}{*}{$\begin{array}{l}\text { Mean } \\
\text { (STD) }\end{array}$} \\
\hline & & 1 & 2 & 3 & 4 & 5 & \\
\hline & & \multicolumn{5}{|c|}{ Temperature $\left({ }^{\circ} \mathrm{C}\right)$} & \\
\hline \multirow{4}{*}{$06 / 22 / 13$} & $00: 00: 00$ & 24.351 & 24,351 & 24.351 & 24.448 & 24.255 & 24.03 \\
\hline & $06: 00: 00$ & 23.773 & 23.773 & 23.773 & 23,773 & 23.377 & $(0.37)$ \\
\hline & $12: 00: 00$ & 23.677 & 23.581 & 23.581 & 23.677 & 23.484 & \\
\hline & $18: 00: 00$ & 24.448 & 24.351 & 24.448 & 24.545 & 24.351 & \\
\hline \multirow{4}{*}{$06 / 23 / 13$} & $00: 00: 00$ & 24.255 & 24.255 & 24.255 & 24.351 & 24.158 & 23.80 \\
\hline & $06: 00: 00$ & 23.484 & 23.484 & 23.484 & 23.484 & 23.292 & $(0,30)$ \\
\hline & $1200: 00$ & 23.773 & 23.677 & 23.773 & 23.773 & 23.581 & \\
\hline & $18: 00: 00$ & 23.773 & 23.773 & 23.773 & 23.869 & 23.677 & \\
\hline \multirow{4}{*}{$06 / 24 / 13$} & $00: 00: 00$ & 24.158 & 24.158 & 24.158 & 24.158 & 23.966 & 24.05 \\
\hline & $06: 00: 00$ & 23.966 & 23.869 & 23.966 & 23.966 & 23.773 & (0.11) \\
\hline & $12 ; 00: 00$ & 24.158 & 24.062 & 24.062 & 24.158 & 23.956 & \\
\hline & $18: 00: 00$ & 24.158 & 24.062 & 24.062 & 24.168 & 23.966 & \\
\hline \multirow{4}{*}{$06 / 25 / 13$} & $00: 00: 00$ & 23.966 & 23.869 & 23.869 & 23.966 & 23.773 & 23.63 \\
\hline & 06:00:00 & 23.677 & 23.581 & 23.677 & 23.677 & 23.484 & (0.19) \\
\hline & $12: 00: 00$ & 23.484 & 23.484 & 23.484 & 23,484 & 23.292 & \\
\hline & $18: 00: 00$ & 23.581 & 23.484 & 23.484 & 23,869 & 23.388 & \\
\hline \multirow{4}{*}{$06 / 28 / 13$} & $00: 00: 00$ & 23.773 & 23.773 & 23.773 & 23.966 & 23.677 & 24.45 \\
\hline & $06: 00: \infty$ & 23.773 & 23.677 & 23.677 & 23.869 & 2.3 .581 & (0.82) \\
\hline & $12: 00: 00$ & 24.545 & 24.931 & 24.158 & 25.902 & 24.255 & \\
\hline & $18: 00: 00$ & 25.610 & $25.5 \cdot 3$ & 25.513 & 25,610 & 25.513 & \\
\hline \multirow{3}{*}{$06 / 27 / 13$} & $00: 00: 00$ & 25.028 & 24.931 & 24.931 & 25.028 & 24.835 & 24.85 \\
\hline & 06:00:00 & 24.835 & 24.738 & 24,738 & 24.835 & 24.641 & $(0.12)$ \\
\hline & $12: 00: 00^{1}$ & $26.488^{\prime}$ & $25.222^{1}$ & $26.781^{1}$ & $26.977^{1}$ & 25,028 & \\
\hline
\end{tabular}

1 Temperatures from these time points not used in mean and standard deviation calculation as mussel holding cages may not have been submerged when data was recorced. 


\section{Appendix 7. Spectrophotometric Summary, SAS Program, Output and Log}

\begin{tabular}{clrc}
\hline $\begin{array}{c}\text { Item } \\
\text { Number }\end{array}$ & \multicolumn{1}{c}{ Item Description } & $\begin{array}{c}\text { Number } \\
\text { of } \\
\text { Pages }\end{array}$ & $\begin{array}{c}\text { Report } \\
\text { Page } \\
\text { Number }\end{array}$ \\
\hline 1 & Spectrophotometric Data - Data Summary with SAS output & 18 & 168 \\
2 & SAS program; Exposure Concentration Analysis & 2 & 186 \\
3 & SAS log; Exposure Concentration Analysis & 5 & 188 \\
\hline
\end{tabular}




\begin{tabular}{|c|c|c|c|}
\hline \multirow{4}{*}{$\begin{array}{l}\text { Study Number: AEH-13-PSEUDO-C6 } \\
\text { Electronic Log (Pages 7-9) } \\
\text { Flle folder: } 12 \\
\text { Oata Source: DU850 spectrophotonieter output (dated: May 29, } 2013 \text { to May 30, 2013) }\end{array}$} & Action & Date & Initiais \\
\hline & Created....... & $6 / 11 / 2013$ & KLW $W^{\prime} v^{\prime}$ \\
\hline & Revised...... & $4 / 25 / 2014$ & KLW KNW \\
\hline & \begin{tabular}{|l} 
Reviewed.... \\
Certifled...... \\
\end{tabular} & 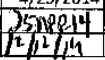 & $\sin _{0}$ \\
\hline
\end{tabular}

Spectrophotometric Data

Test Article: Pseudomonas fluorescens Pf -CL 145A (SDP); lct H: 401P121G3C and 401P12164C Mix

Test Location: Black Rlver, La Crosse, WI

Exposure Da:e: 5/29/2013

Assessment Dates: 6/26-27/2013

Data Explanation

A Absorbance $\{660 \mathrm{~nm}$ ) of water samples was measured on a Dus00 spectrophotometer (S/N 8003098).

2) Triplicate standard dilutions of $25,50,100$ and $200 \mathrm{mg} / \mathrm{L}$ were created from a $2,000 \mathrm{mg} / \mathrm{L}$ (A.I.) reference stock solution (Analytical Stock 1) for developing a linear

regresslon. A second set of $25,50,100$ and $200 \mathrm{mg} / \mathrm{L}$ standard check dilutions were created from a second $2,000 \mathrm{mg} / \mathrm{L}$ (A.I.) reference stock so ut on (Analytical Stock 2) for linear curve verification.

3) Data codes used within SAS

tank= Tank ID (1, through 9)

thero $=$ theorelica concentration

time= sample time $(0,6,12,18$, and 24 hours $)$

$b$ !ank= indicates blank with filtered river water ( $r)$, or water from an untreated control tank $(c)$

abs= measured absorbance of sample

conc $=$ known concertrations (linear regression standards used)

4) Information that is not releva t: to a sample (i.e., enclosure ID for standards) or that will be calculated by SAS (i.e., predicted concentration for standard checks and samples) is denoted by a "." for input into SAS

Data Analysis:

1) A linear regression was completed ir. SAS using the absorbance values of 3 repllcate dilutions of $25,50,100$ and $200 \mathrm{mg} / \mathrm{L}$ test article

2) Standard checks and exposure concentrallons were predicted In SAS using the linear regression

3) The following mean exposure concentrations were determined in SAS:

3a) Mean concentrations for each 'ndividual tank at each sampling time.

3b) Mean cancentrations of each treatment level, control $0 \mathrm{mg} / \mathrm{L}, 50 \mathrm{mg} / \mathrm{L}$ and $100 \mathrm{mg} / \mathrm{L}$, at all sampling times.

3c) Mean concentratior of each treatmert level and duration ( 8 hour treatment and 24 hour treatment).

3d) Std Dev = Standard deviation (population) of each treatment for all time points.

Flle names:

Spectrophotometric Data for SAS Input

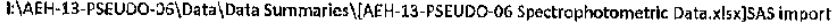

SAS Program/Code

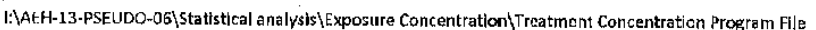

SASLOB

I:AEH-13-PSEUDC-06!Statistical analysisłExposure Concentration\Trea:ment Concentration Log File

SAS Output

I. AEH-13-PSEUJO-06 IStatlstical analysisłtexposure Concentration|Treatment Concentration Results File

Data Anomalies and Devlations:

1) The linear curye and assoclated ca.culated concentrations created with the DU800 Spectrophotometer were not used in data analysis. All repo ted expos ure contentrations were determined in SAS ky comparison to a linear regression curve createc from the absorbance values $(650 \mathrm{~nm})$ of known concentrations $(50,100,200$ and $300 \mathrm{mg} / \mathrm{L}$ ) of test art cle gathered by the DU800 spectrophotometer. Linear regresslon equations (Appendix i, liem 1) were fit using the SAS Proc Reg procedure. Standard check and exposure sample concentrazions were predicted from the regression analysis (Appendix $\mathrm{G}$, Item 1). The Proc Means procedure was used to determine the mean exposure concentration of indlvidual test tanks and treatment groups (Aopendix $G$, Item 1). All concentrations are reported as actlve ingredlent.

2) Tarks 3,4 and 5 were measurec twice for absorbance at $8 \mathrm{~h}$. Initial absorbances appeared ta be high. To verlfy the absorbances, the samples were re-run. The second set of absorbances were still high, whilch may be due to sediment disturbance/turbidity caused by $8 \mathrm{~h}$ mussel removal, Both sets of absorbances we' $e^{\circ}$ averaged for the analysis.

Fila Folder $\frac{13}{1: \text { Nan Number }}$ 
Study Number: AEH-13-PSEUDO-CG

Electronlc Log (Pages 7-9)

Fille Folder: 12

Data Surce: DU800 spectrophotometer output (dated: May 29, 2013 to May 30, 2013)
Test Artlcle: Pseudomonos fluorescens Pf -CL 145A (SDP)

Lot \#: 401P12163C and 401P12164C (Mixed from MB|)

Exposure Date: 5/29/2013 Assessment Dates: 6/26-27/2013

\section{Spectrophotometric Data}

\begin{tabular}{|c|ccc|}
\multicolumn{3}{c|}{ Linear Regression Triplicate Standard } \\
\hline \multirow{2}{*}{ SID Conc (mg/L) } & \multicolumn{3}{|c|}{ Sample Absorbance (660 nm) } \\
\cline { 2 - 4 } & Rep 1 & Rep 2 & Rep 3 \\
\hline \hline 0 & -0.0002 & 0.0004 & -0.0006 \\
25 & 0.0331 & 0.0324 & 0.0344 \\
50 & 0.0689 & 0.0671 & 0.0666 \\
100 & 0.1274 & 0.1264 & 0.1449 \\
200 & 0.2558 & 0.2562 & 0.2543 \\
\hline
\end{tabular}

Exposure Standard Checks

\begin{tabular}{|c|ccc|ccc|}
\hline \multirow{2}{*}{ STD Conc $(\mathrm{mg} / \mathrm{L})$} & \multicolumn{3}{|c|}{ Standard Set \#1 (Abs $660 \mathrm{~nm})$} & \multicolumn{3}{c|}{ Standard Set \#2 $(\mathrm{Abs} 660 \mathrm{~nm})$} \\
\cline { 2 - 7 } & Oh & $6 \mathrm{~h}$ & $12 \mathrm{~h} \mathrm{Std} \mathrm{1}$ & $12 \mathrm{~h} \mathrm{Std2}$ & $18 \mathrm{~h}$ & $24 \mathrm{~h}$ \\
\hline \hline 0 & $\mathrm{n} / \mathrm{a}$ & 0.0082 & 0.0013 & $\mathrm{n} / \mathrm{a}$ & -0.0031 & -0.0356 \\
25 & 0.0301 & 0.0358 & 0.0315 & 0.0479 & 0.0389 & 0.0475 \\
50 & 0.0656 & 0.0696 & 0.0619 & 0.0772 & 0.0652 & 0.0626 \\
100 & 0.1238 & 0.1365 & 0.0875 & 0.1415 & 0.1219 & 0.1192 \\
200 & 0.2481 & 0.2453 & 0.1566 & 0.2731 & 0.2370 & 0.2172 \\
\hline
\end{tabular}

\begin{tabular}{|c|c|c|c|c|c|c|}
\hline \multirow{2}{*}{ Tank Number } & $\begin{array}{c}\text { Exposure Target } \\
(\mathrm{mg} / \mathrm{L})\end{array}$ & \multicolumn{5}{|c|}{ Exposure Concentrations } \\
\cline { 3 - 7 } & 100 & $1 \mathrm{~h}$ & $6 \mathrm{~h}$ & $12 \mathrm{~h}$ & $18 \mathrm{~h}$ & $24 \mathrm{~h}$ \\
\hline \hline 1 & 100 & 0.1508 & 0.1287 & 0.1303 & 0.2271 & 0.1289 \\
2 & 50 & 0.0930 & $0.125 \mathrm{~L}$ & 0.1303 & 0.1237 & 0.1177 \\
3 & 50 & 0.0999 & 0.0587 & $0.0878^{\circ}$ & 0.0649 & $0.06 n$ \\
4 & 0 & 0.0558 & $0.1139^{\circ}$ & 0.0723 & 0.0694 \\
5 & 0.0016 & 0.0004 & $0.0140^{\circ}$ & -0.0024 & 0.0031 \\
6 & 50 & 0.0906 & 0.0690 & 0.0829 & 0.0675 & 0.0708 \\
7 & 0 & 0.0003 & -0.0005 & 0.0012 & -0.0069 & -0.0001 \\
8 & 0 & 0.0008 & 0.0002 & 0.0097 & -0.0037 & -0.0055 \\
9 & 100 & 0.1804 & 0.1329 & 0.1477 & 0.1193 & 0.1262 \\
\hline
\end{tabular}

Init|al tank absorbance $(0.0946)$ and second absorbance $(0.0809)$ measurements were averaged for the analys $\mid s$.

${ }^{b}$ In|t|lat tank absorbance $\{0.1187)$ and second absorbance $\{0.1072\}$ measurements were averaged for the analysis.

'Initlal tank absorbance $[0.0161)$ and second absorbance $(0.0119]$ measurements were averaged for the analysis, 


\begin{tabular}{|c|c|c|c|c|c|c|}
\hline tank & thero & time & blank & abs & conc & \\
\hline . & 0 & 0 & r & -0.0002 & 0.0000 & \\
\hline . & 25 & 0 & $r$ & 0.0331 & 25.0000 & \\
\hline . & 50 & 0 & r & 0.0689 & 50.0000 & \\
\hline . & 100 & 0 & $r$ & 0.1274 & 100.0000 & \\
\hline . & 200 & 0 & r & 0.2558 & 200.0000 & AEH-13-PSEUDO-06 \\
\hline . & 0 & 0 & $r$ & 0.0004 & 0.0000 & \\
\hline . & 25 & 0 & $r$ & 0.0324 & 25.0000 & \\
\hline . & 50 & 0 & r & 0.0671 & 50.0000 & \\
\hline . & 100 & 0 & $r$ & 0.1264 & 100.0000 & \\
\hline . & 200 & 0 & $r$ & 0.2562 & 200.0000 & \\
\hline . & 0 & 0 & $r$ & $-0,0006$ & 0.0000 & \\
\hline . & 25 & 0 & r & 0.0344 & 25.0000 & \\
\hline . & 50 & 0 & $r$ & 0.0666 & 50.0000 & \\
\hline . & 100 & 0 & $r$ & 0.1449 & 100.0000 & \\
\hline . & 200 & 0 & $r$ & 0.2543 & 200.0000 & \\
\hline . & 25 & 0 & $r$ & 0.0301 & . & \\
\hline . & 50 & 0 & $r$ & 0.0656 & . & \\
\hline . & 100 & 0 & $r$ & 0.1238 & . & \\
\hline . & 200 & 0 & $r$ & 0.2481 & . & \\
\hline . & 0 & 6 & c & 0.0082 & . & \\
\hline . & 25 & 6 & c & 0.0358 & . & \\
\hline . & 50 & 6 & c & 0.0696 & . & \\
\hline . & 1.00 & 6 & c & 0.1365 & . & \\
\hline . & 200 & 6 & c & 0.2453 & . & \\
\hline . & 0 & 12 & $r$ & 0.0013 & . & \\
\hline . & 25 & 12 & $r$ & 0.0315 & . & \\
\hline . & 50 & 12 & $r$ & 0.0619 & . & \\
\hline . & 100 & 12 & $r$ & 0.0875 & . & \\
\hline . & 200 & 12 & $r$ & 0.1566 & . & \\
\hline . & 25 & 12 & $r$ & 0.0479 & . & \\
\hline . & 50 & 12 & $r$ & 0.0772 & . & \\
\hline . & 100 & 12 & $r$ & 0.1415 & . & \\
\hline . & $\begin{array}{c}200 \\
0\end{array}$ & $\begin{array}{l}12 \\
18\end{array}$ & $r$ & 0.2731 & . & \\
\hline . & 25 & 18 & $c$ & 0.0389 & . & \\
\hline . & 50 & 18 & c & 0.0652 & . & \\
\hline . & 100 & 18 & c & 0.1219 & . & \\
\hline . & 200 & 18 & $\mathrm{c}$ & 0.2370 & . & \\
\hline . & 0 & 24 & c & -0.0056 & . & \\
\hline . & 25 & 24 & c & 0.0475 & . & \\
\hline . & 50 & 24 & c & 0.0626 & . & \\
\hline . & 100 & 24 & c & 0.1192 & . & \\
\hline . & 200 & 24 & c & 0.2172 & . & \\
\hline 1 & 100 & 1 & $r$ & 0.1508 & . & 3 \\
\hline 2 & $\begin{array}{c}100 \\
50\end{array}$ & $\begin{array}{l}1 \\
1\end{array}$ & $r$ & $\begin{array}{l}0.1630 \\
0.0937\end{array}$ & . & \\
\hline
\end{tabular}




\begin{tabular}{|c|c|c|c|c|}
\hline 4 & 50 & 1 & $r$ & 0.0999 \\
\hline 5 & 0 & 1 & $r$ & 0.0016 \\
\hline 6 & 50 & 1 & $r$ & 0.0906 \\
\hline 7 & 0 & 1 & $r$ & 0.0003 \\
\hline 8 & 0 & 1 & $r$ & 0.0008 \\
\hline 9 & 100 & 1 & $r$ & 0.1804 \\
\hline 1 & 100 & 6 & $c$ & 0.1287 \\
\hline 2 & 100 & 6 & $c$ & 0.1251 \\
\hline 3 & 50 & 6 & c & 0.0587 \\
\hline 4 & 50 & 6 & $c$ & 0.0658 \\
\hline 5 & 0 & 6 & $\mathrm{c}$ & 0.0004 \\
\hline 6 & 50 & 6 & c & 0.0690 \\
\hline 7 & 0 & 6 & c & -0.0005 \\
\hline 8 & 0 & 6 & $\mathrm{c}$ & 0.0002 \\
\hline 9 & 100 & 6 & $c$ & 0.1329 \\
\hline 1 & 100 & 12 & $r$ & 0.1303 \\
\hline 2 & 100 & 1.2 & $r$ & 0.1303 \\
\hline 3 & 50 & 12 & $r$ & 0.0878 \\
\hline 4 & 50 & 12 & $r$ & 0.1130 \\
\hline 5 & 0 & 12 & $r$ & 0.0140 \\
\hline 6 & 50 & 12 & $r$ & 0.0829 \\
\hline 7 & 0 & 12 & $r$ & 0.0012 \\
\hline 8 & 0 & 12 & $r$ & 0.0097 \\
\hline 9 & 100 & 12 & $r$ & 0.1477 \\
\hline 1 & 100 & 18 & c & 0.1271 \\
\hline 2 & 100 & 18 & c & 0.1237 \\
\hline 3 & 50 & 18 & c & 0.0649 \\
\hline 4 & 50 & 18 & $\mathrm{c}$ & 0.0723 \\
\hline 5 & 0 & 18 & $c$ & -0.0024 \\
\hline 6 & 50 & 18 & $c$ & 0.0675 \\
\hline 7 & 0 & 18 & c & -0.0069 \\
\hline 8 & 0 & 18 & $c$ & -0.0037 \\
\hline 9 & 100 & 18 & c & 0.1193 \\
\hline 1 & 100 & 24 & c & 0.1289 \\
\hline 2 & 100 & 24 & c & 0.1177 \\
\hline 3 & 50 & 24 & c & 0.0619 \\
\hline 4 & 50 & 24 & c & 0.0694 \\
\hline 5 & 0 & 24 & $c$ & 0.0031 \\
\hline 6 & 50 & 24 & c & 0.0708 \\
\hline 7 & 0 & 24 & c & -0.0001 \\
\hline 8 & 0 & 24 & $c$ & -0.0055 \\
\hline 9 & 100 & 24 & $c$ & 0.1262 \\
\hline
\end{tabular}

\section{AEH-13-PSEUDO-06}

Page 4 of 18 


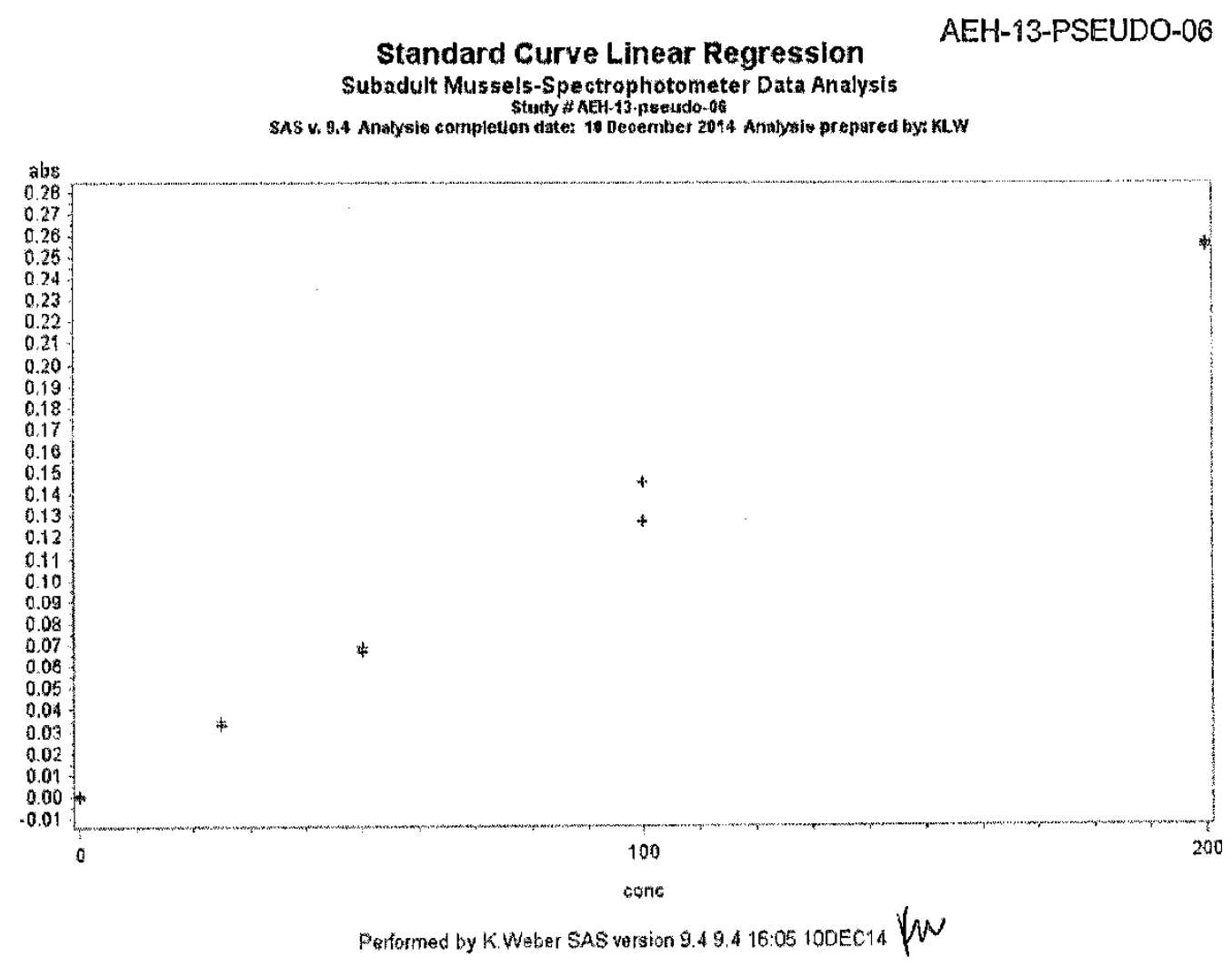

Page 5 of 18

filc://I:/AEH-13-PSEUDO-06/Statistical\%20analysis/Exposure\%20Concentration/sasht... 12/10/2014 


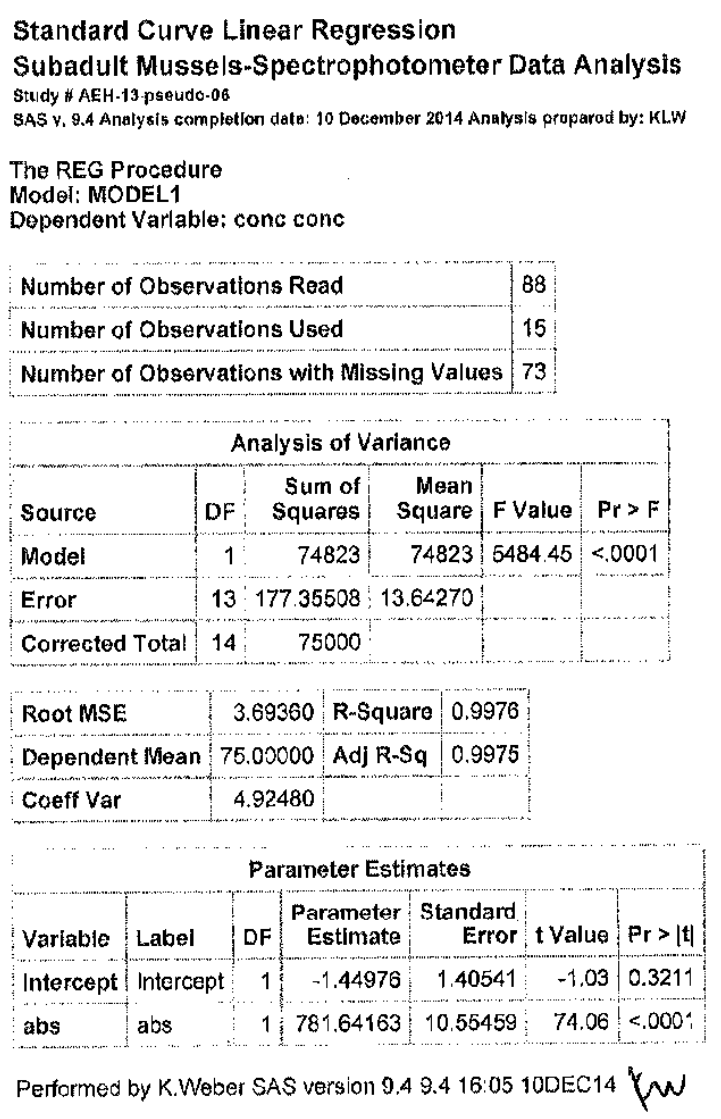

Page 6 of 18

file://I:/AEH-13-PSEUDO-06/Statistical\%20analysis/Exposure\%20Concentration/sasht... 12/10/2014 

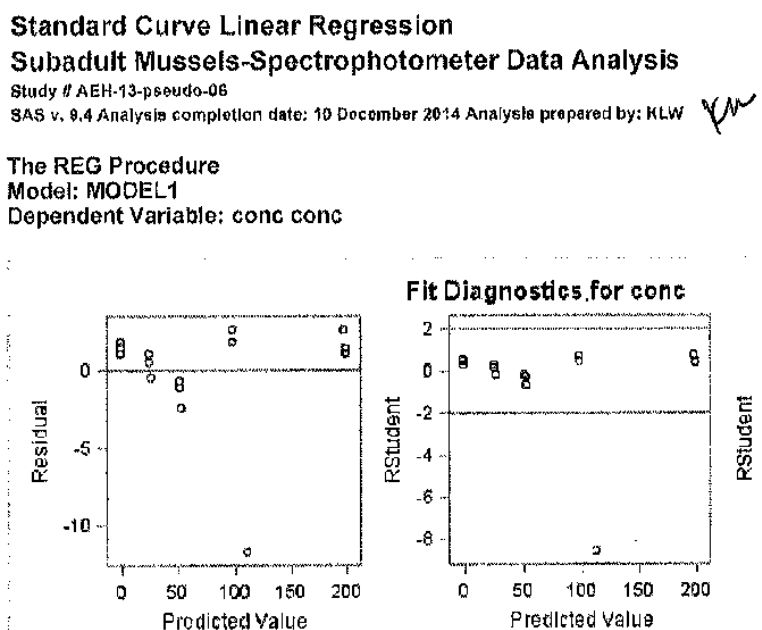

Fit Diagnostics for conc
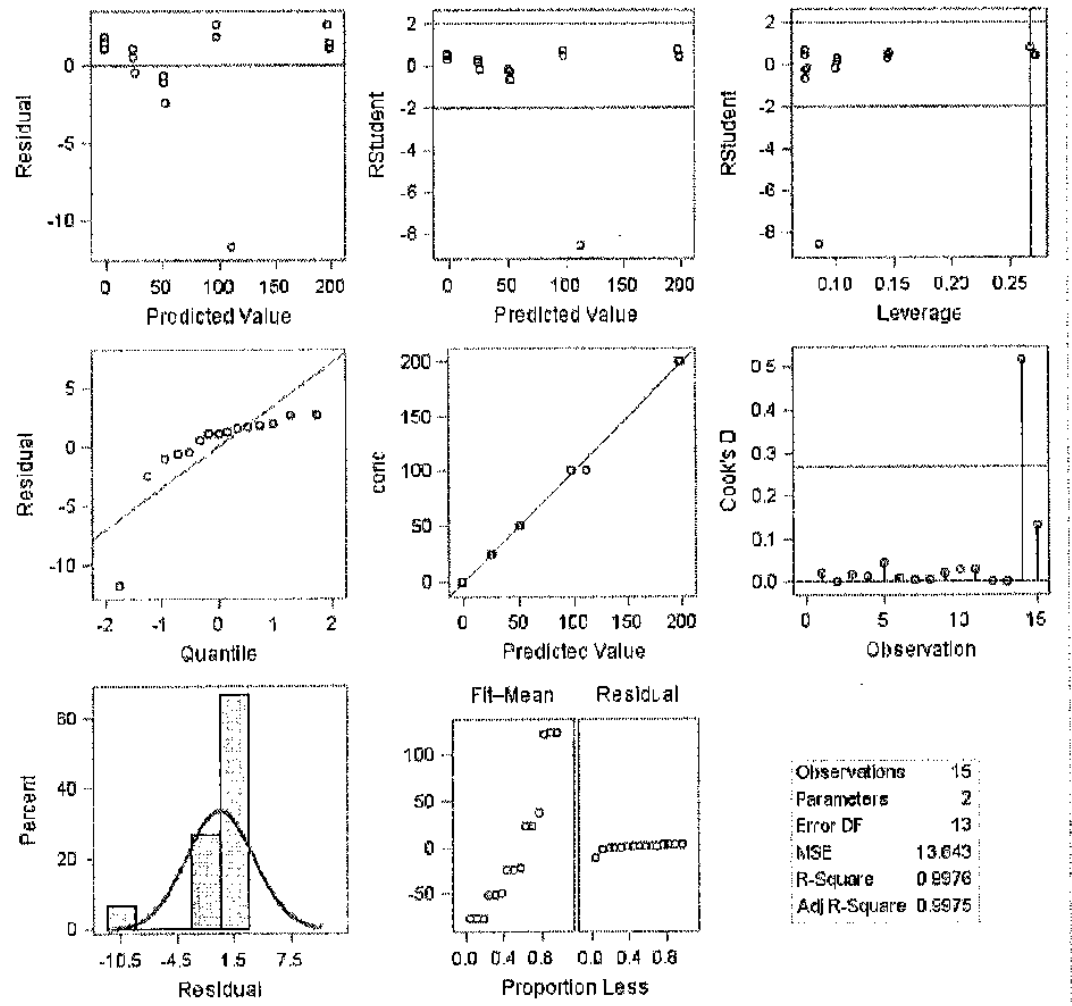

Page 7 of 18 


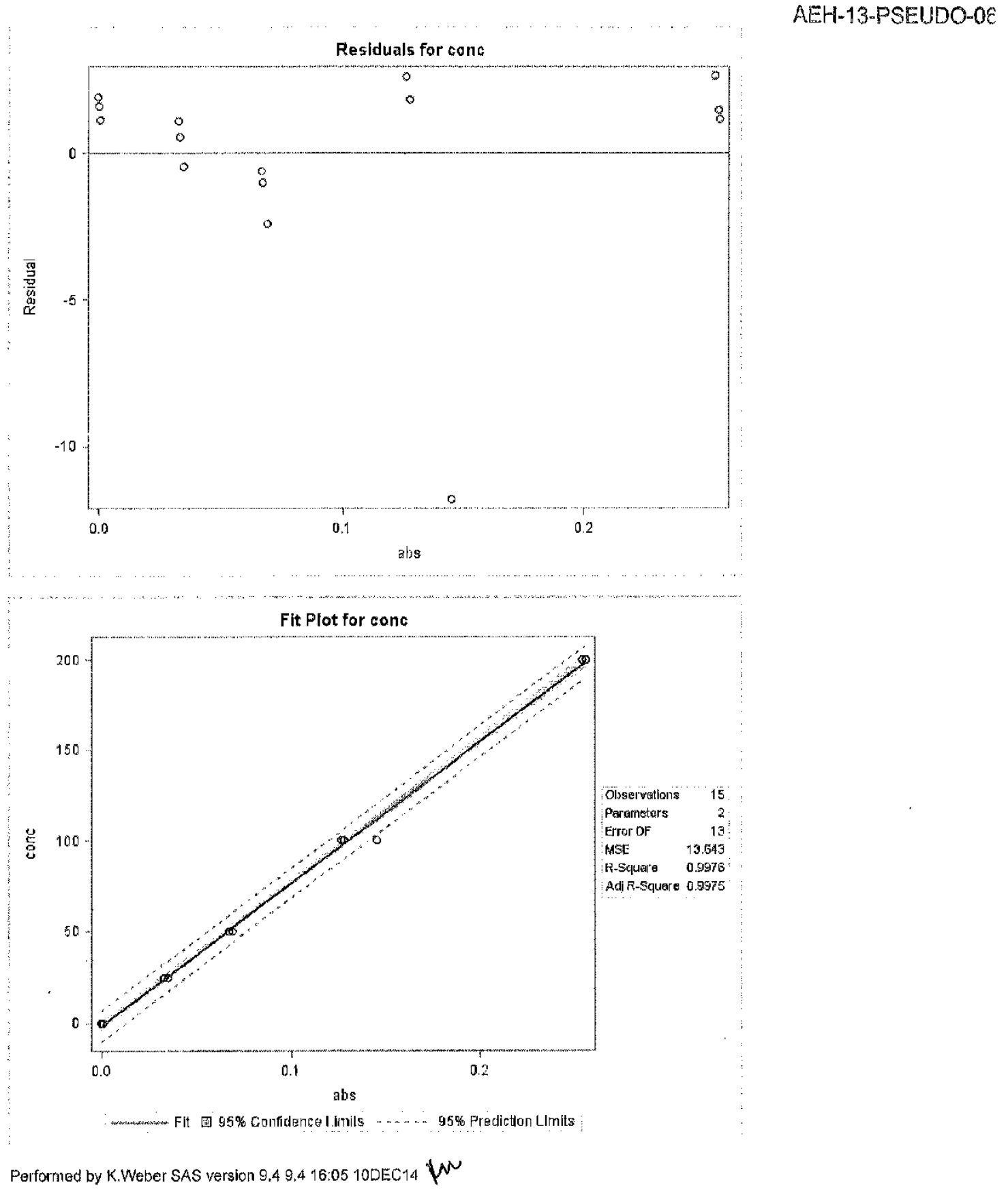

Page 8 of 18

file://I:/AEH-13-PSEUDO-06/Statistical\%20analysis/Exposure\%20Concentration/sasht... 12/10/2014 
Data flle with predicted concentrations from the linear regression

Data lines with conc listed are the standards used to create the regression

Data lines without conc listed are standard checks (no tank listed) or samples (tank listed)

Obs tank thero time blank abs conc predlcted_ppm

\begin{tabular}{|c|c|c|c|c|c|c|c|}
\hline & & & & & & & \\
\hline 1 & . & 0 & $0:$ & ${ }^{r}$ & -0.0002 & 0 & -1.606 \\
\hline 2 & . & 25 & 0 & $r$ & 0.0331 & 25 & 24.423 \\
\hline 3 & . & 50 & 0 & $r$ & 0.0689 & 50 & 52.405 \\
\hline 4 & . & 100 & 0 & $r$ & 0.1274 & 100 & 98.131 \\
\hline 5 & $\therefore$ & 200 & $0:$ & $r$ & 0.2558 & 200 & 198.494 \\
\hline 6 & $\therefore$ & 0 & $0^{\prime}$ & $r$ & 0.0004 & 0 & -1.137 \\
\hline 7 & . & 25 & 0 & $r$ & 0.0324 & 25 & 23.875 \\
\hline 8 & . & 50 & 0 & $r$ & 0.0671 & 50 & 50.998 \\
\hline 9 & . & 100 & 0 & $r$ & 0.1264 & 100 & 97.350 \\
\hline 10 & . & 200 & 0 & $r$ & 0.2562 & 200 & 198.807 \\
\hline 11 & $\therefore$ & 0 & 0 & $r$ & -0.0006 & 0 & -1.919 \\
\hline 12 & . & 25 & 0 & $r$ & 0.0344 & 25 & 25.439 \\
\hline 13 & & 50 & 0 & $r$ & 0.0666 & 50 & 50.608 \\
\hline 14 & . & 100 & 0 & $r$ & 0.1449 & 100 & 111.810 \\
\hline 15 & . & 200 & 0 & $r$ & 0.2543 & 200 & 197.322 \\
\hline 16 & . & 25 & 0 & $r$ & 0.0301 & & 22.078 \\
\hline 17 & $\therefore$ & 50 & 0 & $r$ & 0.0656 & & 49.826 \\
\hline 18 & . & 100 & 0 & $r$ & 0.1238 & & 95.317 \\
\hline 19 & :... & 200 & 0 & $r$ & 0.2481 & & 192.476 \\
\hline 20 & 1 & 100 & 1 & $r$ & 0.1508 & & 116.422 \\
\hline 21 & 2 & 100 & 1 & I & 0.1630 & & 125.958 \\
\hline 22 & 3 & 50 & 1 & $r$ & 0.0937 & & 71.790 \\
\hline 23 & 4 & 50 & 1 & $r$ & 0.0999 & & 76.636 \\
\hline 24 & 5 & 0 & 1 & $r$ & 0.0016 & & -0.199 \\
\hline 26 & 6 & 50 & $1:$ & 1 & 0.0906 & & 69.367 \\
\hline 26 & 7 & 0 & 1 & $r$ & 0.0003 & & -1.215 \\
\hline 27 & 8 & 0 & $1:$ & $r$ & 0.0008 & & -0.824 \\
\hline 28 & 9 & 100 & 1 & $r$ & 0.1804 & & 139.558 \\
\hline 29 & & 0 & 6 & $c$ & 0.0082 & & 4.960 \\
\hline 30 & & 25 & 6 & $c$ & 0.0358 & & 26.533 \\
\hline 31 & & 50 & 6 & $c$ & 0.0696 & & 52.952 \\
\hline 32 & i & 100 & 6 & $c$ & 0.1365 & & 105.244 \\
\hline 33 & . & 200 & 6 & c & 0.2453 & & 190.287 \\
\hline 34 & 1 & 100 & 6 & $\mathrm{c}$ & 0.1287 & & 99.148 \\
\hline 35 & 2 & 100 & 6 & $c$ & 0.1251 & & 96.334 \\
\hline 36 & 3 & 50 & 6 & $c$ & 0.0587 & & 44.433 \\
\hline 37 & 4 & 50 & 6 & $c$ & 0.0658 & & 49.982 \\
\hline 38 & 5 & 0 & 6 & 0 & 0.0004 & & -1.137 \\
\hline
\end{tabular}

Page 9 of 18 
AEH-13-PSEUDO-06

\begin{tabular}{|c|c|c|c|c|c|c|}
\hline 39 & 6 & 50 & & $\mathrm{c}$ & 0.0690 & 52.484 \\
\hline 40 & 7 & 0 & 6 & $c$ & -0.0005 & -1.841 \\
\hline 41 & 8 & 0 & 6 & $c$ & 0.0002 & -1.293 \\
\hline 42 & 9 & 100 & 6 & c & 0.1329 & 102.430 \\
\hline 43 & . & 0 & 12 & $r$ & 0.0013 & -0.434 \\
\hline 44 & . & 26 & 12 & $r$ & 0.0315 & 23.172 \\
\hline 45 & $\therefore$ & 50 & 12 & $r$ & 0.0619 & 46.934 \\
\hline 46 & : & 100 & 12 & $r$ & 0.0875 & 66.944 \\
\hline 47 & . & 200 & 12 & $r$ & 0.1566 & 120.955 \\
\hline 48 & i. & 25 & 12 & $r$ & 0.0479 & 35.991 \\
\hline 49 & $\therefore$ & 50 & 12 & $r$ & 0.0772 & 58.893 \\
\hline 50 & . & 100 & $12:$ & $r$ & 0.1415 & 109.153 \\
\hline 51 & $\therefore$ & 200 & $12 ;$ & $r$ & 0.2731 & 212.017 \\
\hline 52 & 1 & 100 & 12 & $r$ & 0.1303 & 100.398 \\
\hline 53 & 2 & 100 & 12 & $r$ & 0.1303 & 100.398 \\
\hline 54 & 3 & 50 & 12 & $r$ & 0.0878 & 67,178 \\
\hline 55 & 4 & 50 & 12 & $r$ & 0.0140 & 9.493 \\
\hline 56 & 5 & 0 & 12 & $r$ & 0.0161 & 11.135 \\
\hline 57 & 6 & 50 & 12 & $r$ & 0.0829 & 63.348 \\
\hline 58 & 7 & 0 & 12 & $r$ & 0.0012 & -0.512 \\
\hline 59 & 8 & 0 & 12. & $r$ & 0.0097 & 6.132 \\
\hline 60 & 9 & 100 & 12 & $r$ & 0.1477 & 113.999 \\
\hline 61 & . & 0 & 18 & $c$ & -0.0031 & -3.873 \\
\hline 62 & $\therefore$ & 25 & 18 & $c$ & 0.0389 & 28.956 \\
\hline 63 & . & 50 & 18 & $c$ & 0.0652 & 49.513 \\
\hline 64 & 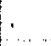 & 100 & 18 & $c$ & 0.1219 & 93.832 \\
\hline 65 & . & 200 & 18 & $c$ & 0.2370 & 183.799 \\
\hline 66 & 1 & 100 & 18 & $c$ & 0.127 & 97.897 \\
\hline 67 & 2 & 100 & 18 & $c$ & 0.1237 & 95.239 \\
\hline 68 & 3 & 50 & 18 & $\mathrm{c}$ & 0.0649 & 49.279 \\
\hline 69 & 4 & 50 & 18 & $c$ & 0.0723 & 55.063 \\
\hline 70 & 5 & 0 & 18 & c & -0.0024 & -3.326 \\
\hline 71 & 6 & 50 & 18 & $c$ & 0.0675 & $51.31^{4}$ \\
\hline 72 & 7 & 0 & 18 & $c$ & -0.0069 & -6.843 \\
\hline 73 & 8 & 0 & 18 & $c$ & -0.0037 & -4.342 \\
\hline 74 & 9 & 100 & 18 & $c$ & 0.1193 & 91.800 \\
\hline 75 & . & 0 & 24 & $c$ & -0.0056 & -5.827 \\
\hline 76 & . & 25 & 24 & $c$ & 0.0475 & 35.678 \\
\hline 77 & . & 50 & 24 & $c$ & 0.0626 & 47.481 \\
\hline 78 & 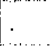 & 100 & 24 & $c$ & 0.1192 & 91.722 \\
\hline 79 & . & 200 & 24 & $c$ & 0.2172 & 168.323 \\
\hline $80 !$ & 1 & 100 & 24 & $c$ & 0.1289 & 99.304 \\
\hline 81 & 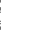 & & & & & \\
\hline
\end{tabular}

Page 10 of 18 


\begin{tabular}{|c|c|c|c|c|c|c|}
\hline & 2 & 100 & 24 & $c$ & 0.1177 & 90.549 \\
\hline 82 & 3 & 50 & 24 & $\mathrm{c}$ & 0.0619 & 46.934 \\
\hline 83 & 4 & 50 & 24 & $\mathrm{c}$ & 0.0694 & 52.796 \\
\hline 84 & 5 & $0:$ & 24 & $\mathrm{c}$ & 0.0031 & 0.973 \\
\hline 85 & 6 & 50 & 24 & $c$ & 0.0708 & 53.890 \\
\hline 86 & 7 & 0 & 24 & $c$ & -0.0001 & -1.528 \\
\hline 87 & 8 & 0 & 24 & c & -0.0055 & -5.749 \\
\hline 88 & 9 & 100 & 24 & $c$ & 0.1262 & 97,193 \\
\hline
\end{tabular}

A EH-13-PSEUDO-06

Page 11 of 18 
Mean treatment concentration by tank for the entire exposure period Individual tank means

The MEANS Procedure

$\tan k=1$

Analys is Variable: predicted ppm Predicted
Value of conc

$\tan k=2$

\begin{tabular}{|c|c|c|c|}
\hline \multicolumn{4}{|c|}{$\begin{array}{c}\text { Analysis Variable : predicted_ppm Predicted } \\
\text { Value of conc }\end{array}$} \\
\hline Mean & Std Dev & $\begin{array}{l}\text { Lower } 95 \% \\
\text { Cl. for Maan }\end{array}$ & $\begin{array}{l}\text { Upper } 95 \% \\
\text { CL. for Mean }\end{array}$ \\
\hline 101.7 & 14.0090 & 84.3012 & 119.1 \\
\hline
\end{tabular}

$\tan k=3$

\begin{tabular}{|c|c|c|c|}
\hline Mean & Std Dev & $\begin{array}{r}\text { Lower } 95 \% \\
\text { CL for Mean }\end{array}$ & $\begin{array}{l}\text { Upper } 95 \% \\
\mathrm{CL} \text { for Mean }\end{array}$ \\
\hline 55.9227 & 12.6038 & 40.2730 & 71.5725 \\
\hline
\end{tabular}

$\operatorname{tank}=4$

\begin{tabular}{|c|c|c|c|}
\hline \multicolumn{4}{|c|}{$\begin{array}{c}\text { Analysis Variable : predicted_ppm Predlcted } \\
\text { Value of conc }\end{array}$} \\
\hline Mean & Std Dev & $\begin{array}{l}\text { Lowor } 95 \% \\
\text { CL for Mean }\end{array}$ & $\begin{array}{l}\text { Upper } 95 \% \\
\text { CL for Mean }\end{array}$ \\
\hline 48.7942 & 24.3745 & 18.5292 & 79.0591 \\
\hline
\end{tabular}

tank $=5$

\begin{tabular}{|c|c|c|c|}
\hline \multicolumn{4}{|c|}{$\begin{array}{c}\text { Analysis Varlable : predicted_ppm Predicted } \\
\text { Value of conc }\end{array}$} \\
\hline Mean & Std Dov & $\begin{array}{l}\text { Lower } 95 \% \\
\text { CL for Mean }\end{array}$ & $\begin{array}{r}\text { Upper } 95 \% \\
\text { CL for Mean }\end{array}$ \\
\hline 1.4892 & 5.6177 & $-5,4860$ & 8.46 \\
\hline
\end{tabular}

$\tan k=6$

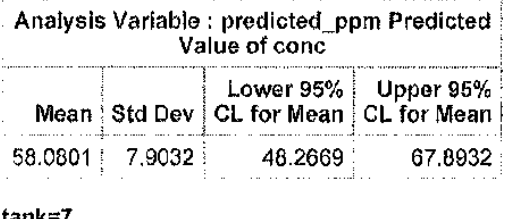

tank=7

Analysis Varlable : predicted_ppm Predicted 


\begin{tabular}{|c|c|c|c|}
\hline \multicolumn{4}{|c|}{ Value of conc } \\
\hline Mean & Sta DeY & $\begin{array}{l}\text { Lower } 95 \% \\
\text { CL. for Moan }\end{array}$ & $\begin{array}{r}\text { Upper } 95 \% \\
\text { CL. for Mean }\end{array}$ \\
\hline-2.3877 & 2.5388 & -5.5401 & 0.7646 \\
\hline \multicolumn{4}{|l|}{$\tan k=8$} \\
\hline \multicolumn{4}{|c|}{$\begin{array}{l}\text { Analysis Variable : predicted_ppm Predicted } \\
\text { Value of conc }\end{array}$} \\
\hline Mean & Std Dev & $\begin{array}{l}\text { Lower } 95 \% \\
\text { CL. for Mean }\end{array}$ & $\begin{array}{r}\text { Upper } 95 \% \\
\text { CL for Mean }\end{array}$ \\
\hline-1.2153 & 4.5954 & -6.9212 & 4.4907 \\
\hline
\end{tabular}

AEH-13-PSEUDO-06

$\tan k=9$

Analysis Variabls : predicted ppm Predicted

\begin{tabular}{|c|c|c|c|}
\hline Mean & Std Dev & $\begin{array}{l}\text { Lower } 95 \% \\
\text { CL for Moan }\end{array}$ & $\begin{array}{l}\text { Upper } 95 \% \\
\text { CL for Mean }\end{array}$ \\
\hline 109.0 & 18.9552 & 85.4602 & 132. \\
\hline
\end{tabular}

Performed by K. Weber SAS version $9.49 .416: 05$ 10DEC14 (W

Page 13 of 18 
Mean treatment concentration by treatment group at each sampling time (replicate tanks combined for each sample time)

\begin{tabular}{|c|c|c|c|}
\hline \multicolumn{3}{|c|}{ thero $=0$ t $\mid m e=1$} & \\
\hline \multicolumn{4}{|c|}{$\begin{array}{l}\text { Analysis Variable : predicted_ppm Predicted } \\
\text { Value of conc }\end{array}$} \\
\hline Mean & Std Dev & $\begin{array}{l}\text { Lower } 95 \% \\
\text { CL for Mean }\end{array}$ & $\begin{array}{l}\text { Upper } 95 \% \\
\text { CL for Mean }\end{array}$ \\
\hline-0.7463 & 0.5126 & -2.0195 & 0.5270 \\
\hline
\end{tabular}

thero $=0$ time $=6$

\begin{tabular}{|c|c|c|c|}
\hline \multicolumn{4}{|c|}{$\begin{array}{c}\text { Analysis Variable : predicted_ppm Predicted } \\
\text { Value of conc }\end{array}$} \\
\hline Mean & Sta Dev & $\begin{array}{l}\text { Lower } 95 \% \\
\text { Cl. for Mean }\end{array}$ & $\begin{array}{r}\text { Upper } 95 \% \\
\text { CL for Mean }\end{array}$ \\
\hline-1.4237 & 0.3694 & $-2,3413$ & -0.5061 \\
\hline
\end{tabular}

thero $=0$ time $=12$

Analysis Variable : predicted_ppm Predicted

\begin{tabular}{r|r|r|r|} 
& \multicolumn{2}{c|}{ Valtue of conc } \\
\hline Mean & Std Dev & $\begin{array}{r}\text { Lower } 95 \% \\
\text { CL. for Mean }\end{array}$ & $\begin{array}{r}\text { Upper } 95 \% \\
\text { CL for Mean }\end{array}$ \\
\hline 5.5850 & 5.8425 & -8.9285 & 20.0985 \\
\hline
\end{tabular}

thero $=0$ time $=18$

\begin{tabular}{|c|c|c|c|}
\hline \multicolumn{4}{|c|}{$\begin{array}{c}\text { Analysis Variable : predicted_ppm Predlcted } \\
\text { Value of conc }\end{array}$} \\
\hline Mean & Std Dev & $\begin{array}{l}\text { Lower } 95 \% \\
\text { CL. for Mean }\end{array}$ & $\begin{array}{r}\text { Upper } 95 \% \\
\text { CL. for Mean }\end{array}$ \\
\hline 4.8369 & 1.8102 & -9.3336 & 0.3401 \\
\hline
\end{tabular}

therowe time $=24$

\begin{tabular}{|c|c|c|c|}
\hline \multicolumn{4}{|c|}{$\begin{array}{c}\text { Analysis Variable : predicted_ppm Predicted } \\
\text { Value of conc }\end{array}$} \\
\hline Mean & Std Dev & $\begin{array}{l}\text { Lower } 95 \% \\
\text { CL for Mean }\end{array}$ & $\begin{array}{l}\text { Upper } 96 \% \\
\text { CL for Mean }\end{array}$ \\
\hline 2.1011 & 3.3975 & -0.5410 & 6.3388 \\
\hline
\end{tabular}

thero $=50$ time $=1$

Analys ls Variable : predicted_ppm Predicted
Value of conc

thero $=60$ time $=6$

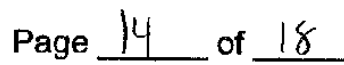

Analysis Varlable : predicted_ppm Predicted 


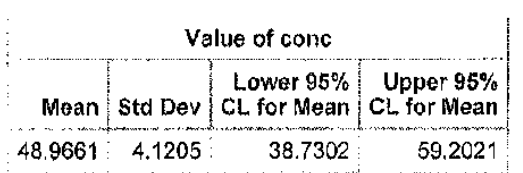

thero $=50$ time $=12$

\begin{tabular}{|c|c|c|c|}
\hline \multicolumn{4}{|c|}{$\begin{array}{c}\text { Analysis Variable : predicted_ppm Predicted } \\
\text { Value of conc }\end{array}$} \\
\hline Mean & Std Dev & $\begin{array}{l}\text { Lower } 95 \% \\
\text { CL for Mean }\end{array}$ & $\begin{array}{l}\text { Upper } 95 \% \\
\text { CL for Mean }\end{array}$ \\
\hline 46.6733 & 32.2558 & $-33,4545$ & 126.8 \\
\hline
\end{tabular}

thero $=50$ time $=18$

\begin{tabular}{|c|c|c|c|}
\hline \multicolumn{4}{|c|}{$\begin{array}{c}\text { Analysis Variable: predicted_ppm Predicted } \\
\text { Value of conc }\end{array}$} \\
\hline Mean & Std Dev & $\begin{array}{r}\text { Lower } 95 \% \\
\text { CL for Mean }\end{array}$ & $\begin{array}{l}\text { Upper } 95 \% \\
\text { CL for Mean }\end{array}$ \\
\hline 51.8843 & 2.9344 & 44.5949 & 59.1736 \\
\hline
\end{tabular}

thero $=50$ time $=24$

Analysis Variable : predicted_ppm Predicted

\begin{tabular}{|c|r|r|r|}
\multicolumn{3}{c|}{ Value of conc } \\
\hline Mean & Std Dev & $\begin{array}{r}\text { Lower 95\% } \\
\text { CL for Mean }\end{array}$ & $\begin{array}{r}\text { Upper 95\% } \\
\text { CL for Mean }\end{array}$ \\
\hline 51.2068 & 3.7407 & 41.9143 & 60.4993 \\
\hline
\end{tabular}

thero $=100$ time $=1$

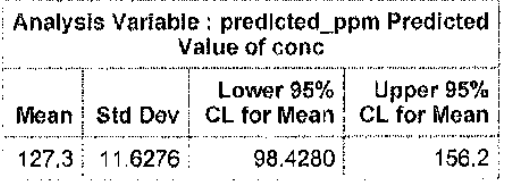

thero $=100$ tlme $=6$

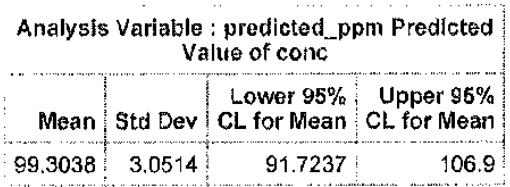

thero $=100$ time $=12$

Analysis Variable: predicted ppm Predicted

\begin{tabular}{|c|c|c|c|}
\hline \multicolumn{3}{c|}{ Value of conc } \\
\hline Mean & Std Dev & $\begin{array}{r}\text { Lower 95\% } \\
\text { CL for Moran }\end{array}$ & $\begin{array}{r}\text { Upper } 95 \% \\
\text { CL for Mean }\end{array}$ \\
\hline 104.9 & 7.8523 & 85.4255 & 124.4 \\
\hline
\end{tabular}

thero $=100$ t.me $=18$

Page 15 of 18

Analysis Varlable ; predicted_ppm Predicted

file:///I:/AEH-13-PSEUDO-06/Statistical\%20analysis/Exposure\%20Concentration/sasht... 12/10/2014 


\begin{tabular}{|c|c|c|c|}
\hline \multicolumn{4}{|c|}{ Value of conc } \\
\hline Mean & Std Dev & $\begin{array}{r}\text { Lower } 95 \% \\
\text { CL for Mean }\end{array}$ & $\begin{array}{r}\text { Upper } 95 \% \\
\mathrm{CL} \text { for Mean }\end{array}$ \\
\hline 4.9788 & 3,0567 & 87.3854 & 102.6 \\
\hline
\end{tabular}

AEH-H-PSEUDO-06

thero $=100$ tine $=24$

Analysis Variable : predicted_ppm Predlcted Value of conc

Lower 95\% Upper 95\%

Mean Std Dev CL for Mean CL for Mean

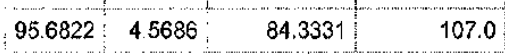

Performed by K.Weber SAS version $9.49,416: 05$ 10DEC14

Page 16 of 18

file://I:/AEH-13-PSEUDO-06/Statistical\%20analysis/Exposure\%20Concentration/sasht... 12/10/2014 
Mean treatment concentration by treatment group (replicate tanks combined)

The MEANS Procedure

theros $=0$

Analysis Variable : predicted ppm Predicted

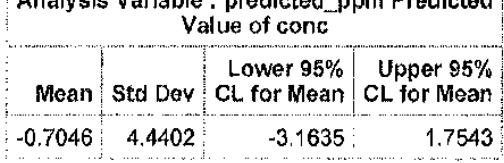

thero $=50$

Analysis Variable : predicted ${ }_{\text {ppm Predicted }}$

\begin{tabular}{|c|c|c|c|}
\hline \multicolumn{4}{|c|}{ Value of conc } \\
\hline Mean & Std Dev & Lower $95 \%$ & $\begin{array}{r}\text { Upper } 95 \% \\
\text { for foan }\end{array}$ \\
\hline 4.2657 & 15.8067 & 45.5122 & 63.0191 \\
\hline
\end{tabular}

thero $=100$

Analysis Varlable : predicted_ppm Predicted

\begin{tabular}{|c|c|c|c|}
\hline Moan & Std Dev & $\begin{array}{l}\text { Lower } 95 \% \\
\text { CL for Mean }\end{array}$ & $\begin{array}{r}\text { Upper } 95 \% \\
\text { CL for Mean }\end{array}$ \\
\hline 104.4 & 13.6820 & 96.8650 & 112.0 \\
\hline
\end{tabular}

Performed by K.Weber SAS version $9.49 .416: 05$ 10DEC14

Page 17 of 18

file:///1/AEH-13-PSEUDO-06/Statistical\%20analysis/Exposure\%20Concentration/sasht.., 12/10/2014 


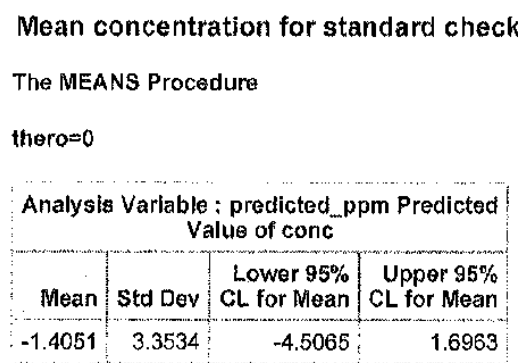

thero $=25$

\begin{tabular}{|c|c|c|c|}
\hline \multicolumn{4}{|c|}{$\begin{array}{c}\text { Analysis Variable : predicted_ppm Predicted } \\
\text { Value of conc }\end{array}$} \\
\hline Mean & Std Dev & $\begin{array}{l}\text { Lower } 95 \% \\
\text { CL for Mean }\end{array}$ & $\begin{array}{r}\text { Upper } 95 \% \\
\text { CL for Mean }\end{array}$ \\
\hline 28.7346 & 6.0170 & 22.4202 & 35.0491 \\
\hline
\end{tabular}

thero $=50$

\begin{tabular}{|c|c|c|c|}
\hline \multicolumn{4}{|c|}{$\begin{array}{l}\text { Analysis Variable : predicted_ppm Predicted } \\
\text { Value of conc }\end{array}$} \\
\hline Mean & Std Dev & $\begin{array}{l}\text { Lower } 95 \% \\
\text { CL for Mean }\end{array}$ & $\begin{array}{l}\text { Upper } 95 \% \\
\text { CL for Mean }\end{array}$ \\
\hline 50.9333 & 4.4405 & 46.2732 & 55.5933 \\
\hline
\end{tabular}

thero $=100$

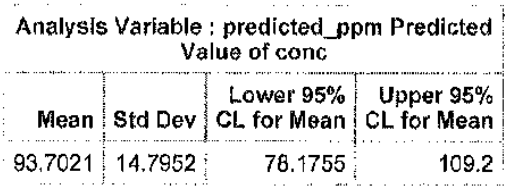

thero $=200$

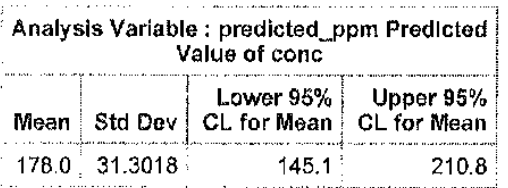

Performed by K.Weber SAS version 9.49 .4 16:05 100EC14 ${ }^{N}$

File Folder: 13 Item Number:

Page 18 of 18 
ods html close; $/ *$ close previous * $/$;

ods htm1; $/$ * open new */;

ods graphics on;

AEH-13-PSEUDO-06

DM 'LOG; ClEAR; OUTPUT; CleAR;'; * CLEAR LOG AND OUTPUT;

FOOTNOTE1 'Performed by K. Weber SAS version 9.4' \&SYSVER \&SYSTIME \&SYSDATE;

options ls=97 ps=54 formdlim= ' - pageno = 1 nocenter nodate nosource2;

title1 'Standard Curve Linear Regression';

title2 'Subadult Mussels-Spectrophotometer Data Analysis';

title3 h=1 'Study \# AEH-13-pseudo-06';

title4 $\mathrm{h}=1$ 'SAS V. 9.4 Analysis completion date: 10 December 2014 Analysis prepared by: KLW';

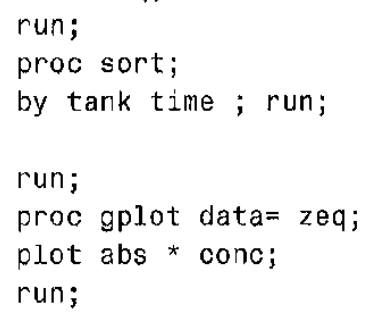

File Folder: 13 Item Number: 2

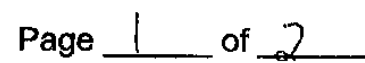


proc sort data $=$ zeq2;

by tank;

AEH-13-PSEUDO-06

run;

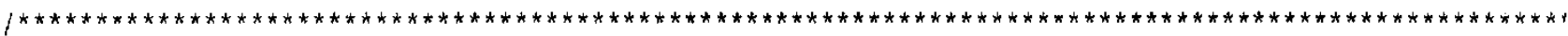

* This procedure produces the mean concentrations for each treatment replicate (tank)over all exposurs

* i.e. It gives the mean concentration of each treatment tank over the entire exposure period

*

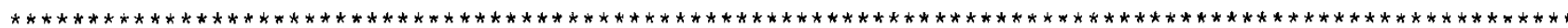

title1 "Mean treatment concentration by tank for the entire exposure period";

title2 "Individual tank means";

proc means data $=$ zeq2 mean std $1 \mathrm{clm}$ uclm $\mathrm{fw}=8$;

by tank;

var predicted_ppm;

run;

proc sort;

by thero time;

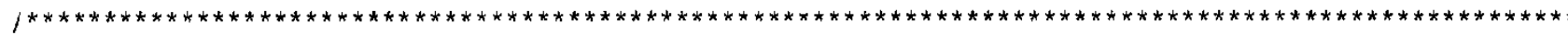

* This procedure produces the mean concentrations for each treatment group by sampling time

* 1.e. It gives the mean concentration of the three control, $50 \mathrm{ppm}$, and 100 ppm treatments

* at each sample time over the entire exposure

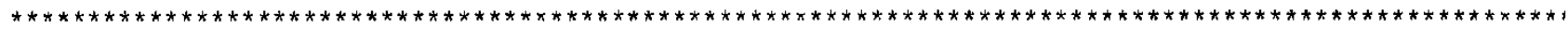

title1 "Mean treatment concentration by treatment group at each sampling time";

title2 "(replicate tanks combined for each sample time)";

proc means data $=$ zeq2 mean std $1.1 \mathrm{~m} u c 1 \mathrm{~m} f w=8$;

by thero time;

var predicted_ppm;

run;

title1 "Mean treatnent concentration by treatment group";

title2 "(replicate tanks combined)";

proc means data = zeq2 mean std $10 \mathrm{~lm} u c l m$ fw $=8$;

by thero;

var predicted_ppm;

run;

data zeq3; set output_out;

if conc > 1 then delete;

if tank $>0.5$ then delete;

run;

proc sort;

by thero;

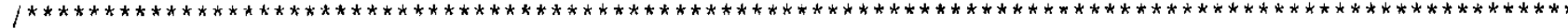

* This procedure produces the mean concentrations for the standard checks for all time periods

* 1.e. It gives the mean conc. of the 50ppm, 100ppm, and 200ppm standard checks at 1, 6, 12,18 and:

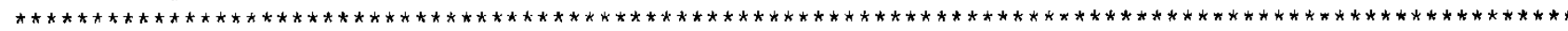

title "Mean concentration for standard checks for all exposure sampling times";

proc means data $=z e q 3$ mean std $1 \mathrm{clm} u c .1 \mathrm{~m} f w=8$;

by thero;

var predicted_ppm;

run;

quit; $\quad W^{2}$
run; $\quad 100 e^{2} 014$

File Folder: 13

Item Number: 2

Page _ 2 of 2 


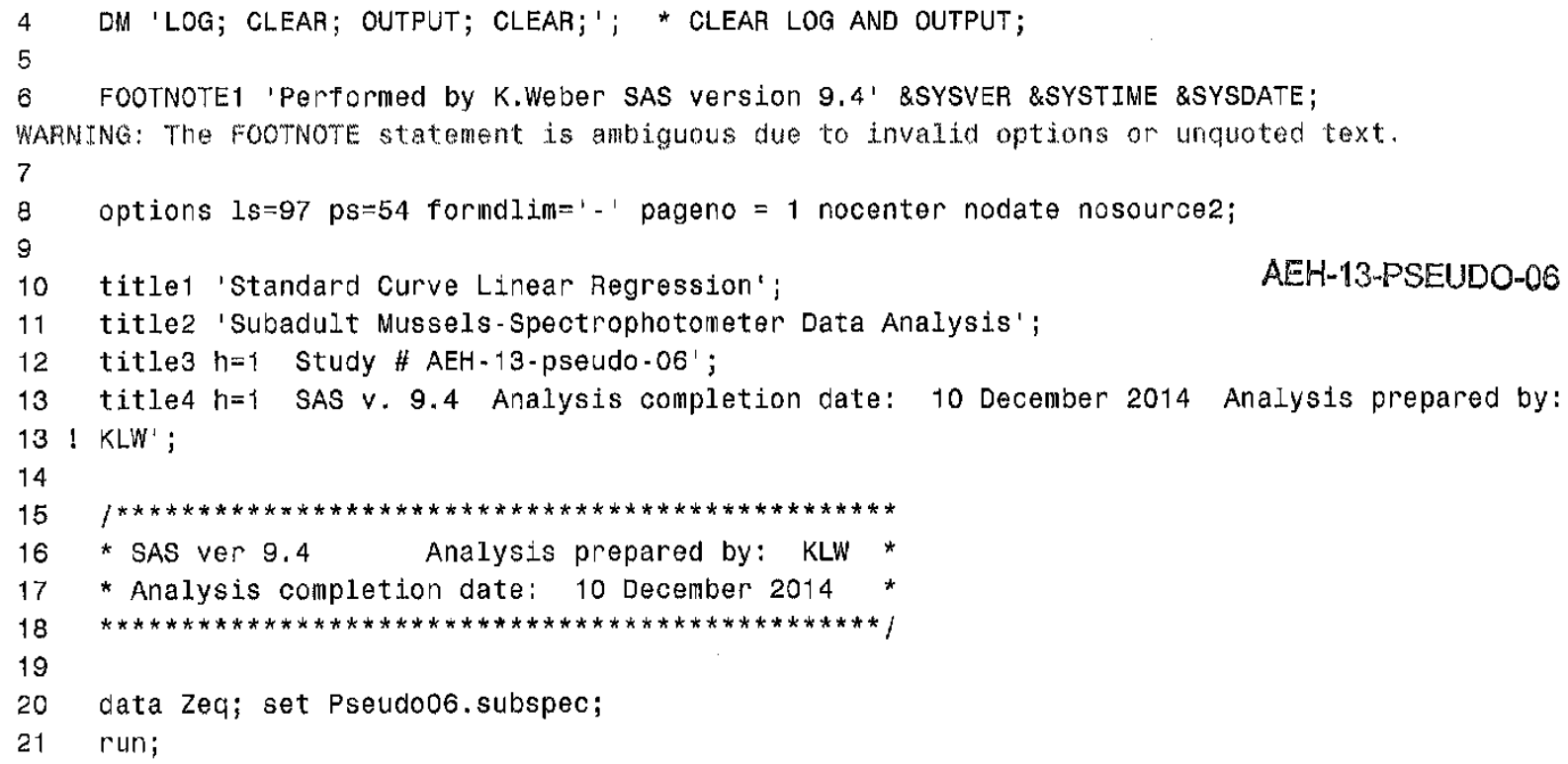




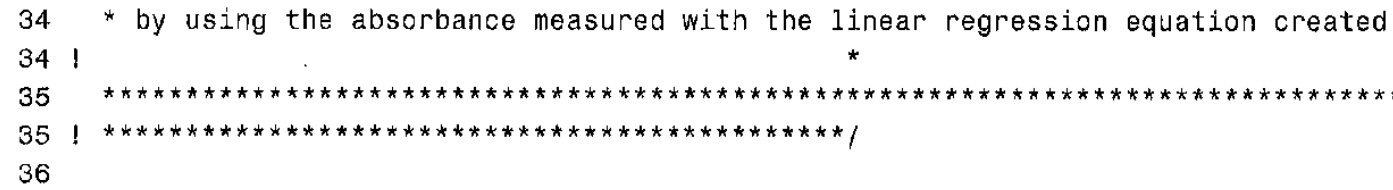

NOTE: There were 88 observations read from the data set WORK. $2 E Q$.

NOTE: PROCEDURE GPLOT used (Total process time):

AEH-13-PSEUDO-06
cpu time
0.21 seconds

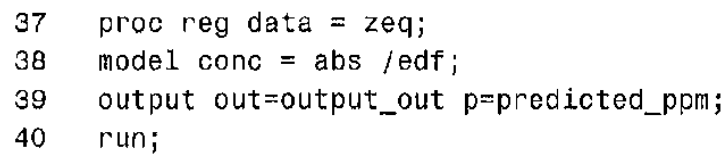


55 if $\operatorname{tank}=" . "$ then delete;
56 run;

NOTE: There were 88 observations read from the data set WORK.OUTPUT_OUT.

NOTE: The data set WORK.ZEQ2 has 45 observations and 7 variables.

NoTE: DATA statement used (Total process time):

$\begin{array}{ll}\text { real time } & 0.01 \text { seconds } \\ \text { cpu time } & 0.01 \text { seconds }\end{array}$

AEH-13-PSEUDO-06

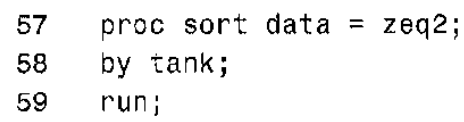

NOTE: There were 45 observations read from the data set WORK.ZEQ2.

NOTE: The data set WORK.ZEQ2 has 45 observations and 7 variables.

NOTE: PROCEDURE SORT used (Total process time):

real time $\quad 0.00$ seconds

cpu time $\quad 0.00$ seconds

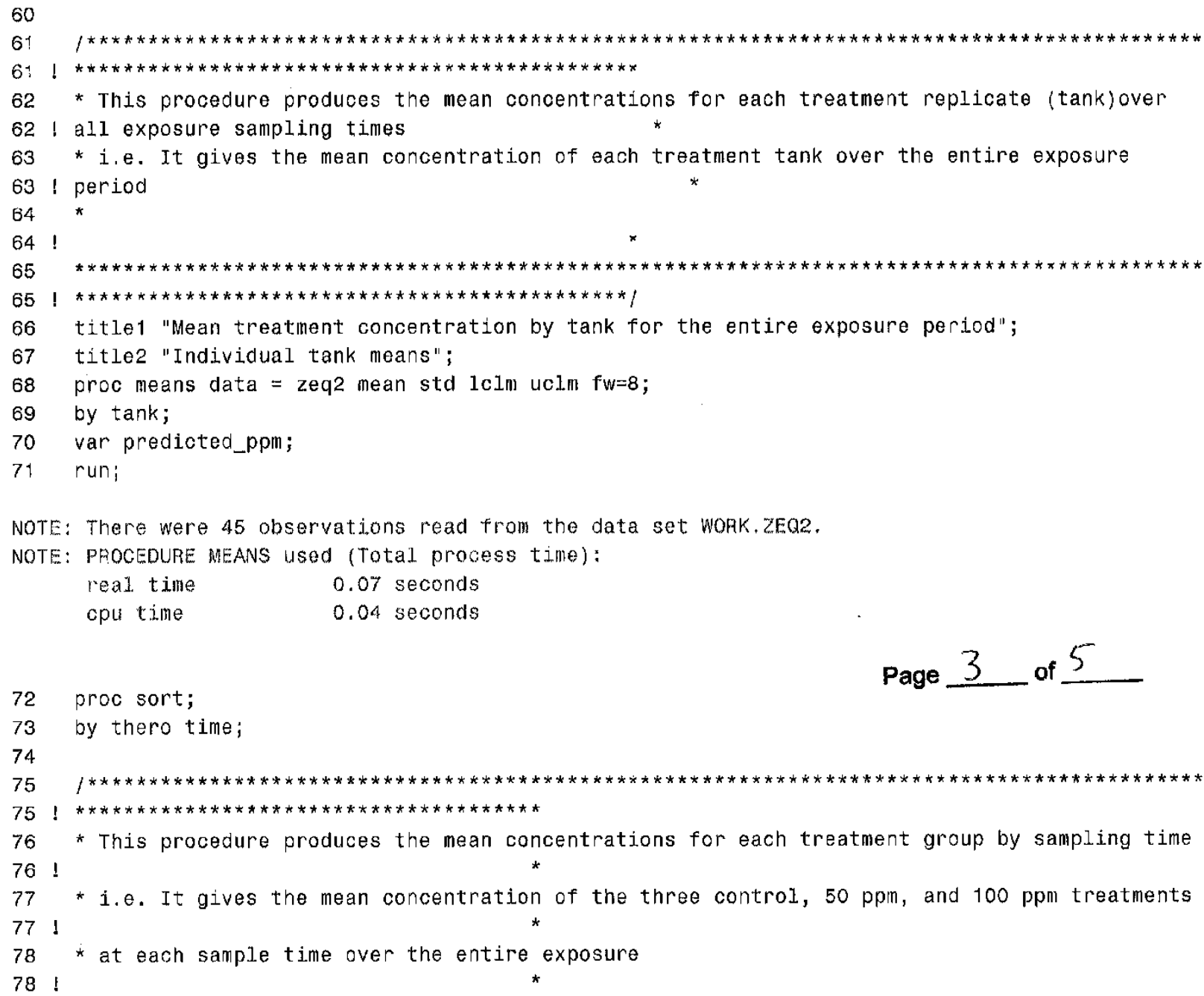




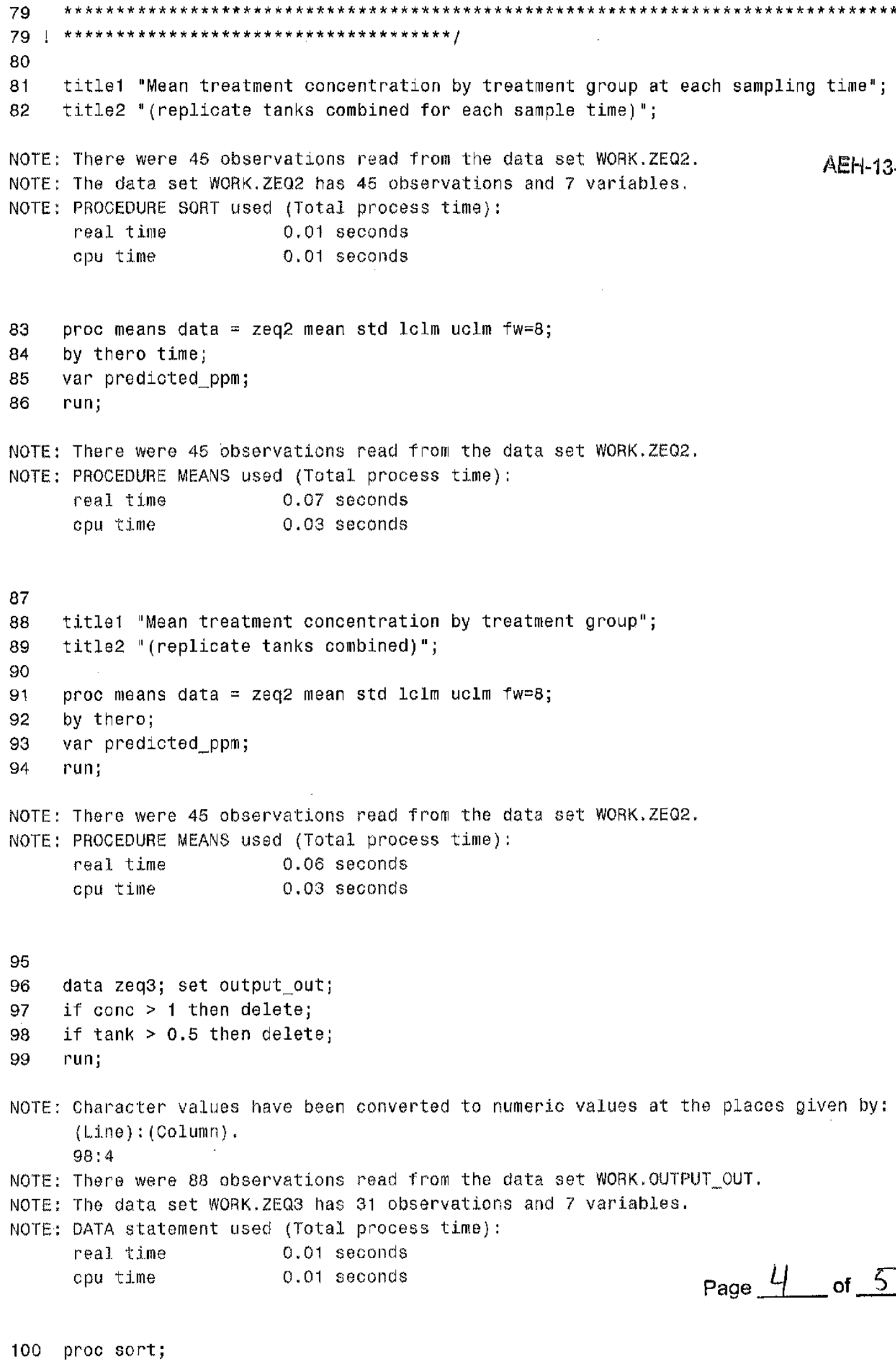




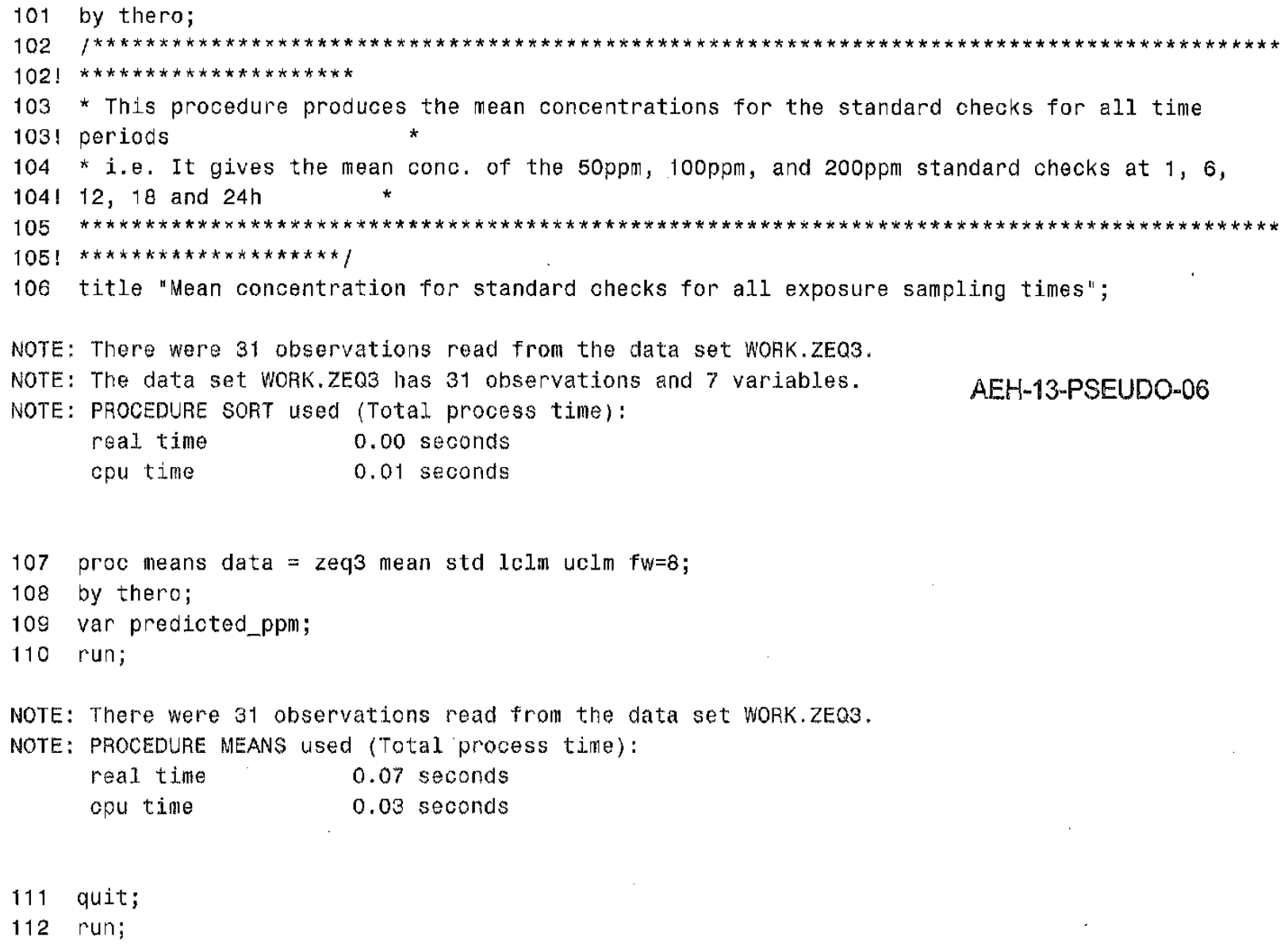

Flle Folder: 13

Item Number: 3

Page 5 of 5 


\section{Appendix 8. Statistical Analysis Including SAS Programs, Outputs and Logs for Survival and Treatment Concentration}

\begin{tabular}{clcc}
\hline $\begin{array}{c}\text { Item } \\
\text { Number }\end{array}$ & \multicolumn{1}{c}{ Item Description } & $\begin{array}{c}\text { Number } \\
\text { of } \\
\text { Pages }\end{array}$ & $\begin{array}{c}\text { Report } \\
\text { Page } \\
\text { Number }\end{array}$ \\
\hline 1 & SAS program for native mussel survival & 2 & 194 \\
2 & SAS log for native mussel survival & 3 & 196 \\
3 & SAS output for native mussel survival & 38 & 199 \\
\hline
\end{tabular}


DM 'LOG; CleAR; OUTPUT; CLEAR;'; * CleAR LOG AND OUTPUT;

FOOTNOTE1 'Performed by K. Weber SAS version' \&SYSVER \&SYSTIME \&SYSDATE;

options $1 \mathrm{~s}=97 \mathrm{ps}=54$ formdlim= ' - pageno = 1 nocenter nodate nosource2; $\quad$ AEH-13-PSEUDO-06

title1 $h=1.5$ 'Statistical analysis of unionid mussel suvival after';

title2 $h=1.5$ 'exposure to various concentrations and durations of Pf-CL145A';

title3 $n=1.5$ 'SAS V. 9.4 Analysis completion date: 10 December 2014 Analysis prepared by: KLW';

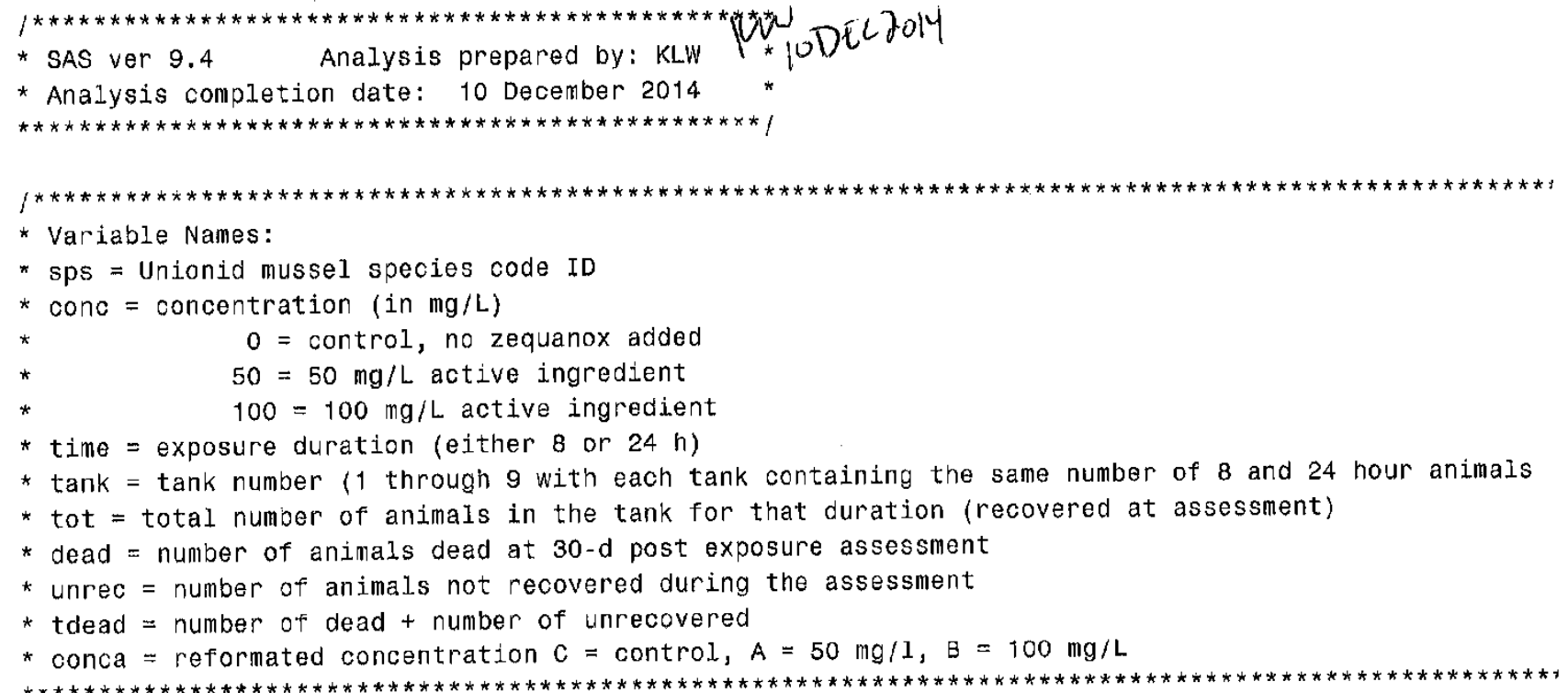


run;

$$
\text { Ko peczoly }
$$

AEE-H-13-PSEUDO-06

FF \# 15

Item No. $\frac{1}{2}$
$\mathrm{Pg}$ 


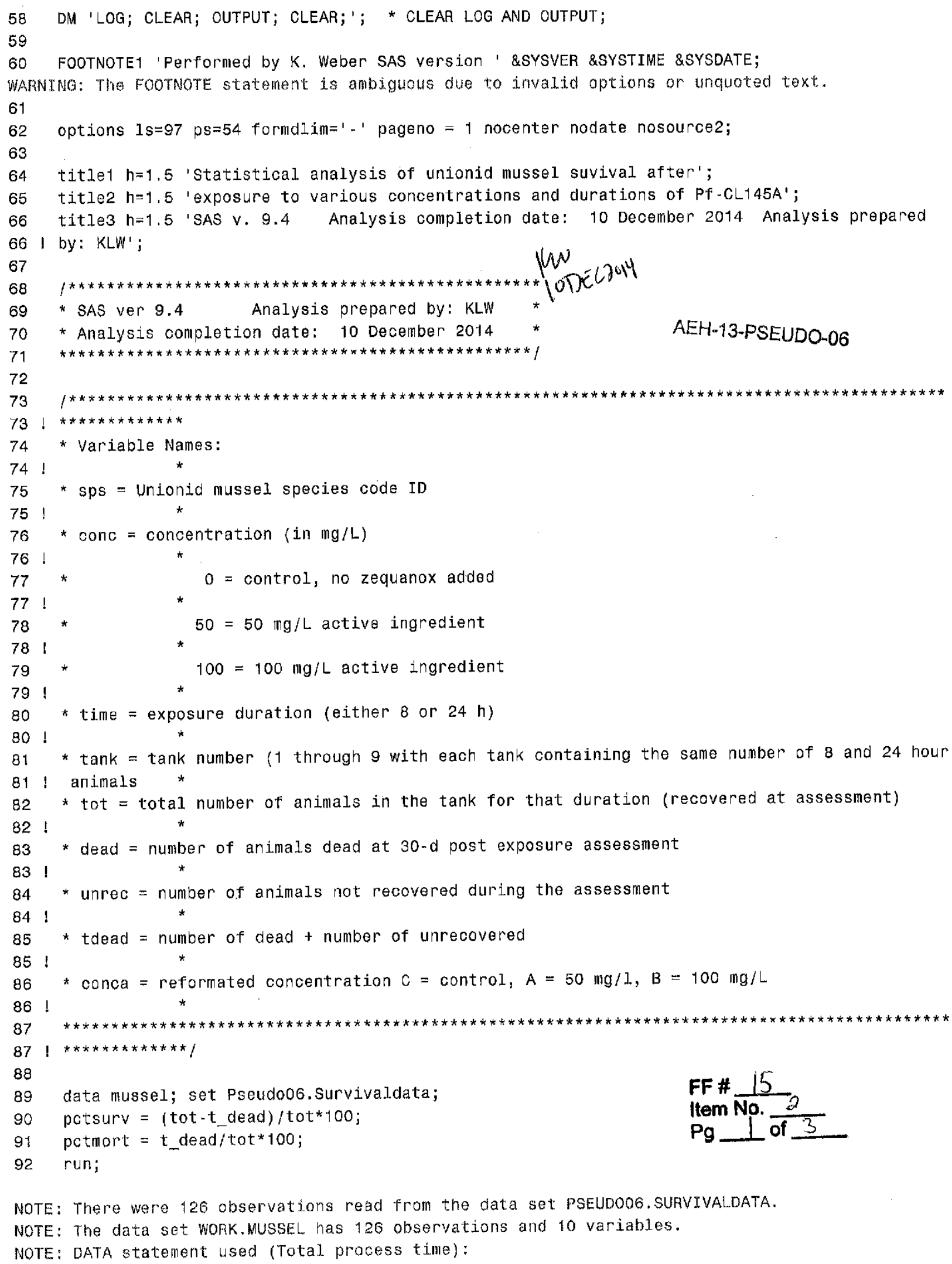


$\begin{array}{ll}\text { real time } & 0.01 \text { seconds } \\ \text { cpu time } & 0.01 \text { seconds }\end{array}$

93

94 proc sort data=mussel; by sps time conc; run;

NOTE: There were 126 observations read from the data set WORK. MUSSEL.

NOTE: The data set WORK.MUSSEL has 126 observations and 10 variables.

NOTE: PROCEDURE SORT used (Total process time):

real time $\quad 0.00$ seconds

cpu time $\quad 0.00$ seconds

AEH-13-PSEUDO-06

95 proc print data=mussel; title4 h=1 'all data'; run;

NOTE: Writing HTML Body file: sashtml1.htm

NOTE: There were 126 observations read from the data set WORK.MUSSEL.

NOTE: PROCEDURE PRINT used (Total process time):

real time 2.03 seconds

cpu time $\quad 0.56$ seconds

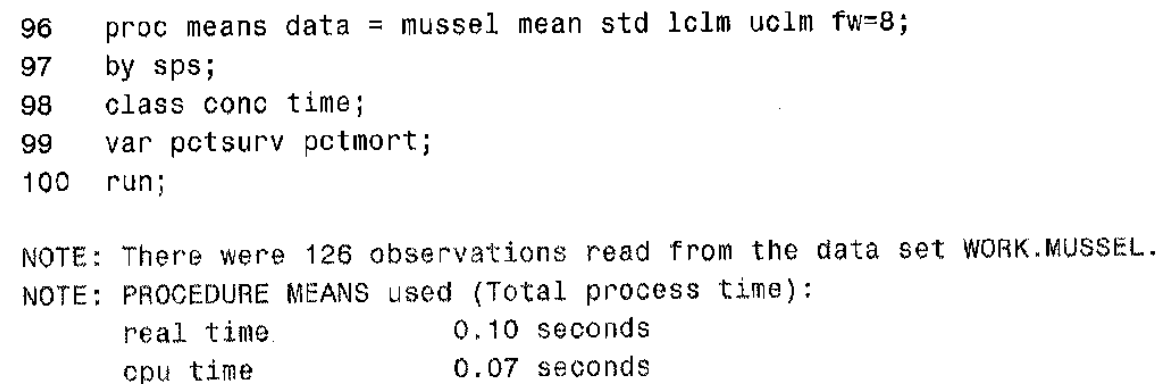

101 Title 'Pro Glimmix Analysis of survival and interactions of species, exposure duration and

101 ! exposure concentration';

102 proc glimmix data $=$ mussel;

103 title4 'Native Unionid Survival';

104 class sps time conc;

105 model. $t$ dead $/$ tot $=$ sps $\mid$ time $\mid$ conc $/ d=$ bin link = logit noint s or;

106 lsmeans sps /pdiff cl ilink or;

107 lsmeans time / pdiff cl ilink or;

108 lsmeans conc/pdiff cl ilink or;

109 lsmeans sps*time /pdiff cl ilink or;

110 lsmeans sps*conc /pdiff cl ilink or;

111 lsmeans time*cono /pdiff cl ilink or;

112 lsmeans sps*time* conc /pdiff cl ilink or ;

113 random _residual_;

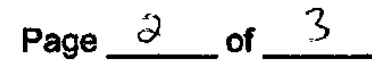

114 run;

NOTE: The model does not contain an intercept. Columns of $x$ are scaled only and not centered. NOTE: Convergence criterion (ABSGCONV=0.00001) satisfied.

NOTE: PROCEDURE GLIMMIX used (Total process time): 
real time

cpu tine
1.13 seconds

0.96 seconds

$$
\text { jopecrout }
$$

\section{AEH-13-PSEUDO-06}

FF \# 15

Item No. 2

$\mathrm{Pg}_{3}$ of 3 


\begin{tabular}{|c|c|c|c|c|c|c|c|c|c|c|}
\hline Obs & $6 \mathrm{ps}$ & conc & time & $\operatorname{tank}$ & tot & clead & unrec & T_dead & petsurv & petmort \\
\hline 1 & FAM & 0 & 8 & 5 & 10 & 0 & 0 & 0 & 100.000 & 0.0000 \\
\hline 2 & FAM & 0 & 8 & 7 & 10 & 0 & 0 & 0 & 100.000 & 0.0000 \\
\hline 3 & FAM & 0 & 8 & 8 & 10 & 0 & 0 & 0 & 100.000 & 0.0000 \\
\hline 4 & FAM & 50 & 8 & 3 & 10 & 0 & 0. & 0 & 100.000 & 0.0000 \\
\hline 5 & FAM & 53 & 8 & 4 & 10 & 0 & 0 & 0 & 100.000 & 0.0000 \\
\hline 6 & FAM : & 50 & 8 & B: & 10 & 0 & 0 & 0 & 100.000 & 0.0000 \\
\hline 7 & FAM & 100 & 8 & 1 & 10 & 0 & 0 & 0 & 100.000 & 0.0000 \\
\hline 8 & FAM & 100 & 8 & 2 & 10 & 0 & 0 & 0 & 100.000 & 0.0000 \\
\hline 9 & FAM & 100 & 8 & 9 & 10 & 0 & 0 & 0 & 100.000 & 0.0000 \\
\hline 10 & FAM & 0 & 24 & 5 & 10 & 0 & 0 & 0 & 100.000 & $0.000 \mathrm{C}$ \\
\hline 11 & FAM & 0 & 24 & 7 & 10 & 0 & 0 & 0 & 100.000 & 0.0000 \\
\hline 12 & FAM & 0 & 24 & 3 & 10 & 0 & 0 & 0 & 100,000 & 0.0000 \\
\hline 13 & FAM & 50 & 24 & 3 & 10 & 0 & 0 & 0 & 100.000 & 0.0000 \\
\hline 14 & FAM & 50 & 24 & 4 & 10 & 0 & 0 & 01 & 100.000 & 0.0000 \\
\hline 15 & FAM & 50 & 24 & 6 & 10 & 0 & 0 & 0 & 100.000 & 0.0000 \\
\hline 16 & FAM & 100 & 24 & 1 & 10 & 0 & 0 & 0 & 100.000 & 0.0000 \\
\hline 17 & FAM & 100 & 24 & 2 & 10 & 0 & 0 & 0 & 100.500 & 0.0000 \\
\hline 18 & FAM & $10 \mathrm{C}$ & 24 & 9 & 10 & 0 & 0 & 0 & 100,000 & 0.0000 \\
\hline 19 & HGE & 0 & 8 & 5 & 8 & 0 & 0 & 0 & 100.000 & 0,0000 \\
\hline 20 & HGE & 0 & 8 & 7 & 8 & 0 & 0 & 0 & 100,000 & 0.0000 \\
\hline 21 & HGE & 0 & 8 & 8 & 8 & $1 ?$ & 0 & $1\}$ & 87.500 & 12.5000 \\
\hline 22 & HGE & 50 & 8 & 3 & 8 & 0 & 0 & 0 & 100.000 & 0.0000 \\
\hline 23 & HGE & 50 & 8 & 4 & 8 & 0 & D & 0 ? & 100.000 & 0.0000 \\
\hline 24 & HGE & 50 & B & e & 8 & 0 & 0 & 0 & 100.000 & 0.0000 \\
\hline 25 & HGE & 100 & 8 & 1. & 8 & 0 & 0 & 0 & 100.000 & 0.0000 \\
\hline 26 & HGE & 100 & 8 & 2 & 8 & 0 & 0 & 01 & 100.000 & 0.0000 \\
\hline 27 & HGE & 100 & 8 & 9 & 8 & 0 & 0 & 01 & 100.000 & 0.0000 \\
\hline 28 & HGE & 0 & 24 & 5 & 8 & 0 & 11 & 1 & 87.500 & 12.5000 \\
\hline 29 & HGE & 0 & 24 & 7 & 8 & 0 & 0 & 01 & 100.000 & 0.0000 \\
\hline 30 & HGE & 0 & 24 & a & 8 & 0 & 0 & 0 & 100.000 & 0.0000 \\
\hline 31 & HCE & 50 & 24 & 3 & 8 & 0 & 0 & 0 & 100.000 & 0.0000 \\
\hline 32 & HGE & 50 & 24 & 4 & 8 & 0 & 0 & 0 & 100000 & 0.0000 \\
\hline 33 & HGE & 50 & 24 & 6 & 8 & 0 & 1 & 1 & 87,500 & 12.5000 \\
\hline 34 & HGE & 100 & 24 & 1 & 8 & 0 & 0 & 0 & 100,000 & 0.0000 \\
\hline 35 & HGE & 100 & 24 & 2 & $\theta$ & 0 & 0 & 0 & 100.000 & 0.0000 \\
\hline 36 & HOE & 100 & 24 & 9 & 8 & 1 & 0 & 1 & 87.500 & 12.5000 \\
\hline 37 & $\mathrm{HIC}$ & 0 & 8 & 5 & 10 & 0 & 0 & 0 & 100.000 & 0.0000 \\
\hline 38 & HIC & 0 & 8 & 7 & 10 & 0 & 0 & 0 & 100.000 & 0.0000 \\
\hline 39 & $\mathrm{HIC}$ & 0 & 8 & 8 & 10 & a & 0 & 0 & 100.000 & 0.0000 \\
\hline 40 & $\mathrm{HIC}$ & 50 & 8 & 3 & 10 & 0 & c & 0 & 100,000 & 0.0000 \\
\hline 41 & $\mathrm{HIC}$ & 50 & 8 & 4 & 10 & 01 & 0 & 0 & 100.000 & 0.0000 \\
\hline 42 & $\mathrm{HIC}$ & 50 & 8 & $B$ & 10 & 0 & 0 & 0 & 100.000 & 0,0000 \\
\hline 43 & $\mathrm{HIC}$ & 100 & 8 & 1 & 10 & 0 & 0 & 0 & 100,000 & 0.0000 \\
\hline 44 & $\mathrm{HIC}$ & 100 & 8 & 2 & 10 & 0 & 0 & 0 & 100.000 & 0.0000 \\
\hline 46 & $\mathrm{HIC}$ & 100 & 8 & 9 & 10 & 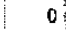 & 0 & 0 & 100,000 & 0.0000 \\
\hline
\end{tabular}

\section{AEH-13-PSEUDO-06}

FF \# 15

Item No. 3

file://C:/Users/klweber/AppData/Local/Temp/1/SAS\%20Temporary\%20Files/_TD3400_.. 12/10/2014 


\begin{tabular}{|c|c|c|c|c|c|c|c|c|c|c|}
\hline 46 & HIC & 0 & 24 & 5 & 10 & 01 & 0 & 0 & 100,000 & 0.0000 \\
\hline 47 & HIC & 0 & 24 & 7 & 10 & $0 !$ & 0 & 0 & 100.000 & 0,0000 \\
\hline 48 & $\mathrm{HIC}$ & 0 & 24 & 8 & 10 & 0 & 0 & 01 & 100.000 & 0.0000 \\
\hline 49 & HIC & 50 & 24 & 3 & 10 & 0 & 0 & 0 & 100.000 & $0.000 \mathrm{C}$ \\
\hline 60 & $\mathrm{HIC}$ & 50 & 24 & 4 & 10 & 0 & 0 & 0 & 100.000 & 0.0000 \\
\hline 51 & $\mathrm{HIC}$ & 50 & 24 & 6 & 10 & 0 & 0 & 0 & 100.000 & 0.0000 \\
\hline 62 & HIC & 100 & 24 & 1 & 10 & $0:$ & 0 & 0 & 100.000 & 0.0000 \\
\hline 53 & $\mathrm{H} \mid \mathrm{C}$ & 100 & 24 & 2 & 10 & 0 & 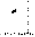 & 1 & 90.000 & 10.0000 \\
\hline 64 & $\mathrm{HIC}$ & 100 & 24 & $\theta$ & 10 & 01 & 0 & 0 & 100.000 & 0.0000 \\
\hline 55 & PIG & 0 & 8 & 5 & 8 & 0 & 0 & 0 & 100.000 & 0.0000 \\
\hline 56 & PIG & c & 8 & 7 & 8 & 0 & 0 & 0 & 100.000 & 0.0000 \\
\hline 57 & PIG & c & 8 & 8 & 8 & 0 & 0 & 0 & 100.000 & 0.0000 \\
\hline 58 & $P \mid G$ & 50 & B & 3 & 8 & 01 & 0 & 0 & 100,000 & 0.0000 \\
\hline 59 & $P I G$ & 50 & 8 & 4 & 8 & 0 & 0 & 0 & 100.000 & 0.0000 \\
\hline 60 & PIG & 50 & 8 & 6 & 8 & 0 & 0 & 0 & 100.000 & 0,0000 \\
\hline 61 & PIG & 100 & 8 & 1 & 8 & 0 & 0 & 0 & 100.000 & 0,0000 \\
\hline 62 & PIG & 100 & 8 & 2 & 8 & 0 & 0 & 0 & 100.000 & 0.0000 \\
\hline 63 & PIG & 100 & 8 & 9 & 8 & 0 & 0 & 0 & 100.000 & 0.0000 \\
\hline 64 & PIG & 0 & 24 & 5 & 8 & 0 & 0 & 0 & 100.000 & 0.0000 \\
\hline 65 & PIG & a & 24 & 7 & 8 & 0 & 0 & 0 & 100.000 & 0.0000 \\
\hline 66 & PIG & 0 & 24 & $a$ & 8 & 0 & 0 & 01 & 100.000 & 0.0000 \\
\hline 67 & PIG & 50 & 24 & 3 & $\varepsilon$ & 0 & 0 & 0 & 100.000 & 0.0000 \\
\hline 68 & PIG & 50 & 24 & 4 & 8 & 0 & 0 & 0 & 100.000 & 0.0000 \\
\hline 69 & PIG & 50 & 24 & 6 & 8 & 0 & 0 & 0 & 100,000 & 0.0000 \\
\hline 70 & PIG & 100 & 21 & 1 & 8 & 0 & 0 & 0 & 100.000 & 0.0000 \\
\hline 71 & PIG & 40 & 24 & 2 & 8 & 0 & 0 & 0 & 100.000 & 0.0000 \\
\hline 72 & PIG & 100 & 24 & 9 & 8 & 0 & 0 & 0 & 100.000 & 0.0000 \\
\hline 73 & PPB & 0 & 8 & 5 & 9 & 0 & 0 & 0 & 100.000 & 0.0000 \\
\hline 74 & PPB & 0 & 8 & 7 & $\theta$ & 0 & 0 & 0 & 100.000 & 0.0000 \\
\hline 75 & PPB & 0 & $8:$ & 8 & 9 & 0 & 0 & 0 & 100.000 & 0.0000 \\
\hline 76 & $\mathrm{PPB}$ & 50 & 8 & 3 & 9 & 0 & 0 & 0 & 100.000 & 0.0000 \\
\hline 77 & PPB & 50 & 8 & 4 & 9 & 0 & 0 & 0 & 100.000 & 0.0000 \\
\hline 78 & $\mathrm{PPB}$ & 50 & 8 & 6 & 9 & 0 & 0 & 0 & 100.000 & 0.0000 \\
\hline 79 & PPB & 100 & 8 & 1 & 9 & 0 & 0 & 0 & 100.000 & 0.0000 \\
\hline 80 & PPB & 100 & 8 & 2 & 9 & 0 & 0 & 0 & 100.000 & 0.0000 \\
\hline 81 & $\mathrm{PPB}$ & 100 & $8:$ & 9 & 9 & 0 & $0:$ & 0 & 100.000 & 0.0300 \\
\hline 82 & PPB & 0 & 24 & 5 & 9 & 0 & 0 & 0 & 100.000 & 0.0000 \\
\hline 83 & PPB & 0 & 24 & 7 & 9 & 0 & c & 0 & 150000 & 0.0000 \\
\hline 84 & PPB & 0 & 24 & 8 & $\theta$ & 0 & 0 & 0 & 100.000 & 0.0000 \\
\hline 85 & PPB & 50 & 24 & 3 & $\theta$ & 0 & 1 & 1 & 88.889 & 11.1111 \\
\hline 86 & PPB & 50 & 24 & 4 & 9 & 0 & 0 & 0 & 100.000 & 0,0000 \\
\hline 87 & PPB & 50 & 24 & 6 & 9 & 0 & 0 & 0 & 100.000 & 0.0000 \\
\hline 88 & PPB & 100 & 24 & 1 & 9 & 0 & 0 & 0 & 100.000 & 0,0000 \\
\hline 80 & PPB & 100 & 24 & 2 & 9 & 0 & 1 & 1 & 88.889 & 11.1111 \\
\hline 90 & PPB & 100 & 24 & 9 & 9 & 0 & 0 & 0 & 100.000 & 0.0000 \\
\hline 91 & THR & 0 & 8 & 5 & $10)$ & 0 & 0 & 0 & 100.000 & 0.0000 \\
\hline 92 & THR & 0 & 8 & 7 & 10 & 0 & 0 & 01 & 100.000 & 0.0000 \\
\hline 93 & THR & c & 8 & 8 & 10 & 0 & 0 & 0 & 100.000 & 0.0000 \\
\hline 94 & THR & 50 & 8 & 3 & 10 & 0 & 0 & 0 & 100,000 & 0,0000 \\
\hline
\end{tabular}

\section{AEH-13-PSEUDO-06}

file://C:/Users/klweber/AppData/Local/Temp/1/SAS\%20Tcmporary\%20Files/_TD3400_... 12/10/2014 


\begin{tabular}{|c|c|c|c|c|c|c|c|c|c|c|}
\hline & THR & 50 & 8 & 4 & 10 & 0 & 0 & 0 & 100,000 & 0.0000 \\
\hline 96 & THR & 50 & a & 6 & 10 & 0 & 0 & 0 & 100.000 & 0.0000 \\
\hline 97 & THR & 100 & 8 & 1 & 10 & 0 & 0 & 0 & 100.000 & 0.0000 \\
\hline 98 & THR & 100 & 8 & 2 & 10 & 0 & 0 & 0 & 100.600 & 0.0000 \\
\hline 99 & THR & 100 & $8 !$ & 9 & 10 & 0 & $0:$ & 0 ; & 100.000 & 0.0000 \\
\hline 100 & THR & 0 & 24 & 5 & 10 & 0 & 3 & 0 & 100.000 & 0.0000 \\
\hline 101 & THR & a & 24 & 7 & 10 & 0 & 0 & 0 & 100.000 & 0.0000 \\
\hline 102 & THR & 0 & 24 & 8 & 10 & 0 & 0 & 0 & 100,000 & 0.0000 \\
\hline 103 & THR & 50 & 24 & 3 & 10 & 0 & 0 & 0 & 100.000 & 0.0000 \\
\hline 104 & THR & 50 & 24 & 4 & 10 & 0 & 0 & 01 & 100.000 & 0.0000 \\
\hline 105 & THR & 50 & 24 & $B$ & 10 & 0 & 0 & 0 & 100.000 & 0.0000 \\
\hline 106 & THR & 100 & 24 & 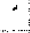 & 10 & $0 !$ & 0 & 0 & 100.000 & 0.0000 \\
\hline 107 & THR & 100 & 24 & 2 & 10 & 0 & 0 & 0 & $100.000 !$ & 0.0000 \\
\hline 108 & THR & 100 & 24 & 9 & 10 & 0 & 0 & 0 & 100.000 & 0.0000 \\
\hline 109 & WAS & 0 & 8 & 5 & 10 & 0 & 0 & 01 & 100.000 & 0.0000 \\
\hline 110 & WAS & 0 & 8 & 7 & 10 & 0 & 0 & 0 & 100,000 & 0.0030 \\
\hline 111 & WAS & 0 & 8 & 8 & 10 & 0 & 0 & $0:$ & 100.000 & 0.0000 \\
\hline 112 & WAS: & 50 & 8 & 3 & 10 & 0 & 0 & 0 & 100.000 & 0.0000 \\
\hline 113 & WAS & 50 & 8 & 4 & 10 & $1 !$ & $c$ & 1 & 90.000 & 10.0000 \\
\hline 114 & WAS & 50 & 8 & 6 & 10 & 0 & $c$ & 0 & 100.000 & 0.0000 \\
\hline 115 & WAS & 100 & 8 & 1 & 10 & 0 & 0 & 0 & 100.000 & 0.0000 \\
\hline 116 & WAS & 130 & 8 & 2 & 10 & 0 & 0 & 0 & 100.000 & 0.0000 \\
\hline 117 & WAS & 100 & 8 & 9 & 10 & 0 & 0 & 0 & 100.000 & 0,0000 \\
\hline 118 & WAS & 0 & 24 & 5 & 10 & 0 & 0 & 0 & 100.000 & 0.0000 \\
\hline 119 & WAS & 0 & 21 & 7 & 10 & 0 & 0 & 0 & 100.000 & 0.0000 \\
\hline 120 & WAS & 0 & 24 & 8 & 10 & 01 & 0 & 0 & 100.000 & 0.0000 \\
\hline 121 & WAS & 50 & 24 & 3 & 10 & 0 & 0 & 0 & 100.000 & $0.0<00$ \\
\hline 122 & WAS & 50 & 24 & 4 & 10 & 0 & 0 & 0 & 100.000 & 0.0000 \\
\hline 123 & WAS & 50 & 24 & 6 & 10 & 0 & 0 & 0 & $100.000)$ & 0.0000 \\
\hline 124 & WAS & $10 \mathrm{c}$ & 24 & 1 & 10 & 0 & 0 & 0 & 100.000 & 0,0000 \\
\hline 125 & WAS & 100 & 24 & 2 & 10 & 0 & 0 & 0 & 100.000 & 0,0000 \\
\hline 126 & WAS & 100 & 24 & $\theta$ & 10 & 0 & 0 & 0 & 100.000 & 0.0000 \\
\hline
\end{tabular}

Pefformed by K. Weber SAS version 9.416:18 10DEC14 W 


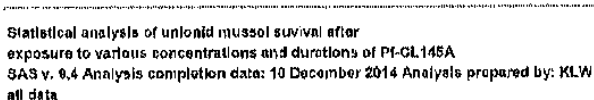

The MEANS Procedure

8psmFAM

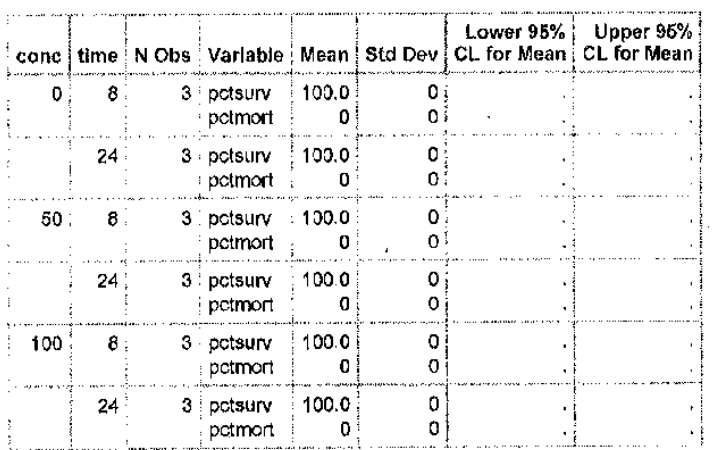

spsWHGE

\begin{tabular}{|c|c|c|c|c|c|c|c|}
\hline onc & time & N Obs & Variable & Mean & Std Dev & $\begin{array}{l}\text { Lower } 96 \% \\
\text { CL for Mean }\end{array}$ & $\begin{array}{l}\text { Upper } 95 \% \\
\text { CL for Mean }\end{array}$ \\
\hline 0 & 8 & 3 & $\begin{array}{l}\text { pctsurv } \\
\text { pctmort }\end{array}$ & $\begin{array}{r}95.8333 \\
4.1667\end{array}$ & $\begin{array}{l}7.2169 \\
7.2169\end{array}$ & $\begin{array}{r}77.9056 \\
-13.7611\end{array}$ & $\begin{array}{r}113.8 \\
22.0944\end{array}$ \\
\hline & 24 & 3 & $\begin{array}{l}\text { pctsurv } \\
\text { pctmort }\end{array}$ & $\begin{array}{r}95,8333 \\
4.1667 \\
\end{array}$ & $\begin{array}{l}7.2168 \\
7.2168\end{array}$ & $\begin{array}{r}77.9056 \\
-13.7611\end{array}$ & $\begin{array}{r}113.8 \\
22.0944 \\
\end{array}$ \\
\hline 50 & 8 & 3 & $\begin{array}{l}\text { petsurv } \\
\text { pctmort }\end{array}$ & $\begin{array}{r}100.0 \\
0\end{array}$ & $\begin{array}{l}0 \\
0 \\
0\end{array}$ & & \\
\hline & 24 & 3 & $\begin{array}{l}\text { petsurv } \\
\text { pctmort }\end{array}$ & $\begin{array}{r}95.8333 \\
4.1667\end{array}$ & $\begin{array}{l}7.2169 \\
7.2169\end{array}$ & $\begin{array}{r}77.9056 \\
-13.7611\end{array}$ & $\begin{array}{r}113.8 \\
22.0944 \\
\end{array}$ \\
\hline 100 & 8 & 3 & $\begin{array}{l}\text { petsury } \\
\text { petmort }\end{array}$ & $\begin{array}{r}100.0 \\
0\end{array}$ & $\begin{array}{l}0 \\
0\end{array}$ & & \\
\hline & 24 & 3 & $\begin{array}{l}\text { pctsurv } \\
\text { pctmort }\end{array}$ & $\begin{array}{r}95.8333 \\
4.1667\end{array}$ & $\begin{array}{l}7.2169 \\
7,2169\end{array}$ & $\begin{array}{r}77.9056 \\
-13.7611\end{array}$ & $\begin{array}{r}113.8 \\
22.0944 \\
\end{array}$ \\
\hline
\end{tabular}

spg=HIC

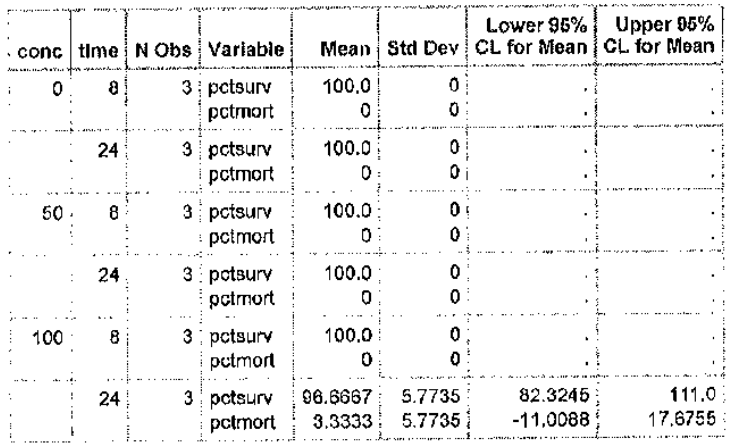

$\mathrm{sps}=\mathrm{PIG}$

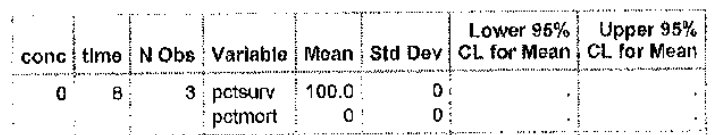

file://C:/Users/klweber/AppData/Local/Temp/1/SAS\%20Temporary\%20Files/_TD3400_... 12/10/2014 


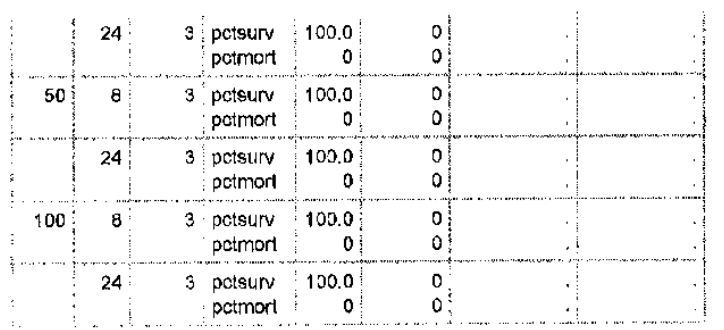

sps=PPB

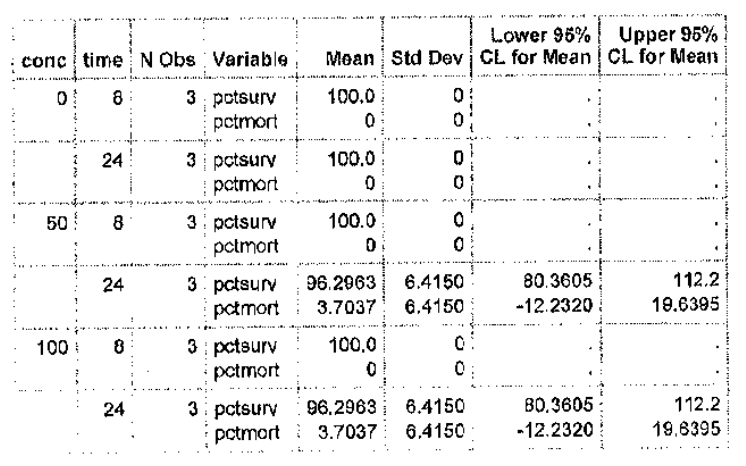

sps=THR

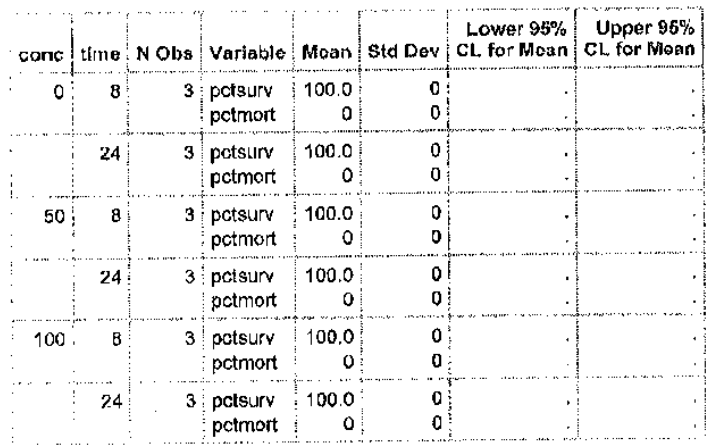

sps=WAS

\begin{tabular}{|c|c|c|c|c|c|c|c|}
\hline one & $\operatorname{tim} \theta$ & NObs & Varlable & Mean & Std Dey & $\begin{array}{l}\text { Lower } 95 \% \\
\text { CL for Mean }\end{array}$ & $\begin{array}{l}\text { Upper } 95 \% \\
\text { CL for Wean }\end{array}$ \\
\hline 0 & 8 & 3 & $\begin{array}{l}\text { potsurv } \\
\text { pctmort }\end{array}$ & $\begin{array}{r}100.0 \\
0\end{array}$ & $\begin{array}{l}0 \\
0\end{array}$ & . & \\
\hline & 24 & 3 & $\begin{array}{l}\text { petsurv } \\
\text { petmort }\end{array}$ & $\begin{array}{r}100.0 \\
0\end{array}$ & $\begin{array}{l}0 \\
0\end{array}$ & . & \\
\hline 50 & 8 & 3 & $\begin{array}{l}\text { pctsurv } \\
\text { pctmort }\end{array}$ & $\begin{array}{r}96.6667 \\
3.3333\end{array}$ & $\begin{array}{l}5.7735 \\
5.7735\end{array}$ & $\begin{array}{r}82.3245 \\
-11.0088\end{array}$ & $\begin{array}{r}111.0 \\
17.6755\end{array}$ \\
\hline & 24 & 3 & $\begin{array}{l}\text { pctsurv } \\
\text { pctmort }\end{array}$ & $\begin{array}{r}100.0 \\
0\end{array}$ & $\begin{array}{l}0 \\
0\end{array}$ & & \\
\hline 100 & 8 & 3 & $\begin{array}{l}\text { petsury } \\
\text { pctmort }\end{array}$ & $\begin{array}{r}100.0 \\
0\end{array}$ & 0 & . & i \\
\hline & 24 & 3 & $\begin{array}{l}\text { potsurv } \\
\text { pctmort }\end{array}$ & $\begin{array}{r}100.0 \\
0\end{array}$ & 0 & & . \\
\hline
\end{tabular}

file://C:/Users/klweber/AppData/Local/Temp/1/SAS\%20Temporary\%20Files/_TD3400_... 12/10/2014 
Ferformed by K. Waber SAS version 9.4 16:18 100EC14 WW

AEH-13-PSEUDO-06

file://C:/Lsers/klwcber/AppData/Local/Temp/1/SAS\%20Temporary\%20Files/_TD3400_... 12/10/2014 
Pro Glimmix Analysis of survival and interactions of species, exposure duratlon and exposure concentration

Native Unionid Survival

The GLIMAMIX Procedure

\begin{tabular}{|l|l|}
\hline \multicolumn{1}{|c|}{ Model Information } \\
\hline Data Set & WORK.MUSSEL \\
\hline Response Variable (Events) & T_dead \\
\hline Response Varlable (Trlals) & tot \\
\hline Response Distribution & Binomial \\
\hline Link Function & Logit \\
\hline Varience Functlon & Default \\
\hline Variance Matrlx & Dlaconal \\
\hline Estimation Technique & Maximum Llkellhood \\
\hline Degrees of Freedom Method & Resldual \\
\hline
\end{tabular}

AEH-13-PSEUDO-06

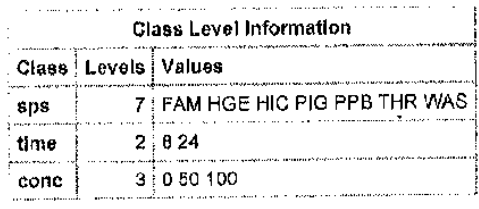

Number of Observations Read ? 126

Number of Observations Used 128

Numbor of Events

Number of Trials

Dimensions

Covarlance Parameters $\quad 1$ i

Columns in $X \quad 95$

Columns in $\mathbf{Z} \quad 0_{\mathrm{i}}$

Subjects (Blocks In $\mathrm{V}$ ) 1

Max Obs per Subject 126

Optimization information

Optimization Tochnique Newton-Raphson:

Parameters In Optimization 42

Lower Boundaries 0

Upper Boundaries 0

Fixed Effects Not Profiled

\begin{tabular}{|c|c|c|c|c|c|}
\hline \multicolumn{6}{|c|}{ Iteration HIstory } \\
\hline Iteratlon & Restarts & Evaluatlons & $\begin{array}{l}\text { Olyjective } \\
\text { Function }\end{array}$ & Change & $\underset{\text { Gradlent }}{\text { Max }}$ \\
\hline 0 & & 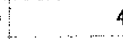 & 34.035735638 & & 1.810595 \\
\hline 1 & & 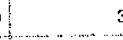 & 22.74397212 & 11.29176352 & 0.625184 \\
\hline 2 & & 3 & 18.866503838 & 3.87746828 & 0.22236 \\
\hline 3 & & 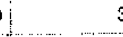 & 17.463447727 & 1.41305611 & 0.681531 \\
\hline 4 & & 9 & 16.834755697 & 0.51869203 & 0.029984 \\
\hline 5 & & 0 & 16.744093109 & 0.19066259 & 0.011029 \\
\hline 6 & & o & 16.673973015 & 0.07012009 & 0.004057 \\
\hline
\end{tabular}

file://C:/Users/klweber/AppData/Local/Temp/1/SAS\%20Tcmporary\%20Files/_TD3400_... 12/10/2014 


\begin{tabular}{|r|r|r|r|r|r|r|}
\hline 7 & 0 & 3 & 16.64818008 & 0.02579293 & 0.001493 \\
\hline 8 & 0 & 3 & 16.63869177 & 0.00948831 & 0.000549 \\
\hline 9 & 0 & 3 & 16.635201267 & 0.00349050 & 0.000202 \\
\hline 10 & 0 & 3 & 16.63391719 & 0.00128408 & 0.000074 \\
\hline 11 & 0 & 3 & 16.633444805 & 0.00047238 & 0.000027 \\
\hline 12 & 0 & 3 & 16.633271024 & 0.00017378 & 0.00001 \\
\hline 13 & 0 & 3 & 16.633207094 & 0.00006393 & $3.7 \mathrm{E}-6$ \\
\hline
\end{tabular}

Convergence crlterlon (ABSGCONV=0.00001) satisfied.

\begin{tabular}{|l|c|}
\hline \multicolumn{2}{|c|}{ Fit Statlstics } \\
\hline-2 Log Likellhood & 33.27 \\
\hline AlC (smaller is better) & 117.27 \\
\hline AICC (smaller is better) & 160.78 \\
\hline BIC (smaller is better) & 236.39 \\
\hline CAIC (smaller is better) & 278.39 \\
\hline HQIC (smaller is better) & 165.66 \\
\hline Pearson Chii-Square & 16.64 \\
\hline Pearson Chi Square / DF & 0.20 \\
\hline
\end{tabular}

\begin{tabular}{|c|c|c|c|c|c|c|c|c|}
\hline \multicolumn{9}{|c|}{ Paremeter Estlmates } \\
\hline Effect & sps & time & cone & Estlmate & Standard Error & $D F$ & it Valuo & $P r>|t|$ \\
\hline sps & FAM & & & -17.1184 & 423.72 & 84 & -0.04 & 0.9678 \\
\hline sps & HGE & & & -3.1355 & 0.4546 & 84 & -6.80 & $<.0001$ \\
\hline sps & $\mathrm{HIC}$ & & & -3.3673 & 0.4527 & 84 & -7.44 & $<.0001$ \\
\hline sps & PIG & & & -16.9240 & 429.87 & 84 & -0.04 & 0.9687 \\
\hline sps & PPB & & & -3.2581 & 0.4536 & 84 & -7.18 & $<.0001$ \\
\hline sps & THR & & & -17.1184 & 423.72 & 84 & -0.04 & 0.8679 \\
\hline sps & WAS & & & -17.1184 & 423.72 & 84 & -0.04 & 0.9679 \\
\hline time & & 8 & & $-963 E-13$ & 599.23 & 84 & -0.00 & 1.0000 \\
\hline time & & 24 & & 0 & & & & \\
\hline sps*time & FAM & $B$ & & 9.63E-11 & 847.44 & 84 & 0.00 & 1.0000 \\
\hline spstime & FAM & 24 & & 0 & & . & . & \\
\hline $\operatorname{sps} \sin ^{*}$ & HGE & 8 & & -13.7885 & 737.47 & 84 & -0.02 & 0.9851 \\
\hline spss"time & HGE & 24 & & 0 & & $\therefore$ & $\therefore$ & 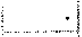 \\
\hline sps ${ }^{*}$ time & $\mathrm{HIC}$ & 8 & & -13.7511 & 733.91 & 34 & -0.02 & 0.9851 \\
\hline sps*time & HIC & 24 & & 0 & & & & \\
\hline spstime & PIG & 8 & & $9.63 \mathrm{E}-11$ & 853.61 & 84 & 0.00 & 1.0000 \\
\hline sps*time & PIG & 24 & & 0 & & $\therefore$ & $\therefore$ & $\therefore$ \\
\hline spsetime & PPB : & 8 & & -13.7678 & 735.49 & 84 & -0.02 & 0.9851 \\
\hline $\operatorname{sps}^{\kappa} \operatorname{tims}$ & PPB & 24 & & 0 & $\therefore$ & & & \\
\hline sps time & THIR : & 8 & & $9.63 \mathrm{E}-11$ & 847.44 & 84 & 0.00 & 1.0000 \\
\hline sps"time & THR & 24 & & c & & & & \\
\hline $\operatorname{sps}{ }^{*} \operatorname{tm} \theta$ & WAS & 8 & & 0 & & & & \\
\hline spsttime & WAS & 24 & & 0 & & & & \\
\hline conc & & & 0 & $-136 \mathrm{E}-12$ & 599.23 & 84 & $-0,00$ & 1.0000 \\
\hline conc & & & 50 & $-177 \mathrm{E}-12$ & 599.23 & 84 & -0.00 & 1.0000 \\
\hline $\operatorname{conc}$ & & & 100 & 0 & 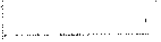 & & & : \\
\hline sps"cone & FAM & & 0 & $1.36 \mathrm{E}-10$ & 847.44 & 84 & 0.00 & 1.0000 \\
\hline sps"conc & FAM & & 50 & $1.77 \mathrm{E}-10$ & 847.44 & 84 & 0.00 & 1.0000 \\
\hline & & 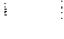 & & & & & & \\
\hline
\end{tabular}

file://C:/Users/klweber/AppData/Local/Temp/1/SAS\%20I'emporary\%20Files/_TD3400_... 12/10/2014 


\begin{tabular}{|c|c|c|c|c|c|c|c|c|}
\hline ops*cone & FAM & & 100 & 0 & & & : & \\
\hline spstcons & $\mathrm{HGE}$ & & 0 & $1.36 \mathrm{E}-10$ & 599.23 & 84 & 0.00 & 1.0000 \\
\hline sps*conc & HGE & & 50 & $1.77 \mathrm{E}-10$ & 598.23 & 84 & 0.00 & 1.0000 \\
\hline sps*conc & $\mathrm{HGE}$ & & 100 & 0 & & $\therefore$ & & \\
\hline sps ${ }^{\circ} \operatorname{con} c$ & HIC & & 0 & -13.7511 & 733.91 & 84 & -0.02 & 0.0851 \\
\hline spe*cons & HIS & & 50 & $-13,7511$ & 733.91 & 84 & $-0,02$ & 0.9851 \\
\hline spstcons & HIC & & 100 & 0 & & 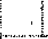 & & \\
\hline $\mathrm{sps}^{*} \operatorname{conc}$ & $F \mid G$ & & 0 & $1.36 \mathrm{E}-10$ & 853.61 & 84 & 0.00 & 1.0000 \\
\hline sps*cone & FIG & & 50 & $1.77 \mathrm{E}-10$ & 853.61 & 64 & 0.00 & 1.0000 \\
\hline sps"conc & $\mathrm{FIO}$ & & 100 & 0 & & $\therefore$ & & \\
\hline sps"cone & PPB & & 0 & -13.7678 & 735.49 & 84 & -0.02 & 0.9851 \\
\hline $\operatorname{sps}{ }^{*}$ cone & PPB : & & 50 & $1.77 \mathrm{E}-10$ & 599.23 & 84 & 0.00 & 1.0000 \\
\hline spstconc & PPB & & 100 & 0 & $\therefore$ & 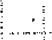 & & \\
\hline $8 p^{*} \operatorname{conc}$ & THR & & 0 & $1.36 \mathrm{E}-10$ & 847.44 & 84 & 0.00 & 1.0000 \\
\hline sps*conc & THR & & 50 & $1.77 \mathrm{E}-10$ & 847.44 & 84 & 0.00 & 1.0000 \\
\hline sps"conc & THR & & 100 & 0 & & & & \\
\hline sps"cone & WAS & & 0 & 0 & & & & \\
\hline sps*conc & WAS & & 50 & 0 & & ${ }^{\circ}$ & ${ }^{\circ}$ & 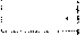 \\
\hline $\mathrm{sps}^{*} \mathrm{conc}$ & WAS & & 100 & 0 & & & & \\
\hline time conc & & 8 & 0 & $1.84 \mathrm{E}-10$ & 847.44 & 84 & 0.00 & 1.0000 \\
\hline time conc & & 8 & 50 & 13.7511 & 733.91 & 84 & 0.02 & 0.9851 \\
\hline time*conc & & 8 & $: 00$ & 0 & & & & \\
\hline time conc & & 24 & 0 & C & & & & 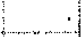 \\
\hline timecone & & 24 & 50 & 0 & & & & \\
\hline time $e^{*}$ cone & & 24 & 100 & 0 & & & & \\
\hline spstime*conc & FAM & 8 & 0 & $-184 E-12$ & 1198.47 & 84 & -0.00 & 1.0000 \\
\hline spstime cone & FAM : & 8 & 50 & -13.7511 & 1121.06 & 84 & -0.01 & 0.9902 \\
\hline sps ${ }^{*}$ time"cone & FAM & 8 & 100 & 0 & & & $\cdot$ & \\
\hline sps thme*colsc & FAM & 24 & 0 & 0 &. & 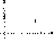 & . & \\
\hline $\mathrm{sps}^{*} \mathrm{tim} \mathrm{e}^{*} \mathrm{conc}$ & FAM & 24 & 50 & 0 & & & . & \\
\hline sps*time*conc & FAM & 24 & 100 & 0 & & & . & \\
\hline sps"time"conc & HGE & 8 & 0 & 13.7885 & 950.24 & 64 & 0.01 & 0.9885 \\
\hline spsttime*cone & HGE & 8 & 50 & -13.7511 & 852,99 & 86 & -0.01 & 0.9885 \\
\hline spstime*conc & HGE & 8 & 100 & 0 & . & . & & \\
\hline sps*tims* conc & HGE & 24 & 0 & 0 & & $\therefore$ & & $\therefore$ \\
\hline $\operatorname{sps}{ }^{*} t i m e * c o n c$ & HGE & 24 & 50 & 0 & & . & & . \\
\hline $\operatorname{sps}^{*}$ tlme*conc & HGE & 24 & 100 & 0 & & & & $\therefore$ \\
\hline sps stime $^{*}$ conc & $\mathrm{HIC}$ & 8 & 0 & 13.7511 & 1121.06 & 84 & 0.01 & 0.9902 \\
\hline sps*time*conc & HIC & 8 & so & $-192 E-12 i$ & 1037.90 & 84 & -0.00 & 1.0000 \\
\hline sps ${ }^{*}$ time ${ }^{*}$ conc & HIC & 8 & 100 & 0 & & & & \\
\hline spstime*conc & HIC & 24 & 0 & 0 & & . & & \\
\hline spsttlmetconc & 410 & 24 & 50 & 0 & & $\therefore$ & & \\
\hline sps timenconc & $-11 \mathrm{C}$ & 24 & 100 & 0 & &. & . & $\therefore$ \\
\hline sps"tlme conc & PIG & 8 & 0 & $-184 E-12$ & 1207.19 & 84 & -0.00 & 1.0000 \\
\hline sps*time*cono & PIG & 8 & 50 & -13.7511 & 1130.38 & 84 & -0.01 & 0.9903 \\
\hline sps ${ }^{* t i m e} e^{*} c o n c$ & $P 1 G$ & 8 & 100 & 0 & & & & \\
\hline sps"time*conc & PIG & 24 & 0 & 0 & & $\ldots$ & & \\
\hline sps"time*conc & PIG & 24 & $5 \mathrm{C}$ & 0 & & $\cdot$ & & \\
\hline sps $^{*}$ timetconc & $P I G$ & 24 & 100 & 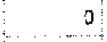 & & . & & \\
\hline
\end{tabular}

\section{AEH-13-PSEUDO-06}

file://C:/Users/klweber/AppData/Local/Temp/1/SAS\%20'Temporary\%20Files/_TD3400_.. 12/10/2014 


\begin{tabular}{|c|c|c|c|c|c|c|c|c|}
\hline & PFB & 8 & 0 & 13.7678 & 1124.17 & 84 & 0.01 & 0.8903 \\
\hline sps*time*conc & $\mathrm{PPB}$ & $B$ & 50 & -13.7511 & 949.93 & 84 & -0.01 & 0.9885 \\
\hline sps*time*cons & PPB & 8 & 100 & 0 & & . & & \\
\hline $\mathrm{sps}^{*} \mathrm{t} \mid \mathrm{m} \theta^{*} \mathrm{conc}$ & 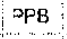 & 24 & 0 & 0 & & & & \\
\hline sps"time"conc & PPB & 24 & 50 & 0 & & & & \\
\hline sps*tlme"conc & PPB & 24 & 100 & 0 & . & & & \\
\hline$\$ p s^{*}$ tlme conc & THR & 8 & 0 & $-184 E-12$ & 1198.47 & 84 & .000 & 1.0000 \\
\hline sps*time*conc : & : THR & 8 & $5 C$ & -13.7511 & 1121.06 & 84 & -0.01 & 0.9902 \\
\hline sps*time*conc & THR & $B$ & 100 & $0:$ & & & & $\therefore$ \\
\hline sps"time*cone & THR & 24 & $c$ & 0 & & & & $\therefore$ \\
\hline spo*time*cone & THR & 24 & 50 & 0 & & & & . \\
\hline sps*time*conc & THR & 24 & 100 & 0 & & & & $\therefore$ \\
\hline sps $^{* t i m e}$ conc & WAS & 8 & 0 & 0 & & & & \\
\hline $\operatorname{sps}^{*} t$ time"conc & WAS & 8 & 50 & 0 & & & & \\
\hline sps ${ }^{*}$ time ${ }^{\star}$ conc & WAS & 8 & 100 & 0 & & & & 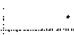 \\
\hline $\mathrm{sps}^{* 11} \mathrm{e}^{*}$ conc & WAS & 24 & 0 & 0 & & & & \\
\hline sps*time*conc & WAS & 24 & 50 & 0 & & & & $\therefore$ \\
\hline sps"time*cons & WAS & 24 & $\infty$ & 0 & & & & \\
\hline Res|dual & & & & 0.1981 & & & & $\therefore$ \\
\hline
\end{tabular}

\section{AEH-13-PSEUDO-06}

\begin{tabular}{|c|c|c|c|c|}
\hline \multicolumn{5}{|c|}{ Type III Tests of Fixed Effects } \\
\hline Effect & Num DF & Den DF & F Value & $\mathrm{Pr}>\mathrm{F}$ \\
\hline sps & 6 & 84 & 0.00 & $1.000 \mathrm{C}$ \\
\hline time & 1 & 84 & 0.00 & 0.9823 \\
\hline $\operatorname{sps}^{*}$ time & 6 & 84 & 0.00 & 1.0000 \\
\hline conc & 2 & 84 & 0.00 & 1.0000 \\
\hline sps"conc & 12 & 84 & 0.00 & 1.0000 \\
\hline time cons & 2 & 84 & 0.00 & 0.9898 \\
\hline sps*tim & 12 & 84 & 0.00 & 1,0000 \\
\hline
\end{tabular}

\begin{tabular}{|c|c|c|c|c|c|c|c|c|c|}
\hline \multicolumn{10}{|c|}{ Odds Ratlo Estimates } \\
\hline sps & tlme & conc & sps & time & conc & Estlinate & $D F$ & $95 \%$ Confic & nce Limits \\
\hline FAM & & & WAS & & & 0.101 & 84 & $<0.001$ & $>998.989$ \\
\hline HGE & & & WAS & & & $>099.999$ & 84 & $<0.001$ & $>999.999$ \\
\hline HIC & & & WAS & & & 1.000 & 84 & $<0.001$ & $>999.998$ \\
\hline $\mathrm{P} \mid \mathrm{G}$ & & & WAS & & & 0.123 & 84 & $<0.001$ & $>899.989$ \\
\hline PPB & & & WAS & & & 10.912 & 84 & $<0.001$ & $>999.899$ \\
\hline THR & & & WAS & & & 0.101 & 84 & $<0.001$ & $>099.998$ \\
\hline & 8 & & & 24 & & 0.072 & 84 & $<0.001$ & $>999.998$ \\
\hline & & 0 & & & 100 & 0.375 & 84 & $<0.001$ & $>999.999$ \\
\hline & & 50 & & & 100 & 1.000 & 84 & $<0.001$ & $>999.98 \theta$ \\
\hline
\end{tabular}

sps Least Squares Moans

\begin{tabular}{|c|c|c|c|c|c|c|c|c|c|c|c|c|}
\hline sps & Estimate & Standard Error & $\mathrm{DF}$ & t value & $\mathrm{Pr}>|\mathrm{t}|$ & Alpha & Lower & Upper & Mean & $\begin{array}{r}\text { Standard } \\
\text { Error } \\
\text { Mean }\end{array}$ & $\begin{array}{c}\text { Lower } \\
\text { Mean }\end{array}$ & $\begin{array}{l}\text { Upper } \\
\text { mean }\end{array}$ \\
\hline FAM & .17 .1184 & 172.98 & 84 & -0.10 & 0.9214 & 0.05 & -361.12 & 326.88 & $3.678 \mathrm{E}-8$ & $6.362 E-6$ & $148 \mathrm{E}-159$ & 1.0000 \\
\hline HGE & -7.7317 & 101.32 & 84 & $-0,08$ & 0.9394 & 0.05 & -209.22 & 193.78 & 0.000439 & 0.04441 & $1.37 E_{-91}$ & 1.0000 \\
\hline HIC & -14.8265 & 157.91 & $84:$ & -0.09 & 0.9254 & 0.05 & .328 .85 & 290.20 & $3.638 \mathrm{E}-7$ & 0.000057 & $152 E-145$ & 1.0000 \\
\hline PIG & -16.9240 & 175.49 & 84 & -0.10 & 0.8234 & 0.05 & $-365,91$ & 332.06 & $4.467 \mathrm{E}-8$ & $7.839 E-6$ & $122 E-161$ & 1.0000 \\
\hline $\mathrm{PPB}$ & -12.4366 & 142.15 & 84 & -0.09 & 0.5305 & 0.05 & .295 .12 & 270.25 & $3.97 \mathrm{E}-6$ & 0.000564 & $674 E-131$ & 1.0000 \\
\hline
\end{tabular}

file://C:/Users/klweber/AppData/Local/Temp/l/SAS\%20Temporary\%20Files/ TD3400_.. 12/10/2014 


\begin{tabular}{|c|c|c|c|c|c|c|c|c|c|c|c|c|c|c|}
\hline THR & -17.1184 & 184 & 172.98 & 84 & -0.10 & 0.9214 & 0.05 & $5:-361.12$ & \multicolumn{2}{|c|}{$326.88: 3.678 \mathrm{E}-8$} & $8.362 E-6$ & \multicolumn{2}{|c|}{$159 \quad 1.0000$} & \\
\hline WAS & -14.826 & & 157.91 & 84 & -0.09 & 0.9254 & 0.05 & -328.85 & \multicolumn{2}{|c|}{$299.20 / 3,638 E-7$} & 0.000057 & $7152 E-145$ & 1.0000 & \\
\hline \multicolumn{15}{|c|}{ Differences of sps Least Squares Means } \\
\hline sps & sps $E$ & Estimate & \multicolumn{2}{|c|}{ Standard Error } & $D F$ & t Value & $\operatorname{Pr}>|1|$ & Alpha & Lower & \multicolumn{2}{|c|}{ Upper Odds Ratto } & \multicolumn{2}{|c|}{$\begin{array}{r}\text { Lower Confictence } \\
\text { LImit for Odds } \\
\text { Ratio }\end{array}$} & $\begin{array}{r}\text { Upper Confidence } \\
\text { Litult for Odds } \\
\text { Ratlo }\end{array}$ \\
\hline FAM & HGE & -9.3867 & & 200.47 & 84 & -0.05 & 0.9628 & 0.05 & -400.053 & 380.28 & $<0.001$ & & $<0.001$ & $>999.999$ \\
\hline FAM & $\mathrm{HIC}$ & -2.2918 & & 234.22 & 84 & -0.01 & 0.9922 & 0.05 & $-468.07 / 4$ & 463.48 & 0.101 & & $<0.001$ & $>999.999$ \\
\hline FAM & PIG & $-0.1 \theta 43$ & & 46.42 & 84 & -0.00 & 0.9994 & 0.05 & $- 4 9 0 . 2 2 \longdiv { 4 }$ & 489.83 & 0.823 & & $<0.001$ & $>999.999$ \\
\hline FAM & PPB & -4.6817 & & 23.90 & 84 & -0.02 & 0.9834 & 005 & 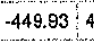 & 440.57 & 0.009 & & $<0.001$ & $>998.989$ \\
\hline FAM & THR:- & $-933 E-17$ & & 44,64 & 84 & -0.00 & 1.0000 & 0.05 & $-486,48 \quad 4$ & 486.49 & 1.000 & & $<0.001$ & $>999.999$ \\
\hline FAM & WAS & $-2,2918$ & & 34.22 & 84 & -0.01 & 0.9922 & 0.05 & -468.074 & 463.48 & 0.101 & & $<0.001$ & $>999.999$ \\
\hline HGE & HIC & 7.0949 & & 87.62 & 84 & 004 & $0.869 \theta$ & 0.05 & -366.013 & 380.20 & $>999.999$ & & $<0.001$ & $>999.999$ \\
\hline HIGE & PIG & 8.1924 & & 02,64 & 84 & 0.05 & 0.9639 & 0.05 & -393.784 & 412.17 & $>999.999$ & & $<0.001$ & $>099.998$ \\
\hline HGE & PPB & 4.7050 & & 174.57 & 84 & 0.03 & 0.9783 & 0.05 & -342.443 & 351.85 & 110.494 & & $<0.001$ & $>099.999$ \\
\hline HGE & THR & 9.3867 & & 00.47 & 84 & 0.05 & 0.9628 & 0.05 & -389.28 & 108.05 & $>999,998$ & & $<0.001$ & $>999.999$ \\
\hline $\mathrm{HGE}$ & WAS & 7.0949 & & 87.62 & 84 & 0.04 & 0.9699 & 0.05 & $-366.61 / 3$ & 380.20 & $>999.999$ & & $<0.001$ & $>990.999$ \\
\hline HIC & PIG & 2.0975 & & 236.08 & 64 & 0.01 & 0.9929 & 0.05 & -467.374 & 471.57 & 8.146 & & $<0.001$ & $>999.999$ \\
\hline $\mathrm{HIC}$ & $P P B$ & -2.3899 & & 12.47 & 84 & -0.01 & 0.9911 & 0.05 & $- 1 2 4 . 9 1 \longdiv { 4 }$ & 420.13 & 0.092 & & $<0.001$ & $>999.999$ \\
\hline HIC & THR & 2.2918 & & 34.22 & 84 & 0.01 & 0.9922 & 0.05 & $-463.48 \quad 4$ & 468.07 & 8.893 & & $<0.001$ & $>999.898$ \\
\hline $\mathrm{HIC}$ & WAS & $9.03 \mathrm{E}-12$ & & 223.32 & 84 & 0.00 & 1.0000 & 0.05 & $-444.10 \quad 4$ & 444.10 & 1.000 & & $<0.001$ & $>998.999$ \\
\hline PIG & $\mathrm{PPB}$ & -4.4874 & & 225.84 & 84 & -0.02 & 0.9842 & 0.05 & $-453,60$ & 444.63 & 0.011 & & $<0,001$ & $>999.999$ \\
\hline PIG & THR & 0.1943 & & 246.42 & 84 & 0.00 & 0.9994 & 0.05 & -489834 & 490.22 & 1.215 & & $<0.001$ & $>999.999$ \\
\hline गIG & WAS & -2.0975 & & 236.08 & 84 & -0.01 & 0.9929 & 0.05 & -171.57 & 487.37 & 0.123 & & $<0.001$ & $>999.999$ \\
\hline $\mathrm{PPB}$ & THR & 4.6817 & & 223.90 & 84 & 0.02 & 0.9834 & 0.05 & -440.57 & 449.93 & 107.958 & & $<0.001$ & $>999.909$ \\
\hline PPB & WAS & 2.3899 & & 212,47 & 84 & 0.01 & 0.9911 & 0.06 & -420.13 & 424.91 & 10.912 & & $<0.001$ & $>999.999$ \\
\hline THR & WAS & -2.2918 & & 234.22 & 84 & -0.01 & 0.9922 & 0.05 & -468.07 & 463.48 & 0.101 & & $<0.001$ & $>999.990$ \\
\hline & & & & & & time Lea & gast Squar & ares Mea & ans & & & & & \\
\hline time & Estimat & ate Stande & Lard Error & $D F t$ & Value & $|\operatorname{Pr}>| t \mid$ & 1 Alpha & Lower & er Upper & Mea: & $\begin{array}{r}\text { Standard } \\
\text { Error } \\
\text { Mean }\end{array}$ & $\begin{array}{l}\text { Lower } \\
\text { Mean }\end{array}$ & $\begin{array}{l}\text { Upper } \\
\text { Meanl }\end{array}$ & \\
\hline 8 & -15.738 & & 88.3777 & 84 & $=0.18$ & 0.8591 & 0.05 & -191.49 & 19160.01 & $11.462 \mathrm{E}$ & $E-7: 0.000013$ & 6.89E-84 & 1.0000 & \\
\hline 24 & -13.113 & & 78.4078 & 84 & -0.17 & 0.8676 & 0.05 & -169.04 & $14 \quad 142.81$ & $2.017 \mathrm{E}$ & $E-6: 0.000158$ & $3.88 E-74$ & 1.0000 & \\
\hline & & & & & & Differe & rences of & of time leo & ceast Squa & Jares Mea & ans & & & \\
\hline time & time $E$ & Estlmate & Standtard E & Error & $\mathrm{DF}$ & tValue $p$ & $\operatorname{Pr}>|t|$ & Alpha & Lower & Upper 0 & Odds Ratlo & $\begin{array}{l}\text { Lower Conf } \\
\text { Limit for }\end{array}$ & $\begin{array}{l}\text { idence } \\
\text { r Odes } \\
\text { Ratio }\end{array}$ & $\begin{array}{r}\text { Upper Confikence } \\
\text { Limit for Odds } \\
\text { Ratio }\end{array}$ \\
\hline 8 & 24 & -2.6244 & & 18.15 & 84 & -0.020 & 0.9823 & 0.05 & -237.572 & 232.32 & 0.072 & & $<0.001$ & $>099.999$ \\
\hline & & & & & & conc Le & east Squa & Jares Med & eans & & & & & \\
\hline conc & Estima & nate Stand & dard Error & $\mathrm{DF}$ & t Value & $\operatorname{Pr}>|t|$ & 1) Alpha & Lower & er Upper & & ean $\begin{array}{r}\text { Standard } \\
\text { Error } \\
\text { Mean }\end{array}$ & $\begin{array}{l}\text { Lower } \\
\text { Mean }\end{array}$ & Upper & \\
\hline 0 & -15.07 & 799 & 105.21 & 84 & -0.14 & 40.8864 & 0.05 & -224.3 & $31: 194.15$ & $15 \quad 2.824 E$ & $E = 7 \longdiv { 0 . 0 0 0 0 3 0 }$ & $10 \quad 3.85 E-98$ & 1.0000 & \\
\hline 50 & -14.09 & 991 & $10 c, 84$ & 84 & -0.14 & $4 \quad 0.8891$ & 0.05 & -214.6 & 63186.43 & \begin{tabular}{l|l}
3 & $7.531 \mathrm{E}$
\end{tabular} & $E-7 / 0.000076$ & $6 \quad 6.14 E-84$ & 1.0000 & \\
\hline 100 & -14.09 & 991 & 100.84 & 34 & -0.14 & $\begin{array}{lll}4 & C .8891\end{array}$ & $1 \quad 0.05$ & -214.63 & 63 186.43 & $73.531 \mathrm{E}$ & E. $7 \quad 0.000076$ & $6 \quad 6.14 \mathrm{E}-94$ & 1.0000 & \\
\hline & & & & & & Differ & rences of & of conc $L$ & Least Squ & UAres Nie & eans & & & \\
\hline conc & cona & Estimate & Standard & d Error & DF & t value & $|\mathrm{Pr}>| \mathrm{t} \mid$ & Alpha & Lower & Upper & Odds Ratlo & $\begin{array}{r}\text { Lower Con } \\
\text { Limit fo }\end{array}$ & $\begin{array}{l}\text { nfldence } \\
\text { for Odds } \\
\text { Ratio }\end{array}$ & $\begin{array}{r}\text { Upper Confidence } \\
\text { Limit for Odds } \\
\text { Ratlo }\end{array}$ \\
\hline 0 & 50 & -0.9807 & & 145.73 & 84 & -0.01 & 0.9948 & 0.05 & -290.79 & 288.82 & 0.375 & & $<0.001$ & $>999.999$ \\
\hline
\end{tabular}

file://C:/Users/klweber/AppDala/Local/Temp/1/SAS\%20Temporary\%20Files/_TD3400_... 12/10/2014 
SAS Output

Page 12 of 38

\section{AEH-13-PSEUDO-06}

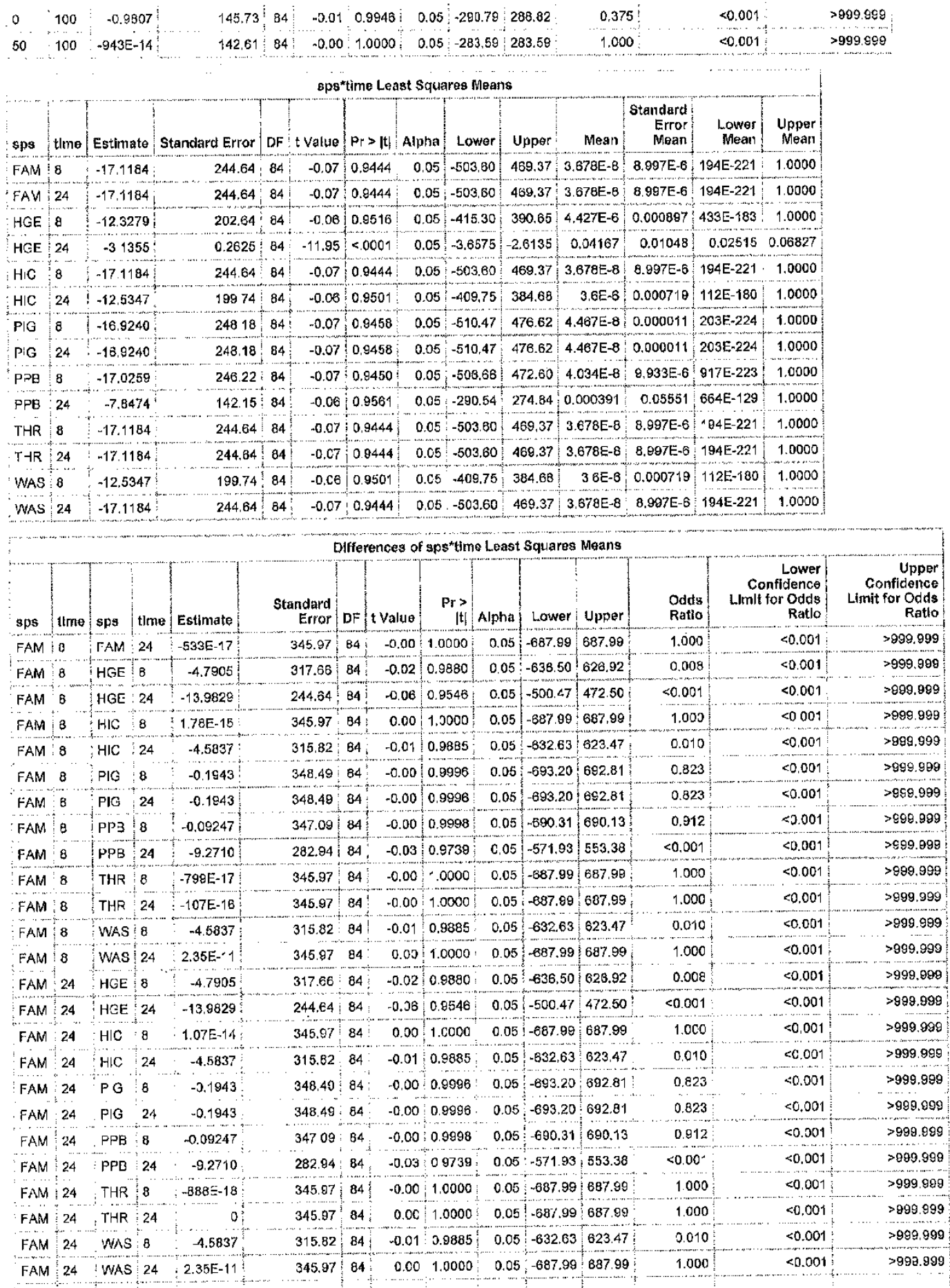

file://C:/Users/klweber/AppData/Local/Temp/1/SAS\%20Temporary\%20Files/_TD3400 ... 12/10/2014 
AEH-13-PSEUDO-06

\begin{tabular}{|c|c|c|c|c|c|c|c|c|c|c|c|c|c|c|}
\hline HGE & 8 & $\mathrm{HGE} 2$ & 24 & $-9 .{ }^{\wedge} 924$ & 20264 & 84 & -0.05 & 0.9639 & 0.05 & -412.17 & 393.78 & $<0.001$ & $<0.001$ & $>999.999$ \\
\hline HGE & 8 & $H I C \quad B$ & 8 & 4.7905 & 31768 & 84 & 0.02 & 0.9880 & 0.05 & -626.92 & 636.50 & 120.364 & $<0.001$ & $>999.999$ \\
\hline HGE & 8 & $\mathrm{HIC}$ & 24 & 0.2068 & 284.54 & $84 !$ & 0.00 & 0.9994 & 0.05 & -565.63 & 566.04 & 1.230 & $<0.001$ & $>999.999$ \\
\hline HGE & 8 & $P I G$ & 8 & 4.5962 & 320.40 & $\theta 4$ & 0.01 & 09886 & 0.05 & -632.56 & 841,76 & 09.105 & $<0.001$ & $>999.999$ \\
\hline HGE & 8 & $\mathrm{PIG}$ & 24 & 4.5962 & 320.40 & 84 & 0.01 & 0.9886 & 0.05 & -632.56 & 641.76 & 99.105 & $<0.001$ & $>999.999$ \\
\hline HGE & 8 & PPB 8 & 8 & 4.6980 & 318.88 & 84 & 0.01 & 0.9883 & 0.05 & $|-629.44|$ & 638.83 & 109.733 & $<0.001$ & $>990.999$ \\
\hline $\mathrm{HCE}$ & 8 & PPB 2 & 24 & -4.4805 & 247,53 & 84 & -0.02 & 0.9856 & 0.05 & -496.72 & 487.76 & 0.011 & $<0.001$ & $>999.999$ \\
\hline HGE & 8 & THR 8 & 8 & 4.7905 & 317.68 & 84 & 0.02 & 0,9880 & 0.05 & -626.92 & 636.50 & 120.364 & $<0.001$ & $>999.999$ \\
\hline $\mathrm{HGE}$ & 8 & THR & 24 & 4.7905 & 317.66 & 84 & 0.02 & 0.9880 & 0.05 & -628.92 & 636.50 & 120.264 & $<0.001$ & $>099.998$ \\
\hline HGE & 8 & WAS & 8 & 0.2068 & 284.54 & 84 & 0.00 & 0.9094 & 0.05 & -565.83 & 568.04 & 1.230 & $<C .001$ & $>998.999$ \\
\hline HGE & 8 & WAS 2 & 24 & 4.7905 & 317.66 & 84 & 0.62 & 0.9880 & 0.05 & -626.92 & 636.50 & 120.364 & $<0.001$ & $>099.990$ \\
\hline HGE & 24 & HIC & $B$ & 13.9829 & 244.64 & 84 & 0.06 & 0.9546 & 0.05 & -472.50 & 50047 & $>999.999$ & $<0.001$ & $>999.999$ \\
\hline HGE : & 24 & HIC 2 & 24 & 9.3092 & 199.74 & $84:$ & 0.05 & 0.9626 & 0.05 & -387.81 & 406.81 & $>999.999$ & $<0.001$ & $>998.999$ \\
\hline HGE & 24 & $P G: 8$ & 8 & 13.7885 & 248.18 & 84 & 0.06 & 0.8558 & 0.05 & -479.75 & 507.33 & $>999999$ & $<0.001$ & $>099099$ \\
\hline HGE & 24 & PIG 2 & 24 & 13.7865 & 248.18 & 84 & 0.08 & 0.9558 & $0.05 ?$ & -479.75 & 507,33 & $>999.999$ & $<0.001$ & $>999.999$ \\
\hline HGE & 24 & PPB 8 & 8 & 12.8904 & 246.22 & 84 & 0.06 & 0.9551 & 0.05 & -475.74 & 503.52 & $>999.989$ & $<0.001$ & $>999.999$ \\
\hline HGE & 24 & $P P B$ & 24 & 4.7119 & 142.15 & 84 & 0.03 & 0.9736 & 0.05 & -277.98 & 287.40 & 111.260 & $<0.001$ & $>999,999$ \\
\hline HGE & 24 & THR 8 & 8 & 13.9829 & 244,64 & 84 & 0.06 & 0.9546 & 005 & -472.50 & 500.47 & $>999.999$ & $<0.001$ & $>999.999$ \\
\hline HGE & 24 & THR 2 & 24 & 13.2829 & 244.64 & 84 & 0.06 & 0.9546 & 0.05 & -472.50 & 500.47 & $>999.800$ & $<0,001$ & $>999.999$ \\
\hline HGE & 24 & WAS & 8 & 9.3992 & 189.74 & 84 & 0.06 & 0.9626 & 0.05 & -387.81 & 406.61 & $>998.999$ & $<0.001$ & $>099.999$ \\
\hline HGE & 24 & WAS 2 & 24 & 13,9829 & 244.64 & 84 & 0.06 & 0.9548 & 0.05 & -472.50 & 500.47 & $>999.999$ & $<0.001$ & $>999.999$ \\
\hline $\mathrm{HIC}$ & 8 & $\mathrm{HIC}$ & 24 & -4.5837 & 315.82 & 84 & -0.01 & 0.9885 & 0.05 & $-632,63$ & 623.47 & 0.010 & $<0.601$ & $>999.998$ \\
\hline HIC & 8 & PIG & 8 & -0.1943 & 348.49 & 84 & -0.00 & 0.9996 & 0.05 & -69320 & 692.81 & 0.823 & $<0.001$ & $>999.999$ \\
\hline HIC & 8 & PIG & 24 & -0.1943 & 348.49 & 84 & -0.00 & 0.9996 & 0.05 & -69320 & 692.81 & 0.823 & $<0.001$ & $>999.990$ \\
\hline $\mathrm{HIC}$ & 8 & $\mathrm{PPB}$ & 8 & -0.09247 & 347.59 & 84 & -0.00 & 0.8998 & 0.05 & $-690,31 \mid$ & 690.13 & 0.912 & $<0.001$ & $>999.999$ \\
\hline 10 & 8 & $\mathrm{PPB}: 2$ & 24 & -9.2710 & 282.94 & 84 & -0.03 & 0.9739 & 0.05 & -571.93 & 552.38 & $<0.001$ & $<0.001$ & $>999.989$ \\
\hline HIC & 8 & THR E & 8 & -115E-16 & 345.97 & 84 & -0.00 & 1,0000 & 0.05 & $|-687.90|$ & 687.89 & 1.000 & $<0.001$ & $>998.990$ \\
\hline $\mathrm{HIC}$ & 8 & THR & 24 & $-129 E-16$ & 345.87 & 84 & -0.00 & 1.0000 & 0.05 & -687.99 & 687.99 & 1.000 & $<0.001$ & $>999.999$ \\
\hline $\mathrm{HIC}$ & 8 & WAS & 8 & -4.6837 & 315.82 & 84 & -0.01 & 0.9885 & 0.05 & -632.63 & 623.47 & 0.010 & $<0.001$ & $>899.999$ \\
\hline $\mathrm{HIC}$ & 8 & WAS & 24 & $2.35 \mathrm{E}-11$ & 345.97 & 84 & 0.00 & .0000 & 0.05 & -687.99 & 687.99 & 1.000 & $<0.001$ & $>999.999$ \\
\hline$H I C$ & 24 & PIG & 8 & 4.3894 & 318.58 & 84 & 0.01 & 0.8890 & 0.05 & -629.14 & 637.92 & 80.588 & $<0.001$ & $>099.999$ \\
\hline HIC & 24 & $\mathrm{P} \mid \mathrm{G}$ & 24 & 4.3894 & $3 \nmid 8.58$ & 84 & 0.01 & 0.9890 & 0.05 & -629.14 & 637.82 & 80.588 & $<0.001$ & $>999.899$ \\
\hline HIC & 24 & PPB & 8 & 4,4912 & 317.05 & 84 & 0.01 & 0.9887 & 0.05 & -626.00 & 634.98 & 89.230 & $<0.001$ & $>999.999$ \\
\hline HIC & 24 & PPB & 24 & $-4,6873$ & 245.16 & 84 & -0.02 & 0.9848 & 0.05 & -492.22 & 482.85 & 0.009 & $<0.001$ & $>999.999$ \\
\hline HIC & 24 & THR & 8 & 45837 & 315.82 & 84 & 0.01 & 0.9885 & 0.05 & -623.47 & 632.63 & 97.876 & $<0.001$ & $>999.999$ \\
\hline $\mathrm{HIC}$ & 24 & THR & 24 & 45837 & 315.82 ; & 84 & 0.01 & 0.9885 & 0.05 & -623.47 & 632.63 & 97.875 & $<0.001$ & $>999.999$ \\
\hline $\mathrm{HIC}$ & 24 & WAS & 8 & $-544 E-4$ & 282.48 & 84 & -0.00 & 1.0000 & 0.05 & 561.74 & 561.74 & 1.000 & $<0.001$ & $>999.999$ \\
\hline $\mathrm{HIC}$ & 24 & WAS & 24 & 4.5837 & 315.82 & 84 & 0.01 & 0.9885 & 0.05 & -623.47 & 632.63 & 97.875 & $<0.001$ & $>999.999$ \\
\hline PIG & 8 & $P \mid G$ & 24 & $179 \mathrm{E}-15$ & 350.99 & 84 & 0.00 & 1.0000 & 0.05 & -687.97 & 697.97 & 1.000 & $<0.001$ & $>998.998$ \\
\hline$P \mid G$ & 8 & 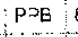 & 8 & 0.1019 & 349.60 & 84 & 0.00 & 0,9996 & 0.05 & -695.11 & 695.31 & 1.107 & $<0.001$ & $>999.999$ \\
\hline$P I G$ & 8 & PPB & 24 & -9.0767 & 286.01 & 84 & -0.03 & 0.9748 & 0.05 & -577.84 & 559.69 & $<0.001$ & $<0.001$ & $>999.999$ \\
\hline$P I G$ & 8 & THR & 8 & 0.1943 & 348.49 & $84 ?$ & 0.00 & 0.8996 & 0.05 & -692.81 & 693.20 & 1.215 & $<0.001$ & $>999.999$ \\
\hline$P \mid G$ & 8 & THR & 24 & 0.1943 & $348<9$ & 84 & 0.00 & 0.9996 & 0.05 & -692.81 & 693.20 & 1.215 & $<0.001$ & $>999.999$ \\
\hline $\mathrm{PIO}$ & 8 & WAS & 8 & -4.3894 & 31858 & 84 & -0.01 & 0.9890 & 0.05 & -637.92 & 629.14 & 0.012 & $<0.001$ & $>099.999$ \\
\hline$P \mid G$ & 8 & WAS & 24 & 0.1943 & 348.49 & 84 & 0.00 & 0.9896 & 0.05 & 692.81 & 693.20 & 1.215 & $<0.001$ & $>999.998$ \\
\hline$P \mid G$ & 24 & $\mathrm{PPB}$ & 8 & 0.1019 & 349.60 & 84 & 0.00 & 0.8998 & 0.05 & -695.11 & 695,31 & 1.107 & $<0.001$ & $>999.999$ \\
\hline$P G$ & 24 & PPB & 24 & -9.0767 & 286.01 & 84 & -0.03 & 0.9748 & 0.05 & -577.84 & 559.69 & $<0.001$ & $<0.001$ & $>999.999$ \\
\hline $\mathrm{PIG}$ & 24 & TIPR & 8 & 0.1943 & 348.48 & 84 & 0.00 & 0.8996 & 0.05 & -692.81 & 693.20 & 1.215 & $<0.001$ & $>999.999$ \\
\hline$P \mid G$ & 24 & THR & 24 & 0.1943 & 348.49 & 84 & 0.00 & 0.9996 & 0.05 & -692.81 & 693.20 & 1.215 & $<0.001$ & $>999.099$ \\
\hline
\end{tabular}

file://C:/Users/klweber/AppData/Local/Temp/1/SAS\%20Tcmporary\%20Files/_TD3400_.. 12/10/2014 


\section{AEH-13-PSEUDO-06}

\begin{tabular}{|c|c|c|c|c|c|c|c|c|c|c|c|c|c|c|}
\hline & 24 & WAS & 8 & -4.3894 & 318.58 & 84 & -0.01 & 0.9880 & 0.05 & -637.92 & 829.14 & 0.012 & $<0.001$ & $>999.99 \theta$ \\
\hline PIO & 24 & WAS & 24 & 0.1943 & 348.49 & 84 & 0,00 & 0.9996 & 0.05 & $-6 \theta 2.81$ & 683.20 & 1.215 & $<0.001$ & $>099,999$ \\
\hline $\mathrm{PPB}$ & 8 & PPB & 24 & -9.1785 & 284.31 & 84 & -0.03 & 0.9743 & 0.05 & $-574,55$ & 556.20 & $<0.001$ & $<0.001$ & $>999.999$ \\
\hline PPB & 8 & THR & 8 & 0.09247 & 347.09 & 84 & 0.00 & 0.9998 & 0.05 & -690.13 & 690.31 & 1.097 & $<0.001$ & $>999.99 \theta$ \\
\hline $\mathrm{PPB}$ & 8 & THR & 24 & 0.09247 & 347.09 & 84 & 0.00 & 0.9998 & 0.05 & -690.13 & 690.31 & 1.097 & $<0.001$ & $>999.999$ \\
\hline PPB & 8 & WAS & 8 & -4.4912 & 317.05 & 84 & -0.01 & 0.9887 & 0.05 & -634.98 & 626.00 & 0.011 & $<0.001$ & $>999.999$ \\
\hline $\mathrm{PPB}$ & 8 & WAS & 24 & 0.09247 & 347.09 & 84 & 0.00 & 0.9998 & 0.05 & -690.13 & 690.31 & 1.097 & $<0.001$ & $>999.999$ \\
\hline PPB & 24 & THR & 8 & 9.2710 & 282.94 & 84 & 0.03 & 0.9739 & 0.05 & .55338 & $5 / 1.93$ & $>999.998$ & $<0.001$ & $>989.999$ \\
\hline $\mathrm{PPB}$ & 24 & THR & 24 & 9.2710 & 282.94 & 84 & 0.03 & 0.9739 & 0.05 & -55338 & 571.93 & $>999.99 \theta$ & $<0.001$ & $>999.990$ \\
\hline $\mathrm{FPB}$ & 24 & WAS & 8 & 4.6873 & 245.16 & 84 & 0.02 & 0.9848 & 0.05 & -482.85 & 492.22 & 108.562 & $<0.001$ & $>999.999$ \\
\hline $\mathrm{FPB}$ & 24 & WAS & 24 & 8.2710 & 282.94 & 84 & 0.03 & 0.9739 & 0.05 & $-553,38$ & 571.93 & $>999.999$ & $<0.001$ & $>999.999$ \\
\hline THR & 8 & THR & 24 & $-178 \mathrm{E}-17$ & 345.97 & 84 & -0.00 & 1.0000 & 0.05 & $-687,99$ & 687,99 & 1.000 & $<0.001$ & $>999.098$ \\
\hline THR & 8 & WAS & 8 & -4.5837 & 315.82 & 84 & -0.01 & 0.9885 & 0.05 & $-632,63$ & 623.47 & $c .010$ & $<0,001$ & $>999.999$ \\
\hline THR & 8 & WAS & 24 & $2.35 E-11$ & $3<5.97$ & 84 & 0.00 & 1.0000 & 0.05 & -687.99 & 687.99 & 1.000 & $<0001$ & $>999.898$ \\
\hline $\mathrm{THR}$ & 24 & WAS & 8 & -4.5837 & 315.82 & 84 & -0.01 & 0.9885 & 0.05 & $-632,63$ & 623.47 & 0.010 & $<0.001$ & $>999.999$ \\
\hline THR & 24 & WAS & 24 & $2.35 E-11$ & 345.97 & 84 & 0.00 & 1.0000 & 0.05 & -687.99 & 687.89 & 1.050 & $<0.001$ & $>999.998$ \\
\hline WAS & 8 & WAS & 24 & 4.5837 & 315.82 & 84 & 0.01 & 0.9885 & C. 05 & -823.47 & 632.63 & 87.875 & $<0.001$ & $>999.890$ \\
\hline
\end{tabular}

\begin{tabular}{|c|c|c|c|c|c|c|c|c|c|c|c|c|c|}
\hline \multicolumn{14}{|c|}{ sps*conc Least Squares Means } \\
\hline ps & conc & Estlmate & d Error & $\mathrm{DF}$ & t Valuo & $\operatorname{Pr}>|t|$ & Alpha & ower & Upper & Mean & $\begin{array}{r}\text { Standard } \\
\text { Error } \\
\text { Wean }\end{array}$ & $\begin{array}{c}\text { Lower } \\
\text { Mean }\end{array}$ & $\begin{array}{l}\text { Upper } \\
\text { Mean }\end{array}$ \\
\hline FAM & 0 & -17.1184 & 299.62 & 84 & -0.08 & 0.9548 & 0.05 & .612 .94 & 578.70 & $3.678 \mathrm{E}-8$ & 0.000011 & $637 \mathrm{E}-269$ & 1.0000 \\
\hline FAM : & 50 & -17.1184 & $299.62:$ & 84 & -0.06 & 0.8546 & 0.05 & -612.94 & 578.70 & $3.678 \mathrm{E}-8$ & 0.000011 & $637 \mathrm{E}-269$ & 1.0000 \\
\hline FAM & 100 & -17.1184 & 299.62 & 84 & $-0,06$ & 0.8546 & 0.05 & -612.94 & 578.70 & $3.678 \mathrm{E}-8$ & 0.000011 & $637 \mathrm{E}-269$ & 1.0000 \\
\hline HGE & 0 & -3.1355 & 0.3215 & 84 & 75 & 5 & 05 & -3.7748 & -2.4962 & 0.04167 & 0.01284 & 0.02243 & 0.07313 \\
\hline HGE & 50 & -10.0298 & 214.93 & 84 & -0.05 & 9629 & 0.05 & -437.45 & 17.39 & 0.000044 & 0.009471 & 104E-192 & 1.0000 \\
\hline HGE ? & 100 & -10.0298 & 214.93 & 84 & -0.05 & 0.9628 & 0.05 & -437.45 & 417.39 & 0.000044 & 0.009471 & $104 \mathrm{E}-192$ & 1.0000 \\
\hline $\mathrm{HIC}$ & 0 & -17. & 2 & 84 & -006 & 0.9546 & 0.05 & -312.84 & 578.70 & $3.678 \mathrm{E}-8$ & 0.000011 & $637 E-269$ & 1.0000 \\
\hline HIC & 50 & -17.1184 & 299.62 & 84 & 2.06 & 9546 & 0.05 & -612.94 & 578.70 & $3.678 E-8$ & 0.000011 & $637 E-269$ & 1.0000 \\
\hline $\mathrm{HIC}$ & 100 & -10.2428 & 211.86 & 84 & -0.05 & 0.961 & 0.05 & -431.55 & 411.07 & 0.000036 & 0.007544 & $38 \mathrm{E}-180$ & 1.0000 \\
\hline PIG & 0 & -16.9240 & 303.96 & 84 & .0 .06 & 0.9557 & 0.05 & -621. & 587.54 & $4.467 \mathrm{E}-8$ & 0.000014 & $136 \mathrm{E}-272$ & 1.0000 \\
\hline$P I G$ & 50 & -16.8240 & 303.96 & 84 & $-0,06$ & 0.9557 & 0.05 & -621.39 & 587.54 & $4.467 \mathrm{E}-8$ & 000014 & 272 & 0000 \\
\hline PIG & 100 & -16.8 & 303.96 & 84 & -0.06 & 0.9557 & 0.05 & -621.39 & 587.54 & $4.467 \mathrm{E}-8$ & 0,000014 & $136 \mathrm{E}-272$ & .0000 \\
\hline PPB & 0 & -1 & 301.55 & 84 & .0 .06 & 1 & 0.05 & -616.70 & 582.65 & $4.034 \mathrm{E}-8$ & 0.000012 & $148 \mathrm{E}-270$ & 1.0000 \\
\hline PPB & 60 & -10.1420 & 213.23 & 84 & -0.05 & 0.9622 & 0.05 & -434 & 413.89 & 0000039 & 0.008398 & 276E-191 & 1.0000 \\
\hline PPB & 100 & -10.1420 & 213.23 & 84 & -0.05 & 0.8622 & 0.05 & -43417 & 413.89 & 0.000039 & 0.008398 & 276E-191 & 1.0000 \\
\hline THR & 0 & -17.1184 & 289.62 & 84 & -0.06 & 0.9546 & 0.05 & $-612,94$ & 578.70 & $3.67 \mathrm{BE}-8$ & 0.000011 & $=-269$ & 1.0000 \\
\hline THR & 50 & -17.1184 & 299.62 & 84 & -0.06 & 0.9548 & 0.05 & -612.84 & 578.70 & $3.678 \mathrm{E}-8$ & 0,000011 & $637 \mathrm{E}-263$ & 1.0000 \\
\hline -HR & 100 & -17.1184 & 299.62 & 84 & -0.06 & 0.9546 & 0.05 & -612.94 & 578,70 & $3.6 / 8 E-8$ & $0.000 \mathrm{C} 11$ & $637 E_{-269}$ & 1.0000 \\
\hline WAS & 0 & 184 & 299.62 & 84 & -0.06 & 0.9546 & 0.05 & -612.94 & 578.70 & $3.678 \mathrm{E}-\mathrm{B}$ & 0.000011 & $637 \mathrm{E}-269$ & 1.0000 \\
\hline WAS & 50 & -10.2 & 211.86 & 84 & .05 & 0.9816 & 0.05 & -431.55 & 411.07 & 0.000036 & 0.007544 & $38 E-189$ & 1.0000 \\
\hline WAS & 100 & -17.1184 & 299.62 & 84 & -0.06 & 0.9546 & 0.05 & -612.94 & 578.70 & $3.678 \mathrm{E}-8$ & $0.00 \mathrm{C} 011$ & $637 \mathrm{E}-269$ & 1.0000 \\
\hline
\end{tabular}

\begin{tabular}{|c|c|c|c|c|c|c|c|c|c|c|c|c|c|c|}
\hline \multirow[b]{2}{*}{ sps } & \multicolumn{12}{|c|}{ Differences of sps"conc Least Squares Means } & \multirow[b]{2}{*}{$\begin{array}{r}\text { Lower } \\
\text { Confidence } \\
\text { Limit for Odds } \\
\text { Ratio }\end{array}$} & \multirow[b]{2}{*}{$\begin{array}{r}\text { Upper } \\
\text { Confidence } \\
\text { Limit for Odels } \\
\text { Ratlo }\end{array}$} \\
\hline & cone & sps & conc & Estimate & $\begin{array}{l}\text { Standard } \\
\text { Error }\end{array}$ & $D F$ & t Value & $\begin{array}{r}\operatorname{Pr}> \\
|t|\end{array}$ & Alpha & Lower & Upper & $\begin{array}{l}\text { Odds } \\
\text { Ratio }\end{array}$ & & \\
\hline FAM & 0 & FAM & 50 & $9.1 \mathrm{E}-1 \mathrm{~s}$ & 423.72 & $84:$ & 0.00 & 1.0000 & 0.05 & -842.62 & 812.62 & 1.000 & $<0.001$ & $>999.999$ \\
\hline FAM & 0 & FAM & 100 & $-533 \mathrm{E}-17$ & 423,72 & 84 & -0.00 & 10000 & 0.05 & -842.62 & 842.62 & $1 . \mathrm{coo}$ & $<0.001$ & $>999.989$ \\
\hline AM & 0 & HGE & 0 & -13.9829 & 289.62 & 84 & -0.05 & 09629 & 0.05 & -609.80 & 581.84 & $<0.001$ & $<0.001$ & $>999.999$ \\
\hline
\end{tabular}

file://C:/Users/klweber/AppData/Local/Temp/1/SAS\%20Tcmporary\%20Files/_TD3400_.. 12/10/2014 


\begin{tabular}{|c|c|c|c|c|c|c|c|c|c|c|c|c|c|c|}
\hline FAM & 0 & HGE & 50 & -7.0886 & 368.74 & 84 & -0.020 & 0.8847 & 0.05 & -740.36 & 726.18 & $<0.001$ & $<0.001$ & $>099,999^{\prime}$ \\
\hline FAM & 0 & HGE & 100 & -7.0886 & 368.74 & 84 & -0.020 & 0.0847 & 0.05 & -740.36 & 726.18 & $<0.001$ & $<0.001$ & $>999.999$ \\
\hline FAM & 0 & HIC & 0 & $3.55 E-15$ & 423.72 & 84 & $0.00: 1$ & 1.0000 & 0.05 & .842 .62 & 842.62 & 1.000 & $<0.001$ & $>899.999$ \\
\hline FAM & 0 & HIC & 50 & $3.55 \mathrm{E}-15$ & 423.72 & 84 & $0.00 ! 1$ & 1.0000 & 0.05 & -842.62 & 842.62 & 1.000 & $<0.001$ & $>999.989$ \\
\hline FAM & 0 & $\mathrm{HIC}$ & 100 & -6.8755 & 36695 & 84 & -0.02 & 0.9851 & 0.05 & -736.60 & 722.85 & 0.001 & $<0.001$ & $>999.999$ \\
\hline FAM & 0 & $P \mid G$ & 0 & -0.1943 & 426.81 & 84 & $-0.00 \cdot 0$ & 0.8996 & 0.05 & -848.94 & 848.56 & 0.823 & $<0.001$ & $>099,999$ \\
\hline FAM & 0 & $P \mid G$ & 50 & $-0,1943$ & 426.81 & 84 & -0.000 & 0.9896 & 0.05 & -848.94 & 848.56 & 0.823 & $<0, C 01$ & $>999.999$ \\
\hline FAM & 0 & $\mathrm{PIG}$ & 100 & -0.1043 & 426.81 & 84 & -0.00 & 0.9896 & 0.05 & -848.94 & 848.56 & 0.823 & $<0.001$ & $>999,899$ \\
\hline FAM & 0 & PPB & 0 & -0.09247 & 425.09 & 84 & -0.0010 & 09898 & 0.05 & -845.44 & 845,25 & 0.912 & $<0,001$ & $>999.999$ \\
\hline FAM & 0 & PPB & 50 & -6.9764 & 367.75 & 84 & -0.02 & 0.0849 & 0.05 & -738.28 & 724.33 & $<0.001$ & $<0.001$ & $>999.999$ \\
\hline FAM & 0 & PPB & 100 & -6.9764 & 367.75 & 84 & -0.020 & 0.9849 & 0.05 & .738 .28 & 724,33 & $<0.001$ & $<0.001$ & $>999.990$ \\
\hline FAM & 0 & THR & 0 & $-72 E-18$ & 423.72 & 84 & -0.00 & 1,0000 & 0.05 & -842.62 & 842,62 & 1.000 & $<0.001$ & $>999,999$ \\
\hline FAM & 0 & THR & 50 & $-711 E-17$ & 423.72 & 84 & -0.00 & 1,0000 & 0.05 & -842.62 & 842.62 & 1.060 & $<0001$ & $>999.999$ \\
\hline FAM & 0 & THR & 100 & $-711 \mathrm{E}-17$ & 423.72 & 84 & $-0.0 \mathrm{C}$ & 1.0000 & 0.05 & -842.62 & 842.62 & $1.0 c 0$ & $<0.001$ & $>999.999$ \\
\hline FAM & 0 & WAS & 0 & $1.19 \mathrm{E}-11$ & 423.72 & 84 & 0.00 & 1.0000 & 0.05 & -842.32 & 842.62 & 1.000 & $<0.001$ & $>999.999$ \\
\hline FAM & 0 & WAS & 50 & -6.8755 & 366.95 & 84 & -0.02 & 0.9851 & 0.05 & -736.60 & 722.85 & 0.001 & $<0.001$ & $>099.999$ \\
\hline$=A M$ & 0 & WAS & 100 & $-327 \mathrm{E}-13$ & 423.72 & 84 & -0.00 & 1.0000 & 0.05 & $-842,62$ & 842.62 & 1.000 & $<0.001$ & $>999,999$ \\
\hline FAM & 50 & FAM & 100 & $-592 \mathrm{E}-17$ & 423.72 & 84 & -0.00 & 1.0000 & 0.05 & -842.62 & 842.62 & 1.000 & $<0.001$ & $>999.990$ \\
\hline FAM & 50 & HGE & 0 & $-13.982 \mathrm{~g}$ & 299.62 & 84 & -0.05 & 0.9629 & 0.05 & -609.80 & 581.84 & $<0.001$ & $<0.001$ & $>999.999$ \\
\hline FAM & 50 & $\mathrm{HGE}$ & 50 & -7.0886 & 368.74 & 84 & -0.02 & 0.9847 & 0.05 & -740.36 & 726.18 & $<0.001$ & $<0.001$ & $>999.999$ \\
\hline FAM & 50 & HGE & 100 & -7.0886 & 368.74 & 84 & -0.02 & 0.9847 & 0.05 & -740.36 & 725.18 & $<0.001$ & $<0.001$ & $>999.990$ \\
\hline FAM & 50 & $\mathrm{HIC}$ & 0 & $3.75 \mathrm{E}-15$ & 423.72 & 84 & 0.00 & 1.0000 & 0.05 & -842.62 & 842,62 & 1000 & $<0.001$ & $>999.999$ \\
\hline FAM & 50 & $\mathrm{HIC}$ & 50 & 0 & 423.72 & 84 & 0.00 & 1.0000 & 0.05 & $-842,62$ & 842.62 & 1.000 & $<0.001$ & $>999.999$ \\
\hline FAM & 50 & HIC & 100 & -6.8755 & 386.95 & 84 & -0.02 & 0.9851 & 0.05 & -736.60 & 722.85 & $0.001 i$ & $<0.001$ & $>998.999$ \\
\hline FAM & 50 & PIG & 0 & -0.1943 & 426.81 & 84 & -0.00 & C. 9896 & 0.05 & -848.94 & 348.56 & 0.823 & $<0.001$ & $>998.999$ \\
\hline FAM & 50 & DIG & 50 & $-0.19 / 3$ & 426.81 & 84 & -0.00 & C.9998 & 0.05 & -648.94 & 848.56 & 0.823 & $<C .001$ & $>998.899$ \\
\hline FAM & 50 & PIG & 100 & -0.1943 & 426.81 & $84^{3}$ & -0.00 & 0.9096 & 0.05 & -848.84 & 848.56 & 0.823 & $<0.001$ & $>959.999$ \\
\hline FAM & 50 & PPB & 0 & -0.09247 & 425.09 & 81 & -0.00 & 0.9998 & 0.05 & -845.44 & 845.25 & 0.912 & $<0.001$ & $>999.999$ \\
\hline FAM & 50 & PPB & 50 & -6.9764 & 367.75 & 84 & 0.02 & 0.9849 & 0.05 & -738.28 & 724.33 & $<0,001$ & $<0.001$ & $>999.999$ \\
\hline FAM & 50 & $\mathrm{PPB}$ & 100 & -6.9764 & 367.75 & 84 & -0.02 & 0.9849 & 0.05 & -73828 & 724.33 & $<0.001$ & $<0.001$ & $>999.999$ \\
\hline FAM & 50 & THR & 0 & $-72 E-16$ & 423,72 & 84 & -0.00 & 1.0000 & 0.05 & -842.62 & 842.62 & 1.000 & $<0.001$ & $>909.999$ \\
\hline FAM & 50 & THR & 50 & $-107 \mathrm{E}-16$ & 423.72 & 84 & -0.00 & 1.0000 & 0.05 & 842.62 & 842.62 & 1.000 & $<0.001$ & $>999.999$ \\
\hline FAM & 50 & THR & 100 & $-355[-17$ & 423.72 & 84 & -0.00 & 1,0000 & 0.05 & -842.62 & 842.62 & 1.000 & $<0.001$ & $>999.999$ \\
\hline FAM & 50 & WAS & 0 & 1.19E-11 & 423.72 & 84 & 0.00 & 1.0000 & 0.05 & -842.62 & 842,62 & 1.000 & $<0.001$ & $>999.999$ \\
\hline FAM & 50 & WAS & 50 & -6.8755 & 366.95 & 84 & -0.02 & 0.9851 & 0.05 & -736.60 & 722.85 & C.001! & $<0.001$ & $>999.999$ \\
\hline$F A M$ & 50 & WAS & 100 & $-327 \mathrm{E}-13$ & 423.72 & 84 & -0.00 & 1.0000 & 0.05 & -842.82 & 842.62 & 1.050 & $<0.001$ & $>999.999$ \\
\hline FAM & 100 & HGE & 0 & -13.9829 & 299.62 & 84 & -0.05 & 0.9629 & 0.05 & -609.80 & 581.84 & $<0.001$ & $<0.001$ & $>999.999$ \\
\hline FAM & 100 & HGE & 50 & -7.0886 & 368.74 & 84 & -0.02 & 0.9847 & 0.05 & -740.36 & 726.18 & $<0,001$ & $<0.001$ & $>999.999$ \\
\hline FAM & 100 & HGE & 100 & -7.0888 & 368.74 & 84 & -0.02 & 0.9847 & 0.05 & -740.36 & 726.18 & $<0.001$ & $<0,001$ & $>989.909$ \\
\hline FAM & 100 & $\mathrm{HIC}$ & 0 & $9.23 \mathrm{E}-15$ & 423.72 & 84 & 0.00 & 1.0000 & 0.05 & -842.62 & 842.62 & 1.000 & $<0.001$ & $>999.999$ \\
\hline FAM & 100 & HIC & 50 & $7.11 E-15$ & 423.72 & 84 & 0.00 & 1,0000 & 0.05 & -842.62 & 842.62 & 1.000 & $<0.001$ & $>999.999$ \\
\hline FAM & 100 & $\mathrm{HIC}$ & 100 & -6.8755 & 366.95 & 84 & -0.02 & 0.9851 & 0.05 & 736.60 & 722.85 & 0.001 & $<0.001$ & $>999.999$ \\
\hline FAM & 100 & PIG & 0 & -0.1943 & 426.81 & 84 & -0.00 & 0.0996 & 0.05 & -848.94 & 848.56 & 0.823 & $<0.001$ & $>999.999$ \\
\hline FAM & 100 & $\mathrm{PIG}$ & 50 & -0.1943 & 426.81 & 84 & -0.00 & 0.9996 & 0.05 & -848.94 & 848.56 & 0.823 & $<0.001$ & $>999.999$ \\
\hline FAM & 100 & $\mathrm{PIG}$ & 100 & -0.1943 & 426.81 & 84 & 0.00 & 0.8986 & 0.05 & -848.94 & B48.56 & 0.823 & $<0.001$ & $>999.999$ \\
\hline FAM & 100 & PPB & 0 & -0.09247 & 425.09 & 84 & -0.00 & 0.9098 & 0.05 & -845.44 & 845.25 & 0.912 & $<0.001$ & $>999.999$ \\
\hline FAM & 100 & $\mathrm{PP3}$ & 50 & -6.9764 & 367.75 & 84 & 0.02 & 0.9849 & 0.05 & -738.26 & 724.33 & $<0.001$ & $<0.001$ & $>999.999$ \\
\hline FAM & 100 & PPB & 100 & -6.9704 & 367.75 & 64 & -0.02 & 08849 & 0.05 & -738.28 & 724.33 & $<0.001$ & $<0.001$ & $>999.999$ \\
\hline FAM & 100 & THR & 0 & $-902 E-19$ & 42372 & 84 & -0.00 & 1.0000 & 0.05 & -842.62 & 842.62 & 1.000 & $<0.001$ & $>999.999$ \\
\hline
\end{tabular}

file://C:/Users/klweber/AppData/Local/Lemp/1/SAS\%20Temporary\%20Files/_TD3400_.. 12/10/2014 
AEH-13-PSEUDO-06

\begin{tabular}{|c|c|c|c|c|c|c|c|c|c|c|c|c|c|c|}
\hline & 100 & THR & 50 & $-355 \mathrm{E}-17$ & 423.72 & 84 & 0.00 & .0000 & 0.05 & -842.62 & 842.62 & 1.000 & $<0.001$ & $>999.999$ \\
\hline FAM & 100 & THR & 100 & 0 & 423.72 & 84 & 0.00 & 1.0000 & 0.05 & -842.62 & 842.62 & 1.000 & $<0.001$ & $>999.999$ \\
\hline FAM & 100 & WAS & 0 & $1.19 \mathrm{E}-11$ & 423.72 & 84 & 0.00 & 1.0000 & c.05 & -842.62 & 842.62 & 1.000 & $<0.001$ & $>999.999$ \\
\hline FAM & 100 & WAS & 50 & -8.8755 & 366.95 & 84 & -0.02 & 0.9851 & 0.05 & -736.60 & 722.85 & $0.001 !$ & $<0.001$ & $>999.999$ \\
\hline FAM & 100 & WAS & 100 & $-327 E-13$ & 423.72 & 84 & -0.00 & 1.0000 & 0.05 & -842.62 & 842.62 & 1.000 & $<0.001$ & $>999.999$ \\
\hline HGE & 0 & $\mathrm{HGE}$ & 50 & 6.8943 & 214.93 & 84 & 0.03 & 0.9745 & 0.05 & -420.53 & 434,31 & 986,608 & $<0,001$ & $>890.909$ \\
\hline HGE & 0 & HGE & 100 & 6.6943 & 214.93 & 84 & 0.03 & 0.9745 & 0.05 & -420.53 & 431.31 & 886.608 & $<0.001$ & $>999.999$ \\
\hline HGE & 0 & HIC & 0 & 13.9829 & 299.62 & 84 & 0.05 & 0.9629 & 0.05 & -581.84 & 609.80 & $>999.999$ & $<0.001$ & $>099.999$ \\
\hline HGE & 0 & $\mathrm{HIC}$ & 50 & 13.9829 & 299.62 & $84^{i}$ & 0.05 & 0.9629 & 0.05 & -581.84 & 608.80 & $>999.999$ & $<0,001$ & $>890.999$ \\
\hline HGE & 0 & $\mathrm{HIC}$ & 100 & 7.1073 & 211.26 & 84 & 0.03 & 0.8733 & 0.05 & -414.20 & 428.42 & $>999.999$ & $<0.001$ & $>999.999$ \\
\hline $\mathrm{HGE}$ & 0 & $\mathrm{PIG}$ & 0 & 13.7885 & 303.96 & 84 & 0.05 & 0.9639 & 0.05 & -590.67 & 618.25 & $>999.999$ & $<0.0 c 1$ & $>089.998$ \\
\hline $\mathrm{HGE}$ & 0 & PIG & 50 & 13.7885 & 303.98 & 84 & 0.05 & 0.9639 & 0.05 & -590.67 & 618.25 & $>999.999$ & $<0.001$ & $>999.998$ \\
\hline HGE & 0 & PIG & 100 & 13.7885 & 303.96 & 84 & 0.05 & 0.9638 & 0.05 & -590.67 & 618.25 & $>999.999$ & $<0.001$ & $>999.999$ \\
\hline HGE & 0 & PP3 & 0 & 13.8904 & 301.55 & 84 & 0.05 & 0.8634 & 0.05 & -585.78 & 613.56 & $>999,999$ & $<0.001$ & $>999.989$ \\
\hline HGE & 0 & PPB & 50 & 7.0065 & 213.23 & 84 & 0.03 & 0.9739 & 0.05 & -417.03 & 431.04 & $>998.999$ & $<0.001$ & $>999.998$ \\
\hline HGE & 0 & PPB & 100 & 7.0085 & 21323 & 84 & $0.03:$ & 0.9739 & 0.05 & -417.03 & 431.04 & $>999.999$ & $<0.001$ & $>009.998$ \\
\hline HGE & 0 & THR & 0 & 13.9829 & 299.62 & 84 & 0.05 & 0.9629 & 0.05 & -581.84 & 609.80 & $>099.988$ & $<0.001$ & $>999.999$ \\
\hline HGE & 0 & THR & 50 & 13.9829 & 298.62 & 84 & 0.05 & 0.9629 & 0.05 & -581.84 & 609.80 & $>999.999$ & $<0,001$ & $>999999$ \\
\hline $\mathrm{HGE}$ & 0 & THR & 100 & 13.9829 & 299,62 & 84 & 0.05 & 0.9629 & 0.05 & .581 .84 & 609.80 & $>999.999$ & $<0.001$ & $>999,999$ \\
\hline HGE & 0 & WAS & 0 & 13.9829 & 299.62 & 84 & 0.05 & 0.8628 & 0.05 & -581.84 & 600.80 & $>999.989$ & $<0001$ & $>999.999$ \\
\hline HGE & 0 & WAS & 50 & 7.1073 & 211.86 & 84 & 0.03 & 0.9733 & 0.05 & -414.20 & 426.42 & $>999.998$ & $<0.001$ & $>899.999$ \\
\hline $\mathrm{HGE}$ & 0 & WAS & 100 & 13.9829 & 299.62 & 84 & 0.05 & 0.9628 & 0.05 & -581.84 & 600.80 & $>999.899$ & $<0,001$ & $>999.999$ \\
\hline HGE & 50 & HGE & 100 & $1.46 \mathrm{E}-11$ & 303.86 & 84 & 0.00 & 1.0000 & 0.05 & -604.46 & 604.46 & 1.000 & $<0.001$ & $>999.999$ \\
\hline HGE & 50 & HIC & 0 & $7.0886 !$ & 368.74 & 84 & 0.02 & 0.9847 & 0.05 & -726.18 & 740.36 & $>999.999$ & $<0.001$ & $>999,999$ \\
\hline$-1 G E$ & 50 & HIC & 50 & 7.0886 & 368.74 & 84 & 0.02 & 0.0847 & 0.05 & -726.18 & 740,36 & $>999,999$ & $<0.001$ & $>999.999$ \\
\hline HCE & 50 & $\mathrm{HIC}$ & 100 & 0.2131 & 301.80 & 84 & 0.00 & 0.9994 & 0.05 & $-599,94$ & 600.37 & 1.237 & $<0.001$ & $>999.909$ \\
\hline $\mathrm{HGE}$ & 50 & $\mathrm{PIG}$ & 0 & 8.8943 & 372.28 & 84 & 0.02 & 0.0853 & 0.05 & 733.42 & 747.21 & 986.608 & $<0.001$ & $>999.999$ \\
\hline HGE & 50 & PIG & 50 & 6.8843 & 372.28 & 84 & 0.021 & 0.9853 & 0.05 & $\begin{array}{r}-733.42 \\
\end{array}$ & 747.21 & 986,608 & $<0.001$ & $>999.999$ \\
\hline FGE & 50 & PIG & 100 & 6.8943 & 372.28 & 84 & 0.02 & 0.9853 & 0.05 & -733.42 & 747.21 & 986.608 & $<0.001$ & $>999.999$ \\
\hline HGE & 50 & PPB & 0 & 6.9961 & 370.31 & 84 & 0.02 & 0.9850 & 0.05 & -729.41 & 743,40 & $>999.999$ & $<0.001$ & $>998.990$ \\
\hline HGE & 50 & PPB & 50 & 0.1122 & 302.76 & 84 & 0.00 & 0.9997 & 0.05 & -601.96 & 602.18 & 1.119 & $<0.001$ & $>999.990$ \\
\hline HGE & 50 & PPB & 100 & 0.1122 & 302.76 & 84 & 0.00 & 0.0987 & 0.05 & -601.96 & 502,18 & 1.119 & $<0.001$ & $>999.999$ \\
\hline $\mathrm{HGE}$ & 50 & $T H R$ & 0 & 7.0886 & 368.74 & 84 & 0.02 & 0.9847 & 0.05 & -726.18 & 740.36 & $>999.999$ & $<0.001$ & $>998.999$ \\
\hline HOE & 50 & THR & 50 & 7.0886 & 368.74 & 84 & 0.02 & 0.9847 & 0.05 & -726.18 & 740.36 & $>999.899$ & $<c .001$ & $>989.999$ \\
\hline $\mathrm{HGE}$ & 50 & THR & 100 & 7.0886 & 368.74 & 84 & 0.02 & 0.9847 & 0.05 & -726.18 & 740.36 & $>999.999$ & $<0.001$ & $>999.999$ \\
\hline HGE & 50 & WAS & 0 & 7.0886 & $3 e 8.74$ & 84 & 0.02 & 0.9847 & 0.05 & -726.18 & 740.36 & $>999.999$ & $<0.001$ & $>999.999$ \\
\hline HGE & 50 & WAS & 50 & 0.2131 & 301.80 & 84 & 0.00 & 0.9994 & 0.05 & -599.84 & 600.37 & 1.237 & $<0.001$ & $>999.990$ \\
\hline HGE & 50 & WAS & 100 & 7.0883 & 368.74 & 81 & 0.02 & 0.9847 & 0.05 & -726.18 & 740.36 & $>999.999$ & $<0.001$ & $>999.999$ \\
\hline HGE & 100 & $\mathrm{HIC}$ & 0 & 70886 & 368.74 & 64 & 0.02 & 0.9847 & 0.05 & -726.18 & 740.36 & $>999.999$ & $<0.001$ & $>999.999$ \\
\hline HGE & 100 & HIC & 50 & 7.0886 & 368.74 & 84 & 0.02 & 0.9847 & 0.05 & -726.18 & 740.36 & $>999.999$ & $<0.001$ & $>999.899$ \\
\hline HGE : & 100 & $\mathrm{HIC}$ & 100 & $0.2: 31$ & 301,80 & 84 & 0.00 & 0.9984 & 0.05 & -598.94 & $6 \mathrm{CO} .37$ & 1.237 & $<0.001$ & $>999.999$ \\
\hline HGE & 100 & PIG & 0 & 6.8943 & 372.28 & 84 & 0.02 & 0.9853 & 0.05 & . 733.42 & 747.21 & 986.608 & $<0.001$ & $>999.969$ \\
\hline HGE & 100 & PIG & 50 & 3.8943 & 372,28 & 84 & 0.02 & 0.9853 & 0.05 & -733.42 & 747.21 & 986.608 & $<0.001$ & $>999.999$ \\
\hline$H G E$ & 100 & PL & 100 & ล.8943! & 372.28 & 84 & 0.02 & 0.9853 & 0.05 & -733.42 & 747.21 & 886.608 & $<0.001$ & $>990.999$ \\
\hline HGE & 100 & PP8 & 0 & $6.9961 i$ & 370.31 & 84 & 0.02 & 0.9050 & 0.05 & -729.41 & 743.40 & $>899,998$ & $<0.001$ & $>999.999$ \\
\hline HGE & 100 & $P P B$ & 50 & 0.1122 & 302.76 & 84 & C.00 & 0.9997 & 0.05 & -601.96 & 602.18 & 1.119 & $<0.001$ & $>989.989$ \\
\hline HGE & 100 & PPB & 100 & 0.1122 & 302.76 & 84 & 0.00 & 0.9997 & 0.05 & -601.96 & 602,18 & 1.119 & $<0.001$ & $>999.999$ \\
\hline HGF & 100 & THR & 0 & 7.0886 & 368.74 & 84 & 0.02 & 0.9847 & 0.05 & -726.18 & 740.36 & $>999.988$ & $<0.001$ & $>999.998$ \\
\hline HGE & 100 & THR & 50 & 7.0886 & 368.74 & 84 & 0.02 & 0.9847 & 0.05 & -726.18 & 740.36 & $>999.999$ & $<0,001$ & $>999.998$ \\
\hline
\end{tabular}

file://C:_Lsers/klweber/AppData/l,ocal/Temp/1/SAS\%20Temporary\%20Files/_TD3400_... 12/10/2014 


\begin{tabular}{|c|c|c|c|c|c|c|c|c|c|c|c|c|c|c|}
\hline & 100 & THR & 100 & 7.0886 & 368.74 & 84 & 0.02 & 0.5847 & 0.05 & .726 .10 & 740.36 & $>998.999$ & $<0.001$ & $>999.999$ \\
\hline HGE & 100 & WAS & 0 & 7.0886 & 368.74 & 84 & 0.02 & 0.5847 & 0.05 & -726.18 & 740.36 & $>099.999$ & $<0.001$ & $>999.999$ \\
\hline HGE & 100 & WAS & 50 & 0.2131 & $301.80 !$ & 84 & 0.00 & 0.9994 & 0.05 & -599.94 & 600.37 & 1.237 & $<0.001$ & $>999.999$ \\
\hline HGE & 100 & WAS & 100 & 7.0885 & 368.74 & 84 & 0.02 & 0.9847 & 0.05 & .726 .18 & 740.38 & $>999.999$ & $<0.001$ & $>999.999$ \\
\hline HIC & 0 & $\mathrm{H} \mid \mathrm{C}$ & 50 & 0 & 423.72 & 84 & 0.00 & 1.0000 & 0.05 & -842.62 & 842.62 & 1.000 & $<0.001$ & $>999.999$ \\
\hline $\mathrm{HIC}$ & 0 & $\mathrm{H} \mid \mathrm{C}$ & 100 & -6.8755 & 366,95 & 84 & -0.02 & 0.9851 & 0.05 & 736.60 & 722.85 & 0.001 & $<0.001$ & $>999.999$ \\
\hline $\mathrm{HIC}$ & 0 & PIG & 0 & -0.1943 & 426.81 & 84 & -0.00 & 0.9996 & 0.05 & -848.94 & 848.56 & 0.823 & $<0.0<1$ & $>999.990$ \\
\hline $\mathrm{HIC}$ & 0 & PIG & 50 & $-C .1043$ & 42681 & 84 & -0.00 & 0.8996 & 0.05 & -848.94 & 848.56 & 0.823 & $<0.001$ & $>999.999$ \\
\hline $\mathrm{HIC}$ & 0 & PIG & 100 & -0.1943 & 42681 & 84 & -0.00 & 0.9996 & 0.05 & -848.94 & 848.56 & 0.823 & $<0.001$ & $>990.999$ \\
\hline $\mathrm{HIC}$ & 0 & PPB & 0 & -0.09247 & 425.09 & 84 & -0.00 & 0.9998 & 0.05 & -845.44 & 845.25 & 0.912 & $<0.001$ & $>999.999$ \\
\hline $\mathrm{HICC}$ & 0 & $\mathrm{PPB}$ & 50 & -6.9764 & 367.75 & 84 & -0.02 & 0.9849 & 0.05 & .738 .28 & 724.33 & $<0.001$ & $<0.001$ & $>\theta \theta 9.99 \theta$ \\
\hline $\mathrm{HIC}$ & 0 & PPB & 100 & -6.9734 & 367.75 & 84 & -0.02 & 09849 & 0.05 & -738.28 & 724.33 & $<0.001$ & $<0.001$ & $>999999$ \\
\hline HIC & 0 & THR & 0 & $-107 E-16$ & 423.72 & 84 & -0.00 & 10000 & 0.05 & -842.62 & 842.62 & 1.000 & $<0.001$ & $>999.999$ \\
\hline $\mathrm{HIC}$ & 0 & THR & 50 & $-107 \mathrm{E}-16$ & 423.72 & 84 & -0.00 & 1.0000 & 0.05 & -842.62 & 842.62 & 1.000 & $<0.001$ & $>999.999$ \\
\hline $\mathrm{HIC}$ & 0 & THR & 100 & $-711 \mathrm{E}-17$ & 423.72 & 84 & -0.00 & 1.0000 & 0.05 & 842.62 & 842.62 & 1.000 & $<0001$ & $>999.899$ \\
\hline $\mathrm{HIC}$ & 0 & WAS & 0 & $1.18 \mathrm{E}-11$ & 423.72 & 84 & 0.08 & 1,0000 & 0.05 & -842.62 & 842.62 & 1.000 & $<0.001$ & $>999.999$ \\
\hline $\mathrm{HIC}$ & 0 & WAS & 50 & -6.8755 & 366.95 & 84 & -0.02 & 0.9851 & 0.05 & -736.60 & 722.85 & 0.001 & $<0.001$ & $>999.999$ \\
\hline $\mathrm{HIC}$ & 0 & WAS & 100 & $-327 \mathrm{E}-13$ & 423.72 & 84 & -0.00 & 1.0000 & 0.05 & $-842.62 \mid$ & 842.62 & 1.600 & $<0.001$ & $>989.999$ \\
\hline $\mathrm{HIC}$ & 50 & $\mathrm{HIC}$ & 100 & -6.8756 & 368.95 & 84 & $-0.62 !$ & 0.9851 & 0.05 & -736.80 & 722.85 & 0.001 & $<0.001$ & $>999.989$ \\
\hline 卅C & 50 & $P \mid G$ & 0 & -0.1943 & 426.81 & 84 & -0.00 & 0.9996 & 0.05 & -848.94 & 848.56 & 0.823 & $<0.001$ & $>999.999$ \\
\hline HIC & 50 & $P^{\prime} G$ & 50 & -0.1943 & 426.81 & 84 & -0.00 & 0.9996 & 0.05 & -848.94 & 648.56 & 0.823 & $<0.001$ & $>999.9 \theta 8$ \\
\hline $\mathrm{HIC}$ & 50 & $P . G$ & 100 & -0.1943 & 426.81 & 84 & -0.00 & 0.9998 & 0.05 & -848.94 & 848.56 & 0.823 & $<0.001$ & $>998.999$ \\
\hline $\mathrm{HIC}$ & 50 & PPB & 0 & -0.09247 & 425.09 & 84 & $-0,00$ & 0.8998 & 0.05 & -845.44 & 845.25 & 0.912 & $<0.001$ & $>999.990$ \\
\hline $\mathrm{HIC}$ & 50 & PPB & 50 & -6.9764 & 367.75 & 84 & -0.02 & 0.9849 & 0.05 & -738.28 & 724.33 & $<000$ & $<0.001$ & $>999.098$ \\
\hline HIC & 50 & PPB & 100 & -8.9764 & 367.75 & 84 & -0.02 & 0.9849 & 0.05 & -738.28 & 724.33 & $<0.001$ & $<0.001$ & $>999.999$ \\
\hline HC & 50 & $T H R$ & 0 & $-116 E-16$ & 423.72 & 84 & .000 & 1.0000 & 0.05 & -842.62 & 842.62 & 1.000 & $<0.001$ & $>999.999$ \\
\hline HIC & 50 & THR & 50 & $-124 E+16$ & 423.72 & 84 & -0.00 & 1.0000 & 0.05 & -842.62 & 842,62 & 1.000 & $<0.001$ & $>999.999$ \\
\hline $\mathrm{HIC}$ & 50 & THR & 100 & $-755 \mathrm{E}-17$ & 423.72 & 84 & $-0,00$ & 1.0000 & 2.05 & -842.62 & 342.62 & 1.000 & $<0.001$ & $>998.999$ \\
\hline $\mathrm{HIC}$ & 50 & WAS & 0 & 1.19E-11 & 423.72 & 84 & 0.00 & 1.0000 & 0.05 & -842.62 & 842.62 & 1.000 & $<0.001$ & $>985.999$ \\
\hline $\mathrm{HIC}$ & 50 & WAS & 50 & -6.8755 & 366.95 & 84 & -0.02 & 0.9851 & 0.05 & $-736,60$ & 722.85 & 0.001 & $<0.001$ & $>999.999$ \\
\hline HIC & 50 & WAS & 100 & $-327 E-13$ & 423.72 & 84 & -0.00 & 1.0000 & 0.05 & $-842.62 \mid$ & 842.62 & 1.000 & $<\mathrm{c} .001$ & $>898.099$ \\
\hline $\mathrm{HIC}$ & 100 & PG & 0 & 6.6812 & 370.51 & 84 & 0.02 & 0.8857 & 0.05 & -730.12 & 743.48 & 797.276 & $<0.021$ & $>999.999$ \\
\hline HIC & 100 & PIG & 50 & 6.6812 & 370.51 & 84 & 0,02 & 0.9857 & 0.05 & .73012 & 743.48 & 787.276 & $<0.001$ & $>899.999$ \\
\hline $\mathrm{HIC}$ & 100 & PIG & 100 & 6.6812 & 370.51 & 84 & 0.02 & 0.9857 & 0.05 & -730.12 & 743.48 & 797.276 & $<0,001$ & $>999.999$ \\
\hline HIC & 100 & PPB & 0 & 67831 & 368.54 & 84 & 0.02 & 0.9854 & 0.05 & $-726,09$ & 738.66 & 882.773 & $<0.001$ & $>999.999$ \\
\hline HIC & 100 & PPB & 50 & .01008 & 300.58 & 84 & -0.00 & 0.9997 & 0.05 & $-597,85$ & 597.65 & 0.904 & $<0.001$ & $>999.999$ \\
\hline $\mathrm{HIC}$ & 100 & $\mathrm{PPB}$ & 100 & -0.1008 & 300.59 & 84 & -0.00 & 0,9997 & 0.05 & -597.85 & 597.65 & 0.904 & $<0.001$ & $>999.999$ \\
\hline HIC & 100 & THR & 0 & 6.8755 & 366.95 & 84 & 0.02 & 0.9851 & 0.05 & $-722,85$ & 736.60 & 968.300 & $<0.001$ & $>999.999$ \\
\hline $\mathrm{HIC}$ & 100 & THR & 50 & 6.8755 & 366.95 & 84 & 0.02 & 0.8851 & 0.05 & -722.85 & 736.60 & 968.300 & $<0.001$ & $>999.999$ \\
\hline $\mathrm{H} \mid \mathrm{C}$ & 100 & THR & 100 & 6.8755 & 366.95 & 84 & 0.02 & 0.9851 & 0.05 & -722.85 & 736.60 & 968.300 & $<0.001$ & $>999.999$ \\
\hline $\mathrm{HIC}$ & 100 & WAS & 0 & $6.8755^{\circ}$ & 366.95 & 84 & 0.02 & 0.9851 & 0.05 & -722.85 & 736.60 & 968.300 & $<0.001$ & $>999.998$ \\
\hline $\mathrm{HIC}$ & 100 & WAS & 50 & $4.79 E-11$ & 299.62 & 84 & 0.00 & 1.0000 & 0.05 & -595.82 & 585.82 & 1.000 & $<0.001$ & $>999.998$ \\
\hline $\mathrm{HIC}$ & 100 & WAS & 100 & 6.8755 & 366.95 & 84 & 0.02 & 0.9851 & 0.05 & -722.85 & 736.60 & 868.300 & $<0.001$ & $>999.999$ \\
\hline PIG & 0 & PIC & 50 & $1.97 \mathrm{E}-15$ & 429.87 & 84 & 0.00 & $\therefore .0000$ & 0.05 & -854.84 & 854.84 & 1.000 & $<0.001$ & $>898.999$ \\
\hline $\mathrm{PIG}$ & 0 & $\mathrm{PIS}$ & 100 & $1.08 \mathrm{E}-15$ & 429.87 & 84 & 0.00 & 1.0000 & 0.05 & -854.84 & 854.84 & 1.300 & $<0.001$ & $>999.999$ \\
\hline PIG & 0 & $\mathrm{PPB}$ & 0 & 0.1019 & 428.17 & 84 & C. 00 & 0.9998 & 0.05 & -851.36 & 851.56 & 1.107 & $<0.001$ & $>999.999$ \\
\hline PIG & 0 & $\mathrm{PPB}$ & 50 & -6.7820 & 371.30 & 84 & -0.02 & 0.9855 & 0.05 & -745.14 & 731.58 & 0.001 & $<0,001$ & $>998.999$ \\
\hline PIG & 0 & PPB & 100 & -6.7820 & 371.30 & 84 & -0.02 & 0.9855 & 0.05 & .745 .14 & 731.58 & 0.001 & $<0.001$ & $>999.999$ \\
\hline $\mathrm{PIG}$ & 0 & THR & 0 & 0.1943 & 426,81 & 84 & 0.00 & 0.9998 & 0.05 & -848.56 & 848.94 & 1.215 & $<0.001$ & $>999.999$ \\
\hline
\end{tabular}

file://C:/Users/klweber/AppData/Local/Temp/1/SAS\%20Temporary\%20Files/_TD3400_.. 12/10/2014 


\section{AEH-13-PSEUDO-06}

\begin{tabular}{|c|c|c|c|c|c|c|c|c|c|c|c|c|c|c|}
\hline & 0 & THR & 50 & 0.1943 & 426.81 & 84 & 0.00 & 0.9996 & 0.05 & -848.56 & 848.91 & 1.215 & $<0.001$ & $>999.990$ \\
\hline PIG & 0 & THR & 100 & 0.1943 & 426.81 & 84 & $0.00: 0$ & 0.9996 & 0.05 & -848.56 & 848.94 & 1.215 & $<0.001$ & $>999.999$ \\
\hline PIG & 0 & WAS & 0 & 0.1943 & 426.81 & 84 & 0.000 & 0.9996 & 0.05 & -848.56 & 848.94 & 1.215 & $<0.001$ & $>999.999$ \\
\hline PIG & 0 & WAS & 50 & -6.6812 & 370.51 & 84 & -0.02 & 0.9857 & 0.05 & -743.48 & 730.12 & 0.001 & $<0.001$ & $>999.999$ \\
\hline $\mathrm{P} \mid \mathrm{G}$ & 0 & WAS & 100 & 0.1943 & 426.81 & 84 & 0.00 & 0.9996 & 0.05 & -848.56 & $8<8.94$ & 1.215 & $<0.001$ & $>099.998$ \\
\hline$P \mid G$ & 50 & PIG & 100 & $-888 E-18$ & 429.87 & 84 & $-0.00 \vdots 1$ & 1,0000 & 0.05 & $-854,84$ & 854,84 & 1.000 & $<0.001$ & $>999.999$ \\
\hline$P \mid G$ & 50 & PPB & 0 & 0.1019 & 428.17 & 84 & $0.00: 0$ & 0.9998 & 0.05 & -851.36 & $85 \div .56$ & 1.107 & $<0.001$ & $>999.999$ \\
\hline$P G$ & 50 & PPB & 50 & -6.7820 & 371.30 & 84 & -0.02 & 0.8855 & 0.05 & -745.14 & 731.58 & $0.001 !$ & $<0.001$ & $>999.899$ \\
\hline$P, G$ & 50 & PPS & 100 & .6 .7820 & $37130^{\circ}$ & 84 & $-0.02+0$ & 0.8855 & 0.05 & -745.14 & 731.58 & 0.001 & $<0.001$ & $>999.999$ \\
\hline $\mathrm{P} \mid \mathrm{G}$ & 50 & THR & 0 & C. 1943 & 426.81 & 84 & 0.00 & 0.9996 & 0.05 & -848.56 & 848.94 & 1.215 & $<0.001$ & $>990.998$ \\
\hline$P \mid G$ & 50 & THR & 50 & $0.1943^{\prime}$ & $426,8^{\prime}$ & 84 & 0.00 & 09996 & 0.05 & -848.56 & 848.94 & .215 & $<0,001$ & $>999$ 099 \\
\hline $\mathrm{PIG}$ & 50 & THR & 100 & 0.1943 & 426.81 & 84 & 0.00 & 0.9996 & 0.05 & -848.56 & 848.94 & 1.215 & $<0.001$ & $>999.899$ \\
\hline PIG & 50 & WAS & 0 & 0.1943 & 426.81 & 84 & 0.00 & 0.9996 & 0.05 & -848.58 & 846.94 & 1.215 & $<0.001$ & $>999.999$ \\
\hline PIG & 50 & WAS & 50 & -6.6812 & 370.51 & 84 & -0.02 & 0.9857 & 0.05 & -743.48 & 730.12 & 0.001 & $<0.001$ & $>999.999$ \\
\hline$P \mid G$ & 50 & WAS & 100 & 0.1843 & 426.81 & 84 & 0.00 & 0.9996 & 0.05 & -848.56 & 848.94 & 1.215 & $<0,001$ & $>909.999$ \\
\hline IG & 100 & PPB & 0 & 0.1019 & 428.17 & 84 & 0.00 & 0.9998 & 0.05 & -851.36 & 851.56 & 1.107 & $<0,001$ & $>999.999$ \\
\hline PIG & 100 & $P{ }_{B}$ & 50 & $-6.782 \mathrm{C}$ & 371.30 & 84 & -0.02 & 0.9855 & 0.05 & -745.14 & 731.58 & 0.001 & $<0.001$ & $>899.999$ \\
\hline PIG & 100 & PPB & 100 & -6.7820 & 371.30 & 84 & -0.02 & 0.9855 & 0.05 & -745.14 & 731,58 & 0.001 & $<0.001$ & $>099.999$ \\
\hline PIG & 100 & THR & 0 & 0.1943 & 428.81 & 84 & $0.00: 0$ & 0.9996 & 0.05 & $-848,56$ & 843.94 & 1.215 & $<0.001$ & $>999.999$ \\
\hline PIG & 100 & THR & 50 & 0.1943 & 426.81 & 84 & 000 & 0.9998 & 0.05 & -848.56 & 848.84 & $1.2^{\wedge} 5$ & $<0.001$ & $>999.099$ \\
\hline PIG & 100 & THR & 100 & 0.1943 & 426.81 & 84 & 0.00 & 0.9996 & 0.05 & $-848,56$ & 848.94 & 1.215 & $<0.001$ & $>999.999$ \\
\hline FIG & 100 & WAS & 0 & 0.1943 & 426.81 & 84 & 0.00 & 0.9996 & 0.05 & -848.66 & 348.94 & 1.215 & $<0.001$ & $>999.990$ \\
\hline PIG & 100 & WAS & 50 & -6.6812 & 370.51 & 84 & -0.02 & 0.9857 & 0.05 & -743.48 & 730.12 & 0.001 & $<0.001$ & $>999.999$ \\
\hline $\mathrm{PIO}$ & 100 & WAS & 100 & 0.1943 & 426.81 & 84 & 0.00 & 0.9998 & 0.05 & -848.56 & 848.94 & 1.215 & $<c, 001$ & $>989.909$ \\
\hline $\mathrm{PPB}$ & 0 & PPB & 50 & -6.8839 & 369.33 & 84 & -0.02 & 0.9852 & 0.05 & -74133 & 727.56 & 0.001 & $<0.001$ & $>989.999$ \\
\hline PPB & 0 & PPB & 100 & -6.8839 & 369.33 & 84 & -0.02 & 0.9852 & 0.05 & -741.33 & 727.56 & 0.001 & $<0.001$ & $>999.999$ \\
\hline PPB & 0 & THR & 0 & 0.09247 & 425.09 & 84 & 0.00 & 0.9998 & 0.05 & -815.25 & 845.44 & 1.097 & $<0.001$ & $>999.999$ \\
\hline PPB & 0 & THR & 50 & 0.08247 & 425.09 & 84 & 0.00 & 0.9998 & 0.05 & -845.25 & 845.44 & 1.097 & $<0.001$ & $>999.999$ \\
\hline PPB & 0 & THR & 100 & 009247 & 425.09 & 84 & 0.00 & 0.9998 & 0.05 & -845.25 & 845.44 & 1.097 & $<0.001$ & $>999.999$ \\
\hline $\mathrm{PPB}$ & 0 & WAS: & 0 & 0.09247 & 425.09 & 84 & 0.00 & 0.9998 & 0.05 & -845.25 & 845.44 & 1.097 & $<0.001$ & $>999.999$ \\
\hline $\mathrm{PPB}$ & 0 & WAS & 50 & -6.7831 & 368.54 & 84 & $-\mathrm{c} .02$ & 0.9854 & 0.05 & .739 .66 & 726.09 & 0.001 & $<0.001$ & $>999.999$ \\
\hline PPB & 0 & WAS & 100 & 0.09247 & 425.09 & 84 & 0.00 & 0.9998 & 0.05 & -845.25 & 845.44 & 1.097 & $<0.001$ & $>999.999$ \\
\hline $\mathrm{PPB}$ & 50 & PPB & 100 & $1.08 E-15$ & 301.55 & 84 & 0.00 & 1.0000 & 0.05 & -599.67 & 599.67 & 1.000 & $<0.001$ & $>999.999$ \\
\hline $\mathrm{PPB}$ & 50 & THR & 0 & 6.9764 & 367.75 & 84 & 0.02 & 0.9849 & 0.05 & -724.33 & 738.28 & $>999.999$ & $<0.001$ & $>999.998$ \\
\hline PPB & 50 & THR & 50 & 6.9764 & 367.75 & 84 & 0.02 & 0.9849 & 0.05 & -724.33 & 738.28 & $>999.999$ & $<0.001$ & $>999.999$ \\
\hline $\mathrm{PPB}$ & 50 & TH? & 100 & 6.9764 & 367.75 & 84 & 0.02 & 0.9849 & 0.05 & -724.33 & 738.28 & $>999.999$ & $<0,001$ & $>999.999$ \\
\hline P?B & 50 & WAS & 0 & 6.9764 & 367.75 & 84 & 0.02 & 0.9849 & 0.05 & -724.33 & 738.28 & $>999.999$ & $<0.001$ & $>999,999$ \\
\hline PPB & 50 & WAS & 50 & 0.1008 & 300.50 & 84 & 0.00 & 0.9997 & 0.05 & -597.65 & 597.85 & 1.106 & $<0001$ & $>999.999$ \\
\hline PPB & 50 & WAS & 100 & 6.9764 & 36775 & 84 & 0.02 & 0.9849 & 0.05 & .724 .33 & 738.28 & $>999.969$ & $<0.001$ & $>999.999$ \\
\hline $\mathrm{PPB}$ & 100 & THR & 0 & 6.9764 & 367.75 & 84 & 0.02 & 09849 & 0.05 & -724.33 & 738.28 & $>999.999$ & $<0.001$ & $>999.999$ \\
\hline PPB & 100 & THR & 50 & 6.9784 & 367.75 & 84 & 0.02 & 0.9849 & 0.05 & -724.33 & 738.28 & $>999.989$ & $<0.001$ & $>999.999$ \\
\hline $\mathrm{PPB}$ & 100 & THR & 100 & 6.9764 & 367.75 & 84 & 0.02 & 0.9849 & 0.05 & -724.33 & 738.28 & $>999.999$ & $<0.001$ & $>999.999$ \\
\hline PPB & 100 & WAS & 0 & 6.9764 & 367.75 & 84 & 0.02 & 0.9848 & 0.05 & -724.33 & 738.28 & $>999.998$ & $<0.001$ & $>999.909$ \\
\hline PPB & 100 & WAS & 50 & 0,1008 & 300.59 & 84 & 0.60 & 0.9997 & 0.05 & -597.65 & 597.85 & 1.106 & $<0.001$ & $>999.999$ \\
\hline PPB & 100 & WAS & 100 & 6.9764 & 367.75 & 84 & 0.02 & 0.9848 & 0.05 & -724.33 & 738.28 & $>999999$ & $<0.001$ & $>999.999$ \\
\hline $\mathrm{THR}$ & 0 & THR & 50 & $-178 E-17$ & 423.72 & 84 & $-0,00$ & 1.0000 & 0.05 & $-842,62$ & 842.62 & 1,000 & $<0.001$ & $>989.999$ \\
\hline THR & 0 & $T H R$ & 100 & $3.9 \mathrm{E}-15$ & 423.72 & 84 & $0.00 \vdots$ & 1.0000 & 0.05 & -842.62 & 342.62 & 1.000 & $<0.001$ & $>999.999$ \\
\hline THR & 0 & WAS & 0 & $1.19 \mathrm{E}-11$ & 423.72 & 84 & 0.00 & 1.0000 & 0.05 & -842.62 & 342.62 & 1.000 & $<0.001$ & $>999.999$ \\
\hline $\begin{array}{l}\text { THR } \\
\text { THR }\end{array}$ & 0 & : WAS: & 50 & -6.8755 & 366.95 & 84 & -0.02 & 0.9851 & 0.05 & -736.60 & 722.85 & 0.001 & $<0.001$ & $>999.999$ \\
\hline
\end{tabular}

file://C:/Users/klweber/AppData/Local/Temp/1/SAS\%20Temporary\%20Files/_TD3400_.. 12/10/2014 


\section{AEH-13-PSEUDO-06}

\begin{tabular}{|c|c|c|c|c|c|c|c|c|c|c|c|c|c|c|}
\hline & 0 & WAS & 100 & $-327 E-13$ & 423.72 & 84 & -0.00 & 1.0000 & 0.05 & -842.62 & 842,62 & 1.000 & $<0.001$ & $>999.999$ \\
\hline THR & 60 & THR & 100 & 5.33E-15 & 423.72 & 84 & 0.00 & 1,0000 & 0.05 & -842.62 & 842.62 & 1.000 & $<0.001$ & $>999.998$ \\
\hline THR & 50 & WAS & 0 & $1.19 \mathrm{E}-11$ & 423.72 & 84 & 0.00 & 1.0000 & 0.05 & -842.62 & $8<2,62$ & 1.000 & $<0.001$ & $>999.999$ \\
\hline - HR & 50 & WAS & 50 & -6.8755 & 366.95 & 84 & -0.02 & 0.9851 & 0.05 & -736.60 & 722.85 & 0.501 & $<0.001$ & $>999.999$ \\
\hline THR & 50 & WAS & 100 & $-327 E-13$ & 423.72 & 84 & .0 .00 & 1.0000 & 0.05 & -842.62 & 842.62 & 1.000 & $<0.001$ & $>999.999$ \\
\hline THR & 100 & WAS & 0 & $1.19 \mathrm{E}_{-11}$ & 423.72 & 84 & 0.00 & 1.0000 & 0.05 & $-842,62$ & 842.62 & 1.000 & $<0.001$ & $>999.998$ \\
\hline THR & 100 & WAS & 50 & -6.6755 & 366.95 & 84 & -0.02 & 0.8851 & 0.05 & -736.60 & 722.85 & 0.001 & $<0.001$ & $>999,999$ \\
\hline $\mathrm{THR}$ & 100 & WAS & 100 & $-327 \mathrm{E}-13$ & 423.72 & 84 & -0.00 & 1.0000 & 0.05 & -842.62 & 842,62 & 1.000 & $<0.001$ & $>989.998$ \\
\hline WAS & 0 & WAS & 50 & -6.8755 & 366.85 & 84 & $-0,02$ & 0.9851 & 0.05 & -736.60 & 722.85 & 0.001 & $<0.001$ & $>999.999$ \\
\hline WAS & 0 & WAS & 100 & $-445 E-13$ & 423.72 & 84 & -0.00 & 1.0000 & 0.05 & -842.62 & 842.62 & 1,000 & $<0.001$ & $>999.998$ \\
\hline WAS & 50 & WAS & 100 & 6.8755 & 366.95 & 84 & 0.02 & 0.9851 & 0.05 & -722.85 & 736.60 & 968.300 & $<0.001$ & $>999.999$ \\
\hline
\end{tabular}

\begin{tabular}{|c|c|c|c|c|c|c|c|c|c|c|c|c|c|}
\hline \multicolumn{14}{|c|}{ time"conc Least Squares Means } \\
\hline time & $\operatorname{con} c$ & Estimate & Standard Error & DF & t Value & $P r>|t|$ & a & er & per & Mean & $\begin{array}{r}\text { Standard } \\
\text { Error } \\
\text { Mean }\end{array}$ & & \\
\hline 8 & 0 & -15.0799 & 148.79 & $84 !$ & -0.10 & 0.9195 & 005 & -310.97 & 280.81 & $2.824 \mathrm{E}-7$ & 0.000042 & $887 \mathrm{E}-138$ & 1.0000 \\
\hline 8 & 50 & -1 & 15 & 84 & 10 & 7 & 05 & -311.69 & 281,52 & $2.809 \mathrm{E}-7$ & 0.000042 & $432 E-138$ & 1.0000 \\
\hline 8 & 100 & -17.0496 & 160,97 & 84 & -0.11 & 0.9159 & 0.05 & 7.15 & 303.05 & $3.939 \mathrm{E}-8$ & $6.34 \div E-6$ & $378 \mathrm{E}-148$ & 1.0000 \\
\hline 24 & 0 & -1 & 148.79 & 84 & -0.10 & 0.9195 & 0.05 & -310.97 & 280.81 & $2.824 E-7$ & 00042 & 887E-138: & 1.0000 \\
\hline 24 & 50 & -13.1130 & 76 & 84 & -0.10 & 0.9233 & 0.05 & -283.06 & 256.84 & $2.019 \mathrm{E}-6$ & 0,000274 & $117 \mathrm{E}-125$ & 1.0000 \\
\hline 24 & 100 & -11.1486 & 121.50 & 84 & -0.09 & 0.9271 & 0.05 & -252.77 & 230.48 & 0.000014 & 0.001749 & $167 \mathrm{E}-112$ & 1.0000 \\
\hline
\end{tabular}

\begin{tabular}{|c|c|c|c|c|c|c|c|c|c|c|c|c|c|c|}
\hline \multirow[b]{2}{*}{ time } & \multicolumn{14}{|c|}{ Differences of tlmetconc Least Squares Means } \\
\hline & cone & time & cone & Estimate & $\begin{array}{l}\text { Standard } \\
\text { Error }\end{array}$ & $\mathrm{DF}$ & tValue & $\begin{array}{r}\operatorname{Pr}>1 \\
|t|\end{array}$ & Alpha & Lower & Upper & $\begin{array}{l}\text { Odds } \\
\text { Ratio }\end{array}$ & $\begin{array}{r}\text { Lower } \\
\text { Confidence } \\
\text { Limlt for Odds } \\
\text { Ratio }\end{array}$ & $\begin{array}{r}\text { Upper } \\
\text { Confidence } \\
\text { Limit for Odds } \\
\text { Ratio }\end{array}$ \\
\hline 8 & 0 & 8 & 50 & 0.005351 & 210,68 & $84:$ & 0.00 & 1.0000 & 0.05 & -418.95 & 418.86 & 1.005 & $<0.001$ & $=999.999$ \\
\hline$B$ & 0 & 8 & 100 & 1.9698 & 218.20 & 84 & 0.01 & 0.9929 & 0.05 & -433.94 & 437.88 & 7.169 & $<0.001$ & $>998.999$ \\
\hline 8 & 0 & 24 & 0 & $1.25 \mathrm{E}-1$ & 210.42 & 84 & 0.00 & 1,0000 & 0.05 & -418.45 & 418.45 & 1.000 & $<0.001$ & $>999.999$ \\
\hline 8 & 0 & 24 & 50 & -1.9668 & 201.41 & 84 & -0.01 & 0.9922 & 0.05 & -402.50 & 398.56 & 0.140 & $<0.001$ & $>999.089$ \\
\hline 8 & 0 & 24 & 100 & -3.9313 & 192.10 & 84 & -0.02 & 0.9837 & 0.05 & $-385,94$ & 378.08 & 0.020 & $<0.001$ & $>998.999$ \\
\hline 8 & 50 & 8 & 100 & 19644 & 219.45 & 84 & 0.01 & 0.9929 & 0.05 & -434.43 & 438.36 & 7.131 & $<0.001$ & $>999.989$ \\
\hline 8 & 50 & 24 & 0 & -0.00535 & 210.68 & 84 & -0.00 & 1.0000 & 0.05 & .418 .96 & 418.95 & 0.985 & $<0001$ & $>899.999$ \\
\hline 8 & 50 & 24 & 50 & -1.9722 & 201.68 & 84 & -0.01 & 0.9822 & 0.05 & -403.03 & 398.08 & 0.139 & $<0.001$ & $>899.999$ \\
\hline 8 & 50 & 24 & 100 & -3.8336 & 192.38 & 84 & -0.02 & 0.9837 & 0.05 & -386.53 & 378.63 & 0.020 & $<0.001$ & $>999.999$ \\
\hline 8 & 100 & 24 & 0 & -1.9698 & 21920 & 84 & -0.01 & 0.9929 & 0.05 & -437.88 & 433.94 & 0.139 & $<0.001$ & $>099.999$ \\
\hline 8 & 100 & 24 & 50 & -3.9368 & 210.57 & 84 & -0.02 & 09851 & 0.05 & -422.37 & 414.80 & C.020 & $<0.001$ & $>999.989$ \\
\hline 8 & 100 & 24 & 100 & -5.9011 & 201.68 & 84 & -0.03 & 09767 & 0.05 & -406.96 & 395,16 & 0.003 & $<0.001$ & $>998.999$ \\
\hline 24 & 0 & 24 & 50 & -1.9668 & $201.4^{1}$ & 84 & -0.01 & 0.8922 & 0.05 & .402 .50 & 398.56 & C.140 & $<0.001$ & $>999.999$ \\
\hline 24 & 0 & 24 & 100 & -3.9313 & 192.10 & 84 & -0.02 & 0.9837 & 0.05 & -385.94 & 378.08 & 0.02 .0 & $<0.001$ & $>999.999$ \\
\hline 24 & 50 & 24 & 100 & -1.9644 & 182.18 & 84 & -0.01 & 0.9914 & 0.05 & -364.26 & 360.33 & 0.140 & $<0.001$ & $>999.999$ \\
\hline
\end{tabular}

\begin{tabular}{|c|c|c|c|c|c|c|c|c|c|c|c|c|c|c|}
\hline \multicolumn{15}{|c|}{ sps*tine*conc Least Squares Means } \\
\hline sps & time & cone & Estimate & Standard Error & $D F$ & $t$ Value & $\mathrm{Pr}>\{\mathrm{t} \mid$ & Alpha & Lowar & Upper & Mean & $\begin{array}{r}\text { Standard } \\
\text { Error } \\
\text { Mean }\end{array}$ & $\begin{array}{c}\text { Lower } \\
\text { Mean }\end{array}$ & $\begin{array}{l}\text { Upper } \\
\text { Mean }\end{array}$ \\
\hline FAM & 8 & 0 & -17.1184 & 423.72 & 84 & -0.04 & 0.9679 & 0.05 & -859.74 & 825.50 & $3.678 \mathrm{E}-8$ & 0.000016 & 0 & 1.0000 \\
\hline FAM & 8 & 50 & -17.1184 & 423.72 & 84 & -0.04 & 0.9679 & 0.05 & -859.74 & 825.50 & $3.678 \mathrm{E}-8$ & 0.000016 & 0 & 1.0000 \\
\hline FAM & 8 & 100 & -17.1184 & 423.72 & 84 & -0.04 & 0.9679 & 0.05 & -859.74 & 825.50 & $3.678 \mathrm{E}-8$ & 0.000016 & 0 & 1.0000 \\
\hline FAM & 24 & 0 & -17.1184 & 423.72 & 84 & -0.04 & 0.9679 & 0.05 & -859.74 & 825.50 & $3.678 E-8$ & 0.000016 & D & 1.0000 \\
\hline FAM & 24 & 50 & .17 .1184 & 423.72 & 84 & -0.04 & 0.9679 & 0.05 & -859.74 & 325.50 & $3.67 \mathrm{BE}-8$ & 0.000016 & 0 & 1.0000 \\
\hline
\end{tabular}

file://C:/Users/klweber/AppData/Local/Temp/1/SAS\%20Temporary\%20Files/_TD3400_... 12/10/2014 


\begin{tabular}{|c|c|c|c|c|c|c|c|c|c|c|c|c|c|c|}
\hline FAM & 24 & 100 & -17.1184 & 423.72 & $84:$ & -0.04 & 0.9679 & 0.05 & -859.74 & 825.50 & $3.678 \mathrm{E}-8$ & 0.000016 & 0 & 1.0000 \\
\hline HGE & 8 & 0 & -3.1355 & 0,4546 & 84 & -6.90 & $<.0001:$ & 0.05 & -4.0396 & -2.2314 & 0.04167 & 0.01815 & 0.01730 & 0.09697 \\
\hline HGE & 8 & 50 & -16.9240 & 429.87 & 84 & -0.04 & 0.9687 & 0.05 & -871.76 & 837.92 & $4.467 \mathrm{E}-8$ & 0.000010 & 0 & 1.0000 \\
\hline HGE & 8 & 100 & -16.9240 & 29.87 & 84 & -0.04 & 0.9687 & 0.05 & -871.76 & 837.92 & 4.467E-8 & 0,000018 & 0 & 1.0000 \\
\hline HGE & 24 & 0 & -3.1355 & 0.4546 & 84 & -6.90 & $<.000^{n}$ & 0.05 & 4.0396 & -2.2314 & 0.04167 & $0.0^{\wedge} 815$ & 0.01730 & 0.09697 \\
\hline GE & 24 & 50 & -3.1355 & 0.4546 & 84 & -6.90 & $5,000^{\circ}$ & 0.05 & -4.0396 & -2.2314 & 0.04167 & 0.0 .815 & 0.01730 & 0.09697 \\
\hline HGE & 24 & 130 & -3.1355 & 0.4546 & 84 & -6.90 & $<, 0001$ & 0.05 & -4.0396 & -2.2314 & 0.04167 & 0.01815 & 0.01730 & 0.09697 \\
\hline $\mathrm{HIC}$ & 8 & 0 & -17.1184 & 423.72 & 84 & -0.04 & 0.9679 & 0.05 & -859.74 & 825.50 & $3.878 E-8$ & 0.000016 & 0 & 1.0000 \\
\hline $\mathrm{HIC}$ & 8 & 50 & -17.1184 & 423.72 & 84 & -0.04 & 09679 & 0.05 & -859.74 & 825.50 & $3.678 E-8$ & 0.000016 & 0 & 1.0000 \\
\hline $\mathrm{HIC}$ & 8 & 100 & -17.1184 & 423.72 & 84 & -0.04 & 0.9679 & 0.05 & -859.74 & 825.50 & $3.678 \mathrm{E}-8$ & 0.000016 & 0 & 1.0000 \\
\hline $\mathrm{HIC}$ & 24 & 0 & -17.1184 & 423.72 & 84 & -0.04 & 0.9679 & 0.05 & 859.74 & 825.50 & $3.678 E-8$ & 0.000016 & 0 & 1.0000 \\
\hline $\mathrm{HIC}$ & 24 & 50 & -17.1184 & 423.72 & 84 & -0.04 & 0.9870 & 0.05 & -850.74 & 825.50 & $3.678 E-8$ & 0.000016 & 0 & 1.0000 \\
\hline Hic & 24 & 100 & -3.3673 & 0.4527 & 84 & -7.44 & $<.0001$ & 0.05 & -4.2675 & -2.4671 & 0.03333 & 0.01458 & 0.01382 & 0.07820 \\
\hline PIG & 8 & 0 & -16.9240 & 428.87 & 84 & -0.04 & 0.9687 & 0.05 & -871.76 & 837,92 & $4.467 \mathrm{E}-8$ & 0.000010 & 0 & 1.0000 \\
\hline 기 & 8 & 50 & $-16,8240$ & 9.87 & 84 & -0.04 & 0.9687 & 0.05 & -871.76 & 837.92 & $4.467 \mathrm{E}-8$ & 0.000019 & 0 & 1.0000 \\
\hline PIG & 8 & 100 & -16.9240 & 429.87 & 84 & -0.04 & 0.8687 & 0.05 & -871.76 & 837.92 & $4.467 \mathrm{E}-8$ & 0.000019 & 0 & 1.0000 \\
\hline PIG & 24 & 0 & -16.9240 & 429.87 & 84 & -0.04 & 0.0887 & 0.05 & -871.76 & 837.92 & $4,467 \mathrm{E}-8$ & 0.000019 & 0 & 1.0000 \\
\hline PIG & 24 & 50 & .16 .9240 & 429.87 & 84 & -0.04 & 0.9687 & 0.05 & -871.76 & 837.92 & $4.467 \mathrm{E}-8$ & 0.000019 & 0 & 1.0000 \\
\hline$P \mid G$ & 24 & 100 & -16.9240 & 429.87 & 84 & -0.04 & 0.9687 & 0.05 & .871 .78 & 837.92 & $4.467 \mathrm{E}-8$ & 19 & 0 & 1.0000 \\
\hline PPB & $B$ & 0 & 59 & 426.46 & 84 & -0.04 & 0.9682 & 0.05 & -865.08 & 831.04 & $4.034 \mathrm{E}-8$ & 0.000017 & 0 & 1.0000 \\
\hline FPB & 8 & 50 & -17.0259 & 426.46 & 84 & -0.04 & 0.8682 & 0.05 & -865.09 & 831.04 & $4.034 \mathrm{E}-8$ & 0.000017 & 0 & 1.0000 \\
\hline PPB & 8 & 100 & -17.0258 & 426.46 & 8 & 04 & 0.9682 & 0.05 & -865.09 & 831.04 & $4.034 \mathrm{E}-8^{\prime}$ & 0.000017 & 0 & 1.0000 \\
\hline $\mathrm{PPB}$ & 24 & 0 & -17.0259 & 426.46 & 84 & -0.04 & 0.9632 & 0.05 & $-865,09$ & 31.04 & $4.034 \mathrm{E}-8$ & 0.050017 & 0 & 1.0000 \\
\hline PPB & 24 & 50 & -3.2581 & 0.4536 & 84 & -7.18 & $<.0001$ & 0.05 & -4.1600 & -2.3562 & 0.03704 & 0.01618 & 0.01537 & 0.08658 \\
\hline $\mathrm{PPl}$ & 24 & 100 & -37 & 0.4536 & 84 & -7.18 & $<.0001$ & 0.05 & -4.1600 & -2.3562 & 0.03704 & 0.01618 & 37 & 0.08658 \\
\hline THR & 8 & 0 & -17.1184 & 423.72 & $B$ & -0.04 & 0.9679 & 0.05 & -859.74 & 825.50 . & $3.678 \mathrm{E}-8$ & 0.000016 & 0 & 1.0000 \\
\hline THR & 8 & 50 & -17.1184 & 423.72 & 8 & -0.04 & 0.9679 & 0.05 & -85974 & 825.50 & $3.678 \mathrm{E}-8$ & 0.000016 & 0 & 1.000 \\
\hline THR & 8 & 100 & -17.1184 & 423.72 & 8 & -0.04 & 0.967 & 0.05 & -859.74 & $B 25.50$ & $3.678 \mathrm{E}-8$ & 0.000016 & 0 & 1.0000 \\
\hline THF & 24 & 0 & -17.1184 & 423.72 & 84 & -0.04 & 0.9679 & 0.05 & -859.74 & 825.50 & $3.678 \mathrm{E}-8$ & 0.000016 & 0 & 1.0000 \\
\hline THR & 24 & 50 & 34 & 423.72 & 84 & -0.04 & 0.9679 & 0.05 & -859.74 & 825.50 & $3.678 E-8$ & 6 & 0 & 1.0000 \\
\hline THR & 24 & 100 & -17.1184 & 423.72 & 8 & -0.04 & 0.9679 & 0.05 & -859.74 & 825.50 & $3.678 \mathrm{E}-6$ & 0.000016 & 0 & 1.0000 \\
\hline WAS & 8 & 0 & -17.1184 & 423.72 & 8 & -0.04 & 0.9679 & 0.05 & -859.74 & 825.50 & $3.67 \mathrm{BE}-8$ & 0.000016 & 0 & 1.0000 \\
\hline WAS & $\theta$ & 50 & -3.3673 & 0.4527 & 84 & -7.44 & $<.0001$ & 0.05 & $-4.26 / 5$ & -2.4671 & 3333 & 01459 & 0.01382 & 0.07820 \\
\hline WAS & 8 & 10 & 34 & 72 & 84 & -0.04 & 0.9678 & 0.05 & -858.74 & 825.50 & $678 \mathrm{E}-8$ & 0018 & 0. & 1.0000 \\
\hline WAS & 24 & ? & -17.1184 & 72 & 8 & -0.04 & 0.9679 & 0.05 & -859.74 & 825.50 & $3.6 \% 8 \mathrm{E}-8$ & 0.000016 & 0 & 1.0000 \\
\hline WAS & 24 & 50 & -17.1184 & 2 & 8 & -0.04 & 79 & 0.05 & -859.74 & 325.50 & $3.678 \mathrm{E}-8$ & 0.000016 & 0 & 1.00 \\
\hline WAS & 24 & 100 & -17.1184 & 423.72 & 84 & -0.04 & 0.9679 & 0.05 & -859.74 & 825.50 & $3.678 \mathrm{E}-8$ & 0.000016 & 0 & 1.0000 \\
\hline
\end{tabular}

\begin{tabular}{|c|c|c|c|c|c|c|c|c|c|c|c|c|c|c|c|c|}
\hline \multirow[b]{2}{*}{$\operatorname{sps}$} & \multicolumn{16}{|c|}{ Dlfferences of sps"time*tonc Least Squares Means } \\
\hline & $\operatorname{tim} \theta$ & conc & $\operatorname{sps}$ & tlme & conc & Estimate & $\begin{array}{r}\text { Standard } \\
\text { Error }\end{array}$ & $\mathrm{DF}$ & t Value & $\begin{array}{r}\operatorname{Pr}>\mid \\
|t|\end{array}$ & Alpha & Lower & Upper & & $\begin{array}{r}\text { Lower } \\
\text { Confldence } \\
\text { Limit for } \\
\text { Odds } \\
\text { Ratio }\end{array}$ & $\begin{array}{r}\text { Upper } \\
\text { Confidence } \\
\text { Limit for } \\
\text { Odkls } \\
\text { Ratlo }\end{array}$ \\
\hline FAM : & 8 & 0 & FAM & 8 & 50 & $-164 \mathrm{E}-17$ & 598.23 & 84 & -0.00 & 1.0000 & 0.05 & -1191.64 & 1191.64 & 1.000 & $<0.001$ & $>999.999$ \\
\hline FAM & 8 & 0 & FAM & 8 & 100 & $5.42 \mathrm{E}-15$ & 599.23 & 84 & 0.00 & 1.0000 & 005 & -1181.64 & 1191.64 & 1.000 & $<0.001$ & $>999.999$ \\
\hline FAM & 8 & 0 & FAM & 24 & 0 & 1.04E-15 & 599.23 & 84 & 0.00 & 1.0000 & 0.05 & -1191.64 & 1191.64 & 1.000 & $<0.001$ & $>999.999$ \\
\hline FAM & 8 & 0 & FAM & 24 & $5 C$ & $1.98=-15$ & 599.23 & 34 & 0.00 & 1.0000 & 0.05 & -1191.64 & 1191,64 & 1.000 & $<0.001$ & $>999.990$ \\
\hline FAM & 8 & 3 & FAM & 24 & 100 & $-151 E-16$ & 599,23 & 84 & -0.00 & 1.0000 & 0.05 & -1191.64 & 1191.64 & 1.000 & $<0.001$ & $>999.999$ \\
\hline$M$ & 8 & 0 & HGE & 8 & $\mathrm{C}$ & -13.9829 & 423.72 & 84 & -0.03 & 0.9738 & 0.05 & -856.60 & 828.63 & $<0.001$ & $<0.001$ & $>999.999$ \\
\hline FAM & 8 & 0 & $\mathrm{HGE}$ & 8 & 50 & 1943 & 803.59 & 84 & -0.00 & $C .9097$ & 0.05 & -1200.51 & 1200.12 & 0.823 & $<0.001$ & $>999.999$ \\
\hline
\end{tabular}

file://C:/Users/klweber/AppData/l ocal/Temp/1/SAS\%20Temporary\%20Files/_TD3400_.. 12/10/2014 


\begin{tabular}{|c|c|c|c|c|c|c|c|c|c|c|c|c|c|c|c|c|}
\hline FAM & 8 & 0 & HGE & 8 & 100 & -0.1943 & 603.59 & $8<$ & -0.00 & 0.9997 & 0.05 & -1200.51 & 1200.12 & 0.823 & $<0.001$ & $>999.999$ \\
\hline FAM & 8 & 0 & HGE & 24 & 0 & -13.9829 & 423.72 & 84 & -0.03 & 0.9738 & 0.05 & -856.60 & 828.63 & $<0.001$ & $<0.001$ & $>\$ 98.999$ \\
\hline FAM & 8 & 0 & HGE & 24 & 50 & -13.9829 & 423.72 & 84 & -0.03 & 0.9738 & 0.05 & -856.60 & 828.63 & $<0.001$ & $<0.001$ & $>999.999$ \\
\hline FAM & 8 & 0 & HGE & 24 & 100 & -13.8829 & 423.72 & 84 & -0.03 & 0.9738 & 0.05 & -856.60 & 828.63 & $<0.001$ & $<0,001$ & $>899.999$ \\
\hline FAM & 8 & 0 & $\mathrm{HIC}$ & 8 & 0 & $1.78 \mathrm{E}-15$ & 599.23 & 84 & 0.00 & 1.0000 & 0.05 & $-11 £ 1.64$ & 1191.64 & 1.000 & $<0.001$ & $>998.999$ \\
\hline FAM & 8 & 0 & $\mathrm{HIC}$ & 8 & 50 & 0 & 598.23 & 84 & 0.00 & 1.0000 & 0.05 & -1191.64 & 1191.64 & 1.000 & $<0.001$ & $>999.999$ \\
\hline FAM & 8 & $\because 0$ & $\mathrm{HIC}$ & 8 & 100 & $7.11 \mathrm{E}-15$ & 599.23 & 84 & 0.00 & 1.0000 & 0.05 & -1191.64 & 1191.64 & 1.000 & $<0.001$ & $>989.990$ \\
\hline FAM & 8 & 0 & $\mathrm{HIC}$ & 24 & 0 & $6.37 \mathrm{E}-15$ & 599.23 & 84 & 0.00 & 1.0000 & 0.05 & -1191.64 & 1191.84 & 1.000 & $<0.001$ & $>999.999$ \\
\hline FAM & 8 & 0 & $\mathrm{HLC}$ & 24 & 50 & $355 \mathrm{E}-15$ & 599.23 & 84 & 0.00 & 1.0000 & 0.05 & -1191.64 & 1191.64 & 1.000 & $<0.001$ & $>999.999$ \\
\hline FAM & 8 & 0 & $\mathrm{HIC}$ & 24 & 100 & -13.7511 & 423.72 & 84 & -0.03 & 0.9742 & 0.05 & -856.37 & 828.87 & $<0.001$ & $<0.001$ & $>999,999$ \\
\hline FAM & 8 & 0 & $\mathrm{PIG}$ & 8 & 0 & $-0.19<3$ & 603.59 & 84 & -0.00 & 0.9997 & 0.05 & $-1200,51$ & 1200.12 & 0.823 & $<0.001$ & $>999.999$ \\
\hline FAM & 8 & 0 & $P \mid G$ & 8 & 50 & -0.1943 & 603.59 & 84 & -0.00 & 0.9997 & 0.05 & -1200.51 & 1200.12 & 0.823 & $<0.001$ & $>999.999$ \\
\hline FAM & 8 & 0 & $\mathrm{PIG}$ & 8 & 100 & -0.1943 & 603.59 & 84 & -0.00 & 0.9997 & 0.05 & -1200.51 & 1200.12 & 0.823 & $<0.001$ & $>999.999$ \\
\hline FAM & 8 & 0 & $P \mid G$ & 24 & 0 & -0.1943 & 603.59 & 84 & -0.00 & 0.8987 & 0.05 & -1200.51 & 1200.12 & 0.823 & $<0.001$ & $>999.999$ \\
\hline FAM & 8 & 0 & $\mathrm{PIG}$ & 24 & 50 & -0.1943 & 803.59 & 84 & -0.00 & 0.8997 & 0.05 & -1200.51 & 1200.12 & 0.823 & $<0.001$ & $>999.990$ \\
\hline FAM & 8 & 0 & $\mathrm{PIG}$ & 24 & 150 & -0.1943 & 603.59 & 84 & -0.00 & 0.9997 & 0.05 & -1200.51 & 1200.12 & 0.823 & $<0.001$ & $>999.999$ \\
\hline FAM & 8 & 0 & $\mathrm{PPB}$ & 8 & 0 & -0.09247 & 601.17 & 84 & -0.00 & 0.9999 & 0.05 & -1195.59 & 119541 & 0.912 & $<0.001$ & $>999.998$ \\
\hline FAM & 8 & 0 & $\mathrm{PPB}$ & 8 & 50 & -0.09247 & 601.17 & 84 & -0.00 & 0.8999 & 0.05 & -1195.59 & 1195.41 & 0.812 & $<0.001$ & $>999.999$ \\
\hline FAM & 8 & 0 & PPB & 8 & 100 & -0.09247 & 601.17 & 84 & -0.00 & 0.9999 & 0.05 & -1195.59 & 1195.41 & 0.912 & $<0.001$ & $>009.999$ \\
\hline FAM & 8 & 0 & PPB & 24 & 0 & -0.09247 & 601.17 & 84 & -0.00 & 0.8999 & 0.05 & $-1 \times 95.59$ & $1195.4^{\circ}$ & 0.912 & $<0.001$ & $>999.999$ \\
\hline FAM & 8 & 0 & $\mathrm{PPB}$ & 24 & 60 & -13.8603 & 423.72 & 84 & -0.03 & 0.9740 & 0.05 & -856.48 & 828.76 & $<0.001$ & $<0.001$ & $>999.899$ \\
\hline FAM & 8 & 0 & PPB & 24 & 100 & -13.8603 & 423.72 & 84 & -0.03 & 0.9740 & 0.05 & -856.48 & 828.78 & $<0.001$ & $<0.001$ & $>999.898$ \\
\hline FAM & 8 & 0 & THR & 6 & 0 & $-729 \mathrm{E}-17$ & 599,23 & 84 & -0.00 & 1.0000 & 0.05 & -1191.64 & 1191.64 & 1.000 & $<0.001$ & $>999.999$ \\
\hline FAM & 8 & 0 & THR & 8 & 50 & $-711 \mathrm{E}-17$ & 589.23 & 84 & -0.00 & 1.0000 & O.C5 & -1191.64 & 1191.64 & 1.000 & $<0.001$ & $>999.999$ \\
\hline * FAM & 8 & 10 & THR & 8 & 100 & 0 & 599.23 & 84 & 0.00 & 1.0000 & 0.05 & $-1191,64$ & 119164 & 1.000 & $<0.001$ & $>999.989$ \\
\hline FAM & 8 & 0 & THR & 24 & 0 & $-107 E-1 B$ & 598.23 & 84 & -0.00 & 1.0000 & 0.05 & -1191.64 & 1191.64 & 1.000 & $<0.001$ & $>099.999$ \\
\hline FAM & 8 & 0 & THR & 24 & 50 & -356E-17 & 599.23 & 84 & -0.00 & 1.0000 & 0.05 & -1191.64 & 1191.64 & 1.000 & $<0.001$ & $>999.999$ \\
\hline FAM & 8 & 0 & THR & 24 & 100 & $-711 E-17$ & 599.23 & 84 & -0.00 & 1.0000 & 0.05 & -1191.64 & 1191.64 & 1.000 & $<0.001$ & $>999.999$ \\
\hline FAM & 8 & 0 & WAS & 8 & 0 & $-318 E-13$ & 599.23 & 84 & -0.00 & 1.0000 & 005 & -1191.64 & 1191.64 & 1.000 & $<0.001$ & $>999.999$ \\
\hline FAM & 8 & 0 & WAS & 8 & 50 & -13.7511 & 423.72 & 84 & -0.03 & 0.9742 & 0.05 & $-856,37$ & 828.87 & $<0,001$ & $<0.001$ & $>998.999$ \\
\hline FAM & 8 & 0 & WAS & 8 & 100 & $1.55 E-11$ & 699,23 & 84 & 0.00 & 1.0000 & 0.05 & $-\{191.64$ & 1191.64 & 1.000 & $<0.001$ & $>999.999$ \\
\hline FAM & 8 & 0 & WAS & 24 & 0 & $5.56 \mathrm{~F}_{-}-11$ & 589.23 & 84 & 0.00 & 1.0000 & 0.05 & -1191.64 & 1191.64 & 1.000 & $<0.001$ & $>999,999$ \\
\hline FAM & 8 & 0 & WAS & 24 & 50 & $9.59 \mathrm{E}-11$ & 599.23 & 84 & 0.00 & 1.0000 & 0.05 & -1191.64 & 1191.64 & 1.000 & $<0.001$ & $>999.999$ \\
\hline FAM & 8 & 0 & WAS & 24 & 100 & $-808 \mathrm{E}-13$ & 599.23 & 84 & -0.00 & 1.0000 & 0.05 & -1191.64 & 1191.64 & 1.000 & $<0.001$ & $>999.990$ \\
\hline$=A M$ & 8 & 50 & FAM & 8 & 100 & $6.51 E-15$ & 598.23 & 84 & 0.00 & 1.0000 & 0.05 & -1191.64 & 1191.64 & 1,000 & $<0.001$ & $>999.999$ \\
\hline FAM & 8 & 50 & FAM & 24 & 0 & $2.68 \mathrm{E}-15$ & 599.23 & 84 & 0.00 & 1.0000 & 0.05 & -1191.64 & 1191.64 & 1,000 & $<0.001$ & $>999.999$ \\
\hline FAM & 8 & 50 & FAM & 24 & 50 & $2.58 \mathrm{E}-15$ & 599.23 & 84 & 0.00 & 1.0000 & 0.05 & -1191.64 & 1191.64 & 1.000 & $<0.001$ & $>999.999$ \\
\hline FAM & 8 & 50 & FAM & 24 & 100 & $-14 E-15$ & 599,23 & 84 & -0.00 & 1.0000 & 0.05 & -1191.64 & 1191.64 & 1.000 & $<0.001$ & $>999.999$ \\
\hline FAM & 8 & 50 & HGE & 8 & 0 & -13.9829 & 423.72 & 84 & -0.03 & C. 9738 & 0.05 & -856.60 & 828.63 & $<0.001$ & $<0.001$ & $>999.999$ \\
\hline FAM & 8 & 50 & HGE & 8 & 50 & -0.1943 & 603.59 & 84 & -0.00 & 0.9997 & 0.05 & -1200.51 & 1200.12 & 0.823 & $<0.001$ & $>999.999$ \\
\hline FAM & 8 & 50 & $\mathrm{HGE}$ & 8 & 100 & -0.1943 & 603.59 & 84 & 0.00 & 0.9997 & 0.05 & -1200.51 & 1200.12 & 0.823 & $<0.001$ & $>999.989$ \\
\hline FAM & 8 & 50 & HGE & 24 & 0 & -13.9829 & 423.72 & 84 & 0.03 & 0.9738 & 0.05 & -856.60 & 828.63 & $<0.001$ & $<0.001$ & $>999.999$ \\
\hline FAM & 8 & $5 \mathrm{C}$ & HGE & 24 & 50 & -13.9829 & 423.72 & 84 & -0.03 & 0.9738 & 0.05 & -856.60 & 828.63 & $<0.001$ & $<0.001$ & $>999.999$ \\
\hline FAM & 8 & 50 & $\mathrm{HGE}$ & 24 & 100 & -13.9829 & 423.72 & 84 & -0.03 & $0.9 / 38$ & 0.05 & -858.60 & 828.63 & $<0.001$ & $<0.001$ & $>999.999$ \\
\hline FAM & 8 & 50 & $\mathrm{HIC}$ & 8 & 0 & $3.85 \mathrm{~F}-15$ & 599.23 & 84 & 0.00 & 1.0000 & 0.05 & -1191.64 & $119^{\wedge} .64$ & 1.000 & $<0.001$ & $>999.999$ \\
\hline FAM & 8 & 50 & HIC & 8 & 50 & $3.55 \mathrm{E}-15$ & 589.23 & 84 & 0.00 & 1.0000 & 0.05 & -1191.64 & 1191.64 & 1.000 & $<0.001$ & $>999.999$ \\
\hline FAM & 8 & 50 & HIC & 8 & 100 & $1.07 \mathrm{E}-14$ & 599.23 & 84 & 0.00 & 1.0000 & 0.05 & -1191.64 & $119 \cdot 64$ & 1.000 & $<0.001$ & $>999.999$ \\
\hline FAM & 8 & 50 & $\mathrm{H} \mid \mathrm{C}$ & 24 & 0 & $8.01 \mathrm{E}-15$ & 599.23 & 84 & 0.00 & 1,0000 & 0.05 & -1191.64 & 1191.64 & 1.000 & $<0.001$ & $>999.999$ \\
\hline FAM & 8 & 50 & HIC & 24 & 50 & 3.55E-15 & 599.23 & 84 & 0.00 & 1.0000 & C.05 & -1191.64 & 1191.84 & 1.000 & $<0.001$ & $>999.999$ \\
\hline FAM & & & & & & & & 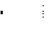 & & $\vdots$ & & & & & & \\
\hline
\end{tabular}




\begin{tabular}{|c|c|c|c|c|c|c|c|c|c|c|c|c|c|c|c|c|}
\hline & 8 & 50 & IIC & 24 & 100 & -13.7511 & 423.72: & 84 & -0.03 & 0.9742 & 0.05 & -856.37 & 828.87 & $<0.001$ & $<0.001$ & 999.999 \\
\hline & 8 & 50 & PIG & 8 & 0 & -0.1843 & 603.59 & 84 & -0.00 & 0.9997 & 0.05 & -1200.51 & 1200.12 & 0.823 & $<0.001$ & $>\$ 89.999$ \\
\hline FAM & 8 & 50 & PIG & 8 & 50 & -0.1943 & 603.59 & 84 & -0.00 & 0.8997 & 0.05 & -1200.51 & 1200.12 & 0.823 & $<0,001$ & $>999.999$ \\
\hline AM & 8 & 50 & PIG & 8 & 100 & -0.1843 & 603.59 & 84 & -0.00 & 0.9997 & 0.05 & -1200.51 & 1200.12 & 0.823 & $<0.001$ & $>999.999$ \\
\hline FAM & 8 & 50 & PIG & 24 & 0 & -0.1943 & 603.59 & 84 & -0.00 & 0.9997 & 0.05 & -1200.51 & 1200.12 & 0.823 & $<0.001$ & $>999.999$ \\
\hline AM & 8 & 50 & PIG & 24 & 50 & $-0.18<3$ & 603.59 & 84 & 0.00 & 0.9997 & 0.05 & $-1200,51$ & 1200.12 & 0.823 & $<0.001$ & $>999.999$ \\
\hline FAM & 8 & $: 50$ & 'PIG & 24 & 100 & $-0.18<3$ & 603.50 & 84 & -0.00 & 0.9997 & 0.05 & -1200.51 & 1200.12 & 0.823 & $<0.001$ & $>999.999$ \\
\hline FAM & 8 & 50 & PPB & 8 & 0 & -0.09241 & 601.17 & 84 & -0.00 & 0.9999 & 0.05 & 1195.59 & 1195.41 & 0.912 & $<0,001$ & $>999.999$ \\
\hline FAM & 8 & 50 & PPB & 8 & 50 & -0.09247 & 601.17 & 84 & -0.00 & 0.9999 & 0.05 & -1195.59 & 1185.41 & 0.912 & $<0.001$ & $>999.990$ \\
\hline FAM & 8 & 50 & PPB & 18 & 100 & -0.09247 & 601.17 & 84 & -0.00 & 0.9999 & 0.05 & -1195.59 & 1195.41 & 0.912 & $<0.001$ & $>999.999$ \\
\hline FAM & 8 & 50 & PPB & 24 & 10 & -0.09247 & 601.17 & 84 & -0.00 & 0.9999 & 0.05 & -1195.59 & 1195.41 & 0.912 & $<0.001$ & $>990.899$ \\
\hline FAM & 8 & 50 & PPB & 24 & 50 & -13.8603 & 423.72 & 84 & -0.03 & 0.9740 & 0.05 & -856.48 & 828.76 & $<0.001$ & $<0.001$ & $>999.999$ \\
\hline FAV & 8 & 50 & $P P B$ & 24 & 120 & -13.8603 & 423.72 & 84 & -0.03 & 0.9740 & 0.05 & -856.48 & 828.76 & $<0.001$ & $<0.001$ & $>999.999$ \\
\hline FAM & 8 & 50 & THR & 8 & 0 & $729 \mathrm{E}-17$ & 599.23 & 84 & -0.00 & 10000 & 0.05 & {$[-1191.64$} & 1191.64 & 1.000 & $<0.001$ & $>999.909$ \\
\hline FAM & 8 & 50 & THR & 8 & 50 & $=107 E-16$ & 599.23 & 84 & -0.00 & 1.0000 & 0.05 & $\mid-1 \times 91.64$ & 1191.64 & 1.000 & $<0.001$ & $>999.998$ \\
\hline FAM & 8 & 50 & THR & B & 100 & 0 & 599.23 & 84 & 0.00 & 1.0000 & 0.05 & $\mid-1: 91.64$ & 119164 & 1.000 & $<0.001$ & $>980.999$ \\
\hline FAM & 8 & 50 & THR & 24 & 0 & $-711 E-17$ & 599.23 & 84 & .0 .00 & 1.0000 & 0.05 & {$[-191.64$} & 1191.64 & 1.000 & $<0.001$ & $>999.999$ \\
\hline FAM & 8 & 50 & THR & 24 & 50 & $-711 \mathrm{E}-17$ & 599.23 & 84 & -0.00 & 1.0000 & 0.05 & -1191.64 & 1191.64 & 1,000 & $<0.001$ & $>999.898$ \\
\hline FAM & 8 & 50 & THR & 24 & 100 & $711 \mathrm{E}-17$ & 599.23 & 84 & -0.00 & 1.0000 & 0.05 & -1191.64 & 1191.64 & 1.000 & $<0.001$ & $>999.998$ \\
\hline FAM & 8 & 50 & WAS & 8 & 0 & $-318 E-13$ & 599.23 & 84 & -0.00 & 1.0000 & 0.05 & -1191.64 & 1191.64 & 1.000 & $<0.001$ & $>999999$ \\
\hline FAM : & 8 & 50 & WAS & 8 & so & -13.7511 & 423.72 & 84 & -0.03 & 0.9742 & 0.05 & -856.37 & 828.87 & $<0.001$ & $<0.001$ & $>099.809$ \\
\hline FAM & 8 & 50 & WAS & 8 & 100 & $1.55 \mathrm{E}-11$ & 599.23 & 84 & 0.00 & 1.0000 & 0.05 & $-11 \theta 1.64$ & 1191.64 & 1.000 & $<0.001$ & $>999.999$ \\
\hline FAM & 8 & 50 & WAS & 24 & 0 & $5.55 E-11$ & 599.23 & 84 & 0.00 & 1.0000 & 005 & -1191.64 & 1191.64 & 1.000 & $<0.00$ & $>999.999$ \\
\hline FAM : & 8 & 50 & WAS & 24 & 50 & $9.59 E-11$ & 599.23 & 84 & 0.00 & 1.0000 & 0.05 & $-1191,64$ & 1191.64 & 1.000 & $<0.001$ & $>989.999$ \\
\hline FAM & 8 & 50 & WAS & 24 & 100 & $-808 E-13$ & 598,23 & 84 & -0.00 & 1.0000 & 0.05 & -1191.64 & 1191.64 & 1.00 & $<0.001$ & $>999.999$ \\
\hline FAM & 8 & 100 & FAM & 24 & 0 & $-438 E-17$ & 599.23 & 84 & -0.00 & 1.0000 & 0.05 & $-1191,64$ & 1191.84 & 1.000 & $<0.00$ & $>999,899$ \\
\hline$=A M$ & 8 & 100 & FAM & 24 & 50 & $-343 E-17$ & 599.23 & 84 & $-0,00$ & 1.0000 & 0.05 & -1101.64 & 1181.64 & 1.000 & $<0.00$ & $>999.999$ \\
\hline FAM & 8 & 100 & FAM & 24 & 100 & 205E-16 & 599.23 & 84 & -0.00 & 1.0000 & 0.05 & -1191.64 & 1191.64 & 1.000 & $<0.00$ & 999.890 \\
\hline FAM & 8 & 100 & $\mathrm{HGE}$ & 8 & 10 & -13.9829 & 423.72 & 84 & -0.03 & 0.9738 & 0.05 & $|-856.60|$ & 828,63 & $<0,00$ & $<0.0$ & $>999.999$ \\
\hline FAM & 8 & 100 & HGE & 8 & 50 & -0.1943 & 603.59 & 84 & -0.00 & 0.9997 & 0.05 & -1200.51 & 1200.12 & 0.823 & $<0.00$ & $>999.999$ \\
\hline FAM & 8 & $10 c$ & HGE & 8 & 100 & -0.1343 & 603.59 & 84 & -0.00 & 0.9997 & 0.05 & -1200.51 & 1200.12 & 0.82 & $<0.00$ & $>999.999$ \\
\hline FAM & 8 & 100 & HGE & 24 & 0 & 3.98 & 423.72 & 84 & -0.03 & {$[0.9738$} & 0.05 & -856.60 & 828.63 & $<0,001$ & $<0.00$ & $>999.989$ \\
\hline FAM & 8 & 100 & HGE & 24 & 50 & -13.9829 & 423.72 & 84 & -0.03 & 0.9738 & 0.05 & -856.60 & 828.63 & $<0.00^{\circ}$ & $<0.001$ & $>999.990$ \\
\hline FAM & 8 & 100 & HGE & 24 & 100 & -13.9829 & 423.72 & 84 & -0.03 & 0.9738 & 0.05 & -856.60 & 828.33 & $<0.001$ & $<0.0$ & $>998.999$ \\
\hline FAM & 8 & 100 & HIC & 8 & 10 & $-311 E-17$ & 580.23 & 84 & -0.00 & 1.0000 & 0.05 & -1191.64 & 1191.64 & 1.000 & $<0.00$ & $>999.999$ \\
\hline FAM & 8 & 100 & $\mathrm{HIC}$ & 8 & 50 & $-365 E-17$ & 599.23 & 84 & -0.00 & 1.0000 & 0.05 & -1191.64 & 1191.0 & 1.000 & $<0.00$ & $>899.99 \theta$ \\
\hline FAM & 8 & 100 & $\mathrm{HIC}$ & $\therefore$ & 100 & $3.55 \mathrm{E}-15$ & 599.23 & 84 & 0.00 & 1.0000 & 0.05 & -1191.64 & 1191.64 & 1.000 & $<0.00$ & $>999.999$ \\
\hline FAM & 8 & 100 & HIC & 24 & 0 & $1.05 E-15$ & 599.23 & 84 & 0.00 & 1.0000 & 0.05 & -1191.64 & 1191.64 & 1.000 & $<0.00$ & $>999.999$ \\
\hline FAM & 8 & 100 & $\mathrm{HIC}$ & 24 & 50 & $-178 E-17$ & 599.23 & 84 & .0 .00 & ${ }^{2} .0000$ & C. 05 & -1191.64 & $119: 64$ & 1.000 & $<0.00$ & $>999.999$ \\
\hline FAM & 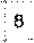 & 100 & $\mathrm{HIC}$ & 24 & 100 & -13.7511 & 423.72 & 84 & -0.03 & 0.9742 & 0.05 & -856.37 & 828.87 & $<0.001$ & $<0.00$ & $>999.999$ \\
\hline FAM & 8 & 100 & $\mathrm{PIG}$ & 8 & 0 & -0.1940 & 603.59 & ${ }^{84}$ & -0.00 & 0.9997 & 0.05 & -1200.51 & 1200.12 & 0.823 & $<0.00$ & $>999.999$ \\
\hline FAM & 8 & 100 & $\mathrm{PlG}$ & . & 50 & -0.1943 & 603.59 & 84 & -0.00 & 0.9997 & 0.05 & -1200.51 & 1200,12 & 0.823 & $<0.001$ & $>999.999$ \\
\hline FAM & 8 & 100 & $\mathrm{PIG}$ & 8 & 100 & -0.1843 & 603.59 & 84 & -0.00 & 0.2997 & 0.05 & -1200.51 & 1200.12 & 0.823 & $<0.001$ & $>999.999$ \\
\hline FAM & 8 & 100 & PIG & 24 & 0 & -0.1943 & 603.59 & 84 & -0.00 & 0.9997 & 0.05 & -1200.51 & 1200,12 & 0.823 & $<0.001$ & $>999.999$ \\
\hline FAM & 8 & 100 & PIG & 24 & 50 & 0.1943 & 03.59 & 84 & -0.00 & 0.9997 & 0.05 & -1200.61 & 1200.12 & 0.823 & $<0.001$ & $>999.999$ \\
\hline FAM & 8 & 200 & $\mathrm{PIO}$ & 24 & 100 & -0.194 & 603.58 & 84 & -0.00 & 0.9997 & 0.05 & -1200.51 & 1200.12 & 0.823 & $<0.001$ & $>999.999$ \\
\hline FAM & 8 & $: 100$ & PPB & 8 & 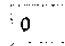 & -0.09 & .17 & 84 & -0.00 & 0.9999 & 0.05 & -1195.59 & .1185 .41 & 0.912 & $<0.001$ & $>999.899$ \\
\hline FAM & 18 & 100 & PPB & 8 & 50 & -0.08247 & 601.17 & $\vdots 84$ & -0.00 & 0.9999 & 0.05 & -1195.59 & $1195<1$ & 0.912 & $<0.001$ & $>999.998$ \\
\hline FAM & 8 & 100 & PPB & 8 & 100 & 0.09247 & 601.17 & 84 & -0.00 & $0.9999_{i}$ & 0.05 & $\because 95.59$ & 1195.4 & 0.912 & $<0.001$ & $>999.989$ \\
\hline & & & & & & & & & & & & & & & & \\
\hline
\end{tabular}


AEH-13-PSEUDO-06

\begin{tabular}{|c|c|c|c|c|c|c|c|c|c|c|c|c|c|c|c|c|}
\hline & 8 & 100 & PPB & 24 & 0 & -0.09247 & 001.17 & 84 & -0.00 & 0.9998 & 0.05 & -1195.59 & 1195,41 & 0.812 & $<0.001$ & $>999.999$ \\
\hline FAM & 8 & 100 & $\mathrm{PPB}$ & 24 & 50 & -13.8603 & 423.72 & 84 & -0.030 & 0.9740 & 0.95 & -856.48 & 828.78 & $<0.001$ & $<0.001$ & $>989 . \theta 99$ \\
\hline FAM & 8 & 00 & $\mathrm{PPB}$ & 24 & 100 & $-13,8603$ & 423.72 & 84 & $-0.03: 0$ & 0.9740 & 0.05 & -856.48 & 828.76 & $<0.001$ & $<0.001$ & $>999.999$ \\
\hline FAM & 8 & $: 00$ & THR & 8 & 0 & $-144 E-16$ & 599.23 & 84 & -0.00 & 1.0000 & 0.05 & -1191.64 & 1191.64 & 1.000 & $<0.001$ & $>999.989$ \\
\hline FAM & 8 & 100 & THR & 8 & 50 & $-142 E-16$ & 599.23 & 84 & -0.00 & 1.0000 & 0.05 & -1191.64 & 1191.64 & 1.000 & $<0.001$ & $>099.999$ \\
\hline FAM & 8 & 100 & THR & 8 & 100 & $-355 \mathrm{E}-17$ & 599.23 & 84 & $-0.00: 1$ & 1.0000 & 0.05 & -1191.64 & 1181,64 & 1.000 & $<0.001$ & $>999.998$ \\
\hline FAV & 8 & 100 & THR & 24 & 0 & $-142 E-16$ & 599.23 & 84 & $-0.00 ; 1$ & 1,0000 & 0.05 & -1191.64 & 1191.64 & 1.000 & $<0.001$ & $>999.999$ \\
\hline FAM & 8 & 100 & THR & 24 & 50 & $-107 \mathrm{E}-{ }^{\wedge} 6$ & 598.23 & 84 & $-0.00: 1$ & 1.0000 & 0.05 & -1191.64 & 1191.64 & 1.000 & $<0.001$ & $>980.999$ \\
\hline FAM & 8 & 100 & THR & 24 & 100 & $-107 \mathrm{E}-18$ & 599.23 & 84 & -0.00 & 1.0000 & 0.05 & -1191.64 & $1191.6 \%$ & 1.000 & $<0.001$ & $>999.999$ \\
\hline FAM & 8 & 100 & WAS & 8 & 0 & $-318 \mathrm{E}-13$ & 599.23 & 84 & -0.00 & 10000 & 0.05 & -1191.64 & 1191.64 & 1.000 & $<0.001$ & $>999.999$ \\
\hline FAM & 8 & 100 & WAS & 8 & 50 & -13.7511 & 423.72 & 84 & -0.030 & 0.9742 & 0.05 & -856.37 & B28.87 & $<0.001$ & $<0.001$ & $>999.999$ \\
\hline FAM & 8 & 100 & WAS & 8 & 100 & $1.54 \mathrm{E}-11$ & 599,23 & 84 & $0.00:$ & 1.0000 & 0.05 & $-1: 91,64$ & 1191,64 & 1.000 & $<0.001$ & $>999.998$ \\
\hline FAM & 8 & 100 & WAS : & 24 & 0 & $5.55 \mathrm{E}-11$ & 590.23 & 84 & 0.00 & 1.0000 & 0.05 & $-1,191,64$ & 1191,64 & 1.000 & $<0.001$ & $>099.998$ \\
\hline FAM & 8 & 100 & WAS & 24 & 50 & $9.59 \mathrm{E}-11$ & 599.23 & 84 & $0.00 ?$ & 1.0000 & 0.05 & -1191.64 & 1191.64 & 1.000 & $<0.001$ & $>999.999$ \\
\hline FAM & 8 & 100 & WAS & 24 & 100 & $-808 \mathrm{E}-13$ & 589.23 & 84 & -3.00 & 1.0000 & 0.65 & -1191.64 & 1191.64 & 1.000 & $<0.001$ & $>\theta \theta 9.899$ \\
\hline FAM & 24 & 0 & FAM & 24 & 50 & 9.44E-16 & 599.23 & 84 & 0.00 & 1.0000 & 0.05 & $-1191,64$ & 1191.64 & 1.000 & $<0.001$ & $>999.999$ \\
\hline FAM & 24 & 0 & FAM & 24 & 100 & $-101 \mathrm{E}-10$ & 599.23 & 84 & $-0.00 \vdots$ & 1.0000 & 0.05 & -1191.64 & 1121.64 & 1.000 & $<0.001$ & $>999899$ \\
\hline FAM : & 24 & 0 & HGE & 8 & 0 & -13.9829 & 423.72 & 84 & -0.03 & 0.9738 & 005 & -856.60 & 828.63 & $<0.001$ & $<0.001$ & $>999.899$ \\
\hline FAM & 24 & 0 & $\mathrm{HGE}$ & 8 & 50 & -0.1943 & 603.59 & 84 & -0.00 & 0.9997 & 0.05 & -1200.51 & 1200.12 & 0.823 & $<0.001$ & $>999.999$ \\
\hline FAM & 24 & 0 & HGE & 8 & 100 & -0.1943 & 603.50 & 84 & -0.000 & 0.9997 & 0.05 & -1200.51 & 1200.12 & 0.823 & $<0.001$ & $>999.999$ \\
\hline FAM & 24 & 0 & HGE & 24 & c & -13.8829 & 423.72 & 34 & -0.030 & 0.9738 & 0.05 & -856.60 & 828.63 & $<0.001$ & $<0.001$ & $>099.999$ \\
\hline FAM & 24 & 0 & HGE & 24 & 50 & -13.9829 & 423.72 & 84 & -0.030 & 0.9738 & 0.05 & $-856,60$ & 828.63 & $<0.001$ & $<0.001$ & $>999.999$ \\
\hline FAM & 24 & 0 & $\mathrm{HGE}$ & 24 & 100 & -13.9829 & 423.72 & 84 & $-0.03: 0$ & 0.9738 & 0.05 & -856.60 & 828.63 & $<0,001$ & $<0.001$ & $>999.999$ \\
\hline FAM & 24 & 0 & $\mathrm{HIC}$ & 8 & 0 & $1.9 \mathrm{E}-15$ & 599.23 & 84 & 0.00 & 1.0000 & 0.05 &.-1191.64 & 1191.64 & 1.000 & $<0.001$ & $>999.999$ \\
\hline FAM & 24 & 0 & $\mathrm{HIC}$ & 8 & 50 & $3.55 E-15$ & 599.23 & 84 & 0.00 & 1.0000 & 0.05 & -1191.64 & 1191.64 & 1.000 & $<0.001$ & $>999.099$ \\
\hline FAM & 24 & 0 & $\mathrm{HLC}$ & 8 & 100 & $8.88 \mathrm{E}-15$ & 599.23 & 84 & 0.00 & 1.0000 & 0.05 & -1191.64 & 1181.64 & 1,000 & $<0.001$ & $>999.999$ \\
\hline FAM & 24 & 0 & $\mathrm{HIC}$ & 24 & 0 & $5.33 \mathrm{E}-15$ & 599.23 & 84 & 0.00 & 1.0000 & 0.05 & -1191.64 & 1191.64 & 1.000 & $<0.001$ & $>999.089$ \\
\hline FAM & 24 & $c$ & $\mathrm{HIC}$ & 24 & 50 & $3.55 E-15$ & 599.23 & 84 & 0.00 & 1.0000 & 0.05 & -1191.64 & 1191.64 & 1.000 & $<0.001$ & $>996.999$ \\
\hline FAM & 24 & 0 & $\mathrm{HIC}$ & 24 & 100 & -13.7511 & 423.72 & 84 & -0.03 & 0.9742 & 0.05 & -856.37 & B28.87 & $<0.001$ & $<0.001$ & $>999.999$ \\
\hline FAM & 24 & 0 & PIG & 8 & 0 & -0.1943 & $603.59 !$ & 84 & -0.00 & 0.9997 & 0.05 & -1200.51 & 1200.12 & 0.823 & $<0.001$ & $>999.099$ \\
\hline FAM & 24 & 0 & PIG & 8 & 50 & -0.1943 & 603.59 & 84 & -0.00 & 0.9997 & 0.05 & -1200.51 & 1200.12 & 0.823 & $<0.001$ & $>999.999$ \\
\hline FAM & 24 & 0 & $\mathrm{PIG}$ & 8 & 100 & -0.1943 & 603.59 & 86 & $-0,00$ & 0.9997 & 0.05 & -1200.51 & 1200.12 & 0.823 & $<0.001$ & $>999.999$ \\
\hline FAM & 24 & 0 & $P \mid G$ & 24 & 0 & -0.1943 & 603.59 & 64 & -0.00 & 0.9997 & 0.05 & -1200.51 & 1200.12 & 0.823 & $<0.001$ & $>999.899$ \\
\hline FAM & 24 & 0 & $\mathrm{PIG}$ & 24 & 50 & -0.1843 & 603.59 & 84 & -0.00 & 0.9997 & 0.05 & -1200.51 & 1200.12 & 0.823 & $<0.001$ & $>999.990$ \\
\hline FAM & 24 & 0 & PIG & 24 & 100 & -0.1843 & 603.59 & 84 & -0.00 & 0.9997 & 0.05 & -1200.51 & 1200.12 & 0.823 & $<0.001$ & $>999.999$ \\
\hline FAM & 24 & 0 & $\mathrm{PPB}$ & 8 & 0 & -0.09247 & 601.17 & 84 & 0.00 & 0.9999 & 0.05 & -1195.50 & 1195.41 & 0.912 & $<0.001$ & $>999.999$ \\
\hline FAM & 24 & 0 & PPB & 8 & 50 & -0.09247 & 601.17 & 84 & -0.00 & 0.9989 & 0.05 & -1185.59 & 1195.41 & 0.912 & $<0.001$ & $>999.999$ \\
\hline FAM & 24 & 0 & PPB & 8 & 100 & -0.08247 & 601.17 & 84 & -0.00 & 0.9999 & 0.05 & -1195.59 & 1195,41 & 0.912 & $<0.001$ & $>999.999$ \\
\hline FAM & 24 & 0 & PPB & 24 & 0 & -0.09247 & 601.17 & 84 & -0.00 & 0.9999 & 0.05 & -1195.59 & 118541 & 0.912 & $<0.001$ & $>999.999$ \\
\hline $\mathrm{FAM}$ & 24 & 0 & PPB & 24 & 50 & $-13,6603$ & 423.72 & 84 & -0.03 & 0.8740 & 0.05 & -856.48 & 828.76 & $<0.001$ & $<0.001$ & $>990.999$ \\
\hline FAM & 24 & 10 & PPB & 24 & 150 & $-13,8603$ & 423.72 & 84 & -0.03 & 0.9740 & 0.05 & -856.48 & 828.76 & $<0.001$ & $<0.001$ & $>999.899$ \\
\hline FAM & 24 & 0 & THR & 8 & 0 & $-108 E-\wedge 6$ & 599.23 & 84 & -0.00 & 1,0000 & 0.05 & $-\{191.64$ & 1191.64 & 1.000 & $<0.001$ & $>999.989$ \\
\hline FAM & 24 & 0 & THR & 8 & 50 & $-107 \mathrm{E}-16$ & 599.23 & 84 & $-0,00$ & 1,0000 & 0.05 & -1191.64 & 1191.64 & 1.000 & $<0.001$ & $>999.999$ \\
\hline FAM : & 24 & 0 & THR & 8 & 100 & $-3545-17$ & 599.23 & 84 & -0.00 & 1.0000 & 0.05 & -1191.64 & 1191.64 & 1.000 & $<0.001$ & $>999.899$ \\
\hline FAM & 24 & 0 & THR & 24 & 0 & $-107 \mathrm{E}-16$ & 599.23 & $84:$ & $-0,00$ & 1,0000 & 0.05 & -1191.64 & 1191.64 & 1.000 & $<0.001$ & $>999.999$ \\
\hline FAM & 24 & 0 & THR & 24 & 50 & $-711 \mathrm{E}-17$ & 598.23 & 84 & $-0,00$ & 1.0000 & 0.05 & -1191.64 & 1191.64 & 1,000 & $<0.001$ & $>999.809$ \\
\hline FAM & 24 & 0 & THR : & 24 & 100 & $-107 \mathrm{E}-16$ & 599.23 & 84 & -0.00 & 1.0000 & 0.05 & -1191.64 & 1191.64 & 1.000 & $<0.001$ & $>999.999$ \\
\hline FAM : & 24 & i. & WAS & 8 & 0 & $-31 \mathrm{BE}-13$ & 599.23 & 84 & -0.00 & 1.0000 & 0.05 & $-1191,64$ & 1191.64 & 1.000 & $<0.001$ & $>999.999$ \\
\hline FAM & 24 & 0 & WAS & 8 & 50 & -13.7511 & 423.72 & 84 & -0.03 & 0.9742 & 0.05 & -856.37 & 828.87 & $<0.001$ & $<0.001$ & $>999.999$ \\
\hline FAM : & & & & & $i$ & & & & & & & & & & & \\
\hline
\end{tabular}

file://C:/Users/klweber/AppData/I ,ocal/Temp/1/SAS\%20Temporary\%20Files/.TD3400_.. 12/10/2014 
SAS Output

Page 24 of 38

AEH-13-PSEUDO-06

\begin{tabular}{|c|c|c|c|c|c|c|c|c|c|c|c|c|c|c|c|c|}
\hline & 24 & $: 0$ & VAS: & & 100 & $E_{111}$ & .25 & 84 & $0 . \infty 01$ & 1.0000 & 0.05 & -1191.64 & 1191.64 & 1.000 & $<0.001$ & $>989.899$ \\
\hline AM & 24 & 0 & WAS: & 24 & 0 & $5.55 E-11$ & 599.23 & 84 & 0.001 & 1.000 & 0.05 . & -1191.64 & 1191.64 & 1.000 & $<0.001$ & $>999.999$ \\
\hline FAM : & 24 & $\vdots 0$ & WAS & 24 & 50 & $59 \mathrm{E}-11$ & $99.23 !$ & 84 & $0.00 \cdot 1$ & 1.0000 & 0.05 . & -1191.84 & 1191.64 & 1.000 & $<0,001$ & $>999.999$ \\
\hline FAM & 24 & 0 & WAS & 24 & 100 & $08 \mathrm{E}-13$ & 999.23 & 84 & $\begin{array}{lll}-0.00 & 1\end{array}$ & 1.0000 & 0.05 & $-1181,64$ & 1191.64 & 1.000 & $<0.001$ & $>999.999$ \\
\hline FAM & 24 & 50 & FAM & 24 & 100 & $-171 E-16$ & 598.23 & 84 & -0.00 & 1.0000 & 0.05 & -1191.64 & 1191,84 & 1.000 & $<0.001$ & 99.999 \\
\hline FAM & 24 & 50 & HGE & 8 & 10 & 3.9828 & 423.72 & 84 & -0.030 & 0.9738 & 0.05 & -856.60 & 828.63 & $<0.001$ & $<0.001$ & $>999.999$ \\
\hline FAM & 24 & 50 & HGE & 8 & 50 & -0.1943 & 603.59 & 84 & -0.00 & 0.8997 & 0.05 & -1200.51 & 1200.12 & 0.823 & $<0.001$ & $>999.999$ \\
\hline FAM & 24 & 50 & HGE & 8 & 100 & -0.1943 & 603.59 & 84 & -0.00 & 0.9997 & 0.05 & -1200.51 & 1200.12 & 0.823 & $<0.001$ & $>999.999$ \\
\hline FAM & 24 & 50 & HGE & 24 & 0 & -13.9829 & 423.72 & 84 & -0.030 & 0.9738 & 0.05 & -858.60 & 828.63 & $<0,001$ & $<0.001$ & $>999.999$ \\
\hline $\mathrm{AM}$ & 24 & 50 & $\mathrm{HGE}$ & 24 & 50 & -13.0829 & 423.72 & 84 & -0.030 & 0.9738 & 0.05 & -856.60 & 828,63 & $<0.001$ & $<0,001$ & $>999.999$ \\
\hline FAV & 24 & 50 & HOE & 24 & 100 & -13.9829 & 423.72 & 84 & -0.0310 & 0.9738 & 0.05 & -856.60 & 828.63 & $<0.001$ & $<0.001$ & $>999.999$ \\
\hline FAM & 24 & 50 & $\mathrm{HC}$ & 8 & 0 & $1.11 \mathrm{E}-15$ & 598.23 & 84 & $0.00 ! 1$ & 1.0000 & 0.05 & -1191.64 & 1191,64 & 1.000 & $<0.001$ & $>999.999$ \\
\hline FAM & 24 & 50 & $\mathrm{HIC}$ & 8 & 50 & 0 & 599.23 & 84 & 0.001 & 1.0000 & 0.05 & -1191.64 & 1101.64 & 1.000 & $<0.001$ & $>999.999$ \\
\hline FAM & 24 & 50 & HIC & 8 & 100 & $7.11 \mathrm{E}-15$ & 599.23 & 84 & 0.001 & 1,0000 & 0.05 & $-1 \cdot 91,64$ & 119164 & 1.000 & $<0.001$ & $>999,999$ \\
\hline FAM & 24 & 50 & $\mathrm{HIC}$ & 24 & 0 & 4.54E-15 & 590.23 & 84 & 0.001 & 1.0000 & 0.05 & $-1191,64$ & 1191.64 & 1.000 & $<0.001$ & $>999.999$ \\
\hline FAM & 24 & 50 & $\mathrm{HCC}$ & 24 & 50 & $1.78 E-15$ & 599.23 & 84 & 0.001 & 1.0000 & 0.05 & $-1191,64$ & 1191.64 & 1,000 & $<0,001$ & $>999,999$ \\
\hline FAM & 24 & 50 & $\mathrm{HIC}$ & 24 & 100 & -13.7511 & 423.72 & 84 & -0.030 & 0.9742 & 0.65 & -856.37 & 828.87 & $<0.001$ & $<0.001$ & $>999.899$ \\
\hline FAM & 24 & 50 & PIG & 8 & 0 & -0.1943 & 603.59 & 84 & $-0.00=0$ & 0.9987 & 0.05 & -1200.51 & 1200.12 & 0.823 & $<0.001$ & $>999.999$ \\
\hline FAM & 24 & 50 & $\mathrm{PIG}$ & 8 & 50 & -0.1943 & 603.59 & 84 & -0.0010 & 0.9987 & 0.05 & -1200.51 & 1250.12 & 0.823 & $<0.001$ & $>999.999$ \\
\hline FAM & 24 & 50 & PIG & 8 & 100 & -0.1943 & 603,59 & 84 & -0.00 & 0.9997 & 0.05 & -1200.51 & 1200.12 & 0.823 & $<0.001$ & $>999.999$ \\
\hline FAM & 24 & 50 & PIG & 24 & 10 & -0.1943 & 603.59 & 84 & $-0.00 \mathrm{j}$ & 0.8997 & 0.05 & $-1200,51$ & 1200.12 & 0.823 & $<0.001$ & $>999.999$ \\
\hline FAM & 24 & 50 & PIG & 24 & 50 & -0.1843 & 603.59 & 84 & .0 .0010 & 0.8907 & 0.05 & $-1200,51$ & 1200.12 & 0.823 & $<0.001$ & $>998.999$ \\
\hline FAM & 24 & 50 & PIG & 24 & 100 & -0.1943 & 603.59 & 84 & -0.00 & 0.9997 & 0.05 & -1200.51 & 1200.12 & 0.823 & $<0.00$ & $>999.899$ \\
\hline FAM & 24 & 50 & PPB & 8 & 0 & -0.09247 & 601.17 & 34 & -0.00 & 0.9999 & 0.05 & $-1195,59$ & 1195.41 & 0.912 & $<0.001$ & $>999.999$ \\
\hline$=A M$ & 24 & 50 & PPB & 8 & 50 & -0.09247 & 601.17 & 84 & $-0,000$ & 0.9999 & 0.05 & -1195.59 & 1195.41 & 0.912 & $<0.001$ & $>999.999$ \\
\hline FAM & 24 & 50 & $\mathrm{PPB}$ & 8 & 100 & -0.09247 & 601.17 & 84 & -0.000 & 0.9999 & 0.05 & -1195.59 & 1195,41 & 0.912 & $<0.00$ & $>999.999$ \\
\hline FAM & 24 & 50 & PPB : & 24 & 0 & -0.09247 & 601.17 & 84 & -0.000 & 0.9999 & 0.05 & -1195.59 & 1185.41 & 0.912 & $<0.00$ & $>989.999$ \\
\hline FAM : & 24 & $5 c$ & $\mathrm{PPB}$ & 24 & 60 & -13.8803 & 423.72 & 84 & 0.030 & 0.0740 & 0.05 & -856.48 & 828.73 & $<0.001$ & $<0.001$ & $>999.999$ \\
\hline FAM & 24 & 50 & PPB & 24 & 100 & -13.8503 & 423.72 & 84 & -0.030 & 0.9740 & 0.05 & -856.48 & 828.76 & $<0.00^{-1}$ & $<0.00$ & $>999.999$ \\
\hline FAM & 24 & 50 & THR & 8 & 0 & $-108 \mathrm{E}-16$ & 599.23 & 84 & -0.00 & 1.0000 & 0.05 & -1191.64 & 1191.64 & 1.000 & $<0.0$ & $>999,990$ \\
\hline FAM & 24 & 50 & THR : & 8 & 50 & $-142 E-16$ & 599.23 & 8 & -0.00 & 1.0000 & 0.05 . & -1191.64 & 1191.64 & 1.000 & $<0.001$ & $>999,999$ \\
\hline FAM & 24 & 50 & THR & 8 & 100 & $-355 E-17$ & 599.23 & 84 & -0.001 & 1.0000 & 0.05 & -1191.64 & 1191.6 & 1.00 & $<0.00$ & $>999.899$ \\
\hline FAM & 24 & 50 & THR & 24 & 10 & $-107 \mathrm{E}-16$ & 599.23 & 84 & -0.00 & 1.0000 & 0.05 & -1191.64 & 1191.64 & 1.000 & $<0.00$ & $>999.999$ \\
\hline FAM & 24 & 50 & THR & 24 & 50 & $-107 \mathrm{E}-16$ & 599.23 & 84 & -0.00 & 1.0000 & 0.05 & -1191.64 & 1181,64 & 1.000 & $<0,00$ & 999.999 \\
\hline AM & 24 & 50 & THR & 24 & 100 & $-107 E-16$ & 590.23 & 84 & -0.00 & 1.0000 & 0.05 & -1191.64 & $119^{n} \cdot 64$ & 1.000 & $<0.0$ & $>899.999$ \\
\hline FAM & 24 & 50 & WAS & 8 & 0 & $-318 E-13$ & 599.23 & 84 & -0.00 & $\therefore 000$ & $c .05$ & -1191.64 & 1191.64 & 1.000 & $<0.00$ & $>999.999$ \\
\hline FAM & 24 & 50 & WAS & 8 & 50 & -13.7511 & 423.72 & 84 & -0.03 & 0.9742 & 0.05 & $|-856.37|$ & 828.8 & $<0.00$ & $<0.00$ & $>999.999$ \\
\hline FAM & 24 & 50 & WAS & 8 & 100 & $1.54 \mathrm{E}-11$ & 599.23 & 84 & 0.00 & 1.0000 & 0.05 & $\mid-1181.84$ & 1491.64 & 1.000 & $<0.0$ & $>999.999$ \\
\hline FAM & 24 & 50 & WAS & 24 & 0 & $5.55 E-11$ & 599.23 & 84 & 0.00 & 1.0000 & 0.05 & -1191.64 & 1191.64 & 1.000 & $<0.00$ & $>989.999$ \\
\hline FAM & 24 & 50 & WAS & 24 & 50 & $9.59 \mathrm{E}-11$ & 590.23 & 84 & 0.00 & 1.0000 & 0.05 & $-1191,64$ & 1181.64 & 1.000 & $<0.0$ & 999.999 \\
\hline FAM & 24 & 50 & WAS & 24 & 100 & $-808 E-13$ & 599.23 & 84 & -0.00 & 1.0000 & 0.05 & -1191.64 & 1191.64 & 1.000 & $<0.001$ & $>999.999$ \\
\hline FAM & 24 & 00 & $\mathrm{HGE}$ & 8 & 0 & -13.8829 & 423.72 & 84 & $-0.03: 0$ & 0.9738 & 0.05 & $-856,60$ & 828.63 & $<0.001$ & $<0.001$ & $>999.999$ \\
\hline FAM & 24 & 100 & $\mathrm{HGE}$ & 8 & 50 & $-0,1943$ & 603.59 & 84 & -0.00 & 0,9997 & 0.05 & -1200.51 & 1200.12 & 0.823 & $<0.001$ & $>999.999$ \\
\hline FAM & 24 & 100 & $\mathrm{HGE}$ & 8 & 100 & $-0,1943$ & 603.59 & 84 & -0.00 & 0.9997 & 0.05 & $-1200,51$ & 1200.12 & 0.823 & $<0.001$ & $>899.989$ \\
\hline FAM & 24 & 100 & HGE & 24 & 0 & -13.9829 & 3.72 & 84 & -0.03 & 0.9738 & 0.05 & -856.60 & 828.63 & $<0.001$ & $<0.001$ & $>999.989$ \\
\hline FAM & 24 & 100 & HGE & 24 & 50 & $-13,0829$ & 423.72 & 84 & -0.03 & 09738 & 0.05 & -856.60 & 828.63 & $<0.001$ & $<0.001$ & $>999.999$ \\
\hline AMM & 24 & 100 & HGE & 24 & 100 & 3.9829 & 423.72 & 84 & -0.03 & 0.9738 & 0.05 & -856.60 & 828.63 & $<0.001$ & $<0.001$ & $>989.999$ \\
\hline FAM & 24 & 100 & $\mathrm{HIC}$ & 8 & 0 & $1.81 E-4$ & 99.23 & 84 & 0.00 & 1,0000 & 0.05 & $-\because 191.64$ & 1191.64 & 1.000 & $<0.001$ & 999.899 \\
\hline$M$ & 24 & 100 & $\mathrm{HIC}$ & 8 & 50 & $1.78 \mathrm{E}-{ }^{\wedge} 4$ & 599.23 & 84 & 0.00 & 1.0000 & 0.05 & $-1191,64$ & 1191.64 & 1.000 & $<0.001$ & $>999.899$ \\
\hline & & & & & & & & & & & & & & & & \\
\hline
\end{tabular}

file://C:/Users/klweber/Appl)ata/Local/Temp/1/SAS\%20Temporary\%20Files/_TD3400_.. 12/10/2014 


\section{AEHH-13-PSEUDO-06}

\begin{tabular}{|c|c|c|c|c|c|c|c|c|c|c|c|c|c|c|c|c|}
\hline & 24 & 100 & $\mathrm{HIC}$ & 8 & 100 & $9 E-14$ & 9.23 & 84 & 0.00 & 1.0000 & 0.05 & 1.64 & 1.64 & 1.000 & $<0.001$ & 999. \\
\hline A.M. & 24 & 100 & HiC & 24 & 0 & $2.16 \mathrm{E}-14$ & 599.23 & 84 & 0.00 & 1.0000 & 0.05 & -1191.64 & 1191.64 & 1.000 & $<0.001$ & $>999.999$ \\
\hline FAM & 24 & 100 & HIC & 24 & 50 & $1.95 E-14$ & 599.23 & 84 & 0.00 & 10000 & 0.05 & -1191.84 & 1191.64 & 1.000 & $<0.001$ & $>090.999$ \\
\hline FAM & 24 & 100 & HIC & 24 & 100 & -13.7511 & 423.72 & 84 & -0.03 & 0.9742 & 0.05 & -856.37 & 828.87 & $<0,001$ & $<0.001$ & $>999.999$ \\
\hline FAM & 24 & 100 & PIG & 8 & 0 & -0.1943 & 603,59 & 84 & -0.00 & 0.9997 & 0.05 & -1200.51 & 12.0012 & 0.823 & $<0.001$ & $>999.998$ \\
\hline FAM & 24 & 100 & PIG & 8 & 50 & -0.1943 & 603.59 & 84 & -0.00 & 0.9997 & 0.05 & 200.51 & 1200.12 & 0.823 & $<0.001$ & $>999.999$ \\
\hline FAM & 24 & 100 & PlG & 8 & 100 & -0.1943 & 603.50 & 84 & -0.00 & 0.8997 & 0.05 & -1200.51 & 1200.12 & 0.823 & $<0.001$ & $>999.999$ \\
\hline FAM & 24 & 100 & PIG & 24 & 0 & -0.1913 & 603.59 & 84 & -0.00 & 0.9997 & 0.05 & -1200.51 & $1200: 2$ & 0.823 & $<0.001$ & $>090.989$ \\
\hline FAM: & 24 & 100 & PIG & 24 & 50 & -0.1943 & 603.59 & 84 & -0.00 & 0.9997 & 0.05 & -1200.51 & 1200.12 & 0.823 & $<0.001$ & $>989.989$ \\
\hline FAM & 24 & 100 & PIG & 24 & 100 & -0.1943 & 603.59 & 84 & -0.00 & 0.9897 & 0.05 & -1200.51 & 1200.12 & 0.823 & $<0.001$ & $>999.899$ \\
\hline FAM & 24 & 100 & PPB & 8 & 0 & -0.09247 & 601.17 & 84 & -0.00 & 0.9999 & 0.05 & -1195.59 & 1195.41 & 0.912 & $<0,001$ & $>999.999$ \\
\hline FAM & 24 & 100 & PPB : & 8 & 50 & -0.09247 & 601.17 & 84 & -0.00 & 0.0990 & 0.05 & -1195.50 & 1195.41 & 0.912 & $<0.001$ & $>998.999$ \\
\hline FAM & 24 & 100 & PPB & 8 & 100 & -0.09247 & 601.17 & 84 & -0.00 & 0.9999 & 0.05 & 1185.59 & 1195.41 & 0.812 & $<0.001$ & $>999.899$ \\
\hline FAM & 24 & 100 & PPB & 24 & 0 & -0.09247 & 601.17 & 84 & $-0,00$ & $0.999 \theta$ & 0.05 & -1195.59 & 1195.41 & 0.912 & $<0.001$ & $>998.999$ \\
\hline FAM & 24 & 100 & PPB & 24 & 50 & -13.8603 & 423,72 & 84 & -0.03 & 0,9740 & 0.05 & -856.48 & 828.76 & $<0,001$ & $<0.001$ & $>399.999$ \\
\hline FAM & 24 & 100 & PPB & 24 & 100 & -13.8603 & 423.72 & 84 & -0.03 & 0.9740 & 0.05 & -856.48 & 828.76 & $<0,001$. & $<0.001$ & $>999.999$ \\
\hline FAM & 24 & 100 & THR & 8 & 0 & 6.92E-15 & 599.23 & 84 & 0.00 & 1.0000 & 0.05 & -1191.64 & 1191.64 & 1.000 & $<0.001$ & $>999.999$ \\
\hline FAM & 24 & 100 & THR & 8 & 50 & $3.55 \mathrm{E}-15$ & 699.28 & 84 & 0.00 & 1.0000 & 0.05 & -1191.64 & 1191.54 & 1.000 & $<0.00$ & $>999.990$ \\
\hline FAM & 24 & 100 & THR & 8 & 100 & $1,42 E-14$ & 599.23 & 84 & 0.00 & 1.0000 & 0.05 & 1191.64 & 1191,64 & 1.000 & $<0.00$ & $>999.999$ \\
\hline FAM : & 24 & 100 & THR & 24 & 0 & $7.11 \mathrm{E}-15$ & 599.23 & 84 & 0.00 & 1.0000 & 0.05 & -1191.64 & 1191.64 & 1.000 & $<0.00$ & $>999.999$ \\
\hline FAM & 24 & 100 & THR & 24 & 50 & $7.11 \mathrm{E}-15$ & 599.23 & 84 & 0.00 & 1.0000 & 0.05 & -1191.64 & 1191,64 & 1.000 & $<0.00$ & $>999.999$ \\
\hline FAM & 24 & 100 & THR: & 24 & 100 & 7.11E-15 & 599.23 & 84 & 0.00 & 1.0000 & 0.05 & -1191.64 & 1191.64 & 1.000 & $<0.0$ & $>989.99$ \\
\hline FAM & 24 & 100 & WAS & 8 & 0 & $-317 E-13$ & 599.23 & 84. & -0.00 & .0000 & 0.05 & -1191.64: & 1191.64 & 1.000 & $<0.00$ & $>999.999$ \\
\hline FAM & 24 & 100 & WAS : & 8 & 50 & -13.7511 & 423,72 & 84 & -0.03 & 0.9742 & 0.05 & -856.37 & 828.87 & $<0.001$ & $<0.00$ & $>999.998$ \\
\hline FAM & 24 & 100 & WAS & 8 & 100 & $1.55 \mathrm{E}-11$ & 599.23 & 84 & 0.00 & 1.0000 & 0.05 & -1181.64 & 1191.64 & 1.000 & $<0.00$ & $>999.99$ \\
\hline FAM & 24 & 100 & WAS: & 24 & 0 & $5.56 \mathrm{E}-11$ & 599.23 & 84 & $0.00^{\circ}$ & 1.0000 & 0.05 & $-1191,84$ & 1191,64 & 1.000 & $<0.00$ & $>999.899$ \\
\hline FAM & 24 & $: 00$ & WAS & 24 & 50 & $9.59 \mathrm{E}-11$ & 599.23 & 84 & 0.00 & 1,0000 & 0.05 & -1191.64 & 1191.64 & 1.00 & $<0.0$ & $>999.999$ \\
\hline FAM & 24 & 100 & WAS & 24 & 100 & $-808 E-13$ & 599.23 & 84 & -0.00 & 1.0000 & 0.05 & -1191.84 & 1191.64 & 1.00 & $<0.0$ & $>909.999$ \\
\hline HGE & 8 & 0 & HGE : & 8 & 50 & 13.7885 & 429.87 & 84 & 0.03 & 0.9745 & 0.05 & -841.05 & $868.63=$ & $>899.998$ & $<0.001$ & $>999.999$ \\
\hline HGE & 8 & 0 & HGE & 8 & $: 100$ & 13.7885 & 429.87 & 84 & 0.03 & 09745 & 0.05 & -841.05 & 868.63 & $>999.999$ & $<0.0$ & $>999.999$ \\
\hline HGE & 8 & 0 & HGE & 24 & 0 & $1.65 E-15$ & 0.6430 & 84 & 0.00 & 1.0000 & 0.05 & -1.2786 & 1.2786 & 1.000 & 0,27 & 3.592 \\
\hline HGE & 8 & 0 & HGE & 24 & 50 & $2.13 \mathrm{E}-15$ & 0.6430 & 84 & 0.00 & 1.0000 & 0.05 & -1.2786 & 12786 & 1.00 & 0.2 & 3.592 \\
\hline HGE & 8 & 0 & HGE & 24 & 100 & $2.09 E-15$ & 0.6430 & 84 & 0.00 & 1.0000 & 0.05 & -1.2786 & 1.2786 & 1.000 & 0.2 & 3.592 \\
\hline HGE & 8 & 0 & HIC & 8 & 0 & 13.9829 & 423.72 & 84 & 0.03 & 0.9738 & 0.05 & -828.63 & 856.30 & $>989,999$ & $<0.001$ & $>999.999$ \\
\hline HGE & 8 & 0 & HIC & 8 & 50 & 13.9829 & 423.72 & 84 & 0.03 & 0.9738 & 0.05 & -828.63 & 356.60 & $>999.999$ & $<0.001$ & 999,999 \\
\hline HGE & 8 & 0 & $\mathrm{HIC}$ & 8 & 100 & 13.9829 & 423.72 & 84 & 0.03 & 0.9738 & 0.05 & -828.63 & 856.60 & $>999.899$ & $<0.001$ & $>999.999$ \\
\hline 116E & 8 & 0 & : HIC & 24 & $: 0$ & 13.9829 & 423.72 & 84 & 0.03 & 0.9738 & 005 & -828.63 & 856.60 & $>999.999$ & $<0.001$ & $>988.999$ \\
\hline HGE: & 8 & 0 & HIC, & 24 & 50 & 13.9829 & 423.72 & 84 & 0.03 & 0.9738 & 0.05 & -328.63 & 856.60 & $>998.999$ & $<0.001$ & $>999.999$ \\
\hline HGE : & 8 & 0 & $\mathrm{HIC}$ & 24 & 100 & 0.2318 & 0.8416 & 84 & 0.36 & 0.7188 & 0.05 & -1.0441 & 1.5077 & 1.261 & 0.352 & 4.516 \\
\hline HGE & 8 & 0 & $\mathrm{PIG}$ & 8 & c & 13.7885 & 429.87 & 84 & 0.03 & 0.9745 & 0.05 & -841.05 & 868.63 & $>989,999$ & $<0.001$ & $>899.999$ \\
\hline FGE & 8 & 0 & PIG & 8 & 50 & 13.7885 & 429.87 & 84 & 0.03 & C.9745 & 0.05 & 841.05 & 868.63 & $>999.989$ & $<0.001$ & $>999.899$ \\
\hline HGE & 8 & 0 & $\mathrm{PIG}$ & 8 & 100 & 13.7885 & 429.87 & 84 & 0.03 & 0.9745 & 0.05 & -841.05 & 868.63 & $>999.809$ & $<0.001$ & $>999.999$ \\
\hline $\mathrm{HGE}$ & 8 & 0 & PIG & 24 & 0 & 13.7835 & 429.87 & 84 ! & 0.03 ? & 0.9745 & 0.05 & -841.05 & 868.63 & $>999.999$ & $<0.001$ & $>999.999$ \\
\hline HGE & 8 & 0 & PIG & 24 & 50 & 13.7885 & 429.87 & 84 & 0.03 & 0.9745 & 0.05 & -841.05 & 868.63 & $>999.999$ & $<0.001$ & $>989.999$ \\
\hline FGE: & 8 & 0 & PIG & 24 & 10 & 13.7885 & 429.87 & 84 : & 0.03 & 0.9745 & 0.05 & -841.05 & 868.63 & $>999.899$ & $<0.001$ & $>999.999$ \\
\hline HGE & 8 & 0 & PPB & 8 & 0 & 13.8904 & 426.46 & 84 & 0.03 & 0.9741 & 0.05 & -834.17 & 861.95 & $>999.999$ & $<0.001$ & $>999.999$ \\
\hline HGE & 8 & 0 & PPB & 8 & 50 & 13.8904 & 426.48 & 84 & 0.03 & 0.9741 & 0.05 & -834.17 & 861,95 & $>999.998$ & $<0.001$ & $>999.999$ \\
\hline HGE & 8 & 0 & PPB & 8 & 100 & 13.8904 & 426.46 & 84 & 0.03 & 0.9741 & 0,05 & -834.17 & 861.95 & $>999.999$ & $<0.001$ & $>999.898$ \\
\hline & 8 & 0 & PPB & 24 & 0 & 13.8904 & 426.46 & 84. & 0.03 & 0.9741 & 0.05 & 34.17 & 861,95 & $>999.999$ & $<0.001$ & $>099,999$ \\
\hline
\end{tabular}

file://C:/Users/klweber/AppData/Local/Temp/l/SAS\%20Temporary\%20Files/_TD3400 ... 12/10/2014 
AEH-13-PSEUDO-06

\begin{tabular}{|c|c|c|c|c|c|c|c|c|c|c|c|c|c|c|c|c|}
\hline & 8 & & PPB & 24 & 50 & 0.1226 & 0.8422 & 84 & 0.19 & $0.8491 \mid$ & 0.05 & $\therefore 1545$ & 1.3997 & 1.130 & 0.315 & 4.054 \\
\hline$G E$ & 8 & 0 & PPB & 24 & 100 & 0.1226 & 0,8422 & 84 & 0.10 & 0.8481 & 0.05 & -1.1545 & 1.3997 & 1.130 & 0.315 & 4.054 \\
\hline IGE & 8 & 0 & THR & 8 & 0 & 13.9829 & 423.72 & 84 & 0.03 & 0.9738 & 0.05 & -828.63 & 856.60 & $>999.999$ & $<0.001$ & $>999.999$ \\
\hline IGE & 8 & 0 & THR & 8 & 50 & 13.9829 & 423.72 & 84 & 0.03 & 0.9738 & 0.05 & -828.63 & 856.60 & $>999.999$ & $<0.001$ & $>099.999$ \\
\hline TGE & 8 & 0 & THR & 8 & 100 & 13.9829 & 423.72 & 84 & 0.03 & 0.9738 & 0.05 & -828.63 & 856.60 & $>999.999$ & $<0.001$ & $>999.999$ \\
\hline GE & 8 & 0 & THR : & 24 & 0 & 13.9829 & 423.72 & 84 & 0.03 & 0.9738 & 0.05 & -828.63 & 853.60 & $>999.999$ & $<0.001$ & $>899.999$ \\
\hline HGE & 8 & 0 & THR & 24 & 50 & 13.9829 & 423,72 & 84 & 0.03 & 0.9738 & 0.05 & -828.63 & 856.60 & $>900.999$ & $<0.001$ & $>989.999$ \\
\hline$G E$ & 8 & 0 & THR : & 24 & 100 & 13.9820 & 423.72 & 84 & 0.03 & 0.9738 & 0.05 & -828.63 & 856.60 & $>999.999$ & $<0.001$ & $>999.999$ \\
\hline $\mathrm{GE}$ & 8 & $?$ & WAS & 8 & 0 & 13.9829 & 423.72 & 84 & $0.03 !$ & 0.9738 & 0.05 & -828.63 & 856.80 & $>998.999$ & $<0.001$ & $>899999$ \\
\hline GE & 8 & 0 & WAS & 8 & 50 & 0.2318 & 0.6416 & 84 & 0.36 & 0.7188 & 0.05 & -1.0441 & 1.5077 & 1.261 & 0.352 & 4.516 \\
\hline $\mathrm{GE}$ & $\theta$ & 0 & WAS: & 8 & 100 & 13.9829 & 423.72 & 84 & 0.03 & 0.9738 & 0.05 & -828.63 & 856.60 & $>999.999$ & $<0.001$ & $>999.999$ \\
\hline GGE & 8 & 0 & WAS! & 24 & c & 13.9829 & 423.72 & 84 & 0.03 & 0.9738 & 0.05 & -828.63 & 856.60 & $>990.999$ & $<0.001$ & $>999.999$ \\
\hline $\mathrm{HGE}$ & $B$ & 0 & WAS & 24 & EO & 13.9828 & 423.72 & 34 & 0.03 & 0.9738 & 0.05 & -828.63 & 856.60 & $>999.999$ & $<0.00$ & $>999,999$ \\
\hline HGE & 8 & 0 & WAS & 24 & 100 & 13.9828 & 423.72 & 84 & 0.03 & 0.9738 & 005 & -828.63 & 856.60 & $>999.999$ & $<0.00$ & $>\theta 99.999$ \\
\hline $\mathrm{HGE}$ & 8 & 50 & HGE & 8 & 100 & 2.,92E-11 & 607.93 & 34 & 0.00 & 1.0000 & 0.05 & -1208.93 & 1208.83 & 1.000 & $<0.00$ & $>989.999$ \\
\hline IGE & 8 & 50 & HGE & 24 & 10 & -13.7885 & 429.87 & 84 & -0.03 & 0.9745 & 0.05 & -868.63 & 841.05 & $<0.001$ & $<0,001$ & $>999.999$ \\
\hline -GGE & 8 & 50 & HGE & 24 & 50 & -13.7885 & 429.87 & B4 & -0.03 & 0.9745 & 0.05 & -868.63 & 841.05 & $<0.001$ & $<0.00$ & $>999.989$ \\
\hline HGE & 8 & 50 & HQE & 24 & 100 & -13.7885 & 428.87 & 84 & -0.03 & 0.9745 & 0.05 & -868.63 & 841.05 & $<0.001$ & $<0.00$ & $>999.999$ \\
\hline HGE & 8 & 50 & HIC & 8 & 0 & 0.1943 & 603.59 & 84 & 0.00 & 0.9997 & 0.05 & -1200.12 & 1200.51 & 1.215 & $<0,00$ & $>999.990$ \\
\hline HGE & 8 & 50 & HIC & 8 & 50 & 0.1943 & 603.59 & 84 & 0.00 & 0.8997 & 0.05 & -120012 & 1200.51 & 1.215 & $<0.00$ & $>999.999$ \\
\hline $\mathrm{HQE}$ & 8 & 50 & HIC & 8 & 100 & 0.1943 & 603.58 & 84 & 0.00 & 0.9997 & 0.05 & -1200.12 & 1200.51 & 1.215 & $<0.00$ & $>999.999$ \\
\hline HGE & 8 & $5 C$ & HIC & 24 & 0 & 0.1943 & 603.59 & 84 & 0.00 & 0.9997 & 0.05 & -1200.12 & 1200.5 & 1.215 & $<0.0$ & $>999,999$ \\
\hline hGE & $B$ & 50 & HIC & 24 & 50 & 0.1943 & 603.59 & 84 & 0.00 & 0.9997 & 0.05 & -1200.12 & 1200.51 & 1.215 & $<0.00$ & $>999.999$ \\
\hline HOE & 8 & 50 & HIC & 24 & 100 & -13.5567 & 429.87 & 84 & -0.03 & 0.9749 & 0.05 & -868.40 & 841.28 & $<0.00^{1}$ & $<0.0$ & $>999.989$ \\
\hline GE: & 8 & 50 & PIG & 8 & 0 & $-31 E-16$ & 607.83 & 84 & -0.00 & 1.0000 & 0.05 & -1208.93 & 1208.93 & 1.000 & $<0.00$ & $>999.99$ \\
\hline HGE & 8 & 50 & PIG & 8 & 50 & $-539 E-18$ & 607.93 & 84 & -0.00 & 1.0000 & 0.05 & -1208.93 & 1208.93 & 1.00 & $<0.00$ & $>998.999$ \\
\hline HGE & $B$ & 50 & PIG & 8 & 100 & $-31 E-16$ & 607.93 & 84 & -0.00 & 1.0000 & 0.05 & -1208.93 & 1208.93 & 1.0 & $<0.00$ & $>998.999$ \\
\hline HGE & 8 & 50 & PIG & 24 & 0 & $32 E-17$ & 607.03 & 84 & $-0,00$ & .0000 & c.05 & -1208.93 & 1208.93 & 1.00 & 0.0 & $>999.99$ \\
\hline HGE & 8 & 50 & $P I G$ & 24 & 50 & $-132 E-17$ & 607.93 & 84. & -0.00 & $\therefore .0000$ & 0.05 & -1208.93 & 1208.93 & 1.00 & $<0.0$ & $>999.999$ \\
\hline HGE: & 8 & 50 & $P \mid G$ & 24 & 100 & $2.23 \mathrm{E}-15$ & 807.93 & 84 & 0.00 & 1.0000 & 0.05 & -1208.93 & 1208.9 & 1.00 & $<0$. & 999.998 \\
\hline HGE & 8 & 50 & PPB & 8 & 0 & 0.1019 & 605.52 & 84. & 0.00 & 0.9999 & 0.05 & -1204.04 & 1204.2 & 1.10 & $<0.001$ & $>999.99$ \\
\hline HGE & 8 & 50 & PPB & 8 & 50 & 0.1019 & 605.52 & 84 & 0.00 & 0.9999 & 0.05 & -1204.04 & 1204.25 & 1.10 & $<0.001$ & $>999.995$ \\
\hline HGE & 8 & 50 & PPB & 8 & 100 & 0.1018 & $605.52 !$ & 84 & 0.00 & 0.9999 & 0.05 & -1204.04 & 1204.25 & 1.10 & $<0.00$ & $>999.999$ \\
\hline HGE & 8 & 50 & $\mathrm{PPB}$ & 24 & 0 & 0.1619 & 605.52 & 84 & 0.00 & 0.9999 & 0.35 & -1204.04 & 1204.25 & 1.10 & $<0.001$ & $>999.999$ \\
\hline HGE & 8 & 50 & $\mathrm{PPB}$ & 24 & 50 & -13.6659 & 429.87 & 84 & $-0,03:$ & 0.9747 & 0.05 & -868.51 & 841.17 & $<0.00$ & $<0.001$ & $>999.999$ \\
\hline HGE & 8 & 50 & PPB : & 24 & 100 & -13.6659 & 429.87 & 84 & -0.03 & 0.9747 & 0.05 & -868.51 & 841.17 & $<0.001$ & $<0.001$ & $>999.99$ \\
\hline HGE & 8 & 50 & THR & 8 & 0 & 0.1943 & 603.59 & 84 & 0.00 & 0.9997 & 0.05 & -1200.12 & 1200.51 & 1.215 & $<0.001$ & $>999.999$ \\
\hline HGE & 8 & 50 & THR & 8 & 50 & $0.18<3$ & 603.59 & 84 & 0.00 & 0.9997 & 0.05 & -1200.12 & 1200,51 & 1.21 & $<0.001$ & 999.999 \\
\hline HGE & 8 & 50 & THR & 8 & 100 & $0.19 \times 3$ & 603.59 & 8 & 0.00 & 0.9997 & 0.05 & -1200.12 & 1200.51 & 1.21 & $<0,00$ & 999.99 \\
\hline HGE & 8 & 50 & THR & 24 & 10 & 0.1943 & 603.59 & 84 & 0.00 & 0.9997 & 0.05 & 1200.12 & 1200.51 & 1.215 & $<0.00$ & $>999.999$ \\
\hline HGE & 8 & 50 & THR & 24 & 50 & 0.1943 & 803.59 & 84 & 0.00 & 0.9997 & 0.05 & -1200.12 & 120051 & 1.215 & $<0.001$ & $>999.999$ \\
\hline HGE & 8 & 50 & THR & 24 & 100 & 192 & 603.59 & 84 & 0.00 & 0.9987 & 0.05 & 1200.12 & $1200.5^{\circ}$ & 1.21 & $<0.001$ & $>999.899$ \\
\hline HGE & 8 & 50 & WAS & 8 & $\therefore$ & 0.19 & 603.59 & 84 & 0.00 & 09997 & 0.05 & -1200.12 & 1200.51 & 1.215 & $<0.001$ & $>899.899$ \\
\hline HGE & 8 & 50 & WAS & 8 & 50 & -135567 & 429.87 & 84 & -0.03 & 0.9749 & 0.05 & -868.40 & 841.28 & $<0.001$ & $<0.001$ & $>999.999$ \\
\hline HGE & 8 & 50 & WAS & 8 & 100 & 0.184 & 603.59 & 84 & $0.00:$ & 0.9997 & 0.05 & $-200,12$ & 1200.51 & 1.215 & $<0.001$ & $>999.899$ \\
\hline HGE & 8 & 50 & WAS & 24 & 0 & 0.1943 & 603.59 & 84 & 0.00 & 0.9097 & 0.05 & -1200.12 & 1200.51 & 1.215 & $<0.001$ & $>999.999$ \\
\hline MIGE & 8 & 50 & WAS & 24 & 50 & 0.1943 & 603.59 & 84 & 0.00 & 0.9997 & 0.05 & -1200.12 & 1230.51 & 1.215 & $<0.001$ & $>999.999$ \\
\hline HGE & 8 & 50 & WAS & 24 & 100 & 943 & 603.59 & 84 & 0.00 & 0.9997 & 0.05 & -1200.12 & 1200.51 & 1.215 & $<0.001$ & $>999,99$ \\
\hline 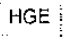 & 8 & 100 & HGE & 24 & 0 & 7885 & 429,87 & 84 & -0.03 & 0.9745 & 0.05 & -868.63 & 341.05 & $<0.001$ & $<0.001$ & $>999.99$ \\
\hline
\end{tabular}

file://C:/Users/klweber/AppData/Local/Temp/1/SAS\%20Temporary\%20Files/_TD3400_...12/10/2014 


\section{AEH-13-PSEUDO-06}

\begin{tabular}{|c|c|c|c|c|c|c|c|c|c|c|c|c|c|c|c|c|}
\hline & 8 & 100 & HGE & 24 & 50 & -13.7885 & 429.87 & 84 & -0.03 & 09745 & 0.05 & -868.63 & 641.05 & $<0.001$ & $<0.001$ & $>899.999$ \\
\hline GGE & 8 & 100 & HGE & 24 & 100 & -13.7885 & 429.87 & 84 & -0.03 & 0.9745 & 0.05 & -868.63 & 841.05 & $<0.001$ & $<0.001$ & $>999.999$ \\
\hline HSE & 8 & 100 & $\mathrm{HIC}$ & 8 & 0 & 0.1943 & 603,59 & 84 & 0.00 & 0.9997 & 0.05 & .1200 .12 & 1200.51 & 1.215 & $<0.001$ & $>999.999$ \\
\hline HGE & 8 & 100 & $\mathrm{HIC}$ & 8 & 50 & 0.1843 & 603.59 & 84 & 0.00 & 0.9997 & 0.05 & -1200.12 & 1200.51 & 1.215 & $<0.001$ & $>999.998$ \\
\hline HGE & 8 & 100 & $\mathrm{HIC}$ & 8 & 100 & 0.1943 & 603.59 & 84 & 0.00 & 0,9997 & 0.05 & -200.12 & 120051 & 1.215 & $<0.001$ & $>999.999$ \\
\hline HGE & 8 & 100 & HIC & 24 & 0 & 0.1943 & 603.59 & 84 & 0.00 & 0.9997 & 0.05 & -200.12 & $1200.5:$ & 1.215 & $<0.001$ & $>899,999$ \\
\hline HGF & 8 & 100 & HIC & 24 & 50 & 0.1943 & 603.59 & 84 & 0.00 & 0.9997 & 0.05 & -1200.12 & 1200.5 & 1.215 & $<0.001$ & $>999.999$ \\
\hline HGE & 8 & 100 & HIC & 24 & 100 & -13.5567 & 429.87 & 84 & -0.03 & 0.9749 & 0.05 & -868.40 & 841.28 & $<0.001$ & $<0.001$ & $>999.999$ \\
\hline HGE & 8 & 100 & PIG & 8 & 0 & $-292 E-13$ & 607.93 & $B 4$ & $-3,00$ & 1.0000 & 0.05 & -1208.93 & 1208.93 & 1.000 & $<0.001$ & $>890.980$ \\
\hline HGE & 8 & 100 & PIG & 8 & 50 & $-292 E-13$ & 607.93 & 84 & -0.00 & 1.0000 & 0.05 & -1208.83 & 1208.93 & 1.000 & $<0.001$ & $>999.999$ \\
\hline HGE & $a$ & 100 & PIG & 8 & $10 \mathrm{C}$ & $-292 E-13$ & 607.93 & 84 & $-0,00$ & 1.0000 & 0.05 & -1208.93 & 1208.93 & 1.000 & $<0.001$ & $>999.999$ \\
\hline HGE & 8 & 100 & PIG & 24 & 0 & $-292 E-13$ & 607.93 & 84 & -0.00 & 1.0000 & 0.05 & -1208.93 & 1208.93 & 1.000 & $<0.001$ & $>999.999$ \\
\hline HGE & 8 & 100 & PIG & 24 & 50 & $-292 E-13$ & 607.93 & 84 & -0.00 & 1.0000 & 0.05 & 41208.93 & 1208.93 & 1.000 & $<0.001$ & $>999.999$ \\
\hline HGE & 8 & 100 & $P I G$ & 24 & 100 & $-292 E-13$ & 607.93 & 84 & -0.00 & 1.0000 & 0.05 & -1208.93 & 1208.93 & 1.000 & $<0.001$ & $>999.999$ \\
\hline HGE & 8 & 100 & PPB & 8 & C & 0.1019 & 605.52 & 84 & $0.00 i$ & 0.9999 & 005 & -1204.04 & 1204.25 & 1.107 & $<0.001$ & $>988.999$ \\
\hline HGE & 8 & 100 & PPB & 8 & 50 & 0.1019 & 605.52 & 84 & 0.00 & 0.9998 & 0.05 & -1204.04 & 1204.25 & 1.107 & $<0.001$ & $>999.999$ \\
\hline $\mathrm{HGE}$ & 8 & 100 & PPB & 8 & 100 & 0.1019 & 605.52 & 34 & 0.00 & 0.9999 & 0.05 & -1204.04 & 1204.26 & 1,107 & $<0.001$ & $>999.999$ \\
\hline - $G E$ & 8 & 100 & PPB & 24 & 0 & 0.1019 & 605.52 & 84 & 0.00 & 0.9989 & 0.05 & -1204.04 & 1204.25 & 1.107 & $<0.001$ & $>999.999$ \\
\hline HGE & 8 & 100 & PPB & 24 & 50 & $-13,6659$ & 429.87 & 84 & $-0,03$ & 0.9747 & 0.05 & -858.51 & 841.17 & $<0.001$ & $<0.001$ & $>999,900$ \\
\hline HGE & 8 & 100 & $\mathrm{PPB}$ & 24 & 100 & -13.6659 & 429.87 & 84 & -0.03 & 0.9747 & 0.05 & -868.51 & 841.17 & $<0,001$ & $<0.001$ & $>999.999$ \\
\hline $\mathrm{HGE}$ & 8 & 100 & THIR & 8 & 0 & 0.1943 & 603.58 & 84 & 0.00 & 0.9997 & 0.05 & $-1200.12 i$ & 1200.51 & 1.215 & $<0.001$ & $=999.99 \theta$ \\
\hline $\mathrm{HGE}$ & 8 & 100 & THR & 8 & 50 & 0.1943 & $603.59 ?$ & 84 & 0.00 & 0.9997 & 0.05 & -1200.12 & 1200.51 & 1.215 & $<0.001$ & $>999.999$ \\
\hline $\mathrm{HGE}$ & 8 & 100 & THR & 8 & 100 & 0.1943 & 603.59 & 84 & 0.00 & 0.9997 & 0.05 & -1200.12 & $12 \mathrm{Co} 0.51$ & 1.215 & $<0.001$ & $>999.999$ \\
\hline RGE & 8 & 100 & THR & 24 & 0 & 0.1943 & 603.59 & 84 & 0.00 & 0.9997 & 0.05 & -1200.12 & 1200.51 & 1.215 & $<0.001$ & $>999.999$ \\
\hline HGE & 8 & 100 & THR & 24 & 50 & 0.1943 & 603.59 & 84 & 0.00 & 0.9997 & 0.05 & -1200.12 & 1200.51 & 1.215 & $<0.001$ & $>999.999$ \\
\hline $\mathrm{HGE}$ & 8 & 100 & THR & 24 & 100 & 0.1843 & 603.58 & 84 & 0.00 & 0.9997 & 0.05 & 1200.12 & 1200.51 & 1.215 & $<0.001$ & $>889.899$ \\
\hline HGE & 8 & 100 & WAS & 8 & 0 & 0.1943 & 603.59 & 84 & 0.00 & 0.9997 & 0.05 & -1200.12 & 1200.51 & 1.215 & $<0.001$ & $>999.999$ \\
\hline HGE & 8 & 100 & WAS & 8 & 50 & -13.5567 & 429.87 & 84 & -0.03 & 0.9749 & 0.05 & -868.40 & 841.28 & $<0.001$ & $<0.001$ & $>999.999$ \\
\hline $\mathrm{HGE}$ & 8 & 100 & WAS & $\theta$ & 100 & 0.1843 & 603.58 & 84 & 0.00 & 0.9997 & 0.05 & -1200.12 & 1200.51 & 1.215 & $<0.001$ & $>999.999$ \\
\hline HGE & 8 & 100 & WAS & 24 & 0 & 0.1943 & 603.59 & 84 & 0.00 & 0.9997 & 0.05 & -1200.12 & 1200.51 & 1.215 & $<0,001$ & $>999.999$ \\
\hline HGE & 8 & 100 & WAS & 24 & 50 & 0.1943 & 603.59 & 84 & 0.00 & 0.9997 & 0.05 & -1200.12 & 1200.51 & 1.215 & $<0.001$ & $>999.999$ \\
\hline HGE & 8 & 100 & WAS & 24 & 100 & 0.1943 & 603.59 & 84 & 0.00 & 0.9997 & 0.05 & -1200.12 & 1200.51 & 1.215 & $<0.001$ & $>999.999$ \\
\hline HGE & 24 & 0 & HGE & 24 & 50 & 4.82E-16 & 0.8430 & 84 & 0.00 & 1.0000 & 0.05 & -1.2786 & .2796 & 1.000 & 0.278 & 3.592 \\
\hline $\mathrm{HGE}$ & 24 & 0 & HGE & 24 & 100 & 4.38E-16 & 0.6430 & 84 & 0.00 & 1.0000 & 0.05 & -1.2786 & 1.2786 & 1.000 & 0.278 & 3.592 \\
\hline HGE & 24 & 0 & $\mathrm{HIC}$ & 8 & 0 & 13.8829 & 423.72 & 84 & 0.03 & 0.9738 & 0.05 & -828.63 & 856.60 & $>999.999$ & $<0.001$ & $>999.999$ \\
\hline HGE & 24 & 0 & $\mathrm{H} I \mathrm{C}$ & 8 & 50 & 13,9829 & 423.72 & 84 & 0.03 & 0.9738 & 0.05 & -828.63 & 856.60 & $>999.999$ & $<0.001$ & $>999.999$ \\
\hline $\mathrm{HGE}$ & 24 & 0 & $\mathrm{HIC}$ & B & 100 & 13,9829 & 423.72 & 84 & $0.03 ?$ & 0.9738 & 0.05 & -828.63 & 856.60 & $>980.999$ & $<0.001$ & $>999.998$ \\
\hline HGE & 24 & 0 & $\mathrm{H} \mid \mathrm{C}$ & 24 & 0 & 13.8829 & 423.72 & 84 & 0.03 & 0.9738 & 0.05 & $-828,63$ & 856,60 & $>999.999$ & $<0.001$ & $>999.999$ \\
\hline HGE & 24 & 0 & $\mathrm{HIC}$ & 24 & 50 & 13.9828 & 423.72 & 84 & 0.03 & 0,9738 & 0.05 & -828.63 & 856.60 & $>999.999$ & $<0.001$ & $>899.999$ \\
\hline HGE & 24 & 0 & HIC & 24 & 100 & 0.2318 & 0.6416 & 84 & 0.36 & 0.7188 & 0.05 & $-1.0441 ?$ & 1.5077 & 1.261 & 0.362 & 4.518 \\
\hline HGE & 24 & 0 & $\mathrm{PIG}$ & 8 & 0 & 13.7885 & 429.87 & 84 & 0.03 & 0.9745 & 0.05 & -841.05 & 868.63 & $>999.999$ & $<0.001$ & $>999.999$ \\
\hline HGE & 24 & 0 & $P \mid G$ & 8 & 50 & 13.7885 & 429.87 & 84 & 0.03 & 09745 & 0.05 & -841.05 & 868.63 & $>999.999$ & $<0.001$ & $>999.989$ \\
\hline HGE & 24 & 0 & PIG & 8 & 100 & 13.7885 & 429.87 & 84 & 0.03 & 0.9745 & 0.05 & -841.05 & 868,63 & $>999,999$ & $<0.001$ & $>899.999$ \\
\hline HGE & 24 & 0 & PIG & 24 & 0 & 13.7885 & 429.87 & 84 & $0.03:$ & $0.9 / 45$ & 0.65 & -841.05 & 868.63 & $>999.999$ & $<0.001$ & $>999.899$ \\
\hline $\mathrm{HSE}$ & 24 & 0 & $\mathrm{PIO}$ & 24 & 50 & 13.7885 & 429.87 & 84 & 0.03 & 0.9745 & 0.05 & -841.05 & 868.63 & $>999.999$ & $<0.001$ & $>999.999$ \\
\hline HGE & 24 & 0 & $\mathrm{P} \mid \mathrm{G}$ & 24 & 100 & 13.7885 & 429.87 & 84 & 0.03 & 0.9745 & 0.05 & $-841.05 !$ & 868.63 & $>999.999$ & $<0.001$ & $>999.999$ \\
\hline IIGE & 24 & 0 & PPB & 8 & 0 & 13.8904 & 426.46 & 84 & 0.03 & 0.8741 & 0.05 & -834.17 & 861.95 & $>999.999$ & $<0.001$ & $>999.999$ \\
\hline $\mathrm{HGE}$ & 24 & 0. & PPB & 8 & 50 & 13.8904 & 428.46 & 84 & 0.03 & 0.9741 & 0.05 & -834.17 & 831.95 & $>999.998$ & $<0.001$ & $>999.999$ \\
\hline HGE & 24 & 0 & PPB : & 8 & 100 & 13.8904 & 426.46 : & 84 & 0.03 & 0.9741 & $0.05^{i}$ & -834.17 & 861.95 & $>998.999$ & $<0,001$ & $>999.999$ \\
\hline
\end{tabular}

file://C:/Users/klweber/AppData/Local/Temp/1/SAS\%20Temporary\%20Files/_TD3400_.. 12/10/2014 


\begin{tabular}{|c|c|c|c|c|c|c|c|c|c|c|c|c|c|c|c|c|}
\hline & 24 & 0 & PPB & 24 & 0 & 8904 & 26.46 & 84 & $0.03:$ & 0.9741 & 0.05 & -834.17 & 861.95 & $>999.999$ & $<0.001$ & $\$ 99,999$ \\
\hline GE & 24 & 0 & PPB & 24 & 50 & 0.1226 & 0.6422 & 84 & 0.19 & 0.8481 & 0.05 & -1.1545 & 1.3997 & 1.130 & 0.315 & 4.054 \\
\hline IGE & 24 & 0 & PPB & 24 & 100 & 0.1226 & 6422 & 84 & 0.19 & 0.8491 & 0.05 & -1.1545 & 1.3997 & 1.130 & 0.315 & 4.054 \\
\hline GGE & 24 & 0 & THR & 8 & 0 & 13.9829 & 423.72 & 84 & 0.03 & 0.8738 & 0.05 & -828.63 & 856.60 & $>999.899$ & $<0.001$ & $>999.999$ \\
\hline GE & 24 & 0 & THR & $B$ & 50 & 13.9829 & 423.72 & 84 & 0.03 & 0.8738 & 0.05 & -828.63 & 856.60 & $>999.999$ & $<0.001$ & $>999.999$ \\
\hline AGE & 24 & 0 & THR & 8 & 100 & 13.9829 & 23.72 & 84 & 0.03 & 0.9738 & 0.05 & -828.63 & 856.60 & $>998.999$ & $<0.001$ & $>999,999$ \\
\hline GE & 24 & 0 & THR & 24 & 0 & 13,9829 & 423.72 & 84 & 0.03 & 0.9738 & 0.05 & $-828,63$ & 856.60 & $>999.999$ & $<0.001$ & $>999.399$ \\
\hline GE & 24 & 10 & THR & 24 & 50 & 13.9829 & 423.72 & 84 & 0.03 & 0.9738 & 0.05 & -828.63 & 856.60 & 2999.999 & $<0.001$ & $>899.999$ \\
\hline GE & 24 & 0 & THR & 24 & 100 & 13.9829 & 423.72 & 84 & 0.03 & 0.9738 & 0.05 & -828.63 & 856.60 & $>998.999$ & $<0.001$ & $>999.999$ \\
\hline HGE & 24 & 0 & WAS & 8 & 0 & 13.9829 & 423.72 & 84 & 0.03 & 0.9738 & 0.05 & -828.63 & 856.60 & $>999.999$ & $<0.001$ & $>999.999$ \\
\hline HGE & 24 & 0 & WAS & 8 & 50 & 0.2318 & 0.6416 & 84 & 0.36 & 0.7188 & 0.05 & -1.0441 & 1.5077 & 1.261 & 0.352 & 4.516 \\
\hline HGE & 24 & 0 & WAS & 8 & 100 & 13.9829 & 423.72 & 84 & 0.03 & 0.9738 & 0.05 & -828.63 & 856.50 & $>998.999$ & $<0.001$ & $>999.999$ \\
\hline HGE & 24 & 0 & WAS: & 24 & 0 & 13.9829 & 423.72 & 84 & 0.03 & 09738 & 0.05 & -828.63 & 856.80 & $>999.999$ & $<0.001$ & $>999.999$ \\
\hline HGE & 24 & 10 & WAS & 24 & 50 & 13.9829 & 423.72 & 84 & 0.03 & 0.9738 & 0.05 & -828.63 & 856.60 & $>999.999$ & $<0.001$ & $>999.098$ \\
\hline HGE : & 24 & 0 & WAS & 24 & 100 & 13.9829 & 423.72 & 84 & 0.03 & 0.9738 & 0.05 & -828.63 & 85660 & $>998.999$ & $<0.001$ & $>999.999$ \\
\hline $\mathrm{GEE}$ & 24 & 50 & HGE & 24 & 100 & $434 E-19$ & 0.6430 & 84 & -0.00 & 1.0000 & 0.05 & -1.2786 & 1.2786 & 1.000 & 0,278 & 3.592 \\
\hline HGE & 24 & 50 & HIC & 8 & 0 & 13.9829 & 423.72 & 84 & 0.03 & 0.9738 & 0.05 & -828.63 & 856.60 & $>999.999$ & $<0,001$ & $>999.999$ \\
\hline HGE & 24 & 50 & HIC & 8 & 50 & 13.9829 & 423.72 & 84 & $0.03 !$ & 0.9738 & 0.05 & -828.63 & 856.60 & $>999.999$ & $<0.001$ & $>999.899$ \\
\hline HGE & 24 & 50 & $\mathrm{HIC}$ & 8 & 100 & 13.9829 & 423.72 & B4 & 0.03 & 0.9738 & 0.05 & -828.63 & 856.60 & $>999.999$ & $<0.001$ & $>999.899 !$ \\
\hline HGE & 24 & 50 & $\mathrm{HCC}$ & 24 & 0 & 13.9829 & 423.72 & 84 & 0.03 & 0.9738 & 0.05 & -828.63 & 856.60 & $>999.299$ & $<0.001$ & $>999.999$ \\
\hline HGE & 24 & 50 & $\mathrm{HIC}$ & 24 & 50 & 13.8829 & 423.72 & 84 & 0.03 & 0.9738 & 0.05 & -828.63 & 858.60 & $>999.999$ & $<0.00$ & $99999 \theta$ \\
\hline HGE & 24 & 50 & HIC & 24 & 100 & 0.2318 & 0.6416 & 84 & 0.36 & 0.7188 & 0.05 & -1.0441 & 1.5077 & 1.26 & 0.35 & 4.518 \\
\hline HGE & 24 & 50 & PIG & 8 & 0 & 13.7885 & 428.87 & 84 & 0.03 & 0.9745 & 0.05 & -841.05 & 868.63 & $>999.999$ & $<0.001$ & $>999.999$ \\
\hline HGE & 24 & 50 & $P \mid G$ & 8 & 50 & 13.7885 & 429.87 & 84 & 0.03 & 0.9745 & 0.05 & -841.05 & 868.63 & $>999.999$ & $<0.00$ & $>999.999$ \\
\hline HGE & 24 & 50 & PIG & 8 & 100 & 13.7885 & 429.87 & 84 & 0.03 & 0.9745 & 0.05 & -841.05 & 868.63 & $>999.999$ & $<0.00$ & $>999.998$ \\
\hline HGE & 24 & 50 & :PIG & 24 & 0 & 13.7885 & 429.87 & 84 & 0.03 & 0.9745 & 0.05 & -841.05 & 868.63 & $>999.999$ & $<0.00$ & $>999.99 \theta$ \\
\hline IGE & 24 & 50 & FIG & 24 & 50 & 13.7885 & 429.87 & 84 & 0.03 & 0.9745 & 0.06 & -841.05 & 868.63 & $>999,899$ & $<0.0$ & $>999.999$ \\
\hline HGE & 24 & 50 & PIO & 24 & 100 & 13.7885 & 428.87 & 84 & 0.03 & c. .9745 & 0.05 & -841.05 & 868.63 & $>999.999$ & $<0.00$ & $>999.999$ \\
\hline HGE & 24 & 50 & PPB & 8 & 0 & 13.8904 & 426.46 & 84 & 0.03 & 0.9741 & 0.05 & -334.17 & 861.95 & $>999.909$ & $<0.00$ & $>999.999$ \\
\hline HGE & 24 & 50 & PPB & 8 & 50 & $13.8904^{4}$ & 426.46 & 84 & 0.03 & 0.9741 & 0.05 & -834.17 & 861.95 & $>899.999$ & $<0.00$ & $>999.999$ \\
\hline HGE & 24 & 50 & PPB : & $: 8$ & 100 & 13.8904 & 426.46 & 84 & 0.03 & 0.9741 & 0.05 & -834.17 & 861.95 & $>890.999$ & $<0.00$ & $>999.999$ \\
\hline IGE & 24 & 50 & $\mathrm{PPB}$ & 24 & 0 & 13.8904 & 426.46 & 84 & 0.03 & 0.9741 & 0.05 & -834.17 & 861.05 & $>999.98$ & $<0.00$ & 7998.999 \\
\hline UGE & 24 & $5 \mathrm{C}$ & PPB & 24 & 50 & 0.1226 & 0.6422 & 84 & 0.19 & 0.8491 & 0.05 & -1.1545 & 1.3997 & 1.13 & 0.31 & 4.054 \\
\hline HGE & 24 & 50 & PPB & 24 & 100 & 0.1226 & 0.6422 & 84 & 0.18 & 0.8491 & 0.05 & -1.1545 & 1.3997 & 1.13 & 0.31 & 4.054 \\
\hline HGE & 24 & 50 & THR & 8 & 0 & 13.9829 & 423.72 & 84 & 0.03 & 0.8738 & 0.05 & -828.63 & 856.60 & $>999.99$ & $<0.00$ & 989.999 \\
\hline HGE & 24 & 50 & TIIR & 8 & 50 & 13.9829 & 423.72 & 8 & 0.03 & 0.9738 & 0.05 & -828.63 & 856.60 & $>999.99$ & $<0.00$ & $>999.999$ \\
\hline HGE & 24 & 50 & THR & 8 & 100 & 13.9829 & 423.72 & 84 & 0.03 & 0.9738 & $c .05$ & -828.63 & 856.60 & $>999.99$ & $<0.00$ & $>999.999$ \\
\hline HGE & 24 & 50 & THR & 24 & 8 & 13.9829 & 423.72 & 84 & 0.03 & 0.9738 & 0.05 & -828.63 & 856.60 & $>999.99$ & $<0.001$ & $>989.999$ \\
\hline HGE & 24 & 50 & THR & 24 & 50 & 13.9829 & 423.72 & 84 & 0.03 & 0.9738 & 0.05 & -828.63 & 856.60 & $>999.999$ & $<0.001$ & $>999.999$ \\
\hline HGE & 24 & 50 & THR & 24 & 100 & 13.9828 & 423.72 & 84 & 0.03 & 0.9738 & 0.05 & -828.63 & 856,60 & $>999.999$ & $<0.00$ & $>999.999$ \\
\hline HGE & 24 & 50 & WAS & 8 & 0 & 13.9829 & 423.72 & $84:$ & 0.03 & 0.9738 & 0.05 & -828.63 & $856.6 \mathrm{C}$ & $>999.998$ & $<0.001$ & $>999.999$ \\
\hline HGE & 24 & 50 & WAS & 8 & 50 & 0.2318 & 6416 & 84 & 0.36 & 0.7188 & 0.55 & -1.0441 & 1.5077 & 1.26 & 0.35 & 4.516 \\
\hline HGE & 24 & 50 & WAS & 8 & 100 & 13.9829 & 423.72 & $84:$ & 0.03 & 0.9738 & 0.05 & -828.63 & 856.60 & $>999.999$ & $<0.001$ & $>999.899$ \\
\hline HGE & 24 & 50 & WAS & 24 & 0 & $13.882 \theta^{\circ}$ & 423.72 & 84 & 0.03 & 0.9738 & 0.05 & -828.63 & 856.60 & $>999.999$ & $<0.001$ & $>909.999$ \\
\hline HGE & 24 & 50 & WAS & 24 & 50 & 13.9829 & 423.72 & 84 & 0.03 & 0.9738 & 0.05 & -828.63 & 856.60 & $>999.899$ & $<0.001$ & $>999.999$ \\
\hline HGE & 24 & 50 & WAS & 24 & 100 & 13.9829 & 423.72 & 84 & 0.03 & 0.9738 & 0.05 & -828.63 & 856.80 & $>999.899$ & $<0.001$ & $>999.999$ \\
\hline HGE & 24 & 100 & $\mathrm{HIC}$ & 8 & 0 & 13,9829 & 423.72 & 84 & $0.09:$ & 0.8738 & 0.05 & -828.63 & 856.60 & $>999.999$ & $<0.001$ & $>999.999$ \\
\hline HGE & 24 & 100 & $\mathrm{HIC}$ & 8 & 50 & 13 & 3.72 & 8 & 0.03 & 0.9738 & 0.05 & -828.63 & 85660 & $>999.999$ & $<0,001$ & $>999.899$ \\
\hline HGE & 24 & 100 & HIC & 8 & 10 & 13.8829 & 423.72 & 84 & 0.03 & $0.9 / 38$ & 0.05 & -828 & 60 & $>999.999$ & $<0.001$ & $>999.999$ \\
\hline 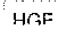 & & & & & & & & & & & & & & & & \\
\hline
\end{tabular}

file://C:/Users/klweber/AppData/_ocal/Temp/1/SAS\%20Temporary\%20Files/_TD3400_... 12/10/2014 


\section{AEH-13-PSEUDO-06}

\begin{tabular}{|c|c|c|c|c|c|c|c|c|c|c|c|c|c|c|c|c|}
\hline & 24 & 100 & HIC & 24 & 0 & .9829 & 3.72 & 84 & 0.03 & 0.9738 & 0.05 & .828 .83 & 856.60 & $>999.89 \mathrm{C}$ & $<0.00$ & $>999.998$ \\
\hline HGE & 24 & 100 & $\mathrm{HIC}$ & 24 & 50 & 13.9829 & 423.72 & 84 & 0.03 & 0.8738 & 0.05 & -828.63 & 856.60 & $>999.999$ & $<0.001$ & $>899.999$ \\
\hline GGE & 24 & 100 & HIC & 24 & 100 & 0.2318 & 6416 & 84 & 0.36 & 0.7188 & 0.05 & -1.0441 & 1.5077 & 1.261 & 0.352 & 4.516 \\
\hline HGE & 24 & 100 & $P \mid G$ & 8 & 0 & 13.7885 & 429.87 & 84 & 0.03 & 0.9745 & 0.05 & -841.05 & 868.63 & $>999,999$ & $<0.001$ & $>999.999$ \\
\hline HGE & 24 & 100 & $\mathrm{PIG}$ & 8 & 50 & 13.7885 & 429.87 & 84 & 0.03 & 0.9745 & 0.05 & -841.05 & 868.63 & $>999.899$ & $<0.001$ & $>999.999$ \\
\hline HGE & 24 & 100 & $\mathrm{PIG}$ & 8 & 100 & 13.7885 & 429.87 & 84 & 0.03 & 0.9745 & 0.05 & -841.05 & 868.63 & $>998.999$ & $<0.001$ & $>999,999$ \\
\hline HGE & 24 & 100 & PIG & 24 & 0 & 13.7885 & 429.87 & 84 & 0.03 & 0.9745 & 0.05 & -841.05 & 868.63 & $>998.999$ & $<0.001$ & $>998.999$ \\
\hline HQE & 24 & 100 & $P \mid G$ & 24 & 50 & 13.7885 & 429.87 & 84 & 0.03 & 0.9745 & 0.05 & -841.05 & 868.63 & $>999.899$ & $<0,001$ & $>999.999$ \\
\hline HGE & 24 & 100 & PIG & 24 & 100 & 13.7885 & 429.87 & 84 & 0.03 & 0.9745 & 0.05 & -841.05 & 868.63 & $>999.999$ & $<0.001$ & $>999.999$ \\
\hline HGE & 24 & 100 & PPB & 8 & 0 & 13.8904 & 426.46 & 84 & 0.03 & 09741 & 0.05 & -834.17 & 861.95 & $>999.999$ & $<0.001$ & $>999.999$ \\
\hline HSE & 24 & 100 & PPB & 8 & 50 & 13.8904 & 426.46 & 84 & 0.03 & 09741 & 0.05 & -834.17 & 861.95 & $>999,999$ & $<0.001$ & $>999.999$ \\
\hline HCE & 24 & 100 & PPB & 8 & 100 & 13.8904 & 426.46 & 84 & 0.03 & 0.9741 & 0.05 & -834.17 & 861.95 & $>999.999$ & $<0,001$ & $>999.999$ \\
\hline HGE: & 24 & 100 & $P P B$ & 24 & 0 & 13.8904 & 426.46 & 84 & 0.03 & 0.9741 & 0.05 & -834.17 & 86195 & $>999.999$ & $<0.001$ & $>999.999$ \\
\hline $\mathrm{HGE}$ & 24 & 100 & PPB & 24 & 50 & 0.1226 & 0.6422 & 84 & 0.19 & 0.8491 & 0.05 & -1.1545 & 1.9997 & 1.130 & 0.315 & 4.054 \\
\hline HGE & 24 & 100 & PPB & 24 & 100 & 0.1226 & 0.6422 & 84 & 0.19 & 0.8491 & 0.05 & -1.1545 & 1.3997 & 1.130 & 0.315 & 4.054 \\
\hline HGE & 24 & 100 & THR & 8 & 0 & 13.9829 & 423.72 & B4 & 0.03 & 0.9738 & 0.05 & -828.63 & 856.60 & $>999,999$ & $<0,001$ & $>999.899$ \\
\hline GEE & 24 & 100 & THR & 8 & 50 & 13.9829 & 423,72 & 84 & 0.03 & 0.9738 & 0.05 & -828.63 & 855.60 & $>999.898$ & $<0.001$ & $>999.998$ \\
\hline HGE & 24 & 100 & THR & 8 & 100 & 13.9829 & 423.72 & 84 & 0.03 & 0.9738 & 0.05 & -828.03 & 853.80 & $>999.998$ & $<0.00$ & $>099.999$ \\
\hline HGE & 24 & 100 & THR & 24 & 10 & 13.9828 & 423.72 & 84 & 0.03 & 0.9738 & 0.05 & $-828,63$ & 856.60 & $>999.999$ & $<0.001$ & $>899999$ \\
\hline HGE & 24 & 100 & THR & 24 & 50 & 13.0829 & 423.72 & 84 & 0.03 & 0.9738 & 0.05 & -828.63 & 856.60 & $>999.999$ & $<0.001$ & $>998.999$ \\
\hline HGE & 24 & 100 & THR & 24 & 100 & 13.9829 & 423.72 & 84 & 0.03 & 0.9738 & 0.05 & -828.63 & 856.60 & $>999.999$ & $<0.001$ & $>999,099$ \\
\hline HGE & 24 & 100 & WAS & 8 & 0 & 13.9829 & 423.72 & 84 & 0.03 & 0.9738 & 005 & -828.63 & 856.60 & $>999.999$ & $<0,001$ & $>999.999$ \\
\hline HGE & 24 & 100 & WAS & 8 & 50 & 0.2318 & 0.6416 & 84 & 0.36 & 0.7188 & 0.05 & -1.0441 & 1.5077 & 1.26 & 0.352 & 4.510 \\
\hline HGE & 24 & 100 & WAS: & .8 & 100 & 13.9828 & 423.72 & 84 & 0.03 & 0.9738 & 0.05 & -828.63 & 856.60 & $>909.985$ & $<0.001$ & $>999.999$ \\
\hline UGE: & 24 & 100 & WAS: & 24 & 0 & 13.9820 & 423.72 & 84 & 0.03 & 0.9738 & 0.05 & -828.63 & 858.60 & $>999.999$ & $<0.001$ & $>999.999$ \\
\hline HGE & 24 & 100 & WAS & 24 & 50 & 13.9829 & 42.3 .72 & 84 & 0.03 & C.9738 & 0.05 & -828.63 & 856.60 & $>898.999$ & $<0.001$ & $>999.999$ \\
\hline HGE & 24 & 100 & WAS: & 24 & 100 & 13.9829 & 423,72 & 84 & 0.03 & 0.9738 & 0.05 & -828.63 & 856.60 & $>999.999$ & $<0.001$ & $>999.999$ \\
\hline HIC & 8 & 0 & HIC & 8 & 50 & $3.56 E-15$ & 599.23 & 84 & 0.00 & 1.0000 & 0.05 & -1191.64 & 1181.64 & 1.000 & $<0.001$ & $>999.899$ \\
\hline HIC & 8 & 0 & HIC & 8 & 100 & $5.33 E-15$ & 599.23 & 84 & 0.00 & 1.0000 & 0.05 & -1191.64 & 1191.64 & 1.000 & $<0,001$ & $>999.999$ \\
\hline HIC & 8 & 0 & HIC & 24 & 0 & $3.42 \mathrm{E}-15$ & 589.23 & 84 & 0.00 & 1.0000 & 0.05 & -1191.64 & 1181.64 & 1.000 & $<0.00$ & $>999.999$ \\
\hline FIC & 8 & 0 & HIC & 24 & 50 & $1.78 \mathrm{E}-15$ & 599.23 & 84 & 0.00 & 1.5000 & 0.05 & -1191.64 & 1181.64 & 1.000 & $<0.001$ & $>998.999$ \\
\hline HIC & 8 & 0 & HIC & 24 & 100 & -13.7511 & 423.72 & 84 & -0.03 & 0.9742 & 0.05 & -856.37 & 828.37 & $<0.001$ & $<0.00$ & $>999.899$ \\
\hline HIC & 8 & $\mathrm{c}$ & PIG & 8 & 0 & -0.1943 & 603.59 & 84 & -0.00 & 0.8997 & 0.05 & -1200.51 & 1200.12 & 0.823 & $<0.00$ & $>999.999$ \\
\hline HIC & 8 & c & PIG & 8 & 50 & -0.1943 & 603.59 & 84 & -0.00 & 0.9997 & 0.05 & -1200.51 & 1200.12 & 0.823 & $<0.001$ & $>998.999$ \\
\hline HIC & 8. & 0 & PIG & 8 & $\infty$ & -0.1943 & 603.59 & 84 & -0.00 & 0.9997 & 0.05 & -1200.51 & 1200.12 & 0.823 & $<0.00$ & $>999.999$ \\
\hline HIC & $B$ & 0 & PIG & 24 & 0 & -0.1943 & 603.59 & 84 & -0.00 & 0.9997 & C.05 & -1200.51 & 1200.12 & 0.823 & $<0.00$ & $>989.999$ \\
\hline HIC & 8 & 0 & PIG & 24 & 50 & -0.1943 & 603.59 & 84 & -0.00 & 0.9997 & 0.05 & -1200.51 & 1200.12 & 0.823 & $<0.001$ & $>999.998$ \\
\hline HIC & 8 & 0 & PIG & 24 & 100 & -0.1943 & 603.58 & 84 & -0.00 & 0.9997 & 0.05 & -1200.51 & 1200.12 & 0.823 & $<0.00$ & $>989.999$ \\
\hline $\mathrm{HIC}$ & 8 & 0 & PPB & 8 & 0 & -0.09247 & $601.17^{i}$ & 84 & -0.00 & 0.9999 & 0.05 & -1195.50 & 1195,41 & 0.912 & $<0.001$ & $>999.999$ \\
\hline Hic & 8 & 0 & PPB & $: 8$ & 50 & -0.09247 & 601.17 & 84 & -0.00 & 0.9999 & 0.05 & -1185.59 & 1195.41 & 0.912 & $<0.001$ & $>999.999$ \\
\hline HIC & 8 & 0 & PPB & 8 & 100 & -0.09247 & 601.17 & 84 & -0.00 & 0.9999 & 0.05 & -1185.59 & $1 \uparrow 95.41$ & 0.912 & $<0.001$ & $>999.999$ \\
\hline $\mathrm{HIC}$ & 8 & 0 & $\mathrm{PPB}$ & 24 & 0 & -0.09247 & 601.17 & 84 & -0.00 & 0.9999 & 0.05 & $-1185,59$ & 1195,41 & 0.912 & $<0.001$ & $>999.999$ \\
\hline $\mathrm{H} I \mathrm{C}$ & 8 & 0 & PPB & 24 & 50 & -13.8603 & 423.72 & 84 & -0.03 & 0.9740 & 0.05 & -856.48 & 828.76 & $<0.001$ & $<0.001$ & $>999.999$ \\
\hline $\mathrm{HIC}$ & 8 & 0 & $\mathrm{PPB}$ & 24 & 100 & -13.8603 & 423.72 & 84 & -0.03 & 0.9740 & 0.05 & -856.48 & 828.76 & $<0.001$ & $<0.001$ & $>999.999$ \\
\hline HIC & 8 & 0 & THR & 8 & 0 & $-108 E-16$ & 599,23 & 84 & -0.00 & 1.0000 & 0.05 & -1181.61 & 1181.64 & 1.000 & $<0.001$ & $>999.999$ \\
\hline HIC & 8 & 0 & THIR & 8 & 50 & $-142 E-16$ & 599.23 & 84 & -0.00 & 1,0000 & 0.05 & -1191.64 & 1191.64 & 1.000 & $<0.001$ & $>998.999$ \\
\hline HIC & $\theta$ & 0 & THR & 8 & 100 & -355E-17 & 599.23 & 84 & -0.00 & 1,0000 & 0.05 & -1191.64 & 1191,64 & 1.000 & $<0.001$ & $>999.999$ \\
\hline HIC & 8 & 0 & THR & 24 & 0 & - $-142 E-16$ & 599.23 & 84 & -0.00 & 1.0000 & 0.05 & 1.91 .64 & 1101.64 & 1.000 & $<0.001$ & $>999.999$ \\
\hline 1110 & 8 & 0 & THR & 24 & 50 & $-142 \mathrm{E}-16$ & 69.23 & 84 & -0.00 & 10000 & 0.05 & 1.1401 .64 & 118164 & 1.000 & $<0,001$ & $>899,999$ \\
\hline
\end{tabular}

file://C:/Users/klweber/AppData/l,ocal/Temp/1/SAS\%20Temporary\%20Files/_TD3400_... 12/10/2014 


\section{AEH-13-PSEUDO-06}

\begin{tabular}{|c|c|c|c|c|c|c|c|c|c|c|c|c|c|c|c|c|}
\hline & 8 & 0 & THR: & 24 & 100 & 107E-16 & 98.23 & 84 & $0.00: 1$ & 1.0000 & 0.05 & $-1191,64$ & 1101.64 & 1.000 & $<0.001$ & $>898.999$ \\
\hline IC & 8 & 0 & WAS & 8 & 0 & $-318 E-13$ & 599.23 & 84 & -0.00 & 1.0000 & 0.05 & -1191.64 & 1191.64 & 1.000 & $<0.001$ & $>999.998$ \\
\hline IC & 8 & 0 & WAS & 8 & $: 50$ & .13 .7511 & $\mid 23.72$ & 84 & $-0.03=0$ & 0.9742 & 0.05 & -856.37 & 828.87 & $<0.001$ & $<0.001$ & $>099.998$ \\
\hline $\mathrm{HIC}$ & 8 & 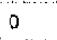 & AS & 8 & 100 & $54 E-11$ & 99.233 & 84 & 0.001 & 1.0000 & 0.05 & $-1191,64$ & 1191.64 & 1.000 & $<0.001$ & $>999.999$ \\
\hline HIC & 8 & 0 & WAS & 24 & 0 & $6.55 E-11$ & 589.23 & 84 & 0.00 & 1,0000 & $0.05:$ & -1191.64 & 1191.64 & 1.000 & $<0.001$ & $>999999$ \\
\hline$\| C$ & 8 & 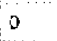 & WAS & 24 & 50 & 8.59E-11 & 599.23 & 84 & 0.00 & 1.0000 & 0.05 & 91.64 & 1191.64 & 1.000 & $<0.001$ & $>990.999$ \\
\hline HIC & 8 & 3 & WAS & 24 & 100 & O8E-13 & 699.23 & 84 & -0.00 & 1.0000 & 0.05 & 44 & 1191,64 & 1.000 & $<0.001$ & $>999.999$ \\
\hline $\mathrm{HIC}$ & 8 & 50 & HIC & $B$ & 100 & $7.11 E-15$ & 599.23 & 34 & 0.00 & 1.0000 & 005 & -1191.64 & 1191.64 & 1.000 & $<0.001$ & $>899.999$ \\
\hline $\mathrm{HIC}$ & 8 & 50 & $\mathrm{HIC}$ & 24 & 0 & 0 & 599.23 & 84 & 0.00 & 1.0000 & 0.05 & -1101.64 & 1191.64 & 1.000 & $<0.001$ & $>899.999$ \\
\hline IC & 8 & 50 & $\mathrm{HIC}$ & 24 & 50 & 0 & 589.23 & 81 & 0.00 & 1.0000 & 0.05 & $-1191,64$ & 1191.64 & 1.000 & $<0.001$ & $>999.999$ \\
\hline HIC & 8 & 50 & $: H I C$ & 24 & 100 & -13.7511 & 42.3 .72 & 34 & $-0.03 i 0$ & 0.9742 & 0.05 & $-856,37$ & 828.87 & $<0.001$ & $<0.001$ & $>990.098$ \\
\hline Hil & 8 & 50 & PIG & 8 & 0 & -0.1943 & 603.59 & 84 & -0.00 & 0,0907 & 0.05 & -1200.51 & 1200.12 & 0.823 & $<0.001$ & $>990.999$ \\
\hline HIC & 8 & 50 & PIG & 8 & 50 & -0.1943 & 603.59 & B4. & -0.00 & 0.9997 & 0.05 & -1200.51 & 1200.12 & 0.82 & $<0.001$ & $>999.999$ \\
\hline$\because \mathrm{CC}$ & 8 & 50 & PIG & 8 & 100 & -0.1943 & 603.59 & 84 & -0.00 & 0.9997 & 0.05 & -1200.51 & 1200.12 & 0.823 & $<0.001$ & $>999.999$ \\
\hline$H C$ & 8 & 50 & PIG & 24 & 10 & -0.1943 & 603.59 & 84 & -0.00 & 0.9997 & 0.05 & $-1200,51$ & 1200.12 & 0.823 & $<0.001$ & $>799.999$ \\
\hline HIC & 8 & 50 & $\mathrm{PIO}$ & 24 & 50 & -0.1943 & 603.59 & 84 & -0.00 & 0.9997 & 0.05 & -1200.51 & 1200.12 & 0.823 & $<0.001$ & $>909.999$ \\
\hline HIC & 8 & 50 & PIG & 24 & 100 & -0.1943 & 603.59 & 84 & -0.00 & 0.9997 & 0.05 & -1200.51 & $120 \mathrm{C} .12$ & 0.823 & $<0,00$ & $>999.999$ \\
\hline HIC & 8 & 50 & PPB & 8 & 0 & -0.09247 & 601.17 & 84 & -0.00 & 0.9989 & 0.05 & -1195.59 & 1185.41 & 0.91 & $<0.00$ & $>999.999$ \\
\hline HIC & $B$ & 50 & PPB & 8 & 50 & -0.09247 & 601.17 & 84 & -0.00 & 0.9999 & 0.05 & -1195.50 & 1195.4 & 0.8 & $<0.001$ & $>999.999$ \\
\hline F.1C & 8 & 50 & PPB & 8 & 100 & -0.09247 & 601.17 & 84 & -0.00 & 0.9998 & 0.05 & -1185.59 & $\begin{array}{l}1195.41 \\
\end{array}$ & 0.912 & $<0.00$ & $>999.999$ \\
\hline HIS & 8 & 50 & PPB & 24 & 0 & -0.09247 & 601.17 & 84 & -0.00 & 0.8989 & 0.05 & -1195.59 & 1195.41 & 0.91 & $<0.001$ & $>999.898$ \\
\hline HIC & 8 & 50 & PPB & 24 & 50 & $=13.8603$ & 423.72 & 84 & -0.03 & 0.9740 & 0.05 & -856.48 & 828.76 & $<0.00$ & $<0.00$ & $>999.999$ \\
\hline $\mathrm{HIC}$ & 8 & 50 & PPB & 24 & 100 & -13.8603 & 423.72 & 84 & -0.03 & 0,8740 & 0.05 & -856.48 & 828.78 & $<0.001$ & $<0.00$ & $>989.899$ \\
\hline $\mathrm{HIC}$ & 8 & 50 & THR: & 8 & 0 & $.108 E-16$ & 599.23 & 84 & -0.00 & 1.0000 & 0.05 & -1191.64 & 1191.6 & 1.0 & $<0.00$ & $>859.999$ \\
\hline HIC & ${ }^{8}$ & 50 & THR & 8 & 50 & -142E-16 & 599.23 & 84 & -0.00 & 1.0000 & 0.05 & -1191.64 & 1191.64 & 1.00 & $\$ 0.00$ & $>099.99$ \\
\hline $\mathrm{HIC}$ & 8 & 50 & THR: & 8 & 100 & $-355 \mathrm{E}-17$ & 599.23 & 84 & -0.00 & $\because .0000$ & $c .05$ & -1191.64 & $119^{9} .6$ & 1.000 & $<0.00$ & $>999.999$ \\
\hline $\mathrm{HIC}$ & 8 & 50 & THR & 24 & 0 & $-124 \mathrm{E} \sim 16$ & 590.23 & $84:$ & -0.00 & 1.0000 & 0,05 & -1191.64 & 1191. & 1.0 & $<0.00$ & 999.999 \\
\hline HIC & 8 & 50 & THR & 24 & 50 & $-124 E-16$ & 589.23 & 84 & -0.00 & 1.0000 & 0.05 & $-1191.64 \mid$ & $1 \times 91.64$ & 1.0 & $<0.0$ & 909. \\
\hline HIC & 8 & 50 & THK & 24 & 100 & -107E-16 & 599.23 & 84 & -0.00 & 1.0000 & 0.05 & {$[-1191.64$} & 1191.6 & 1.000 & $<0.0$ & $>999.999$ \\
\hline HIC & 8 & 50 & WAS & 8 & 0 & $-318 \mathrm{E}-13$ & 589,23 & 84 & -0.00 & 1.0000 & 0.05 & -1191.64 & $1 \cdot 91.6$ & 1.0 & $<0.0$ & 999.999 \\
\hline $\mathrm{HIC}$ & 8 & 50 & WAS & 8 & 50 & -13.751 & 423.72 & 84 & -0.03 & 0.974 & 0.05 & -858.37 & 28.87 & $<0.00$ & $<0.00$ & 999. \\
\hline $\mathrm{HIC}$ & 8 & 50 & WAS & 8 & 100 & $1.54 \mathrm{E}-11$ & 590.23 & 84 & 0.00 & 1,00 & 0.05 & {$[1191.64$} & 1191.6 & 1.00 & 0.0 & $>999.998$ \\
\hline HIC & 8 & 50 & WAS & 24 & 0 & $6.55 \mathrm{E}-11$ & 599.23 & 84 & 0.00 & 1.0000 & 0.05 & -1191.64 & 1191. & 1.0 & 0.0 & 999.999 \\
\hline HIC & B & 50 & WAS & 24 & 50 & Q.59E-11 & 599.23 & 84 & $0.00:$ & 1,0000 & 0.05 & -1191.64 & 1191.6 & 1.000 & $<0.0$ & $>999.999$ \\
\hline HIC & 8 & 50 & WAS & 24 & 100 & $-808 \mathrm{E}-13$ & 599.23 & 84 & -0.00 & 1.0000 & 0.05 & -1181.64 & 1191.6 & 1.00 & $<0.0$ & $>999.999$ \\
\hline IHC & 8 & 100 & HIC & 24 & 0 & $-355 \mathrm{E}-17$ & 599.23 & 84 & -0.00 & 1.0000 & 0.05 & -1191.84 & 1191.6 & 1.00 & 00.0 & 999,999 \\
\hline $\mathrm{HIC}$ & 8 & 100 & $\mathrm{HIC}$ & 24 & 50 & $-654 \mathrm{E}-1$ & 599.23 & 84 & -0.00 & 1.0000 & 0.05 & $-1191,64$ & 119164 & 1.00 & $<0.06$ & $>999.999$ \\
\hline HIC & 8 & $: 100$ & $\mathrm{HIC}$ & 24 & 100 & -13.761 & 423.72 & 84 & -0.03 & 0.9742 & 0.05 & $-856,37$ & 828.87 & $<0.001$ & 0.0 & 999,999 \\
\hline HIC & 8 & 100 & $P \mid \mathrm{G}$ & 8 & 0 & -0.1943 & 603.59 & 84 & -0.00 & 09997 & 0.05 & -1200.51 & 1200.12 & 0.823 & $<0.00$ & $>999.998$ \\
\hline$H$ & 8 & 100 & $P \mid G$ & 8 & 50 & -0.1943 & 603.59 & 84 & $-0.00^{i}$ & 0.8997 & 0.05 & -1200.51 & $1200 \cdot 2$ & 0.823 & $<0.0$ & 9999.89 \\
\hline $\mathrm{HC}$ & 8 & 100 & PIC & 8 & $; 100$ & -0.1943 & 603.59 & 84 & -0.00 & 0.9997 & 0.05 & $-200,51$ & 1200.12 & 0.82 & $<0.001$ & $>999.999$ \\
\hline $\mathrm{HIC}$ & 8 & 100 & PIG & 24 & i & -0.1843 & 803.58 & 84 & -0.00 । & 0.9997 & 0.05 & $-1200,51$ & 1200.12 & 0.823 & $<0,001$ & $>999.899$ \\
\hline $\mathrm{HIC}$ & 8 & 100 & $\mathrm{PIG}$ & 24 & 50 & -0.1943 & 603.59 & 84 & -0.00 & 0.9997 & 0.65 & -1200.51 & 1200.12 & 0.823 & $<0.001$ & 999.899 \\
\hline HIC & 8 & 100 & PIG & 24 & 100 & -0.1943 & 3.59 & 84 & -0.00 & 0.9997 & 0.05 & -1200.51 & 1230.12 & 0.823 & $<0,0$ & $>999.999$ \\
\hline HiC & 8 & 100 & PPB & 8 & 0 & -0.09247 & 601.17 & 84 & -0.00 & 0.9989 & 0.05 & -1105.59 & 1195.41 & 0.812 & $<0.001$ & $>999.999$ \\
\hline HIC & 8 & 100 & PPB & 8 & 50 & -0.09247 & 601.17 & 84 & -0.00 & 0.9999 & 0.05 & -1195.59 & 1185.41 & 0.912 & 0.001 & $>999.899$ \\
\hline HIC & 8 & 100 & PPB & 8 & 100 & -0.09247 & 601.17 & 84 & -0.00 & 0.9899 & 0.05 & 1195.59 & : 1195.41 & 0.812 & $<0,001$ & $>999.999$ \\
\hline IC & 8 & 100 & PPB & 24 & 0 & -0.0 & 601.17 & 84 & -0.00 & 0.8089 & 0.05 & $-1195,59$ & 1195.41 & 0.9 & $<0.0$ & 99 \\
\hline IIC & g & 100 & PPB & 24 & 50 & -13.8603 & 3.72 & 84 & -0.03 & 0.9740 & 005 & -856.48 & 828.70 & $<0.001$ & $<0.001$ & $>999.9$ \\
\hline
\end{tabular}

file://C:/Users/klweber/AppData/Local/Temp/1/SAS\%20Temporary\%20Files/_TD3400_.. 12/10/2014 


\begin{tabular}{|c|c|c|c|c|c|c|c|c|c|c|c|c|c|c|c|c|}
\hline & 8 & 100 & PPB & 24 & 150 & -13.8603 & 423.72 & 84 & $-0.03 !$ & 0.9740 & 0.05 & -856.48 & 828.76 & $<0.001$ & $<0.001$ & $>999.999$ \\
\hline $\mathrm{HIC}$ & 8 & 100 & THR & 8 & 0 & $-179 \mathrm{E}-18$ & 599.23 & 84 & -0.00 & 1.0000 & 0.05 & -1101.64 & 1191.64 & 1.000 & $<0.001$ & $>999.999$ \\
\hline $\mathrm{HIC}$ & 8 & 100 & THR & 8 & 50 & $-213 \mathrm{E}-16$ & 599.23 & 84 & -0.00 & 1.0000 & 0.05 & -1191.64 & 1181.64 & 1.000 & $<0.001$ & $>999.999$ \\
\hline $\mathrm{H!C}$ & 8 & 100 & : THR & 8 & 100 & $-977 E-17$ & 599.23 & 84 & -0.00 & 1.0000 & 0.05 & -1191.64 & 1191.64 & 1.000 & $<0,001$ & $>990.999$ \\
\hline $11 \mathrm{C}$ & 8 & 100 & THR & 24 & 3 & $-182 E-16$ & 599.23 & 84 & -0.00 & 1,0000 & 0.05 & -1191.64 & 1191.64 & 1.000 & $<0.001$ & $>999.999$ \\
\hline $\mathrm{HC}$ & 8 & 100 & THR & 24 & 50 & $-173 E-16$ & 599.23 & 84 & -0.00 & 1.0000 & 0.05 & .1191 .64 & $1101,6<$ & 1.000 & $<0.001$ & $>999.999$ \\
\hline $\mathrm{H}: \mathrm{C}$ & 8 & 100 & THR & 24 & 100 & $4173 \mathrm{E}-16$ & 599.23 & 84 & -0.00 & 10000 & 0.05 & -1191.64 & 1191.64 & 1.000 & $<0.001$ & $>999.999$ \\
\hline $\mathrm{HIC}$ & 8 & 100 & WAS & 8 & 0 & $-318 E-13$ & 599.23 & 84 & -0.00 & 1.0000 & 0.05 & -119184 & 119164 & 1.000 & $<0.001$ & $>999.998$ \\
\hline $\mathrm{HIC}$ & 8 & 100 & WAS & 8 & 50 & -13.7511 & 423.72 & 84 & -0.03 & 0.8742 & 0.05 & -858.37 & 828.87 & $<0.001$ & $<0.001$ & $>999.999$ \\
\hline $\mathrm{HIC}$ & 8 & 100 & WAS & 8 & 100 & $1.54 \mathrm{E}-11$ & 599.23 & 84 & 0.00 & 1,0000 & 0.05 & $-1 \times 91.64$ & 1191.64 & 1.000 & $<0.001$ & $>999,999$ \\
\hline $\mathrm{HIC}$ & 8 & 100 & WAS & 24 & 0 & $5.55 \mathrm{E}-11$ & 599.23 & 84 & 0.00 & 1,0000 & 0.05 & -1191.64 & 1191.64 & 1.000 & $<0.001$ & $>999.999$ \\
\hline HIC & 8 & 100 & WAS: & 24 & 50 & $9.59 \mathrm{E}-11$ & 599.23 & 84 & 0.00 & 1,0000 & 0.05 & -181.64 & 1101.64 & 1.000 & $<0.001$ & $>989.899$ \\
\hline HIC & 8 & 100 & WAS & 24 & 100 & $-808 \mathrm{E}-13$ & 599.23 & 84 & -0.00 & 1.0000 & 0.05 & $\begin{array}{r}-191.64 \\
\end{array}$ & 1191.64 & 1.000 & $<0.001$ & $>999.999$ \\
\hline HIC & 24 & 0 & $\mathrm{HIC}$ & 24 & 50 & $-355 \mathrm{E}-17$ & 599.23 & 84 & -0.00 & 1.0000 & $0 . C 5$ & $-1191,64 !$ & 1191.64 & 1.000 & $<0.001$ & $>999.999$ \\
\hline $\mathrm{HIC}$ & 24 & 0. & $\mathrm{HIC}$ & 24 & 100 & -13.7511 & 423.72 & 84 & -2.03 & 0.9742 & 0.05 & $-856,37$ & 828.87 & $<0.001$ & $<0,001$ & $>999999$ \\
\hline $\mathrm{HIC}$ & 24 & 0 & PIG & 8 & 0 & -0.1943 & 603.59 & 84 & -0.00 & 0.9997 & 0.05 & -1200.51 & 1200.12 & 0.823 & $<0.001$ & $>099.999$ \\
\hline $\mathrm{HIC}$ & 24 & 0 & PIG & 8 & 50 & -0.1943 & 603.59 & 84 & -0.00 & 0.9997 & 0.05 & -120051 & 1200.12 & 0.823 & $<0.001$ & $>999.999$ \\
\hline $\mathrm{HIC}$ & 24 & 0 & PIG & 8 & 100 & -0.1943 & 603.59 & 84 & -0.00 & 0.9997 & 0.05 & -1200.51 & 1200.12 & 0.823 & $<0.001$ & $>999,999$ \\
\hline $\mathrm{HIC}$ & 24 & 2 & PIG & 24 & 0 & -0.1943 & 603.59 & 84 & -0.00 & 0.9997 & 0.05 & -1200.51 & 1200.12 & 0.823 & $<0.001$ & $>999.999$ \\
\hline $\mathrm{HIC}$ & 24 & D. & PIG & 24 & 50 & -0.1943 & 603.59 & 84 & -0.00 & 0.9997 & 005 & $-1200,51$ & 1200.12 & 0.823 & $<0.001$ & $>998.999$ \\
\hline $\mathrm{HIC}$ & 24 & 0 & PIG & 24 & 100 & -0.1943 & 603.68 & 84 & -0.00 & 0.9997 & 0.05 & -1200.51 & 1200.12 & 0.823 & $<0.001$ & $>999.998$ \\
\hline $\mathrm{HIC}$ & 24 & 0 & PPB & 8 & $c$ & -0.09247 & 601.17 & 54 & -0.00 & 0.9999 & 0.05 & -1195.59 & 1195.41 & 0.912 & $<0,001$ & $>999.999$ \\
\hline$-11 C$ & 24 & 0 & PPB & 8 & 50 & -0.09247 & 601.17 & 34 & -0.00 & 0.9999 & 0.05 & -1195.59 & 1195.41 & 0.912 & $<0.001$ & $>099.999$ \\
\hline HIC & 24 & 0 & PPB & 8 & 100 & -0.09247 & 601.17 & 84 & -0.00 & 0.9999 & 0.05 & -1195.59 & 1195.41 & 0.812 & $<0.001$ & $>999.909$ \\
\hline $\mathrm{HIC}$ & 24 & 0 & PPB & 24 & 0 & -0.08247 & 601.17 & 84 & -0.00 & $C .8990$ & 0.05 & -1195.59 & 1185,41 & 0.912 & $<0.001$ & $>999.999$ \\
\hline $\mathrm{HIC}$ & 24 & 0 & PPB & 24 & 50 & -13.8603 & 423.72 & 84 & -0.03 & 0.9740 & 0.05 & -858.48 & 828.76 & $<0,001$ & $<0.001$ & $>999.999$ \\
\hline $\mathrm{HIC}$ & 24 & 0 & $\mathrm{PPB}$ & 24 & 100 & -13.8503 & 423.72 & 84 & -0.03 & 0.9740 & 0,05 & -856.48 & 828.75 & $<0.001$ & $<0.001$ & $>999.999$ \\
\hline 10 & 24 & 0 & THR & 8 & 0 & $-144 E-16$ & 599.23 & 84 & -0.00 & 1.0000 & 0.05 & -1181.64 & 1191.64 & 1,000 & $<0.001$ & $>999.989$ \\
\hline HI & 24 & 0 & THR & 8 & 50 & $-178 \mathrm{E}-16$ & 599.23 & 84 & -0.00 & 1.3000 & 0.05 & -1191.64 & 1181.34 & 1,000 & $<0.001$ & $>998.999$ \\
\hline HIC & 24 & 0 & THR & 18 & 100 & $-711 \mathrm{E}-17$ & 599.23 & 84 & $-0,00$ & 1.0000 & 0.05 & -1191.64 & 1191.64 & 1.000 & $<0.001$ & $>999.999$ \\
\hline $\mathrm{HIC}$ & 24 & C. & THR & 24 & 0 & $-142 E-18$ & 599.23 & 84 & -0.00 & 1.0000 & 0.05 & -1191.64 & 1191.84 & 1.000 & $<0.001$ & $>999,909$ \\
\hline $\mathrm{HIC}$ & 24 & c & THR & 24 & 50 & $-178 \mathrm{E}-16$ & 599.23 & 84 & -0.00 & 1.0000 & 0.05 & -1191.64 & 1191.64 & 1.000 & $<0.001$ & $>999.990$ \\
\hline $\mathrm{HIC}$ & 24 & 0 & THR & 24 & $-\infty$ & $-142 E-16$ & 599.23 & 84 & $-0,00$ & 1.0000 & 0.05 & -1191.64 & 1191.64 & 1.000 & $<0.001$ & $>998.999$ \\
\hline $\mathrm{HIC}$ & 24 & 0 & WAS & 8 & 0 & $-318 E-13$ & 599.23 & 84 & -0.00 & 1.0000 & 0.05 & -1191.64 & $119^{\circ} .64$ & 1.000 & $<0.001$ & $>989.099$ \\
\hline $\mathrm{HIC}$ & 24 & $\therefore$ & WAS: & 8 & 50 & -13.7511 & 423.72 & 84 & -0.03 & 0.9742 & 0.05 & -856.37 & 828.87 & $<0.001$ & $<0.001$ & $>899.990$ \\
\hline $\mathrm{HIC}$ & 24 & 0 & WAS & 8 & 100 & $1.54 \mathrm{E}-11$ & 599.23 & 84 & 0.00 & 1.0000 & 0.05 & -1191.64 & 1191.64 & 1.000 & $<0.001$ & $>999.999$ \\
\hline$H I C$ & 24 & 0 & WAS & 24 & 0 & $5.55 \mathrm{E}-11$ & 599.23 & 84 & 0.00 & 1.0000 & 0.05 & -1191.84 & $1-21.64$ & 1.000 & $<0.001$ & $>999.999$ \\
\hline $\mathrm{HIC}$ & 24 & 0 & WAS & 24 & 50 & $9.59 \mathrm{E}-11$ & 599.23 & 84 & 0,00 & 1.0000 & 0.05 & -1191.64 & 1791.64 & 1.000 & $<0.001$ & $>999.999$ \\
\hline $\mathrm{HIC}$ & 24 & 0 & WAS: & 24 & 100 & $-808 E-13$ & 599.23 & 84 & -0.00 & 1.0000 & 0.05 & -1191.64 & $1 / 91.64$ & 1.000 & $<0.001$ & $>989.999$ \\
\hline HIC & 24 & 50 & HIC & 24 & 100 & -13.7511 & 423.72 & 84 & -0.03 & 0.9742 & 0.25 & -856.37 & 828.87 & $<0.001$ & $<0.001$ & $>999.999$ \\
\hline HIC & 24 & 50 & $\mathrm{PIG}$ & 8 & 0 & -0.1843 & 603.59 & 84 & -0.00 & 0.9997 & 0.35 & -1200.51 & 1200.12 & 0.823 & $<0.001$ & $>999.999$ \\
\hline $\mathrm{HIC}$ & 24 & 50 & PIG & 8 & 50 & $-0.1 \subseteq 43$ & 603.59 & 84 & -0.00 & 0.9997 & 0.05 & -1200.51 & 1200.12 & 0.823 & $<0.001$ & $>999.998$ \\
\hline $\mathrm{H} \mid \mathrm{C}$ & 24 & 50 & PIG & 8 & 100 & -0.1943 & 603,59 & 84 & -0.00 & 0.9997 & 0.05 & -1200.51 & 1200.12 & 0.823 & $<0.001$ & $>999.999$ \\
\hline $\mathrm{HIC}$ & 24 & 50 & PIG & 24 & 0 & -0.1943 & 603.59 & 84 & -0.00 & 0.9997 & 0.05 & -1200.51 & 1200.12 & 0.823 & $<0.001$ & $>990,999$ \\
\hline $\mathrm{HIC}$ & 24 & 50 & PIG & 24 & 50 & $-0.19<3$ & 603.69 & 84 & -0.00 & 0.9997 & 0.05 & -1200.51 & 1200.12 & 0,823 & $<0.001$ & $>999.999$ \\
\hline HIC & 24 & 50 & PIG & 24 & 100 & -0.1943 & 603.59 & 84 & -0.00 & 0.9997 & 0.05 & -1200.51 & 120012 & 0.823 & $<0.001$ & $>999.989$ \\
\hline HIC & 24 & 50 & PPB & 8 & 0 & $-0,09247$ & 601.17 & 84 & -0.00 & 0.9899 & 0.05 & -1195.59 & $\begin{array}{r}1195.4^{4} \\
-\end{array}$ & 0.912 & $<0.001$ & $>999.998$ \\
\hline $\mathrm{HIC}$ & 24 & 50 & PPB & 8 & 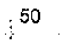 & $-0,09247$ & 601.17 & 84 & -0.00 & 0.9999 & 0.05 & -1105.59 & 1195,4 & 0.912 & $<0.001$ & $>999.999$ \\
\hline $\mathrm{HIC}$ & 24 & 50 & $\mathrm{PPB}$ & 8 & 100 & -0.09247 & 601.17 & 84 & -0.00 & 0.9999 & 0.05 & $-1 \times 95.59$ & 1195.41 & 0.912 & $<0.001$ & $>999.999$ \\
\hline
\end{tabular}

file://C:/Users/klweber/AppData/Local/Temp/1/SAS\%20Temporary\%20Files/_TD3400_.. 12/10/2014 


\section{AEH-13-PSEUDO-06}

\begin{tabular}{|c|c|c|c|c|c|c|c|c|c|c|c|c|c|c|c|c|}
\hline & 24 & 50 & PPB & 24 & 0 & .09247 & 01.17 & 84 & -0.0010 & 0.9990 & 0.05 & $-1195,59$ & 1195.41 & 0.912 & $<0.001$ & \$६.999 \\
\hline ic & 24 & 50 & PPB : & 24 & 50 & $3.86 \mathrm{CB}$ & 423.72 & 84 & $-0.03: 0$ & 0.9740 & 0.05 & -856.48 & 828.76 & $<0.001$ & $<0.001$ & $>999.809$ \\
\hline HIC & 24 & 60 & $\mathrm{PPB}$ & 24 & 100 & 3.8803 & 23.72 & 84 & -0.030 & 0.9740 & 0.05 & -856.48 & 828.76 & $<0.001$ & $<0.001$ & $>999.999$ \\
\hline IIC & 24 & 50 & THR & 8 & 0 & $-104 \mathrm{E}-16$ & 599.23 & 84 & $0.00: 1$ & 1.0000 & 0.05 & -1191.64 & 1191.64 & 1.000 & $<0.001$ & $>\$ 99.999$ \\
\hline HIC & 24 & 50 & THR & 8 & 50 & $-124 E-16$ & 599.23 & 84 & -0.00 & 1.0000 & 0.05 & -1181.64 & 1181.64 & 1.000 & $<0.001$ & $>899.998$ \\
\hline$H I C$ & 24 & 50 & THR & 8 & 100 & $-311 E-17$ & 599.23 & 84 & -0.001 & 1.0000 & 0.05 & -1181.64 & 1191.64 & 1.000 & $<0.001$ & $>999.989$ \\
\hline $\mathrm{HKC}$ & 24 & 50 & $\mathrm{THR}$ & 24 & 10 & $-107 \mathrm{E}-16$ & 599.23 & 84 & $-0.00:$ & 1.0000 & 0.06 & -1181.641 & 1191.64 & 1.000 & $<0.001$ & $>999.999$ \\
\hline HIC & 24 & 50 & THR & 24 & 50 & $-107 E-16$ & 590.23 & 84 & -0.001 & 1.0000 & 0.05 & -1181.54 & 1191.64 & 1.000 & $<0.001$ & $>999.899$ \\
\hline $\mathrm{HIC}$ & 24 & 50 & THR & 24 & 100 & $-107 E-16$ & 598.23 & 84 & -0.0011 & 1.0000 & 0.05 & -1191.64 & 1191,64 & 1.000 & $<0.001$ & $>999.999$ \\
\hline HIC & 24 & 50 & WAS & 8 & 0 & $-318 E-13$ & 589.23 & 84 & $-0.00 ; 1$ & 1.0000 & 0.05 & -1191.64 & 1191.64 & 1.000 & $<0.001$ & $>999.899$ \\
\hline $\mathrm{HIC}$ & 24 & 50 & WAS & 8 & 50 & -13.7511 & 423.72 & 84 & $-0.03 ! 0$ & 0.9742 & 0.05 & -856.37 & 828.87 & $<0.001$ & $<0.001$ & $>999.899$ \\
\hline IC & 24 & 50 & WAS & 8 & 100 & $1.54 E^{-11}$ & 599.23 & 84 & $0.00: 1$ & 10000 & 0.05 & -1191.64 & 1191.64 & 1.000 & $<0.001$ & $>999.998$ \\
\hline $\mathrm{HC}$ & 24. & 50 & WAS & 24 & 0 & $5.55 \mathrm{E}-11$ & 599.23 & 84 & 0.001 & 10000 & 0.05 & -1191.64 & 1191,64 & 1.000 & $<0.001$ & $>990,999$ \\
\hline $\mathrm{H} / \mathrm{C}$ & 24 & 50 & WAS & 24 & 50 & $9.59 F-11$ & 599.23 & 84 & $0.00^{\prime}$ & 10000 & 0.05 & -1191.64 & 1191.64 & 1.000 & $<0.001$ & $>999.999$ \\
\hline $\mathrm{HIC}$ & 24 & 50 & WAS & 24 & 100 & $800 \mathrm{E}-13$ & 599.23 & 84 & $-0.00 ; 1$ & 1.0000 & 0.05 , & $-1 \cdot 9164$ & 119164 & 1.000 & $<0.001$ & $>999.999$ \\
\hline HIC & 24 & 100 & $\mathrm{PIG}$ & 8 & 0 & 13.5567 & 429.87 & 84 & $0.03: 0$ & 0.9749 & 0.05 & -841.28 & 868.40 & $>999.999$ & $<0.001$ & $>999.999$ \\
\hline HIC & 24 & 100 & PIG & 8 & 50 & 13.5567 & 429.87 & 84 & $0.03: 0$ & 0.9749 & 0.65 & -841.28 & 868,40 & $>999.999$ & $<0.001$ & $>999.999$ \\
\hline $\mathrm{HIC}$ & 24 & 100 & $P \mid G$ & 8 & 100 & 13.5567 & 429.87 & 84 & 0.0310 & 0.9749 & 0.05 & -841.28 & 868.40 & $>999.999$ & $<0.001$ & $>\theta 90999$ \\
\hline HIC & 24 & 100 & PIG & 24 & 0 & 13.5567 & 429.87 & 84 & 0.0310 & 0.9749 & 0.05 & $-841,28$ & 868.40 & $>999.999$ & $<0.001$ & $>999.999$ \\
\hline $\mathrm{HIC}$ & 24 & 100 & PIG & 24 & 50 & 13.5567 & 428.87 & 84 & 0.0310 & 0.9749 & 0.05 & -841.28 & $858.40=$ & $>999.999$ & $<0.00$ & $>998,899$ \\
\hline HIC & 24 & 100 & $\mathrm{PIG}$ & 24 & 100 & 13.5567 & 429.87 & 84 & 0.031 & 0.9749 & 0.05 & 841.28 & 888.40 & $>999.899$ & $<0.00$ & $>999.099$ \\
\hline $\mathrm{HIC}$ & 24 & 100 & PPB & 8 & 0 & 13.6586 & 426.46 & 84 & 0.03 & 0.9745 & 0.05 & -834.41 & 861.72 & $>999,899$ & $<0.00$ & $>999.999$ \\
\hline HIC & 24 & 100 & PPB & 8 & 150 & 13.6586 & 426.46 & 84 & 0.03 & 0.9745 & 0.05 & -834.41 & 861.72 & $>999.99$ & $<0,00$ & $>999.999$ \\
\hline IIC & 24 & 100 & PPB & 8 & 100 & 13.6538 & 426.46 & $B 4$ & 0.03 & 0.9745 & 0.05 & -834.41 & 861.72 & $>999.898$ & $<0.00$ & $>999.909$ \\
\hline HIC & 21 & 100 & $\mathrm{PPB}$ & 24 & 0 & 13.6538 & 426.46 & 84 & 0.030 & c.9745 & 0.05 & -834.41 & 861.72 & $>999.899$ & $<0.00$ & $>999.999$ \\
\hline HIC & 24 & 100 & PPB & 24 & 50 & -0.1092 & 0.6408 & 84 & -0.170 & 0.8651 & 0.05 & -1.3835 & 1.1651 & 0.897 & 0.2 & 3.206 \\
\hline Ho & 24 & 100 & PPB & 24 & 100 & -0.1392 & 8408 & 84. & -0.179 & 0.8651 & 0.05 & -1.3835 & 1.1651 & 0.897 & 0.25 & 3.206 \\
\hline hile & 24 & 100 & THR : & 8 & 0 & 13.7511 & 423.72 & 84 & 0.03 & 0.9742 & 0.05 & -828.87 & 856.37 & $>999.999$ & $<0.00$ & $>988,899$ \\
\hline $\mathrm{HIC}$ & 24 & 100 & THR & 8 & 50 & 13.7511 & 423.72 & 84 & 0.03 & 0.9742 & 0.05 & -828.87 & 856.37 & $>999.9$ & $<0.0$ & $>989.999$ \\
\hline $\mathrm{HIC}$ & 24 & 100 & THR & 8 & 00 & 13.7511 & 423.72 & 84 & $0.03:$ & 0.9742 & 0.05 & -828.87 & 856.37 & $>999.890$ & $<0.00$ & $>999.999$ \\
\hline $\mathrm{HIC}$ & 24 & 100 & THR & 24 & 0 & 13.7511 & 423.72 & 84 & 0.03 & 0.9742 & 0.05 & -828.87 & 856.37 & $>999.999$ & $=0.00$ & $>989.999$ \\
\hline $\mathrm{HIC}$ & 24 & 100 & THR & 24 & 50 & 13.7511 & 423.72 & 84 & 0.03 & 0.9742 & 0.05 & -828.87 & 856.37 & $>999.99$ & $<0.0$ & 999.999 \\
\hline HIC & 24 & 100 & THR & 24 & 100 & 13.7511 & $423.72 !$ & 84 & 0.03 & 0.9742 & 0.05 & -828.87 & 856.37 & $>999.99$ & $<0.00$ & $>990.999$ \\
\hline $\mathrm{HIC}$ & 24 & 100 & WAS & 8 & 0 & 13.7511 & 423.72 & 84 & 0.03 & 0.9742 & 0.05 & -828.87 & 856.37 . & $>999.898$ & $<0.00$ & 9999.999 \\
\hline HIC & 24 & 100 & WAS & 8 & 5 & $-362 E-17$ & 0.6402 & 84 & -0.00 & 1.0000 & 0.35 & -1.2731 & .2731 & 1.000 & 0.2 & 3.572 \\
\hline $\mathrm{HIC}$ & 24 & 100 & WAS & 8 & 100 & 13.7511 & 423.72 & 84 & 0.03 & 0.9742 & 0.05 & -828.87 & 856,37 & $>999.990$ & $<0.00$ & 999.998 \\
\hline $\mathrm{HIC}$ & 24 & 100 & WAS & 24 & 0 & 13.7511 & 423.72 & 84 & 0.03 & 0,9742 & 0.05 & -828.87 & 856.37 & $>999.9$ & $<0.0$ & 999.999 \\
\hline $\mathrm{HIC}$ & 24 & 00 & WAS & 24 & 50 & 13.751 & 3.72 & 84 & 0.03 & 0.9742 & 0.05 & -828.87 & 856.37 & $>999.999$ & $<0.0$ & 999.999 \\
\hline $\mathrm{HIC}$ & 24 & 100 & WAS & 24 & 100 & 13.7511 & $23.72 !$ & 84 & 0.03 & 0.9742 & 0.05 & -828.87 & 856.37 & $>999.989$ & $<0.001$ & 999.989 \\
\hline$P I G$ & 8 & 0 & $\mathrm{PIG}$ & 1 & 50 & $1.92 \mathrm{E}-15$ & 7.93 & 84 & 0.00 & 1.0000 & 0.05 & -1208.93 & 1208,93 & 1.000 & $<0.00$ & 999.999 \\
\hline PIG & 8 & 10 & PIG & 8 & 100 & $1.45 \mathrm{E}-16$ & 607.93 & 84 & 0.00 & 1,0000 & 0.05 & $\begin{array}{r}-1208.93 \\
\end{array}$ & 1208 & 1.000 & $<0,001$ & $>999.999$ \\
\hline PIG & 8 & $: 0$ & $\mathrm{PIG}$ & 24 & 0 & $2.32 E=15$ & 607.93 & 84 & 0.00 & 1.0000 & 0.05 & $-1208,93$ & 1208.93 & 1.000 & $<0.001$ & 999.998 \\
\hline PIG & 8 & 0 & $P \mid G$ & 24 & 60 & $2.07 E-15$ & 607.93 & 84 & 0.00 & 1.0000 & 0.05 & $-1208,93$ & 1208.93 & 1.000 & $<0.001$ & $>999.999$ \\
\hline$P \mid G$ & 8 & 0 & $\mathrm{PIG}$ & 24 & 100 & $4.34 E-15$ & 607.93 & 84 & 0.00 & 1.0000 & 0.05 & -1208.93 & 1208.93 & 1.000 & $<0.001$ & $>999,999$ \\
\hline PIG & 8 & 0 & $\mathrm{PPB}$ & 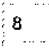 & 0 & 0.1019 & $805.52 !$ & 84 & 0.00 & 0.9999 & 0.05 & $-1204,04$ & 1204.25 & 1.107 & $<0.001$ & 9999.999 \\
\hline$P \mid G$ & 8 & 0 & PPB & 8 & 50 & 0.018 & 605.52 & 84 & 0.00 & 0.9999 & 0.05 & -1204.04 & 1204.25 & 1.107 & $<0.001$ & $>999.999$ \\
\hline$P I G$ & 8 & 0 & $\mathrm{PPB}$ & 8 & 100 & 0.10 & 05.52. & BA: & 0.00 & 0.9999 & 0.05 & -1204.04 & 1204.25 & 1.107 & $<0,001$ & $>999.999$ \\
\hline PIG & 8 & 0 & $\mathrm{PPB}$ & 24 & 0 & 0.1019 & 605.52 & 84 & 0.00 & 0.9999 & 0.05 & -1204.04 & 1204.25 & 1.107 & $<0.001$ & $>999.999$ \\
\hline & 8 & & PPB & 24 & 50 & 13.6650 & 429.87 & 84 & -0.03 & 0.9747 & 0.05 & -868.51 & 1.17 & $<0.001$ & $<0.001$ & $>999.99$ \\
\hline
\end{tabular}

file://C:/Users/klweber/AppData/Local/Temp/l/SAS\%20Temporary\%20Files/_TD3400_.. 12/10/2014 


\section{AEH-13-PSEUDO-06}

\begin{tabular}{|c|c|c|c|c|c|c|c|c|c|c|c|c|c|c|c|c|}
\hline & 8 & 0 & PPB & 24 & 100 & 13.6659 & $429.87\}$ & 84 & $-0.03: 0$ & 0.9747 & 0.05 & -868.51 & 41.17 & $<0.001$ & $<0.001$ & $>998,899$ \\
\hline PIG & 8 & 0 & THR & 8 & 0 & 0.1943 & $603.5 \theta$ & 84 & 0.000 & 0.9997 & 0.05 & -1200.12 & 1200.51 & 1.215 & $<0.001$ & $>999.999$ \\
\hline PIG & 8 & 0 & THR & 8 & 50 & 0.1843 & 603.59 & 84 & 0.00 & 0.9997 & 0.05 & -1200.12 & 1200.51 & 1.215 & $<0.001$ & $>999.999$ \\
\hline PIG & 8 & 0 & THR & 8 & 100 & 0.1943 & 603.59 & 84 & 0.0010 & 0.9997 & 0.05 & -1200.12 & 1200.51 & 1.215 & $<0.001$ & $>999.999$ \\
\hline IG & 8 & 0 & THR & 24 & 0 & 0.1943 & 603.59 & 84 & $0.00: 0$ & 0.9997 & 0.05 & -1200.12 & 12.00 .51 & 1.215 & $<0.001$ & $>999.999$ \\
\hline $\mathrm{PIG}$ & 8 & 0 & THR & 24 & 50 & 0.1843 & B03.59 & 84 & 0.0010 & 0.9997 & 0.05 & -1200.12 & 1200,51 & 1.215 & $<0.001$ & $>999.999$ \\
\hline PIG & 8 & 0 & THR & 24 & 100 & 0.1843 & 603,59 & 84 & 0.0010 & 0.9997 & 0.05 & -1200.12 & 1200,51 & 1.215 & $<0.001$ & $>999.999$ \\
\hline 16 & 8 & 0 & WAS & 8 & 0 & 0.1943 & 603.59 & 84 & 0.000 & 0.8997 & 0.05 & -1200.12 & 1200.51 & 1.215 & $<0,001$ & $>999.999$ \\
\hline$P \mid G$ & 8 & 0 & WAS & 8 & 50 & -13.5567 & 429.87 & 84 & -0.030 & 0.9749 & 0.05 & -868.40 & 841.28 & $<0,001$ & $<0.001$ & $>999.999$ \\
\hline PIG & ${ }^{8}$ & 0 & WAS & 8 & 100 & 0.1843 & 603.59 & 84 & 0.000 & 0.9987 & 0.05 & $-1200,12 ;$ & 1200.51 & 1.215 & $<0.001$ & $>999.999$ \\
\hline PIG & 8 & 0 & WAS & 24 & 0 & 0.1943 & 803.59 & B4 & $0.00: 0$ & 0.8997 & 0.05 & 200.12 & 1200.51 & 1.215 & $<0.001$ & $>999.999$ \\
\hline P.G & 8 & 0 & WAS: & 24 & 50 & 0.1843 & 603.59 & 84 & 0.00 & 0.9997 & 0.05 & -1200.12 & 1200.51 & 1.215 & $<0.001$ & $>999.999$ \\
\hline PIG & 8 & .0 & WAS & 24 & 100 & 0.1943 & 603.59 & 84 & 0.00 & 0.9997 & 0.05 & -1200.12, & 1200.51 & 1.215 & $<0.001$ & $>999.999$ \\
\hline$P \mid G$ & 8 & 50 & PIG & 8 & 100 & $-176 \mathrm{E}-17$ & 607.93 & 84 & -0.00 & 1.0000 & 0.05 & -1208.93 & 1208.03 & 1.000 & $<0.001$ & $>999.998$ \\
\hline PIG & 8 & 50 & PIG & 24 & 0 & $4.02 \mathrm{E}-16$ & 607.93 & 84 & 0.00 & 1.0000 & 0.05 & 1208,93 & 1208.93 & 1.000 & $<0.001$ & $>899.999$ \\
\hline PIG & 8 & 50 & PIG & 24 & 50 & $114 E-17$ & 607.93 & 84 & -0.00 & 1.0000 & 0.05 & -1208.93 & 1208.93 & 1.000 & $<0.001$ & $>999.899$ \\
\hline$P I G$ & 8 & 50 & PIG & 24 & 100 & $2.42 E-15$ & 607.93 & 84 & 0.00 & 1.0000 & 005 & -1208.93 & 1208.93 & 1.000 & $<0,001$ & $>998.999$ \\
\hline PIG & 8 & 50 & PPB & 8 & 0 & 0.1019 & 605.52 & 84 & 0.00 & 0.9999 & 0.05 & -1204.04, & 1204.2 & 1.107 & $<0,001$ & $>999.998$ \\
\hline PIG & 8 & 50 & PPB & 8 & 50 & 0.1019 & 605.52 & 84 & 0.00 & 0.8989 & 0.05 & -1204.04 & 1204.25 & 1.107 & $<0,00$ & $>999.999$ \\
\hline PIG & 8 & 50 & PPB & 8 & 100 & 0.1019 & 605.52 & 84 & 0.00 & 0.8999 & 0.05 & -1204.04 & 1204.25 & 1.107 & $<0.001$ & $>999.999$ \\
\hline$P \mid G$ & 8 & 50 & PPB & 24 & 0 & 0.1019 & 605.52 & 84 & 0.00 & c.9999 & 0.05 & -1204.04 & 1204.25 & 1.107 & $<0.001$ & $>899.999$ \\
\hline ગG & 8 & 50 & PPB & 24 & 50 & -13.6859 & 429.87 & 84 & -0.03 & c. .9747 & 0.05 & -868.51 & 841.17 & $<0,001$ & $<0.00$ & $>999.999$ \\
\hline PIG & 8 & 50 & PPB & 24 & 100 & -13.6659 & 429.87 & 84 & $-0,03$ & 0.9747 & 0.05 & -838.51 & 841.17 & $<0.001$ & $<0.001$ & $>999,899$ \\
\hline PIG & 8 & 50 & THR & 8 & 0 & 0.1943 & 603.59 & 84 & 0.00 & 0.9997 & 0.05 & -1200.12 & $12 C 0.51$ & 1.215 & $<0.00$ & $>999.999$ \\
\hline PIG & 8 & $5 \mathrm{C}$ & THR : & 8 & 50 & 0.1943 & 603.59 & 84 & 0.00 & 0.9997 & 0.05 & -1200.12 & 1200.51 & 1.215 & $<0.001$ & $>999.998$ \\
\hline PIG & 8 & 50 & THR & 8 & 100 & 0.1943 & 603.59 & 84 & 0.00 & 0.9997 & 0.05 & -1200.12 & 1200.51 & 1.215 & $<0.001$ & $>998.999$ \\
\hline FIG & 8 & 50 & THR : & 24 & 0 & 0.1943 & 603.59 & 84 & 0.00 & 0.9997 & 0.05 & -1200.12 & 1200.5 & 1.21 & $<0.0$ & $>995.999$ \\
\hline PIG & 8 & 50 & THR . & .24 & 50 & 0.1943 & 603.59 & 84 & 0.00 & 0.9997 & 0.05 & -1200.12 & 1200.51 & 1.215 & $<0.00$ & $>989.999$ \\
\hline PIG & 8 & 50 & THR & 24 & 100 & 0.1943 & 603.59 & 84 & 0.00 & 0.9997 & 0.05 & -1200.12 & 1200.5 & 1.215 & $<0.001$ & $>898.999$ \\
\hline $\mathrm{PIO}$ & 8 & 50 & WAS & 8 & 0 & 0.1943 & 603.59 & 84: & 0.00 & 0.9997 & 0.05 & -1200.12 & 1200.51 & 1.215 & $<0.001$ & $>899.999$ \\
\hline PIG & 8 & 50 & WAS: & 8 & 50 & -13.5567 & 429.87 & 84 & -0.03 & 0.9749 & 0.05 & -868.40 & $84 i .28$ & $<0.001$ & $<0.001$ & $>999,999$ \\
\hline PIG & 8 & 50 & WAS & 8 & 100 & 0.1943 & 603.59 & 84 & 0.00 & 0.9997 & 0.05 & -1200.12 & 1200.51 & 1.21 & $<0.00$ & $>899.999$ \\
\hline PIG & 8 & 50 & WAS & 24 & 0 & 0.1943 & 603.59 & 84 & 0.00 & 0.9997 & 0.05 & -1200.12 & 1200.51 & 1.215 & $<0,00$ & $>999.999$ \\
\hline PIG & 8 & 50 & WAS & 24 & 50 & 0.1943 & 603.59 & 84 & 0.0 & 0.9997 & 0.05 & $-1200,12$ & 1200,51 & 1.215 & $<0.001$ & $>999.999$ \\
\hline PIG & 8 & 50 & WAS & 24 & 100 & 0.1943 & 603.59 & 84 & 0.00 & 0.9997 & 0.05 & {$[-1200.12$} & 1200.51 & 1.21 & $<0.00$ & $>999.999$ \\
\hline PIG & 8 & 00 & PIG & 24 & 0 & $2.18 \mathrm{E}-15$ & 607,93 & 84 & 0.00 & 1.0000 & 0.05 & -1208.93 & 1208.93 & 1.000 & $<0,001$ & $>999.999$ \\
\hline PIG & 8 & 100 & PIG & 24 & 50 & 1.92E-15 & 607.93 & 84 & 0.00 & 1,0000 & 0.05 & -1208.93 & 1208.83 & 1.00 & $<0.001$ & $>999,999$ \\
\hline PIG & 8 & 100 & PIG & 24 & 100 & $4.19 E-15$ & 607.93 & 84 & 0.00 & 1.0000 & 0.05 & -1208.93 & 1208.93 & 1.000 & $<0.001$ & $>999.998$ \\
\hline PIG & 8 & 100 & $P P B$ & 8 & 0 & 0.1019 & 605.52 & 84 & 0.00 : & 09999 & 0.05 & -1204.04 & 1204.25 & 1.107 & $<0,001$ & $>999.999$ \\
\hline$P \mid G$ & 8 & 100 & PPB & 8 & 50 & 0.1019 & 805.52 & 84 & 0.00 & 0.9999 & 0.05 & -1204.04 & 1204.25 & 1.107 & $<0.001$ & $>999.999$ \\
\hline$P I G$ & 8 & $: 100$ & PPB & 8 & 100 & 0.1019 & 605.52 & 84 & 0.00 & 0.9999 & 0.05 & -1204.04 & 1204.25 & 1.107 & $<0.001$ & $>899.999$ \\
\hline PIG & 8 & 100 & PPB : & 24 & 0 & 0.1019 & 605.52 & 84 & $0.00^{\mathrm{j}}$ & 0.9999 & 0.05 & -1204.04 & 1204.25 & 1.10 & $<0.001$ & $>999.998$ \\
\hline PIG & 8 & 100 & PPB & 24 & 50 & -13.6659 & 429.87 & 84 & -0.03 & 0.9747 & 0.05 & -868.51 & 841.17 & $<0.001$ & $<0.001$ & $>999.999$ \\
\hline PIS & 8 & 100 & PPB & 24 & 100 & -13.6659 & 429.87 & 84 & $-0,03$ & 0.9747 & $0 . c 5$ & -868.51 & 841.17 & $<0.001$ & $<0.001$ & $>999.999$ \\
\hline $\mathrm{P} \mid \mathrm{G}$ & 8 & 100 & THR & 8 & 0 & 0.1943 & 603.59 & 84 & 0.00 & 0.9997 & 0.05 & -1200.12 & 1200.51 & 1.215 & $<0.001$ & $>999.999$ \\
\hline$P \mid G$ & 8 & 100 & THR & 8 & 50 & 0.1943 & 603.59 & 84 & 0.00 & 0.9997 & 0.05 & -1200.12 & 1200.51 & 1.215 & $<0.001$ & $>999.999$ \\
\hline$P G$ & 8 & 100 & THR & 8 & 100 & 0.943 & 603.59 & 84 & 0.00 & 0.9997 & 0.05 & $-1200,12$ & 1200.51 & 1.215 & $<0.001$ & $>999.999$ \\
\hline $\mathrm{PIO}$ & 8 & 100 & THR & 24 & 0 & 0.1943 & 603.59 & 84 & 0.00 & 0.8997 & 0.05 & -1200.12 & 1200.51 & 1.215 & $<0.001$ & $>999.999$ \\
\hline PIG & 8 & 150 & $\mathrm{THR}$ & 24 & 50 & 0.1943 & 603.59 & 84 & 0.00 & 0.9997 & 0.05 & -1200.12 & 120 & 1.215 & $<0.001$ & $>999.899$ \\
\hline & & & & & & & & & & & & & & & & \\
\hline
\end{tabular}

file://C:/Users/klweber/AppData/Local/Temp/1/SAS\%20Temporary\%20Files/_TD3400 ... 12/10/2014 


\begin{tabular}{|c|c|c|c|c|c|c|c|c|c|c|c|c|c|c|c|c|}
\hline & 8 & 00 & $\mathbb{A R}$ & 24 & 100 & 0.1943 & 603.59 & 84 & $0.00: 0$ & 0.9997 & 0.05 & -1200.12 & 1200.51 & 1.215 & $<0.001$ & $>999.989$ \\
\hline PIG & 8 & 100 & WAS & 8 & 0 & 0.1843 & 603.50 & 84 & $0.00 \div 0$ & 0.9997 & 0.05 & -1200.12 & 1200.51 & 1.215 & $<0.001$ & $>999.999$ \\
\hline$P 16$ & 8 & 100 & WAS & 8 & 50 & 13.5567 & 429.87 & 84 & -0.030 & 0.9749 & 0.05 & -868.40 & 841.28 & $<0,001$ & $<0.001$ & $>990.999$ \\
\hline FIG & 8 & 100 & WAS & 8 & 100 & 0.1943 & 603.59 & 84 & 0.0010 & 0.9997 & 0.05 & -1200.12 & 1200,51 & 1.215 & $<0.001$ & $>999.999$ \\
\hline PIG & 8 & 100 & WAS & 24 & 0 & 0.1943 & 803.59 & 84 & 0.000 & 0.9997 & 0.05 & -1200.12 & 1200.51 & 1.215 & $<0.001$ & $>999.999$ \\
\hline PIG & 8 & 100 & WAS & 24 & 50 & 0.1943 & 803.59 & 84 & 0.000 & 0.9997 & 0.05 & -1200.12 & 120051 & 1.215 & $<0.001$ & $>999.999$ \\
\hline $\mathrm{PIG}$ & 8 & 100 & WAS & 24 & 100 & 0.1943 & 603.59 & 84 & 0.000 & 0.8987 & 0.05 & -1200.12 & 120051 & 1.215 & $<0.001$ & $>999.999$ \\
\hline $\mathrm{P} \mid \mathrm{G}$ & 24 & 0 & $\mathrm{PIG}$ & 24 & 50 & $-257 E_{n} 18$ & 607,93 & 84 & -0.001 & 1.0000 & 0.05 & -1208.93 & 1208.93 & 1.000 & $<0.001$ & $>999.999$ \\
\hline $\mathrm{P} \mid \mathrm{G}$ & 24 & 0 & $\mathrm{PIG}$ & 24 & 100 & $2.01 \mathrm{E}-15$ & 807.93 & 84 & 0.001 & 1.0000 & 0.05 & -208.93 & 1208.93 & 1.000 & $<0.001$ & $>999.999$ \\
\hline $\mathrm{P} \mid \mathrm{G}$ & 24 & 0 & PPB & 8 & 0 & 0.1019 & 605.52 & 84 & 0.000 & 0.9999 & 0.05 & -204.04 & 1204.25 & 1.107 & $<0.001$ & $>999.899$ \\
\hline$P G$ & 24 & 0 & PPB & 8 & 50 & 0.1019 & 605.52 & 64 & 0.00 & 0.9999 & 0.05 & -1204.04 & 1204.25 & 1.107 & $<0,001$ & $>999.898$ \\
\hline$P G$ & 24 & 0 & PPB & 8 & 100 & 0.1018 & 605.52 & 84 & 0.00 & $0.099 \theta$ & 0.05 & -1204.04 & 1204.25 & 1.107 & $<0.001$ & $>999.999$ \\
\hline $\mathrm{PlG}$ & 24 & 0 & PPB & 24 & 0 & 0.1019 & 605.52 & 84 & 0.0010 & 0.9999 & 0.05 & -1204.04 & 1204.25 & 1.107 & $<0.001$ & $>900.999$ \\
\hline $\mathrm{PlG}$ & 24 & 0 & PPB & 24 & 50 & -13.6659 & 428.67 & 84 & -0.030 & 0.0747 & 0.05 & -868.51 & 841.17 & $<0.001\}$ & $<0.001$ & $>999999$ \\
\hline PIG & 24 & 0 & PPB & 24 & 100 & -13.6659 & 429.87 & 84 & -0.03 & 0.9747 & 0.05 & -868.51 & 841.17 & $<0.001$ & $<0.001$ & $>990.999$ \\
\hline PIG & 24 & 0 & THR & 8 & 0 & 0.1943 & 603.59 & 84 & 0.00 & 0.9997 & 0.05 & -1200.12 & 1200.51 & 1.215 & $<0.001$ & $>999,999$ \\
\hline PIG & 24 & 0 & THR & 8 & 50 & 0.1943 & 603.59 & 84 & 0.00 & 0,9997 & 005 & -1200.12 & 1200.51 & 1.215 & $<0.001$ & $>999.999$ \\
\hline$P 1 G$ & 24 & 0 & THR & 8 & 100 & 0.1943 & 603.59 & 84 & 0.00 & 0.9997 & 0.05 & -1200.12 & 1200.51 & 1.215 & $<0.001$ & $>999.809$ \\
\hline$P \mid G$ & 24 & 0 & THR & 24 & 10 & 0.1843 & 603.59 & 84 & 0.00 & 0.9997 & 0.05 & -1200.12 & 1200.51 & 1.215 & $<0.00$ & $>990.999$ \\
\hline PIG & 24 & 0 & THR & 24 & 50 & 0.1943 & 603.59 & 84 & 0.00 & 0.9997 & 0.05 & -1200.12 & 1200.51 & 1.215 & $<0,00$ & $>999.999$ \\
\hline PG & 24 & 0 & THR : & 24 & 100 & 0.1943 & 603.59 & 84 & 0.00 & 0.9997 & 0.05 & -1200.12 & 1200.5 & 1.215 & $<0.001$ & $>990.999$ \\
\hline$P Q$ & 24 & 0 & WAS: & 8 & 0 & 0.1943 & 603.59 & 84 & 0.00 & 0.9997 & 0.05 & -1200.12 & 1200.51 & 1.215 & $<0.00$ & $>999.999$ \\
\hline PIG & 24 & 0 & WAS & 8 & 50 & -13.5567 & 429.87 & 84 & -0.03 & 0.9749 & 0.05 & $-86 \mathbf{B} .40$ & 841.28 & $<0.001$ & $<0.001$ & $>999.899$ \\
\hline PIG & 24 & 0 & WAS & 8 & 100 & 0.1843 & 603.59 & 84 & $0.00:$ & 0.9997 & 0.05 & -1200.12 & 1260.51 & 1.215 & $<0,00$ & $>999.999$ \\
\hline $\mathrm{PIG}$ & 24 & 0 & WAS & 24 & 0 & 0.1943 & 603.59 & $B 4$ & 0.000 & 0.9997 & 0.05 & -1200.12 & 1200.51 & 1.215 & $<0.00$ & $>999,999$ \\
\hline PIG & 24 & 0 & WAS & 24 & 50 & 0.1943 & 603.59 & 84 & 0.00 & 0.9997 & 0.05 & -1200.12 & 1200.51 & 1.215 & $<0.001$ & $>999.999$ \\
\hline PIG & 24 & c & WAS & 24 & 100 & 0.1843 & 603.59 & 84 & 0.00 & 0.9997 & 0.05 & -1200.12 & 1200.51 & 1.215 & $<0.0$ & $>998.999$ \\
\hline FIG & 24 & 50 & $\mathrm{PIG}$ & 24 & $-\infty$ & $2.27 E-15$ & 607.93 & 84 & 0.00 & 1.0000 & 0.05 & -1208.93 & 1208.93 & 1.000 & $<0.00$ & $>999.999$ \\
\hline$P I G$ & 24 & 50 & PPB & 8 & 0 & 0.1019 & 605.52 & 84 & 0.00 & 0.9999 & 0.05 & -1204.04 & 1204.2 & 1.10 & $<0.001$ & $>999.999$ \\
\hline PIG & 24 & 50 & PPB & 8 & 50 & 0.1018 & 605.52 & 84 & 0.00 & 0.9999 & $c .05$ & -1204.04 & 1204.25 & 1.107 & $=0.00$ & $>989.999$ \\
\hline$P I G$ & 24 & 50 & PPB & 8 & 100 & 0.1019 & 605.52 & 84 & 0.00 & 0.9999 & 0.05 & -1204.04 & 1204.25 & 1.107 & $<0.001$ & $>999.999$ \\
\hline PIG & 24 & 50 & PPB & 24 & 0 & 0.1018 & 605,52 & 84 & 0.00 & 0.9999 & 0.05 & -1204.04 & 1204.25 & 1.10 & $<0.001$ & $>899.999$ \\
\hline $\mathrm{PIG}$ & 24 & 50 & PPB & 24 & 50 & $-13,6659$ & 429.87 & 84 & -0.03 & 0.9747 & 0.05 & -868.51 & 841.17 & $<0.001$ & $<0.001$ & $>999.999$ \\
\hline $\mathrm{PIG}$ & 24 & 50 & PPB & 24 & 100 & -13.6659 & 429.87 & 84 & -0.03 & 0.9747 & 0.05 & -868.51 ? & 841.17 & $<0.001$ & $<0.001$ & $>999.999$ \\
\hline$P I G$ & 24 & 50. & THR & 8 & 0 & 0.1943 & 603,59 & 84 & 0.00 & 0.8997 & 0.05 & -1200.12 & 1200.51 & 1.21 & $<0.001$ & $>999.999$ \\
\hline PIG & 24 & $50^{\circ}$ & THR & 0 & 50 & 0.1943 & 603.59 & 84 & 0.001 & 0.9997 & 0.05 & $-1200,12$ & 1200.51 & 1.215 & $<0.001$ & $>999.999$ \\
\hline PIG & 24 & 50 & THR & 8 & 100 & 0.1943 & 603.59 & 84 & 0.00 & 0.9997 & 0.05 & -1200.12 & 1200.51 & 1.215 & $<0.001$ & $>999.999$ \\
\hline PIG & 24 & 50 & THR & 24 & 0 & 0.1843 & 603,59 & 84 & 0.00 & 0.9997 & 0.05 & -1200.12 & 1200.51 & 1.215 & $<0.001$ & $>999.999$ \\
\hline PIG & 24 & $50^{\circ}$ & THR & 24 & 50 & 0.1943 & 603.59 & 84 & 0.00 & 0.9997 & 0.05 & -1200.12 & 1200.51 & 1.215 & $<0.001$ & $>999.999$ \\
\hline PIG & 24 & 50 & THR & 24 & 100 & 0.1943 & 603.59 & 84 & 0.00 & 0.9997 & 0.05 & -1200.12 & 1200.51 & 1.215 & $<0.001$ & $>999.999$ \\
\hline PIG & 24 & 50 & WAS & 8 & 0 & $0.19 \times 3$ & 603.59 & 84 & 0.00 & 0.9997 & 0.05 & -1200.12 & 1200.51 & 1.215 & $<0.001$ & $>989.999$ \\
\hline $\mathrm{PIG}$ & 24 & 50 & WAS & 8 & 50 & 3.5567 & 429.87 & 84 & -0.03 & 09749 & 0.05 & -868.40 & 84128 & $<0.001$ & $<0.001$ & $>999.998$ \\
\hline PIG & 24 & 50 & WAS & 8 & 100 & 0.1943 & 603.59 & 84 & 0.00 & 0.9997 & 0.05 & -1200.12 & 1200.51 & 1.215 & $<0,001$ & $>999,999$ \\
\hline PIG & 24 & 50 & WAS & 24 & 0 & 0,1943 & 603.59 & 84 & 0.00 & 0.9997 & 0.05 & -200.12 & 1200.51 & 1.215 & $<0.001$ & $>899.899$ \\
\hline PIG & 24 & 50 & WAS & 24 & 50 & 0.194 & 603.59 & 84 & 0.00 & 0.9997 & 0.05 & -1200.12 & 1200.51 & 1.215 & $<0,001$ & $>999,899$ \\
\hline PIG & 24 & 50 & WAS & 24 & 130 & 0.1843 & 603.59 & 84 & 0.00 & 0.9997 & 0.05 & -1200.12 & 1200.51 & 1.215 & $<0.001$ & $>099.999$ \\
\hline$P \mid G$ & 24 & 100 & $\mathrm{PPB}$ & 8 & 3 & 0.1019 & 605.52 & 84 & 0.00 & 0.9999 & 0.05 & -1204.04 & 1234.25 & 1.107 & $<0,001$ & $>990.999$ \\
\hline $\mathrm{PIG}$ & 24 & 100 & PPB & 8 & 50 & 0.1019 & 605.52 & 84 & 0.00 & 0.9999 & 0.05 & $-1204,04$ & 1204.25 & 1.107 & $<0.001$ & $>999.999$ \\
\hline PG & 24 & 100 & PPB & 8 & 100 & 1019 & 5.52 & 84 & 0.00 & 0.9999 & 0.05 & -1204.04 & 1204.25 & 1.107 & $<0,001$ & $>999.999$ \\
\hline & & & & & & & & & & & & & & & & \\
\hline
\end{tabular}

file:///C:/Users/klweber/AppData/Local/Temp/1/SAS\%20Temporary\%20Files/..TD3400_.. 12/10/2014 
AEH-13-PSEUDO-06

\begin{tabular}{|c|c|c|c|c|c|c|c|c|c|c|c|c|c|c|c|c|}
\hline & 24 & 100 & PPB & 24 & 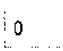 & 0.1019 & 55.52 & 84 & 0.00 & 0.9999 & 0.05 & -1204.04 & 1204.25 & 1.107 & $<0.001$ & $>999.99$ \\
\hline & 24 & 100 & PPB & 24 & 50 & $-13,6659$ & 429.87 & 84 & -0.031 & 0.9747 & 0.05 & -868.51 & 841.17 & $<0.001$ & $<0.001$ & $>999.998$ \\
\hline PIG & 24 & $: 00$ & PPB & 24 & 100 & 3.6659 & 428.87 & 84 & -0.03 : & 0.9747 & 0.25 & -868.51 & 841.17 & $<0.001$ & $<0.001$ & $>999.999$ \\
\hline PIG & 24 & $\infty$ & THR & 8 & 0 & 0.1943 & 603.59 & 84 & 0.00 & 0.8997 & 0.05 & -1200.12 & 1200.51 & 1.215 & $<0.001$ & $>999.999$ \\
\hline iG & 24 & 100 & THR & 8 & 50 & 0.1943 & 603.59 & 84 & 0.00 & 0.8997 & 0.05 & -1200.12 & 1200.51 & 1.215 & $<0.001$ & $>990.999$ \\
\hline $\mathrm{P} \mid \mathrm{G}$ & 24 & 100 & THR & 8 & 100 & $0.19<3$ & 603.59 & $84:$ & 0.00 & 0.9097 & 0,05 & -1200.12 & 1200.51 & 1.215 & $<0.001$ & $>999.999$ \\
\hline PIG & 24 & 100 & THR & 24 & $: 0$ & 0.1943 & 603.59 & 84 & 0.00 & 0.8997 & 0.05 & -1200.12 & $\{200.51$ & 1.215 & $<0.001$ & $>999.99$ \\
\hline PIG & 24 & 100 & THR & 24 & 50 & D. 1943 & 603.59 & 84 & 0.00 & 0.8997 & 0.05 & -1200.12 & 1200.51 & 1.215 & $<0.001$ & $>999.298$ \\
\hline PIG & 24 & 100 & THR & 24 & 100 & 0.1943 & 603.59 & 84 & 0.00, & 0.9997 & 0.05 & -1200.12 & 1200,51 & 1.215 & $<0.001$ & $>999.999$ \\
\hline PIG & 24 & 100 & WAS & 8 & 0 & 0.1943 & 603.59 & 84 & 0.00 & 09997 & 0.05 & -1200.12 & 1200,51 & 1.215 & $<0.001$ & $>009.999$ \\
\hline $\mathrm{PIG}$ & 24 & 100 & WAS & 8 & 50 & -13.5567 & 429.87 & 84 & -0.03 & 0.9749 & 0.05 & $\quad 868.40$ & 84128 & $<0.001$ & $<0.001$ & $>999,989$ \\
\hline$P \mid G$ & 24 & 100 & WAS & 8 & 100 & 0.1943 & 603.58 & 84 & 0.00 & 0.9997 & 0.05 & -1200.12 & 1200.51 & 1.215 & $<0.001$ & $>999.998$ \\
\hline$P \mid G$ & 24 & 100 & WAS & 24 & 0 & 0.1943 & 603.59 & 84 & 0.00 & 0.9997 & 0.05 & -1200.12 & 1200,5 & 1.215 & $<0.001$ & $>999.998$ \\
\hline$P G$ & 24 & 100 & WAS & 24 & 50 & 0.1943 & $603.5 \theta$ & 84 & 0.00 & 0.9097 & 0.05 & -1200.12 & 1200.51 & 1.215 & $<0.001$ & $>999.989$ \\
\hline$P \mid G$ & 24 & 100 & WAS & 24 & 100 & 0.1943 & 603.59 & 84 & 0.00 & 0.9997 & 0.05 & -1200.12 & 1200.51 & 1.216 & $<0.001$ & $>989.999$ \\
\hline$P B$ & 8 & 0 & PPB & 8 & 50 & $-178 E-17$ & 603.11 & 84 & -0.00 & 1.0000 & 0.05 & - 1199.34 & 1199.34 & 1.000 & $<0.001$ & $>999.998$ \\
\hline PPB & 8 & 0 & PPB & $\theta$ & 100 & $1.78 \mathrm{E}-15$ & 603.11 & 84 & 0.00 & 1.0000 & 0.05 & -1199.34 & 1109.34 & 1000 & $<0.001$ & $>999.999$ \\
\hline PPB & 8 & 0 & PPB & 24 & 0 & 1.65E-15 & 603.11 & 84 & 0.00 & 1.0000 & 0.05 & -1199.34 & 1199.34 & 1.000 & $<0.001$ & $>999.899$ \\
\hline $\mathrm{PPB}$ & 8 & 0 & PPB & 24 & 50 & -13.7678 & 426.46 & 84 & -0.03 & 0.0743 & 0.05 & -861.83 & 834.30 & $<0.001$ & $<0.001$ & $>999.99$ \\
\hline PPB & 8 & 0 & PPB & 24 & 100 & -13.7678 & 426.46 & 84 & -0.03 & 0.9743 & 005 & -861.83 & 834.30 & $<0.001$ & $<0.001$ & $>999.909$ \\
\hline PFB & 8 & 0 & THR & 8 & 0 & 0.08247 & 601.17 & 34 & 0.00 & 0.8098 & 005 & -1195.41 & 1195.59 & 1.097 & $<0.001$ & $>999.999$ \\
\hline PPB & 8 & 0 & THR & 8 & 50 & 0.09247 & 601.17 & 84 & 0.00 & 0.9999 & 0.05 & -1 1 195.41 & 1195.59 & 1.097 & $<0.001$ & $>999.995$ \\
\hline$\triangle P B$ & 8 & $\therefore$ & THR & 8 & 100 & 0.09247 & 801.17 & 84 & 0.00 & 0.9999 & 0.05 & $-1195,41$ & 1195.59 & 1.097 & $<0.001$ & $>098.999$ \\
\hline PPB & 8 & $!^{0}$ & THR & 24 & $c$ & 0.09247 & 601.17 & 84 & 0.00 & 0.9999 & 0.05 & -1195.41 & 1195.59 & 1.097 & $<0.001$ & $>999.99$ \\
\hline PPB & 8 & 0 & THR & 24 & 50 & 0.09247 & 801.17 & 84 & 0.00 & c.9999 & 0.05 & 1195.41 & 1195.59 & 1.097 & $<0.001$ & $>999.080$ \\
\hline$P P B$ & 8 & 0 & THR & 24 & 100 & 0.09247 & 601.17 & 84 & 0.00 & 0.9999 & 0.05 & -1195.41 & 1195.59 & 1.097 & $<0.001$ & $>999.999$ \\
\hline PPB & 8 & 0 & WAS & 8 & 0 & 0.09247 & 601.17 & 84 & 0.00 & 0.9998 & 0.05 & -1195.41 & 1195.59 & 1.097 & $<0.0$ & 999.999 \\
\hline $\mathrm{PPB}$ & 8 & 0 & WAS & 8 & 50 & -13.6586 & 426.43 & 84 & -0.03 & 0.9745 & 0.05 & -861.72 & 834.41 & $<0.001$ & $<0.001$ & $>998.99$ \\
\hline PPB & 8 & 0 & WAS & 8 & 100 & 0.09247 & 601.17 & 84 & 0.00 & 0.9999 & 0.05 & -1195.41 & 1195.5 & 1.097 & $<0.001$ & $>999.999$ \\
\hline PPB & 8 & 0 & WAS & 24 & 10 & 0.09247 & 601.17 & 84 & 0.00 & 0.9999 & 0.05 & -1195.41 & 1195.59 & 1.097 & $<0.0$ & $>999.999$ \\
\hline $\mathrm{PPB}$ & 8 & 0 & WAS & 24 & i50 & 0.09247 & 601.17 & 84 & 0.00 & 0.9999 & 0.05 & -1195.41 & 1185.59 & 1.097 & $<0.00$ & $>989.999$ \\
\hline PPB & 8 & 0 & WAS & 24 & 100 & 0.09247 & 601.17 & 84 & 0.00 & 0.8999 & 0.05 & -1195.41 & 1195.59 & 1.097 & $<0.00$ & $>\$ 99.999$ \\
\hline PPB & 8 & 50 & $\mathrm{PPB}$ & 8 & $: 00$ & $3.75 \mathrm{E}-15$ & 603.11 & 84 & 0.00 & .0000 & c.05 & -1199.34 & 1199.34 & 1.000 & $<0.00$ & $>989.998$ \\
\hline PPB & 8 & 50 & PPB & 24 & 0 & $3.55 \mathrm{E}-15$ & B03.11 & 84 & 0.00 & 1.0000 & 0.05 & -1199.34 & 1199.34 & 1000 & $<0.001$ & $>999.999$ \\
\hline PPB & 8 & 50 & PPB & 24 & 50 & -13.7678 & 426.46 & 84 & -0.03 & 0.9743 & 0.05 & -861.83 & 834.30 & $<0.001$ & $<0.001$ & $>999.999$ \\
\hline PPB & 8 & 50 & PPB & 24 & 100 & -13.7678 & $42.6 .4 \mathrm{~B}$ & 84 & -0.03 & 0.9743 & 0.05 & -861.83 & 834.30 & $<0.001$ & $<0.001$ & $>999.999$ \\
\hline PPB & 8 & 50 & THR & 8 & 0 & 0.09247 & 601.17 & 84 & 0.00 & 0.9988 & 0.05 & -1185.41 & 1195.59 & 1.097 & $<0.001$ & $>999.999$ \\
\hline PPB & 8 & 50 & THR & 8 & 50 & $0.0 \$ 247$ & 601.17 & 84 & 0.00 & 0.9999 & 0.05 & -1195.41 & 1185.59 & 1.097 & $<0.001$ & $>999.999$ \\
\hline PPB & 8 & 50 & $\mathrm{THR}$ & 8 & 100 & 0.08247 & 601.17 & 84 & 0.00 & 0.9998 & 0.05 & -1195.41 & 1195.58 & 1.097 & $<0,001$ & $>999.999$ \\
\hline PPB & 8 & 50 & THR & 24 & 0 & 0.09247 & 601.17 & 84 & 0.00 & 0.9999 & 0.05 & -1185.41 & 1195.59 & 1.097 & $<0.001$ & $>999.999$ \\
\hline PPB & 8 & 50 & THR & 24 & 50 & 0.09247 & 601.17 & 84 & 0.00 & 0.9999 & 0.05 & -1195.41 & 119559 & 1.097 & $<0.001$ & $>999.990$ \\
\hline $\mathrm{PPB}$ & 8 & 50 & THR & 24 & 100 & $0.082<7$ & 601.17 & 84 & 0.00 & 0.0990 & 0.05 & -1185.41 & 1195.59 & 1.097 & $<0.001$ & $>999.999$ \\
\hline $\mathrm{PPB}$ & 8 & 50 & WAS & 8 & 30 & 0.08247 & 601.17 & 84 & 0.00 & 0.9999 & 0.05 & -1195.41 & 1195.59 & 1.097 & $<0.001$ & $>990.999$ \\
\hline PPB & 8 & 50 & WAS & 8 & 50 & -13.6586 & 426.46 & 84 & -0.03 & 09745 & 0.05 & $\begin{array}{r}-861,72 \\
\end{array}$ & 834.41 & $<0.001$ & $<0.001$ & $>999.999$ \\
\hline PPB & 8 & 50 & WAS & 8 & 100 & 0.09247 & 601.17 & 84 & 0.00 & 0.8998 & 0.05 & .1195.41 & 1195.59 & 1.097 & $<0.001$ & $>999.998$ \\
\hline PPB & 8 & 50 & WAS & 24 & 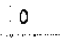 & 0.09247 & 601.17 & 84 & 0.00 & 0.9999 & 0.05 & -1195.41 & 1195.59 & 1.097 & $<0.001$ & $>999.999$ \\
\hline PPB & 8 & 50 & WAS & 24 & 50 & 0.09247 & 601.17 & 84 & 0.00 & 0.9999 & 0.05 & -1195.41 & .1125 .59 & 1.097 & $<0.001$ & $>999.999$ \\
\hline $\mathrm{pPB}$ & 8 & 50 & WAS & 24 & 100 & 0.09247 & 601.17 & $B 4$ & 0.00 & 0.9999 & 0.05 & -1195.41 & 1195.59 & 1.097 & $<0.001$ & $>999,999$ \\
\hline$P P E$ & 8 & 100 & PPB & 24 & 0 & $-178 E_{n} 17$ & 603.11 & 10 & -0.00 & 1.0000 & 0.05 & -1199.34 & 1198.34 & 1.000 & $<0,001$ & $>999.999$ \\
\hline & & & & & & & & & & & & & & & & \\
\hline
\end{tabular}

file://C:/Users/klweber/AppData/Local/Temp/1/SAS\%20Temporary\%20Files/_TD3400_... 12/10/2014 


\begin{tabular}{|c|c|c|c|c|c|c|c|c|c|c|c|c|c|c|c|c|}
\hline & 8 & 00 & PPB & 24 & 50 & -13.7678 & 426.46 & 81 & -0.0310 & 0.9743 & 0.05 & -861.83 & 834.30 & $<0.001$ & $<0.001$ & 999.8 \\
\hline 喵 & 8 & 100 & PPB & 24 & 100 & -13.7678 & 426.46 & 84 & -0.03 & 0.9743 & 0.05 & -861.83 & 834.30 & $<0.001$ & $<0.001$ & $>999.899$ \\
\hline$P P B$ & 8 & 100 & THR & 8 & 0 & 0.09247 & 601.17 & 84 & 0.000 & 0.9999 & 0.05 & -1195.41 & 1195.50 & 1.097 & $<0.001$ & 990.999 \\
\hline $\mathrm{PPB}$ & 8 & 100 & THR & 8 & 50 & 0.09247 & 601.17 & 84 & 0.0010 & 0.9999 & 0.05 & -1195.41 & 1195.59 & 1.097 & $<0.001$ & $>999.999$ \\
\hline PB : & 8 & 100 & $T H R$ & 8 & $10 \mathrm{C}$ & 0.09247 & 801.17 & 84 & $0.00=0$ & 0.9999 & $0.05:$ & -1185.41 & 1195.59 & 1.097 & $<0,001$ & $>999.999$ \\
\hline PPB & 8 & 100 & THR & 24 & 0 & 0.09247 & 601.17 & 84 & 0.000 & 0.8998 & 0.05 & -1185.41 & 1195.59 & 1.097 & $<0.001$ & $>999.999$ \\
\hline PPB & 8 & 100 & THR & 24 & 50 & 0.09247 & 601.17 & 84 & $0,00=0$ & 0.9999 & 0.05 & -1195.41 & 1185.59 & 1.097 & $<0.001$ & $>999999$ \\
\hline PPB & 8 & 100 & THR & 24 & 100 & 09247 & 601.17 & 84 & 0.000 & 0.9999 & 0.05 & -1195.41 & 1195.59 & 1.097 & $<0.001$ & $>\theta 99.999$ \\
\hline PPB & 8 & 100 & WAS & 8 & 0 & 0.09247 & 601.17 & 84 & 0.00 & 0.8899 & 0.05 & -1195.41 & 1195.59 & 1.097 & $<0.001$ & $>999.999$ \\
\hline PPB & 8 & 100 & WAS & 8 & 50 & $-13,6586$ & 426.46 & 84 & -0.0310 & 0.9745 & 0.05 & -861.72 & 834.41 & $<0.001$ & $<0.001$ & $>099.999$ \\
\hline PPB & 8 & 100 & WAS & 8 & 100 & 0.09247 & 601.17 & 84 & $0.00 \mathrm{C}$ & 0.9998 & 0.05 : & 1195.41 & 1195.59 & 1.097 & $<0.001$ & $>999,999$ \\
\hline PPB & 8 & 100 & WAS & 24 & 0 & 0,00247 & 601.17 & 84 & 0.00 & 0.9999 & 0.05 & -1195.41 & 1195.59 & 1.097 & $<0.001$ & $>999.999$ \\
\hline PFB & 8 & $100^{\circ}$ & WAS & 24 & 50 & 0.09247 & 601.17 & 84 & 0.000 & 0.9990 & 0.05 . & -1195.41 & 1105.59 & 1.097 & $<0.001$ & $>999.909$ \\
\hline PFB & 8 & 100 & WAS & 24 & 100 & 0.08247 & 601.17 & 84 & 0.000 & 0.8999 & 005 . & $-1195,41$ & 1195.59 & 1.097 & $<0.001$ & $>992.899$ \\
\hline $\mathrm{PPB}$ & 24 & 0 & PPB & 24 & 50 & -13.7678 & 426.46 & 84 & -0.030 & 0.9743 & 0.05 & -861.83 & 834.30 & $<0.001$ & $<0.001$ & $>999.999$ \\
\hline SPB & 24 & 0 & PPB & 24 & 100 & -13.7878 & 426.48 & 84 & $-0.03: 0$ & 0.9743 & 0.05 & -861.83 & 834.30 & $<0.001$ & $<0,001$ & $>099.999$ \\
\hline PPB & 24 & 0 & THR & 8 & 0 & 0.09247 & 601.17 & 34 & 0.000 & 0.9999 & 0,05 & -1195.41 & 1195.59 & 1.097 & $<0,001$ & $>999.999$ \\
\hline PPB & 24 & 0 & THR & 8 & 50 & 0.09247 & 801.17 & 84 & 0.000 & 0.9999 & 0.05 & $-1195.41 !$ & 1195.59 & 1.097 & $<0.001$ & $>999,89 \theta$ \\
\hline PPB & 24 & 0 & THR & 8 & 100 & 0.09247 & 601.17 & 84 & 0.000 & 0.8999 & 0.05 & -1195.41 & 1185.59 & 1.097 & $<0.001$ & $>999.999$ \\
\hline PPB & 24 & 0 & THR & 24 & 0 & 0.09247 & 601.17 & 84 & 0.000 & 0.9999 & 0.05 & -1195.41 & 1195.59 & 1.097 & $<0,00$ & $>999.99 \theta$ \\
\hline PPB & 24 & 0 & $\mathrm{THR}$ & 24 & 50 & 0.09247 & 601.17 & 84 & 0.000 & 0.9999 & 0.05 & -1195.41 & 1195.59 & 1.097 & $<0.00$ & $>989.999$ \\
\hline PPB & 24 & 0 & THR & 24 & 100 & 0,09247 & 601.17 & 84 & 0.000 & c. 9999 & 0.05 & -1195.41 & 1195.58 & 1.097 & $<0.00$ & $>999.999$ \\
\hline PPB & 24 & 0 & WAS & 8 & 0 & 0.09247 & 601.17 & 84 & 0.000 & 0.9999 & 0.05 & -1195.41 & 1195.59 & 1.097 & $<0.00$ & $>999.999$ \\
\hline PPB & 24 & 0 & WAS & 8 & 50 & -13.8586 & 426.46 & 84 & $-0,03$ & 0.9745 & 0.05 & -861.72 & 834.41 & $<0,001$ & $<0.00$ & $>999.999$ \\
\hline PPB & 24 & 0 & WAS & 8 & 100 & 0.09247 & 601.17 & 84 & 0.00 & 0.9999 & 0.05 & -1195.41 & 1195.59 & 1.097 & $<0.00$ & $=999.099$ \\
\hline PPB & 24 & 0 & WAS & 24 & 0 & 0.09247 & 601.17 & 84 & 0.0010 & 0.9999 & 0.05 & -1195.41 & 1195.59 & 1.09 & $<0.00$ & $>988.999$ \\
\hline PPB & 24 & 0 & WAS & 24 & 50 & 0.09247 & 601.17 & 84 & 0.00 & 0.8999 & 0.05 & -1195.41 & 1195.59 & 1.097 & $<0.00$ & 999.999 \\
\hline $\mathrm{PPB}$ & 24 & $c$ & WAS & 24 & 100 & 0.09247 & 601.17 & 84 & 0.001 & 0.9999 & 0.05 & -1195.41 & 1195.59 & 1.00 & $<0.00$ & 988.998 \\
\hline PPB & 24 & 50 & PPB & 24 & 100 & $-302 E-18$ & 0.6414 & 84 & -0.00 & 1.0000 & 0.05 & -1.2755 & 1.2755 & 1.000 & 0.2 & 3.581 \\
\hline $\mathrm{PPB}$ & 24 & 50 & THR & 8 & 0 & 13.8603 & 423,72 & 84 & $0.03 !$ & 0.9740 & 0.05 & 828.76 & 856.48 & $>999.999$ & $<0.001$ & 999.999 \\
\hline $\mathrm{PPB}$ & 24 & 50 & THR & 8 & 50 & 13.8603 & 423.72 & 84 & 0.03 & 0.9740 & 0.05 & 828.76 & 856.48 & $>999.999$ & $<0.00$ & $>999.899$ \\
\hline $\mathrm{PPB}$ & 24 & 50 & THR & 8 & 100 & 13,8603 & 423.72 & $84^{1}$ & 0.03 & 0.9740 & 0.05 & -828.76 & 856.48 & $>999.99$ & $<0.00$ & $>999.999$ \\
\hline $\mathrm{PPB}$ & 24 & 50 & THR & 24 & 0 & 13.8603 & 423.72 & 84 & 0.03 & 0.9740 & 0.05 & -828.76 & 856.48 & $>999.99 \theta$ & $<0.001$ & $>899.999$ \\
\hline PPB & 24 & 50 & THR & 24 & 50 & 13.8603 & 423.72 & 84 & 0.03 & 0.9740 & C.05 & -828.76 & 856.48 & $>999.989$ & $<0,00$ & 999.999 \\
\hline $\mathrm{PPB}$ & 24 & 50 & THR & 24 & 100 & 13.8603 & 423.72 & 84 & 0.03 & 0.9740 & 0.05 & -828.76 & 856.48 & $>999.999$ & $<0.0$ & 999.999 \\
\hline PPB & 24 & 50 & WAS & 8 & 0 & 13.8603 & 423.72 & 84 & 0.03 & 0.9740 & 0.05 & -828.76 & 856.48 & $>999.990$ & $=0.00$ & 999.999 \\
\hline PPB & 24 & 50 & WAS & 8 & 50 & 1092 & 0.6408 & 84 & 0.17 & 0.8651 & 0.05 & -1.1651 & 1.3835 & 1.11 & 0.3 & 3.989 \\
\hline PPB & 24 & 50 & WAS & 8 & 100 & 13.8603 & 423,72 & 84 & 0.03 & 0.9740 & 0.05 & -828.76 & 856.48 & $>999.899$ & $<0.00$ & 999.999 \\
\hline PPB & 24 & 50 & WAS & 24 & 0 & 13.8603 & $423.72 !$ & 84 & 0.03 & 0.9740 & 0.05 & -828.76 & 856.48 & $>998.999$ & $<0.001$ & 999.999 \\
\hline PPB & 24 & 50 & WAS & 24 & 50 & 13.8603 & 423.72 & 84 & 0.03 & 0.9740 & 0.05 & -828.76 & 856.48 & $>999.989$ & $<0.001$ & 999.999 \\
\hline PPB & 24 & 50 & WAS & 24 & 100 & 13 & 423.72 & 8 & 0.03 & 0.9740 & 0.05 & -828.76 & 856.48 & $>998.999$ & $<0.00$ & 909,998 \\
\hline PPB & 24 & 00 & THR & 8 & 0 & 13.8603 & 423.72 & 84 & 0.03 & 0.9740 & 0.05 & -828.76 & 856.48 & $>999.999$ & $<0.001$ & 999.999 \\
\hline PrB & 24 & 100 & THR & 8 & 50 & 13,8603 & 423.72 & 84 & 0.03 & 0.9740 & 0.05 & -828.76 & 856.48 & $>999.999$ & $<0.001$ & $>999.999$ \\
\hline PPB & 24 & 100 & THR & 8 & 100 & 13 & 23.72 & 84 & 0.03 & 0.9740 & 0.05 & -828.76 & 856.48 & $>998.999$ & $<0.001$ & 989.999 \\
\hline $\mathrm{PPB}$ & 24 & 100 & THIR & 24 & 0 & 13.8603 & $23.72:$ & 84 & 0.03 & 0.9740 & 0.05 & -828.76 & 856.48 & $>899.999$ & $<0.001$ & $>999.999$ \\
\hline PPB & 24 & 100 & THR & 24 & 50 & 13,6603 & 423.72 & 84 & 0.03 & $0.9740^{\prime}$ & 0.05 & -828.76 & $856 \angle 8:$ & $>999.999$ & $<0,001$ & $>890.999$ \\
\hline PPB & 24 & 100 & THR & 24 & 100 & 13.8603 & 72 & $84:$ & 0.03 & 09740 & 0.05 & -828.76 & 856.48 & $>999.999$ & $<0.001$ & $>999.999$ \\
\hline PPB & 24 & 100 & WAS & 8 & 0 & 13.8603 & 423.72 & 84 & 0.03 & 09740 & 0.05 & -828.76 & 856.48 & $>899.999$ & $<0.001$ & $>999.999$ \\
\hline PPB & 24 & 100 & WAS : & 8 & 50 & 82 & 0.8408 & & 0.17 & 0.8651 & 0.05 & -1.1651 & 13835 & 115 & 0.312 & 3.989 \\
\hline
\end{tabular}

file://C:/Users/klweber/AppData/Local/Temp/1/SAS\%20Temporary\%20Files/_TD3400_.. 12/10/2014 


\begin{tabular}{|c|c|c|c|c|c|c|c|c|c|c|c|c|c|c|c|c|}
\hline & 24 & 100 & WAS & g & 100 & 13.8603 & 423.72 & 84 & $0.03: 0$ & 09740 & $0.05^{!}$ & -828.76 & 856,48 & $>999.998$ & $<0.001$ & $>999.999$ \\
\hline$P P B$ & 24 & 100 & WAS & 24 & 0 & 13.8603 & 423.72 & 84 & $0.03: 0$ & 0.9740 & 0.05 & -828.78 & 856,48 & $>998.999$ & $<0.001$ & $>99 \theta .999$ \\
\hline PPB & 24 & 100 & WAS & 24 & 50 & $13.8603 ?$ & 423.72 & 84 & 0.030 & 0.9740 & 0.05 & -828.76 & $856<8$ & $>899.999$ & $<0.001$ & $>999.999$ \\
\hline PPB & 24 & 100 & WAS & 24 & 100 & 13.8603 & 423.72 & 84 & 0.030 & 0.9740 & 0.05 & -828.76 & $856, \angle 8$ & $>989.999$ & $<0.001$ & $>999.999$ \\
\hline THR & 8 & 0 & THR & 8 & 50 & $-355 E-17$ & 599.23 & 84 & $-0.00: 1$ & 1.0000 & $0 . C E$ & $\mid-191.64]$ & 1191.64 & 1.000 & $<0.001$ & $>899.989$ \\
\hline THR & 8 & 0 & THR & 8 & 100 & $7.5 \mathrm{E}-15$ & 599.23 & 84 & 0.001 & 1.0000 & $0 . C E$ & -1191.64 & 1191,64 & 1.000 & $<0.001$ & $>999.999$ \\
\hline THR & 8 & 0 & THR & 24 & 0 & $-468 \mathrm{E}-18$ & 599.23 & 84 & -0.001 & 1.0000 & $0 . C 5$ & .1191 .64 & 1191,64 & 1.000 & $<0.001$ & $>999.999$ \\
\hline THR & 8 & 0 & THR & 24 & 50 & $-659 \mathrm{E}-19 \mid$ & 599.23 & 84 & $-0.00: 1$ & 1.0000 & 0.05 & $\because 191.64$ & 1191.64 & 1.000 & $<0.001$ & $>999,999$ \\
\hline THR & 8 & 0 & THR & 24 & 100 & $-562 \mathrm{E}-19$ & 599.23 & 84 & $-0.00 ! 1$ & 1.0000 & 0.05 & -1191.64 & 1191.64 & 1.000 & $<0.001$ & $>999.999$ \\
\hline$T-1 R$ & 8 & 0 & WAS & 8 & 0 & $-318 \mathrm{E}-13$ & 599.23 & 84 & $-0.00: 1$ & 1.0000 & 0.05 & $-1191,64$ & 1191.64 & 1.000 & $<0.001$ & $>\theta 9999 \theta$ \\
\hline$T-A R$ & 8 & 0 & WAS & 8 & 50 & -13.7511 & 423.72 & 84 & -0.03 & 0.9742 & 0.05 & -856.37 & 828.87 & $<0.001$ & $<0.001$ & $>999.999$ \\
\hline THR & $B$ & 0 & WAS & 8 & 100 & $1.55 \mathrm{E}-11$ & 599.23 & 84 & $0.00: 1$ & 1.0000 & 0.05 & -1191.64 & 1191.64 & 1.000 & $<0.001$ & $>999.999$ \\
\hline THR & 8 & 0 & WAS & 24 & 0 & $5.55 E-11$ & 599.23 & 84 & 0.001 & 1.0000 & 005 & -1191.64 & 1191,64 & 1.000 & $<0.001$ & $>999,999$ \\
\hline THR : & 8 & 0 & WAS & 24 & 50 & $8,59 \mathrm{E}-11$ & 598.23 & 84 & 0.00 & 1.0000 & 0.05 & $-1191,64$ & 1191,64 & 1.000 & $<0.001$ & $>999.999$ \\
\hline THR & 8 & 0 & WAS & 24 & 100 & $-808 E-13$ & 589.23 & 84 & -0.00 & 1.0000 & 0.05 & -1191.64 & 1191.64 & 1.000 & $<0.001$ & $>989.899$ \\
\hline THR & 8 & 50 & THR & 8 & 100 & $1.07 \mathrm{E}-14$ & 599.23 & 84 & 0.00 & 1.0000 & 0.05 & -1191.64 & 1191.64 & 1.000 & $<0.001$ & $>999.999$ \\
\hline THR & 8 & 50 & THIR & 24 & 0 & 3.55E-15 & 599.23 & 84 & 0.00 & 1.0000 & 0.05 & -1191.64 & 1191.64 & 1.000 & $<0.001$ & $>999.990$ \\
\hline THR & 8 & 50 & THR & 24 & 50 & $3.55 E-15$ & 599.23 & 84 & 0.00 & 1.0000 & 0.05 & -1191.84 & 1191.64 & 1.000 & $<0.001$ & $>999.999$ \\
\hline THR & 8 & 50 & THR & 24 & 100 & $3.55 \mathrm{E}-15$ & 599.23 & 84 & 0.00 & 1.0000 & 0.05 & -1191.64 & 1191.64 & 1.000 & $<0.001$ & $>999.999$ \\
\hline THR & 8 & 50 & WAS & 8 & 0 & $-318 E-13$ & 599.23 & 84 & -0.00 & 1.0000 & 0.05 & -1191.64 & 1181.64 & 1.000 & $<0.001$ & $>999.099$ \\
\hline THR & $B$ & 50 & WAS & 8 & 50 & -13.7511 & 423.72 & 84 & -0.03 & 0.9742 & 0.05 & -856.37 & 828.37 & $<0.001$ & $<0.001$ & $>999.999$ \\
\hline THR & 8 & 50 & WAS & 8 & 100 & $1.55 \mathrm{E}-11$ & 598.23 & 84 & 0.00 & 1.0000 & 0.05 & -1191.64 & 1191.64 & 1.000 & $<0.001$ & $>999,999$ \\
\hline THR & 8 & 50 & WAS & 24 & 0 & $5.55 \mathrm{E}-11$ & 599.23 & 84 & 0.00 & 1.0000 & 0.05 & -1191.64 & 1181.54 & 1.000 & $<0.001$ & $>988,999$ \\
\hline THK & 8 & 50 & WAS & 24 & 50 & $9.59 \mathrm{E}-11$ & 599.23 & 84 & 0.00 & 1,0000 & 0.05 & -1191.64 & 1191.64 & 1.000 & $<0.001$ & $>998.999$ \\
\hline THR & 8 & 50 & WAS & 24 & 100 & $-808 \mathrm{E}-13$ & 589.23 & 84 & $-0,00$ & 1.0000 & 0.05 & -1191.64 & 1191.64 & 1.000 & $<0.001$ & $>998.998$ \\
\hline THR & 8 & 100 & THR & 24 & 0 & $-797 E-17$ & 599.23 & 84 & -0.00 & 1.0000 & C.05 & -1191.64 & 1181.64 & 1.000 & $<0.001$ & $>\$ 99.999$ \\
\hline THR & 8 & 100 & THR & 24 & 50 & $-757 \mathrm{E}-17$ & 599.23 & 84 & -0.00 & 1.0000 & 0.05 & -1191.64 & 1191.64 & 1.000 & $<0.001$ & $>999.999$ \\
\hline THR & 8 & 100 & THR & 24 & 100 & $-756 \mathrm{E}-17$ & 599.23 & 84 & -0.00 & 1.0000 & 0.05 & -1191.64 & 1191,64 & 1.000 & $<0,001$ & $>999.999$ \\
\hline THR & 8 & 100 & WAS & 8 & 0 & $-318 \mathrm{E}-13$ & 590.23 & 84 & -0.00 & 1.0000 & 0.05 & -1191.64 & $1+91.64$ & 1.000 & $<0.001$ & $>999.999$ \\
\hline THR & 8 & 100 & WAS & 8 & 50 & -13.7511 & 423,72 & 84 & -0.03 & 0.9742 & 0.35 & -856.37 & 828.87 & $<0.001$ & $<0.001$ & $>999.999$ \\
\hline THR & 8 & 100 & WAS & 8 & 100 & $1.55 \mathrm{E}-11$ & 599.23 & 84 & 0.00 & 1.0000 & 0.05 & $-1191,64$ & 1191.64 & 1.000 & $<0.001$ & $>999.999$ \\
\hline THR & 8 & 00 & WAS & 24 & 0 & $5.55 \mathrm{E}-11$ & 500,23 & 84 & 0.00 & 1.0000 & 0.05 & -1191.64 & 1191.84 & 1.000 & $<0.001$ & $>990.999$ \\
\hline THR & 8 & 00 & WAS & 24 & 50 & $9.59 \mathrm{E}-11$ & 599.23 & 84 & 0.00 & 1.0000 & 0.05 & -1191.64 & 1191.64 & 1.000 & $<0.001$ & $>999.999$ \\
\hline THR & $\theta$ & 100 & WAS & 24 & 100 & $-808 \mathrm{E}-13$ & 589.23 & 84 & -0.00 & 1.0000 & 0.05 & -1191.64 & 1191.64 & 1.000 & $<0.001$ & $>999.998$ \\
\hline THR & 24 & 0 & THR & 24 & 50 & $4.02 \mathrm{E}-16$ & 589.23 & 84 & 0.00 & 1.0000 & 0.05 & $-1191,64$ & 1101,64 & 1.000 & $<0.001$ & $>999.989$ \\
\hline THR & 24 & 0 & THR & 24 & 100 & $4.12 \mathrm{~F}-16$ & 599.23 & 84 & 0.00 & 10000 & 0.05 & -1191.64 & 110164 & 1.000 & $<0.001$ & $>999.999$ \\
\hline THR & 24 & 0 & WAS & 8 & 0 & $-318 E-13$ & 509.23 & 84 & -0.00 & 10000 & 0.05 & $-1 \times 91.64$ & 1191.64 & 1.000 & $<0.001$ & $>999.899$ \\
\hline THR & 24 & 0 & WAS & 8 & 50 & $-13,75 \times 1$ & 423.72 & 84 & -0.03 & 0.9742 & 0.05 & -856.37 & 828.87 & $<0.001$ & $<0.001$ & $>999.999$ \\
\hline THR & 24 & 0 & WAS & 8 & 100 & $1.55 \mathrm{E}-11$ & 599.23 & 84 & 0.00 & 1.0000 & 0.05 & -101.64 & 1191.64 & 1.000 & $<0.001$ & $>999.999$ \\
\hline THR & 24 & 0 & WAS & 24 & 0 & $5.55 \mathrm{E}-11$ & 599.23 & 84 & 0.00 & 1,0000 & 0.05 & -1191.64 & 1191.64 & 1.000 & $<0.001$ & $>999.990$ \\
\hline THR & 24 & 0 & WAS & 24 & 50 & $9.59 \mathrm{E}-11$ & 599.23 & 84 & 0.00 & 1.0000 & 0.06 & $-1191,64$ & 1191.64 & 1.000 & $<0.001$ & $>999.999$ \\
\hline$-H R$ & 24 & o & WAS & 24 & 100 & $-808 \mathrm{E}-13$ & 599.23 & 84 & -0.00 & 1.0000 & 0.05 & -1191.64 & 1101.64 & 1.000 & $<0.001$ & $>999.999$ \\
\hline TIIR & 24 & 50 & THR & 24 & 100 & $8.72 \mathrm{E}-18$ & 599.23 & 84 & 0.00 & 1.0000 & 0.05 & $-1191,64$ & 1191.64 & 1.000 & $<0.001$ & $>999.899$ \\
\hline THR & 24 & 50 & WAS & 8 & 0 & $-318 E-13$ & 599.23 & 84 & 0,00 & 1.0000 & 0.05 & -1191.64 & 1191.64 & 1.000 & $<0.001$ & $>999.999$ \\
\hline THR & 24 & 50 & WAS & 8 & 50 & -13.7511 & 423.72 & 84 & $-0,03$ & 0.9742 & 0.05 & -856.37 & 828.87 & $<0.001$ & $<0,001$ & $>999.999$ \\
\hline THR & 24 & 50 & WAS & 8 & 100 & $1.55 E-11$ & 599.23 & 84 & 0.00 & 1.0000 & 0.05 & -1101.64 & 1181.64 & 1.000 & $<0.001$ & $>999,999$ \\
\hline THR & 24 & 50 & WAS & 24 & 0 & $5.55 \mathrm{E}-11$ & 599.23 & 84 & 0.00 & 1.0000 & 0.05 & -1191.64 & 1191.64 & 1.000 & $<0.001$ & $>999.999$ \\
\hline$T H R$ & 24 & 50 & WAS & 24 & 50 & $9.59 E-11$ & 599.23 & 84 & 0.00 & 1.0000 & 0.05 & -1191.64 & 1191.64 & 1.000 & $<0.001$ & $>999.990$ \\
\hline$T H R$ & 24 & 50 & WAS & 24 & $1 \mathrm{co}$ & $-808 E-13$ & 599.23 & 34 & -0.00 & 1.0000 & 0.05 & $-1191,64$ & 1191.64 & 1.000 & $<0,001$ & $>999.999$ \\
\hline
\end{tabular}

file://C:/Users/klwcbcr/AppData/Local/Temp/1/SAS\%20Temporary\%20Files/_TD3400_.. 12/10/2014 


\section{AEH-13-PSEUDO-06}

\begin{tabular}{|c|c|c|c|c|c|c|c|c|c|c|c|c|c|c|c|c|}
\hline & 24 & 100 & WAS & 8 & 0 & $-318 E-13$ & 599.23 & 84 & -0.00 & 1.0000 & 0.65 & -1191.64 & 1191,64 & 1.000 & $<0.001$ & $>999.999$ \\
\hline$H R$ & 24 & 100 & WAS & 8 & 50 & -13.7511 & 423.72 & 84 & -0.03 & 0.9742 & 0.05 & -856.37 & 828.87 & $<0.001$ & $<0.001$ & $>999.998$ \\
\hline THR & 24 & 150 & WAS & 8 & $10 \mathrm{C}$ & $1.56 \mathrm{E}-11$ & 599.23 & 84 & $0.00 ?$ & 1.0000 & 0.05 & -1191.64 & 1191.64 & 1.000 & $<0.001$ & $>899,898$ \\
\hline THR & 24 & 150 & WAS & 24 & 0 & $5.55 \mathrm{E}-11$ & 589,23 & 84 & 0.00 & 1.0000 & 0.05 & $.1\{91.64$ & 1191.64 & 1.000 & $<0.001$ & $>999.999$ \\
\hline TAR & 24 & 100 & WAS & 24 & 50 & $9.59 \mathrm{E}-11$ & 599.23 & 84 & 0.00 & 1.0000 & 0.05 & -1191.64 & 1191.64 & 1.000 & $<0.001$ & $>899.999$ \\
\hline$T-H R$ & 24 & 100 & WAS & 24 & $10 \mathrm{c}$ & $-808 E-13$ & 599.23 & 84 & -0.00 & 1.0000 & 0.05 & -1191.64 & 1191.64 & 1.000 & $<0.001$ & $>999.999$ \\
\hline WAS & 8 & 0 & WAS & 8 & 50 & -13.7511 & 423.72 & 84 & -0.03 & 0.9742 & 0.05 & -856.37 & B28.87 & $<0.001$ & $<0.001$ & $>999.999$ \\
\hline WAS & 8 & 0 & WAS & 8 & 100 & $4.72 E-11$ & 599.23 & 84 & 0.00 & 1.0000 & 0.05 & -1101.64 & 1191.64 & 1,000 & $<0.001$ & $>999.890$ \\
\hline WAS & 8 & 0 & WAS & 24 & 0 & $8.72 E-11$ & 599.23 & 84 & 0.00 & 1.0000 & 0.05 & -1191.64 & 1191.64 & 1.000 & $<0.001$ & $>999.999$ \\
\hline WAS & 8 & 3 & WAS & 24 & 50 & $1.28 \mathrm{E}-10$ & 599.23 & 84 & 0.00 & 1.0000 & 0.05 & -1191.64 & 1191.64 & 1.000 & $<0.001$ & $>999.999$ \\
\hline WAS & 8 & 0 & WAS & 24 & 100 & $-401 E-13$ & 599.23 & 84 & -0.00 & 1.0000 & 0.05 & -1101.64 & 1191.64 & 1.000 & $<0.001$ & $>999,989$ \\
\hline WAS & 8 & 50 & WAS & 8 & 100 & 13.7511 & 423.72 & 84 & 0.03 & 0.9742 & 005 & -828.87 & 856.37 & $>999.999$ & $<0.001$ & $>999.989$ \\
\hline WAS & 8 & 50 & WAS & 24 & 0 & 13.7511 & 423.72 & 84 & 0.03 & 0.9742 & 0.05 & -828.87 & 856.37 & $>990.999$ & $<0.001$ & $>999.999$ \\
\hline WAS & 8 & 50 & WAS & 24 & 50 & 13.7511 & 423.72 & 84 & 0.03 & 0.9742 & 0.05 & -828.87 & 856.37 & $>999.999$ & $<0.001$ & $>999.999$ \\
\hline WAS & 8 & 50 & WAS & 24 & 100 & 13.7511 & 423.72 & 84 & 0.03 & 0.9742 & 0.05 & -828.87 & 856.37 & $>990.999$ & $<0.001$ & $>999.990$ \\
\hline WAS & 8 & 100 & WAS & 24 & C & 4E-11 & 599.23 & 84 & 0.00 & 1.0000 & 0.05 & $-1191,64$ & 1181.64 & 1.000 & $<0.001$ & $>999.999$ \\
\hline WAS & 8 & 100 & WAS & 24 & 50 & $8.04 E-11$ & 599.23 & 84 & 0.00 & 1.0000 & 0.05 & -1181.64 & 1191.64 & 1.000 & $<0.001$ & $>999.999$ \\
\hline WAS & 8 & 100 & WAS & 24 & 100 & $-963 E-13$ & 599.23 & 84 & -0.00 & 1.0000 & 0.05 & -1191.64 & 1191.64 & 1.000 & $<0.001$ & $>999,999$ \\
\hline WAS & 24 & 0 & WAS & 24 & 60 & $4.04 \mathrm{E}-11$ & 599.23 & 84 & 0.00 & 1.0000 & 0.05 & -1101.64 & 1191,64 & 1.000 & $<0.001$ & $>999.999$ \\
\hline WAS & 24 & 0 & WAS & 21 & 100 & $-136 E-12$ & 599.23 & 84 & -0.00 & 1.0000 & 0.05 & -1181.64 & 1191.64 & 1,000 & $<0.001$ & $>999.990$ \\
\hline WAS & 24 & 50 & WAS & 24 & 100 & $-177 \mathrm{E}-12$ & 599.23 & 84 & -0.00 & 1.0000 & 0.05 & -1191.64 & 1181.64 & 1.000 & $<0.001$ & $>998.999$ \\
\hline
\end{tabular}

Performed by K. Weber SAS version 9.4 16:18 10DEC14

FF \# 15

Item No. 3

$\mathrm{Pg} 38$ of 38

filc://C:/Lsers/klweber/AppData/Local/Temp/1/SAS\%20Temporary\%20Files/_TD3400_... 12/10/2014 


\section{Appendix 9. Survival Assessment Summary}

\begin{tabular}{clcc}
\hline $\begin{array}{c}\text { Item } \\
\text { Number }\end{array}$ & \multicolumn{1}{c}{ Item Description } & $\begin{array}{c}\text { Number } \\
\text { of } \\
\text { Pages }\end{array}$ & $\begin{array}{c}\text { Report } \\
\text { Page } \\
\text { Number }\end{array}$ \\
\hline 1 & Mortality Data & 4 & 238 \\
2 & Plain Pocketbook (L. cardium) Mortality Summary & 1 & 242 \\
3 & Hickorynut (O. olivaria) Mortality Summary & 1 & 243 \\
4 & Washboard (M. nervosa) Mortality Summary & 1 & 244 \\
5 & Higgins Eye (L. higginsii) Mortality Summary & 1 & 245 \\
6 & Fatmucket (L. siliquoidea) Mortality Summary & 1 & 246 \\
7 & Threeridge (A. plicata) Mortality Summary & 1 & 247 \\
8 & Wabash Pigtoe (F. flava) Mortality Summary & 1 & 248 \\
\hline
\end{tabular}




\begin{tabular}{|c|c|c|c|}
\hline Study Number: AEH-13-PSEUDO-06 & Action & Date & Initfals \\
\hline E ectronic log (Page 10) & Created...... & $1 / 24 / 2014$ & $J \mathrm{KW} / \mathrm{N}$ \\
\hline Flle Foldcr: $12 \mathrm{a}-12 \mathrm{~g}$ & Revised....... & $4 / 25 / 2014$ & KLW MN \\
\hline Data Source: Nat|ve Mussel Survlval Assessment & \begin{tabular}{|l} 
Reviewed.... \\
Certifled......
\end{tabular} & $\begin{array}{l}254014 \\
12 / 12\end{array}$ & $\frac{16}{52}$ \\
\hline
\end{tabular}

\section{Mortality Data}

Test Artcle: Pseudomonas fivorescens of - CLL 145A (SD); lot 4401 P12163C and 401P12164C Mix Test _ocation: Black Rlver, La Crosse, WI

Exposure Date: $5 / 29 / 2013$

Assessment Rates: 6/26-27/2013

Fllename(s)

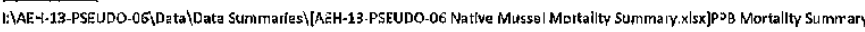

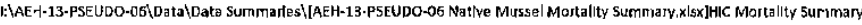

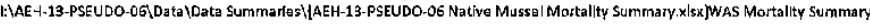

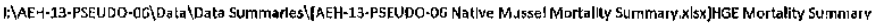

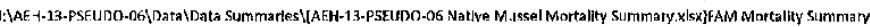

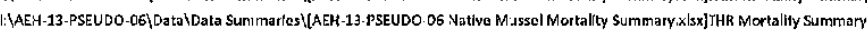
I: AAEH-13-PSEUDO-06:DatalData Summarles)(AEH-13-P5EUDO-06 Vative M.J5sel Mortality Summary.kisX]PIG Mortality Summary

\section{Mortality/unrecovered Summary}

\begin{tabular}{|c|c|c|c|c|}
\hline $\begin{array}{c}\text { Common name, sclentific, three letter } \\
\text { abbrevlation }\end{array}$ & $\begin{array}{l}\text { Treatment } \\
\text { Group }\end{array}$ & Duration & Tag ID & $\begin{array}{c}\text { Deadf } \\
\text { Unrecovered }\end{array}$ \\
\hline \multirow{2}{*}{ Plaln pocketbook, L. carofium, $P P B$} & 100 & 2.4 & A1.93 & $\mathrm{u}$ \\
\hline & 50 & 24 & A191 & $\mathrm{u}$ \\
\hline Hickorynut $_{s}$ O. oljivario, HiC & 100 & 24 & 0010 & iv \\
\hline Washboard, M. nervoso, WAS & 50 & 8 & 1002 & $D$ \\
\hline \multirow{4}{*}{ H ggins eYe, L. higginsii, HGE } & 0 & 24 & 8051 & $\mathrm{Ju}$ \\
\hline & 50 & 24 & B117 & $u$ \\
\hline & 0 & $\mathrm{~g}$ & B110 & D \\
\hline & 100 & 24 & 8048 & $\mathrm{D}$ \\
\hline Fatmucket, L. siliquoidea, FAM & $\mathrm{N} / \mathrm{A}$ & $\mathrm{N} / \mathrm{A}$ & $\mathrm{N} / \mathrm{A}$ & $\mathrm{N} / \mathrm{A}$ \\
\hline Threer'age, A. plifcata, THR & $\mathrm{N} / \mathrm{A}$ & $\mathrm{N} / \mathrm{A}$ & N/A & $\mathrm{N} / \mathrm{A}$ \\
\hline Wabash ptgtoe, F, flava, FIG & $\mathrm{N} / \mathrm{A}$ & $\mathrm{N} / \mathrm{A}$ & $N / A$ & $\mathrm{~N} / \mathrm{A}$ \\
\hline
\end{tabular}

\section{Data Explanation:}

1) Data calumns

Species: three letter code abbreviation as llsted above

Treatment Group: Control $0 \mathrm{mg} / \mathrm{L}, 50 \mathrm{mg} / \mathrm{L}, 100 \mathrm{mg} / \mathrm{L}$

Exposure Duration; 8 hour expostre or 24 hour exposure duration

Test Tank \#: 1-9

$\mathrm{N}$ : number of native mussels in tans

Dead: number of mortalities tha: occurred during 30 day holding perlod

Unrecovered; number of mussels not recovered after treatment or after 30 day holding period

\% Survival= Percent survival cf native mussels in a glven test group. ( ( $\mathrm{N}$-dead $) / \mathrm{N}) * 100$

2) Data codes usec' within SAS

sps- three letter code abbrevlatlons as listed above

conc= theoretical concentration

time= exposure duration (8h or $24 \mathrm{~h}$ )

tank= Test Tank \#1-9

tot= Total ir rissels of specles of given exposure duration In test tank

dead= number of nor talities

uniecs number of unrecovered mussels

T dead $\approx$ sum of unrecovered mussels and mortalities

File names:

Spectrophotometric Data for SAS Input

:IAEH-13-PSEUDO-06\DatałData Summaries \[AEH-13-PSEUDO-06 Native Mussel Mortality Summary.xIsx]SAS

SAS Program/Code

I: $\backslash A E H-13-P S E U D O-06 \backslash$ Statistical analysis\Survival Program File

SAS LOg

SAS Output

I:AEH-13-PSEJDDO-06\Statistlcal analysls tSurvival Log File

I: LAEH-13-PSEUDO-06\Slatlstical analysis\Survival Results file

Data Anomalies and Deviations:

All unrecovered mussels were treated as mortalitles in statlstical analysls.

$$
\begin{aligned}
& \text { Flle Folder } \frac{12}{1} \\
& \text { Item Number } \frac{1}{\text { Page . } 1}
\end{aligned}
$$




\begin{tabular}{|c|c|c|c|c|c|c|c|c|}
\hline sps & conc & time & $\operatorname{tank}$ & tot & dead & unrec & $T$ dead & \\
\hline $\mathrm{HIC}$ & 0 & 8 & 5 & 10 & 0 & 0 & 0 & \\
\hline $\mathrm{H} \mid \mathrm{C}$ & 0 & 8 & 7 & 10 & 0 & 0 & 0 & \\
\hline HIC & 0 & 8 & 8 & 10 & 0 & 0 & 0 & \\
\hline $\mathrm{HIC}$ & 0 & 24 & 5 & 10 & 0 & 0 & 0 & AEH-13-PSEUDO-06 \\
\hline $\mathrm{HIC}$ & 0 & 24 & 7 & 10 & 0 & 0 & 0 & \\
\hline $\mathrm{HIC}$ & 0 & 24 & 8 & 10 & 0 & 0 & 0 & \\
\hline $\mathrm{HIC}$ & 50 & 8 & 3 & 10 & 0 & 0 & 0 & \\
\hline HIC & 50 & 8 & 4 & 10 & 0 & 0 & 0 & \\
\hline HIC & 50 & 8 & 6 & 10 & 0 & 0 & 0 & \\
\hline HIC & 50 & 24 & 3 & 10 & 0 & 0 & 0 & \\
\hline HIC & 50 & 24 & 4 & 10 & 0 & 0 & 0 & \\
\hline HIC & 50 & 24 & 6 & 10 & 0 & 0 & 0 & \\
\hline HIC & 100 & 8 & 1 & 10 & 0 & 0 & 0 & \\
\hline HIC & 100 & 8 & 2 & 10 & 0 & 0 & 0 & \\
\hline HIC & 100 & 8 & 9 & 10 & 0 & 0 & 0 & \\
\hline $\mathrm{HIC}$ & 100 & 24 & 1 & 10 & 0 & 0 & 0 & \\
\hline HIC & 100 & 24 & 2 & 10 & 0 & 1 & 1 & \\
\hline HIC & 100 & 24 & 9 & 10 & 0 & 0 & 0 & \\
\hline WAS & 0 & 8 & 5 & 10 & 0 & 0 & 0 & \\
\hline WAS & 0 & 8 & 7 & 10 & 0 & 0 & 0 & \\
\hline WAS & 0 & 8 & 8 & 10 & 0 & 0 & 0 & \\
\hline WAS & 0 & 24 & 5 & 10 & 0 & 0 & 0 & \\
\hline WAS & 0 & 24 & 7 & 10 & 0 & 0 & 0 & \\
\hline WAS & 0 & 24 & 8 & 10 & 0 & 0 & 0 & \\
\hline WAS & 50 & 8 & 3 & 10 & 0 & 0 & 0 & \\
\hline WAS & 50 & 8 & 4 & 10 & 1 & 0 & 1 & \\
\hline WAS & 50 & 8 & 6 & 10 & 0 & 0 & 0 & \\
\hline WAS & 50 & 24 & 3 & 10 & 0 & 0 & 0 & \\
\hline WAS & 50 & 24 & 4 & 10 & 0 & 0 & 0 & \\
\hline WAS & 50 & 24 & 6 & 10 & 0 & 0 & 0 & \\
\hline WAS & 100 & 8 & 1 & 10 & 0 & 0 & 0 & \\
\hline WAS & 100 & 8 & 2 & 10 & 0 & 0 & 0 & \\
\hline WAS & 100 & 8 & 9 & 10 & 0 & 0 & 0 & \\
\hline WAS & 100 & 24 & 1 & 10 & 0 & 0 & 0 & \\
\hline WAS & 100 & 24 & 2 & 10 & 0 & 0 & 0 & \\
\hline WAS & 100 & 24 & 9 & 10 & 0 & 0 & 0 & \\
\hline FAM & 0 & 8 & 5 & 10 & 0 & 0 & 0 & \\
\hline FAM & 0 & 8 & 7 & 10 & 0 & 0 & 0 & \\
\hline FAM & 0 & 8 & 8 & 10 & 0 & 0 & 0 & \\
\hline FAM & 0 & 24 & 5 & 10 & 0 & 0 & 0 & \\
\hline FAM & 0 & 24 & 7 & 10 & 0 & 0 & 0 & \\
\hline FAM & 0 & 24 & 8 & 10 & 0 & 0 & 0 & \\
\hline FAM & 50 & 8 & 3 & 10 & 0 & 0 & 0 & \\
\hline FAM & 50 & 8 & 4 & 10 & 0 & 0 & 0 & \\
\hline FAM & 50 & 8 & 6 & 10 & 0 & 0 & 0 & Pege $\partial$ \\
\hline FAM & 50 & 24 & 3 & 10 & 0 & 0 & 0 & \\
\hline
\end{tabular}




\begin{tabular}{|c|c|c|c|c|c|c|c|c|}
\hline FAM & 50 & 24 & 4 & 10 & 0 & 0 & 0 & \\
\hline FAM & 50 & 24 & 6 & 10 & 0 & 0 & 0 & \\
\hline FAM & 100 & 8 & 1 & 10 & 0 & 0 & 0 & AEH-13-PSEUDO-06 \\
\hline FAM & 100 & 8 & 2 & 10 & 0 & 0 & 0 & \\
\hline FAM & 100 & 8 & 9 & 10 & 0 & 0 & 0 & \\
\hline FAM & 100 & 24 & 1 & 10 & 0 & 0 & 0 & \\
\hline FAM & 100 & 24 & 2 & 10 & 0 & 0 & 0 & \\
\hline FAM & 100 & 24 & 9 & 10 & 0 & 0 & 0 & \\
\hline THR & 0 & 8 & 5 & 10 & 0 & 0 & 0 & \\
\hline THR & 0 & 8 & 7 & 10 & 0 & 0 & 0 & \\
\hline THR & 0 & 8 & 8 & 10 & 0 & 0 & 0 & \\
\hline THR & 0 & 24 & 5 & 10 & 0 & 0 & 0 & \\
\hline THR & 0 & 24 & 7 & 10 & 0 & 0 & 0 & \\
\hline THR & 0 & 24 & 8 & 10 & 0 & 0 & 0 & \\
\hline THR & 50 & 8 & 3 & 10 & 0 & 0 & 0 & \\
\hline THR & 50 & 8 & 4 & 10 & 0 & 0 & 0 & \\
\hline THR & 50 & 8 & 6 & 10 & 0 & 0 & 0 & \\
\hline THR & 50 & 24 & 3 & 10 & 0 & 0 & 0 & \\
\hline THR & 50 & 24 & 4 & 10 & 0 & 0 & 0 & \\
\hline THR & 50 & 24 & 6 & 10 & 0 & 0 & 0 & \\
\hline THR & 100 & 8 & 1 & 10 & 0 & 0 & 0 & \\
\hline THR & 100 & 8 & 2 & 10 & 0 & 0 & 0 & \\
\hline THR & 100 & 8 & 9 & 10 & 0 & 0 & 0 & \\
\hline THR & 1.00 & 24 & 1 & 10 & 0 & 0 & 0 & \\
\hline THR & 100 & 24 & 2 & 10 & 0 & 0 & 0 & \\
\hline THR & 100 & 24 & 9 & 10 & 0 & 0 & 0 & \\
\hline PPB & 0 & 8 & 5 & 9 & 0 & 0 & 0 & \\
\hline PPB & 0 & 8 & 7 & 9 & 0 & 0 & 0 & \\
\hline PPB & 0 & 8 & 8 & 9 & 0 & 0 & 0 & \\
\hline $\mathrm{PPB}$ & 0 & 24 & 5 & 9 & 0 & 0 & 0 & \\
\hline PPB & 0 & 24 & 7 & 9 & 0 & 0 & 0 & \\
\hline PPB & 0 & 24 & 8 & 9 & 0 & 0 & 0 & \\
\hline PPB & 50 & 8 & 3 & 9 & 0 & 0 & 0 & \\
\hline PPB & 50 & 8 & 4 & 9 & 0 & 0 & 0 & \\
\hline PPB & 50 & 8 & 6 & 9 & 0 & 0 & 0 & \\
\hline PPB & 50 & 24 & 3 & 9 & 0 & 1. & 1 & \\
\hline PPB & 50 & 24 & 4 & 9 & 0 & 0 & 0 & \\
\hline PPB & 50 & 24 & 6 & 9 & 0 & 0 & 0 & \\
\hline PPB & 100 & 8 & 1 & 9 & 0 & 0 & 0 & \\
\hline PPB & 100 & 8 & 2 & 9 & 0 & 0 & 0 & \\
\hline PPB & 100 & 8 & 9 & 9 & 0 & 0 & 0 & \\
\hline PPB & 100 & 24 & 1 & 9 & 0 & 0 & 0 & \\
\hline PPB & 100 & 24 & 2 & 9 & 0 & 1 & 1 & \\
\hline PPB & 100 & 24 & 9 & 9 & 0 & 0 & 0 & \\
\hline HGE & 0 & 8 & 5 & 8 & 0 & 0 & 0 & \\
\hline HGE & 0 & 8 & 7 & 8 & 0 & 0 & 0 & \\
\hline HGE & 0 & 8 & 8 & 8 & 1 & 0 & 1 & Pago \\
\hline
\end{tabular}




$\begin{array}{lcccccccc}\text { HGE } & 0 & 24 & 5 & 8 & 0 & 1 & 1 & \\ \text { HGE } & 0 & 24 & 7 & 8 & 0 & 0 & 0 & \text { AEH-13-PSEUDO-06 } \\ \text { HGE } & 0 & 24 & 8 & 8 & 0 & 0 & 0 & \\ \text { HGE } & 50 & 8 & 3 & 8 & 0 & 0 & 0 & \\ \text { HGE } & 50 & 8 & 4 & 8 & 0 & 0 & 0 & \\ \text { HGE } & 50 & 8 & 6 & 8 & 0 & 0 & 0 & \\ \text { HGE } & 50 & 24 & 3 & 8 & 0 & 0 & 0 & \\ \text { HGE } & 50 & 24 & 4 & 8 & 0 & 0 & 0 \\ \text { HGE } & 50 & 24 & 6 & 8 & 0 & 1 & 1 \\ \text { HGE } & 100 & 8 & 1 & 8 & 0 & 0 & 0 \\ \text { HGE } & 100 & 8 & 2 & 8 & 0 & 0 & 0 \\ \text { HGE } & 100 & 8 & 9 & 8 & 0 & 0 & 0 \\ \text { HGE } & 100 & 24 & 1 & 8 & 0 & 0 & 0 \\ \text { HGE } & 100 & 24 & 2 & 8 & 0 & 0 & 0 \\ \text { HGE } & 100 & 24 & 9 & 8 & 1 & 0 & 1 \\ \text { PIG } & 0 & 8 & 5 & 8 & 0 & 0 & 0 \\ \text { PIG } & 0 & 8 & 7 & 8 & 0 & 0 & 0 \\ \text { PIG } & 0 & 8 & 8 & 8 & 0 & 0 & 0 \\ \text { PIG } & 0 & 24 & 5 & 8 & 0 & 0 & 0 \\ \text { PIG } & 0 & 24 & 7 & 8 & 0 & 0 & 0 \\ \text { PIG } & 0 & 24 & 8 & 8 & 0 & 0 & 0 \\ \text { PIG } & 50 & 8 & 3 & 8 & 0 & 0 & 0 \\ \text { PIG } & 50 & 8 & 4 & 8 & 0 & 0 & 0 \\ \text { PIG } & 50 & 8 & 6 & 8 & 0 & 0 & 0 \\ \text { PIG } & 50 & 24 & 3 & 8 & 0 & 0 & 0 \\ \text { PIG } & 50 & 24 & 4 & 8 & 0 & 0 & 0 \\ \text { PIG } & 50 & 24 & 6 & 8 & 0 & 0 & 0 \\ \text { PIG } & 100 & 8 & 1 & 8 & 0 & 0 & 0 \\ \text { PIG } & 100 & 8 & 2 & 8 & 0 & 0 & 0 \\ \text { PIG } & 100 & 8 & 9 & 8 & 0 & 0 & 0 \\ \text { PIG } & 100 & 24 & 1 & 8 & 0 & 0 & 0 \\ \text { PIG } & 100 & 24 & 2 & 8 & 0 & 0 & 0 \\ \text { PIG } & 100 & 24 & 9 & 8 & 0 & 0 & 0 & \\ & & & & & & 0 & \\ \end{array}$

FF \# $\frac{12}{\text { No. } \frac{1}{4}}$
$\mathrm{Pg}$ of 4 
Study Number: AEH-13-PSEUDO-26

Mussel species: Plain Pocketbook (Lampsifis cardlum )

Eiectronic Log (Page 10)

File Folder 12a
Test Article: Pseudomonas fluorescens Pf-CL 145A (SDP)

Artlcle lct \#: 401P12163C and 401P12164C Mix

Exposure Date: 5/29/2013

Assessment Dates: 6/26-27/2013

Plain Pocketbook (L. cardium) Mortality Summary $/ 2 \cdot / 2 \cdot 14$

\begin{tabular}{|c|c|c|c|c|c|c|c|}
\hline Specles & $\begin{array}{c}\text { Treatment } \\
\text { Group }(\mathrm{mg} / \mathrm{L})\end{array}$ & $\begin{array}{l}\text { Exposure } \\
\text { Duration }\end{array}$ & $\begin{array}{c}\text { Tank } \\
\#\end{array}$ & $\mathbf{N}$ & Dead & Unrecovered & \% Survival \\
\hline \multirow{30}{*}{ PP8 } & \multirow{10}{*}{ Control (0) } & & 5 & 9 & 0 & 0 & 100.0 \\
\hline & & 8 & 7 & 9 & 0 & 0 & 100.0 \\
\hline & & & 8 & 9 & 0 & 0 & 100.0 \\
\hline & & Mean/total & $\mathrm{N} / \mathrm{A}$ & 27 & 0 & 0 & 100.0 \\
\hline & & $S D$ & N/A & 0.0 & 0.0 & 0.0 & 0.0 \\
\hline & & & 5 & 9 & 0 & 0 & 100.0 \\
\hline & & 24 & 7 & 9 & 0 & 0 & 100.0 \\
\hline & & & 8 & 9 & 0 & 0 & 100.0 \\
\hline & & Mean/total & $\mathrm{N} / \mathrm{A}$ & 27 & 0 & 0 & 100.0 \\
\hline & & SD & $\mathrm{N} / \mathrm{A}$ & 0.0 & 0.0 & 0.0 & 0.0 \\
\hline & \multirow{10}{*}{50} & \multirow{3}{*}{8} & 3 & 9 & 0 & 0 & 100.0 \\
\hline & & & 4 & 9 & 0 & 0 & 100.0 \\
\hline & & & 6 & 9 & 0 & 0 & 100.0 \\
\hline & & Nean/total & $\mathrm{N} / \mathrm{A}$ & 27 & 0 & 0 & 100.0 \\
\hline & & SD & $N / A$ & 0.0 & 0.0 & 0.0 & 0.0 \\
\hline & & \multirow{3}{*}{24} & 3 & 9 & 0 & 1 & 88.9 \\
\hline & & & 4 & 9 & 0 & 0 & 100.0 \\
\hline & & & 6 & 9 & 0 & 0 & 1000 \\
\hline & & Mean/total & $\mathrm{N} / \mathrm{A}$ & 27 & 0 & 1 & 96.3 \\
\hline & & SD & $\mathrm{N} / \mathrm{A}$ & 0.0 & 0.0 & 0.5 & 5.2 \\
\hline & \multirow{10}{*}{100} & \multirow{3}{*}{8} & 1 & 9 & 0 & 0 & -000 \\
\hline & & & 2 & 9 & 0 & 0 & $\therefore 00.0$ \\
\hline & & & 9 & 9 & 0 & 0 & 200.0 \\
\hline & & Mean/total & $\mathrm{N} / \mathrm{A}$ & 27 & 0 & 0 & -00.0 \\
\hline & & SD & $\mathrm{N} / \mathrm{A}$ & 0.0 & 0.0 & 0.0 & 0.0 \\
\hline & & \multirow{3}{*}{24} & 2 & 9 & 0 & 0 & 4000 \\
\hline & & & 2 & 9 & 0 & 1 & 88.9 \\
\hline & & & 9 & 9 & 0 & 0 & 100.0 \\
\hline & & Mean/total & $\mathrm{N} / \mathrm{A}$ & 27 & 0 & 1 & 96.3 \\
\hline & & SD & $\mathrm{N} / \mathrm{A}$ & 0.0 & 0.0 & 0.5 & 5.2 \\
\hline
\end{tabular}

File Folder 120

Item Number

Page 1 of 1 
Study Number: AEH-13-PSEUDO-06

Mussel species: Hickorynut (Obovaria olivaria)

Electronic Log (Page 10)

File Folder $12 b$
Test Article: Pseudomonas fluorescens Pf-CL. 145A (SDP) Article of \#: 401P12163C and 401P12164C Mix Exposure Date: 5/29/2013

Assessment Dates: 6/26-27/2013

Hickorynut (O. olivaria) Mortality Summary $ル-/ L-/ 4$

\begin{tabular}{|c|c|c|c|c|c|c|c|}
\hline Specles & $\begin{array}{c}\text { Treatment } \\
\text { Group }(\mathrm{mg} / \mathrm{L})\end{array}$ & $\begin{array}{l}\text { Exposure } \\
\text { Duration } \\
\end{array}$ & $\begin{array}{c}\text { Tank } \\
\# \\
\end{array}$ & $N$ & Dead & Unrecovered & $\%$ Survival \\
\hline \multirow{30}{*}{ HIC } & \multirow{13}{*}{ Control $(0)$} & & 5 & 10 & 0 & C & 100.0 \\
\hline & & 8 & 7 & 10 & 0 & 0 & 100.0 \\
\hline & & & 8 & 10 & 0 & 0 & 100.0 \\
\hline & & Mean/total & $\mathrm{N} / \mathrm{A}$ & 30 & 0 & 0 & 100.0 \\
\hline & & SD & $N / A$ & 0.0 & 0.0 & 0.0 & 0.0 \\
\hline & & & 5 & 10 & 0 & 0 & 100.0 \\
\hline & & 24 & 7 & 10 & 0 & 0 & 100.0 \\
\hline & & & 8 & 10 & 0 & 0 & 100.0 \\
\hline & & Mean/total & N/A & 30 & 0 & 0 & 100.0 \\
\hline & & SD & N/A & 0.0 & 0.0 & 0.0 & 0.0 \\
\hline & & & 3 & 10 & 0 & 0 & 100.0 \\
\hline & & 8 & 4 & 10 & 0 & 0 & 100.0 \\
\hline & & & 6 & 10 & 0 & 0 & 100.0 \\
\hline & \multirow{5}{*}{50} & Mean/total & $N / A$ & 30 & 0 & 0 & 100.0 \\
\hline & & SD & $\mathrm{N} / \mathrm{A}$ & 0.0 & 0.0 & 0.0 & 0.0 \\
\hline & & & 3 & 10 & 0 & 0 & 100.0 \\
\hline & & 24 & 4 & 10 & 0 & 0 & 100,0 \\
\hline & & & 6 & 10 & 0 & 0 & 100,0 \\
\hline & \multirow{12}{*}{100} & Nean/total & $\mathrm{N} / \mathrm{A}$ & 30 & 0 & 0 & 100,0 \\
\hline & & SD & $\mathrm{N} / \mathrm{A}$ & 0.0 & 0.0 & 0.0 & 0.0 \\
\hline & & \multirow{3}{*}{8} & 1 & 10 & 0 & 0 & 100.0 \\
\hline & & & 2 & 10 & 0 & 0 & 100.0 \\
\hline & & & 9 & 10 & 0 & 0 & 100.0 \\
\hline & & Mean/total & $\mathrm{N} / \mathrm{A}$ & 30 & 0 & 0 & 100.0 \\
\hline & & SD & $\mathrm{N} / \mathrm{A}$ & 0.0 & 0.0 & 0.0 & 0.0 \\
\hline & & \multirow{3}{*}{24} & 1 & 10 & 0 & 0 & 100.0 \\
\hline & & & 2 & 10 & 0 & 1 & 90.0 \\
\hline & & & 9 & 10 & 0 & 0 & 100.0 \\
\hline & & Mean/total & $\mathrm{N} / \mathrm{A}$ & 30 & 0 & 1 & 96.7 \\
\hline & & SD & $\mathrm{N} / \mathrm{A}$ & 0.0 & 0.0 & 0.5 & 4.7 \\
\hline
\end{tabular}

File Foider $1 \mathrm{dh}$

Item Number I

Page 1 of 1 
Study Number: AEH-13-PSEUDO-06

Mussel specles: Washboard (Megalonaias nervosa)

Electronic Log (Page 10)

File Folder $12 \mathrm{c}$
Test Article: Pseudomonas fluorescens Pf-CL 145A (SDP)

Article lot \#: 401P12163C and 401P12164C Mix

Exposure Date: $5 / 29 / 2013$

Assessment Dates: 6/26-27/2013

Washboard (M. nervosa) Mortality Summary $-/ L / 2 \cdot j h$

\begin{tabular}{|c|c|c|c|c|c|c|c|}
\hline Species & $\begin{array}{c}\text { Treatment } \\
\text { Group }(\mathrm{mg} / \mathrm{L})\end{array}$ & $\begin{array}{l}\text { Exposure } \\
\text { Duration }\end{array}$ & $\begin{array}{c}\text { Tank } \\
\#\end{array}$ & $\mathbf{N}$ & Dead & Unrecovered & \% Survival \\
\hline \multirow{30}{*}{ WAS } & \multirow{10}{*}{ Control $(0)$} & & 5 & 10 & 0 & 0 & 100.0 \\
\hline & & 8 & 7 & 10 & 0 & 0 & 100.0 \\
\hline & & & 8 & 10 & 0 & 0 & 100.0 \\
\hline & & Mean/total & $\mathrm{N} / \mathrm{A}$ & 30 & 0 & 0 & 100.0 \\
\hline & & SD & N/A & 0.0 & 0.0 & 0.0 & 0.0 \\
\hline & & & 5 & 10 & 0 & 0 & 100.0 \\
\hline & & 24 & 7 & 10 & 0 & 0 & 100.0 \\
\hline & & & 8 & 10 & 0 & 0 & 100.0 \\
\hline & & Mean/total & $\mathrm{N} / \mathrm{A}$ & 30 & 0 & 0 & 100.0 \\
\hline & & So & $N / A$ & 0.0 & 0.0 & 0.0 & 0.0 \\
\hline & \multirow{9}{*}{50} & \multirow{3}{*}{8} & 3 & 10 & 0 & 0 & 100.0 \\
\hline & & & 4 & 10 & 1. & 0 & 90.0 \\
\hline & & & $G$ & 10 & 0 & 0 & 100.0 \\
\hline & & Mcan/total & $N / A$ & 30 & 1 & 0 & 96.7 \\
\hline & & SD & N/A & 0.0 & 0.5 & 0.0 & 4.7 \\
\hline & & \multirow{3}{*}{24} & 3 & 10 & 0 & 0 & 100.0 \\
\hline & & & 4 & 10 & 0 & 0 & 100.0 \\
\hline & & & 6 & 10 & 0 & 0 & 100.0 \\
\hline & & Mean/total & $\mathrm{N} / \mathrm{A}$ & 30 & 0 & 0 & 100.0 \\
\hline & \multirow{11}{*}{100} & & $\mathrm{~N} / \mathrm{A}$ & 0.0 & 0.0 & 0.0 & 0.0 \\
\hline & & \multirow{3}{*}{8} & 1 & 10 & 0 & 0 & 1.00 .0 \\
\hline & & & 2 & 10 & 0 & 0 & 100.0 \\
\hline & & & 9 & 10 & 0 & 0 & 100.0 \\
\hline & & Mean/total & $\mathrm{N} / \mathrm{A}$ & 30 & 0 & 0 & 100.0 \\
\hline & & SD & $\mathrm{N} / \mathrm{A}$ & 0.0 & 0.0 & 0.0 & 0.0 \\
\hline & & \multirow{3}{*}{24} & 1 & 10 & 0 & 0 & 100.0 \\
\hline & & & 2 & 10 & 0 & 0 & 100.0 \\
\hline & & & 9 & 10 & 0 & 0 & 100.0 \\
\hline & & Nean/total & $\mathrm{N} / \mathrm{A}$ & 30 & 0 & 0 & 100.0 \\
\hline & & $\mathrm{SD}$ & $\mathrm{N} / \mathrm{A}$ & 0.0 & 0.0 & 0.0 & 0.0 \\
\hline
\end{tabular}

File Folder 120

Item Number

Page 1 of 1 
Study Number: AEH-13-PSEUDO-06

Mussel specles: Hlgg'ns Eye (Lompsilis higginsil)

Electronic Log (Page 10)

File Folder 12d
Test Article: Pseudomonas fluorescens of $-\mathrm{CL}$ 145A (SDP)

Article ot \#: 401P12163C and 401P12164C Mix

Exposure Date: 5/29/2013

Assessment Dates: 6/26-27/2013

Higgins Eye (L. higginsii) Mortality Summary $/ L-1 / \mu$

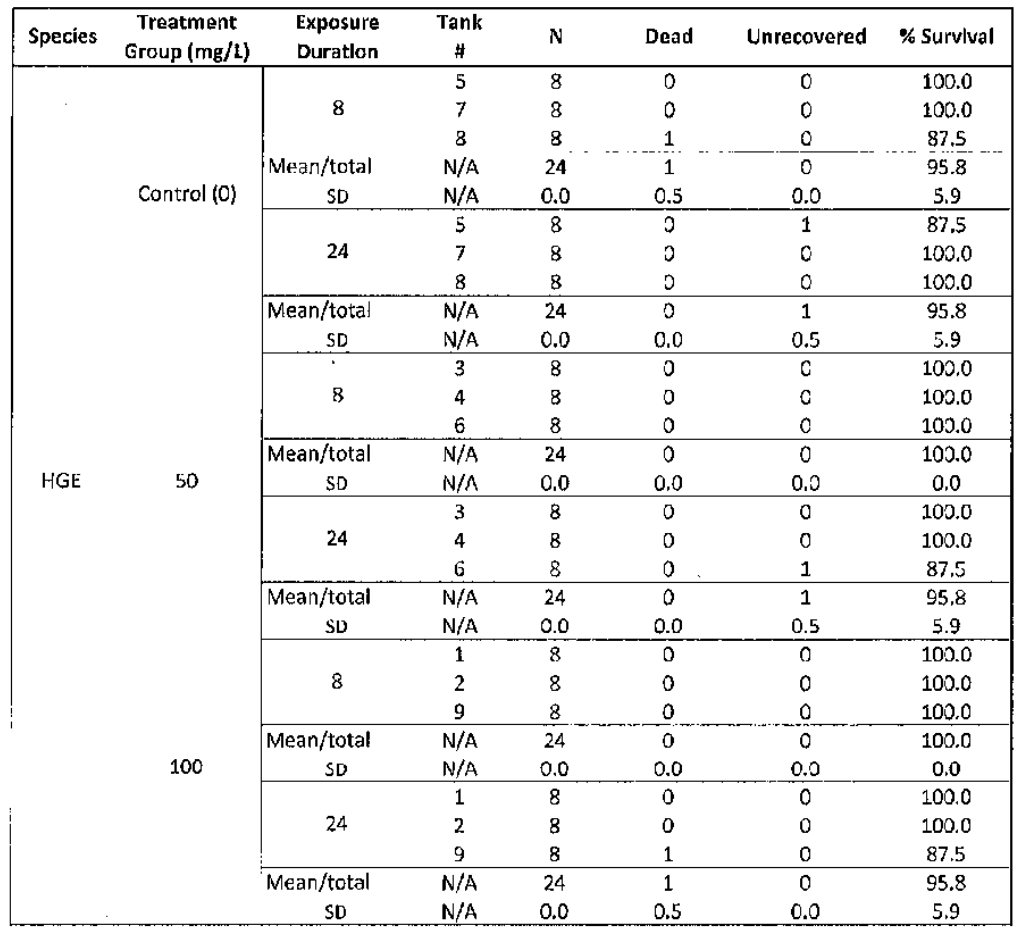

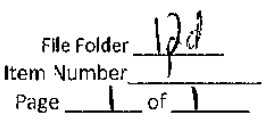


Study Number: AEH-13-PSEUDO-06

Mussel species: Fatmucket (Lampsilis siliquoidea)

Electronic Log (Page 1.C)

File Folder 220
Test Article: Pseudomonas fluorescens Pf-CL. 145A (SDP) Article lot \#; 401P12163C and 401P12164C Mix Exposure Date: $5 / 29 / 2013$

Assessment Dates: 6/26-27/2013

Fatmucket (L. siliquoidea) Mortality Summary $\pi-12-14$

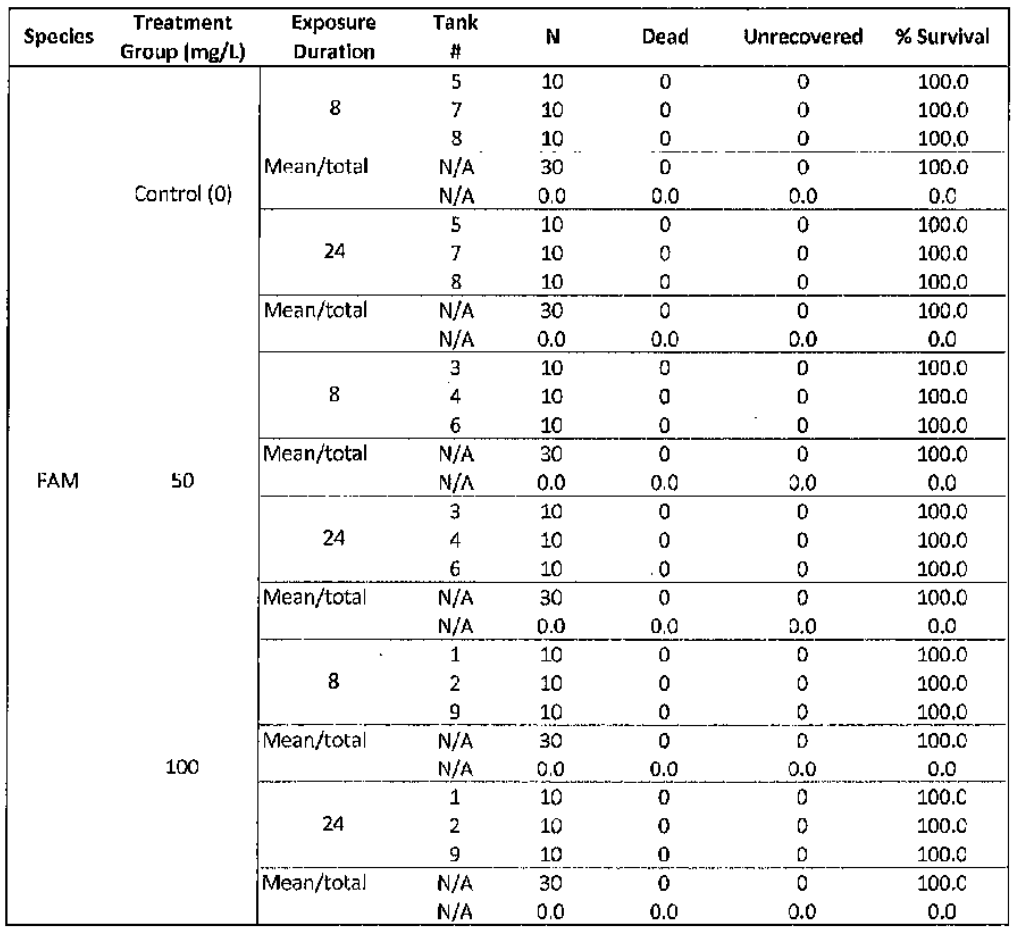

File Folder $12 \ell$

Item Number

Page 
Study Number: AEH-13-PSEUDO-05

Mussel species: Threeridge (Amblema plicata)

Electronic Log (Page 10)

File Folder $12 f$
Test Arlicle: Pseudomonas fiuorescens Pf $-\mathrm{CL}$ 145A (SDP) Artlcle lot \#: 401P12.163C and 401P12164C MIX Exposure Date: 5/29/2013

Assessmeาt Dates: 6/26-27/2013

Threeridge (A. plicata) Mortality Summary

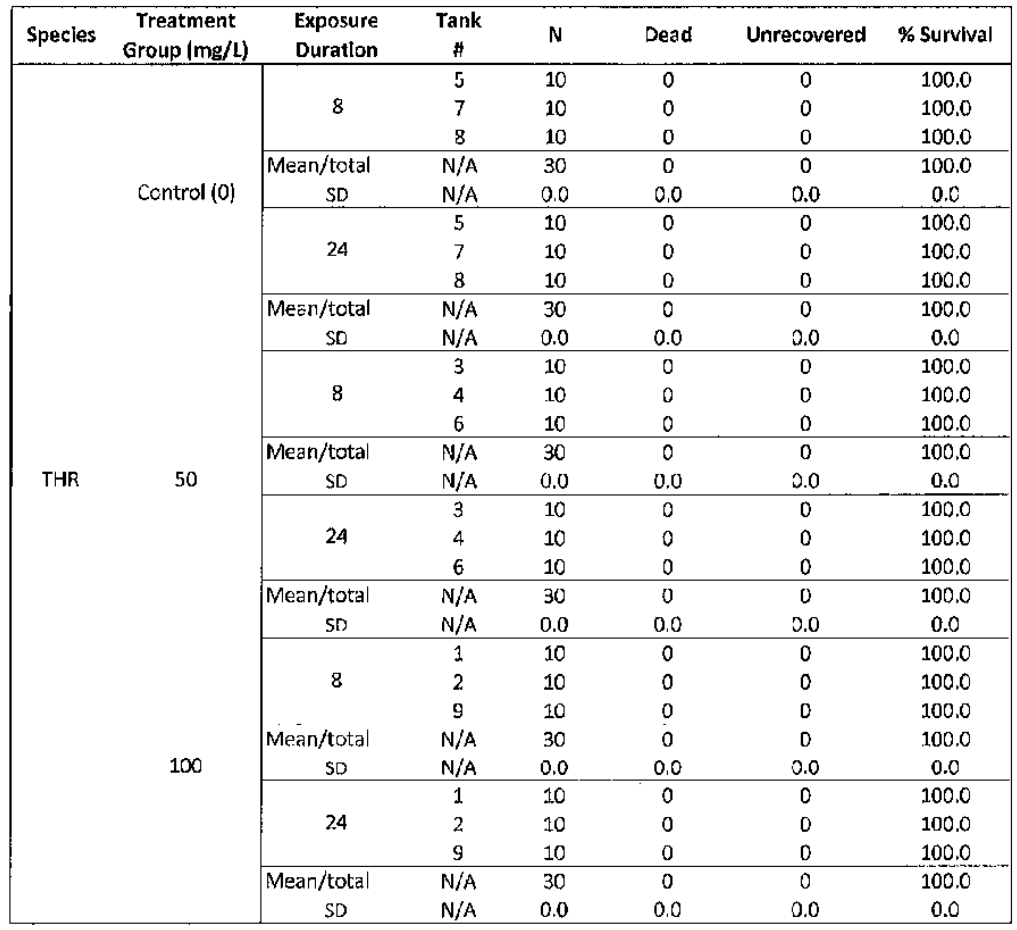

File Folder iof

Item Number

Page 1 of 1 
Study Number: AEH-13-PSEUDO-06

Mussel species: Wabash Pigtoe (Fusconala flava)

Electronic Log (Page 10)

File Folder $12 \mathrm{~g}$
Test Article: Pseudomonas fluorescens Pf-CL 145A (SDP) Article lot \#: 401P12163C and 401P12164C Mix Exposurc Date: $5 / 29 / 2013$

Assessment Dates: 6/26-2\%/2013

$12 / 12 / 14$

Wabash Pigtoe (F. flava) Mortality Summary

\begin{tabular}{|c|c|c|c|c|c|c|c|}
\hline Specles & $\begin{array}{c}\text { Treatment } \\
\text { Group (mg/L) }\end{array}$ & $\begin{array}{l}\text { Exposure } \\
\text { Duration }\end{array}$ & $\begin{array}{c}\text { Tank } \\
\#\end{array}$ & $\mathbf{N}$ & Dead & Unrecovered & $\%$ Surviva \\
\hline \multirow{30}{*}{$P \mid G$} & \multirow{12}{*}{ Control (0) } & & 5 & 8 & 0 & 0 & 100.0 \\
\hline & & 8 & 7 & 8 & 0 & 0 & 100,0 \\
\hline & & & 8 & 8 & 0 & 0 & 100.0 \\
\hline & & Mean/total & $\mathrm{N} / \mathrm{A}$ & 24 & 0 & 0 & 100.0 \\
\hline & & SD & N/A & 0.0 & 0.0 & 0.0 & 0.0 \\
\hline & & & 5 & 8 & 0 & 0 & 100.0 \\
\hline & & 24 & 7 & 8 & 0 & 0 & 100,0 \\
\hline & & & 8 & 8 & 0 & 0 & 100.0 \\
\hline & & Mean/total & $N / A$ & 24 & 0 & 0 & 100.0 \\
\hline & & SD & N/A & 0.0 & 0.0 & 0.0 & 0.0 \\
\hline & & & 3 & 8 & 0 & 0 & 100.0 \\
\hline & & 8 & 4 & 8 & 0 & 0 & 100.0 \\
\hline & \multirow{6}{*}{50} & & 6 & 8 & 0 & 0 & 100.0 \\
\hline & & Mean/total & $\mathrm{N} / \mathrm{A}$ & 24 & 0 & 0 & 100.0 \\
\hline & & SD & $\mathrm{N} / \mathrm{A}$ & 0.0 & 0.0 & 0.0 & 0.0 \\
\hline & & & 3 & 8 & 0 & 0 & 100.0 \\
\hline & & 24 & 4 & 8 & 0 & 0 & 100,0 \\
\hline & & & 6 & 8 & 0 & 0 & 100,0 \\
\hline & \multirow{12}{*}{100} & Mean/total & $\mathrm{N} / \mathrm{A}$ & 24 & D & 0 & 100,0 \\
\hline & & SD & $\mathrm{N} / \mathrm{A}$ & 0.0 & 0.0 & 0.0 & 0.0 \\
\hline & & & 1 & 8 & 0 & 0 & 100.0 \\
\hline & & 8 & 2 & 8 & 0 & 0 & 100.0 \\
\hline & & & 9 & 8 & 0 & 0 & 100,0 \\
\hline & & Miean/total & $\mathrm{N} / \mathrm{A}$ & 24 & 0 & 0 & 100.0 \\
\hline & & SD & $\mathrm{N} / \mathrm{A}$ & 0.0 & 0.0 & 0.0 & 0.0 \\
\hline & & & 1 & 8 & 0 & 0 & 100.0 \\
\hline & & 24 & 2 & 8 & 0 & 0 & 100.0 \\
\hline & & & 9 & 8 & 0 & 0 & 100.0 \\
\hline & & Mean/total & $\mathrm{N} / \mathrm{A}$ & 24 & 0 & 0 & 100.0 \\
\hline & & SD & $\mathrm{N} / \mathrm{A}$ & 0.0 & 0.0 & 0.0 & 0.0 \\
\hline
\end{tabular}

File Folder $12 \mathrm{~g}$

Item Number $\frac{1}{1}$ 
